Manuel Filgueira Barral

\title{
Modelo cinético não-estruturado para crescimento e produção de glicoproteína recombinante do vírus da raiva em linhagem S2 de células de Drosophila melanogaster.
}

Tese apresentada ao Programa de PósGraduação Interunidades em Biotecnologia USP/Instituto Butantan/IPT, para obtenção do Título de Doutor em Biotecnologia. 


\section{Manuel Filgueira Barral}

\section{Modelo cinético não-estruturado para crescimento e produção de glicoproteína recombinante do vírus da raiva em linhagem S2 de células de Drosophila melanogaster.}

Tese apresentada ao Programa de PósGraduação Interunidades em Biotecnologia USP/Instituto Butantan/IPT, para obtenção do Título de Doutor em Biotecnologia.

Área de concentração: Biotecnologia

Orientadora: Dra. Elisabeth de Fatima Pires Augusto 


\section{FICHA CATALOGRÁFICA}

DADOS DE CATALOGAÇÃO NA PUBLICAÇÃO (CIP)

Serviço de Biblioteca e Informação Biomédica do

Instituto de Ciências Biomédicas da Universidade de São Paulo

reprodução não autorizada pelo autor

Barral, Manuel Filgueira.

Modelo cinético não-estruturado para crescimento e produção de glicoproteína recombinante do virus da raiva em linhagem S2 de células de Drosophila melanogaster / Manuel Filgueira Barral. -- São Paulo, 2010.

Orientador: Elisabeth de Fátima Pires Augusto.

Tese (Doutorado) - Universidade de São Paulo. Instituto de Ciências Biomédicas. Programa de Pós-Graduação Interunidades em Biotecnologia USP/IPT/Instituto Butantan. Área de concentração: Biotecnologia. Linha de pesquisa: Cultivo de células animais.

Versão do título para o inglês: Unstructured kinetic model for growth and production of the recombinant rabies virus glycoproteine in $\mathrm{S} 2$ cell strain from Drosophila melanogaster.

Descritores: 1. Drosophila melanogaster S2 2 Células de inseto 3. Modelagem matemática 4. Modelo cinético 5. Modelo nãoestruturado 6. Glicoproteina do virus rábico I. Augusto, Elisabeth de Fátima Pires II. Universidade de São Paulo. Instituto de Ciências Biomédicas. Programa de Pós-Graduação Interunidades em Biotecnologia USP/IPT/Instituto Butantan III. Título. 
À Rocilda, ao Heitor e à Marília pelo apoio, estímulo e pelo tempo privado ao nosso convívio.

In memoriam a meus pais, Faustino e Maria Luísa e aos meus queridos amigos de graduação, Nuno Álvaro Luz Lacerda e ao Luis Eduardo Tomazzini e ao Luis Carlos Urenha, amigo de escola e de trabalho, com quem gostaria de compartilhar este momento. 


\section{AGRADECIMENTOS}

À Beth, pela orientação, estímulo e pela oportunidade de participar de um grupo pesquisa como este.

Ao Marcelo pelos dados, pela amizade, apesar da diferença de idade, e pelo apoio nos momentos de dificuldades com dispositivos eletrônicos e com as novas e velhas versões de certos aplicativos.

À Kamila, Adriana e Fabiana pelos dados e pela estimulante convivência neste projeto.

À Rosane pelo apoio nos momentos críticos e pela amizade permanente destes últimos anos.

Patrícia Léo e ao Aldo pelas contribuições nas discussões havidas durante o projeto.

Ao Renato pelo seu apoio técnico no projeto

Ao Fabríco Sensato, pela amizade, pelo estímulo à pesquisa e pelo exemplo de dedicação e seriedade na vida e no trabalho.

Aos meus queridos amigos Murilo, Ana, José Carlos e Carla, amigos certos de horas certas e incertas, por seu apoio e paciência comigo.

À equipe do projeto temático, em especial ao Renato e ao Ronaldo, pelo agradável e produtivo convívio no projeto.

Ao LBI e ao ao IPT pela possibilidade de realizar este trabalho. 
Our remedies oft in ourselves do lie

Wich we ascribe to heaven: fated sky Give us scope, only doth backward pull Our slow designs when we ourselves are dull (W. Shakespeare, All's well that ens well, act 1, scene 1)

Nossos remédios vivem em nós mesmos, Mas os atribuímos a Deus, nosso fado Nos dá escolha livre, fracassamos Se com preguiça à luta nós nos damos. (W. Shakespeare, Bom é o que acaba bem, ato 1, cena 1, tradução de Bárbara Heliodora). 


\section{RESUMO}

BARRAL, M. F. Modelo cinético não-estruturado para crescimento e produção de glicoproteína recombinante do vírus da raiva em linhagem $\mathrm{S2}$ de células de Drosophila melanogaster. 2010. 205p. (Doutorado em Biotecnologia) - Instituto de Ciências Biomédicas, Universidade de São Paulo, São Paulo, 2010.

Este trabalho propôs um modelo matemático não-estruturado para descrever o crescimento de uma linhagem recombinante de Drosophila melanogaster (S2AcGPV2) e a expressão da glicoproteína G do vírus da raiva (GPV). Para formular o modelo, foram considerados dez ensaios nos quais as células foram cultivadas em meio TC100 modificado e livre de soro fetal bovino, em bioreator isento de bolhas, operando em batelada, sob diferentes condições de controle do percentual de oxigênio dissolvido $\left(\mathrm{pO}_{2}\right)$ e concentrações iniciais de glicose (GLC) e glutamina (GLN). O modelo proposto considera oito variáveis de estado (células viáveis, $\mathrm{Xv}$, células não-viáveis, Xd, GLC, GLN, alanina, ALA, glutamato, GLU, amônio, $\mathrm{NH}_{4}{ }^{+}$, GPV) e vinte parâmetros cinéticos, descrevendo quatro situações metabólicas, com dinâmicas distintas, que são função de diferentes condições de limitação em GLC e/ou GLN. O equacionamento considera os seguintes fenômenos: a) a velocidade específica de crescimento é limitada por GLC $\left(\mathrm{k}_{\mathrm{GLC}}=0,6 \mathrm{~g} / \mathrm{L}\right)$ e $\mathrm{GLN}\left(\mathrm{k}_{\mathrm{GLN}}=26 \mathrm{mg} / \mathrm{L}\right)$ e inibida por $\mathrm{NH}_{4}^{+}$ $\left.\left(\mathrm{k}_{\mathrm{NH} 4}=44 \mathrm{mg} / \mathrm{L}\right) ; \mathrm{b}\right)$ a velocidade específica de morte é uma cinética de ordem zero; c) a velocidade específica de produção de $\mathrm{NH}_{4}{ }^{+}$é associada ao crescimento e estimulada pelo esgotamento de GLC, visto que nessa condição a célula não é mais capaz de formar ALA; d) a velocidade específica de formação de ALA é parcialmente associada ao crescimento; e) a velocidade específica de síntese de GPV é associada ao crescimento e inibida por $\mathrm{NH}_{4}{ }^{+}$ $\left(\mathrm{k}_{\mathrm{dGPV} / \mathrm{NH} 4}=35 \mathrm{mg} / \mathrm{L}\right)$; f) há degradação de GPV na fase de crescimento estacionária; $\left.\mathrm{g}\right)$ há síntese de GLN quando GLN <0,10 g/L; h) há consumo de GLC para a formação de material celular e de ALA; i) há consumo de GLU em condições limitantes de GLN. A variabilidade metabólica foi ainda incorporada ao modelo mediante fatores que representam a influência das concentrações de $\mathrm{pO}_{2}$, GLC e GLN na velocidade específica de crescimento máxima $\left(\mu_{\mathrm{Xmax}}\right)$ e nos fatores de conversão: $\mathrm{Y}_{\mathrm{X} / \mathrm{GLC}}, \mathrm{Y}_{\mathrm{X} / \mathrm{GLN}}, \mathrm{Y}_{\mathrm{NH} 4 / \mathrm{X}}, \mathrm{Y}_{\mathrm{GPV} / \mathrm{X}}, \mathrm{Y}_{\mathrm{ALA} / \mathrm{GLC}}, \mathrm{Y}_{\mathrm{NH} 4 / \mathrm{GLN}}$. Os parâmetros do modelo foram ajustados usando a técnica de otimização da busca de parâmetros por poliedros flexíveis, integração das equações diferenciais pelo método de Gear e considerando uma função objetivo definida como a somatória quadrática da diferença entre o valor previsto pelo modelo e o valor experimental da variável, normalizada pelo valor médio entre esses dois valores. Este estudo validou um modelo cinético aplicável à fase exponencial do cultivo e à toda a dinâmica do processo com níveis diferentes de significância de $95 \%$ e $85 \%$, respectivamente.

Palavras-chave: Drosophila melanogaster. S2. Células de inseto. Metabolismo. Modelagem matemática. Modelo não-estruturado. Proteína recombinante. Glicoproteína do vírus rábico.. 


\begin{abstract}
BARRAL, M. F. Unstructured kinetic modelling for growth and recombinant rabies virus glycoprotein production in a $\mathbf{S 2}$ strain cell line of Drosophila melanogaster. 205p. $\mathrm{Ph}$. D Thesis (Biotechnology). - Instituto de Ciências Biomédicas, Universidade de São Paulo, São Paulo, 2010.

A mathematical unstructured model for growth of a Drosophila melanogaster recombinant strain (S2AcGPV2) and the expression of glycoprotein G of rabies virus (GPV) was proposed. To formulate the model, ten experiments were considered in which cells were cultivated in a modified TC100 medium, fetal serum free, in a bubble free bench bioreactor, operating in batch mode, under different dissolved oxygen $\left(\mathrm{pO}_{2}\right)$ control and initial concentrations of glucose (GLC) and glutamine (GLC). The proposed model considers eight state variables (viable cells, Xv, non-viable cells, Xd, GLC, GLN, alanine, ALA, glutamate, GLU, ammonium, NH4 + and GPV) and twenty kinetic parameters, describing four metabolic situations, with different dynamics, which are function of different conditions of GLC or GLN limitations. The following phenomena were considered: a) the specific growth rate is limited by GLC $\left(\mathrm{k}_{\mathrm{GLC}}=0.6 \mathrm{~g} / \mathrm{L}\right)$ and $\mathrm{GLN}\left(\mathrm{k}_{\mathrm{GLN}}=26 \mathrm{mg} / \mathrm{L}\right)$ and inhibited by $\mathrm{NH}^{+}\left(\mathrm{k}_{\mathrm{NH} 4}=\right.$ $44 \mathrm{mg} / \mathrm{L})$; b) the specific death rate is a zero order kinetic; c) the specific $\mathrm{NH} 4^{+}$production rate is growth associated and stimulated by exhaustion of GLC, since in this condition cells can no longer form ALA; d) specific ALA production rate is growth partialy associated; e) the specific GPV synthesis rate is growth associated and inhibited by $\mathrm{NH}_{4}^{+}$ $\left(\mathrm{k}_{\mathrm{dGPV} / \mathrm{NH} 4}=35 \mathrm{mg} / \mathrm{L}\right)$; $\left.\mathrm{f}\right) \mathrm{GPV}$ degradation of GPV occurs at stationary growth phase; $\left.\mathrm{g}\right)$ GLN synthesis occurs when GLN $<0.10 \mathrm{~g} / \mathrm{L}$; h) GLC is consumption for cell formation and ALA synthesis; i) GLU is consumed under GLN limitation. The cell metabolic versatility was also incorporated to the model as factors that represent the influence of pO2, GLC and GLN concentrations over maximum specific rate $(\mu \mathrm{Xmax})$ and over the conversion factors $\left(\mathrm{Y}_{\mathrm{X} / \mathrm{GLC}}\right.$, $\left.\mathrm{Y}_{\mathrm{X} / \mathrm{GLN}}, \mathrm{Y}_{\mathrm{NH} 4 / \mathrm{X}}, \mathrm{Y}_{\mathrm{GPV} / \mathrm{X}}, \mathrm{Y}_{\mathrm{ALA} / \mathrm{GLC}}, \mathrm{Y}_{\mathrm{NH} / \mathrm{GLN}}\right)$. Model parameters were fitted to experimental data using the flexible geometric simplex optimization method and considering an objective function defined as the sum of squared difference between the value predicted by the model and the experimental value of the variable, normalized by the average between these two values. The integration of differential equations was made by the Gear method Different kinetic models were applied to the exponential growth phase, and to the complete process dynamics, and were validated with distinguished significance levels of $95 \%$ and $85 \%$ respectively.
\end{abstract}

Keywords: Drosophila melanogaster S2. Insect cells. Metabolism. Mathematical modeling. Unstrutured model. Recombinant protein. Rabies virus glycoprotein. 


\section{LISTA DE TABELAS}

Tabela

Pág.

Tabela 3.1 Caracterização de sistemas de expressão em uso.

Tabela 3.2. Exemplos de modelos para velocidades específicas de crescimento. 25 FONTE: Augusto et al. (2008)

Tabela 3.3. Exemplos de modelos para velocidades específicas de morte celular. 27 FONTE: Augusto et al. (2008).

Tabela 3.4. Exemplos de modelos para velocidades específicas de formação de $\mathbf{2 8}$ produto. FONTE: Augusto et al.(2008)

Tabela 3.5. Classificação de biorreatores. 'FONTE: Chico, Rodríguez e Figueiredo 30 (2008)

Tabela 4.1. Tratamento utilizado para extração de GPV de uma amostra celular.

FONTE: Aguiar (2010)

Tabela 5.1. Variação dos parâmetros de cultivo das células S2AcGPV2 e 51 S2AcGPV2-KTC100.

Tabela 5.2. Equações do Modelo 1

Tabela 5.3. Valores dos parâmetros para os diversos modelos.

$\begin{array}{ll}\text { Tabela 5.4. Equações do modelo } 4 . & \mathbf{6 7}\end{array}$

Tabela 5.5. Equações do modelo $5 \quad \mathbf{7 5}$

Tabela 5.6. Equações do modelo $6 \quad 119$

Tabela 5.7. Valores dos parâmetros para o modelo 6. Ensaios considerados Ma-07 a 128

Ma-12, Ma-15 e Ma-16. (5 \% < pO2 < $80 \% ; 1,1 \mathrm{~g} / \mathrm{L}<\mathrm{GLC}_{0}<10,0 \mathrm{~g} / \mathrm{L} ; 0,6 \mathrm{~g} / \mathrm{L}<$ $\left.\mathrm{GLN}_{0}<3,5 \mathrm{~g} / \mathrm{L}\right)$. Célula S2AcGPV2.

Tabela 5.8. Intervalo adotado para ajuste dos parâmetros para o modelo 6a. $\quad \mathbf{1 3 0}$

$\begin{array}{ll}\text { Tabela 5.9 Estimativa das variâncias experimentais } & \mathbf{1 3 1}\end{array}$

Tabela 5.10 Estimativa das variâncias experimentais $\quad \mathbf{1 3 1}$

Tabela 5.11. Valores de F para o modelo 6a. 132

Tabela 5.12. Valores dos fatores de conversão utilizados no modelo $6 \mathrm{~b} . \quad 137$

Tabela 5.13. Intervalo adotado para ajuste dos parâmetros para o modelo $6 \mathrm{~b}$. $\quad \mathbf{1 3 7}$

$\begin{array}{ll}\text { Tabela 5.14. Valores de F para o modelo } 6 \mathrm{~b} . & \mathbf{1 3 8}\end{array}$

Tabela 5.15. Intervalo adotado para ajuste dos parâmetros para o modelo 6c. $\quad 139$

Tabela 5.16. Valores de F para o modelo 6c $\quad 143$ 


\section{LISTA DE FIGURAS}

Figura

Figura 3.1. Representação do vírion da raiva e do posicionamento da glicoproteína na sua estrutura. FONTE: Hammons e Narciso (2005)

Figura 3.2. Esquema simplificado das principais vias metabólicas identificadas em células de inseto Os principais substratos com molduras em preto, principais subprodutos em azul, intermediários do anabolismo em vermelho, moldura em verde (a) indica vias metabólicas preferenciais quando há excesso de glicose e moldura roxo (b) indica vias metabólicas preferenciais com limitação de glicose. As enzimas mais relevantes estão indicadas: 1- DHAP deidrogenase, 2-Lactatodeidrogenase, 3Piruvato decarboxilase e etanol desidrogenase, 4- Glutamato-piruvato transaminase, 5- Glutamato sintase (NADH-GOGAT), 6- Glutamina sintetase, 7- Glutaminase, 8Glutamato desidrogenase. FONTE: baseada em Drews et al. (2000) e Ikonomou, Schneider e Agathos (2003).

Figura 3.3. Reator de ondas.

Figura 3.4. Reator tipo agitado com células ancoradas em microcarregador (destaque para microcarregadores).

Figura 3.5. Biorreator de fibras ocas. FONTE: Fiber Cell System (2008)

Figura 3.6. Reator de leito fixo. FONTE: Meisenholder (1999)

Figura 3.7. Reator de leito Fluidizado. FONTE: Warnock, Merten e Al Rubeai (2006)

Figura 4.1. Determinação da velocidade esepcífica máxima de crescimento $\left(\mu_{\mathrm{Xmax}}\right)$, instante final da fase de crescimento lag $\left(t_{\mathrm{lag}}\right)$, instante final da fase de crescimento exponencial ( $\mathrm{t}_{\mathrm{exp}}$ ). Ensaio RE-5, Quadro A.1, Anexo A)

Figura 4.2. Determinação do tempo transcorrido até o final do crescimento celular $\left(t_{\text {fim }}\right)$ e do tempo transcorrido até início de morte celular $\left(t_{\text {morte }}\right)$ (Ensaio Ma-05, Quadro A.1, Anexo A).

Figura 4.3. Determinação de tempo para que ocorra redução no teor de GPV por $10^{7}$ células, $\left(\mathrm{t}_{\mathrm{GPVEmax}}\right)$ e do tempo transcorrido até se atingir a concentração máxima de GPV ( $\left.\mathrm{t}_{\mathrm{GPV} \text { max }}\right)$. (Ensaio Ma-06, Anexo A, Quadro A.1).

Figura 4.4. Exemplo da determinação de fator de rendimento $\mathrm{Y}_{\mathrm{GPV} / \mathrm{X}}$ (Ensaio Ma-06, Quadro A.1, Anexo A).

Figura 5.1. Principais etapas da modelagem matemática. FONTE: baseado em Bassanezi (2002)

Figura 5.2. Variação da concentração de GPV e do teor de GPV nas células S2AcGPV2 (Ensaio Ma-3, Quadro A.1, Anexo A). $\mathrm{t}_{\mathrm{EXP}}$ - linha contínua azul; $\mathrm{t}_{\mathrm{FIM}}$ linha tracejada azul; $t_{\mathrm{MORTE}}$ - linha tracejada vermelha; $t_{\mathrm{GPVE}, \max }$ - linha contínua preta; $\mathrm{t}_{\mathrm{GPV} \max }$, linha tracejada preta.

Figura 5.3. Comparação entre dados experimentais e as previsões do modelo 1a para o ensaio Ma-02, $\mathrm{pO}_{2}=5 \%$ (Quadro A.1, Anexo A). (linha contínua, previsões do modelo; símbolos, dados experimentais).

Figura 5.4. Comparação entre dados experimentais e as previsões do modelo 1a para o ensaio Ma-03, $\mathrm{pO}_{2}=30 \%$ (Quadro A.1, Anexo A). (linha contínua, previsões do modelo; símbolos, dados experimentais).

Figura 5.5. Comparação entre dados experimentais e as previsões do modelo $1 \mathrm{~b}$ para o ensaio Ma-02, $\mathrm{pO}_{2}=5 \%$ (Quadro A.1, Anexo A) (linha contínua, previsões do modelo; símbolos, dados experimentais).

Figura 5.6. Comparação entre dados experimentais e as previsões do modelo $1 \mathrm{~b}$ para o 
ensaio Ma-03, $\mathrm{pO}_{2}=5 \%$ (Quadro A.1, Anexo A) (linha contínua, previsões do modelo; símbolos, dados experimentais).

Figura 5.7. Comparação entre dados experimentais e as previsões do modelo $1 \mathrm{~b}$ para o ensaio Ma-04, $\mathrm{pO}_{2}=50 \%$ (Quadro A, 1 , Anexo A) (linha contínua, previsões do modelo; símbolos, dados experimentais).

Figura 5.8. Comparação entre dados experimentais e as previsões do modelo $1 \mathrm{~b}$ para o ensaio Ma-06, $\mathrm{pO}_{2}=80 \%$ (Quadro A.1, Anexo A) (linha contínua, previsões do modelo; símbolos, dados experimentais).

Figura 5.9. Influência do teor de oxigênio dissolvido na velocidade específica máxima de crescimento, Célula S2AcGPV2 para o conjunto de ensaios Ma-7 a Ma-10 (Quadro A.1, Anexo A).

Figura 5.10. Comparação entre dados experimentais e as previsões do modelo 2 para o ensaio Ma-07, Célula S2AcGPV2, $\mathrm{pO}_{2}=5 \%$ (Quadro A.1, Anexo A). (linha contínua, previsões do modelo; símbolos, dados experimentais).

Figura 5.11. Comparação entre dados experimentais e as previsões do modelo 2 para o ensaio Ma-08, célula S2AcGPV2. $\mathrm{pO}_{2}=50 \%$ (Quadro A.1, Anexo A). (linha contínua, previsões do modelo; símbolos, dados experimentais).

Figura 5.12. Comparação entre dados experimentais e as previsões do modelo 2 para o ensaio Ma-09, S2AcGPV2, $\mathrm{pO}_{2}=80 \%$ (Quadro A.1, Anexo A). (linha contínua, previsões do modelo; símbolos, dados experimentais).

Figura 5.13. Comparação entre dados experimentais e as previsões do modelo 2 para o ensaio Ma-10, S2AcGPV2, $\mathrm{pO}_{2}=30 \%$ (Quadro A.1, Anexo A). (linha contínua, previsões do modelo; símbolos, dados experimentais).

Figura 5.14. Comparação entre dados experimentais e as previsões do modelo 3 para o ensaio Ma-7, Célula S2AcGPV2, $\mathrm{pO}_{2}=5 \%$ (Quadro A.1, Anexo A). (linha contínua, previsões do modelo; símbolos, dados experimentais).

Figura 5.15. Comparação entre dados experimentais e as previsões do modelo 3 para o ensaio Ma-8, célula S2AcGPV2, $\mathrm{pO}_{2}=50 \%$ (Quadro A.1, Anexo A). (linha contínua, previsões do modelo; símbolos, dados experimentais).

Figura 5.16. Comparação entre dados experimentais e as previsões do modelo 3 para o ensaio Ma-9, S2AcGPV2, $\mathrm{pO}_{2}=80 \%$ (Quadro A.1. Anexo A). (linha contínua, previsões do modelo; símbolos, dados experimentais).

Figura 5.17. Comparação entre dados experimentais e as previsões do modelo 3 para o ensaio Ma-10, S2AcGPV2, $\mathrm{pO}_{2}=30 \%$ (Quadro A.1, Anexo A). (linha contínua, previsões do modelo; símbolos, dados experimentais).

Figura 5.18. Fator de correção $\mathrm{Fc}_{1}, \mu_{\mathrm{Xmax}, \mathrm{i}} / \max \left(\mu_{\mathrm{xmax}, \mathrm{i}}\right)$, em função da concentração de oxigênio dissolvido, $\mathrm{pO}_{2}$.

Figura 5.19. Fator de correção $\mathrm{Fc}_{2}, \mathrm{Y}_{\mathrm{X} / \mathrm{GLC}, \mathrm{i}} / \max \left(\mathrm{Y}_{\mathrm{X} / \mathrm{GLC}, \mathrm{i}}\right)$, em função da concentração de oxigênio dissolvido, $\mathrm{pO}_{2}$.

Figura 5.20. Fator de correção $\mathrm{Fc}_{3}, \mathrm{Y}_{\mathrm{GPV} / \mathrm{X}, \mathrm{i}} / \max \left(\mathrm{Y}_{\mathrm{GPV} / \mathrm{X}, \mathrm{i}}\right)$, em função da concentração de oxigênio dissolvido, $\mathrm{pO}_{2}$.

Figura 5.21. Fator de correção $\mathrm{Fc}_{4}, \mathrm{Y}_{\mathrm{GPV} / \mathrm{GLC}, \mathrm{i}} / \max \left(\mathrm{Y}_{\mathrm{GPV} / \mathrm{GLC}, \mathrm{i}}\right)$, em função da concentração de oxigênio dissolvido, $\mathrm{pO}_{2}$.

Figura 5.22. Fator de correção $\mathrm{Fc}_{5}, \mathrm{Y}_{\mathrm{NH} 4 / \mathrm{X}, \mathrm{i}} / \max \left(\mathrm{Y}_{\mathrm{NH} 4 / \mathrm{X}, \mathrm{i}}\right)$, em função da concentração de oxigênio dissolvido, $\mathrm{pO}_{2}$

Figura 5.23. Comparação entre dados experimentais e as previsões do modelo 4 para o ensaio Ma-07, Célula S2AcGPV2, $\mathrm{pO}_{2}=5 \%$ (Quadro A.1, Anexo A). (linha contínua, previsões do modelo; símbolos, dados experimentais).

Figura 5.24. Comparação entre dados experimentais e as previsões do modelo 4 para o ensaio Ma-8, célula S2AcGPV2, $\mathrm{pO}_{2}=50 \%$ (Quadro A.1, Anexo A). (linha contínua, 
previsões do modelo; símbolos, dados experimentais).

Figura 5.25. Comparação entre dados experimentais e as previsões do modelo 4 para o ensaio Ma-09, S2AcGPV2, $\mathrm{pO}_{2}=80 \%$ (Quadro A.1, Anexo A), (linha contínua, previsões do modelo, símbolos azuis, dados experimentais).

Figura 5.26. Comparação entre dados experimentais e as previsões do modelo 4 para o ensaio Ma-10, S2AcGPV2, $\mathrm{pO}_{2}=30 \%$ (Quadro A.1, Anexo A). (linha contínua, previsões do modelo; símbolos, dados experimentais).

Figura 5.27. Consumo de glutamina e glutamato no ensaio Ma-02, célula S2AcGPV2-

KTC100. A linha vertical indica o limiar de concentração de glutamina para início do consumo de glutamato.

Figura 5.28. Fator de conversão $\mathrm{Fc}_{6}, \mathrm{Y}_{\mathrm{X} / \mathrm{GLN}, \mathrm{i}} / \max \left(\mathrm{Y}_{\mathrm{X} / \mathrm{GLN}, \mathrm{i}}\right)$, em função da concentração de oxigênio dissolvido, $\mathrm{pO}_{2}$

Figura 5.29. Fator de conversão $\mathrm{Fc}_{7}, \mathrm{Y}_{\mathrm{X} / \mathrm{GLU}, \mathrm{i}} / \max \left(\mathrm{Y}_{\mathrm{X} / \mathrm{GLU}, \mathrm{i}}\right)$, em função da concentração de oxigênio dissolvido, $\mathrm{pO}_{2}$.

Figura 5.30. Fator de conversão $\mathrm{Fc}_{8}, \mathrm{Y}_{\mathrm{X} / \mathrm{GLN}, \mathrm{i}} / \max \left(\mathrm{Y}_{\mathrm{X} / \mathrm{GLN}, \mathrm{i}}\right)$, em função da concentração de oxigênio dissolvido, $\mathrm{pO}_{2}$.

Figura 5.31. Fator de conversão $\mathrm{Fc}_{9}, \mathrm{Y}_{\mathrm{X} / \mathrm{GLN}, \mathrm{i}} / \max \left(\mathrm{Y}_{\mathrm{X} / \mathrm{GLN}, \mathrm{i}}\right)$, em função da concentração de oxigênio dissolvido, $\mathrm{pO}_{2}$.

Figura 5.32. Comparação entre dados experimentais e as previsões do modelo 5 para o ensaio Ma-02, célula S2AcGPV2-KTC100, $\mathrm{pO}_{2}=5 \%$ (Quadro A.1, Anexo A). (linha contínua, previsões do modelo; símbolos , dados experimentais).

Figura 5.33. Comparação entre dados experimentais e as previsões do modelo 5 para o ensaio Ma-03, célula S2AcGPV2-KTC100, $\mathrm{pO}_{2}=30 \%$ (Quadro A.1, Anexo A). (linha contínua, previsões do modelo; símbolos, dados experimentais).

Figura 5.34. Evolução da concentração de glicose sob diferentes $\mathrm{GLC}_{0}$ (Ensaios Ma10, Ma-11, Ma-12 e Ma-14; Quadro A1, Anexo A). Linhas verticais indicam o final da fase exponencial em cada ensaio

Figura 5.35. Evolução da concentração de glutamina nos ensaios com diferentes $\mathrm{GLC}_{0}$ (Ensaios Ma-10, Ma-11, Ma-12 e Ma-14; Quadro A1, Anexo A). Linhas verticais, final da fase exponencial

Figura 5.36. Evolução da concentração de glicose nos ensaios com diferentes GLN $_{0}$ (Ensaios Ma-10, Ma-15, Ma-16 e Ma-17; Quadro A1, Anexo A). Linhas verticais, final da fase exponencial.

Figura 5.37. Evolução da concentração de glutamina nos ensaios com diferentes $\mathrm{GLN}_{0}$ (Ma-10, Ma-15, Ma-16 e Ma-17; Quadro A1, Anexo A). Linhas verticais, final da fase exponencial.

Figura 5.38. Evolução da concentração de $\mathrm{NH}_{4}{ }^{+}$. a) Ensaios com diferentes $\mathrm{GLC}_{0}$ (Ma-10, Ma-11, Ma-12 e Ma-14; Quadro A1, Anexo A); b) Ensaios com diferentes $\mathrm{GLN}_{0}$ (Ma-10, Ma-15, Ma-16 e Ma-17; Quadro A1, Anexo A). Linhas verticais, final da fase de crescimento exponencial.

Figura 5.39. Evolução na concentração de glutamato. a) Ensaios com diferentes GLC $_{0}$ (Ma-10, Ma-11, Ma-12 e Ma-14; Quadro A1, Anexo A); b) Ensaios com diferentes $\mathrm{GLN}_{0}$ (Ma-10, Ma-15, Ma-16 e Ma-17; Quadro A1, Anexo A). Linhas verticais, final da fase de crescimento exponencial.

Figura 5.40. Evolução da concentração de lactato. a) Ensaios com diferentes GLC $_{0}$ (Ma-10, Ma-11, Ma-12 e Ma-14; Quadro A1, Anexo A); b) Ensaios com diferentes GLN $_{0}$ (Ma-10, Ma-15, Ma-16 e Ma-17; Quadro A1, Anexo A). Linhas verticais, final da fase de crescimento exponencial.

Figura 5.41. Influência da concentração de $\mathrm{O}_{2}$ na velocidade especifica de crescimento $\left(\mu_{\mathrm{Xmax}}\right)$. Ensaios Ma-07 a Ma-10 (Quadro A1, Anexo A). 
Figura 5.42. Influência da concentração de $\mathrm{O}_{2}$ no fator $\mathrm{Y}_{\mathrm{X} / \mathrm{GLC}}$. Ensaios Ma-07 a Ma- 87 10 (Quadro A.1, Anexo A).

Figura 5.43. Influência da concentração de $\mathrm{O}_{2}$ no fator $\mathrm{Y}_{\mathrm{LAC} / \mathrm{GLC}}$. Ensaios Ma-07 a 87 Ma-10 (Quadro A.1, Anexo A).

Figura 5.44. Influência de $\mathrm{O}_{2}$ no fator $\mathrm{Y}_{\mathrm{ALAC} / \mathrm{GLC}}$. Ensaios Ma-07 a Ma-10 (Quadro A.1, Anexo A).

Figura 5.45. Influência de $\mathrm{O}_{2}$ no fator $\mathrm{Y}_{\mathrm{X} / \mathrm{GLN}}$. Ensaios Ma-07 a Ma-10 (Quadro A.1, 88 Anexo A).

Figura 5.46. Influência de $\mathrm{O}_{2}$ no fator $\mathrm{Y}_{\mathrm{NH} 4 / \mathrm{GLN}}$. Ensaios Ma-07 a Ma-10 (Quadro A.1, 89 Anexo A).

Figura 5.47. Influência de $\mathrm{O} 2$ no fator $\mathrm{Y}_{\mathrm{NH} 4 / \mathrm{GLN}}$. Ensaios Ma-07 a Ma-10 (Quadro A.1, Anexo A).

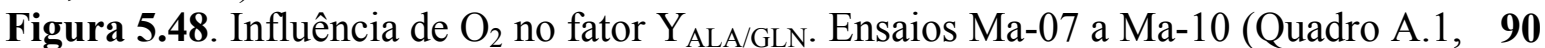
Anexo A).

Figura 5.49. Influência de $\mathrm{O}_{2}$ no fator $\mathrm{Y}_{\mathrm{GPV} / \mathrm{X}}$. Ensaios Ma-07 a Ma-10 (Quadro A.1, 90 Anexo A).

Figura 5.50. Influência de $\mathrm{O}_{2}$ no fator $\mathrm{Y}_{\mathrm{GPV} / \mathrm{GLC}}$. Ensaios Ma-07 a Ma-10 (Quadro A.1, 91 Anexo A).

Figura 5.51. Influência da concentração inicial de GLC na velocidade específica de crescimento, $\left(\mu_{\mathrm{Xmax}}\right)$. Ensaios Ma-10, Ma-11, Ma-12 e Ma-14. (Quadro A.1, Anexo A). Figura 5.52. Influência da concentração inicial de GLC no fator de conversão $Y_{X / G L C}$. Ensaios Ma-10, Ma-11,

Figura 5.53. Influência da concentração inicial de GLC no fator $Y_{L A C / G L C}$. Ensaios Ma-10, Ma-11, Ma-12 e Ma-14. (Quadro A.1, Anexo A).

Figura 5.54. Influência da concentração inicial de GLC no fator $Y_{\mathrm{ALA} / \mathrm{GLC}}$. Ensaios Ma-10, Ma-11, Ma-12 e Ma-14. (Quadro A.1, Anexo A).

Figura 5.55. Influência da concentração inicial de GLC no fator $Y_{X / G L N}$. Ensaios Ma10, Ma-11, Ma-12 e Ma-14. (Quadro A.1, Anexo A).

Figura 5.56. Influência da concentração inicial de GLC no fator $\mathrm{Y}_{\mathrm{NH} 4 / \mathrm{X}}$. Ensaios Ma10, Ma-11, Ma-12 e Ma-14. (Quadro A.1, Anexo A).

Figura 5.57. Influência da concentração inicial de GLC no fator $\mathrm{Y}_{\mathrm{NH} / \mathrm{GLN}}$. Ensaios Ma-10, Ma-11, Ma-12 e Ma-14. (Quadro A.1, Anexo A).

Figura 5.58. Influência da concentração inicial de GLC no fator $Y_{A L A / G L N}$. Ensaios Ma-10, Ma-11, Ma-12 e Ma-14. (Quadro A.1, Anexo A).

Figura 5.59. Influência da concentração inicial de GLC no fator $Y_{G P V / X}$.Ensaios Ma10, Ma-11, Ma-12 e Ma-14. (Quadro A.1, Anexo A).

Figura 5.60. Influência da concentração inicial de GLC no fator $Y_{\mathrm{GPV} / \mathrm{GLC}}$. Ensaios Ma10, Ma-11, Ma-12 e Ma-14. (Quadro A.1, Anexo A).

Figura 5.61. Influência da concentração inicial de GLN na velocidade específica máxima de crescimento. ( Xmax). Ensaios Ma-10, Ma-15, Ma-16 e Ma-17. (Quadro A.1, Anexo A)

Figura 5.62. Influência da concentração inicial de GLN no fator de conversão $Y_{X / G L C}$. Ensaios Ma-10, Ma-15, Ma-16 e Ma-17. (Quadro A.1, Anexo A)

Figura 5.63. Influência da concentração inicial de GLN no fator $Y_{L A C / G L C}$. Ensaios Ma-10, Ma-15, Ma-16 e Ma-17. (Quadro A.1, Anexo A)

Figura 5.64. Influência da concentração inicial de GLN no fator $Y_{A L A C / G L C}$. Ensaios Ma-10, Ma-15, Ma-16 e Ma-17. (Quadro A.1, Anexo A)

Figura 5.65. Influência da concentração inicial de GLN no fator $Y_{X / G L C}$. Ensaios Ma10, Ma-15, Ma-16 e Ma-17. (Quadro A.1, Anexo A).

Figura 5.66. Influência da concentração inicial de GLN no fator $\mathrm{Y}_{\mathrm{NH} 4 / \mathrm{X}}$. Ensaios Ma- 
10, Ma-15, Ma-16 e Ma-17. (Quadro A.1, Anexo A).

Figura 5.67. Influência da concentração inicial de GLN no fator $\mathrm{Y}_{\mathrm{NH} / \mathrm{GLN}}$. Ensaios Ma-10, Ma-15, Ma-16 e Ma-17. (Quadro A.1, Anexo A).

Figura 5.68. Influência da concentração inicial de GLN no fator $Y_{A L A / G L N}$. Ensaios Ma-10, Ma-15, Ma-16 e Ma-17. (Quadro A.1, Anexo A).

Figura 5.69. Influência da concentração inicial de GLN no fator $Y_{\mathrm{GPV} / \mathrm{X}}$. Ensaios Ma10, Ma-15, Ma-16 e Ma-17. (Quadro A.1, Anexo A).

Figura 5.70. Influência da concentração inicial de GLN no fator $Y_{G P V / G L C}$. Ensaios Ma-10, Ma-15, Ma-16 e Ma-17. (Quadro A.1, Anexo A).

Figura 5.71. Evolução da concentração de GLC (a) e GLN (b) durante os cultivos com diferentes concentrações iniciais de GLC (Ensaios Ma-10, Ma-11, Ma-12 e Ma-14). (Quadro A1, Anexo A). Linhas verticais, final do crescimento.

Figura 5.72. Evolução das concentrações de GLC (a) e de GLN (b) nos ensaios com diferentes GLN $_{0}$ (Ensaios Ma-10, Ma-15, Ma-16 e Ma-17). (Quadro A1, Anexo A). Linhas verticais, final do crescimento.

Figura 5.73. Evolução da concentração de $\mathrm{NH}_{4}{ }^{+}$em função da variação de: a) concentração inicial de GLC (Ensaios Ma-10, Ma-11, Ma-12, Ma-14); b) concentração inicial de GLN (Ensaios Ma-10, Ma-15, Ma-16 e Ma-17). (Quadro A1, Anexo A). Linhas verticais, final do crescimento.

Figura 5.74. Evolução da concentração de $\mathrm{NH}_{4}{ }^{+}$e GLC (b) em função da variação da concentração inicial de GLC: a) $\mathrm{GLC}_{0}=10 \mathrm{~g} / \mathrm{L}$ (Ensaio Ma-10); b) $\mathrm{GLC}_{0}=1,0 \mathrm{~g} / \mathrm{L}$ (Ensaio Ma-11) (Quadro A.1, Anexo A).

Figura 5.75. Evolução da concentração de $\mathrm{NH}_{4}{ }^{+}$e $\mathrm{GLC}$ em função da variação da concentração inicial de GLC: a) $\mathrm{GLC}_{0}=5,0 \mathrm{~g} / \mathrm{L}$ (Ensaio Ma-12); b) $\mathrm{GLC}_{0}=15,0 \mathrm{~g} / \mathrm{L}$ (Ensaio Ma-14) (Quadro A.1, Anexo A).

Figura 5.76 Evolução da concentração de ALA; a) Efeito de diferentes GLN $_{0}$ (Ensaios Ma-10, Ma-15, Ma-16, Ma-17; Quadro A.1, Anexo A); b) Efeito de diferentes GLC $_{0}$ (Ensaios Ma-10, Ma-11, Ma-12, Ma-14; Quadro A.1, Anexo A).

Figura 5.77. Evolução da concentração de GLC e a viabilidade celular: a) $\mathrm{GLC}_{0}=$ 10,0 g/L (Ensaio Ma-10, Quadro A.1, Anexo A); b) $\mathrm{GLC}_{0}=5,0 \mathrm{~g} / \mathrm{L}$ (Ensaio Ma-1; Quadro A.1, Anexo A). Linha vertical, esgotamento de glicose.

Figura 5.78. Evolução da concentração de LAC e da viabilidade celular no ensaio Ma$14\left(\mathrm{GLC}_{0}=14 \mathrm{~g} / \mathrm{L}\right)$. Linha vertical, início de morte celular.

Figura 5.79. Evolução da concentração de GLN e da viabilidade celular no ensaio Ma$14\left(\mathrm{GLC}_{0}=14 \mathrm{~g} / \mathrm{L}\right)$. Linha vertical; início de morte celular

Figura 5.80. Evolução da concentração de $\mathrm{NH}_{4}{ }^{+}$e da viabilidade celular no ensaio Ma-14 $\left(\mathrm{GLC}_{0}=14 \mathrm{~g} / \mathrm{L}\right)$. Linha vertical; início de morte celular.

Figura 5.81. Evolução da concentração de GLN e da viabilidade celular: a) Ensaio Ma-15 $\left.\left(\mathrm{GLN}_{0}=0,5 \mathrm{~g} / \mathrm{L}\right) ; \mathrm{b}\right)$ Ma-16 $\left(\mathrm{GLN}_{0}=1,75 \mathrm{~g} / \mathrm{L}\right)$. Linha vertical, início de morte celular.

Figura 5.82. Evolução da concentração de GLC e da viabilidade celular no ensaio Ma$16\left(\mathrm{GLN}_{0}=1,75 \mathrm{~g} / \mathrm{L}\right)$. Linha vertical, início de morte celular

Figura 5.83. Evolução da concentração de GLC e da viabilidade celular no ensaio Ma$15\left(\mathrm{GLN}_{0}=0,6 \mathrm{~g} / \mathrm{L}\right)$. Linha vertical, início de morte celular

Figura 5.84. Evolução da concentração de $\mathrm{NH}_{4}{ }^{+}$e da viabilidade celular no ensaio Ma-15 $\left(\mathrm{GLN}_{0}=0,6 \mathrm{~g} / \mathrm{L}\right)$. Linha vertical, início de morte celular.

Figura 5.85. Evolução da concentração de LAC e da viabilidade celular no ensaio Ma$15\left(\mathrm{GLN}_{0}=0,6 \mathrm{~g} / \mathrm{L}\right)$. Linha vertical, início de morte celular. Linha vertical, início de morte celular

Figura 5.86. Evolução da concentração de GPV e do teor $G_{P V}$ no ensaio Ma-10

100

101

101

102

102

104

104

105

105

106

107

107

108

108

109

109

110

110

111 
$\left(\mathrm{GLC}_{0}=10,0 \mathrm{~g} / \mathrm{L}\right)$. Linhas verticais: $\mathrm{t}_{\mathrm{GPV} \max }$ - linha tracejada; $\mathrm{t}_{\mathrm{GPVEmax}}-$ linha contínua. Figura 5.87 Evolução da concentração de CYS e GLN no ensaio Ma-10 $\left(\mathrm{GLC}_{0}=10,0\right.$ $\mathrm{g} / \mathrm{L})$. Linhas verticais: $\mathrm{t}_{\mathrm{GPV} \max }$ - linha tracejada; $\mathrm{t}_{\mathrm{GPVEmax}}$ - linha contínua.

Figura 5.88. Evolução da concentração de GPV e GPVe no ensaio Ma-11 ( $\mathrm{GLC}_{0}=1,0$ $\mathrm{g} / \mathrm{L})$. Linhas verticais: $\mathrm{t}_{\mathrm{GPV} \max }$ - linha tracejada; $\mathrm{t}_{\mathrm{GPVEmax}}$ - linha contínua.

Figura 5.89. Evolução da concentração de CYS e GLN no ensaio Ma-11 ( $\mathrm{GLC}_{0}=1,0$ $\mathrm{g} / \mathrm{L}$ ). Linhas verticais: $\mathrm{t}_{\mathrm{GPV} \max }$ - linha tracejada; $\mathrm{t}_{\mathrm{GPVEmax}}$ - linha contínua.

Figura 5.90. Evolução da concentração de GPV e GPVe no ensaio Ma-15 $\left(\mathrm{GLN}_{0}=\right.$ $0,6 \mathrm{~g} / \mathrm{L})$. Linhas verticais: $t_{\mathrm{GPV} \max }$ - linha tracejada; $t_{\mathrm{GPVEmax}}$ - linha contínua.

Figura 5.91. Evolução da concentração de CYS e GLN no ensaio Ma-15 $\left(\mathrm{GLN}_{0}=\right.$ $0,6 \mathrm{~g} / \mathrm{L})$. Linhas verticais: $t_{\mathrm{GPV} \max }$ - linha tracejada; $t_{\mathrm{GPVEmax}}$ - linha contínua.

Figura 5.92. Evolução da concentração de GPV e GPV $\mathrm{E}_{\mathrm{E}}$ no ensaio Ma-17 $\left(\mathrm{GLN}_{0}=\right.$ 7,0g/L). Linhas verticais: $t_{\mathrm{GPV} \max }$ - linha tracejada; $\mathrm{t}_{\mathrm{GPVEmax}}$ - linha contínua.

Figura 5.93. Evolução da concentração de CYS e GLN no ensaio Ma-17 $\left(\mathrm{GLN}_{0}=\right.$ 7,0 g/L). Linhas verticais: $\mathrm{t}_{\mathrm{GPV} \max }$ - linha tracejada; $\mathrm{t}_{\mathrm{GPVEmax}}$ - linha contínua.

Figura 5.94. Evolução da concentração de GPV e GPVe no ensaio Ma-07 $\left(\mathrm{GLC}_{0}=\right.$ $\left.10,0 \mathrm{~g} / \mathrm{L}, \mathrm{GLN}_{0}=3,5 \mathrm{~g} / \mathrm{L}\right)$. Linhas verticais: $\mathrm{t}_{\mathrm{GPV} \max }$ - linha tracejada; $\mathrm{t}_{\mathrm{GPVEmax}}$ - linha contínua.

Figura 5.95. Evolução da concentração de CYS e GLN no ensaio Ma-07 ( $\mathrm{GLC}_{0}=10,0$ $\left.\mathrm{g} / \mathrm{L}, \mathrm{GLN}_{0}=3,5 \mathrm{~g} / \mathrm{L}\right)$. Linhas verticais: $\mathrm{t}_{\mathrm{GPV} \max }$ - linha tracejada; $\mathrm{t}_{\mathrm{GPVEmax}}-$ linha contínua.

Figura 5.96. Diagrama de blocos da dinâmica do processo (subrotina FCN) com os IF lógicos para os diferentes blocos identificados no modelo

Figura 5.97 Comparação entre dados experimentais e as previsões do modelo 6a para o ensaio Ma-07, célula S2AcGPV2, $\mathrm{pO}_{2}=5 \%$ (Quadro A.1, Anexo A). (linha contínua, previsões do modelo, símbolos; dados experimentais).

Figura 5.98 Comparação entre dados experimentais e as previsões do modelo 6a para o ensaio Ma-08, célula S2AcGPV2, $\mathrm{pO}_{2}=50 \%$ (Quadro A.1, Anexo A) (linha contínua, previsões do modelo; símbolos, dados experimentais).

Figura 5.99. Comparação entre dados experimentais e as previsões do modelo 6a para o ensaio Ma-09 célula S2AcGPV2, $\mathrm{pO}_{2}=80 \%$ (Quadro A.1, Anexo A). (linha contínua, previsões do modelo; símbolos, dados experimentais).

Figura 5.100. Comparação entre dados experimentais e as previsões do modelo $6 \mathrm{a}$ para o ensaio Ma-10 célula S2AcGPV2, pO2 = 30\% (Quadro A.1, Anexo A). (linha contínua, previsões do modelo; símbolos, dados experimentais).

Figura 5.101. Comparação entre dados experimentais e as previsões do modelo 6a para o ensaio Ma-11 célula S2AcGPV2, $\mathrm{GLC}_{0}=1,0 \mathrm{~g} / \mathrm{L}$ (Quadro A.1, Anexo A). (linha contínua, previsões do modelo; símbolos, dados experimentais).

Figura 5.102. Comparação entre dados experimentais e as previsões do modelo $6 \mathrm{a}$ para o ensaio Ma-12, célula S2AcGPV2, $\mathrm{GLC}_{0}=5,0 \mathrm{~g} / \mathrm{L}$. (Quadro A.1, Anexo A). (linha contínua, previsões do modelo; símbolos, dados experimentais).

Figura 5.103. Comparação entre dados experimentais e as previsões do modelo 6a para o ensaio Ma-15 célula S2AcGPV2, $\mathrm{GLN}_{0}=0,6 \mathrm{~g} / \mathrm{L}$ (Quadro A.1, Anexo A). (linha contínua, previsões do modelo; símbolos, dados experimentais).

Figura 5.104. Comparação entre dados experimentais e as previsões do modelo $6 \mathrm{a}$ para o ensaio Ma-16, célula S2AcGPV2, $\mathrm{GLN}_{0}=1,75 \mathrm{~g} / \mathrm{L}$ (Quadro A.1, Anexo A). (linha contínua, previsões do modelo; símbolos, dados experimentais).

Figura 5.105. Comparação entre dados experimentais e as previsões do modelo $6 \mathrm{~b}$ para o ensaio Ma-07, célula S2AcGPV2, $\mathrm{pO}_{2}=5 \%$ (Quadro A.1, Anexo A). (linha contínua, previsões do modelo; símbolos, dados experimentais). 
Figura 5.106. Comparação entre dados experimentais e as previsões do modelo $6 \mathrm{~b}$ para o ensaio Ma-08, célula S2AcGPV2, $\mathrm{pO}_{2}=50 \%$ (Quadro A.1, Anexo A). (linha contínua, previsões do modelo; símbolos, dados experimentais).

Figura 5.107. Comparação entre dados experimentais e as previsões do modelo $6 \mathrm{~b}$ para o ensaio Ma-09 célula S2AcGPV2, $\mathrm{pO}_{2}=80 \%$ (Quadro A.1, Anexo A). (linha contínua, previsões do modelo; símbolos, dados experimentais).

Figura 5.108. Comparação entre dados experimentais e as previsões do modelo $6 \mathrm{~b}$ para o ensaio Ma-10 célula S2AcGPV2, pO2 = 30\% (Quadro A.1, Anexo A). (linha contínua, previsões do modelo; símbolos, dados experimentais).

Figura 5.109. Comparação entre dados experimentais e as previsões do modelo 6 para o ensaio Ma-11 célula S2AcGPV2, GLC $_{0}=1,0 \mathrm{~g} / \mathrm{L}$ (Quadro A.1, Anexo A). (linha contínua, previsões do modelo; símbolos, dados experimentais).

Figura 5.110. Comparação entre dados experimentais e as previsões do modelo 6 para o ensaio Ma-12, célula S2AcGPV2, $\mathrm{GLC}_{0}=5,0 \mathrm{~g} / \mathrm{L}$ (Quadro A.1, Anexo A). (linha contínua, previsões do modelo; símbolos, dados experimentais).

Figura 5.111. Comparação entre dados experimentais e as previsões do modelo $6 \mathrm{~b}$ para o ensaio Ma-15 célula S2AcGPV2, $\mathrm{GLN}_{0}=0,6 \mathrm{~g} / \mathrm{L}$ (Quadro A.1, Anexo A). (linha contínua, previsões do modelo; símbolos, dados experimentais).

Figura 5.112. Comparação entre dados experimentais e as previsões do modelo $6 \mathrm{~b}$ para o ensaio Ma-16 célula S2AcGPV2, $\mathrm{GLN}_{0}=1,75 \mathrm{~g} / \mathrm{L}$ (Quadro A.1, Anexo A). (linha contínua, previsões do modelo; símbolos, dados experimentais).

Figura 5.113. Comparação entre dados experimentais e as previsões do modelo $6 \mathrm{c}$ para o ensaio Ma-07, célula S2AcGPV2, $\mathrm{pO}_{2}=5 \%$ (Quadro A.1, Anexo A). (linha contínua, previsões do modelo; símbolos, dados experimentais).

Figura 5.114. Comparação entre dados experimentais e as previsões do modelo $6 \mathrm{c}$ para o ensaio Ma-08, célula S2AcGPV2, $\mathrm{pO}_{2}=50 \%$ (Quadro A.1, Anexo A). (linha contínua, previsões do modelo; símbolos, dados experimentais).

Figura 5.115. Comparação entre dados experimentais e as previsões do modelo $6 \mathrm{c}$ para o ensaio Ma-09, célula S2AcGPV2, $\mathrm{pO}_{2}=80 \%$ (Quadro A.1, Anexo A). (linha contínua, previsões do modelo; símbolos, dados experimentais).

Figura 5.116. Comparação entre dados experimentais e as previsões do modelo 6c para o ensaio Ma-10, célula S2AcGPV2, pO2 = 30\% (Quadro A.1, Anexo A). (linha contínua, previsões do modelo, símbolos, dados experimentais).

Figura 5.117. Comparação entre dados experimentais e as previsões do modelo $6 \mathrm{c}$ para o ensaio Ma-11, célula S2AcGPV2, $\mathrm{GLC}_{0}=1,0 \mathrm{~g} / \mathrm{L}$ (Quadro A1, Anexo A). (linha contínua, previsões do modelo; símbolos, dados experimentais).

Figura 5.118. Comparação entre dados experimentais e as previsões do modelo $6 \mathrm{c}$ para o ensaio Ma-12, célula S2AcGPV2, $\mathrm{GLC}_{0}=5,0 \mathrm{~g} / \mathrm{L}$ (Quadro A.1, Anexo A). (linha contínua, previsões do modelo; símbolos, dados experimentais).

Figura 5.119. Comparação entre dados experimentais e as previsões do modelo $6 \mathrm{c}$ para o ensaio Ma-16, célula S2AcGPV2, $\mathrm{GLN}_{0}=1,75 \mathrm{~g} / \mathrm{L}$ (Quadro A.1, Anexo A). (linha contínua, previsões do modelo; símbolos, dados experim 


\section{LISTA DE ABREVIATURAS E SIGLAS}

\begin{tabular}{|c|c|}
\hline ALA & Concentração de alanina \\
\hline AlaTA & Alanina aminotransferase \\
\hline Aprox. & Aproximadamente \\
\hline ASP & Asparagina \\
\hline AspTA & Aspartato aminotransferase \\
\hline ATP & Adenosina trifosfato \\
\hline CAMPATH TM & anticorpo monoclonal kappa IgG1 \\
\hline $\mathrm{CD} 18 \mathrm{~F}$ & Fator do Crescimento do Tipo Insulina \\
\hline CG & Complexo de Golgi \\
\hline $\mathrm{CHO}$ & Células imortalizadas do ovário de hamster chinês \\
\hline CYS & Cistina \\
\hline ELISA & Enzyme-Linked Immuno Sorbent Assay \\
\hline EMm & Enzima málica mitocondrial \\
\hline EPO & Eritropoetina \\
\hline $\mathrm{Fc}$ & Fator de correção para mudança de metabolismo \\
\hline $\mathrm{G} 3 \mathrm{~F}$ & Gliceraldeído 3-fosfato \\
\hline GDH & Glutamato desidrogenase \\
\hline GLC & Concentração de glicose \\
\hline GLN & Concentração de glutamina \\
\hline GOGAT & Glutamina 2-oxoglutarato amido transferase \\
\hline GPV & Glicoproteína $\mathrm{G}$ do vírus da raiva \\
\hline $\mathrm{GPV}_{\mathrm{E}}$ & Teor celular de GPV \\
\hline HPLC & Cromatografia líquida de alta pressão \\
\hline IGF-I & Hormônio do crescimento humano \\
\hline IPL-41 & Meio de cultura para células de inseto \\
\hline $\mathrm{k}_{\mathrm{dALA}}$ & Constante de decomposição de alanina \\
\hline $\mathrm{k}_{\mathrm{dGPV}}$ & Constante de decomposição de GPV \\
\hline $\mathrm{k}_{\mathrm{GLC}}$ & Constante de saturação da glicose no crescimento \\
\hline $\mathrm{k}_{\mathrm{GLN}}$ & Constante de saturação da glutamina no crescimento \\
\hline $\mathrm{k}_{\mathrm{iNH} 4}$ & Constante de inibição do amônio no crescimento \\
\hline $\mathrm{k}_{\mathrm{L}} \mathrm{a}-$ & Coeficiente volumétrico de transferência de $\mathrm{O}_{2}$ \\
\hline $\mathrm{k}_{\mathrm{m}}$ & Constante de morte \\
\hline $\mathrm{k}_{\mathrm{mGLC}}$ & Constante de inibição por glicose na morte celular \\
\hline $\mathrm{k}_{\mathrm{mGLN}}$ & Constante de inibição por glutamina na morte celular \\
\hline $\mathrm{k}_{\mathrm{mNH} 4}$ & Constante de saturação do amônio no crescimento \\
\hline $\mathrm{k}_{\mathrm{O} 2}$ & Constante de saturação do oxigênio no crescimento \\
\hline $\mathrm{k}_{\mathrm{SinGLN}}$ & Constante de síntese de glutamina \\
\hline LAC & Concentração de lactato \\
\hline $\mathrm{m}_{\mathrm{S}}$ & constante de manutenção celular para glicose \\
\hline NADH & Nicotinamida adenina dinucleotídeo fosfato, forma reduzida \\
\hline NADPH & Nicotinamida adenina dinucleotídeo fosfato \\
\hline PBS & Solução-tampão de fosfato \\
\hline $\mathrm{pO}_{2}$ & Concentração de oxigênio dissolvido \\
\hline PAG & Enzima glutaminase ativada por fosfato \\
\hline $\mathrm{PC}$ & Piruvato carboxilase \\
\hline PDH & Piruvato desidrogenase \\
\hline PEPCK & Fosfoenolpiruvato carboxiquinase \\
\hline PPP & Via das pentoses \\
\hline
\end{tabular}




\section{Serina} expressão da glicoproteína do vírus da raiva

Meio TC100 suplementado

Ciclo dos ácidos tricarboxílicos

Viabilidade celular

$\mathrm{Xd}$

Constante de inibição por oxigênio

Concentração de células mortas

$\mathrm{Xv}$

$\mathrm{Y}_{\mathrm{ALA} / \mathrm{GLC}}$

$\mathrm{Y}_{\mathrm{ALA} / \mathrm{GLN}}$

$\mathrm{Y}_{\mathrm{GLNGLU}}$

$\mathrm{Y}_{\mathrm{GPV} / \mathrm{GLC}}$

$\mathrm{Y}_{\mathrm{NH} 4 \mathrm{ALA}}$

$\mathrm{Y}_{\mathrm{NH} 4 / \mathrm{GLN}}$

$\mathrm{Y}_{\mathrm{NH} 4 / \mathrm{GLU}}$

$\mathrm{Y}_{\mathrm{X} / \mathrm{GLC}}$

$\mathrm{Y}_{\mathrm{X} / \mathrm{GLN}}$

$\mathrm{Y}_{\mathrm{X} / \mathrm{GLU}}$

$\alpha_{\mathrm{NH} 4}$

$\alpha_{\mathrm{GPV}}$

Fator de conversão de amônio a células

$\beta_{\mathrm{NH} 4}$ Fator de conversão de GPV a células

$\mu_{\mathrm{X}, \max }$

Constante de proporcionalidade para síntese de alanina

$\Pi_{\mathrm{GPV}}$

Concentração de células viáveis

Fator de conversão de glicose a alanina

Fator de conversão de glutamina a alanina

Fator de conversão de glutamina a glutamato

Fator de conversão de glicose a GPV

Fator de alanina a amônio

Fator de conversão de glutamina a amônio

Fator de conversão de glutamato a amônio

Fator de conversão de glicose a célula

Fator de conversão de glutamina a células

Fator de conversão de glutamato a células

Produtividade em GPV 


\section{SUMÁRIO}

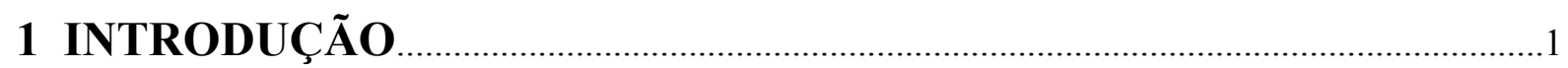

2 OBJETIVOS

3 REVISÃO BIBLIOGRÁFICA ………………….............................................

3.1. Expressão de proteínas heterólogas por micro-organismos e células animais .5

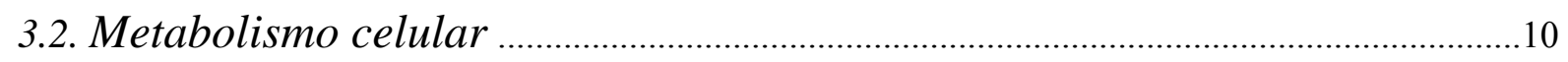

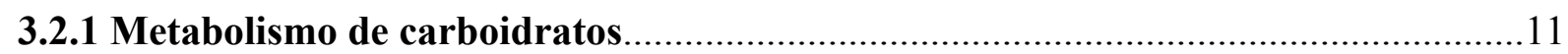

3.2.2 Metabolismo de aminoácidos...........................................................................................

3.2.3 Formação de lactato …………………………………………………………....18

3.2.4 Formação de amônio ..............................................................................................2

3.3 Cinética do crescimento, da morte celular e da formação de produtos em células animais.

3.3.1 Influência de $\mathbf{O}_{2} \mathbf{e} \mathbf{p H}$.....................................................................................24

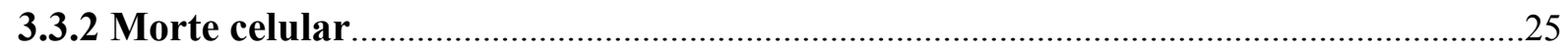

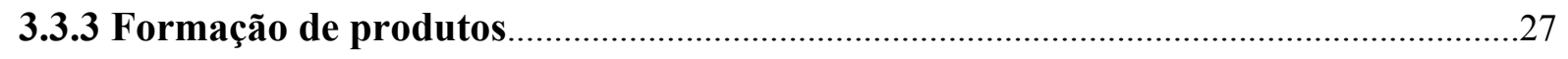

3.4 Biorreatores utilizados para o cultivo de células animais.....................................28

3.4.1 Biorreatores Homogêneos ..........................................................................................30

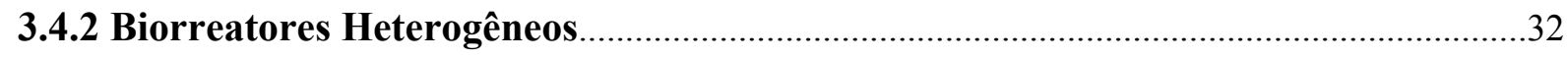

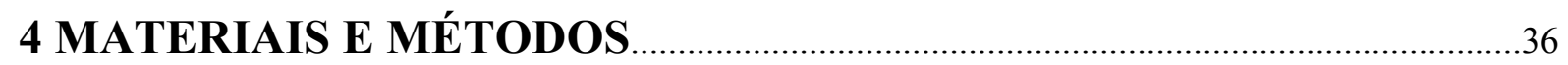

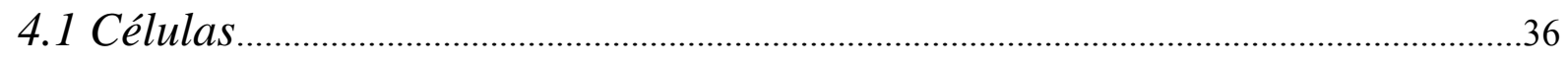

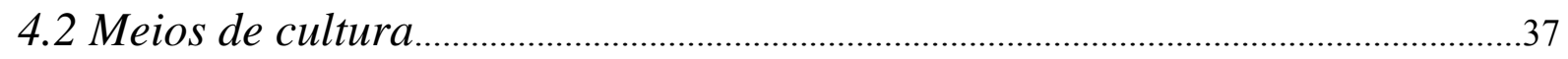

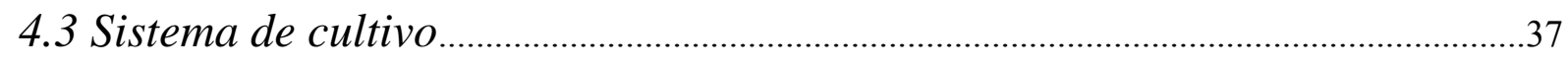

4.4 Métodos analíticos.....................................................................................................

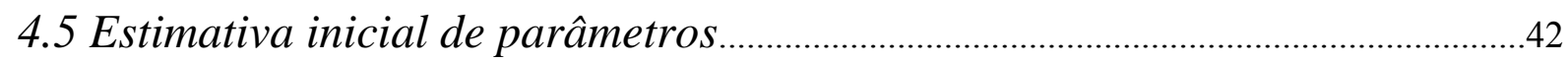

4.5.1 Determinação preliminar da velocidade específica de crescimento $\left(\mu_{\max }\right)$, duração da fase lag $\left(t_{\text {lag }}\right)$ e duração da fase exponencial $\left(t_{\text {exp }}\right)$.........................................................42

4.5.2 Determinação do tempo transcorrido até o final do crescimento celular $\left(t_{\text {fim }}\right)$ e do tempo transcorrido até início de morte celular ( $\left.t_{\text {morte }}\right)$ .43 
4.5.3 Determinação do tempo para que ocorra redução no teor de GPV por $10^{7}$ células, $\mathrm{t}_{\mathrm{GPV} \_ \text {Emax }}\left(\mu \mathrm{g} / \mathbf{1 0}^{7} \mathrm{cel}\right)$, e do tempo transcorrido até se atingir a concentração máxima de GPV, $\mathbf{t}_{\text {GPV_max }},(\mu \mathrm{g} / \mathrm{mL})$..

4.5.4 Determinação preliminar dos fatores de conversão/formação, $Y$. 44

4.6 Métodos numéricos. 44

4.6.1 Função objetivo (FO). .45

4.6.2 Avaliação do ajuste.. 45

5 RESULTADOS OBTIDOS E DISCUSSÃO. 48

5.1 Modelos preliminares .50

5.1.1 Modelo 1. Hipóteses consideradas na modelagem .53

5.1.2 Modelo 2. Influência do Oxigênio sobre o crescimento. 61

5.1.3 Modelo 3. Influência do Oxigênio sobre o crescimento. .64

5.2 Modelos que incorporam a influência do oxigênio dissolvido no metabolismo via fatores de conversão .66

5.2.1 Modelo 4. Influência do Oxigênio sobre o crescimento e metabolismo. 67

5.2.2 Modelo 5. Consumo de glutamato. .74

5.3 Modelos que incorporam a mudança de metabolismo em função das condições do cultivo (GLC, GLN e $\mathrm{pO}_{2}$ ) via fatores de conversão. .81

5.3.1. Análise de Fenômenos (Ensaios Ma-07 a Ma-17).

5.3.2 Modelo 6. Inclusão de fatores para incorporar a influência de $\mathrm{pO}_{2}$, GLC e GLN.

5.3.3 Modelo 6a Ajuste do modelo para a etapa inicial de crescimento (Bloco 1).

5.3.4 Modelo 6b. Ajuste do modelo em todas as fases do processo (Bloco 1, Bloco 2, Bloco 3 e Bloco 4).

5.3.5 Modelo 6c. Ajuste do modelo $6 \mathrm{em}$ todas as fases do processo (Bloco 1, Bloco 2, Bloco 3 e Bloco 4), sem o ensaio Ma-15.

6 CONCLUSÕES. 148

REFERÊNCIAS

ANEXO A - TABELAS DE MEIOS E ENSAIOS. 166 


\section{INTRODUÇÃO}

A expressão de genes em células animais permite a produção de proteínas em grande escala e com características qualitativas aceitáveis tanto para estudos de estrutura/função destas proteínas, como também com finalidades imunológicas e funcionais. Esse desenvolvimento tem gerado grandes avanços na biologia molecular e na medicina preventiva. Um dos aspectos desse desenvolvimento relaciona-se com a capacidade imunizante dessas proteínas e, consequentemente, o seu uso na preparação de vacinas. A incorporação da técnica do DNA recombinante constitui uma etapa inovadora na produção de vacinas e leva à eliminação de riscos de contaminação por resíduos virais e reações indesejáveis, além de permitir o aumento da imunogenecidade com menores custos de produção.

Entre as células animais que têm sido usadas para este fim, encontram-se as células de mamíferos, que embora tenham capacidade de incorporar, manter, expressar constitutivamente e processar convenientemente genes heterólogos, exigem condições de cultura delicadas e dispendiosas, em laboratório e em escala de produção. Células de insetos, como as células de Spodoptera frugiperda ( $\mathrm{Sf} 9$ ), têm sido utilizadas principalmente por permitirem custos de produção menores, sistemas de cultivo mais simples e com maior capacidade de expressão, e, ainda, alta produtividade de proteínas recombinantes (CHA et al., 2005). Contudo essas células apresentam alguns inconvenientes, como por exemplo, a alta sensibilidade das células ao cisalhamento e limitação nos perfis de glicosilação, quando se tem como referência o comportamento das células de mamíferos. Além disso, a expressão de proteína por células de Spodoptera frugiperda (Sf9) têm utilizado genes heterólogos de báculovírus que apresentam o inconveniente de se constituir num sistema de expressão gênica transiente e não permanente e o fato de o pico de expressão ocorrer quando as células já entraram em estágio de morte ocasionado pela infecção viral. A expressão genética estável de proteínas heterólogas em células de dípteros (GALESI, 2007), células embrionárias de dípteros como a linhagem Drosophila melanogaster Schneider 2 (S2), vêm sendo utilizadas para a produção de proteínas recombinantes como anticorpos (KIRKPATRICK et al., 1995), enzimas (GIBSON et al., 1993; BANKS, et al., 2003), inibidores tumorais (VALLE et al., 2001; JEON et al., 2003), fatores de crescimento (LEE et al., 2000;) e antígenos virais (DEMLet al., 1999a, DEMLet al., 1999b, BACHMANN et al., 2004). 
Neste estudo utilizaram-se células de dípteros (Drosophila melanogaster), células S2, nas quais um sistemas de expressão foi estabelecido com sucesso (YOKOMIZO et al., 2007) para a expressão da glicoproteína de membrana do vírus rábico (GPV).

A GPV é o constituinte do vírus da raiva responsável pela resposta imune protetora durante vacinação de animais e humanos. As vacinas contra raiva atualmente em produção e uso são constituídas por partículas virais inativadas ou atenuadas e são produzidas por infecção viral de células de mamíferos.

Além da aplicação da GPV recombinante produzida como vacina, a sua expressão em células S2 também poderá ter uma importante aplicação na produção de componente de kits diagnósticos.

Potencialmente este sistema de expressão de GPV associa as vantagens observadas em células de mamíferos (expressão constitutiva/indutiva) com as vantagens observadas em células de insetos (facilidade de cultivo e baixo custo), sendo assim altamente desejável, sobretudo quando se visa à produção de um imunobiológico como a glicoproteína $\mathrm{G}$ do vírus da raiva (GPV).

Em geral, afirma-se que para produtos de alto valor agregado, como no caso de produtos originados de culturas de células de mamíferos, os custos operacionais do processo são uma parte relativamente pequena dos custos finais do produto devido às necessidades de investimento em pesquisa, desenvolvimento e aprovação do produto. Também em decorrência de características de mercado como a essencialidade do produto e do pequeno número de produtores e os preços praticados, avalia-se que qualquer processo de obtenção seja viável. Somente quando o produto perde essas características, vale dizer, quando a ênfase não é mais a velocidade da oferta do produto ao mercado, é que a forma de operar o processo de obtenção passa a ser vista como fator destacado para assegurar a viabilidade comercial do produto (ROYCE, 1993).

O caso em estudo, embora seja uma alternativa inovadora para a produção de vacina, não é um produto de alto valor agregado, tal como certas proteínas terapêuticas (citocinas, enzimas, fatores de crescimento e antitumorais, por exemplo). Assim, a viabilidade do processo depende de sua eficiente condução. 
A modelagem matemática caracteriza-se por organizar as informações experimentais, prever diferentes situações reais através de simulações, diminuindo o número de ensaios experimentais e constitui a base para otimização do processo.

Quando se examina a evolução dos reatores químicos nos anos 50 e 60, especialmente o aumento da sua capacidade de produção de forma segura, destaca-se (FROMENT; BICHOFF, 1979) o papel importante desempenhado pela modelagem matemática no desenvolvimento desses equipamentos.

A otimização matemática de um equipamento ou processo só é possível quando existe modelo matemático validado e, ainda, uma função objetivo pertinente que define um critério de desempenho desejável para o processo. A determinação da trajetória ótima, resultado imediato da otimização em sistemas operando em modo descontínuo alimentado, ou do ponto ótimo de operação, em sistemas operando em modo contínuo, permite não só obter maiores produtividades de célula e/ou do produto, como assegurar a qualidade do produto, imprescindível nestes processos. Permite também a sua repetibilidade, além de fornecer todas as informações necessárias para o controle do processo.

Contudo a modelagem matemática e o controle de processos biotecnológicos esbarram em três características específicas desses sistemas: a falta de medidas, especialmente as medidas em linhas, a variabilidade (não-reprodutibilidade) de dados e a complexidade cinética dos processos.

Em resumo, a modelagem matemática do processo representa um esforço para identificar, sistematizar e quantificar os principais fenômenos que afetam o crescimento celular e a síntese do produto de interesse e, dessa maneira, racionalizar o processo e otimizar a sua produção, contribuindo para alcançar a sua viabilidade técnico-econômica.

Este estudo faz parte do projeto financiado pela FAPESP "Expressão de genes heterólogos em células de dípteros: biologia molecular e engenharia de processos" que tem como objetivo geral à proposição de um bioprocesso para produção da GPV com células de inseto S2 geneticamente modificadas. Este trabalho insere-se em um subgrupo de trabalho que desenvolveu dois projetos: o estudo cinético de células de Drosophila melanogaster transfectadas para a produção da glicoproteína da raiva em biorreatores (AGUIAR, 2010) e este estudo, modelagem matemática desse processo, a partir dos dados obtidos no primeiro projeto que foi planejado e desenvolvido para essa finalidade. 


\section{OBJETIVOS}

O objetivo deste trabalho é realizar a modelagem matemática do crescimento de células de Drosophila melanogaster Schneider 2, células S2, transfectadas com o gene da glicoproteína do vírus da raiva, GPV, e estabelecer a dinâmica de crescimento e de formação dessa glicoproteína. Esta modelagem consiste na proposição de um modelo matemático fenomenológico constituído por um conjunto de equações diferenciais que descreva os principais fenômenos do processo e que permita prever a evolução dos principais componentes do sistema de cultivo (células, substratos e produtos) ao longo do tempo.

Neste trabalho são consideraras as seguintes variáveis de estado para descrever a dinâmica do processo:

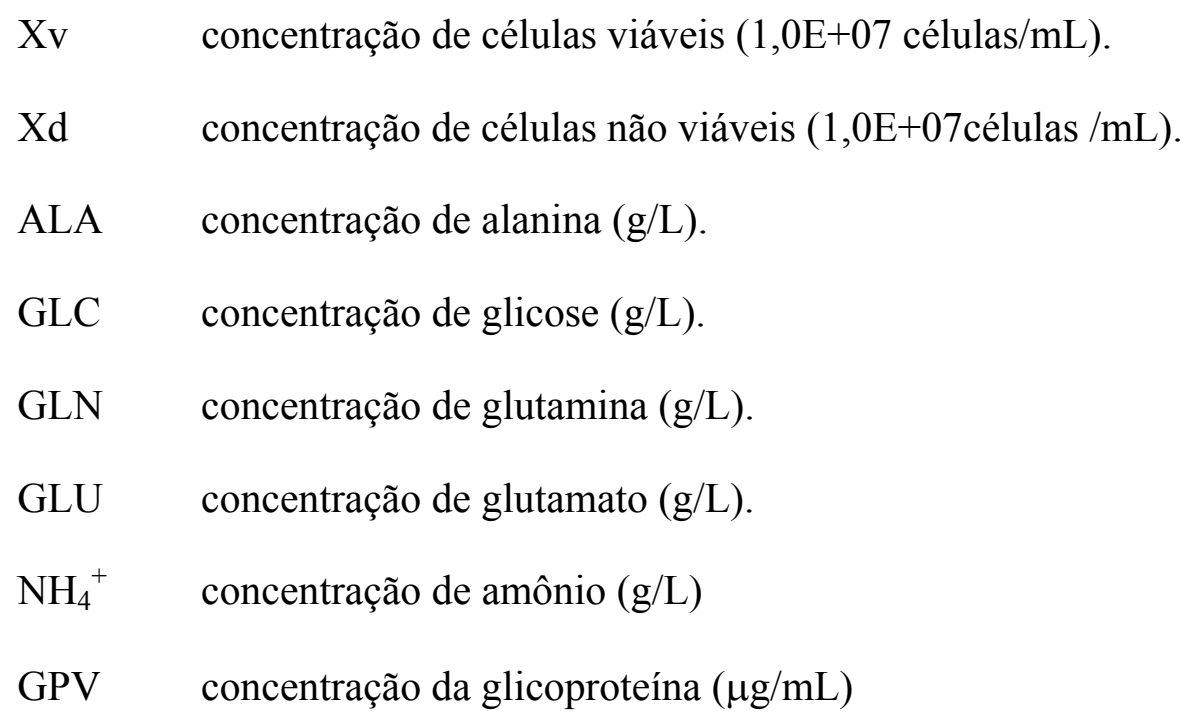

Ao longo do trabalho foram avaliados os resultados dos ajustes do modelo aos dados experimentais e, em função da qualidade dos ajustes obtidos, foram realizadas novas hipóteses de trabalho para modificar o modelo proposto até se alcançar um modelo validado estatisticamente aos dados experimentais. Os dados utilizados foram obtidos por pesquisadores do projeto temático apoiado pela FAPESP, "Expressão de genes heterólogos em células de dípteros: biologia molecular e engenharia de processos" e estão indicados no Quadro 1 do Anexo A. 


\section{REVISÃO BIBLIOGRÁFICA}

\subsection{Expressão de proteínas heterólogas por micro-organismos e células animais.}

A expressão de proteínas heterólogas por micro-organismos e células animais utilizando recombinação genética é um ponto fundamental no atual desenvolvimento da biotecnologia. Essa expressão permite a produção de proteínas bioativas a partir de meios relativamente baratos ao invés de utilizar extrações custosas, com uso intensivo de mão de obra e que resultam em produtos de qualidade variável. A seleção de um sistema de expressão recombinante ótimo é fundamental para definir um processo de produção de proteínas eficaz e viável. Um sistema de expressão ótimo depende, portanto, da sua produtividade, da bioatividade da proteína obtida, do uso previsto para a proteína e das suas características físico-químicas, juntamente com o custo, conveniência e segurança do próprio sistema de expressão. As células hospedeiras utilizadas para a expressão de genes heterólogos tanto podem ser procarióticas ou eucarióticas, sendo que ambas têm vantagens e desvantagens inerentes. Algumas recentes revisões de literatura publicadas por Demain e Vaishnav (2009), Yin et al. (2007), Ikonomou, Schneider e Agathos (2003), bem como os trabalhos de Mirzaei et al.(2009), Shishido et al. (2009), Liu et al. (2008), Cha et al. (2005) ajudam a formam um painel dos sistemas em uso, suas potencialidades e limitações e que estão sistematizados na Tabela 3.1.

Até o momento, Escherichia coli tem sido amplamente utilizada para expressão de proteínas heterólogas devido à suas altas velocidades de crescimento e por apresentar custo relativamente baixo de produção. Como sistema de expressão procariótico, E. coli, não pode realizar as modificações pós-traducionais (por exemplo, glicosilação, acilação de ácidos graxos, fosforilação e formação de ligações dissulfídicas) que muitas vezes são necessárias para o enovelamento adequado das proteínas e pelas suas características funcionais de interesse. Obviamente, essas alterações podem afetar a bioatividade da proteína. A utilização da lise celular para liberação dessas proteínas citoplasmáticas pode resultar na liberação de ácidos nucléicos, endotoxinas ou lipopolissacarídeos que podem denaturar a proteína e limitar as aplicações médicas ou biológicas dos produtos expressos. As proteínas heterólogas obtidas em E. coli são amplamente utilizadas para fins laboratoriais e preparativos devido ao seu baixo custo e conveniência. Muitas proteínas podem ser produzidas rotineiramente e secretadas no meio, atingindo concentrações de gramas por litros. Alguns dos exemplos mais 
destacados de alta expressão de proteínas secretadas incluem fatores de crescimento semelhante à insulina I (IGF-I), a produção do anti-CD18 e a síntese de fosfatase alcalina (YIN et al., 2007).

Saccharomyces cerevisiae tem sido modificada para expressar diferentes genes heterólogos nos últimos 25 anos (HITZEMAN et al., 1981). Por ser uma alternativa econômica e segura, S. cerevisiae tem sido utilizado para produzir medicamentos como a vacina contra hepatite B e pode ser uma alternativa para a produção de vacina para hantavírus (ANTONIUKAS et al., 2006). Além das vantagens de simplicidade do cultivo, rápido crescimento e de baixo custo, que são semelhantes aos de E. coli, o sistema permite que algumas proteínas sintetizadas intracelularmente sejam secretadas para o meio extracelular. Como um eucarioto unicelular, leveduras podem produzir proteínas recombinantes solúveis, enoveladas e submetidas a modificações pós-traducionais essenciais às suas funções terapêuticas.

O uso de células de inseto para produção de proteínas iniciou-se nos anos 80 do século passado para a produção de inseticidas virais, produto que oferecia o atrativo de ser ambientalmente amigável e seguro. Desde então, o uso dessas células vem aumentando como decorrência do desenvolvimento de vetores de báculovírus e linhagens de células de inseto com a capacidade de expressar altos níveis de proteínas heterólogas que, quando produzidas nessas células, sofrem modificações pós-transducionais e enovelamento apropriados para o seu uso como imunobiológicos. Muitos genes heterólogos podem ser eficientemente expressos por esses sistemas de expressão (BEVS-Baculovirus expression vector system) mediante infecção dos insetos ou de linhagens de células insetos (HUYNH e ZIELER, 1999, ZENG et al.,1996). Uma das características mais atraentes do sistema células de inseto é a maior facilidade para ampliação de escala, por ser um sistema que utiliza células em suspensão. É um sistema que oferece segurança, pois os vetores de clonagem são preparados a partir do báculovirus que não infectam vertebrados ou plantas. O sistema não é limitado pela dimensão da proteína, podendo expressar proteínas de qualquer tamanho e, ainda, permite a expressão simultânea de múltiplos genes. Este sistema, no entanto, tem algumas deficiências. Por exemplo, a lise celular não permite que o gene heterólogo seja expresso de forma contínua. Cada ciclo de síntese das proteínas de interesse exige a infecção de novas células de inseto. Assim, este sistema é inferior ao sistema com procarióticos e de levedura, em termos de sua capacidade contínua de produção. Além disso, células de inseto diferem das células de mamíferos nos padrões de glicosilação, por exemplo, nos comprimentos de oligossacarídeos 
formados e no teor de manose de modo que a bioatividade e imunogenicidade dos produtos de expressão com inseto são um pouco diferentes do produto natural. Essas limitações têm sido superadas pelo estabelecimento de linhagens celulares que expressam constitutivamente genes de mamíferos. Essa abordagem tem levado a células de inseto transgênicas com crescimento normal que podem produzir glicoproteínas recombinantes humanizadas. As principais linhagens de células de inseto disponíveis para cultivo industrial são as derivadas de Spodopera frugiperda, conhecidas como Sf9 e Sf21, células-ovo da lagarta Trichoplusia nii, conhecidas como células Hight Five ${ }^{\mathrm{TM}}$ (BTI -Tn-BI-4) e células derivadas de Drosophila melanogaster D-S2 ou S2 (CASTRO et al., 1999; MONTOR e SOGAYAR, 2003; LÉO et al., 2008). Células de inseto derivadas de Drosophila melanogaster, células Schneider S2, têm sido utilizadas como sistema de expressão de um plasmídio de transfecção. Neste sistema de expressão não-lítica do plasmídio, um alto número de cópias de vetores plasmídicos recombinantes são inseridos no genoma da célula hospedeira com a vantagem de que as proteínas heterólogas são estavelmente expressas sem destruição das células produtoras da proteína. Dessa forma, estes sistemas são considerados como excelente ferramenta para a produção glicoproteínas recombinantes.

Sistemas de expressão com células de mamíferos têm várias vantagens sobre os outros sistemas apresentados anteriormente tanto na síntese como no processamento e na secreção de proteínas glicosiladas, especialmente de proteínas eucarióticas. Culturas celulares de células de mamíferos para produção de proteínas recombinantes são particularmente úteis, pois as proteínas frequentemente apresentam enovelamento e glicosilação adequados, eliminando a necessidade de sua renaturação. Essas células eucarióticas também são úteis para a adição de cadeias de ácidos graxos e fosforilação da tirosina, treonina e de grupos hidroxil da serina. A utilização de cultura de células de mamíferos, principalmente de células imortalizadas do ovário de hamster chinês (CHO), ganhou grande impulso a partir do desenvolvimento para a produção de eritropoetina (EPO) e do ativador plasminogênico de tecidos tissular (tPA), na década de 1980, uma vez que essas proteínas altamente glicosiladas não poderiam ser produzidas em sistemas microbianos. As células $\mathrm{CHO}$ constituem o sistema de expressão preferido para a produção de proteínas recombinantes. Em 1997, as vendas de bioterapêuticos produzidos por células de mamíferos atingiram 3,25 bilhões de dólares, enquanto que a produção de bioterapêuticos por E. coli atingiu a 2,85 bilhões (DEMAIN; VAISHNAV, 2009). Em 2006, a produção de proteínas terapêuticas obtidas com sistemas de células de mamíferos chegou a 20 bilhões de dólares e espera-se uma expansão dessa produção em 
função do interesse por anticorpos terapêuticos e vacinas virais produzidas por células de mamíferos (GRIFFIN et al., 2007). Os sistemas de células de mamíferos apresentam, contudo, alguns inconvenientes. Eles apresentam baixa expressão e os processos de produção são caros. Embora com custos relativamente elevados do sistema, tecnologia mais complexa e a possibilidade de contaminação por vírus animais, aspectos que tendem a limitar a sua utilização em larga escala de produção, o sistema de expressão com células de mamíferos é frequentemente utilizado para expressar muitas proteínas heterólogas incluindo proteínas de estruturas virais e peptídeos bioativos para análises funcionais específicas. A Tabela 3.1 sistematiza as principais características dos sistemas apresentados.

A proteína a ser produzida pelo sistema de expressão adotado neste trabalho é a glicoproteína do vírus rábico (GPV). Ela é uma glicoproteína trimérica $(3 \times 65 \mathrm{kDa})$ de membrana que forma espículas. A proteína é composta por 505 aminoácidos, contendo 2 segmentos hidrofóbicos típicos de sua natureza transmembranária. Sua sequência de aminoácidos indica que ela tem três pontos aceptores de oligossacarídeos (N-glicosilação) dos quais apenas um ou dois são efetivamente glicosilados (GAUDIN, 1997). A Figura 3.1 ilustra o vírion da raiva e o posicionamento da glicoproteína na sua estrutura. No vírion são encontradas 1200 moléculas de GPV formando 400 espículas que se projetam na superfície do capsídeo viral e são responsáveis pela ligação do vírus aos receptores da célula hospedeira.

Em células de Drosophila melanogaster Schneider 2 (S2) contendo o gene de GPV, a proteína projeta-se na superfície das células na mesma conformação que no envelope viral. A síntese da GPV pela célula hospedeira começa pela tradução ribossomal, associada ao retículo endoplasmático rugoso (RER), sendo movida pelo retículo até o Complexo de Golgi (CG) e nesse processo ocorre a formação de trímeros e a glicosilação inicial da proteína. A GPV é transportada para o Complexo de Golgi (CG) através de vesículas transportadoras, onde ocorre a hidrólise parcial da fração glicídica da proteína e a adição de novos açúcares, processo denominado glicosilação terminal e que é responsável por parte da especificidade da proteína, pelo destino da GPV e conclui a moldagem da proteína tornando-a estruturalmente e funcionalmente completa. A GPV sofre também uma acetilação durante seu transporte para o CG e é palmitoilada em uma cisteína situada ao lado do carbono terminal da sua região de transmembranal (GAUDIN et al., 1992). 
Tabela 3.1 Caracterização de sistemas de expressão em uso.

\begin{tabular}{|c|c|c|c|c|c|c|c|c|c|c|c|c|c|}
\hline \multirow[t]{2}{*}{ Sistema } & \multirow[t]{2}{*}{$\begin{array}{l}\text { Cresci- } \\
\text { mento }\end{array}$} & \multirow{2}{*}{$\begin{array}{c}\text { Custo } \\
\text { de pro- } \\
\text { dução }\end{array}$} & \multirow{2}{*}{$\begin{array}{c}\text { Nível } \\
\text { expres- } \\
\text { são }\end{array}$} & \multirow{2}{*}{$\begin{array}{l}\text { Funciona- } \\
\text { lidade das } \\
\text { proteínas }\end{array}$} & \multirow{2}{*}{$\begin{array}{c}\text { Disponibili- } \\
\text { dade dos } \\
\text { sistemas de } \\
\text { expressão }\end{array}$} & \multirow[t]{2}{*}{$\begin{array}{c}\text { Pirogê- } \\
\text { nio }\end{array}$} & \multirow[t]{2}{*}{ Excreção } & \multicolumn{6}{|c|}{ Modificações pós-tradução } \\
\hline & & & & & & & & $\begin{array}{l}\text { N-glicosi- } \\
\text { lação }\end{array}$ & $\begin{array}{l}\text { O-glicosi- } \\
\text { lação }\end{array}$ & $\begin{array}{l}\text { Fosfori- } \\
\text { lação }\end{array}$ & $\begin{array}{l}\text { Aceti- } \\
\text { lação }\end{array}$ & Acilação & $\begin{array}{c}\gamma \text {-carboxi- } \\
\text { lação }\end{array}$ \\
\hline E. coli & $\begin{array}{l}\text { Rápido } \\
\mathrm{t}_{\mathrm{g}}=30 \mathrm{~min}\end{array}$ & Baixo & Alto & Pobre & Muito boa & Possível & Pobre & Nenhuma & Não & Não & Não & Não & Não \\
\hline Levedura & $\begin{array}{l}\text { Rápido } \\
\mathrm{t}_{\mathrm{g}}=90 \mathrm{~min}\end{array}$ & Baixo & Alto & Boa & Boa & Não & Muito boa & $\begin{array}{l}\text { Alta em } \\
\text { manose }\end{array}$ & Sim & Sim & Sim & Sim & Não \\
\hline $\begin{array}{l}\text { Cél. de } \\
\text { inseto }\end{array}$ & $\begin{array}{l}\text { Lento } \\
\mathrm{t}_{\mathrm{g}}=18- \\
24 \mathrm{~h}\end{array}$ & Alto & $\begin{array}{l}\text { Muito } \\
\text { Alto }\end{array}$ & Muito boa & Razoável & Não & Muito boa & $\begin{array}{l}\text { Simples, } \\
\text { sem ácido } \\
\text { siálico }\end{array}$ & Sim & Sim & Sim & Sim & Não \\
\hline $\begin{array}{l}\text { Cél. de } \\
\text { mamífero }\end{array}$ & $\begin{array}{l}\text { Lento } \\
\mathrm{t}_{\mathrm{g}}=24 \mathrm{~h}\end{array}$ & Alto & $\begin{array}{l}\text { Muito } \\
\text { Baixo }\end{array}$ & Muito boa & Razoável & Não & Excelente & Sim & Sim & Sim & Sim & Sim & Sim \\
\hline
\end{tabular}

FONTE: baseado em Yin et al. (2009) e Cha et al. (2005) 

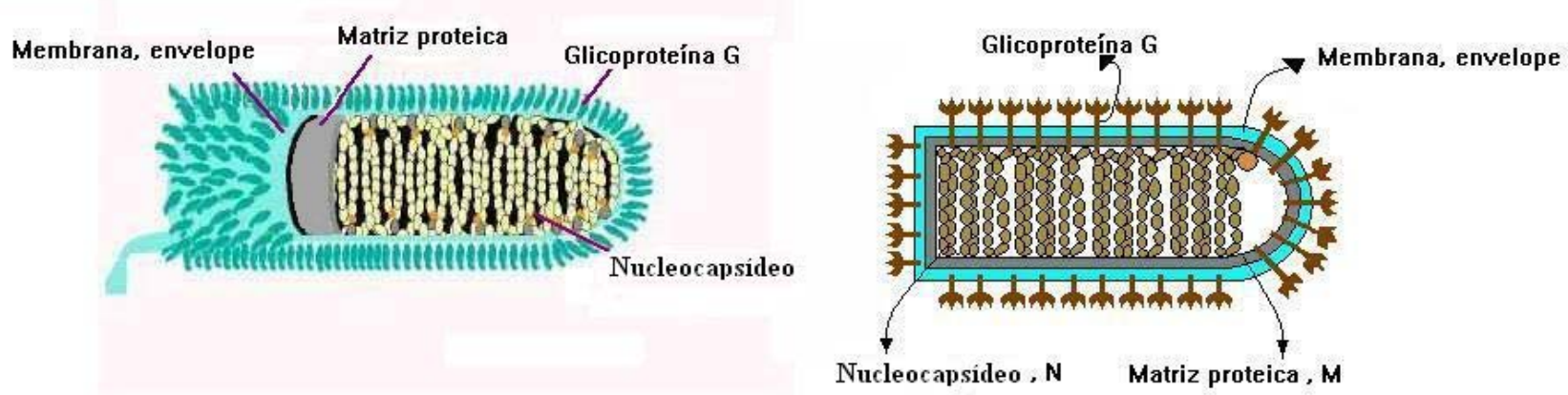

Figura 3.1. Representação do vírion da raiva e do posicionamento da glicoproteína na sua estrutura. FONTE: Hammons e Narciso (2005)

\subsection{Metabolismo celular}

Inicialmente, deve-se destacar que existem poucos estudos específicos sobre o metabolismo de células de Drosophila melanogaster sejam elas selvagens ou recombinantes, células S2 ou rS2. Geralmente, os estudos de metabolismo de células de inseto focam mais especificamente células de Spodoptera frugiperda (Sf9) e Trichoplusia ni (Tn) (FERRANCE; GOEL; ATAAI, 1993; DREWS; PAALME; VILU, 1995; ÖHMAN; LJUNGGREN; HAGGSTROM, 1995; RHIEL; MITCHELLLOGEAN; MURHAMMER, 1997; DOVERSKOG et al., 1997; DOVERSKOG; HAN; HÄGGSTRÖM, 1998; DREWS et al., 2000; DOVERSKOG et al., 2000; BENSLIMANE et al., 2005; BERNAL et al., 2009).

Resultados típicos do metabolismo celular de células recombinantes de Drosophila melanogaster expressando a glicoproteína do vírus da raiva (GPV), células rS2, (SWIECH, 2007; GALESI et al., 2008; BATISTA et al., 2008) indicam que essas células, assim como a maioria das células animais, utiliza glicose (GLC) e glutamina (GLN) como principais fontes de carbono e nitrogênio para suprimir as necessidades nutricionais de seu catabolismo e anabolismo celular. Contudo, os estudos indicam um padrão de formação de metabólitos distinto do comumente observado para células Sf9, Trichoplusia ni (Tn) e células de mamíferos (BOVO et al., 2008; SWIECH et al., 2008; GALESI et al., 2008; BATISTA et al., 2008, 2009a, b) e sugerem para as células S2 um padrão intermediário entre as células de inseto como Sf9 e as células de mamíferos (ÖHMAN; LJUNGGREN; HÄGGSTRÖM, 1995; DOVERSKOG; LJUNGGREN; ÖHMAN, 1997; DREWS et al., 2000; BENSLIMANE et al., 2005; AMABLE; BUTLER, 2008). Células Sf9 cultivadas em excesso de GLC, GLN e oxigênio dissolvido não acumulam lactato ou amônio (ÖHMAN; LJUNGGREN; 
HÄGGSTRÖM, 1995; DOVERSKOG; LJUNGGREN; ÖHMAN, 1997; DREWS et al., 2000). Contudo, algumas linhagens de células Tn, especialmente a Tn-5 (High 5), apresentam um padrão metabólico muito similar ao de células de mamíferos, caracterizado pelo acúmulo de lactato e $\mathrm{NH}_{4}{ }^{+}$em altos níveis (RHIEL; MITCHELL-LOGEAN; MURHAMMER, 1997; BENSLIMANE et al., 2005; SUGIURA; AMANN, 1996). É precisamente devido a esse padrão distinto de formação de lactato e amônio que é possível caracterizar o comportamento de linhagens celulares S2 e rS2 como intermediárias entre células de mamíferos e células de inseto Sf9.

\subsubsection{Metabolismo de carboidratos}

Em células S2, assim como nas células de mamíferos, a glicose é a principal fonte de carbono e a principal fonte de energia. O seu catabolismo ocorre pela via glicolítica e pelo ciclo dos ácidos tricarboxílicos (TCA). Ambas as rotas catabólicas fornecem também precursores e produtos intermediários para as reações de biossíntese. Duas outras vias metabólicas importantes para a geração de produtos intermediários para a biossíntese são a via das pentoses (PPP) e a glutaminólise.

Assim como em outras linhagens de células animais, glicose é normalmente consumida até sua exaustão, representando o principal substrato no cultivo de células S2. A glicose fornece energia e esqueleto carbônico para a obtenção de componentes celulares e a falta desse substrato geralmente resulta em limitação no crescimento celular (BOVO et al., 2008; GALESI et al., 2008; SWIECH et al., 2008). O esgotamento de glicose também tem sido relatado como causa de perda de viabilidade celular (BOVO et al., 2008; BATISTA et al., 2009a).

Em estudos publicados utilizando células S2, GLC é somente esgotada ao final da fase estacionária quando outros componentes do meio podem estar limitando o crescimento celular. Em culturas de S2 e Sf9 em meio IPL-41 suplementado, observa-se esgotamento de GLC somente para células S2 (BATISTA et al., 2009a, b). Esse resultado sugere um fluxo mais intenso de GLC pela via glicolítica em linhagens celulares de dípteros em comparação com linhagens de lepidópteros.

Exceto em estudos com meio de cultura TC-100 (BOVO et al., 2008), no qual a concentração inicial de GLC é baixa (aproximadamente, $1.0 \mathrm{~g} / \mathrm{L}$ ), todos os outros meios utilizados em cultura de células de inseto e indicados na Quadro A.1, Anexo A, mostram condição de 
excesso de GLC que resulta em altas velocidades específicas de crescimento (VALLE et al., 2001; SWIECH et al., 2007; GALESI et al., 2008; BATISTA et al., 2008, 2009a).

Estudos com células Sf9 mostram que os carboidratos também são a principal fonte de carbono, sendo assimilados pelas células por transporte facilitado e metabolizados principalmente pela via glicolítica (BHATIA et al., 1997). Usando substratos marcados e técnicas analíticas precisas (Nuclear Magnetic Ressonance), Drews et al. (2000) esclareceram a alta flexibilidade metabólica encontrada em células Sf9. Resumidamente, o piruvato gerado na glicólise pode desempenhar varias funções participando em várias reações: a) pode ser um agente de ligação entre a glicólise e o ciclo dos ácidos tricarboxílicos (TCA), participando, dessa forma, do catabolismo celular; b) pode ser componente intermediário na síntese de alguns aminoácidos, incluindo a glutamina que, sob condições especiais, pode ser formada e liberada no meio de cultura; c) pode ser um aceptor de $\mathrm{NH}_{4}{ }^{+}$, formando alanina (ALA), num processo de detoxificação, e, ainda; d) pode ser um aceptor de elétrons em etapas anaeróbias, para re-oxidar o excesso da coenzima NADH produzida na glicólise e não transportada à mitocôndria por meio do NADH shunt. Essa função leva à produção de glicerol, etanol ou lactato. As principais vias metabólicas apontadas e sua interligação estão indicadas na Figura 3.2 .

Drews et al. (2000) mostram que, em havendo limitação por glicose, a glutamina é utilizada como fonte de carbono em células Sf9. Destaque-se, ainda, que a produção de alanina é também uma forma de se fazer a interligação entre a via glicolítica e o ciclo dos ácidos tricarboxílicos, pois como já afirmado, o piruvato, resultante da transformação da glicose, pode tanto ser dirigido ao ciclo TCA, como reagir com glutamato para formar alanina, via a reação catalisada pela alanina transaminase (ALTAMIRANO et al., 2007).

$$
\text { piruvato }+ \text { glutamato } \leftrightarrow \text { alanina }+\alpha-\text { cetoglutarato }
$$

$\mathrm{Na}$ ausência de glicose, a alanina pode se transformar em piruvato e glutamato (reação reversa) (BÉDARD et al., 1993).

Oxigênio molecular $\left(\mathrm{O}_{2}\right)$ é essencial no metabolismo aeróbico das células, sendo utilizado como aceptor final de elétrons na cadeia transportadora de elétrons. Em condições de limitação de $\mathrm{O}_{2}$, a co-enzima NADH (nicotinamida adenina dinucleotídeo fosfato - forma reduzida) produzida durante a oxidação dos substratos não pode ser regenerada, assim, as células utilizam outras formas para re-equilibrar o seu potencial redox, regenerando, por 
exemplo, NADH do citosol, pela conversão de piruvato a lactato (Figura 3.2, enzima 2). Com excesso de substrato, as células animais demonstram certa incapacidade de regular o consumo de substratos, ativando vias metabólicas energeticamente menos eficientes e, ainda, liberando sub-produtos (lactato $\mathrm{e} \mathrm{NH}_{4}^{+}$) que são potencialmente tóxicos ao crescimento celular (AMABLE; BUTLER, 2008).

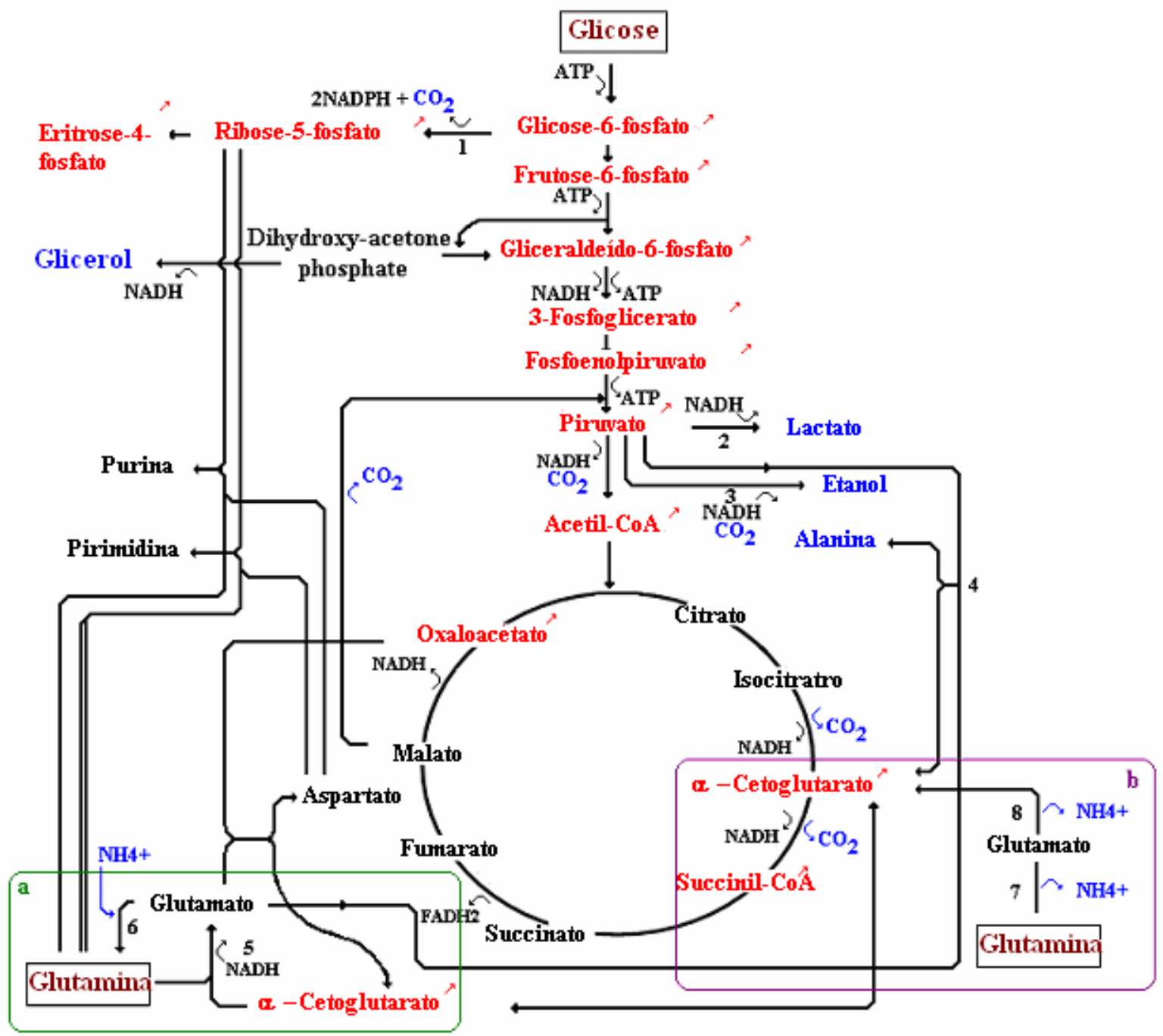

Figura 3.2. Esquema simplificado das principais vias metabólicas identificadas em células de inseto Os principais substratos com molduras em preto; principais subprodutos em azul; intermediários do anabolismo em vermelho (as setas indicam que os produtos são encaminhados a outras vias metabólicas); moldura em verde (a) indica vias metabólicas preferenciais quando há excesso de glicose; e moldura roxo (b) indica vias metabólicas preferenciais com limitação de glicose. As enzimas mais relevantes estão indicadas: 1- DHAP deidrogenase, 2Lactatodeidrogenase, 3- Piruvato decarboxilase e etanol desidrogenase, 4- Glutamato-piruvato transaminase, 5Glutamato sintase (NADH-GOGAT), 6- Glutamina sintetase, 7- Glutaminase, 8- Glutamato desidrogenase. FONTE: baseada em Drews et al. (2000) e Ikonomou, Schneider e Agathos (2003).

Como já mencionado, células Tn-5 apresentam um metabolismo similar ao de linhagens de células de mamíferos, caracterizado por alto nível de produção de LAC, como resposta da cultura às condições de excesso de GLC (RHIEL; MITCHELL-LOGEAN; MURHAMMER, 1997; BENSLIMANE et al., 2005; SUGIURA; AMANN, 1996). Belimane et al. (2005) 
também notaram uma maior proporção do fluxo de GLC a $\mathrm{CO}_{2}$ pelo ciclo dos ácidos tricarboxílicos $(2,7 \%)$ para células $\mathrm{Sf} 9$, em comparação com a proporção encontrada para esse ciclo nas células Tn-5 células $(0.6 \%)$, o que pode explicar a maior produção de LAC em células Tn. Em relação à proporção do fluxo de GLC pela via das pentoses (PPP), os mesmos autores mostraram que células Sf9 têm uma partição inferior do fluxo de carbono por essa via (14\%), quando se compara com o fluxo da mesma via em células Tn (16\%).

Amable e Butler (2008) reviram o metabolismo de células de mamíferos. Segundo esses autores, GLC é transportada às células com ajuda de uma proteína localizada na membrana celular, num processo classificado como transporte facilitado, saturável, bi-direcional e proporcional ao gradiente de concentração. Na glicólise, a enzima hexoquinase catalisa a fosforilação da GLC a glucose-6P, assegurando baixas concentrações de GLC no citoplasma e, consequentemente, permitindo um gradiente máximo e transporte de GLC do meio ambiente para as células.

O fator de rendimento energético obtido no consumo de glicose depende da via metabólica envolvida: a glicólise gera 2 moles de ATP (adenosina trifosfato) por mol de GLC, e no TCA mais de 25 moles de ATP por mol de GLC metabolizada. Já foi indicado como a glicose pode seguir várias vias metabólicas distintas e constata-se que em células de mamíferos a via PPP, que é mediada pela molécula de glicose-6P, é menos ativa que em células de inseto (BENSLIMANE et al., 2005).

Em relação à utilização de outros açúcares por células $\mathrm{S} 2$, de forma similar à observada para células Sf9 (SWIECH et al., 2008b, IKONOMOU; SCHNEIDER; AGATHOS, 2003; BEDARD; TOM; KAMEN, 1993), o consumo de GLC é preferencial em relação a outros açúcares, tais como maltose, sacarose e lactose (BATISTA et al., 2009a). Bedard, Tom e Kamen (1993) indicam que o consumo de outros açúcares inicia-se após a concentração de GLC ter atingido valores baixos (inferiores a $2 \mathrm{~g} / \mathrm{L}$ ).

\subsubsection{Metabolismo de aminoácidos}

Considera-se que os aminoácidos participam na síntese de proteínas ou que são degradados para prover esqueletos carbônicos às reações catabólicas e anabólicas. 
A glutamina é o mais importante substrato do catabolismo e anabolismo de células S2, assim como também o é para células de mamíferos. Estudos com o meio Sf-900 II indicam que a falta de GLN limita o crescimento cuja manifestação é caracterizada pela diminuição da duração da fase exponencial de crescimento (BOVO et al., 2008; SWIECH et al., 2008b) e do final da fase de crescimento (SWIECH et al., 2008b). No entanto, estudos empregando outros meios de cultura (TC-100 suplementado e IPL-41 suplementado) (GALESI et al., 2008; BATISTA et al., 2009) indicam resultados diferentes, reforçando a idéia de alta flexibilidade metabólica das células S2. O papel da GLN nas várias vias metabólicas e os fatores de rendimento observados dependem da linhagem celular empregada.

Em células de mamíferos, GLN é inicialmente convertida na mitocôndria em GLU e $\mathrm{NH}_{4}{ }^{+}$ pela via da glutaminólise (Figura 3.2, enzima 7) (AMABLE; BUTLER, 2008; PALOMARES; LOPEZ; RAMIREZ, 2004). O glutamato produzido pode ser metabolizado de duas maneiras e com diferentes rendimentos de ATP: a) via glutamato desidrogenase (Figura 3.2, enzima 8), formando uma molécula de $\mathrm{NH}_{4}{ }^{+}$e uma molécula of $\alpha$-cetoglutarato $(\alpha-\mathrm{KG})$, alimentando o ciclo TCA para prover compostos intermediários da biossíntese e para geração de energia na cadeia respiratória (até 27 mols de ATP por mol de GLN) e; b) via aminotransferases, pela qual o GLU transfere $\mathrm{NH}_{4}{ }^{+}$estequiometricamente ao oxaloacetato, produzindo aspartato, ou ao piruvato, gerando ALA (Figura 3.2, enzima 4). Neste último caso, a reação leva à formação de 9 moles de ATP por mol de GLN. Em excesso de GLN, observa-se um consumo desregulado de GLN, caracterizado por elevadas velocidades específicas de crescimento e

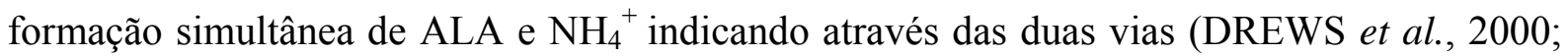
BENSLIMANE et al., 2005; BERNAL et al., 2009; AMABLE; BUTLER, 2008; ELIAS et al., 2003; MENDONÇA; PALOMARES; RAMIREZ, 1999).

O metabolismo de GLN, e a consequente formação de $\mathrm{NH}_{4}{ }^{+}$em células de inseto, mostra um padrão distinto em diferentes células, algumas vezes similar e outras vezes bastante diferente do observado em células de mamíferos. Em excesso de GLN e $\mathrm{O}_{2}$, células de inseto Sf9 não formam $\mathrm{NH}_{4}{ }^{+}$(ÖHMAN; LJUNGGREN; HAGGSTROM, 1995; DOVERSKOG et al., 1997; DREWS et al., 2000). Por outro lado, sob as mesmas condições de cultivo, células Tn-5 caracterizam-se pela produção em altos níveis de $\mathrm{NH}_{4}{ }^{+}$, produção esta comparável à observada em células de mamíferos (RHIEL; CHELLLOGEAN; MURHAMMER, 1997; BENSLIMANE et al., 2005; SUGIURA; AMANN, 1996). 
Estudos conduzidos por Haggstrom (2000) esclareceram grande parte do metabolismo de células de inseto (DREWS et al., 2000; DOVERSKOG et al., 2000). Esses estudos identificaram em células de lepidópteros ( $\mathrm{Sf9}$ entre elas), a presença da enzima NADHdependente glutamina: 2-oxoglutarato aminotransferase, GOGAT, também conhecida como NADH-dependente glutamato sintetase (indicada na Figura 3.2, bloco “a”, enzima 5). Essa via permite a transferência de grupos amino da GLN para $\alpha-K G$, formando GLU, sem liberação de $\mathrm{NH}_{4}^{+}$.

Pela recombinação de GLU e PYR, ALA e $\alpha$-KG (Figura 3.2, enzima 4) são produzidos. Assim, $\alpha-K G$ entra no ciclo TCA e a detoxificação ocorre simultaneamente visto que não há liberação de $\mathrm{NH}_{4}+$. A atividade da enzima GOGAT explica o metabolismo das células $\mathrm{Sf9}$ e a sua capacidade de crescer na ausência de GLN ou GLU (ÖHMAN et al., 1996), a não formação de $\mathrm{NH}_{4}{ }^{+}$e a liberação de grandes quantidades de ALA sob condições de excesso de GLN ou GLU. Doverskog et al. (2000) identificaram também a presença de GDH (enzima 8 na Figuras 3.2) e glutaminase (enzima 7, na Figuras 3.2) em células Sf9. Contudo, o fluxo de GLN via glutaminase e GDH foi muito menor que o fluxo via a enzima GOGAT (11\% e 55\%, respectivamente). Cabe ainda destacar que a dependência da enzima GOGAT da coenzima $\mathrm{NADH}$, ao invés de coenzima nicotinamida adenina dinucleotídio fosfato (NADPH), o que sugere estar essa enzima está mais relacionada com o metabolismo de produção de energia do que com o de biossíntese.

Outra diferença importante entre células de mamíferos e células de inseto reside na maior flexibilidade das últimas quanto ao metabolismo de síntese de aminoácidos. Células de inseto são capazes de sintetizar um maior número de aminoácidos, tais como GLN, GLU e aspartato (ASP), (ÖHMAN et al., 1996), embora esse fato seja pouco importante quando se empregam meios de cultura enriquecidos como o meio Sf-900 II (BERNAL et al., 2009). Essa versatilidade na síntese de aminoácidos pode explicar a sua capacidade de crescer em meio livres de GLN e GLU, desde que suplementados com amônio (ÖHMAN et al., 1996). Em culturas de células de mamíferos, o uso de meios livres de GLN exige suplementação de ASP e/ ou asparagina (ASN) (BEBBINGTON et al., 1992; KEEN e HALE, 1996), para permitir a obtenção de precursores para a biossíntese de GLN. Observa-se ainda que células Sf9 podem crescer em meios sem cistina (CYS) desde que as células estejam no início da fase exponencial de crescimento (DOVERSKOG; HAN; HÄGGSTRÖM, 1998). Verifica-se dessa 
forma, que o consumo de aminoácidos e sua biossíntese dependem do tipo de célula e das condições de cultivo, incluindo entre elas a idade do inóculo e a formulação do meio.

Em meios IPL-41 suplementados e em meio Sf-900 II, linhagens de células S2 mostram um alto consumo de prolina (PRO), CYS, serina (SER) e ASN, podendo ocorrer a sua completa exaustão (BATISTA et al., 2008; SWIECH et al, 2008a, b). Não está suficientemente esclarecido se esses aminoácidos podem limitar o crescimento, mas trabalhos que fizeram a suplementação do meio com PRO conseguiram um aumento significativo da velocidade específica de crescimento $\left(\mu_{\mathrm{Xmax}}\right)$ (SWIECH et al., 2008b). Além disso, deve ser destacado que GLU é consumido apenas depois que GLN tornar-se limitante (em concentrações inferiores a 400-600 mg/L) (BOVO et al., 2008; SWIECH et al., 2008a; GALESI et al., 2008; BATISTA et al., 2009a). Em alguns casos, observa-se produção de GLU ao final do cultivo e um consumo dos demais aminoácidos presentes no meio de cultura muito inferior ao dos anteriormente citados (BOVO et al., 2008).

Como já mencionado, a produção de ALA em células de inseto é uma consequência da oxidação parcial de GLN via alanina aminotransferase (enzima 4, Figura 3.2). A produção de ALA por células S2 é aproximadamente de 1,4 g/L em meio Sf-900 II e em meios IPL-41 suplementados (BATISTA et al., 2009a). Aparentemente, o doador do gupo amino para a produção de ALA depende da formulação do meio de cultura empregado. Em meio Sf-900 II, parece haver uma dependência da disponibilidade PRO, de modo que o esgotamento PRO implica no reconsumo de ALA (SWIECH et al., 2008b). Dada essa flexibilidade metabólica observada em células S2, deve-se considerar que outros fatores podem afetar a formação de ALA como, por exemplo, o nível de oxigênio dissolvido no meio, pois em condições limitantes de $\mathrm{O}_{2}$ a formação de ALA é mais elevada (até 2,7 g/L) do que em situações que não implicam em limitação de $\mathrm{O}_{2}$.

Em meio IPL-41 suplementado, a formação de ALA parece depender diretamente da disponibilidade de GLN (BATISTA et al., 2009a). Apesar disto, quando a concentração GLN é mantida em torno de 2,5 g/L, em batelada alimentada, a produção de ALA é interrompida, o que indica que um outro aminoácido, que não GLN, pode estar limitando o crescimento. Diferentemente do observado em culturas em meio Sf-900 II, não se observa reconsumo de ALA em meio IPL-41 suplementado, apesar de GLN estar completamente esgotada. A fonte de nitrogênio para a produção de ALA em meio TC-100 suplementado com soro na 
formulação é desconhecida, uma vez que ALA é produzida mesmo depois de GLN estar esgotada.

Muitos autores definem a geração de ALA como o destino mais importante para o PYR resultante do metabolismo da GLC pela via glicolítica. Dessa forma, quantidades menores de LAC e $\mathrm{NH}_{4}^{+}$são liberadas no ambiente, contribuindo para a destoxificação das células (RHIEL; MITCHELLLOGEAN; MURHAMMER, 1997; DREWS et al., 2000; BERNAL et al., 2009; IKONOMOU; SCHNEIDER; AGATHOS, 2003). Como já mencionado, Drews et al. (2000) identificaram em células de inseto uma reação catalizada pela enzima GOGAT que permite a transferência de nitrogênio amídico e amínico da GLN para ALA. Eles também verificaram uma baixa geração de ALA em meios de cultura sem GLN, onde GLU age como um doador de nitrogênio. Segundo Drews et al. (2000), a maioria dos outros aminoácidos (como histidina, lisina, treonina, glicina, valina, leucina, isoleucina, fenilalanina, tirosina e triptofano), apesar de serem incorporados como proteína celular, não são relevantes para fins de geração de energia.

\subsubsection{Formação de lactato}

Linhagens de células S2 apresentam diferentes padrões de formação de lactato como consequência da formulação do meio ou a condição inicial. Galesi et al. (2007) e Swiech et al. (2008b) no cultivo de células S2, observaram concentração muito baixa de lactato, mas este composto pode atingir valores de 0,6-3,0 g/L sob diferentes condições (BOVO et al., 2008; SONDERGAARD, 1996; VALLE et al., 2001; LIM; CHA, 2006; SWIECH et al., 2008a; GALESI et al., 2008; BATISTA et al., 2009a). Para Ikonomou, Schneider e Agathos (2003), a produção de LAC ocorre apenas em condições limitantes de $\mathrm{O}_{2}$. Apesar disto, Batista et al. (2009a), trabalhando com meio IPL-41 suplementado, observaram formação de LAC mesmo com pressão parcial de $\mathrm{O}_{2}$ de $40 \%$. Em meio Sf-900 II, com excesso de GLC, parece existir uma clara correlação entre o início da formação do LAC e limitação em GLN (BOVO et al., 2008) ou incapacidade de produção de ALA (BATISTA et al., 2009a).

Segundo Bovo et al. (2008), a produção LAC depende da velocidade específica de consumo de GLC, bem como da relação inicial GLN/GLC que assume valores de 1/5, em Sf-900 II ou em meio TC-100 suplementados e IPL-41, e de até $1 / 2$ no meio TC -100 contendo soro. Se GLC está em alta concentração no sistema no momento da exaustão do aminoácido 
fornecedor de nitrogênio, LAC é formado. Portanto, os dados apresentados por Batista et al. (2009a) indicam que a liberação de LAC não depende exclusivamente da disponibilidade de GLN, mas principalmente da incapacidade de produção de ALA como um meio de evitar a formação de $\mathrm{LAC}$ e $\mathrm{NH}_{4}{ }^{+}$. De fato, neste estudo, o início da produção LAC ocorreu quando ALA atingiu uma concentração constante.

Como formação LAC também depende de excesso de GLC, a disponibilidade de açúcar é de extrema importância. Como GLC torna-se, em geral, limitante em concentrações baixas $(1 \mathrm{~g} / \mathrm{L}$ a $2 \mathrm{~g} / \mathrm{L}$ ), menos LAC é formado, e até mesmo reconsumido. Pode-se, então, considerar o LAC como uma fonte de carbono alternativa para a manutenção das atividades metabólicas (BOVO et al., 2008; BATISTA et al., 2009a).

As culturas de células de mamíferos produzem grandes quantidades de LAC, como resposta ao excesso de GLC no meio, mesmo sob condições não-limitantes de $\mathrm{O}_{2}$ (AMABLE; BUTLER, 2008; ALTAMIRANO et al., 2006a,b; CRUZ et al., 2000a). Algumas hipóteses relacionadas com a produção de LAC são: a) este composto é formado como uma forma de re-equilibrar o potencial redox das células e como um meio de regeneração de NADH no citosol; b) a alta atividade da lactato desidrogenase (Figura 3.2, enzima 2) concorre com piruvato desidrogenase para a conversão de piruvato a lactato no citosol; c) o sistema respiratório pode ser saturado por NADH gerado pela glutaminólise (Figura 3.2, enzimas 7 e 8) no interior da mitocôndria; d) pode haver uma deficiência na atividade enzima-chave que liga a via glicolítica com o ciclo de TCA, como as do complexo piruvatodesidrogenase, fosfoenolpiruvato carboxiquinase ou piruvato carboxilase. Lactato pode ser tóxico em concentrações superiores a 3,6 g/L, mas a situação mais comum a enfrentar diz respeito aos efeitos deletérios que a diminuição do $\mathrm{pH}$ médio pode causar ao cultivo, diminuição essa que pode ser facilmente corrigida através da adição de um álcali (AMABLE; BUTLER, 2008).

Nos sistemas de células de inseto, LAC também é um subproduto do metabolismo anaeróbio da GLC e depende diretamente a sua disponibilidade na cultura (DOVERSKOG et al., 1997). É ainda uma maneira de regenerar NADH quando oxidação completa da GLC pelo ciclo do TCA e cadeia respiratória não é possível (DOVERSKOG et al., 1997; DREWS et al., 2000). 


\subsubsection{Formação de amônio}

Diferentemente do que foi observado para a formação de LAC, a produção de ALA não garante um esgotamento completo do $\mathrm{NH}_{4}{ }^{+}$gerado a partir do metabolismo de aminoácidos e, portanto, algum $\mathrm{NH}_{4}^{+}$sempre é observado no cultivo. Há uma liberação contínua de $\mathrm{NH}_{4}{ }^{+}$, independente do tipo de meio de cultura utilizado. No entanto, a quantidade de $\mathrm{NH}_{4}{ }^{+}$ produzidas em cada condição é muito diferente. Em meio TC-100 suplementado, são observados concentrações de 0,080 g/L (GALESI et al., 2008), enquanto valores elevados de 0,35 g/L (BATISTA et al., 2009a) e 1,1 g/L (SWIECH et al., 2008b) são encontrados em cultivos com meios IPL-41 suplementado e em SF II-900, respectivamente . Em meio TC-100 suplementado, observou-se que a taxa de formação de $\mathrm{NH}_{4}{ }^{+}$diminui à medida que GLN torna-se limitante, demonstrando uma relação direta entre a geração do subproduto e o consumo desse aminoácido. Em outros meios (IPL- 41 suplementado e SF-900II) não há uma relação direta entre a formação de $\mathrm{NH}_{4}{ }^{+}$e o consumo de GLN, sugerindo que o $\mathrm{NH}_{4}{ }^{+}$poder ser formado a partir do metabolismo de outros aminoácidos (BATISTA et al., 2009a).

O padrão de liberação de $\mathrm{NH}_{4}{ }^{+}$por células $\mathrm{S} 2$ é muito semelhante ao observado em células de mamíferos, sugerindo vias metabólicas similares e/ou participação de fluxos entre as vias para ambas células. Em células de mamíferos, a formação de $\mathrm{NH}_{4}{ }^{+}$decorre principalmente da assimilação de GLN pela via da glutaminólise, que produz também GLU (Figura 3.2, enzima 7). Este último pode ainda liberar uma outra molécula de $\mathrm{NH}_{4}{ }^{+}$e originar uma molécula de $\alpha-$ KG (Figura 3.2, via 8) (AMABLE; BUTLER, 2008).

Em células de mamíferos, $\mathrm{NH}_{4}{ }^{+}$é normalmente considerado mais deletério ao crescimento e síntese de produtos que o LAC, mesmo em baixas concentrações (36 mg/L) (AMABLE; BUTLER, 2008). Algumas explicações para essa toxicidade do $\mathrm{NH}_{4}{ }^{+}$incluem perturbação do pH intracelular e de alteração na distribuição de enzimas intracelulares e a ativação de reações que inibem o crescimento celular.

Quanto à perturbação do $\mathrm{pH}$ intracelular, células são incapazes de transportar $\mathrm{NH}_{4}{ }^{+}$através de suas membranas, de tal maneira que a formação de $\mathrm{NH}_{4}{ }^{+}$altera o equilíbrio

$$
\mathrm{NH}_{3}+\mathrm{H}^{+} \Leftrightarrow \mathrm{NH}_{4}^{+} \text {. }
$$

Em contrapartida, amônia $\left(\mathrm{NH}_{3}\right)$ é uma molécula pequena, sem carga, lipofílica, que facilmente se difunde por membranas celulares, diminuindo o $\mathrm{pH}$ na matriz mitocondrial, já que um próton é deixado para trás. Da mesma forma, as moléculas de $\mathrm{NH}_{3}$ também podem facilmente se difundir através da membrana citoplasmática. Este composto pode ser 
transportado de volta como amônio por proteínas transportadoras específicas (AMABLE; BUTLER, 2008; MARTINELLE; WESTLUND; HAGGSTROM, 1998; MARTINELLE; HAGGSTROM, 1999).

A perturbação sobre reações enzimáticas, por outro lado, pode envolver inibição direta de enzimas chave da glicólise, do ciclo TCA e da via PPP, entre outras, bem como o deslocamento do equilíbrio de reações (AMABLE; BUTLER, 2008).

As células Tn-5 têm um padrão metabólico semelhante ao de células de mamíferos com formação de quantidades elevadas de $\mathrm{NH}_{4}{ }^{+}$como uma resposta ao excesso de GLC (RHIEL; MITCHELLLOGEAN; MURHAMMER, 1997; BENSLIMANE et al., 2005; SUGIURA; AMANN, 1996). Benslimane et al. (2005) relataram fluxo de carbono através da TCA cinco vezes maior em células Tn-5 que o observado em células Sf9, o que pode justificar a maior liberação de $\mathrm{NH}_{4}{ }^{+}$em Tn-5. A linhagem celular Sf9 é caracterizada pela não formação de $\mathrm{NH}_{4}{ }^{+}$mesmo sob excesso tanto de GLN como de GLC, como normalmente se verifica no início de qualquer cultivo descontínuo. Essas células, contudo, podem produzir quantidades significativas de $\mathrm{NH}_{4}{ }^{+}$sob condições limitantes de GLC (ÖHMAN; LJUNGGREN; HAGGSTROM, 1995; DREWS et al., 2000), embora, como mencionado antes, é possível observar que as variações metabólicas são dependentes da célula, mas podem também resultar de mudanças nas condições de cultivo.

\subsection{Cinética do crescimento, da morte celular e da formação de produtos para} células animais.

A literatura registra inúmeros trabalhos que buscam identificar os principais substratos e subprodutos que interferem no crescimento de células animais, bem como na síntese de produtos e na quantificação dessa influência na forma de modelos cinéticos.

Augusto et al. (2008), Sidoli et al. (2004) e Pörtner e Schäffer (1996) sistematizaram os principais modelos não-estruturados utilizados para representar o cultivo de células animais. A maioria dos trabalhos citados refere-se à modelagem de hibridomas do crescimento e de formação de anticorpos monoclonais, não se encontrando um grande número de formulações matemáticas para células de inseto. 
Esses modelos cinéticos podem representar a dinâmica do processo, porém também tem limitações. Uma limitação importante dessa modelagem é que a sua capacidade preditiva decorre da incorporação de expressões matemáticas complexas que, normalmente, resultam em não-linearidades tanto em relação aos parâmetros como em relação às variáveis. Isso pode tornar trabalhosa a solução das equações representativas dos modelos. Eles também não são adequados para estudar a atividade relativa de certas vias metabólicas sob diferentes condições da cultura, situação caracterizada pela existência de mais de um estado estacionário fisiológico, situação também conhecida como de multiplicidade de estados estacionários. Para essa situação tem-se recorrido à modelagem metabólica (FOLLSTAD et al., 1999; EUROPA et al., 2000; CRUZ et al., 1999; ZHOU et al., 1997; LINZ et al., 1997; PAREDES et al., 1999).

A modelagem não necessariamente baseia-se em mecanismos cinéticos conhecidos ou propostos, mas pode utilizar funções matemáticas que melhor se adequam aos fenômenos observados. Isso gera um espectro amplo de modelos que vão desde os puramente inferidos empiricamente aos completamente baseados no conhecimento das etapas cinéticas. A maior parte dos modelos incorpora funções empíricas, pois muitos aspectos do comportamento de células ainda não foram elucidados. $\mathrm{O}$ desenvolvimento de modelos exige a incorporação e integração de aspectos particulares do sistema em estudo, enfim de modelos que descrevam cada um dos aspectos específicos envolvidos. A utilização precisa de sub-modelos que correspondam às partes do metabolismo celular é, portanto, de importância fundamental para a construção de um bom modelo cinético capaz de descrever a dinâmica do processo envolvido. Os principais modelos não-estruturados foram desenvolvidos por Batt e Kompala (1989), Bree et al. (1988), Glacken (1989), Dalili e Ollis (1989), Gaertner e Dhurjati (1993a,b), Frame e Hu (1991a,b), Linardos et al. (1991), de Tremblay et al. (1992), Kurokama et al. (1994), Pörtner e Schafer (1996) e Teixeira et al. (2005).

Alguns desses estudos avaliaram os efeitos dos principais componentes dos meios de cultura tais como o soro fetal bovino (THARANKAN; CHAU, 1986; VÉLEZ et al., 1986; DALILI; OLLIS, 1989; KUNKEL et al, 1998), glicose e glutamina, assim como os subprodutos do metabolismo celular, ácido láctico e amônia (REUVENY et al, 1986; GLACKEN et al, 1988; GLACKEN et al, 1989; MILLER et al, 1989a, b; JO et al., 1990; GAERTNER; DHURJATI, 1993a, b; SUAREZ, 2002). Além da composição do meio, também tem sido estudada a influência do teor de oxigênio dissolvido no meio e de fatores ambientais como a temperatura 
e o pH (REUVENY et al., 1986; MCQUEEN; BAILEY, 1990; SURESHKUMAR, 1991; BIRCH et al., 1985; MILLER et al., 1987; GAERTNER; DHURJATI, 1993a).

No cultivo de células animais, a glicose é a principal fonte de carbono e a principal fonte de energia. Quando se fornece glicose ao meio verifica-se que a velocidade específica de crescimento celular é função da concentração da glicose, podendo ser descrita pelo modelo de Monod (MONOD, 1942). Alguns autores utilizam a idéia de um limiar de concentração e uma velocidade mínima de incorporação de glicose (FRAME; HU, 1991b). Quando se utiliza essa noção de limiar de glicose, afirma-se que, abaixo de certa concentração não se percebe crescimento celular, ou ainda, que pode existir crescimento nulo mesmo quando existe glicose no meio. Por outro lado, quando se afirma que há uma velocidade mínima de incorporação de glicose, isso equivale a afirmar que, para qualquer fase do crescimento celular, sempre haverá uma velocidade de consumo de glicose (AUGUSTO et al., 2008).

Junto com glicose, glutamina é apontada como substrato necessário ao catabolismo e anabolismo de células animais (DALILI et al., 1990; SCHNEIDER e LAVOIX, 1990; SCHNEIDER et al., 1996; GAERTNER; DHURJATI, 1993a, b; HARIGAE et al., 1994; LEE et al., 1995; LINZ et al., 1997; GUARDIA et al., 2000; MILLER et al., 1988; JANG e BARFORD, 2000).

Os modelos apresentados para o crescimento celular e síntese de produtos, normalmente obtidos a partir de cultivos contínuos, variam na identificação do substrato limitante. Alguns modelos incorporam glicose, glutamina ou ambos os substratos nas expressões (JANG; BARFORD, 2000), embora também seja apontado que o substrato limitante possa ser outro, ou seja, nem glicose nem glutamina. Miller et al. (1988), por exemplo, verificaram que a velocidade específica de crescimento era independente da concentração de glicose no intervalo de concentrações normalmente empregado nos cultivos celulares e, ainda, caracterizaram a produção de anticorpos monoclonais como não associada ao crescimento.

Além desses dois substratos, alguns modelos também incluem o soro fetal bovino enquanto substrato limitante ou como fator de crescimento, que melhora a velocidade específica máxima de crescimento (GAERTNER; DHURJATI, 1993a; GLACKEN et al., 1989; DALILI; OLLIS, 1989; DALILI et al., 1990). No entanto, a tendência atual é se evitar meios de cultura com soro fetal bovino (BUTLER, 2005). 
Zeng et al. (1998a) estudaram a cinética de crescimento, de morte celular e de formação de anticorpos em seis linhagens de hibridomas, em cultivo contínuo e em perfusão. Os autores constataram que os principais modelos não-estruturados não se aplicavam bem aos cultivos estudados que consideram os substratos normalmente utilizados (glicose e glutamina), assim como os produtos típicos do cultivo (ácido lático, amônia e anticorpos monoclonais). Eles sugerem a existência de fatores limitantes ou autoinibidores ao crescimento, não identificados nos cultivos com hibridomas.

Os modelos cinéticos comumente propostos incluem produtos metabólicos inibidores do crescimento como lactato e amônia. Butler e Jenkins (1989), Newland et al. (1990), Ozturk et al. (1992), Schneider et al. (1996) e Jang e Barford (2000) consideraram ácido láctico e amônia como os principais inibidores do crescimento de células animais quando a concentração de ácido láctico está acima de 40 a 50 mM e quando a concentração de amônia está acima de $2 \mathrm{mM}$.

Augusto et al. (2008) e Pörtner e Schäfer (1996) sistematizaram um conjunto de modelos nãoestruturados para o crescimento de hibridomas e indicados na Tabela 3.2.

\subsubsection{Influência de $\mathrm{O}_{2} \mathrm{e} \mathrm{pH}$.}

A concentração celular final diminui quando a concentração de oxigênio dissolvido é reduzida como decorrência do metabolismo oxidativo, pois ocorre uma incompleta oxidação de glicose e um aumento na velocidade específica de produção de lactato (MILLER et. al., 1987; DEUTSCHMANN; JAGER, 1994).

Um crescimento ótimo da linhagem de células de inseto, Spodoptera frugiperda, foi encontrado para concentrações de oxigênio dissolvido de $70 \%$ da concentração de saturação (DEUTSCHMANN; JAGER, 1994). Para crescimento de hibridomas foram verificadas exigências distintas para o crescimento celular e para a formação de produtos (anticorpos). Autores identificaram uma concentração ótima de $0,5 \%$ da saturação oxigênio dissolvido para o crescimento celular e 50\% da saturação para a formação de produto (MILLER et al., 1987). Alterações metabólicas decorrentes da redução da concentração de oxigênio dissolvido foram constatadas no crescimento e na formação de produtos de células animais (KUNKEL et al., 1998, 2000). 
Tabela 3.2. Exemplos de modelos para velocidades específicas de crescimento.

\begin{tabular}{|c|c|}
\hline Velocidade específica de crescimento & Referência \\
\hline$\mu_{\mathrm{X}}=\mu_{\mathrm{X} \max } \frac{\mathrm{GLC}}{\mathrm{k}_{\mathrm{GLC}}+\mathrm{GLC}} \cdot \frac{\mathrm{GLN}}{\mathrm{k}_{\mathrm{G} \ln }+\mathrm{GLN}}$ & $\begin{array}{l}\text { De Trembay et al. } \\
\text { (1992). }\end{array}$ \\
\hline$\mu_{\mathrm{X}}=\mu_{\min }+\frac{\left(\mu_{\max }-\mu_{\min }\right)\left(\mathrm{GLC}-\mathrm{GLC}_{\text {limiar }}\right)}{\mathrm{k}_{\mathrm{GLC}}+\left(\mathrm{GLC}-\mathrm{GLC}_{\mathrm{limiar}}\right.}$ & Frame e Hu (1991a). \\
\hline$\mu_{\mathrm{X}}=\mu_{\mathrm{X} \max } \frac{\mathrm{GLN}}{\mathrm{k}_{\mathrm{GLN}}+\mathrm{GLN}} \frac{\mathrm{k}_{\mathrm{NH} 3}}{\mathrm{k}_{\mathrm{NH} 3}+\mathrm{NH} 3} \frac{\mathrm{k}_{\mathrm{LAC}}}{\mathrm{k}_{\mathrm{LAC}}+\mathrm{LAC}}$ & Bree et al. (1988). \\
\hline$\mu_{\mathrm{X}}=\mu_{\mathrm{X} \max } \frac{\mathrm{GLC}}{\mathrm{k}_{\mathrm{GLC}}+\mathrm{GLC}} \cdot \frac{\mathrm{k}_{\mathrm{LAC}}}{\mathrm{k}_{\mathrm{LAC}}+\mathrm{LAC}}$ & Kurokawa et al. (1994). \\
\hline$\mu_{\mathrm{X}}=\mu_{\mathrm{X} \max } \frac{\mathrm{GLC}}{\mathrm{k}_{\mathrm{GLC}}+\mathrm{GLC}} \frac{\mathrm{GLN}}{\mathrm{k}_{\mathrm{GLN}}+\mathrm{GLN}} \frac{\mathrm{k}_{\mathrm{NH} 3}}{\mathrm{k}_{\mathrm{NH} 3}+\mathrm{NH} 3} \frac{\mathrm{k}_{\mathrm{LAC}}}{\mathrm{k}_{\mathrm{LC}}+\mathrm{LAC}}$ & $\begin{array}{l}\text { Miller, Blanch e Wilke } \\
\text { (1988) }\end{array}$ \\
\hline$\mu_{\mathrm{X}}=\mu_{\mathrm{X} \max }($ Soro $) \frac{\mathrm{GLC}}{\mathrm{k}_{\mathrm{GLC}}+\mathrm{GLC}}$ & $\begin{array}{l}\text { Dalili; Sayles; Ollis } \\
\text { (1990) }\end{array}$ \\
\hline$\mu=\mu_{X \max } \frac{\mathrm{GLN}}{\mathrm{k}_{\mathrm{GLN}}+\mathrm{GLN}}$ & $\begin{array}{l}\text { Pörtner e Schafer } \\
\text { (1996). }\end{array}$ \\
\hline
\end{tabular}

FONTE: Augusto et al. (2008)

Eventualmente a concentração de oxigênio dissolvido no meio é incorporada ao modelo, quando não se opera com concentração de oxigênio dissolvido constante ou quando se deseja avaliar sua influência na dinâmica do processo.

Como ocorre em culturas microbianas, também existe um $\mathrm{pH}$ ótimo para o cultivo. Para células animais recomenda-se um pH entre pH 7.1 e 7.4. Fora desse intervalo o número de células viáveis diminui acentuadamente (MILLER et al., 1988).

\subsubsection{Morte celular.}

As células animais são frágeis e sensíveis ao efeito de cisalhamento que surge em decorrência da movimentação do fluido no biorreator. Segundo Nollert, Diamond e McIntire (1991), as células de mamíferos respondem às forças hidrodinâmicas em minutos, alterando seu metabolismo celular e a expressão gênica. Dependendo da intensidade dessas forças, as células alteram a velocidade de crescimento celular, a sua morfologia, o metabolismo e a 
expressão genética de metabólitos (NOLLERT et al., 1991; MILLER et al., 1988). Essas forças surgem no meio em função da agitação e aeração imposta ao sistema de cultivo.

Como já foi comentado, na identificação dos fatores ambientais que afetam a viabilidade celular, busca-se determinar as condições de operação que minimizem esses efeitos. Contudo ocorrem determinadas condições na dinâmica do cultivo, inevitáveis, que afetam a viabilidade celular, sendo necessário que os modelos matemáticos considerem os efeitos da composição do meio de cultivo sobre a viabilidade celular. As condições da cultura podem disparar mecanismos de morte celular como necrose e apoptose. A necrose é caracterizada pelo aumento do volume da célula e seu subseqüente rompimento. É causada principalmente por forças externas como tensão de cisalhamento, pelos mecanismos de "ruptura" das bolhas de ar e devido a alterações abruptas de $\mathrm{pH}$ e de pressão osmótica do meio, bem como devido à presença de substâncias tóxicas. A apoptose, também chamada de "morte programada" das células, é determinada pela própria célula, o que significa que esse processo está sob controle genético. Em um processo claro de autodestruição, as células fragmentam o DNA e empacotam o seu conteúdo interno em vesículas (corpos apoptóticos), eliminados para o ambiente, ocasionando a diminuição do volume celular (PELLEGRINI et al., 2008). Novamente, são as condições ambientais que induzem os mecanismos apoptóticos, sendo a causa variável para cada linhagem celular. Em princípio, qualquer limitação nutricional ou inibição do metabolismo pode ativar esse mecanismo. A apoptose em células de inseto foi estudada recentemente por Meneses-Acosta et al. (2001) que caracterizam o fenômeno em cultura de células Sf9. Cowger et al. (1999), Zeng et al. (1998a, b), Deckwer e Hu (1998), Zeng; Hu; Deckwer (1998), Zeng e Deckwer (1999), Lee et al. (1995) desenvolveram modelos cinéticos que quantificam o desaparecimento celular e, dessa forma, incluem a apoptose e a necrose celular. Augusto et al. (2008) e Pörtner e Schäfer (1996) sistematizaram um conjunto de modelos não-estruturados para a velocidade de morte celular que estão indicados na Tabela 3.3 . 
Tabela 3.3. Exemplos de modelos para velocidades específicas de morte celular.

Velocidade específica de morte celular

$$
\begin{aligned}
& \mu_{\mathrm{d}}=\mu_{\mathrm{d}, \text { max }} \frac{\mathrm{NH}_{3}}{\mathrm{k}_{\mathrm{NH} 3}^{\mathrm{d}}+\mathrm{NH}_{3}} \frac{\mathrm{LAC}}{\mathrm{k}_{\mathrm{Lac}}^{\mathrm{d}}+\mathrm{LAC}} \\
& \mu_{\mathrm{d}}=\mathrm{k}_{\mathrm{d}, \text { max }} \frac{\mathrm{NH}_{3}}{\mathrm{k}_{\mathrm{NH} 3}^{\mathrm{d}}+\mathrm{NH}_{3}} \frac{\mathrm{LAC}}{\mathrm{k}_{\mathrm{Lac}}^{\mathrm{d}}+\mathrm{LAC}} \frac{\mathrm{k}_{\mathrm{i}, \mathrm{GLN}}^{\mathrm{d}}}{\mathrm{k}_{\mathrm{i}}^{\mathrm{d}}+\mathrm{GLN}} \\
& \mu_{\mathrm{d}}=\frac{\mathrm{k}_{\mathrm{d}, \max }}{\left(\mu_{\mathrm{X}, \max }-\mathrm{k}_{\mathrm{LAC}}^{\mathrm{d}^{*}}+\mathrm{LAC}\right)\left(\mu_{\mathrm{X}, \max }-\mathrm{k}_{\mathrm{NH} 3}^{\mathrm{d}^{*} \mathrm{NH}_{3}}\right)} \frac{\mathrm{k}_{\mathrm{i}, \mathrm{GLN}}^{\mathrm{d}}+\mathrm{GLN}}{\mathrm{k}_{\text {G }}^{\mathrm{d}}+\mathrm{GLN}}
\end{aligned}
$$

\section{Referência}

Batt e Kompala (1989)

Bree et al. (1988)

De Trembay et al.

FONTE: Augusto et al. (2008).

\subsubsection{Formação de produtos}

Modelar a formação de produtos obtidos no cultivo de células tem sido uma tarefa impulsionada pela necessidade de aumentar a produtividade dos cultivos, ou seja, pela necessidade de aumentar a produção desses produtos de interesse comercial com menores investimentos e custos de produção possível (SIDOLI et al., 2004). Essa modelagem tem sido realizada especialmente no cultivo de hibridomas e na produção de anticorpos monoclonais. Pörtner e Schafer (1996) compararam um conjunto de modelos não estruturados propostos para a cinética de produção de anticorpos monoclonais. Alguns dos modelos utilizam o conceito proposto por Luedeking e Piret (2000) de produção associada e não-associada ao crescimento, ou seja, consideram a produção de anticorpos como uma função linear da velocidade específica de crescimento celular (associada ou parcialmente associada) ou como independente da velocidade da específica de crescimento. Os modelos ainda consideram a concentração de substratos e soro fetal como variáveis que afetam a velocidade específica de produção, como pode ser verificado na Tabela 3.4. 
Tabela 3.4. Exemplos de modelos para velocidades específicas de formação de produto.

\begin{tabular}{ll}
\hline Velocidade específica & Referência \\
\hline$\mu_{P}=d_{o} e^{d_{1} / \mu_{X}}$ & Linardos et al. (1991). \\
$\mu_{P}=\alpha$ & Pörtner e Schafer (1996); \\
$\mu_{P}=\alpha \cdot \mu_{X}+\beta$ & Hiller et al. (1991). \\
$\mu_{P}=\frac{\alpha O}{k_{\mu}+\mu_{X}} \mu_{X}+\beta$ & Frame e Hu (1991b). \\
$\mu_{\mathrm{P}}=\beta(\mathrm{soro}) \frac{\mathrm{GLN}}{\mathrm{k}_{\mathrm{G} \ln }^{\mathrm{p}}+\mathrm{GLN}}$ & De Tramblay et al. (1992). \\
$\mu_{P}=\alpha \cdot k_{d}+\beta$ & Dalili et al. (1990). \\
\hline
\end{tabular}

FONTE: Augusto et al.(2008)

\subsection{Biorreatores utilizados para o cultivo células animais.}

A partir da viabilização do cultivo de células animais in vitro e em larga escala, vêm sendo desenvolvidas técnicas e equipamentos capazes de manter as células nas melhores condições ambientais para a sua proliferação e para a obtenção de produtos imunobiológicos de interesse. Como indicado por Chico, Rodrigues e Figueiredo (2008), os biorreatores, principais equipamentos para o cultivo de células, devem assegurar:

a) $\mathrm{pH}$ adequado, por meio do controle do equilíbrio ácido - base do meio de cultivo;

b) temperatura adequada à propagação das células;

c) troca de gases que permitam um suprimento adequado de $\mathrm{O}_{2}$ e a eliminação de excesso de $\mathrm{CO}_{2}$

d) suprimento adequado de nutrientes seja pela utilização do meios de cultivo próprios seja pela adição programada de nutrientes em função do tempo de cultivo;

e) suporte para adesão celular, no caso de células aderentes;

f) manutenção de assepsia durante o cultivo;

g) tensões de cisalhamento e condições hidrodinâmicas que permitam a homogeneidade do meio cultivo sem causar danos às células. 
Todo cultivo inicia-se com o descongelamento de células de uma ampola de crioconservação e, em seguida, sua propagação é feita em frascos especiais (frasco tipo $\mathrm{T}$, frascos tipo roller e frascos agitados tipo spinner ou Schott).

Devido à necessidade ou não de suporte, exigência característica da linhagem celular empregada, os cultivos celulares podem ser classificados em duas classes fundamentais: cultivos em suspensão e cultivos em suportes. Essa exigência leva ao uso dos diferentes tipos de frascos para a propagação celular inicial e, assim, podem ser utilizadas garrafas tipo roller para células dependentes de suporte ou frascos agitados (spinner ou Schott) para células em suspensão. Os biorreatores são utilizados como última etapa dos cultivos e para se obter altas concentrações celulares e volumes de produção compatíveis com as demandas de mercado, enfim, para suprir as necessidades de produção estabelecidas para o processo.

A classificação dos biorreatores pode ser feita levando em conta várias características do equipamento. Neste trabalho será considerada a classificação proposta por Chico, Rodríguez e Figueiredo (2008), que agrupa os diversos biorreatores em duas categorias relativas às fases presentes nos cultivos, ou seja, os biorreatores são classificados como reatores homogêneos e heterogêneos. Embora todos os cultivos sejam no mínimo bifásicos, pois a células constituem uma fase distinta do meio de cultura, esses reatores podem ser considerados como homogêneos ou pseudo-homogêneos uma vez que as células estão homogeneamente distribuídas na fase líquida. Os reatores nos quais não se observa essa distribuição homogênea, ou ainda, quando as células exigem um suporte sólido para aderência, suporte que leva à formação de gradientes de concentração na sua interface com o meio liquido ou mesmo dentro do suporte, esses reatores são classificados como reatores heterogêneos. A Tabela 3.5 apresenta os principais tipos de reatores e sua classificação.

Todos esses tipos de biorreatores podem ser operados de diferentes formas, ou seja, a sua utilização pode ser feita operando-os em batelada, em batelada alimentada ou em contínuo. Para células animais o cultivo contínuo faz-se com reciclo e com retenção de células no biorreator e a essa forma de condução do processo é denominada de perfusão. 


\subsubsection{Biorreatores Homogêneos.}

Os biorreatores do tipo tanque agitado são os reatores mais utilizados nos processos biotecnológicos em todo o mundo e são similares aos utilizados na fermentação submersa de microorganismos (JAIN; KUMAR, 2007). As razões para essa preferência estão na quantidade de estudos realizados para esse tipo de equipamento, na simplicidade de sua construção e nos vários recursos disponíveis para assegurar as melhores condições ambientais para o cultivo de células animais. Todos esses equipamentos dispõem de controle de $\mathrm{pH}$, temperatura e são construídos para permitir condições de assepsia e homogeneidade das propriedades do meio. Essa homogeneidade é garantida por impelidores instalados no eixo rotatório central do biorreator, além disso, esses equipamentos ainda dispõem de sistema para fornecimento e remoção de gases, garantido a oxigenação e também o controle de $\mathrm{pH}$. Todas essas características têm permitido a construção de biorreatores de até $20000 \mathrm{~L}$ de volume útil (JAIN; KUMAR, 2007; CHICO; RODRÍGUEZ; FIGUEIREDO, 2008). Esses reatores podem ser utilizados tanto para o cultivo de células em suspensão ou para o cultivo de células dependentes de suporte. Nesse último caso, adicionam-se microcarregadores para a adesão das células. Os reatores homogêneos são projetados com bases na cinética homogênea do processo, ou seja, em todos os pontos do meio reacional a concentração dos reagentes e produtos é a mesma e, em decorrência, as velocidades do processo são a mesma.

Tabela 3.5. Classificação de biorreatores.

\begin{tabular}{ll}
\hline Biorreatores Homogêneos & Biorreatores Heterogêneos \\
\hline Tanque agitado & Tanque agitado com microcarregadores \\
Air-lift & Leito empacotado ou leito fixo \\
De ondas & Leito fluidizado \\
& Com crescimento nas superfícies (Roller, \\
& Cell Cube $\AA$, etc.) \\
& Fibra oca \\
\hline
\end{tabular}

FONTE: Chico, Rodríguez e Figueiredo (2008)

Os biorreatores tipo air-lift tem sido usados para produção de anticorpos monoclonais de uso terapêutico ou diagnóstico. Eles proporcionam um meio hidrodinamicamente menos agressivo, pois os perfis de velocidade no fluido não permitem gradientes e velocidade tão elevados como nos tanques agitados e, além disso, dispensam agitação mecânica e, com isso, 
economizam energia. Essas características decorrem da geometria do reator e da existência de um cilindro concêntrico no seu interior por onde é injeta uma corrente gasosa. O gás sob pressão forma bolhas que ascendem no tubo e fazem o líquido circular retornado para a região inferior do reator. A principal limitação desse equipamento está na limitação para ampliação de sua escala de trabalho, pois os maiores reatores descritos na literatura até de $2.000 \mathrm{~L}$ (JAIN; KUMAR, 2007), embora se cite um caso com escala de produção de $10.000 \mathrm{~L}$ (BIRCH et al., 1993).

Biorreatores de ondas (wave bioreactors, disposable bioreactors), ilustrados na Figura 3.3 consistem de uma bolsa estéril de plástico flexível descartável na qual se cultivam as células e uma plataforma móvel sobre a qual se apóia a bolsa. O movimento oscilatório da plataforma gera ondas na interface gás/liquido no interior da bolsa plástica que homogeneízam o meio de cultura. Por não necessitarem de esterilização in house, eles não exigem a validação do processo, pois essa garantia é dada pela empresa que fabrica e fornece as bolsas plásticas. A transferência de oxigênio neste tipo de biorreator e a consequente capacidade de atingir altas concentrações celulares são limitadas, o que restringe o cultivo de grandes volumes de meio, razão pela qual os volumes máximos de cultivo com este tipo de biorreator sejam de até 1000 L (SINGH, 1999; JAIN e KUMAR, 2007; NEGRETE; KOTIN, 2007).

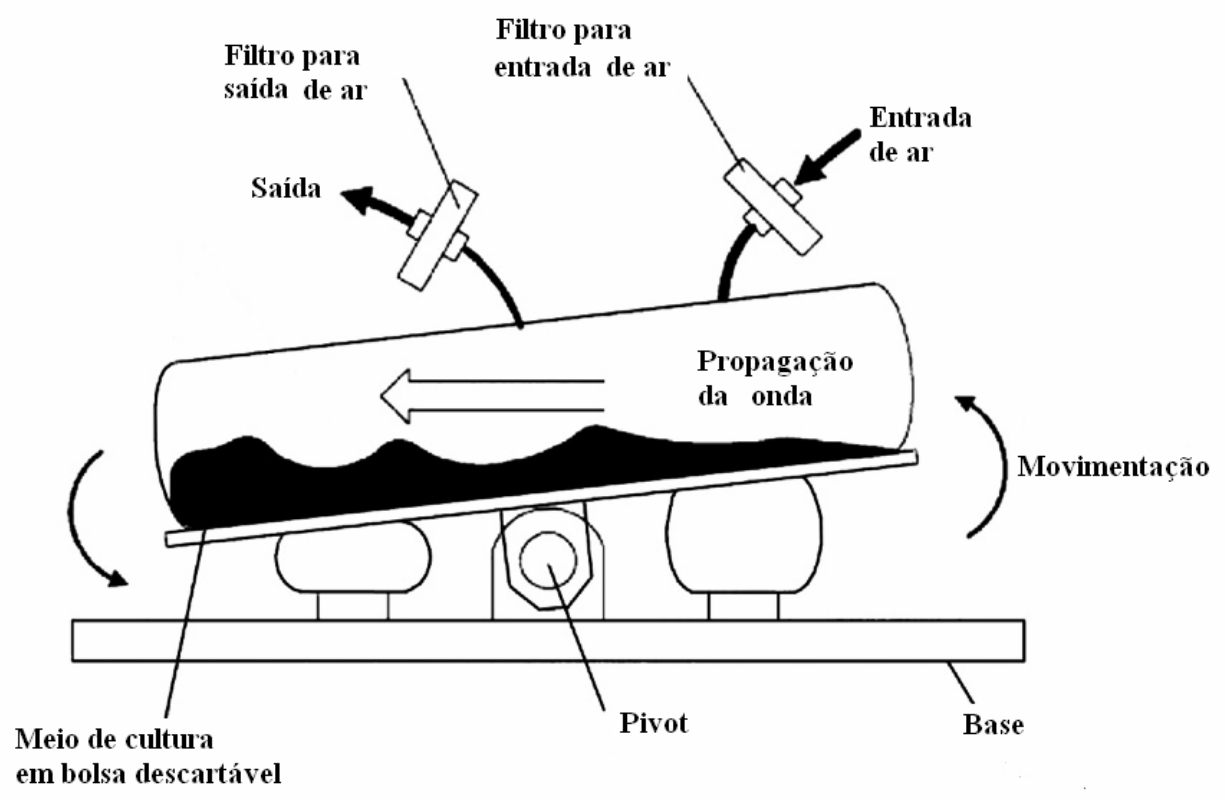

Figura 3.3. Reator de ondas. 


\subsubsection{Biorreatores Heterogêneos}

Esses biorreatores caracterizam-se por utilizaram um suporte sólido para aderência de células e, em decorrência disso, por apresentarem gradientes de concentração no meio reacional. Os reatores do tipo tanque agitado podem ser utilizados nos cultivos (Figura 3.4) com células aderentes quando se incorporam ao meio reacional microcarregadores, partículas feitas de materiais como celulose, dextrana, colágeno, gelatina ou vidro. Esses microcarregadores apresentam características superficiais que permitem a adesão de células. Além dessas características de suas superfícies os microcarregadores podem ser porosos e, dependendo do tamanho dos poros, são classificados como microporosos ou "sólidos" e macro-porosos. Essa é uma qualificação que leva em conta o tamanho da célula e o do poro. Microcarregadores microporosos têm poros com diâmetros inferiores aos das células, o que não permite o seu crescimento no interior da partícula, sendo a fixação das células exclusivamente na sua superfície. Os microcarregadores macroporosos são fabricados com poros entre $10 \mu \mathrm{m}$ e 400 $\mu \mathrm{m}$, dimensões que permitem o crescimento de células no interior das partículas. Nos dois casos a cinética de reação é heterogênea, pois as reações estão sujeitas a etapas difusivas que normalmente controlam a velocidade global de reação a (CHICO; RODRÍGUEZ; FIGUEIREDO, 2008; NILSANG et al., 2008). A eficiência dessa combinação, projeto do reator e microcarregadores, depende da capacidade de fixação das células, da estabilidade dessa adesão ao suporte e, ainda, da preservação da viabilidade das células no tanque agitado.

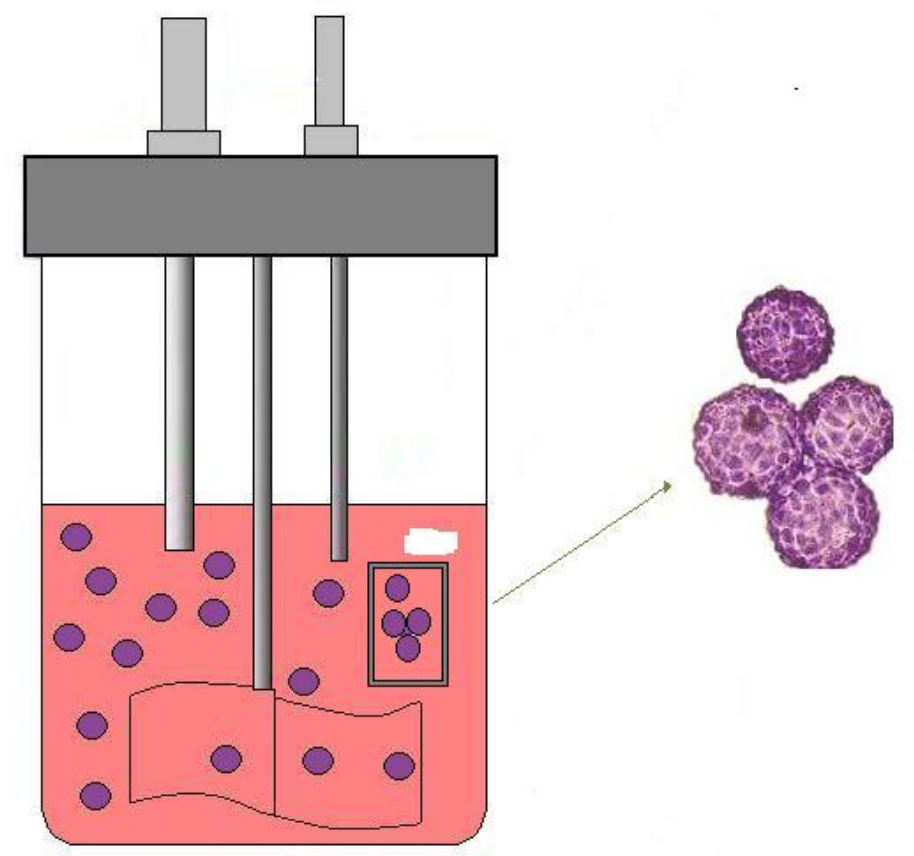

Figura 3.4. Reator tipo agitado com células ancoradas em microcarregador (destaque para microcarregadores). 
Biorreatores com crescimento em superfícies. A maioria das linhagens celulares utilizadas para produtos imunobiológicos é dependente de ancoragem e necessitam de superfícies para adesão. Garrafas rotatórias (roller bottles) e sistemas com múltiplas camadas (CellCube ${ }^{\circledR}$, Cell Factoty) têm sido os sistemas mais comumente utilizados para cultivo dessas células. A ampliação da escala de produção tem sido realizada pelo aumento do número de garrafas ou placas, o que não significa melhoramento da capacidade de produção por unidade do sistema de cultivo utilizado. Além disso, essa forma de cultivo requer mão de obra intensiva e apresenta maiores riscos de contaminação (CHICO; RODRÍGUEZ; FIGUEIREDO, 2008). Essas limitações levaram ao desenvolvimento de outros sistemas de cultivo que fornecem superfícies para ancoragem das células com maior produtividade. Os biorreatores de fibras ocas (hollow fiber bioreactor) são dispositivos que permitem a ancoragem de células dependentes de suporte e aumentam, significativamente, a produtividade dos cultivos e, ainda, permitem altas concentrações de certas proteínas no reator. Eles são constituídos de centenas de pequenos tubos semipermeáveis com diâmetros inferiores a $200 \mu \mathrm{m}$ e com peso molecular de corte característico (molecular weight cut off, MWCO) dispostos em um módulo ou cartucho. As células são inoculadas no espaço externo às fibras (espaço extracapilar) e crescem nessa região. $\mathrm{O}$ meio é bombeado através do espaço interior das fibras (espaço intracapilar). A semipermeabilidade permite que os nutrientes e metabólitos de massa molar baixa (glicose, glutamina, amônia, lactato, proteínas, fatores de crescimento) que possam mover-se livremente através dos poros das fibras. Por outro lado, as proteínas com massa molar elevada, produzidas ou adicionadas ao espaço extracapilar no qual estão alojadas as células, que permanecem retidas no reator, o que aumenta significativamente a concentração do produto de interesse em relação aos outros sistemas e diminui os custos das etapas de concentração e purificação do produto. Além disso, uma vez que as células aderidas ao suporte poroso têm o fornecimento de nutrientes assegurado, a cultura pode ser mantida em atividade contínua por meses o que aumenta a produtividade do sistema (JAIN e KUMAR, 2007; FIBER CELL SYSTEM, 2008). Um esboço do biorreator está indicado na Figura 3.5. 


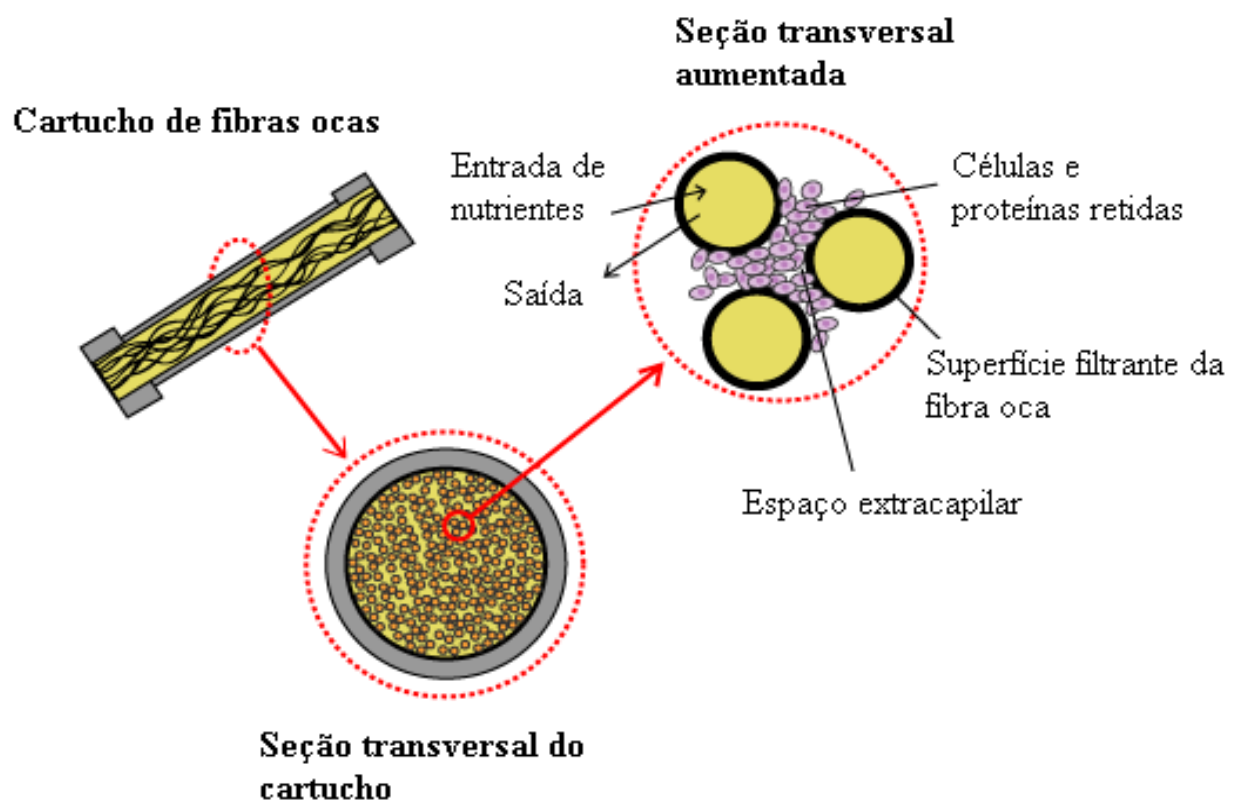

Figura 3.5. Biorreator de fibras ocas. FONTE: Fiber Cell System (2008)

Reatores de leito fixo são normalmente empregados quando a reação envolvida é catalisada por sólidos ou partículas catalíticas. Recebem essa denominação por manterem as partículas fixas dentro do equipamento e também são conhecidos como reatores de leito empacotado. A configuração do leito e a movimentação do líquido através dele podem variar. A forma mais comum desse equipamento consiste de uma coluna cilíndrica recheada com partículas catalíticas constituindo um único leito catalítico embora também sejam encontrados leitos segmentados e com outras geometrias. Um exemplo de biorreator de leito fixo está indicado na Figura 3.6. Os biorreatores de leito fixo permitem a retenção das células aderidas ao suporte, diminuindo ou eliminando as etapas de separação e permitem altas concentrações celulares e, com isso, taxas de reação elevadas, aumentando a produtividade do reator e do processo. Contudo existem dificuldades inerentes a este tipo de biorreator, tais como a manutenção da concentração adequada de oxigênio dissolvido no leito catalítico e formação de caminhos preferenciais, o que limita a produtividade do reator e a sua ampliação de escala sendo que o volume máximo de trabalho para este tipo de biorreator está na faixa de 10 L a 30 L (MEUWLY et al., 2007).

Biorreatores de leito fluidizado permitem manter as partículas e/ou células em suspensão numa determinada região do reator graças ao equilíbrio de forças dinâmicas (força de arrasto da corrente gasosa ou líquida reacional sobre a partícula e sua força peso). Essa fluidização prolonga a vida útil das partículas catalítica e aumenta a produtividade do reator. Esses equipamentos (Figura 3.7) vêm sendo utilizados em bioprocessos com 
microcarregadores para obtenção de retrovírus em volumes de trabalho de até $400 \mathrm{~L}$ (WARNOCK; MERTEN; AL RUBEAI, 2006; JAIN; KUMAR, 2007).

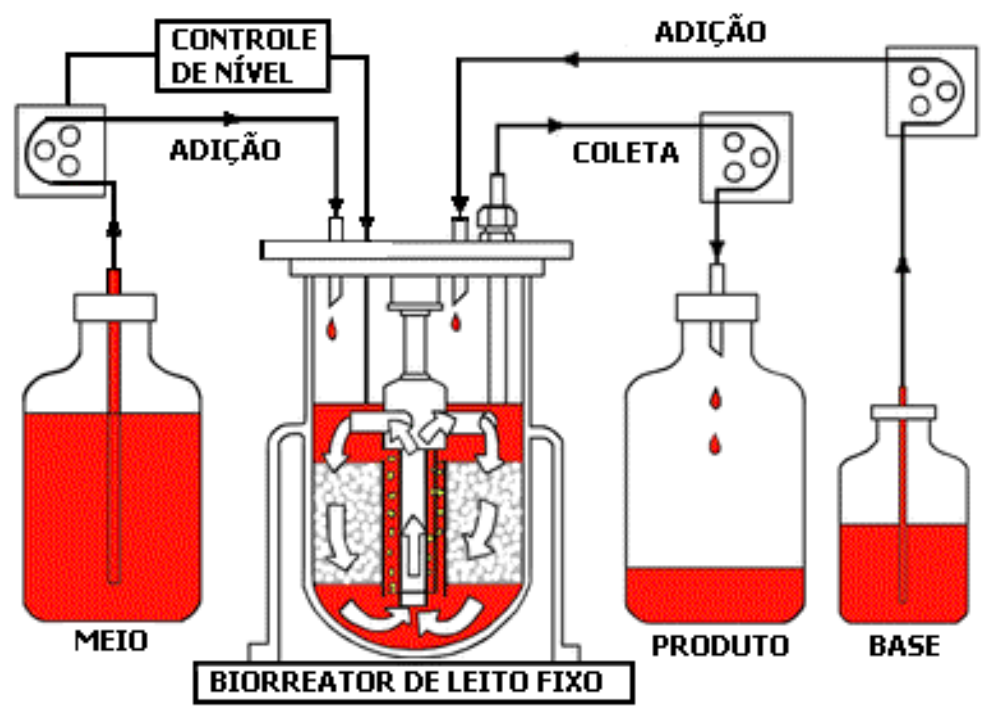

Figura 3.6. Reator de leito fixo. FONTE: Meisenholder (1999)

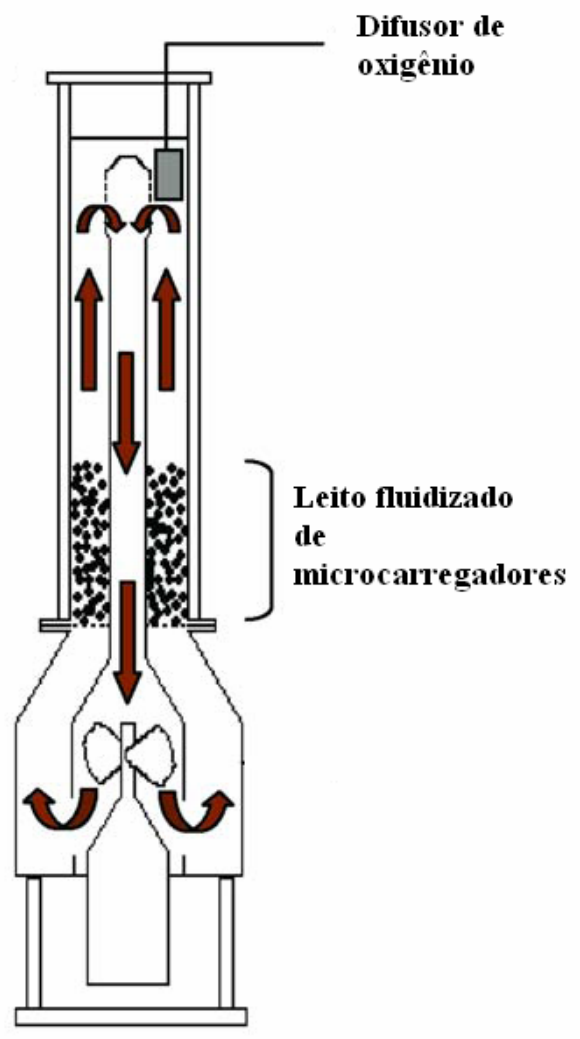

Figura 3.7. Reator de leito Fluidizado. FONTE: Warnock, Merten e Al Rubeai (2006) 


\section{MATERIAIS E MÉTODOS}

Os dados necessários para a formulação de modelo cinético do cultivo de células S2, Drosophila melanogaster, estavelmente transformadas com vetores plasmidiais contendo o gene da glicoproteína $\mathrm{G}$ do vírus da raiva (pAcGPV), foram obtidos por três alunos de doutorado e um de mestrado e estão descritos em Batista et al. (2006), Batista (2007), Batista et al. (2008), Batista et al.(2009a), Galesi (2007), Galesi; Pereira; Moraes (2007), Galesi et al. (2008), Swiech (2007), Swiech et al.(2008a,b,c) e Aguiar (2010), pesquisadores participantes do projeto temático "Expressão de genes heterólogos de células de dípteros: Biologia Molecular e Engenharia de Processos", (FAPESP - 02/09482-3). Os ensaios utilizados estão indicados no Quadro A.1, ANEXO A do Anexo A.

\subsection{Células}

Todos os ensaios considerados utilizaram células S2 Drosophila melanogaster transfectadas com o vetor pAcGPVHygro para expressar de forma constituitva a glicoproteína do vírus da raiva, GPV, segundo procedimento estabelecido por Yokomizo et al. (2007), aqui denominadas células S2AcGPV2. As células foram adaptadas aos vários meios empregados pelos vários pesquisadores - TC100-AG, SF900II ${ }^{\circledR}$ (Invitrogen, USA, Califórnia, Carlsbad) e IPL-FA - o que, em geral, gera subpopulações celulares. Durante o desenvolvimento dos trabalhos isolou-se uma subpopulação da linhagem que expressava maiores quantidades ( 2 a 3 vezes) da proteína GPV quando cultivada em meio Sf900 II $^{\circledR}$ (Gibco, EUA). Essa linhagem foi denominada S2AcGPV2-KSf900. Para isolar esta população, o procedimento utilizado foi de repicar apenas as células mais aderentes ao frasco, descartando as outras. Esse foi um procedimento diferente daquele adotado até então, no qual se procura manter uma população homogênea (células com diferentes capacidades de adesão) durante todas as passagens.

Posteriormente, a subpopulação S2AcGPV2-KSF900 foi adaptada ao meio TC100-AG e recebeu a denominação S2AcGPV2-KTC100 (AGUIAR et al., 2009; AGUIAR, 2010). Infelizmente essa linhagem foi perdida ao longo do trabalho, por problemas de instabilidade ou de preservação. 
Todas as linhagens estudadas eram preservadas em nitrogênio líquido em meio de cultivo fresco, usando como crioprotetores 10\% (v/v) de dimetilsulfoxido (Sigma, EUA) e 50\% (v/v) de soro fetal bovino (Nutricel, Brasil).

\subsection{Meios de cultura}

Os ensaios considerados utilizaram os meios de cultura comumente empregados nos cultivos de células de inseto. O meio utilizado por Galesi (2007), Galesi, Pereira e Moraes (2007,2008) e Aguiar et al. (2009) e Aguiar (2010) foi o meio TC100 (Cultilab, Br) suplementado com glicose, glutamina e no qual se substitui o soro fetal bovino por emulsão lipídica (Invitrogen), pluronic F68 (Sigma) e hidrolisado de levedura (yeastolate) (Invitrogen). O meio SF900 II ${ }^{\circledR}$ utilizado por Swiech (2007), Swiech et al. (2008a,b,c) é também um meio de cultura livre de soro fetal bovino comercializado pela GIBCO (USA). O meio utilizado por Batista (2007) e Batista et al. (2006, 2008, 2009a) foi o meio IPL-41 suplementado com yeastolate (Invitrogen), carboidratos, aminoácidos, lipídios para também eliminar a necessidade de soro feral bovino presente na formulação original. A Tabela A.2 do Anexo A indica a formulação dos meios empregados. Destaque-se que a composição do meio SF900II® não é informada de modo que a composição indicada é resultado de análises feitas por Swiech (2007).

\subsection{Sistema de cultivo}

Batista (2007) utilizou spinners de $1000 \mathrm{~mL}$ de volume total e $400 \mathrm{~mL}$ de volume útil, mantidos numa plataforma magnética, sistema Cellferm®-pro (DASGIP, Jülich, Alemanha), que permitiu o controle da temperatura em $28{ }^{\circ} \mathrm{C}$, da agitação em $55 \mathrm{rpm}$ e do pH em 6,3. O oxigênio dissolvido foi mantido, dependo do ensaio, em 5\%, 20\%, 40\%, 60\%, e 95\% da saturação em ar.Os frascos foram inoculados $7,5 \times 10^{5} \mathrm{cel} / \mathrm{mL}$ (viáveis) e as células foram cultivadas por 72 horas. O controle do oxigênio dissolvido foi feito aumentando-se a vazão de borbulhamento de mistura gasosa $\left(\mathrm{O}_{2}\right.$ e $\left.\mathrm{CO}_{2}\right)$. Durante a fase exponencial de crescimento foi fornecido oxigênio puro. Os ensaios foram conduzidos em batelada. 
Galesi (2007) realizou seus ensaios em biorreator Biostat MD/CPU (B. Braun) com capacidade de 3,0 L e volume útil de 1,5 L operado em batelada e equipado com duas turbinas Rushton ou Pitched blad. A aeração foi realizada com mangueira de silicone (Si-Schlauch, com diâmetro de $3,00 \mathrm{~mm} \pm 0,20 \mathrm{~mm}$ e espessura de parede $0,30 \mathrm{~mm} \pm 0,15 \mathrm{~mm})$. O comprimento total da mangueira foi de $5 \mathrm{~m}$ e 3,5 $\mathrm{m}$ e estavam submersos no início do cultivo. A temperatura do reator foi controlada em $28{ }^{\circ} \mathrm{C}$, a agitação foi mantida entre $50 \mathrm{rpm}$ e $150 \mathrm{rpm}$ e o oxigênio dissolvido, dependendo do ensaio, controlado em $30 \%$ ou $40 \%$. A concentração do inóculo foi de $7,5 \times 10^{5} \mathrm{cel} / \mathrm{mL}$, sendo as células transferidas na fase exponencial do cultivo.

Swiech (2007) utilizou o biorreator Bioflo 110 (New Brunswick Scientific, NJ, USA) com 1L de volume útil. Biorreator estava equipado com turbina de pás retas inclinadas (pitched blade), controle de $\mathrm{pH}$, mantido em 6,20 pela adição de $\mathrm{NaOH} 0,5 \mathrm{M}$ e $\mathrm{H}_{2} \mathrm{SO}_{4}(8 \%)$. O controle de oxigênio dissolvido foi mantido em $50 \%$ da saturação em ar e a aeração do reator foi realizada por difusão do ar através de tubo de silicone e a agitação do sistema variou de $100 \mathrm{rpm}$ até um máximo de $250 \mathrm{rpm}$. Todos os experimentos foram conduzidos a $28{ }^{\circ} \mathrm{C}$ e a concentração do inóculo foi de $5,0 \times 10^{5} \mathrm{cel} / \mathrm{mL}$ e as células transferidas na fase exponencial do cultivo.

Aguiar et al. (2009) e Aguiar (2010) utilizaram biorreator (Biostat MD/CPU, B. Braun) com dorna de $3 \mathrm{~L}$ (1,5 L de volume útil), agitado a $90 \mathrm{rpm}$ por dois impelidores tipo pitched blade com duas pás e ângulo de $45^{\circ}$. A transferência de oxigênio foi feita por difusão através de membrana de silicone (Si-Schlauch, com diâmetro de 3,00 $\mathrm{mm} \pm 0,20 \mathrm{~mm}$ e espessura de parede $0,30 \mathrm{~mm} \pm 0,15 \mathrm{~mm}$ ). O comprimento total da tubulação era de $5 \mathrm{~m}$, sendo que estavam submersos no início do cultivo. O oxigênio dissolvido foi controlado através de um misturador de gases (Gas Mix Unit, B. Braun Biotech) em valores constantes de 5, 30, 50 e $80 \%$ da saturação em ar.

\subsection{Métodos analíticos}

a) Concentração celular: Determinada estatisticamente, por contagem em câmara de Neubauer e microscópio ótico (Axyovert, Zeiss) (FRESHNEY, 2005). 
b) Viabilidade: Determinada pelo método de exclusão por corante azul de Trypan 0,025\% (m/v) (modificado de FRESHNEY, 2005). Aguiar et al. (2009) e Aguiar (2010) também mediram a concentração de $\mathrm{LDH}$, usando o princípio da redução de $\mathrm{NAD}^{+}$durante a conversão de lactato a piruvato (MCQUEEN et al., 1987).

c) Concentração de glicose: Aguiar et al. (2009) e Aguiar (2010) e Galesi et al. (2008) utilizaram o método de cromatografia líquida de alta resolução (HPLC) realizado em equipamento da marca Waters (MA) com detector de índice de refração (W410 ou W2414), injetor automático (W717), software Millenium 3.20, pré-coluna Shodex SC-G e coluna Shodex SC 1011. A temperatura do forno foi de $72^{\circ} \mathrm{C}$ e a fase móvel EDTA $0,01 \mathrm{~N}$, com vazão de 0,6 mL/min. Para a desproteinização das amostras, utilizou-se TCA, $240 \mathrm{~g} / \mathrm{L}$, numa proporção de 4:1 (amostra: ácido tricloroacético). Batista (2007) também fez as determinações de glicose, frutose e lactose por cromatrografia líquida de alta resolução (HPLC) usando a coluna Bio-Rad HPX-87H acoplada a uma bomba de fase móvel e gradiente (Waters 600 E), Autosampler (Waters 717plus) e refratômetro diferencial (Waters 410). Swiech et al. (2008b) fizeram a determinação de glicose enzimaticamente com Analisador Bioquímico YSI (modelo 2700).

d) Concentração de lactato: Aguiar et al. (2009) e Galesi et al. (2008) usaram a mesma metodologia de desproteinização e o mesmo sistema Waters indicado no item c), com précoluna Shodex SH-G e coluna Shodex SH1011, para determinar lactato. A temperatura do forno foi mantida em $60{ }^{\circ} \mathrm{C}$ e a do detector em $45^{\circ} \mathrm{C}$. A fase móvel utilizada foi $\mathrm{H}_{2} \mathrm{SO}_{4} 0,1 \mathrm{~N}$, na vazão de 1,0 mL/min. Batista et al. (2008) e Swiech et al. (2008b) fizeram a determinação de lactato enzimaticamente com Analisador Bioquímico YSI (modelo 2700).

e) Concentração de amônio. Em todos os trabalhos utilizou-se um potenciômetro (Mettler) e um eletrodo específico (9512, Orion) (Aguiar, 2010).

f) Concentração de aminoácidos: Galesi et al. (2008) e Swiech et al. (2008b) fizeram a determinação de glutamina e glutamato enzimaticamente com Analisador Bioquímico YSI (modelo 2700). Os demais aminoácidos foram determinados por Batista et al. (2008) e Swiech et al. (2008b) pelo sistema Pico TagTM que constitui um sistema de cromatografia de alta resolução com coluna de fase reversa (Waters).

Aguiar (2010) determinou a concentração de aminoácidos foi realizada por cromatografia líquida de alta resolução (HPLC) em um equipamento com bomba modelo GP40 (Dionex, 
EUA), detector de absorbância modelo AD20 (Dionex, Sunnyvale, C.A., EUA), injetor automático modelo SpectraSeries AS100 (ThermoSeparations Products, EUA) com loop de $50 \mu \mathrm{L}$, forno para colunas, reator modelo PCX 3100 (Pickering Lab., Mountain View, C.A., EUA) e o programa de integração Peaknet v. 5.1 (Dionex, EUA). O sistema de colunas era composto de uma pré-coluna de lítio de 2x20mm (Pickering Lab., EUA) e de uma coluna High Efficiency Lithium 3x150mm (Pickering Lab., EUA).

A metodologia utilizada por Aguiar (2010) foi a de derivação pós-coluna a $130{ }^{\circ} \mathrm{C}$, com ninidrina (Treone T200, Pickering Lab., EUA). A eluição foi realizada pela variação do pH com os tampões Li280 pH 2,8 e Li 750 pH 7,5 (Pickering Lab., EUA). Tanto a vazão da fase móvel, quanto à de ninidrina foram de $0,3 \mathrm{~mL} / \mathrm{min}$. A pré-coluna e a coluna eram mantidas a $45^{\circ} \mathrm{C}$.

Antes de aplicadas ao cromatógrafo, as amostras eram diluídas com água Milli-Q. Em seguida, tomava-se $1 \mathrm{~mL}$ da solução diluída e adicionava-se $0,6 \mathrm{~mL}$ do reagente Seraprep (Pickering Lab., EUA) e 0,4 mL de solução de padrão interno (D,L-Homoscitina 0,25 g/L). A solução era homogeneizada e o $\mathrm{pH}$, corrigido para a faixa de 1,9 a 2,1 com NaOH 4N (Merck, Brasil). As amostras eram, então, centrifugadas a $10.000 \mathrm{rpm}$, por 10 minutos, à temperatura ambiente. O sobrenadante era filtrado em filtro de porosidade 0,45 $\mu \mathrm{m}$ (Millipore, Brasil) antes da injeção na coluna cromatográfica.

Para cada rodada de análises uma nova curva de calibração era realizada, procedendo-se às diluições necessárias a partir de uma solução mãe contendo todos os aminoácidos de interesse (todos da marca Sigma, EUA). Feito isso, tomava-se $1 \mathrm{~mL}$ de cada diluição e adicionava-se 0,6mL do reagente Lithium Diluent Li220 (Pickering Lab., EUA) e 0,4mL do padrão interno (D,L-Homocistima $0,25 \mathrm{~g} / \mathrm{L}$ ). Cada padrão era então filtrado com membrana de porosidade $0,45 \mu \mathrm{m}$ (Millipore, Brasil). Os padrões obtidos tinham as seguintes concentrações $(\mathrm{mg} / \mathrm{L})$ : 4,38 a 35 para Ácido Aspártico; 4,38 a 35 para L-Asparagina; 25 a 200 para L-Alanina; 8,5 a 67,5 para L-Arginina.HCl; 43,8 a 350 para L-Glutamina; 46,3 a 370 para L-Histidina; 0,625 a 5,0 para L-Isoleucina; 0,938 a 7,5 para L-Leucina; 7,81 a 62,5 para L-Lisina.HCl; 0,625 a 5,0 para L-Metionina; 1,88 a 15,0 para L-Fenilalanina; 4,38 a 35 para L-Prolina; 6,9 a 55 para LSerina; 2,2 a 17,5 para L-Treonina; 1,25 a 10 para L-Triptofano; 1,25 a 10 para L-Valina; 0,375 a 3,0 para L-Cistina.2HCl; 0,938 a 7,5 para L-Tirosina. $2 \mathrm{Na}^{2} 2 \mathrm{H}_{2} \mathrm{O} ; 37,5$ a 300 para LÁcido Glutâmico e 40,6 a 325 para Glicina. 
g) Concentração da glicoproteína do vírus da raiva (GPV A detecção da glicoproteína do vírus da raiva (GPV) foi realizada por Aguiar (2010) utilizando o teste do tipo ELISA (EnzymeLinked Immuno Sorbent Assay) e que emprega o kit Rabies Glycoprotein Enzyme Immunoassay (Instituto Pasteur, França), conforme descrito por Astray et al. (2008)).

Amostras de células do biorreator eram tratadas e armazenadas segundo o tratamento indicado na Tabela 4.1. Para análise da proteína, as amostras contendo $10^{6}$ células totais eram centrifugadas a $250 \mathrm{~g}$, por 5 minutos, a temperatura ambiente. O sobrenadante era descartado e o pellet, rompido, utilizando-se um tampão de lise $(25 \mathrm{mM}$ Tris, $25 \mathrm{mM} \mathrm{NaCl}, 5 \mathrm{mM}$ $\mathrm{MgCl}_{2}$ ) a um $\mathrm{pH}$ de 7,4. Após a homogeneização, as amostras eram incubadas a $4{ }^{\circ} \mathrm{C}$, durante 1 hora, com agitação periódica.

Tabela 4.1. Tratamento utilizado para extração de GPV de uma amostra celular.

\section{TRATAMENTO}

\begin{tabular}{cl}
\hline Quantidade de Células & $10^{6}$ células \\
\hline Centrifugação & $250 \mathrm{~g}, 5$ minutos, temperatura ambiente. \\
& (Subseqüente descarte do sobrenadante). \\
\hline Ressuspensão de células & $500 \mu \mathrm{L}$ de solução tampão com 25mM \\
& TRIS (Merck, Rio de Janeiro, R.J., \\
& Brasil), $25 \mathrm{mM} \mathrm{NaCl} \mathrm{(Sigma,} \mathrm{EUA)} \mathrm{e} \mathrm{5}$ \\
& $\mathrm{mM} \mathrm{MgCl}_{2} \quad$ (Sigma, EUA), 20\% de \\
& glicerol (Merck, EUA) e $1 \mathrm{mM}$ de PMSF \\
& $($ Fluka, EUA)
\end{tabular}

Armazenamento $-20{ }^{\circ} \mathrm{C}$

FONTE: Aguiar (2010)

Após o procedimento de lise, as amostras eram centrifugadas a 10,000 g durante 5 minutos, para a remoção de debris celulares e os sobrenadantes eram analisados com o kit.

A análise fornecia a quantidade de proteína presente em $10^{6}$ células $\left(\mathrm{GPV}_{\mathrm{E}}\right)$. A concentração de GPV era calculada de acordo com a seguinte equação:

$$
G P V=\left(G P V_{E}\right)_{t} \cdot\left(X_{T}\right)_{t}
$$


na qual GPV é a concentração de proteína $(\mathrm{ng} / \mathrm{mL}), \mathrm{GPV}_{\mathrm{E}}$ é o teor celular de GPV (ng/10 ${ }^{7}$ células), $\mathrm{X}_{\mathrm{T}}$ é a concentração total de células no cultivo e "t" é o instante de tempo considerado.

\subsection{Estimativa inicial de parâmetros.}

\subsubsection{Determinação preliminar da velocidade específica de crescimento $\left(\mu_{\max }\right)$, duração} da fase lag $\left(t_{\text {lag }}\right)$ e duração da fase exponencial $\left(t_{\text {exp }}\right)$

Para a análise da ocorrência de limitação por substratos ou inibição por metabólitos é necessário uma análise preliminar da dinâmica do cultivo para identificar os principais fenômenos a serem considerados e que constituirão as hipóteses de trabalho para a construção do modelo cinético do processo. As três grandezas cinéticas indicadas auxiliam essa análise e são determinadas a partir da curva de crescimento como indica a Figura 4.1, $\mu_{\max }$, por regressão linear logarítmica e $t_{\text {lag }}$ e $t_{\text {exp }}$, visualmente.

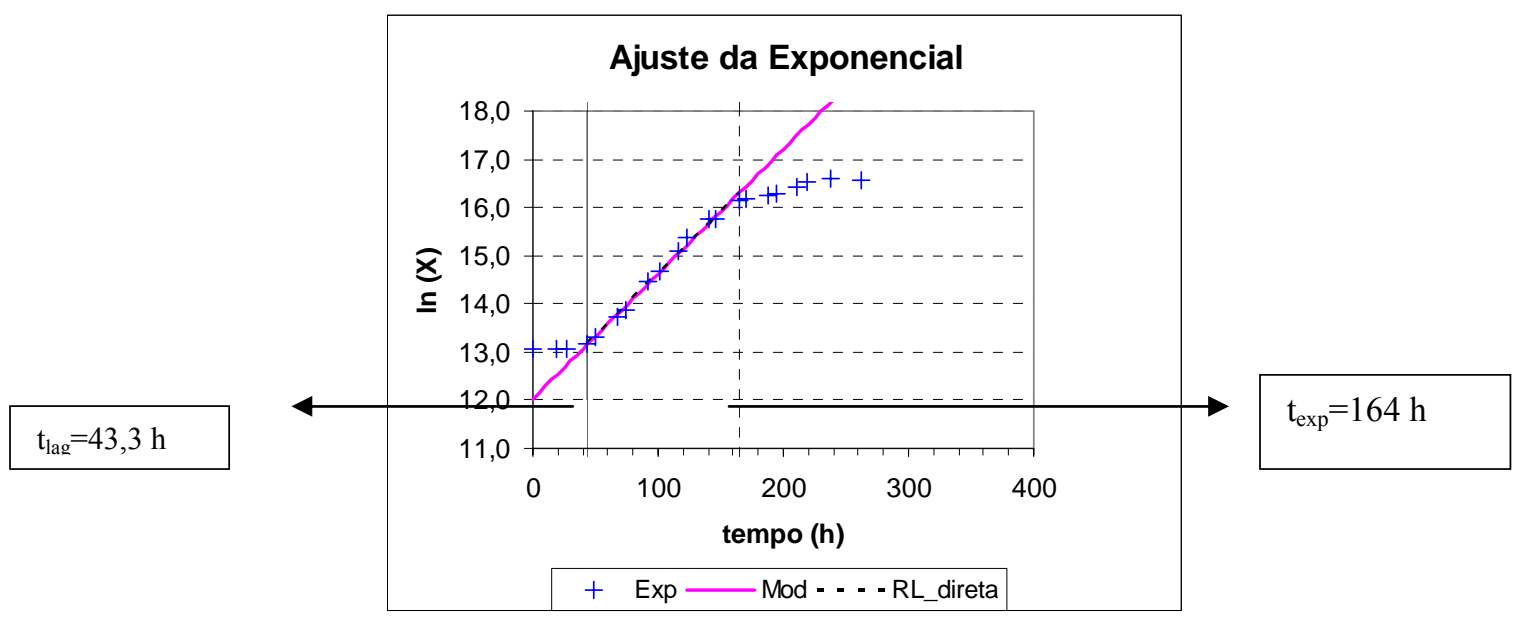

Figura 4.1. Determinação da velocidade esepcífica máxima de crescimento $\left(\mu_{\mathrm{Xmax}}\right)$, instante final da fase de crescimento lag $\left(t_{\text {lag }}\right)$, instante final da fase de crescimento exponencial $\left(t_{\exp }\right)$. RL- Regressão linear. Ensaio RE-5, Quadro A.1, Anexo A) 
4.5.2. Determinação do tempo transcorrido até o final do crescimento celular $\left(t_{\text {fim }}\right)$ e do tempo transcorrido até início de morte celular $\left(\mathbf{t}_{\text {morte }}\right)$

Esses dois instantes serão importantes para relacionar esgotamentos de substratos ou acúmulo de produtos com o fim do crescimento e com a morte celular. Essa determinação, assim como a de $t_{\text {lag }}$ e $t_{\text {exp }}$, é visual como ilustra a Figura 4.2

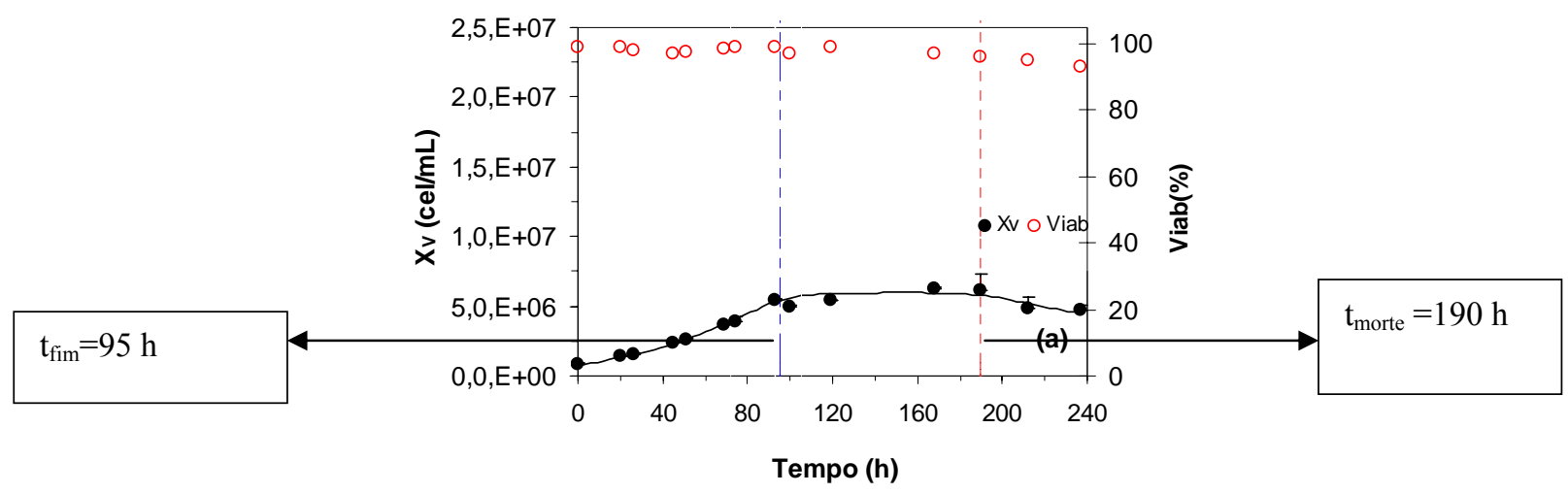

Figura 4.2. Determinação do tempo transcorrido até o final do crescimento celular $\left(\mathrm{t}_{\text {fim }}\right)$ e do tempo transcorrido até início de morte celular $\left(\mathrm{t}_{\text {morte }}\right)$ (Ensaio Ma-05, Quadro A.1, Anexo A).

\subsubsection{Determinação do tempo para que ocorra redução no teor de GPV por $10^{7}$ células,} $\mathbf{t}_{\text {GPVEmax }}$ e do tempo transcorrido até se atingir a concentração máxima de GPV, $\mathbf{t}_{\mathrm{GPV} \text { max}}$.

Como nos casos anteriores, essa determinação é visual, como indica a Figura 4.3

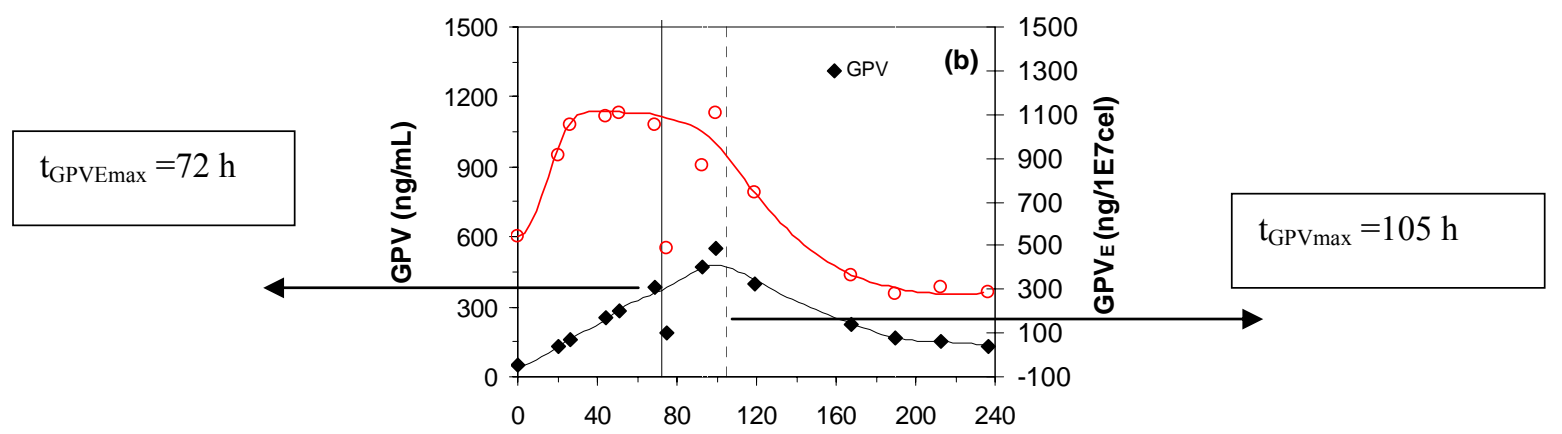

Figura 4.3. Determinação de tempo para que ocorra redução no teor de GPV por $10^{7}$ células, $\left(\mathrm{t}_{\mathrm{GPVEmax}}\right)$ e do tempo transcorrido até se atingir a concentração máxima de GPV ( $\left.\mathrm{t}_{\mathrm{GPV} \max }\right)$. (Ensaio Ma-06, Anexo A, Quadro A.1). 


\subsubsection{Determinação preliminar dos fatores de conversão e de formação, $Y$}

Os fatores de conversão $Y_{\mathrm{X} / \mathrm{GLC}}, \mathrm{Y}_{\mathrm{X} / \mathrm{GLN}}, \mathrm{Y}_{\mathrm{NH} 4 / \mathrm{X}}, \mathrm{Y}_{\mathrm{GPV} / \mathrm{X}}, \mathrm{Y}_{\mathrm{NH} 4 / \mathrm{GLN}}, \mathrm{Y}_{\mathrm{GPV} / \mathrm{GLC}}, \mathrm{Y}_{\mathrm{ALA} / \mathrm{GLC}}$, $\mathrm{Y}_{\mathrm{ALA} / \mathrm{GLN}}$ caracterizam relações estequiométricas do processo em andamento. A estimativa preliminar desses parâmetros do modelo foi feita por regressão linear entre as variáveis envolvidas na fase exponencial do crescimento, como exemplificado na Figura 4.4 para o caso do $\mathrm{Y}_{\mathrm{GPV} / \mathrm{X}}$.

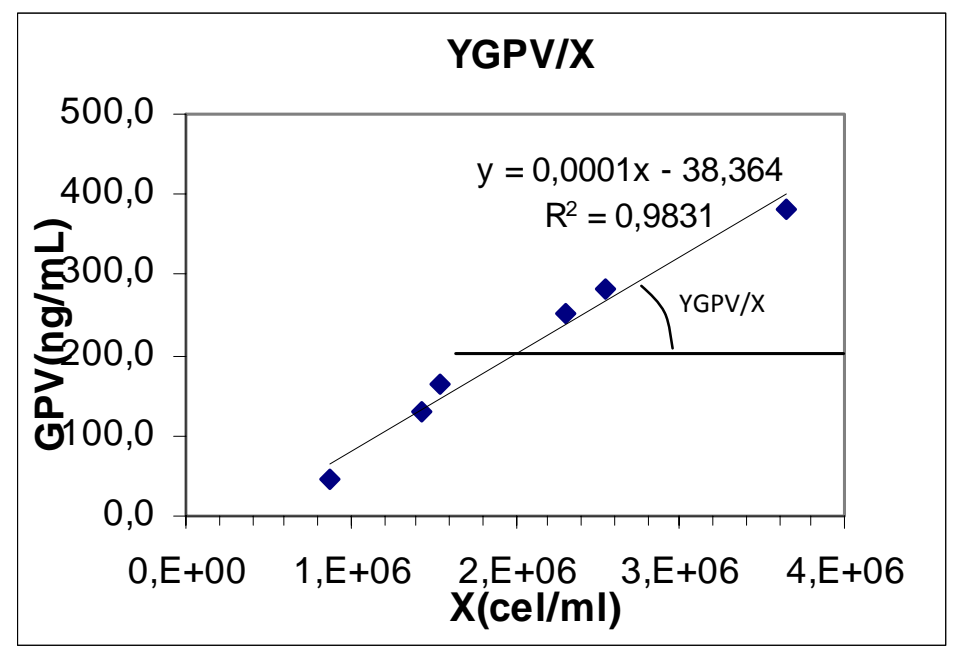

Figura 4.4. Exemplo da determinação de fator de rendimento $\mathrm{Y}_{\mathrm{GPV} / \mathrm{X}}$ (Ensaio Ma-06, Quadro A.1, Anexo A).

\subsection{Métodos numéricos.}

A resolução do conjunto de equações diferenciais não-lineares que representam a dinâmica do processo foi realizada com a sub-rotina SDRIVE que utiliza o método de GEAR para problemas de formulação rígida - stiff problems (KAHANER, 1989). O ajuste dos parâmetros das equações diferenciais foi realizado minimizando-se a diferença entre as previsões do modelo e os resultados experimentais, por meio de programa de otimização que utiliza uma subrotina baseada no algoritmo dos poliedros flexíveis proposta por e Nelder e Mead (1965), revisto por Himmelblau (1970) e implementado em linguagem FORTRAN por Bonomi et al.(1999). 


\subsubsection{Função objetivo (FO).}

A função objetivo utilizada para o ajuste dos parâmetros foi a somatória quadrática dos desvios, diferença entre o valor previsto pelo modelo e o valor experimental da variável, normalizada pelo valor médio entre esses dois valores (Equação 4.2).

$$
F O=S S R=\sum_{j=1}^{n v} \sum_{t i=1}^{n} \sum_{t=1}^{m}\left(\frac{\mathbf{Y}(t, i, j)-\hat{\mathbf{Y}}(t, i, j)}{\frac{\mathbf{Y}(t, i, j)+\hat{\mathbf{Y}}(t, i, j)}{2}}\right)^{2}
$$

Na Equação 4.1 os símbolos utilizados têm os seguintes significados:

$\mathbf{Y}(\mathrm{t}, \mathrm{i}, \mathrm{j})$ : valor da variável $\mathrm{j}$, no ensaio i e no instante $\mathrm{t}$,

$\hat{\mathbf{Y}}(t, i, j)$ : valor simulado da variável $\mathbf{j}$, no ensaio i e no instante $\mathrm{t}$,

\subsubsection{Avaliação do ajuste.}

Os resultados da modelagem são avaliados num primeiro momento pela soma quadrática dos resíduos adimensionalizados, que é a função objetivo, Equação (4.2), e pela comparação dos gráficos das previsões do modelo com os dados experimentais.

Para cada ajuste, calculou-se o coeficiente angular (CA) e o coeficiente de correção $\left(\mathrm{R}^{2}\right)$ para acurva $\mathrm{Y}(\mathrm{t}, \mathrm{i}, \mathrm{j})$ vs $\mathrm{Y}(\mathrm{t}, \mathrm{i}, \mathrm{j})$ construída com todos os pontos usados no ajuste. Os valores obtidos eram comparados com os valores ótimos $\left(\mathrm{CA}=1\right.$ e $\left.\mathrm{R}^{2}=1\right)$.

Contudo, a validação do modelo, ou seja, a avaliação criteriosa se o modelo ajusta-se adequadamente aos dados experimentais é realizada pela aplicação da metodologia estatística proposta por Froment e Hosten (1981) e Volestrky e Votruba (1992) e utilizada por Ferraz (1999) e Suárez (2002). O conceito básico utilizado nessa metodologia para o teste de adequação do modelo consiste em considerar que o resíduo quadrático mínimo, dividido pelo número de graus de liberdade do modelo, é uma estimativa não-viciada da variância do erro experimental. Um modelo não-adequado gera uma variância maior que a variância do erro experimental, uma vez que ela representa a estimativa da variância do erro experimental mais 
o desvio sistemático do modelo aos dados, também chamado de falta de ajuste do modelo (lack off fit, LOF).

A soma quadrática dos resíduos do modelo $\mathrm{SS}_{\mathrm{E}}$ é calculada pela Equação 4.3.

$S S_{E}=s_{i}^{2}=\frac{\sum_{j=1}^{n v} \sum_{t i=1}^{n} \sum_{t=1}^{m}\left(\frac{\mathbf{Y}(t, i, j)-\hat{\mathbf{Y}}(t, i, j)}{\frac{\mathbf{Y}(t, i, j)+\hat{\mathbf{Y}}(t, i, j)}{2}}\right)^{2}}{N p-p}$

Na qual,

$\mathbf{N}_{\mathbf{p}}$ : número de pontos experimentais,

$\mathbf{Y}(\mathrm{t}, \mathrm{i}, \mathrm{j})$ : valor da variável $\mathrm{j}$, no ensaio i e no instante $\mathrm{t}$,

$\hat{\mathbf{Y}}(t, i, j)$ : valor simulado da variável $\mathrm{j}$, no ensaio i e no instante $\mathrm{t}$,

p: número de parâmetros

A estimativa da variância experimental é feita realizando-se médias experimentais de ensaios padrão, ou seja, por medida das variáveis experimentais em replicatas de ensaios mantidos em condições de cultivo consideradas como padrão. A variância experimental é calculada pela Equação 4.4;

$$
\mathrm{SS}_{\mathrm{PE}}=\frac{\sum \sum_{t=0}^{m} \sum_{j=1}^{n}\left[\frac{\mathbf{Y}(t, i, j)-\overline{\mathbf{Y}}(i, j)}{\mathbf{Y}(t, i, j)+\overline{\mathbf{Y}}(i, j)}\right]^{2}}{N_{p}-N_{m}}
$$

Nessa equação,

$\mathbf{Y}(t, i, j)$ : valor da variável $\mathrm{j}$, no ensaio i e no instante $t$,

$\overline{\mathbf{Y}}(i, j)$,: vetor das medias das variáveis medidas no instante $\mathrm{t}$,

$\mathbf{N}_{\mathrm{p}}$ : número total de pontos experimentais,

$\mathbf{N}_{\mathrm{m}}$ : número total de médias de réplicas. 
A soma quadrática dos resíduos, $\mathrm{SS}_{\mathrm{E}}$, pode ser dividida em duas fontes de variação: a variação entre as repetições da variável Y nos pontos na qual foi medida, também chamada de erro puro, $\mathrm{SS}_{\mathrm{PE}}$, e a variação proveniente da falta de adequação do modelo aos dados experimentais, também denominada falta de ajuste (lack off it), $\mathrm{SS}_{\mathrm{LOF}}$. Assim, tem-se:

$\mathrm{SS}_{\mathrm{E}}=\mathrm{SS}_{\mathrm{PE}}+\mathrm{SS}_{\mathrm{LOF}}$

A variância devido à falta de ajuste é calculada rearranjando-se a Equação 4.5:

$\mathrm{SS}_{\mathrm{LOF}}=\mathrm{SS}_{\mathrm{E}}-\mathrm{SS}_{\mathrm{PE}}$

Obtendo-se a variância devido à falta adequação do modelo, $\mathrm{SS}_{\mathrm{LOF}}$, é possível obter a relação $\mathrm{F}_{\mathrm{i}}=\mathrm{SS}_{\mathrm{LOF}} / \mathrm{SS}_{\mathrm{PE}}$ que é uma variável aleatória com distribuição $\mathrm{F}$ com $\mathrm{N}_{\mathrm{p}}-\mathrm{p}$ e $\mathrm{N}_{\mathrm{m}}-\mathrm{N}_{\mathrm{p}}$ graus de liberdade. A adequação do modelo é testada comparando-se os valores de Fi com valor correspondente valor da função F obtida com os correspondentes graus de liberdade e com grau de significância $\alpha$.O modelo na qual $F_{i}$ é maior que $F(N p-p ; N p-N m ; 1-\alpha)$ não representa adequadamente o processo (FROMENT; HOSTEN, 1981). 


\section{RESULTADOS E DISCUSSÃO}

A modelagem matemática do crescimento das células S2AcGPV2 e a da formação da glicoproteína do vírus rábico (GPV) leva a um conjunto mínimo de relações matemáticas que representam a dinâmica do processo e, dessa forma, sintetizam o conhecimento experimental. Essa modelagem é um processo dinâmico e interativo, realizado com auxílio de dados experimentais e hipóteses de trabalho, estas últimas baseadas nas características de um problema real. A modelagem é sempre uma aproximação da realidade e, assim, os conteúdos, a linguagem e os recursos matemáticos necessários devem estar em equilíbrio com os objetivos que se espera do modelo. Baseado em Bassanezi (2002) é possível indicar as principais etapas na formulação de um modelo validado, conforme indica Figura 5.1.

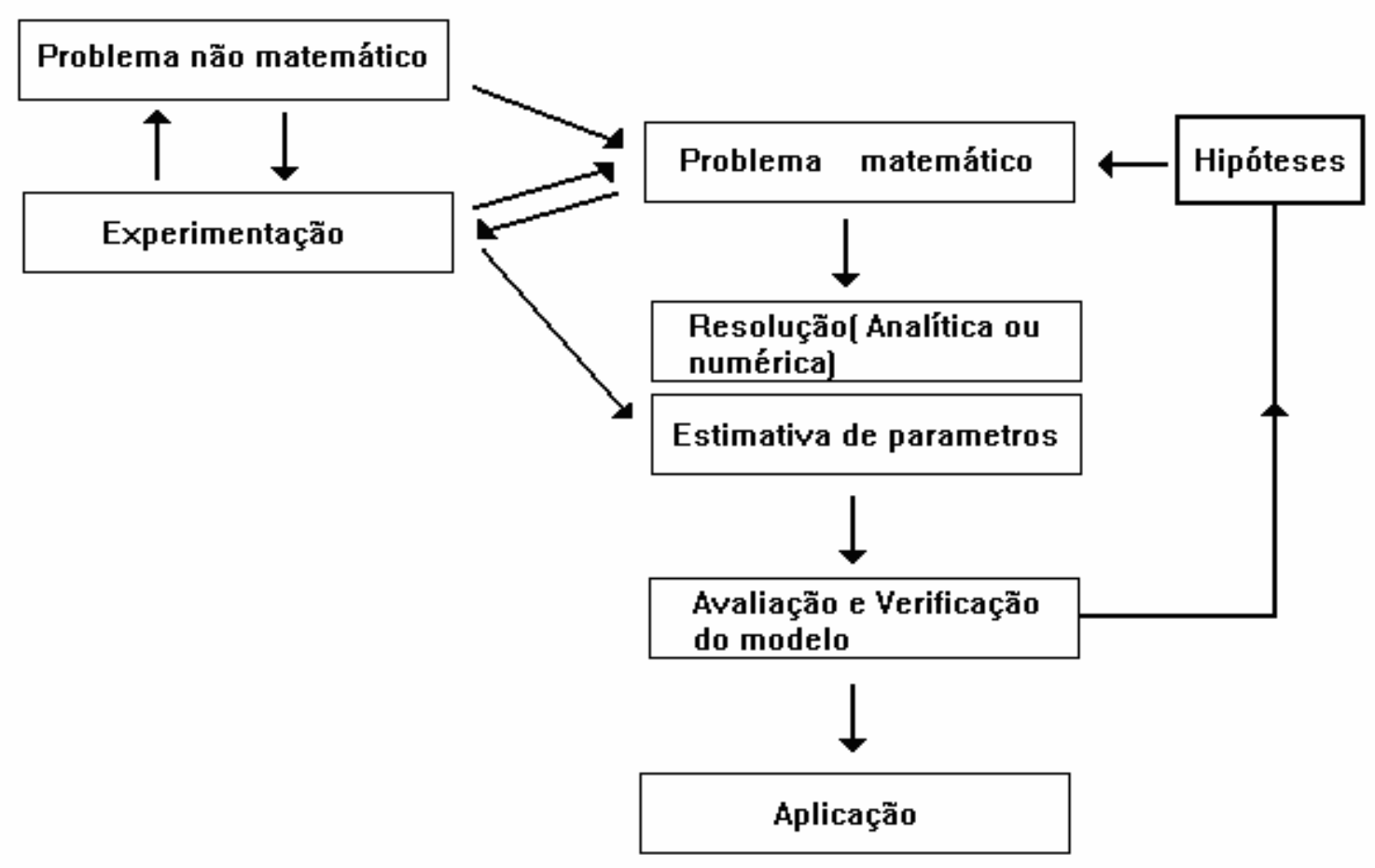

Figura 5.1. Principais etapas da modelagem matemática. FONTE: baseado em Bassanezi (2002)

No estudo de uma situação-problema, como o crescimento celular e formação de uma proteína, é necessário transformar o problema original, problema não-matemático, em um problema matemático, ou seja, é necessário estabelecer relações matemáticas entre as variáveis características do processo. Essas relações decorrem da aplicação de balanços materiais e da utilização de certos modelos cinéticos, admitidos como válidos. O problema matemático resultante é constituído por um conjunto de equações que indicam como 
substratos e produtos variam no tempo. Evidentemente existe uma interdependência entre hipóteses necessárias à formulação do problema matemático e a experimentação, pois esta última pode confirmar ou negar as hipóteses admitidas.

As hipóteses de trabalho constituem, por sua vez, a base fundamental da transformação de um problema não-matemático em um problema matemático. As hipóteses constituem expectativas fundamentadas sobre o problema em estudo e partem de um referencial teórico, ou de forma mais geral, de paradigmas estabelecidos no campo de estudo no qual o problema está enquadrado. As hipóteses constituem, portanto, um conjunto de pressupostos que permitem definir as variáveis relevantes e as relações entre elas que deverão ser avaliadas fazendo-se a comparação entre as previsões do modelo formulado e os resultados experimentais. A partir da avaliação dos resultados, ou de forma mais rigorosa, de testes estatísticos de validação do modelo, pode-se aceitar o modelo como uma descrição adequada dos fenômenos observados ou concluir pela inadequação do modelo proposto e pela necessidade de adotar novas hipóteses que modificarão o modelo proposto.

No caso em estudo, o problema matemático é constituído por um conjunto de equações diferenciais não-lineares que representam a dinâmica do processo. A solução do problema significa, portanto, a integração numérica do conjunto dessas equações. Os resultados da modelagem são avaliados, num primeiro momento, pela soma quadrática dos resíduos adimensionalizada, SSR, (ver item 4.6.2), e pela comparação gráfica das previsões do modelo com os dados experimentais.

No desenvolvimento deste trabalho houve uma sequência que levou à utilização de diferentes conjuntos de dados e formulações de modelos a ser destacada para auxiliar na compreensão da evolução deste trabalho.

O primeiro conjunto de dados utilizados foram os obtidos por Batista (2007), Galesi (2007) e Swiech (2007), pesquisadores do projeto temático que desenvolveram estudos de avaliação da influência dos meios de cultura no crescimento e fisiologia da célula S2AcGPV2. Esses dados permitiram uma primeira compreensão do problema, o equacionamento de modelos e, ainda, permitiram a análise preliminar de parâmetros e grandezas cinéticas.

Para o ajuste desses modelos foram utilizados os ensaios realizados por Aguiar et al. (2009) e Aguiar (2010), mais especificamente, os ensaios Ma-02 a Ma-06 com cultivos da célula 
S2AcGPV2-KTC100 e Ma-07 a Ma-10 com a célula S2AcGPV2. Os modelos desta etapa serão aqui considerados modelos e ajustes preliminares.

Num outro momento, em função de novos ensaios realizados por Aguiar (2010), foram feitas alterações e novas proposições aos modelos que consideraram a influência das condições de cultivo em particular, da concentração de $\mathrm{pO}_{2}$. Os ensaios utilizados nessa etapa foram os ensaios Ma-02 e Ma-03 com a S2AcGPV2-KTC100 e os ensaios Ma-07 a Ma-10 com a célula S2AcGPV2 e correspondem aos modelos que incorporam essas influências nos fatores de conversão influenciados pelo teor de oxigênio dissolvido.

Finalmente, já dispondo de todo o conjunto de ensaios realizados por Aguiar (2010) com a célula S2AcGPV2 e, em especial, dispondo das análises de aminoácidos, foram estudados novos fenômenos do cultivo e ampliado o entendimento da influência das condições de cultivo, especialmente das concentrações de glicose e glutamina no metabolismo do processo. Os ensaios utilizados nesta etapa para formulação de modelo e ajuste de parâmetros foram os ensaios Ma-07 a Ma-17 com a célula S2AcGPV2. Os modelos formulados serão considerados os mais completos, pois, além das correções do fator de conversão por oxigênio, os modelos também incorporam a influência de glicose e glutamina nos fatores de conversão e incorporam na dinâmica do cultivo, ainda, alterações de metabolismo em função das concentrações de glicose e glutamina.

\subsection{Modelos preliminares}

O primeiro entendimento do projeto temático considerava que a modelagem matemática seria realizada a partir dos dados obtidos pelos outros grupos participantes do projeto cujos objetivos não eram a modelagem matemática do processo, mas estudar meios de cultura adequados (BATISTA, 2007; GALESI, 2007) ou aspectos do crescimento e fisiologia da célula (SWIECH, 2007). Esses dados permitiram uma primeira compreensão do problema e um primeiro equacionamento do modelo. Permitiram, ainda, a análise preliminar de grandezas cinéticas. Considerando os valores de algumas dessas grandezas características do cultivo das células S2AcGPV, tais como a velocidade específica de crescimento, a concentração máxima de GPV, o teor máximo de GPV (massa de GPV em $10^{7}$ células máxima, GPV $V_{\mathrm{E}, \max }$ ), valores indicados na Tabela 5.1, observava-se uma grande variação nos valores encontrados, especialmente nas grandezas relacionadas a GPV. 
Tabela 5.1. Variação dos parâmetros de cultivo das células S2AcGPV2 e S2AcGPV2-KTC100.

\begin{tabular}{|c|c|c|c|c|c|c|c|c|c|c|c|c|c|}
\hline \multirow{2}{*}{$\begin{array}{l}\text { Fonte, meio de } \\
\text { cultura, célula, } \\
\text { método GPV }\end{array}$} & \multirow[b]{2}{*}{ Ensaio } & \multicolumn{4}{|c|}{$\mu_{\mathrm{X} \max }\left(\mathrm{h}^{-1}\right)$} & \multicolumn{4}{|c|}{$\operatorname{GPV}_{\text {Max }}(\mathrm{ng} / \mathrm{mL})$} & \multicolumn{4}{|c|}{$\operatorname{GPV}_{E, M a x}(n g / m L)$} \\
\hline & & Valor & Média & DP & $\begin{array}{l}\text { CV } \\
(\%)\end{array}$ & Valor & Média & DP & $\begin{array}{c}\text { CV } \\
(\%)\end{array}$ & Valor & Média & DP & $\begin{array}{l}\text { CV } \\
(\%)\end{array}$ \\
\hline \multirow{5}{*}{$\begin{array}{l}\text { Galesi (2007), } \\
\text { TC100, } \\
\text { S2AcGPV2, } \\
\text { GPV }^{(\mathbf{1})}\end{array}$} & RE-01 & $1,73 \mathrm{E}-02$ & \multirow{5}{*}{$2,26 \mathrm{E}-02$} & \multirow{5}{*}{ 4,79E-03 } & \multirow{5}{*}{21,1} & 98,2 & \multirow{5}{*}{118,3} & \multirow{5}{*}{57,6} & \multirow{5}{*}{48,6} & 359 & \multirow{5}{*}{331} & \multirow{5}{*}{$1,37 \mathrm{E}+02$} & \multirow{5}{*}{41,5} \\
\hline & RE-02 & 1,93E-02 & & & & 199 & & & & 397 & & & \\
\hline & RE-03 & $2,17 \mathrm{E}-02$ & & & & 44,5 & & & & 88,3 & & & \\
\hline & RE-04 & 2,90E-02 & & & & 105 & & & & 406 & & & \\
\hline & RE-05 & $2,59 \mathrm{E}-02$ & & & & 145 & & & & 406 & & & \\
\hline \multirow{4}{*}{$\begin{array}{l}\text { Swiech (2007), } \\
\text { SF900 II, } \\
\text { S2AcGPV2, } \\
\text { GPV }^{(\mathbf{1})}\end{array}$} & Bio_02 & $4,30 \mathrm{E}-02$ & \multirow{4}{*}{$4,35 \mathrm{E}-02$} & \multirow{4}{*}{$5,54 \mathrm{E}-03$} & \multirow{4}{*}{12,7} & 13,4 & \multirow{4}{*}{12,0} & \multirow{4}{*}{3,68} & \multirow{4}{*}{30,8} & 80,2 & \multirow{4}{*}{47,2} & \multirow{4}{*}{$3,00 \mathrm{E}+01$} & \multirow{4}{*}{63,6} \\
\hline & Bio_03 & $4,43 \mathrm{E}-02$ & & & & 7,00 & & & & 55,8 & & & \\
\hline & Bio_04 & $3,66 \mathrm{E}-02$ & & & & 15,7 & & & & 8,13 & & & \\
\hline & Bio_05 & $5,01 \mathrm{E}-02$ & & & & 11,7 & & & & 44,5 & & & \\
\hline \multirow{5}{*}{$\begin{array}{l}\text { Batista (2007), } \\
\text { IPL 41, } \\
\text { S2AcGPV2, } \\
\text { GPV }^{(1)}\end{array}$} & $5 \%$ & 2,89E-02 & \multirow{5}{*}{$2,60 \mathrm{E}-02$} & \multirow{5}{*}{$6,18 \mathrm{E}-03$} & \multirow{5}{*}{23,8} & 23,2 & & & & 61,2 & \multirow{5}{*}{56,1} & & \\
\hline & $20 \%$ & $2,00 \mathrm{E}-02$ & & & & 26,6 & & & & 62,8 & & & 104 \\
\hline & $40 \%$ & 1,94E-02 & & & & 30,9 & 18,5 & 11,9 & 64,3 & 66,8 & & $1,09 \mathrm{E}+01$ & 19,4 \\
\hline & $60 \%$ & 3,39E-02 & & & & 5,70 & & & & 49,8 & & & \\
\hline & $95 \%$ & $2,76 \mathrm{E}-02$ & & & & 5,90 & & & & 40,3 & & & \\
\hline Aguiar (2010), & Ma-02 & $2,50 \mathrm{E}-02$ & & & & 1092 & & & & 661 & & & \\
\hline TC100, & Ma-03 & $2,87 \mathrm{E}-02$ & $2,44 \mathrm{E}-02$ & $3.78 \mathrm{E}-03$ & 15,5 & 1124 & 712 & 474 & 66.6 & 1180 & 895 & $2,79 \mathrm{E}+02$ & 31,1 \\
\hline $\begin{array}{l}\text { S2AcGPV2-K TCI00, } \\
\text { GPV (2) }\end{array}$ & Мa-04 & $2,43 \mathrm{E}-02$ & & & & 163 & & & & 652 & & & \\
\hline GPV(2) & Ma-06 & $1,95 \mathrm{E}-02$ & & & & 469 & & & & 1089 & & & \\
\hline Aguiar (2010), & Мa-07 & $2,63 \mathrm{E}-02$ & & & & 1108 & & & & 2140 & & & \\
\hline TC100, & Ma-08 & $2,40 \mathrm{E}-02$ & & & & 1021 & & & & 2800 & & & \\
\hline S2AcGPV2, & Мa-09 & $2,80 \mathrm{E}-03$ & $2,00 \mathrm{E}-02$ & $1,16 \mathrm{E}-02$ & $5 /, 1$ & 177 & $8 / 8$ & $4 / 3$ & 53,9 & 2090 & 2181 & $4,51 E+U 2$ & 20,6 \\
\hline $\mathrm{GPV}^{(}$ & Ma-10 & $2,70 \mathrm{E}-02$ & & & & 1205 & & & & 1716 & & & \\
\hline
\end{tabular}

Obs. DP = desvio padrão; CV = coeficiente de variação $=100^{*} \mathrm{DP} / \mathrm{Média} ; \mathrm{GPV}^{(\mathbf{1})}=$ determinação de GPV inicial $; \mathrm{GPV}{ }^{(2)}$ determinação de $\mathrm{GPV}$ com alteração na preparação do pellet celular (ASTRAY et al., 2008). 
Essa variação dos valores pode ser explicada pela evolução na metodologia analítica havida ao longo dos trabalhos, por exemplo, na extração de GPV e preparação de pellet para quantificação da proteína, e que afetou os principalmente os primeiros resultados. Também podem ser explicados pela capacidade de ajuste metabólico da célula S2 às condições ambientais do cultivo.

Esse importante aspecto do cultivo das células S2 já foi indicado por Bovo et al. (2008) que justificaram essas variações das velocidades específicas, das concentrações máximas de GPV e dos fatores de conversão/formação como decorrência da adaptação do metabolismo das células $D$. melanogaster, $\mathrm{S} 2$, às condições ambientais dos cultivos em função de adaptação e seleção de subpopulações aos diferentes meios utilizados. A variação de resultados exige cuidados especiais na escolha dos dados a serem utilizados para definição e ajuste do modelo. Uma vez que o conjunto de ensaios apresentava as maiores concentrações de GPV, objetivo fundamental do processo e, ainda, por serem ensaios pensados e planejados para modelagem matemática do cultivo, evidentemente, optou-se por utilizar os dados de Aguiar (2010). Evidentemente os dados selecionados também apresentam uma variação importante, porém os dados utilizados apresentam algumas características fundamentais para a modelagem. Além de buscar uma padronização da célula e do preparo de inóculo, todo o planejamento experimental dos ensaios visa identificar os possíveis fatores que interferem no processo. Nos ensaios considerados, por exemplo, foram padronizadas as demais condições experimentais e testou-se a influência do oxigênio dissolvido. Assim, as alterações podem ser relacionadas com variáveis do processo controladas (neste caso, a concentração de oxigênio dissolvido) e podem ser incorporadas ao modelo.

Vale ressaltar que a flexibilidade metabólica da linhagem celular estuda, bem como o fato de que os dados usados nas construções dos modelos preliminares foram gerados por diferentes grupos, dificultou de maneira clara todo o processo de modelagem.

O primeiro conjunto de dados foi obtido com a célula S2AcGPV2-KTC100 e que passou a expressar nível significativamente maior de GPV, ensaios Ma-02, Ma-03, Ma-04 e Ma-06. O segundo conjunto de dados foi obtido com a célula S2AcGPV adaptada ao meio TC100 suplementado (GALESI, 2007), ensaios Ma-07 a Ma-17. 


\subsubsection{Modelo 1. Hipóteses consideradas na modelagem}

Esse modelo é constituído por seis equações diferenciais e dezessete parâmetros que foram inicialmente ajustados aos dados de dois ensaios (Ma-02 e Ma-03) e, posteriormente, ao conjunto dos ensaios Ma-02, Ma-03, Ma-04 e Ma-06. Para a formulação do primeiro conjunto de equações que constituem o Modelo 1,foram consideradas as seguintes hipóteses que estão incorporadas no conjunto de equações da Tabela 5.2.

a) Cinética homogênea.

Como indicado no item 3.1 da revisão, as células de inseto não são dependentes de ancoragem e são cultivadas em suspensão, em tanques agitados. As condições de agitação e de aeração permitem considerar esta hipótese como perfeitamente adequada para modelagem do processo.

Tabela 5.2. Equações do Modelo $1 a$ e $1 b$

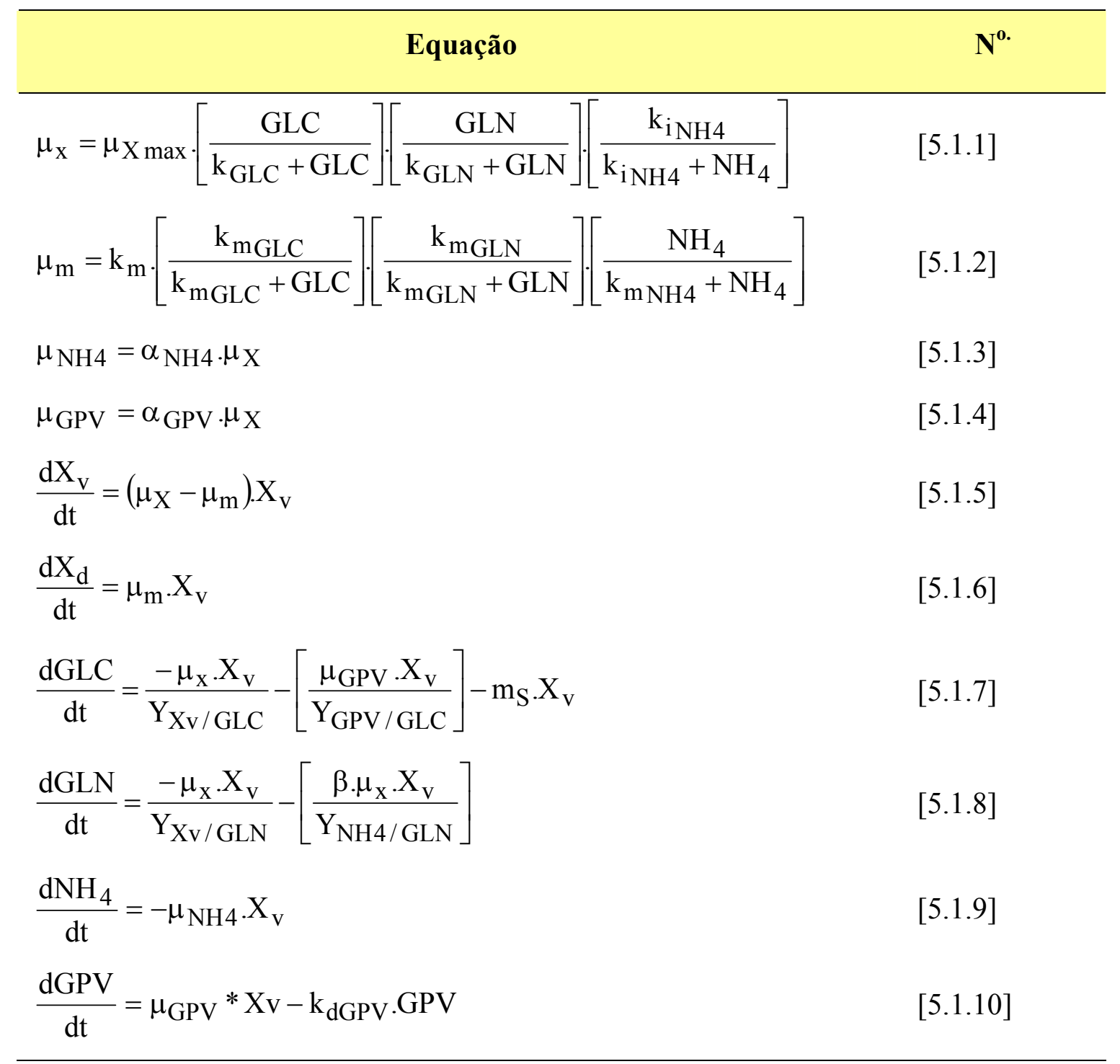


b) A velocidade específica de crescimento é limitada por glicose e glutamina e inibida por amônio (Equação 5.1.1). A limitação do crescimento por glicose e glutamina são referências comuns na literatura consultada (De TREMBAY et al, 1992; MILLER; BLANCH ;WILKE, 1988; DALILI; SAYLES; OLLIS, 1990; PÖRTNER; SCHAFER, 1996). A limitação por glicose foi verificada experimentalmente, especialmente, por Batista (2007) que utilizou meio IPL 41 modificado. A limitação por glutamina também foi constatada experimentalmente por Batista (2007) e Swiech (2007) que utilizaram os meios Tc100 e Sf900, respectivamente, embora Galesi et al. (2008) afirmem que nas condições estudadas este aminoácido não foi um fator limitante na cultura de células S2AcGPV2. Nesse último caso, há indicação de uma possível inibição do crescimento pela formação de amônio no meio de cultura. Lactato, outro inibidor comumente identificado em cultura de células animais, não foi considerado, pois os níveis observados foram muito baixos (inferiores a $0,55 \mathrm{~g} / \mathrm{L}$ ).

c) A velocidade específica de morte celular é inibida por glicose e glutamina e limitada por amônio (Equação 5.1.2). A revisão indica que as presenças de lactato e amônio no meio de cultura estimulam a morte celular. A glutamina e a glicose, ao contrário, são fatores que inibem a morte. Foi proposta uma expressão para a velocidade específica de morte celular que incorpora, de forma simples, a influência da glicose, glutamina e amônio na morte celular, ou seja, inibição hiperbólica de glicose e glutamina e limitação à morte celular, tipo Monod, para o amônio.

d) O consumo de glicose foi considerado para três finalidades do metabolismo celular: crescimento, formação de GPV e manutenção celular (Equação 5.1.7). Neste caso não se considera a formação de outros subprodutos do cultivo como a formação, por exemplo, de lactato ou de alanina. Como já apontado anteriormente, a formação de lactato foi desprezada, pois a concentração máxima encontrada para esse subproduto foi de $0,55 \mathrm{~g} / \mathrm{L}$. A alanina não foi considerada nesta etapa, pois os dados ainda não estavam disponíveis. Como indicado por Galesi et al. (2008) e Ikonomou et al. (2003), a formação de alanina é importante quando glicose e aminoácidos estão em excesso no meio de cultura, o que pode ser a caso do presente estudo. Posteriormente essas análises relativas à formação de alanina foram realizadas e os dados obtidos em Aguiar et al. (2009) e Aguiar (2010).

e) O consumo de glutamina foi considerado para duas finalidades: formação de células viáveis e consumo de glutamina para formação de amônio (Equação 5.1.8). 
f) A formação de $\mathrm{NH}_{4}{ }^{+}$é associada ao crescimento celular (Equação 5.1.3). Os dados disponíveis indicam formação de amônio ao longo de todo o cultivo, embora também se verifique a formação de amônio durante as fases estacionária e de declínio. Esta hipótese, embora em desacordo com os dados experimentais, foi adotada como uma primeira aproximação do problema.

g) A formação de GPV é associada ao crescimento celular (Equação 5.1.4). Como a GPV é uma proteína constitutiva, expressa na membrana celular, faz sentido que a sua síntese esteja associada à velocidade especifica de crescimento.

h) Ocorre degradação de GPV (Equação 5.1.10). Como indica a Figura 5.2 e os dados experimentais obtidos por Batista (2007), Galesi (2007), Swiech (2007) e Aguiar (2010), ocorrem diminuições da concentração e do teor de GPV nas células. Essa diminuição, no caso indicado na Figura 5.2, ocorre desde início da fase estacionária do cultivo e o fenômeno foi incorporado como uma degradação com cinética de primeira ordem (proporcional à concentração da proteína).

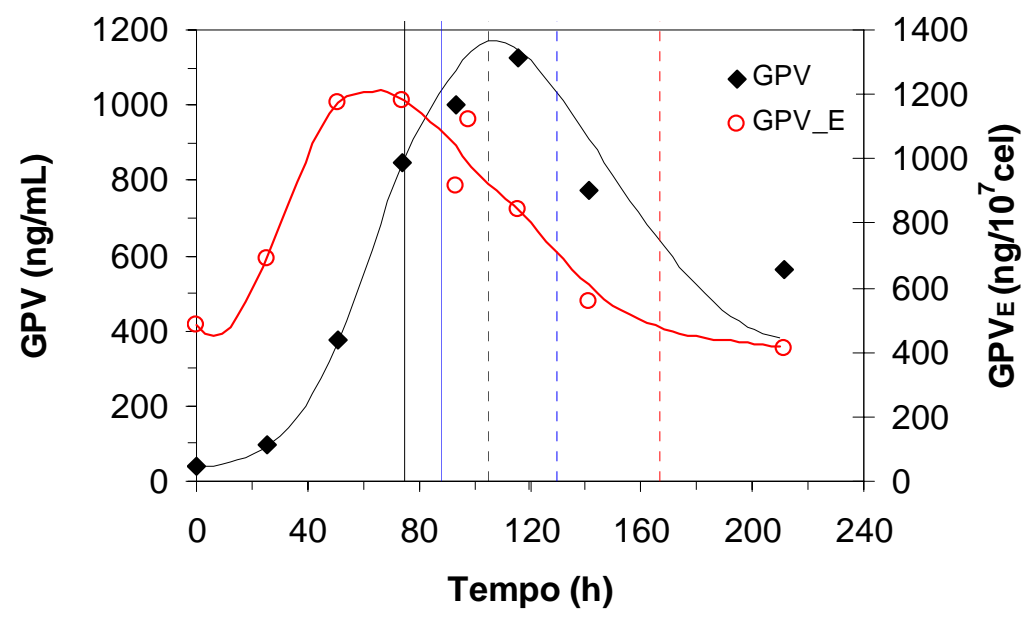

Figura 5.2. Variação da concentração de GPV e do teor de GPV nas células S2AcGPV2 (Ensaio Ma-3, Quadro A.1, Anexo A). $t_{\mathrm{EXP}}$ - linha contínua azul; $\mathrm{t}_{\mathrm{FIM}}$ - linha tracejada azul; $\mathrm{t}_{\mathrm{MORTE}}$ - linha tracejada vermelha; $\mathrm{t}_{\mathrm{GPVE}, \max }$ linha contínua preta; $t_{\mathrm{GPV} \max }$ - linha tracejada preta.

Os parâmetros ajustados e os resultados do ajuste estão indicados nas Figuras 5.3 e 5.4, e na Tabela 5.3 (Modelo 1a).

A partir das Figuras 5.3 e 5.4, constata-se que o modelo não se ajusta adequadamente aos dados experimentais sendo que as previsões do modelo para o crescimento em um ensaio aproximam-se do observado e, em outro ensaio, subestimam o crescimento. 

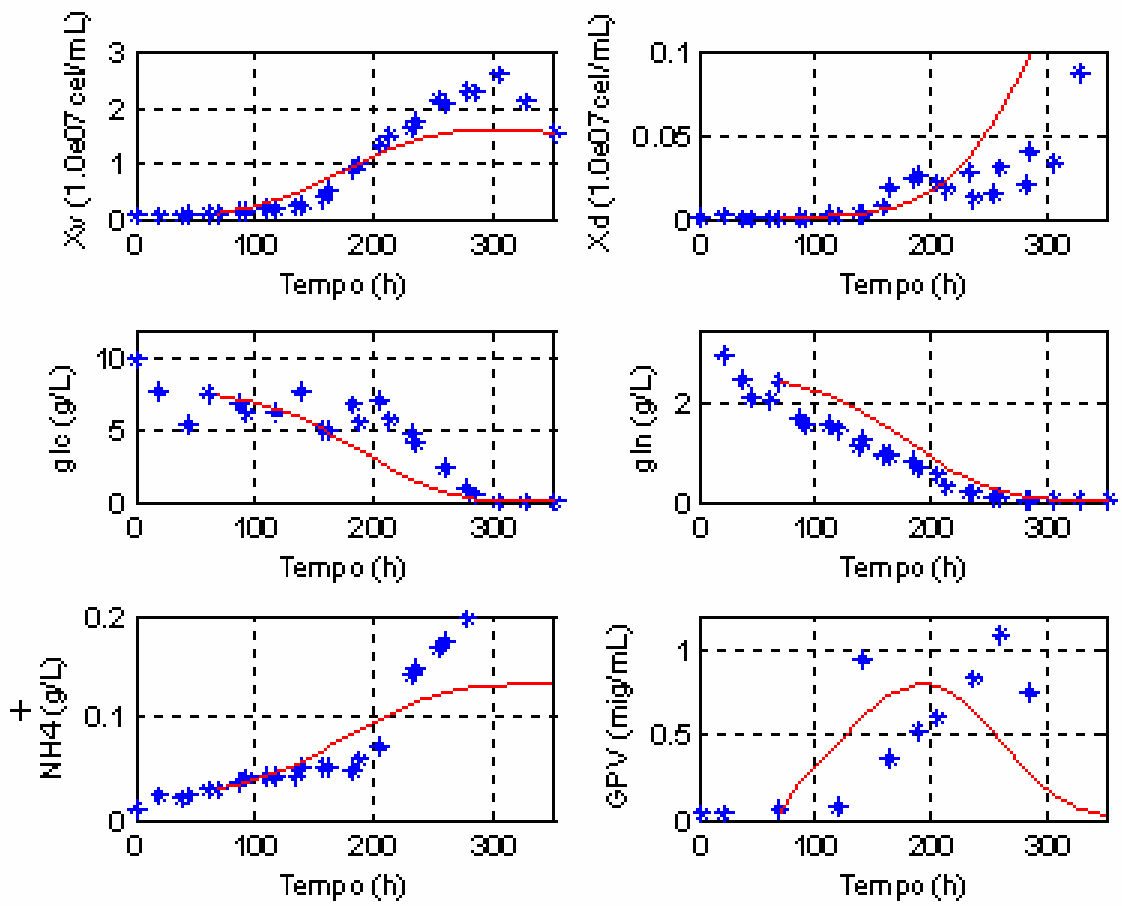

Figura 5.3. Comparação entre dados experimentais e as previsões do modelo 1a para o ensaio Ma- $02, \mathrm{pO}_{2}=$ 5\% (Quadro A.1, Anexo A). (linha contínua, previsões do modelo; símbolos, dados experimentais).
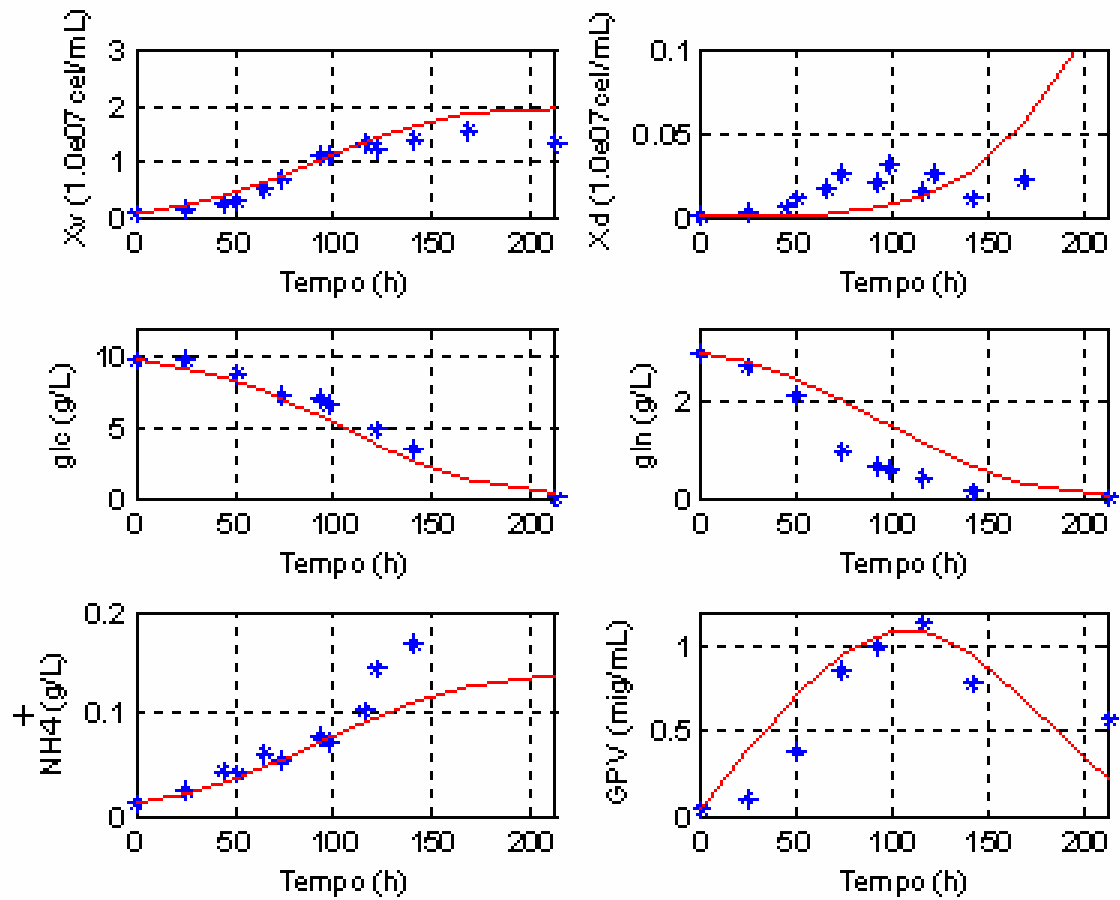

Figura 5.4. Comparação entre dados experimentais e as previsões do modelo 1a para o ensaio Ma-03, $\mathrm{pO}_{2}=30 \%$ (Quadro A.1, Anexo A). (linha contínua, previsões do modelo; símbolos, dados experimentais). 
Tabela 5.3. Valores dos parâmetros para os diversos modelos.

\begin{tabular}{|c|c|c|c|c|c|c|}
\hline & $\begin{array}{l}\text { Modelo 1a } \\
\text { (Ma-02 e Ma-03) }\end{array}$ & $\begin{array}{c}\text { Modelo 1b } \\
\text { (Ma-02; Ma-03; Ma-04; Ma-06) }\end{array}$ & $\begin{array}{c}\text { Modelo } 2 \\
(\text { Ma-07 a Ma-10) }\end{array}$ & $\begin{array}{c}\text { Modelo } 3 \\
(\text { Ma-07 a Ma-10) } \\
\end{array}$ & $\begin{array}{c}\text { Modelo } 4 \\
(\text { Ma-07 a Ma-10) } \\
\end{array}$ & $\begin{array}{r}\text { Modelo } 5 \\
\text { (Ma-02 a M3) } \\
\end{array}$ \\
\hline Célula & S2AcGPV2-KTC100 & S2AcGPV2-KTC100 & S2AcGPV2 & S2AcGPV2 & S2AcGPV2 & $\begin{array}{l}\text { S2AcGPV2- } \\
\text { KTC100 }\end{array}$ \\
\hline $\mathrm{pO}_{2}(\%)$ & $(5,30)$ & $(5,30,50,80)$ & $(5,30,50,80)$ & $(5,30,50,80)$ & $(5,30,50,80)$ & $(5,30)$ \\
\hline Parâmetro & Valor & Valor & Valor & Valor & Valor & Valor \\
\hline$\mu_{\mathrm{Xmax}}(1 / \mathrm{h})$ & $0,778 \mathrm{E}-01$ & 0,995E-01 & $0,776 \mathrm{E}-01$ & 0,999E-01 & $0,500 \mathrm{E}-01$ & $0,258 \mathrm{E}-01$ \\
\hline $\mathrm{k}_{\mathrm{GLC}}(\mathrm{g} / \mathrm{L})$ & $0,291 \mathrm{E}-01$ & $0,178 \mathrm{E}-02$ & $0,202 \mathrm{E}+00$ & $0,120 \mathrm{E}+00$ & $0,218 \mathrm{E}-02$ & $0,411 \mathrm{E}+00$ \\
\hline $\mathrm{k}_{\mathrm{GLN}}(\mathrm{g} / \mathrm{L})$ & $0,779 \mathrm{E}+00$ & $0,156 \mathrm{E}+01$ & $0,200 \mathrm{E}+01$ & $0,762 \mathrm{E}+00$ & $0,666 \mathrm{E}+00$ & $0,456 \mathrm{E}+00$ \\
\hline $\mathrm{k}_{\mathrm{iNH} 4}(\mathrm{~g} / \mathrm{L})$ & $0,268 \mathrm{E}-01$ & $0,149 \mathrm{E}-01$ & $0,492 \mathrm{E}-01$ & $0,188 \mathrm{E}-02$ & $0,498 \mathrm{E}-01$ & $0,132 \mathrm{E}+00$ \\
\hline $\mathrm{k}_{\mathrm{m}}(1 / \mathrm{h})$ & $0,315 \mathrm{E}-01$ & $0,156 \mathrm{E}+00$ & $0,179 \mathrm{E}-01$ & $0,313 \mathrm{E}-03$ & $0,103 \mathrm{E}-01$ & $0,308 \mathrm{E}-01$ \\
\hline $\mathrm{k}_{\mathrm{mGLC}}(\mathrm{g} / \mathrm{L})$ & $0,380 \mathrm{E}+01$ & $0,883 \mathrm{E}+01$ & $0,887 \mathrm{E}+01$ & $0,318 \mathrm{E}+02$ & $0,412 \mathrm{E}+01$ & $0,337 \mathrm{E}+01$ \\
\hline $\mathrm{k}_{\mathrm{mGLN}}(\mathrm{g} / \mathrm{L})$ & $0,433 \mathrm{E}+02$ & $0,770 \mathrm{E}+02$ & $0,993 \mathrm{E}+02$ & $0,997 \mathrm{E}+02$ & $0,999 \mathrm{E}+01$ & $0,964 \mathrm{E}+01$ \\
\hline $\mathrm{k}_{\mathrm{mNH} 4}(\mathrm{~g} / \mathrm{L})$ & $0,403 E+01$ & $0,951 \mathrm{E}+01$ & $0,303 E+01$ & $0,323 \mathrm{E}-01$ & $0,703 \mathrm{E}+00$ & $0,432 \mathrm{E}+00$ \\
\hline$\alpha_{\mathrm{GPV}}\left(\mu \mathrm{g} / 10^{7} \mathrm{cel}\right)$ & $0,628 \mathrm{E}+01$ & $0,103 E+01$ & $0,262 \mathrm{E}+01$ & $0,101 \mathrm{E}+01$ & $0,107 \mathrm{E}+02$ & $0,496 \mathrm{E}+01$ \\
\hline $\mathrm{Y}_{\mathrm{XGLC}}\left(10^{7} \mathrm{cel} / \mathrm{g}\right)$ & $0,274 \mathrm{E}+03$ & $0,579 \mathrm{E}+03$ & $0,308 \mathrm{E}+03$ & $0,412 \mathrm{E}+03$ & $0,635 \mathrm{E}+03$ & $0,133 \mathrm{E}+03$ \\
\hline $\mathrm{Y}_{\mathrm{GPV} / \mathrm{GLC}}(\mu \mathrm{g} / \mathrm{g})$ & $0,635 \mathrm{E}+04$ & $0,254 \mathrm{E}+04$ & $0,515 \mathrm{E}+03$ & $0,746 \mathrm{E}+03$ & $0,393 \mathrm{E}+05$ & $0,825 \mathrm{E}+05$ \\
\hline $\mathrm{m}_{\mathrm{s}}(1 / \mathrm{h})$ & $0,104 \mathrm{E}-07$ & $0,471 \mathrm{E}-04$ & $0,328 \mathrm{E}-05$ & $0,283 \mathrm{E}-05$ & $0,326 \mathrm{E}-04$ & $0,157 \mathrm{E}-05$ \\
\hline $\mathrm{Y}_{\mathrm{X} / \mathrm{GLN}}\left(10^{7} \mathrm{cel} / \mathrm{g}\right)$ & $0,935 \mathrm{E}+03$ & $0,369 \mathrm{E}+03$ & $0,803 \mathrm{E}+03$ & $0,152 \mathrm{E}+04$ & $0,326 \mathrm{E}+04$ & $0,761 \mathrm{E}+03$ \\
\hline$\beta_{\mathrm{NH} 4}\left(\mathrm{mg} / 10^{7}\right.$ cel $)$ & $0,402 \mathrm{E}-03$ & $0,194 \mathrm{E}-03$ & $0,272 \mathrm{E}-03$ & $0,622 \mathrm{E}-02$ & & \\
\hline$\alpha_{\mathrm{NH} 4}\left(\mathrm{~g} / 10^{7} \mathrm{cel}\right)$ & $0,622 \mathrm{E}-04$ & $0,327 \mathrm{E}-04$ & $0,635 \mathrm{E}-04$ & $0,575 \mathrm{E}-04$ & $0,999 \mathrm{E}+00$ & $0,428 \mathrm{E}-04$ \\
\hline $\mathrm{Y}_{\mathrm{NH} 4 / \mathrm{GLN}}(\mathrm{g} / \mathrm{g})$ & $0,998 \mathrm{E}+03$ & $0,576 \mathrm{E}+03$ & $0,175 \mathrm{E}+03$ & $0,963 \mathrm{E}+03$ & $0,467 \mathrm{E}+03$ & $0,206 \mathrm{E}+01$ \\
\hline $\mathrm{k}_{\mathrm{dGPV}}(1 / \mathrm{h})$ & $0,835 \mathrm{E}-01$ & $0,833 \mathrm{E}-02$ & $0,148 \mathrm{E}-01$ & $0,654 \mathrm{E}-03$ & $0,122 \mathrm{E}-01$ & $0,278 \mathrm{E}-01$ \\
\hline $\mathrm{k}_{\mathrm{O} 2}(\mathrm{mg} / \mathrm{L})$ & & & $0,219 \mathrm{E}-01$ & $0,226 \mathrm{E}-01$ & & \\
\hline $\mathrm{W}(\mathrm{mg} / \mathrm{L})$ & & & $0,818 \mathrm{E}+02$ & $0,559 \mathrm{E}+02^{(*)}$ & & \\
\hline $\mathrm{n}$ & & & & $0,139 \mathrm{E}+01$ & & \\
\hline $\mathrm{Y}_{\mathrm{X} / \mathrm{GLU}}\left(10^{7} \mathrm{cel} / \mathrm{g}\right)$ & & & & & & $0,238 \mathrm{E}+04$ \\
\hline $\mathrm{Y}_{\mathrm{NH} / \mathrm{GLU}}(\mathrm{mg} / \mathrm{g})$ & & & & & & $0,142 \mathrm{E}+04$ \\
\hline Ensaios & 2 & 4 & 4 & 4 & 4 & 2 \\
\hline SSR & 89,8 & 125 & 156 & 217 & 707 & 107 \\
\hline SSE & 0,544 & 0,480 & 0,564 & 0,788 & 0,258 & 0,692 \\
\hline
\end{tabular}


O consumo de glutamina é subestimado nos dois ensaios. O modelo também prevê concentrações de $\mathrm{NH}_{4}{ }^{+}$menores que as determinadas experimentalmente e uma degradação intensa da GPV, não suficientemente caracterizada pelos dados utilizados. Observa-se no ensaio Ma-02 um crescimento bem superior ao do ensaio Ma-03. Nos dois ensaios foram mantidas as mesmas condições experimentais, com exceção do nível de oxigênio dissolvido ( $5 \%$ no ensaio Ma-02 e $30 \%$ no ensaio Ma-03). Uma possível razão para a inadequação do ajuste pode estar no fato de que o modelo não leva em conta o efeito do oxigênio no metabolismo celular. Após esta tentativa, o modelo foi ajustado aos ensaios Ma-02, Ma-03, Ma-04 e Ma-06 (Quadro A.1, Anexo A). Os parâmetros ajustados e os resultados do ajuste estão indicados nas Figuras 5.5 a 5.8 e na Tabela 5.3, Modelo 1 b.
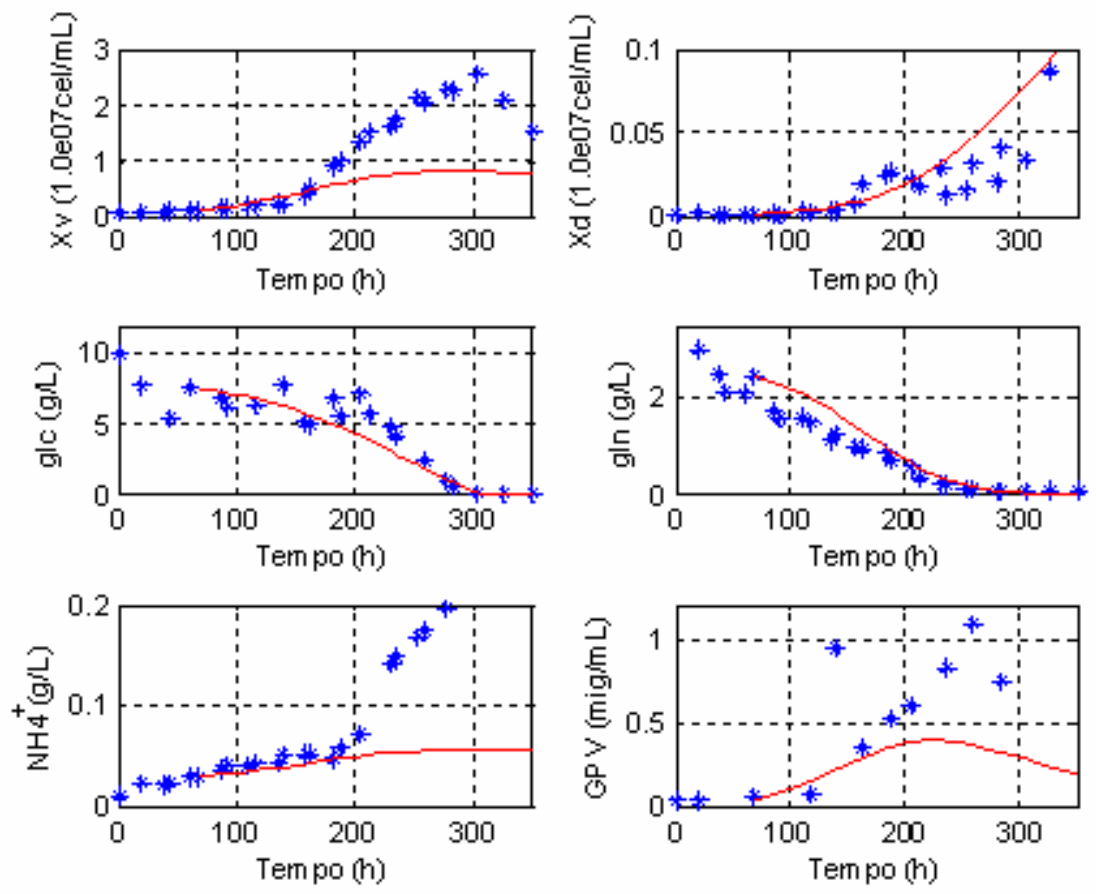

Figura 5.5. Comparação entre dados experimentais e as previsões do modelo $1 \mathrm{~b}$ para o ensaio Ma-02, $\mathrm{pO}_{2}=5 \%$ (Quadro A.1, Anexo A) (linha contínua, previsões do modelo; símbolos, dados experimentais). 

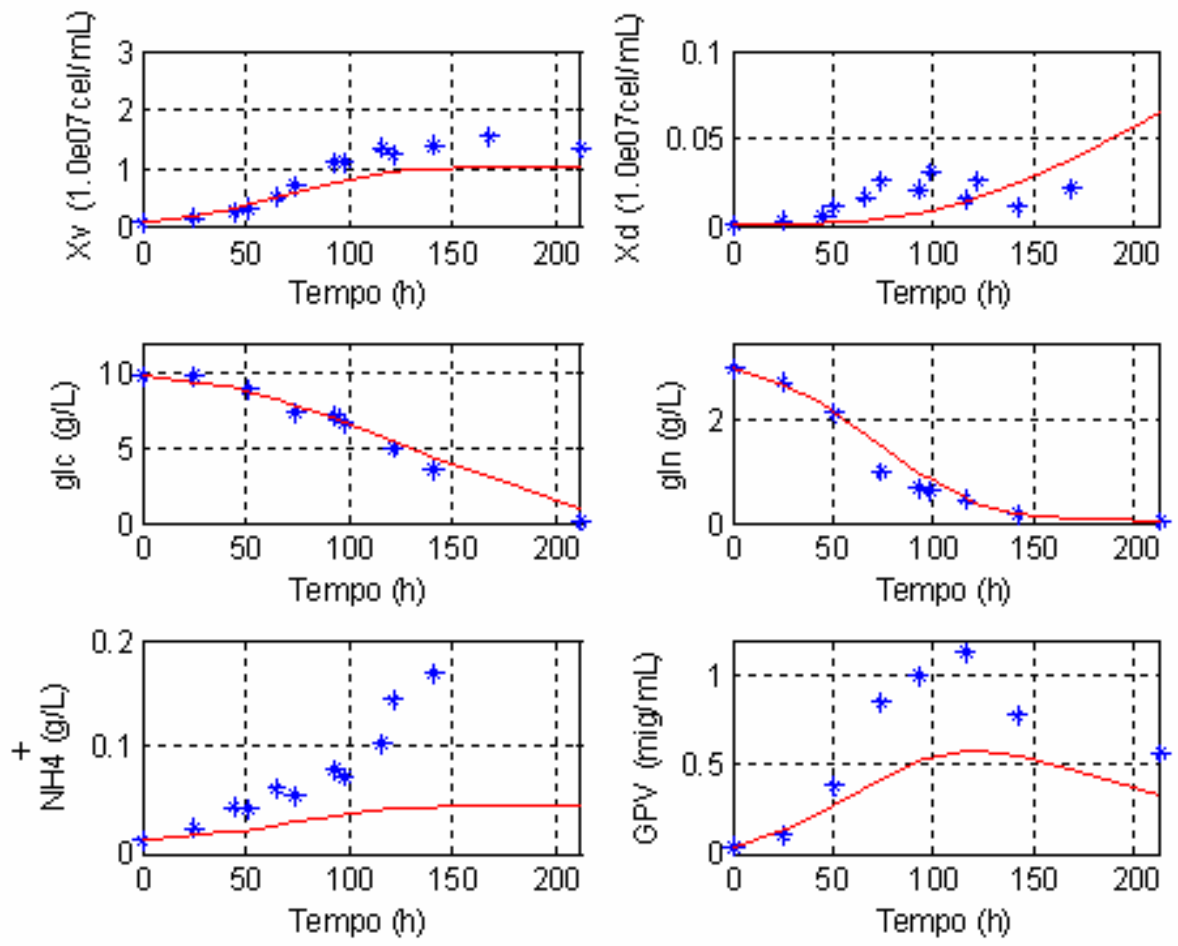

Figura 5.6. Comparação entre dados experimentais e as previsões do modelo $1 \mathrm{~b}$ para o ensaio Ma-03, $\mathrm{pO}_{2}=5 \%$ (Quadro A.1, Anexo A) (linha contínua, previsões do modelo; símbolos, dados experimentais).
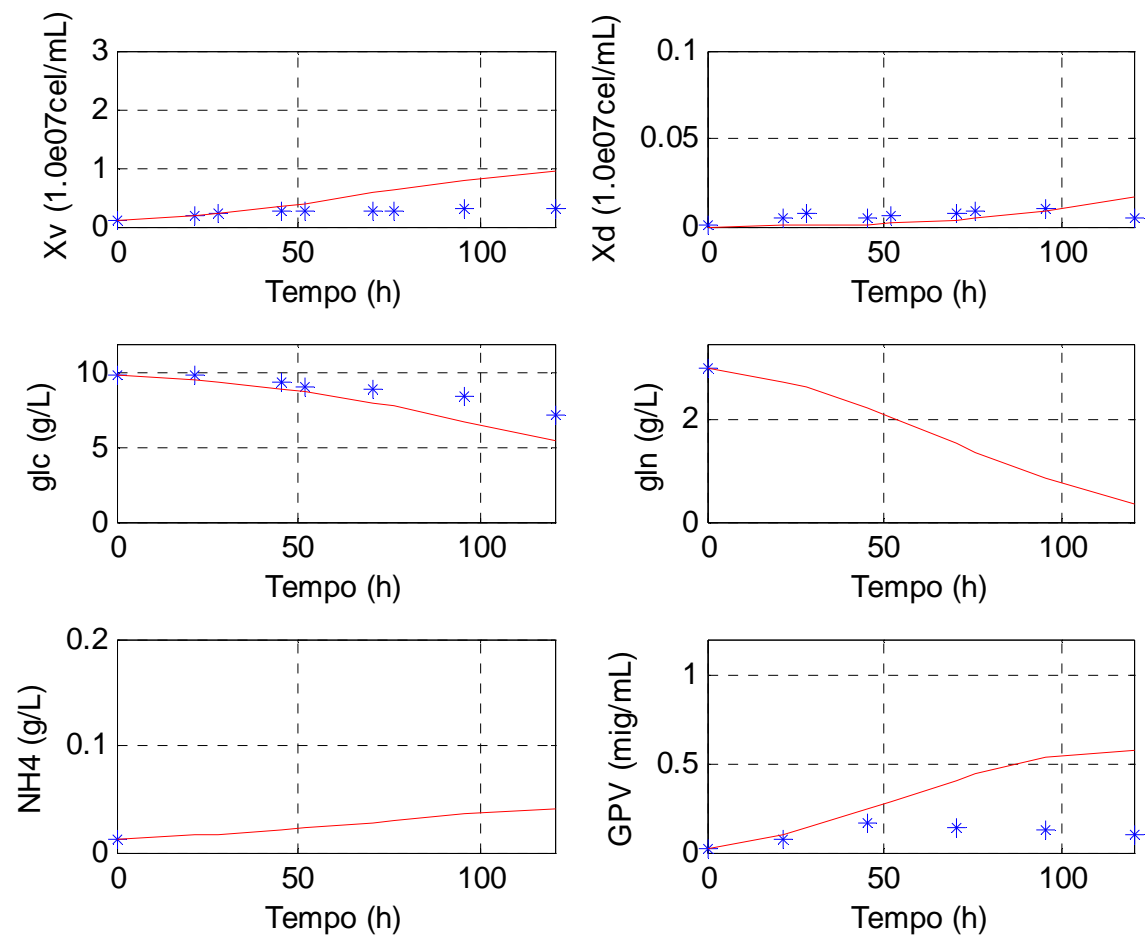

Figura 5.7. Comparação entre dados experimentais e as previsões do modelo $1 \mathrm{~b}$ para o ensaio Ma-04, $\mathrm{pO}_{2}=50 \%$ (Quadro A,1, Anexo A) (linha contínua, previsões do modelo; símbolos, dados experimentais). 

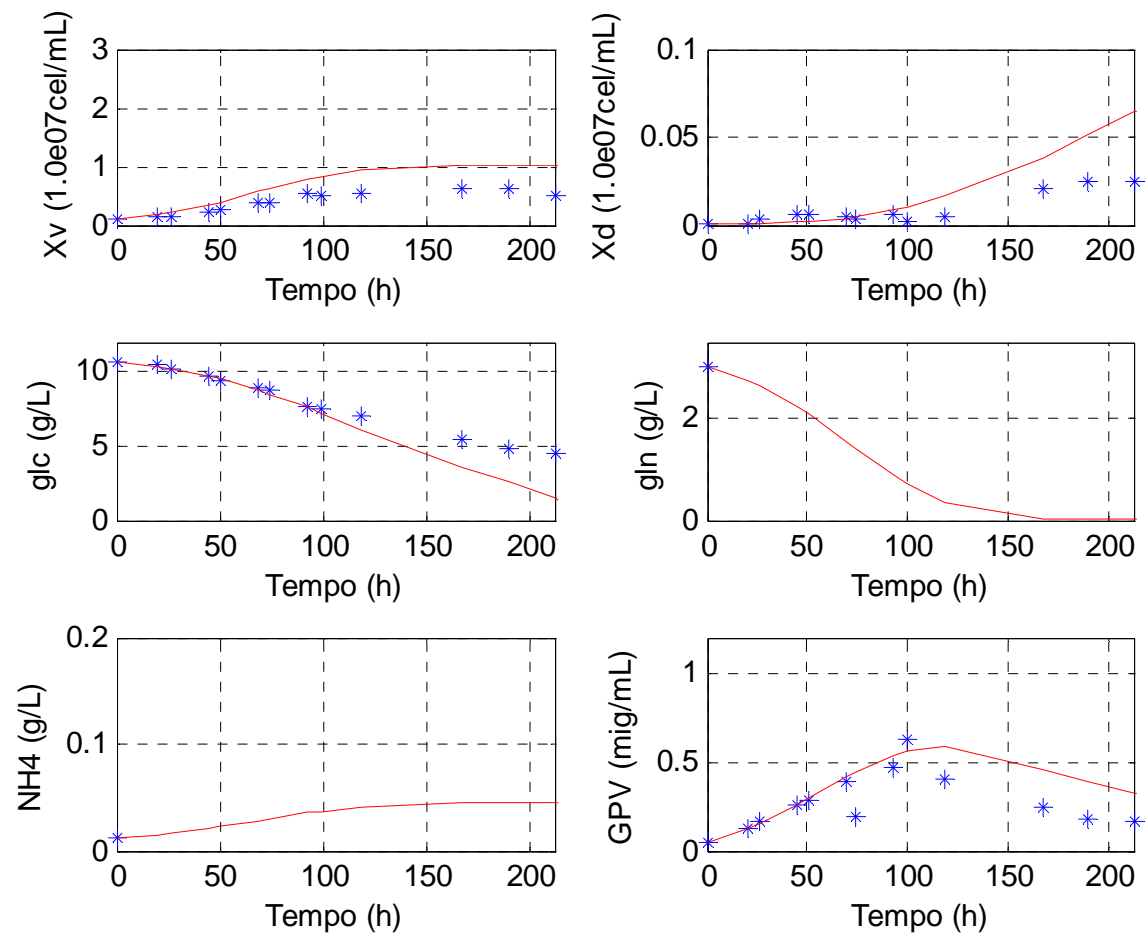

Figura 5.8. Comparação entre dados experimentais e as previsões do modelo $1 \mathrm{~b}$ para o ensaio Ma-06, $\mathrm{pO}_{2}=80 \%$ (Quadro A.1, Anexo A) (linha contínua, previsões do modelo; símbolos, dados experimentais).

Analisando as Figuras 5.5 a 5.8, constata-se que o modelo $1 \mathrm{~b}$ apresenta um ajuste pior aos dados experimentais em comparação ao ajuste indicado nas Figuras 5.3 e 5.4 (Modelo 1a). A falta de ajuste é mais evidente para altas concentrações de células viáveis, ou seja, o modelo prevê crescimento baixo, tendência que se observa em três dos quatro ensaios considerados. Como a medida de glutamina não estava disponível para todos os ensaios, o seu ajuste e as previsões do modelo ficaram comprometidos. O modelo também subestima as taxas de formação de $\mathrm{NH}_{4}{ }^{+}$, especialmente após a fase estacionária de crescimento, Como não se caracterizou um padrão na formação de GPV nos diversos ensaios considerados, as previsões do modelo proposto não parecem adequadas, pois não reproduzem as diversas tendências observadas. Destaque-se, ainda, que os dados já indicavam uma influência do teor de oxigênio dissolvido no crescimento e na formação de GPV, fator não considerado no Modelo 1 (a e b). 


\subsubsection{Modelo 2. Influência do oxigênio dissolvido sobre o crescimento.}

Por problemas de preservação, a célula S2AcGPV2-KTC100 foi perdida e isso obrigou Aguiar (2010) a repetir os experimentos de estudo da influência do $\mathrm{pO}_{2}$ com a linhagem S2AcGPV2.

Realizou-se o ajuste do modelo ao conjunto de dados disponíveis, ensaios Ma-7 a Ma-10, nos quais também se variou a concentração de oxigênio dissolvido. A avaliação preliminar dos parâmetros indicou inibição do crescimento, marcado pela redução da velocidade específica de crescimento à medida que aumentou a disponibilidade de oxigênio dissolvido, como indica a Figura 5.9.

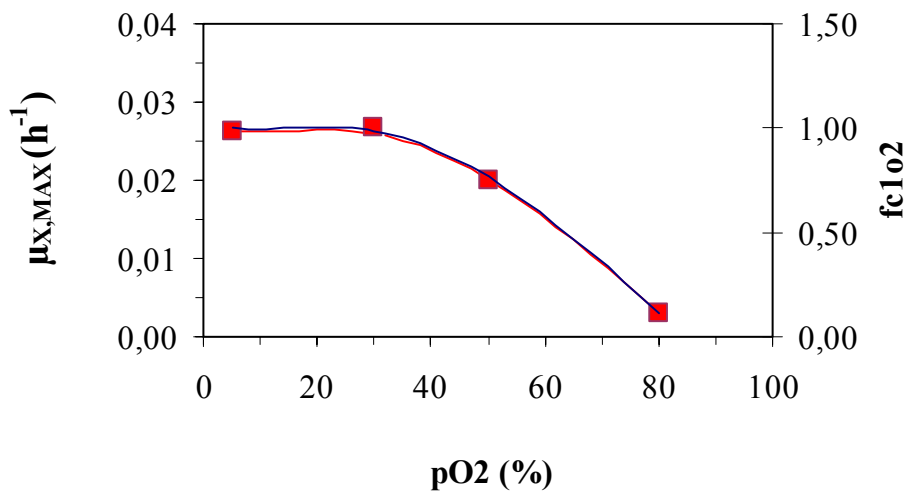

Figura 5.9. Influência do teor de oxigênio dissolvido na velocidade específica máxima de crescimento, Célula S2AcGPV2 para o conjunto de ensaios Ma-7 a Ma-10 (Quadro A.1, Anexo A).

Para incorporar esse efeito inibitório, foi realizado um novo equacionamento para velocidade específica de crescimento, introduzindo a forma de inibição proposta por Andrews (1968) e mantendo as demais hipóteses do modelo 1 e as equações correspondentes (5.1.1 a 5.1.10, Tabela 5.1). A alteração proposta está indicada na Equação 5.2.1 e os resultados podem ser visualizados nas Figuras 5.10 a 5.13. Os valores encontrados para os parâmetros estão indicados na Tabela 5.3 (Modelo 2).

$$
\mu_{\mathrm{X}}=\mu_{\mathrm{X} \max } \cdot\left[\frac{\mathrm{GLC}}{\mathrm{k}_{\mathrm{GLC}}+\mathrm{GLC}}\right] \cdot\left[\frac{\mathrm{GLN}}{\mathrm{k}_{\mathrm{GLN}}+\mathrm{GLN}}\right] \cdot\left[\frac{\mathrm{ki}_{\mathrm{NH} 4}}{\mathrm{k}_{\mathrm{iNH} 4}+\mathrm{NH}_{4}}\right]\left[\frac{\mathrm{O}_{2}}{\mathrm{k}_{\mathrm{O} 2}+\mathrm{O}_{2}+\frac{\mathrm{O}_{2}{ }^{2}}{\mathrm{~W}}}\right]
$$



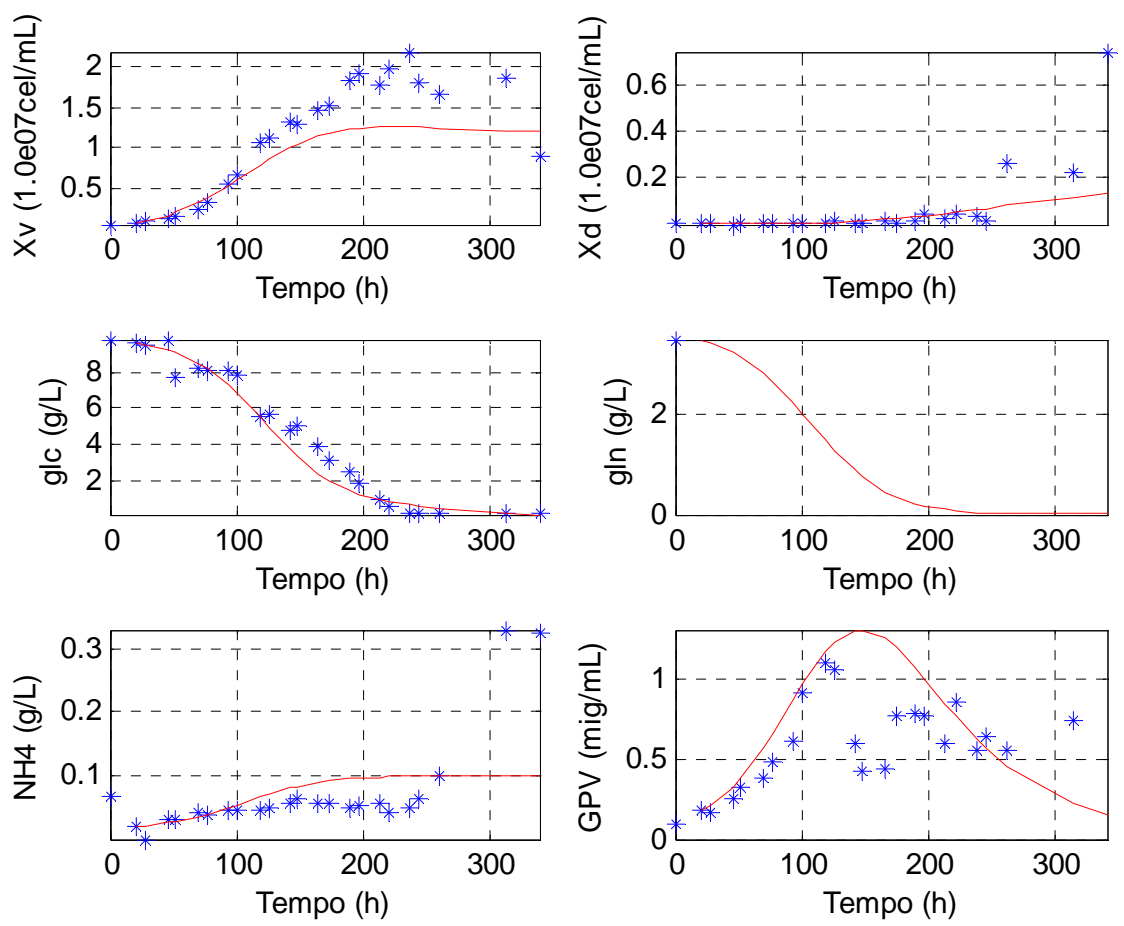

Figura 5.10. Comparação entre dados experimentais e as previsões do modelo 2 para o ensaio Ma-07, Célula S2AcGPV2, $\mathrm{pO}_{2}=5 \%$ (Quadro A.1, Anexo A). (linha contínua, previsões do modelo; símbolos, dados experimentais).
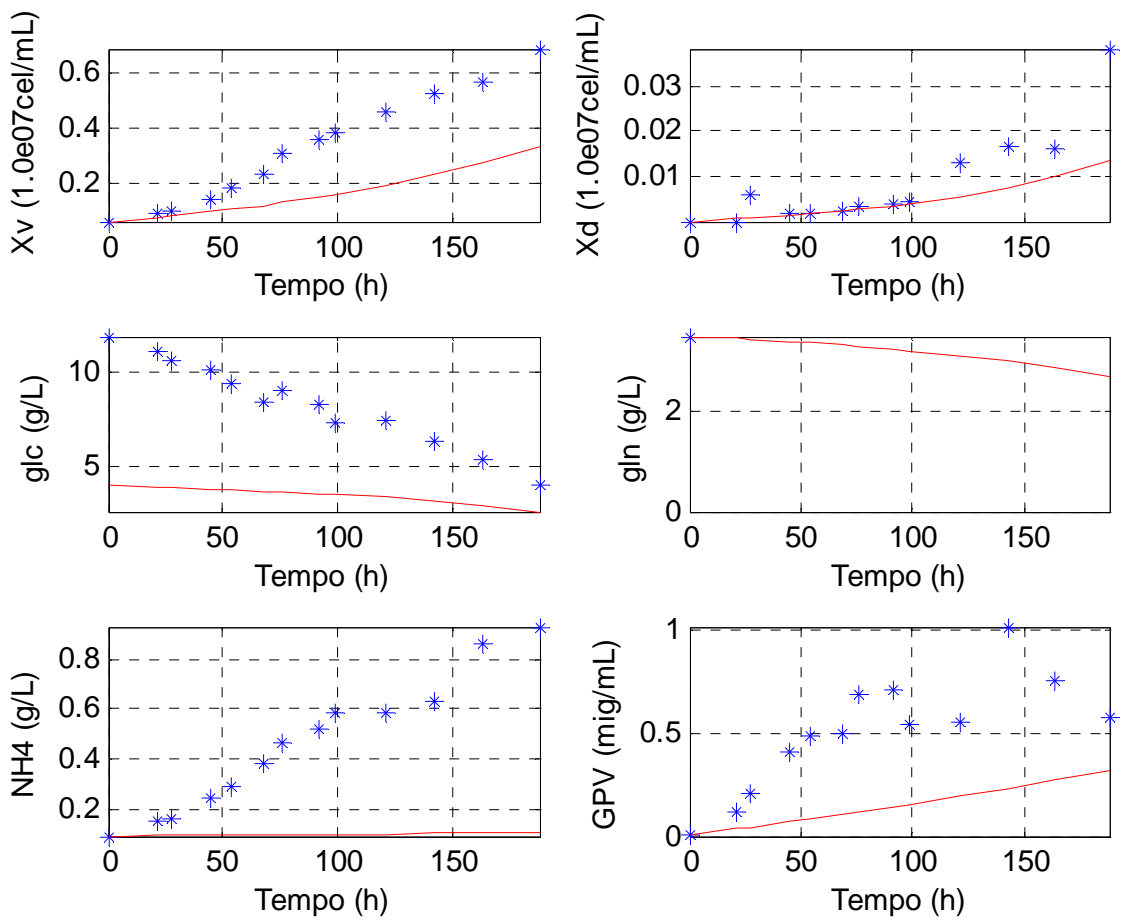

Figura 5.11. Comparação entre dados experimentais e as previsões do modelo 2 para o ensaio Ma-08, célula S2AcGPV2. $\mathrm{pO}_{2}=50 \%$ (Quadro A.1, Anexo A). (linha contínua, previsões do modelo; símbolos, dados experimentais). 

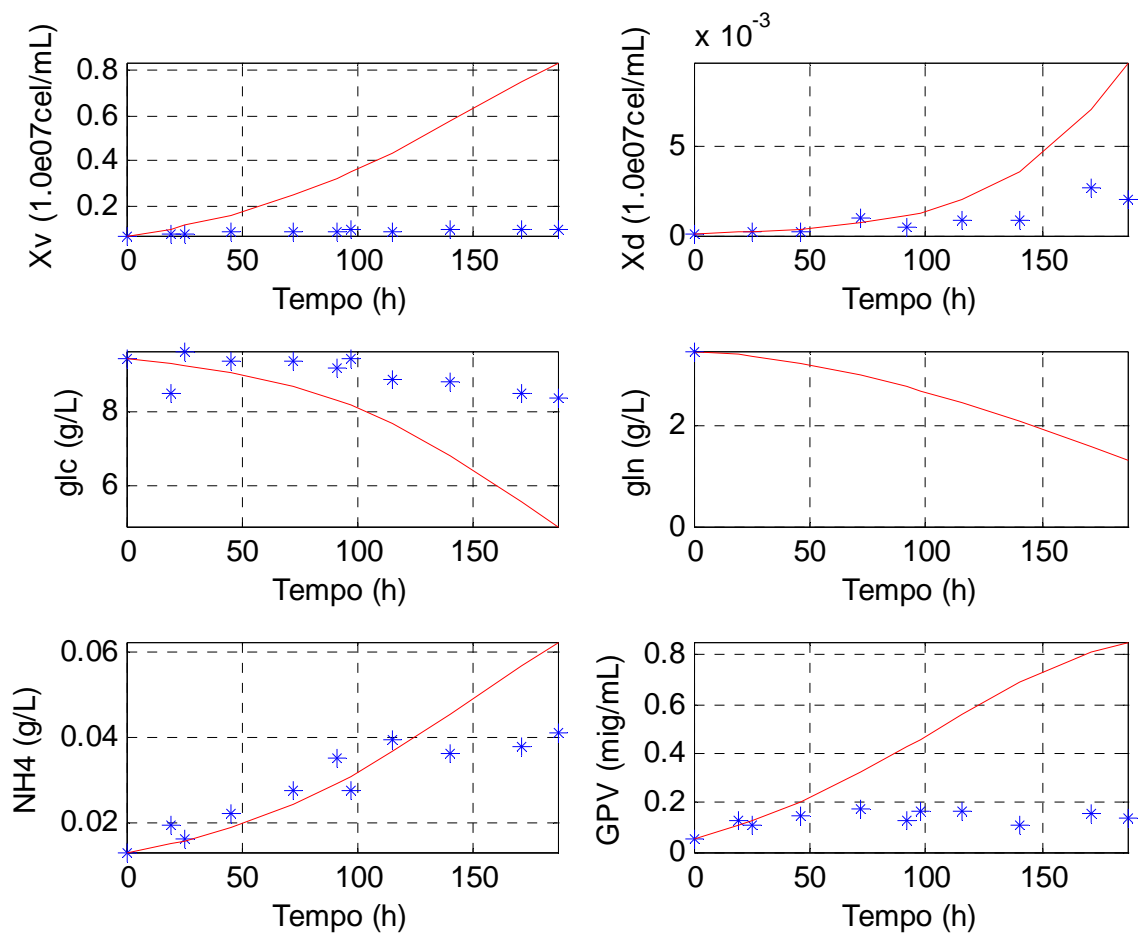

Figura 5.12. Comparação entre dados experimentais e as previsões do modelo 2 para o ensaio Ma-09, $\mathrm{S} 2 \mathrm{AcGPV} 2, \mathrm{pO}_{2}=80 \%$ (Quadro A.1, Anexo A). (linha contínua, previsões do modelo; símbolos, dados experimentais).
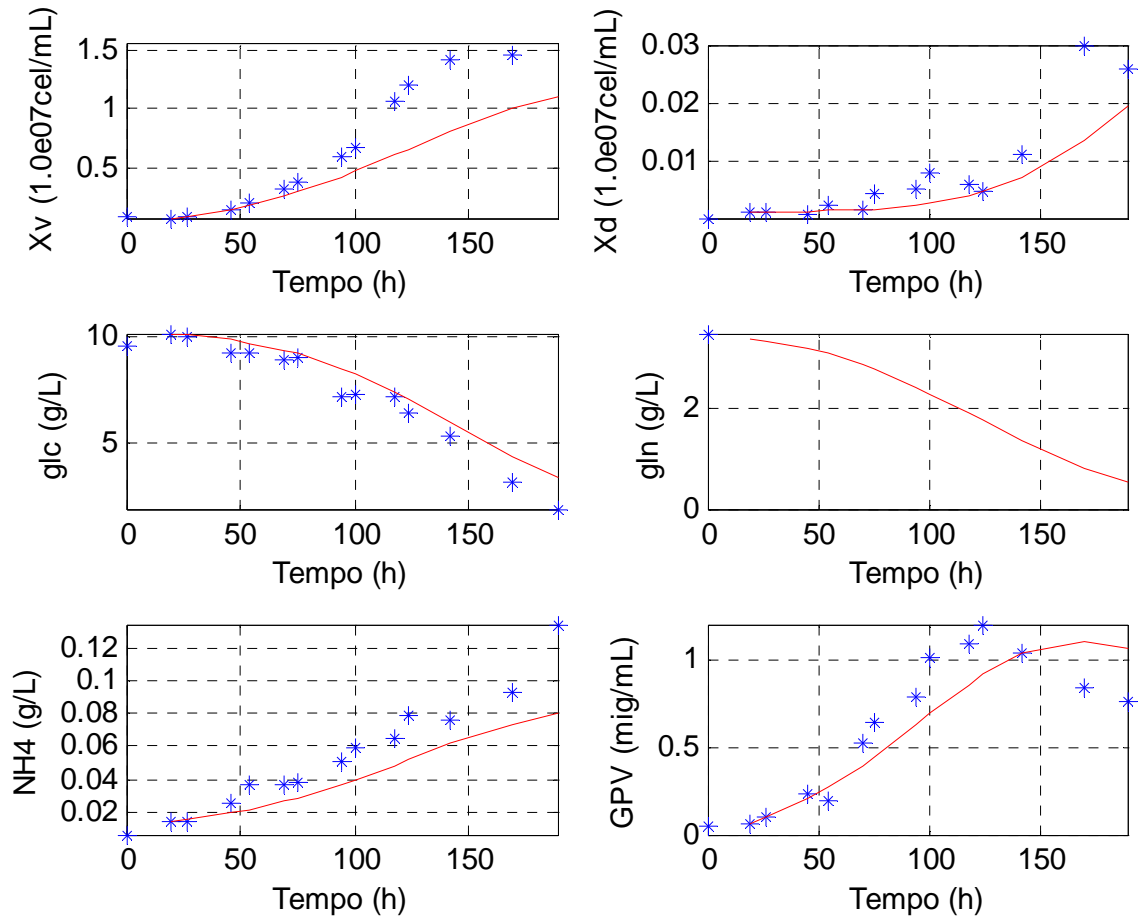

Figura 5.13. Comparação entre dados experimentais e as previsões do modelo 2 para o ensaio Ma-10, $\mathrm{S} 2 \mathrm{AcGPV} 2, \mathrm{pO}_{2}=30 \%$ (Quadro A.1, Anexo A). (linha contínua, previsões do modelo; símbolos, dados experimentais). 
Analisando-se as Figuras 5.10 a 5.13 constata-se que a alteração proposta, modelo 2, não foi suficiente para explicar as variações do comportamento cinético encontradas nos ensaios nos quais se verifica uma forte inibição do crescimento por níveis elevados de oxigênio dissolvido.Em consequência, os ensaios MA-07 e Ma-10, sem inibição por oxigênio, ajustam-se ao modelo.

\subsubsection{Modelo 3. Influência do Oxigênio sobre o crescimento}

Foram admitidas as mesmas hipóteses do modelo 1 (mesmas equações 5.1.1 a 5.1.10) e, neste caso, inclui-se a inibição do $\mathrm{O}_{2}$ na velocidade específica de crescimento segundo o modelo de Wu (1988) e utilizando os mesmo ensaios do caso anterior (Ma-07 a Ma-10). A alteração proposta está indicada pela Equação 5.3.1 e os resultados podem ser visualizados nas Figuras 5.14 a 5.18. Os valores encontrados para os parâmetros estão indicados na Tabela 5.3 (Modelo 3).

$$
\mu_{\mathrm{X}}=\mu_{\mathrm{X} \max } \cdot\left[\frac{\mathrm{GLC}}{\mathrm{k}_{\mathrm{GLC}}+\mathrm{GLC}}\right] \cdot\left[\frac{\mathrm{GLN}}{\mathrm{k}_{\mathrm{GLN}}+\mathrm{GLN}}\right] \cdot\left[\frac{\mathrm{k}_{\mathrm{iNH} 4}}{\mathrm{k}_{\mathrm{iNH} 4}+\mathrm{NH}_{4}}\right]\left[\frac{\mathrm{O}_{2}}{1+\frac{\mathrm{k}_{\mathrm{O} 2}}{\mathrm{O}_{2}}+\left(\frac{\mathrm{O}_{2}}{\mathrm{~W}}\right)^{\mathrm{n}}}\right]
$$
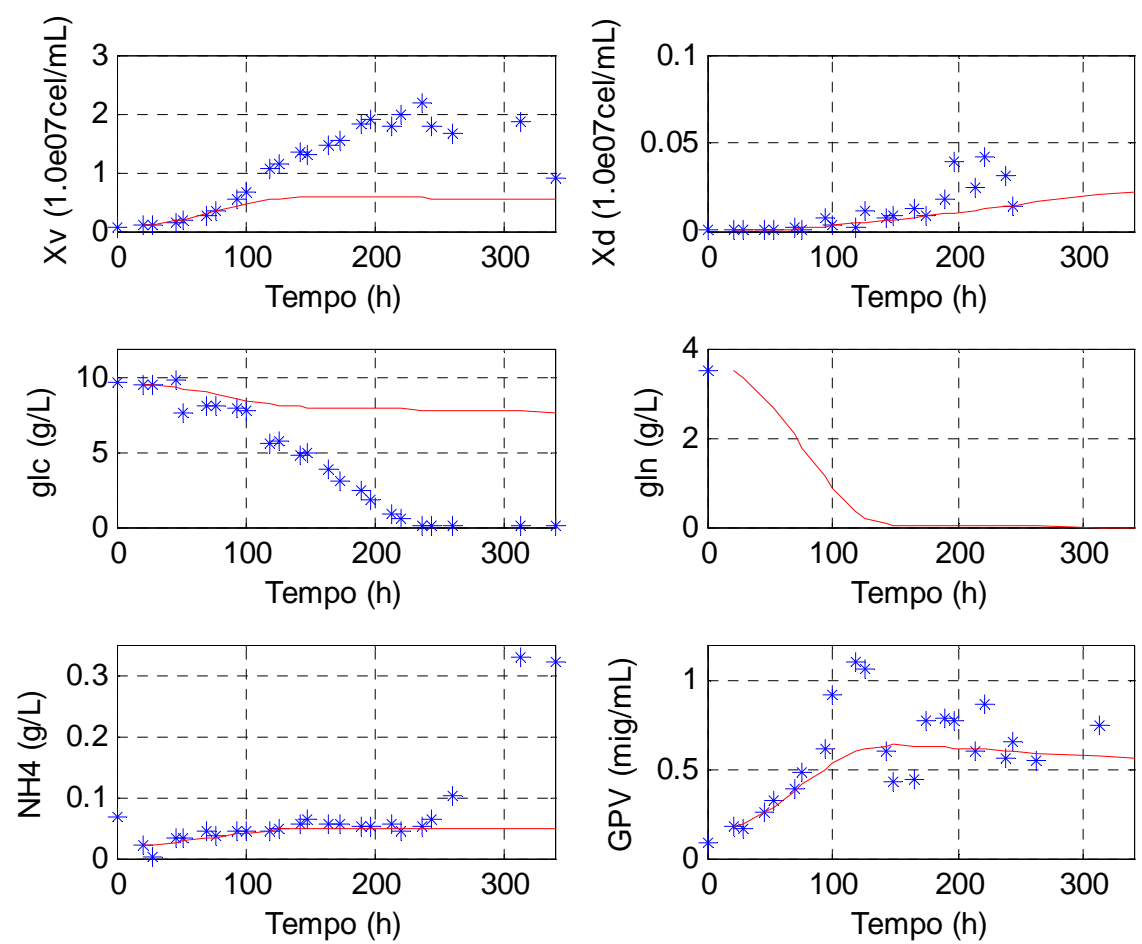

Figura 5.14. Comparação entre dados experimentais e as previsões do modelo 3 para o ensaio Ma-7, Célula S2AcGPV2, $\mathrm{pO}_{2}=5 \%$ (Quadro A.1, Anexo A). (linha contínua, previsões do modelo; símbolos, dados experimentais). 

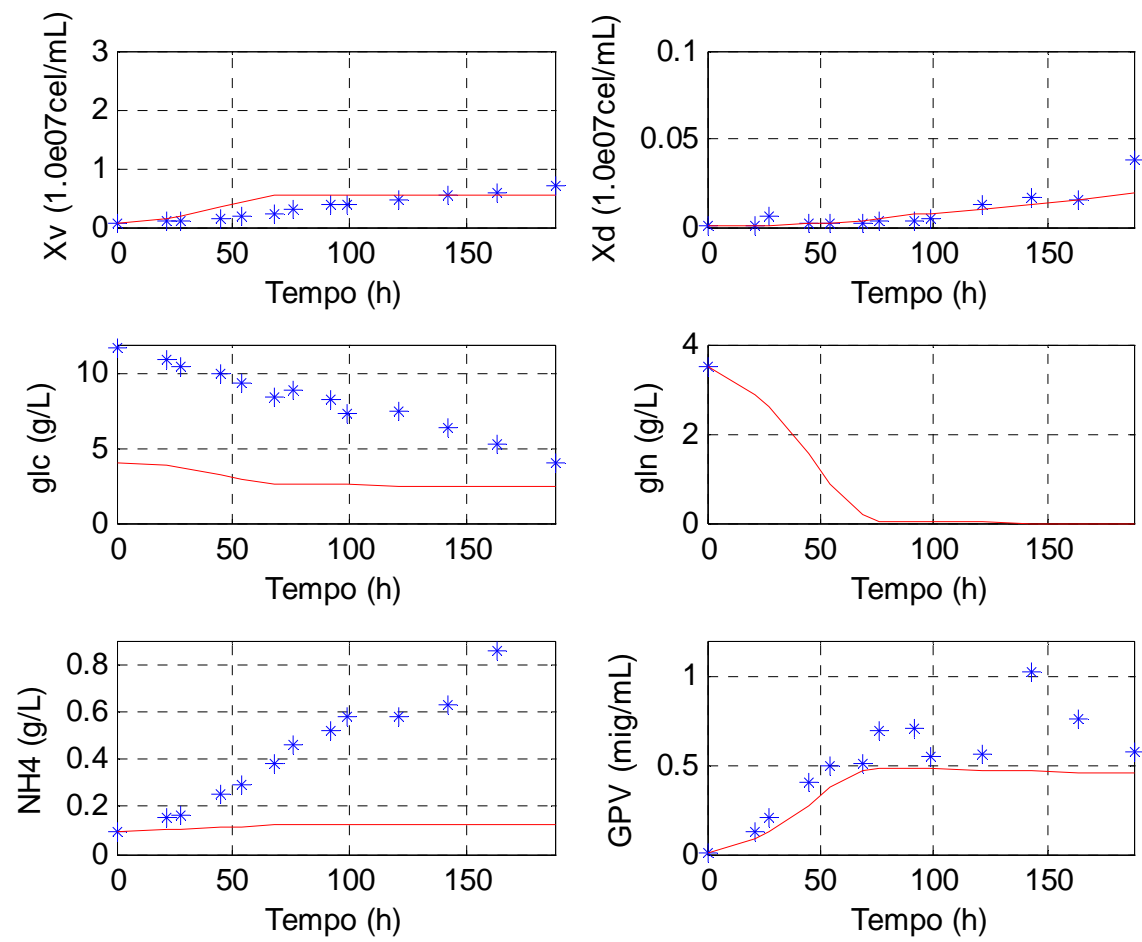

Figura 5.15. Comparação entre dados experimentais e as previsões do modelo 3 para o ensaio Ma-8, célula $\mathrm{S} 2 \mathrm{AcGPV} 2, \mathrm{pO}_{2}=50 \%$ (Quadro A.1, Anexo A). (linha contínua, previsões do modelo; símbolos, dados experimentais).
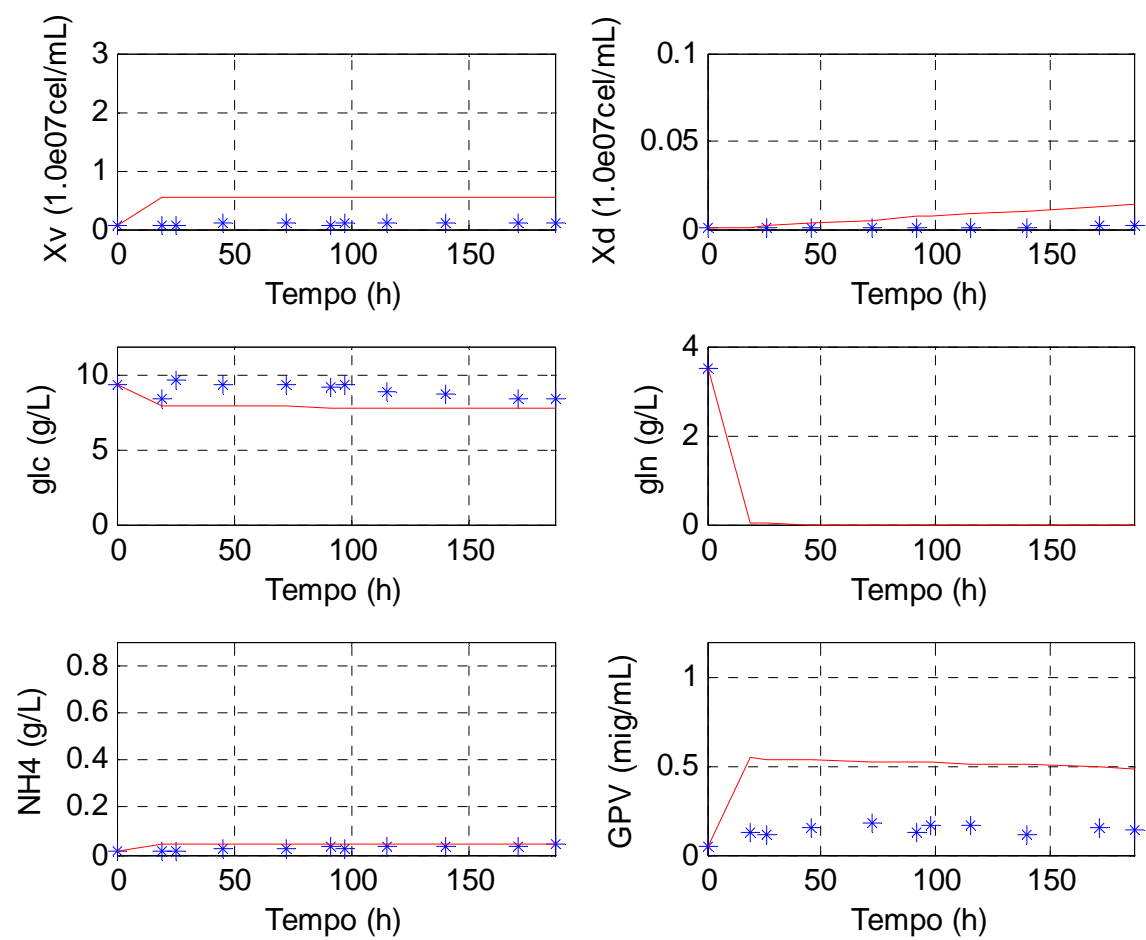

Figura 5.16. Comparação entre dados experimentais e as previsões do modelo 3 para o ensaio Ma-9, $\mathrm{S} 2 \mathrm{AcGPV} 2, \mathrm{pO}_{2}=80 \%$ (Quadro A.1. Anexo A). (linha contínua, previsões do modelo; símbolos, dados experimentais). 

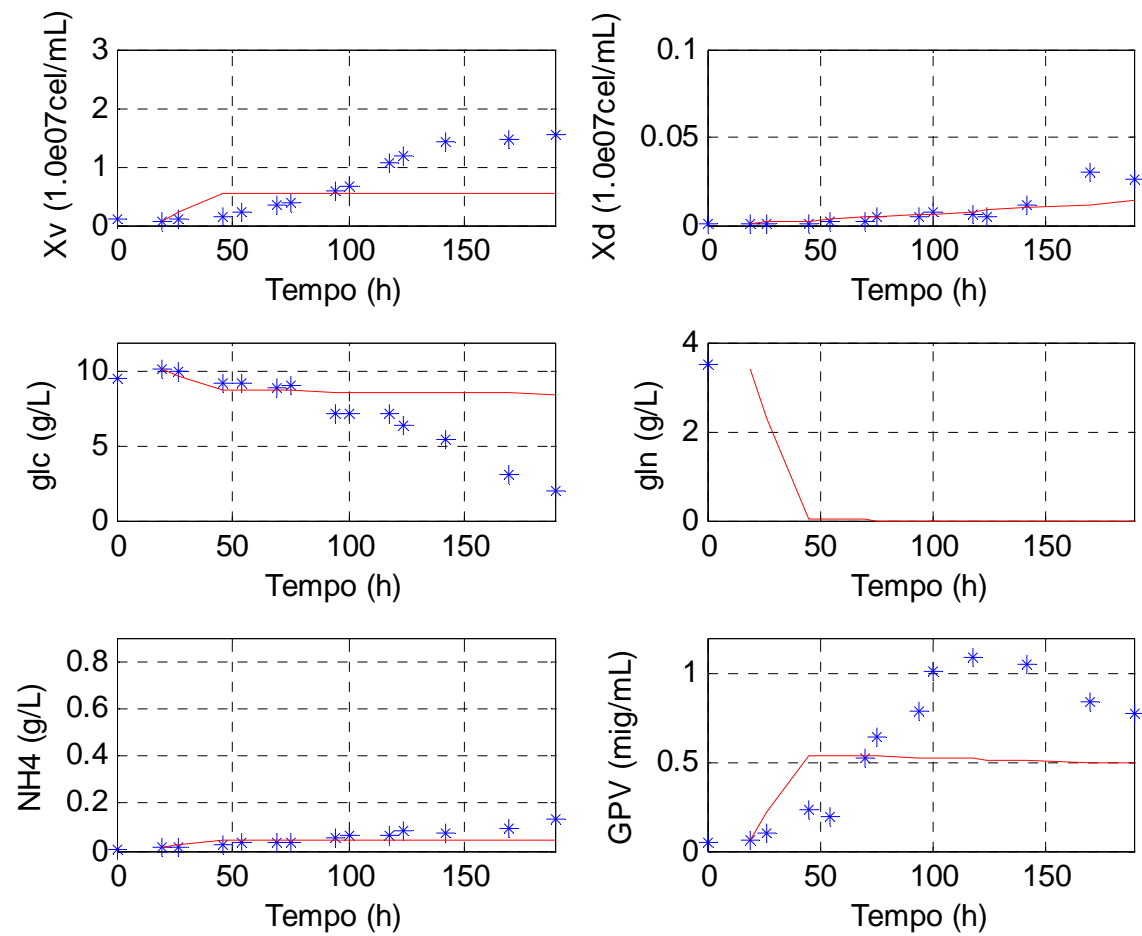

Figura 5.17. Comparação entre dados experimentais e as previsões do modelo 3 para o ensaio Ma-10, S2AcGPV2, $\mathrm{pO}_{2}=30 \%$ (Quadro A.1, Anexo A). (linha contínua, previsões do modelo; símbolos, dados experimentais).

Analisando as Figuras e resíduo do ajuste constata-se que a alteração proposta no modelo 3 é ainda pior que o ajuste anterior, pois a somatória quadrática dos desvios adimensionalizada é maior (Tabela 5.3). O modelo tende a superestimar a inibição pelo oxigênio e os melhores ajustes ocorrem nos ensaios com forte inibição por oxigênio (ensaios Ma-08 e Ma-10). Aguiar (2010) lembra que a literatura indica alta sensibilidade das células de Drosophila melanogaster a altas concentrações de oxigênio dissolvido, especialmente na fase larval do seu desenvolvimento e que as células S2 são células da larva do inseto.

\subsection{Modelos que incorporam a influência do oxigênio dissolvido no} metabolismo via fatores de conversão.

Aguiar (2010) também observou a influência do teor de oxigênio dissolvido no metabolismo celular. Com base nessas observações, buscou-se incorporar a influência do oxigênio dissolvido no metabolismo das células S2 e, dessa forma, incorporar a variabilidade metabólica observada nos cultivos. Isso foi realizado por meio da utilização de fatores de correção sobre algumas grandezas cinéticas como a velocidade específica de crescimento e 
fatores de conversão. Essa tentativa levou à formulação dos modelos caracterizados por incorporar mudanças metabólicas e que são apresentados a seguir.

\subsubsection{Modelo 4. Influência do oxigênio sobre o crescimento e metabolismo.}

Foram admitidas as mesmas hipóteses a) até h) do modelo 1 (Equações 5.1.1 a 5.10) e foram incorporados fatores de correção (Fci) para indicar o efeito do oxigênio sobre as grandezas cinética avaliadas (ver Tabela 5.4 e comentários a seguir).

Tabela 5.4. Equações do modelo 4.

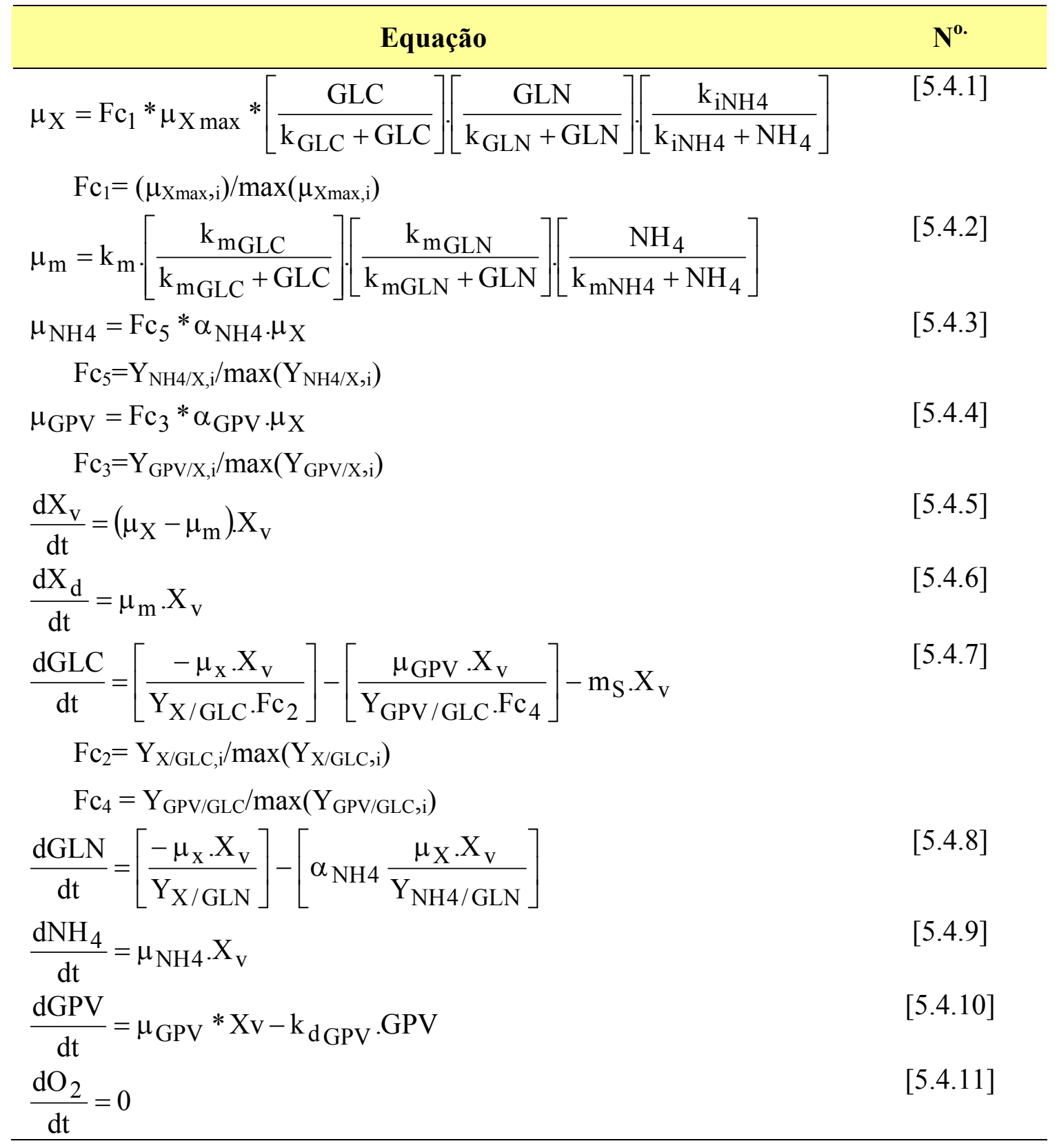


As alterações descritas na Tabela 5.4 são:

a) incorporou-se a influência do oxigênio dissolvido na velocidade específica de crescimento, $\mu$, por meio do fator de correçãoFc $c_{1}$, calculado como relação entre $\mu_{\text {Xmax }}$ do ensaio e o valor máximo entre os vários $\mu_{\mathrm{X} \max }$ determinados, $\mathrm{Fc}_{1}=\frac{\mu_{\mathrm{X} \max , \mathrm{i}}}{\max \left(\mu_{\mathrm{X}_{\max , \mathrm{i}}}\right)}$, indicado na Figura 5.18 (Equação 5.4.1, Tabela 5.4).

b) incorporou-se a influência do oxigênio dissolvido no fator de global conversão de glicose em células, $\mathrm{Y}_{\mathrm{X} / \mathrm{GLC}}$, por meio do fator de correção $\mathrm{Fc}_{2}$, calculado como a relação entre $\mathrm{Y}_{\mathrm{X} / \mathrm{GLC}}$

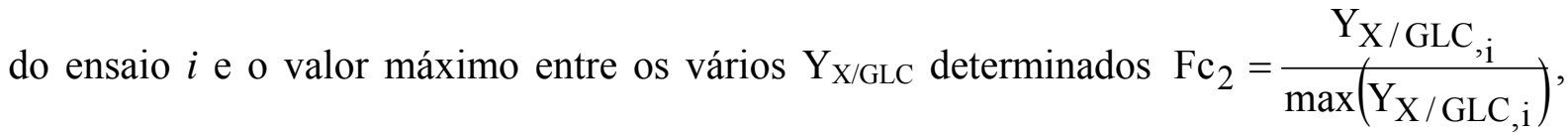
indicado na Figura 5.19 (Equação 5.4.7, Tabela 5.4).

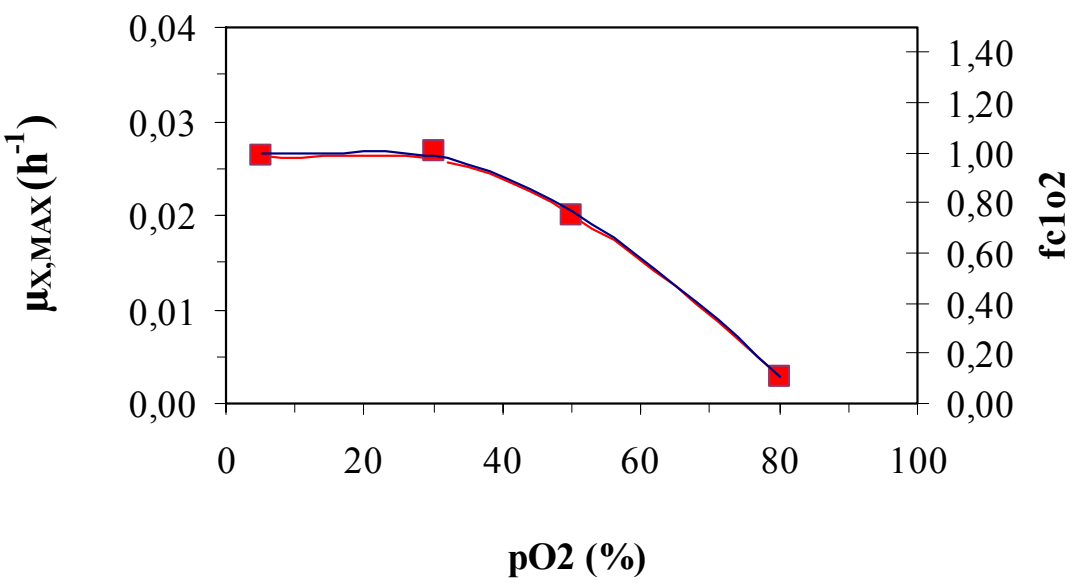

Figura 5.18. Fator de correção $\mathrm{Fc}_{1}, \mu_{\mathrm{Xmax}, \mathrm{i}} / \max \left(\mu_{\mathrm{xmax}, \mathrm{i}}\right)$, em função da concentração de oxigênio dissolvido, $\mathrm{pO}_{2}$.

c) incorporou-se a influência do oxigênio dissolvido no fator global de formação de GPV pelas células, $\mathrm{Y}_{\mathrm{GPV} / \mathrm{X}}$, por meio do fator de correção, $\mathrm{Fc}_{3}$, calculado como relação entre $\mathrm{Y}_{\mathrm{GPV} / \mathrm{X}}$ do ensaio $i$ e o valor máximo entre os vários $\mathrm{Y}_{\mathrm{GPV} / \mathrm{X}}$ determinados, $\mathrm{Fc}_{3}=\frac{\mathrm{Y}_{\mathrm{GPV} / \mathrm{X}, \mathrm{i}}}{\max \left(\mathrm{Y}_{\mathrm{GPV} / \mathrm{X}, \mathrm{i}}\right)}$, indicado na Figura 5.20 (Equação 5.4.4, Tabela 5.4). 


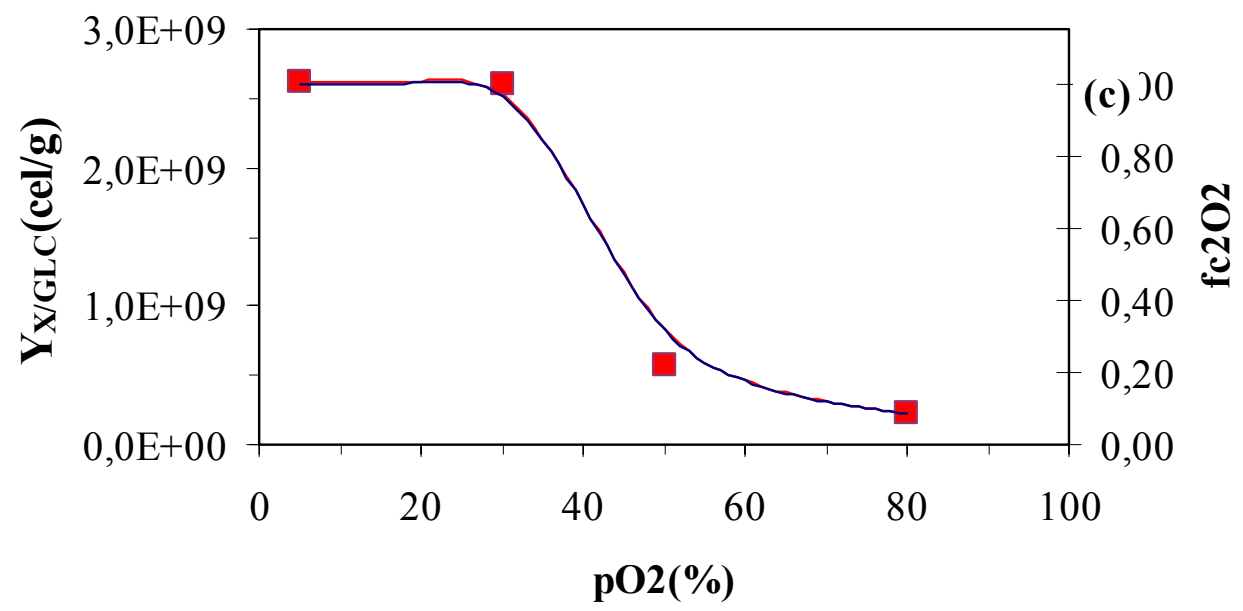

Figura 5.19. Fator de correção $\mathrm{Fc}_{2}, \mathrm{Y}_{\mathrm{X} / \mathrm{GLC}, \mathrm{i}} / \max \left(\mathrm{Y}_{\mathrm{X} / \mathrm{GLC}, \mathrm{i}}\right)$, em função da concentração de oxigênio dissolvido, $\mathrm{pO}_{2}$.

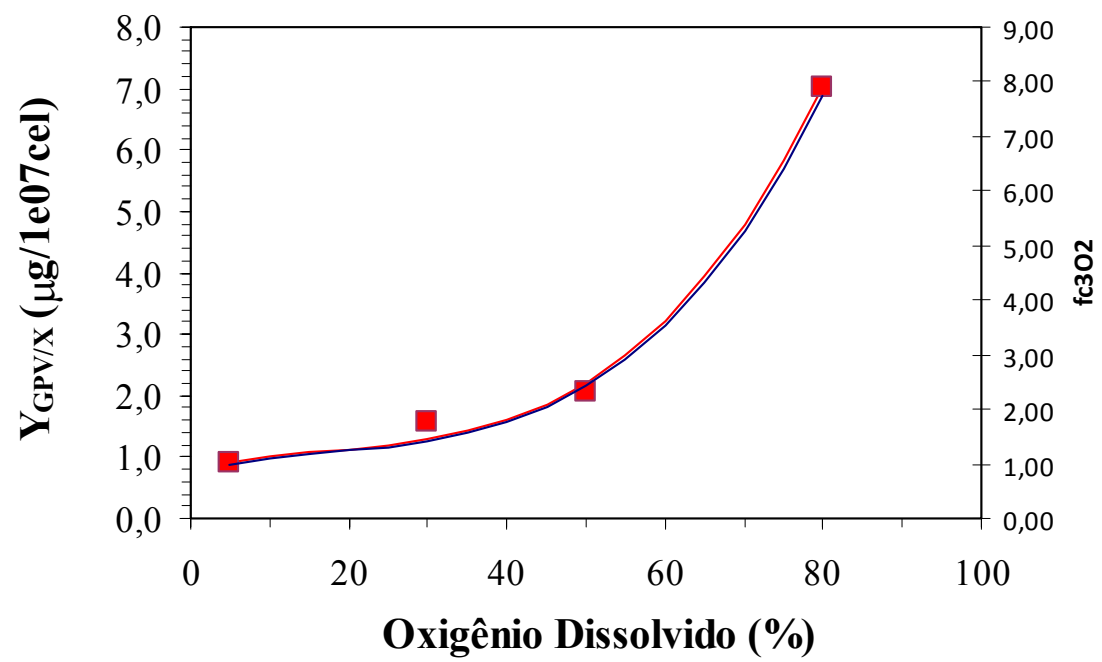

Figura 5.20. Fator de correção $\mathrm{Fc}_{3}, \mathrm{Y}_{\mathrm{GPV} / \mathrm{X}, \mathrm{i}} / \max \left(\mathrm{Y}_{\mathrm{GPV} / \mathrm{X}, \mathrm{i}}\right)$, em função da concentração de oxigênio dissolvido, $\mathrm{pO}_{2}$.

d) incorporou-se a influência do oxigênio dissolvido no fator global de conversão glicose em GPV, $\mathrm{Y}_{\mathrm{GPV} / \mathrm{GLC}}$, por meio do fator de correção $\mathrm{Fc}_{4}$, calculado como relação entre $\mathrm{Y}_{\mathrm{GPV} / \mathrm{GLC}}$ do ensaio e o valor máximo entre os vários $\mathrm{Y}_{\mathrm{GPV} / \mathrm{GLC}}$ determinados, $\mathrm{Fc}_{4}=\frac{\mathrm{Y}_{\mathrm{GPV} / \mathrm{GLC}, \mathrm{i}}}{\max \left(\mathrm{Y}_{\mathrm{GPV} / \mathrm{GLC}, \mathrm{i}}\right)}$, indicado na Figura 5.21 (Equação 5.4.7, Tabela 5.4). 


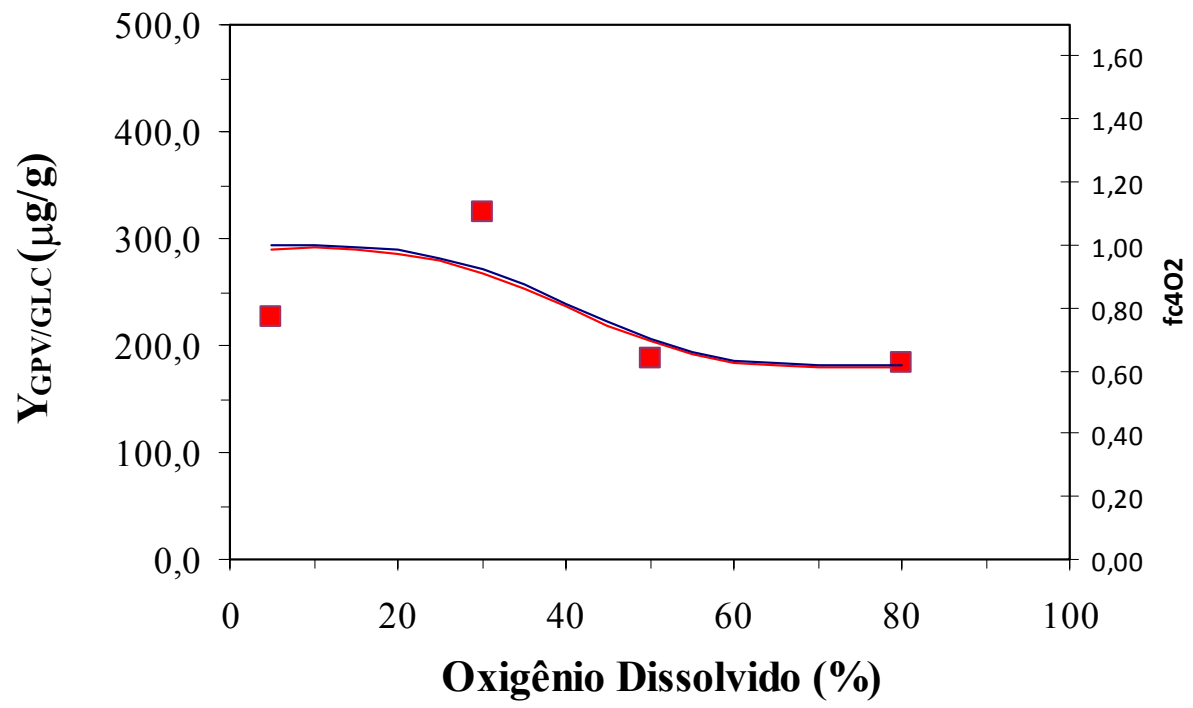

Figura 5.21. Fator de correção $\mathrm{Fc}_{4}, \mathrm{Y}_{\mathrm{GPV} / \mathrm{GLC}, \mathrm{i}} / \max \left(\mathrm{Y}_{\mathrm{GPV} / \mathrm{GLC}, \mathrm{i}}\right)$, em função da concentração de oxigênio dissolvido, $\mathrm{pO}_{2}$.

f) incorporou-se a influência do oxigênio dissolvido no fator global de formação de $\mathrm{NH}_{4}{ }^{+}$ pelas células, $\mathrm{Y}_{\mathrm{NH} 4 / \mathrm{X}}$, por meio do fator de correção $\mathrm{Fc}_{5}$, calculado como a relação entre $\mathrm{Y}_{\mathrm{NH} 4 / \mathrm{X}}$ do ensaio $i$ e o valor máximo entre os vários $\mathrm{Y}_{\mathrm{NH} 4 / \mathrm{X}}$ determinados, $\mathrm{Fc}_{5}=\frac{\mathrm{Y}_{\mathrm{NH} 4 / \mathrm{X}, \mathrm{i}}}{\max \left(\mathrm{Y}_{\mathrm{NH} 4 / \mathrm{X}, \mathrm{i}}\right)}$, indicado na Figura 5.22 (Equação 5.4.3, Tabela 5.4).

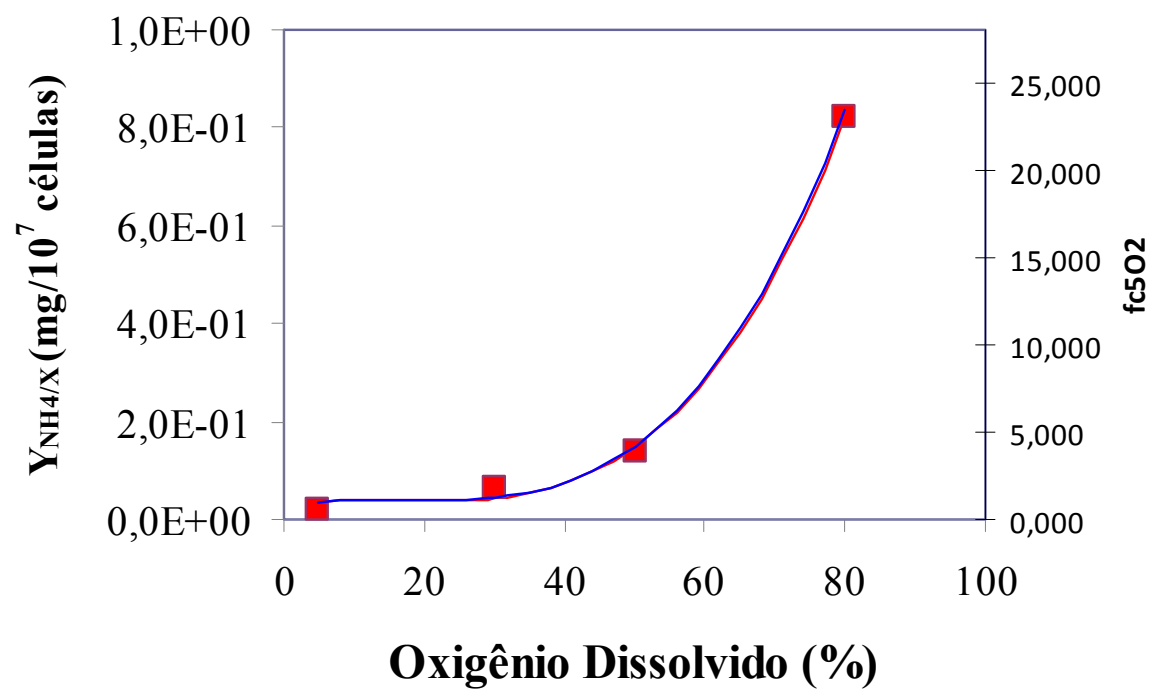

Figura 5.22. Fator de correção $\mathrm{Fc}_{5}, \mathrm{Y}_{\mathrm{NH} / \mathrm{X}, \mathrm{i}} / \max \left(\mathrm{Y}_{\mathrm{NH} / \mathrm{X}, \mathrm{i}}\right)$, em função da concentração de oxigênio dissolvido, $\mathrm{pO}_{2}$ 
Dessa forma, incorpora-se a influência do oxigênio dissolvido no modelo, não apenas na velocidade específica de crescimento, mas também sobre os parâmetros relacionados ao metabolismo celular $\left(\mathrm{Y}_{\mathrm{X} / \mathrm{GLC}}, \mathrm{Y}_{\mathrm{GPV}} / \mathrm{x}, \mathrm{Y}_{\mathrm{GPV} / \mathrm{GLC}}, \mathrm{Y}_{\mathrm{NH} 4 / \mathrm{X}}\right)$. Além dos fatores de correção, foram ainda feitas outras duas modificações em relação aos modelos anteriores. Como todos os fatores são funções do oxigênio dissolvido - mantido constante, mas distinto em cada ensaio essa variável foi incorporada como variável de estado do modelo com dinâmica nula (Equação [5.4.11], Tabela 5.4). Além disso, adotou-se um único parâmetro para modelar a velocidade de formação de $\mathrm{NH}_{4}{ }^{+}, \alpha_{\mathrm{NH} 4}$, indicado na Equação [5.4.8] e que nos modelos anteriores formulada pela Equações [5.1.8] com dois parâmetros $\alpha_{\mathrm{NH} 4}$ e $\beta_{\mathrm{NH} 4}$.

Esse novo modelo é constituído por onze equações diferenciais e dezesseis parâmetros que foram ajustados ao conjunto de dados dos ensaios Ma-07, Ma-08, Ma-09 e Ma-10, (Quadro A1, Anexo A).

Os resultados do ajuste do modelo 4 estão indicados nas Figuras 5.23 a 5.26 e na Tabela 5.3 (Modelo 4).
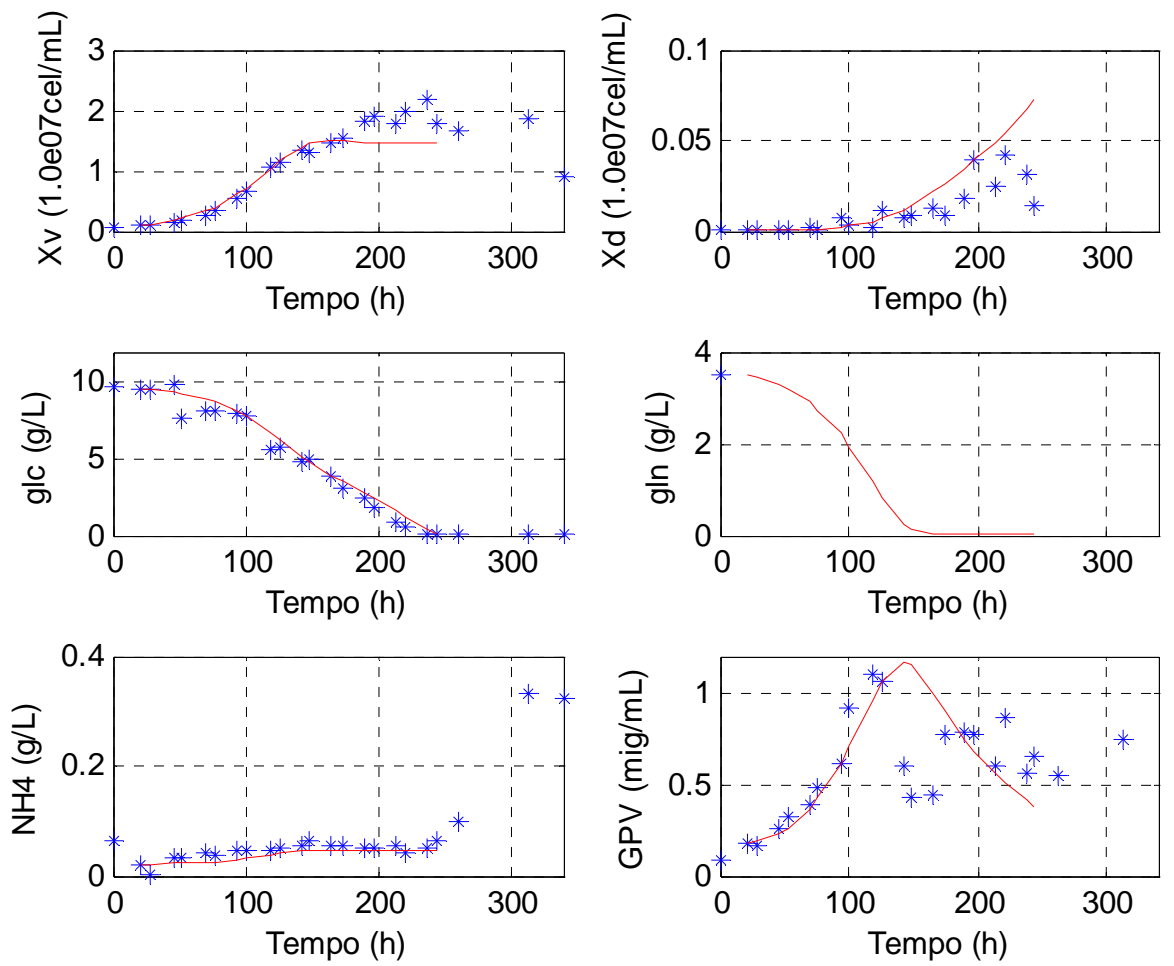

Figura 5.23. Comparação entre dados experimentais e as previsões do modelo 4 para o ensaio Ma-07, Célula S2AcGPV2, $\mathrm{pO}_{2}=5 \%$ (Quadro A.1, Anexo A). (linha contínua, previsões do modelo; símbolos, dados experimentais). 

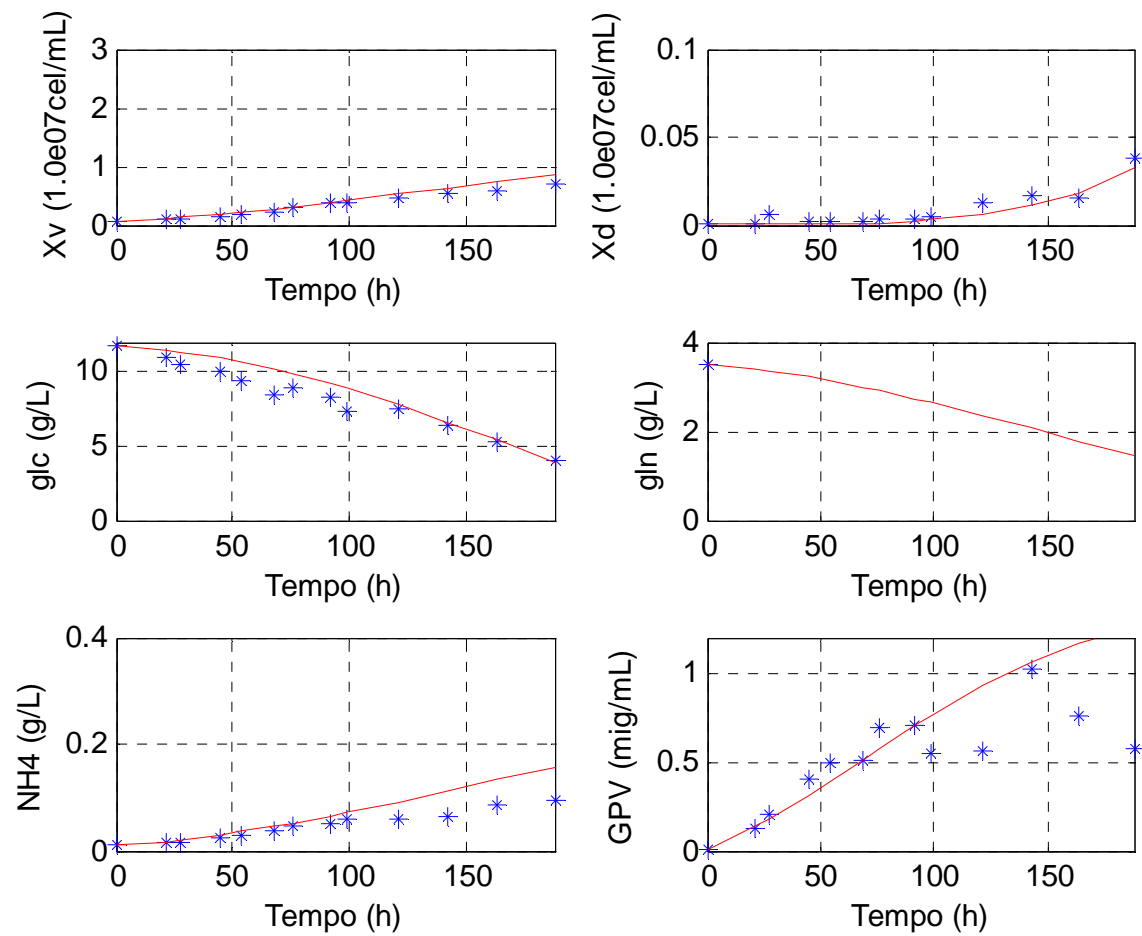

Figura 5.24. Comparação entre dados experimentais e as previsões do modelo 4 para o ensaio Ma-8, célula S2AcGPV2, $\mathrm{pO}_{2}=50 \%$ (Quadro A.1, Anexo A). (linha contínua, previsões do modelo; símbolos, dados experimentais).
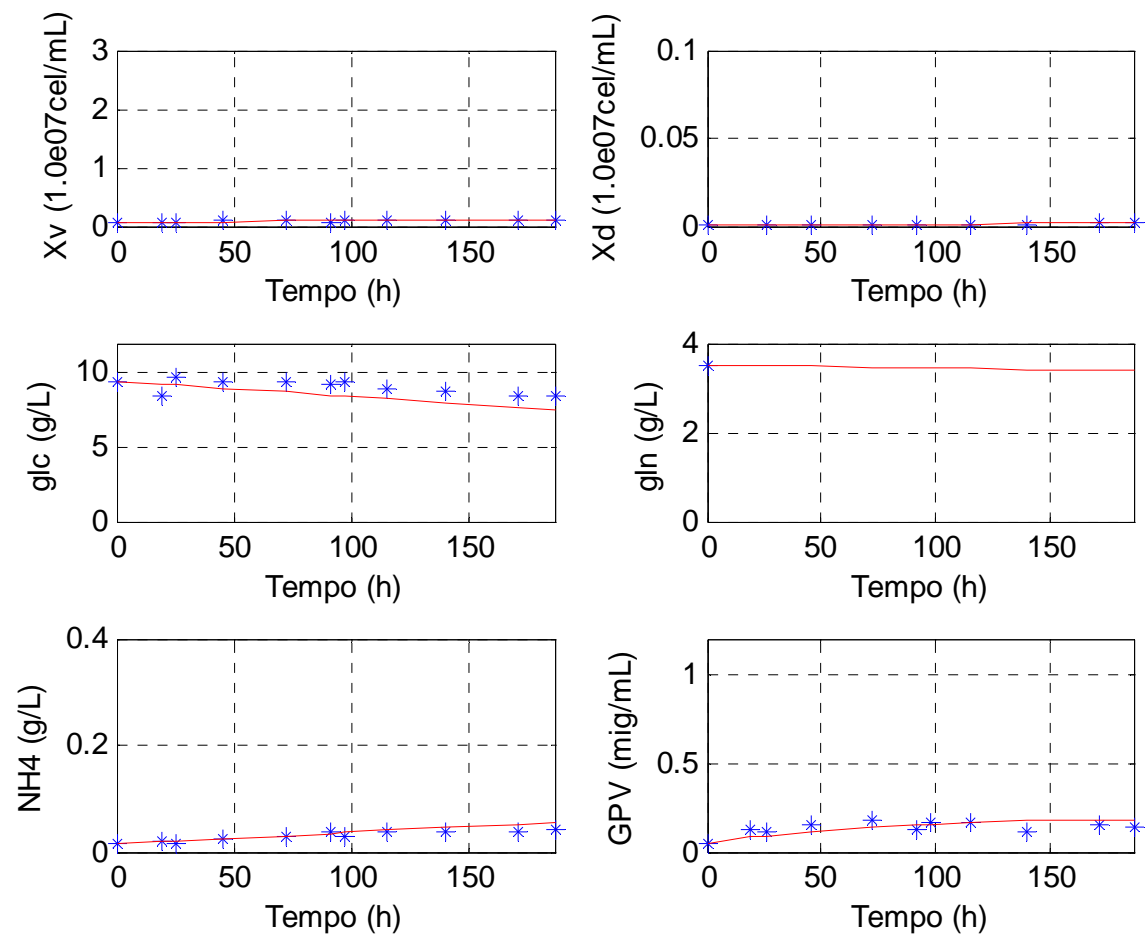

Figura 5.25. Comparação entre dados experimentais e as previsões do modelo 4 para o ensaio Ma-09, S2AcGPV2, $\mathrm{pO}_{2}=80 \%$ (Quadro A.1, Anexo A), (linha contínua, previsões do modelo, símbolos azuis, dados experimentais). 

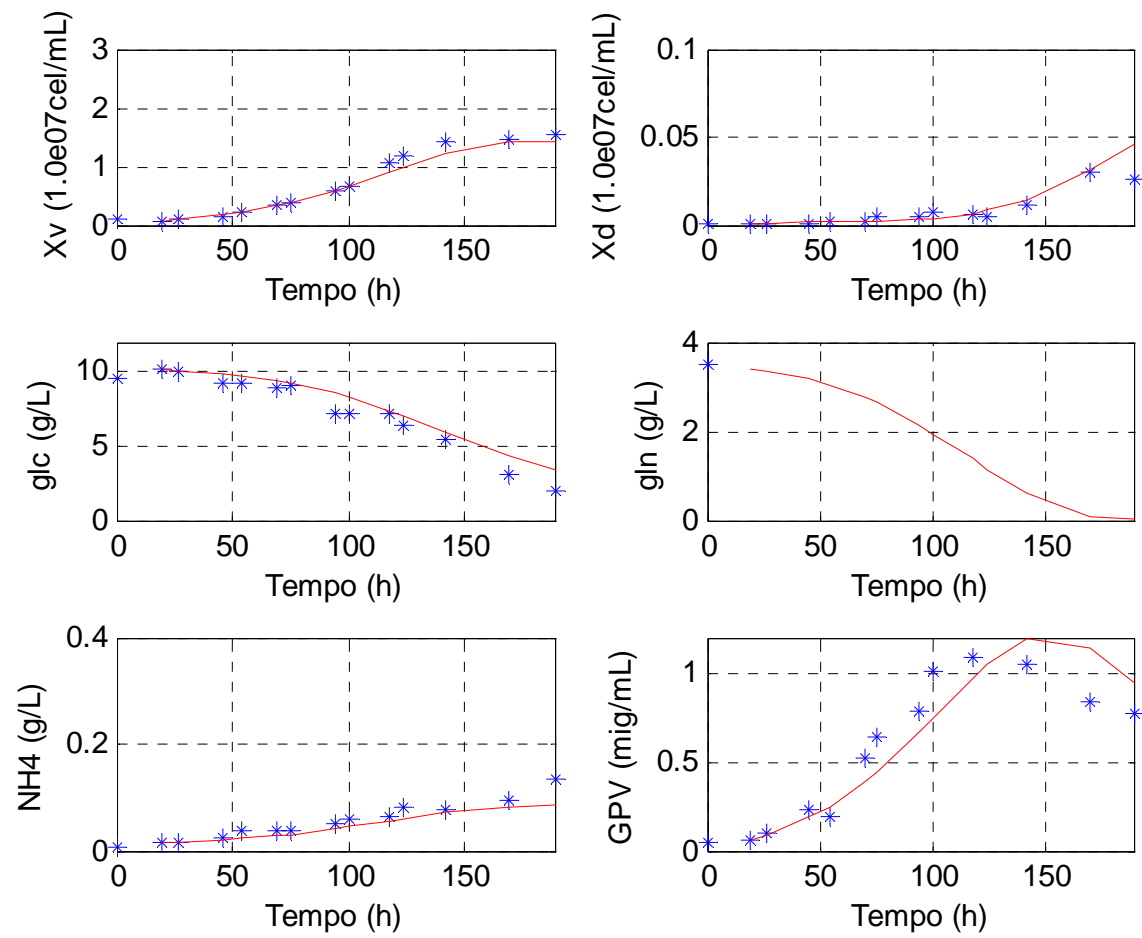

Figura 5.26. Comparação entre dados experimentais e as previsões do modelo 4 para o ensaio Ma-10, S2AcGPV2, $\mathrm{pO}_{2}=30 \%$ (Quadro A.1, Anexo A). (linha contínua, previsões do modelo; símbolos, dados experimentais).

Analisando as Figuras 5.23 a 5.26, constata-se um bom ajuste do modelo aos dados experimentais. Contudo podem ser destacadas algumas previsões do modelo, não observadas experimentalmente. No ensaio Ma-07, Figura 5.23, o modelo prevê um esgotamento da glutamina, após 150 horas de cultivo, que determina uma antecipação da fase estacionária do crescimento. O modelo indica uma destacada degradação da proteína formada que, diante da flutuação das medidas de GPV, especialmente no ensaio Ma-07, deve ser ainda conferida. Verifica-se, portanto, que a incorporação dos fatores de correção dependentes da concentração de oxigênio dissolvido auxilia a modelagem do cultivo e prevê um conjunto de relações importantes entre as variáveis do processo. Por outro lado, existem os aspectos ainda não adequadamente equacionados e a incorporação de fatores de correção traz consigo os riscos de uma solução particular, embora adequada, a um conjunto particular de dados, ou seja, traz o risco de uma solução ad hoc com perda de generalidade a que todo o modelo se propõe. Contudo, face às tentativas anteriores, verifica-se que é uma forma para incorporar mudanças metabólicas identificadas no cultivo. 


\subsubsection{Modelo 5. Consumo de glutamato}

Nos ensaios Ma-02 e Ma-03, realizados com célula S2AcGPV-KTC100, foram feitas análises de glutamina e glutamato. Isso permitiu que fossem avaliadas as concentrações desses dois compostos, que se orientasse o ajuste com esses novos dados, que se avaliasse a influência da concentração de oxigênio dissolvido nos fatores de consumo e, ainda, que se identificasse se houve consumo simultâneo ou preferencial desses substratos. Os dados obtidos permitiram identificar consumo preferencial de glutamina em relação a glutamato como indica a Figura 5.27 .

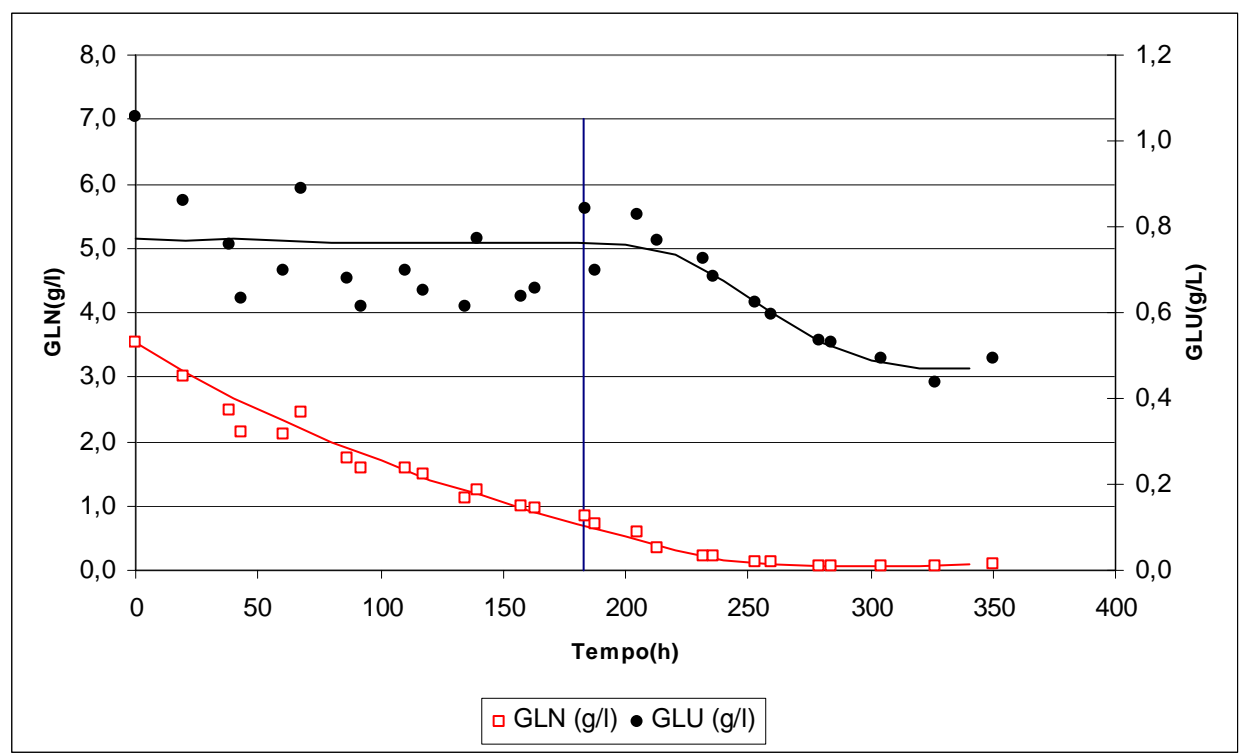

Figura 5.27. Consumo de glutamina e glutamato no ensaio Ma-02, célula S2AcGPV2-KTC100. A linha vertical indica o limiar de concentração de glutamina para início do consumo de glutamato.

Foi também foi identificada a influência do oxigênio dissolvido nos fatores de rendimento desses mesmos substratos. Assim, para a nova proposta de modelo, foram incorporadas as hipóteses propostas anteriores para o Modelo 4, assim como a adição de novos fatores de correção. O novo conjunto de equações que representa o Modelo 5 está indicado na Tabela 5.5 . 
Tabela 5.5. Equações do modelo 5

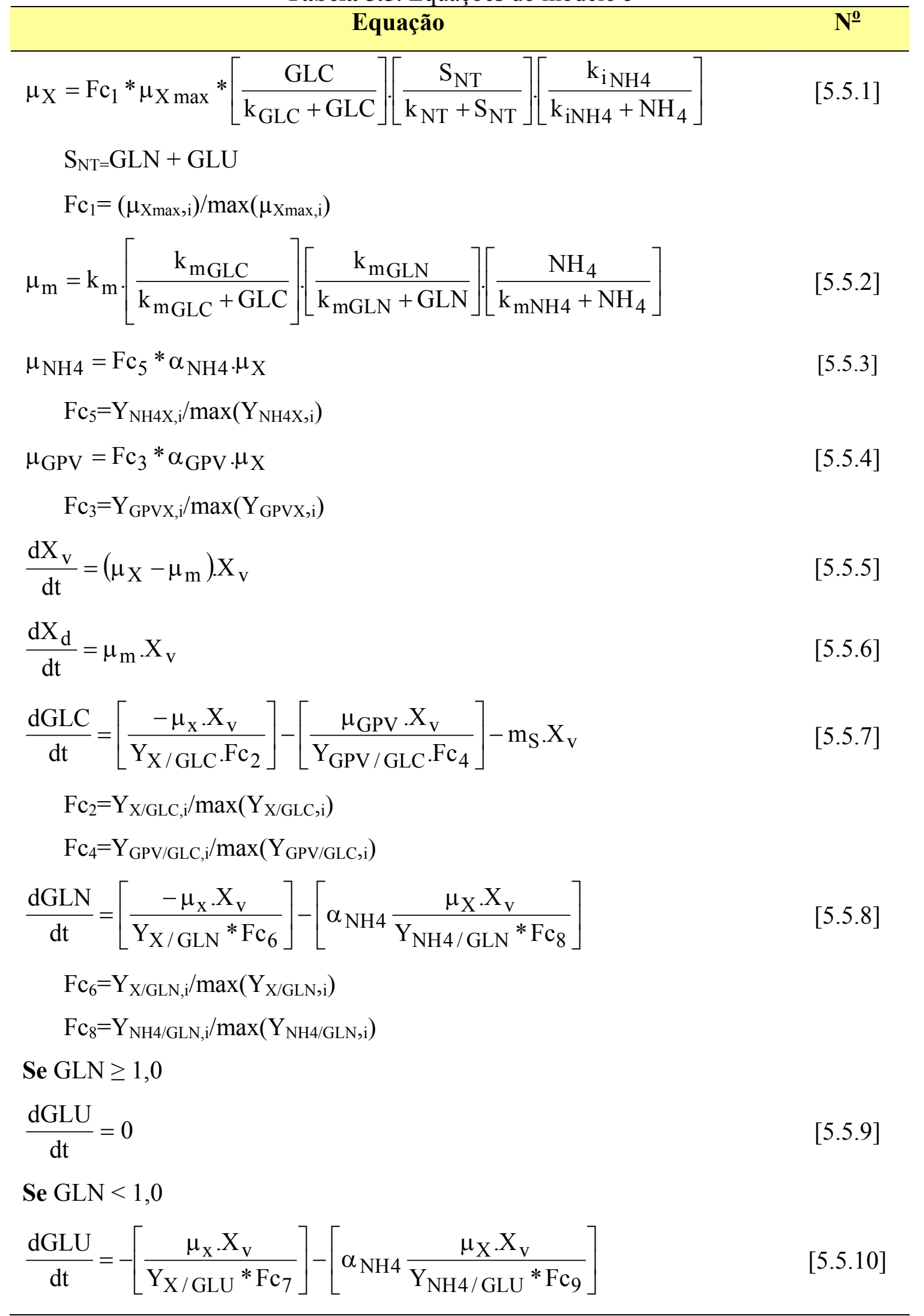




\begin{tabular}{|c|c|}
\hline Equação & N⿳o \\
\hline \multicolumn{2}{|l|}{$\mathrm{Fc}_{7}=\mathrm{Y}_{\mathrm{X} / \mathrm{GLU}, \mathrm{i}} / \max \left(\mathrm{Y}_{\mathrm{X} / \mathrm{GLU}, \mathrm{i}}\right)$} \\
\hline \multicolumn{2}{|l|}{$\mathrm{Fc}_{9}=\mathrm{Y}_{\mathrm{NH} 4 / \mathrm{GLU}, \mathrm{i}} / \mathrm{Max}\left(\mathrm{Y}_{\mathrm{NH} 4 / \mathrm{GLU}, \mathrm{i}}\right)$} \\
\hline$\frac{\mathrm{dNH}_{4}}{\mathrm{dt}}=\mu_{\mathrm{NH} 4} \cdot \mathrm{X}_{\mathrm{v}}$ & {$[5.5 .11]$} \\
\hline$\frac{\mathrm{dGPV}}{\mathrm{dt}}=\mu_{\mathrm{GPV}} * \mathrm{Xv}-\mathrm{k}_{\mathrm{d} \mathrm{GPV}} \cdot \mathrm{GPV}$ & {$[5.5 .12]$} \\
\hline$\frac{\mathrm{dO}_{2}}{\mathrm{dt}}=0$ & {$[5.5 .13]$} \\
\hline
\end{tabular}

As alterações descritas na Tabela 5.5 são:

a) incorporou-se a influência do oxigênio dissolvido no fator de conversão glutamina em células, $\mathrm{Y}_{\mathrm{X} / \mathrm{GLN}}$, por meio do fator de correção $\mathrm{Fc}_{6}$, calculado como relação entre $\mathrm{Y}_{\mathrm{X} / \mathrm{GLN}}$ do

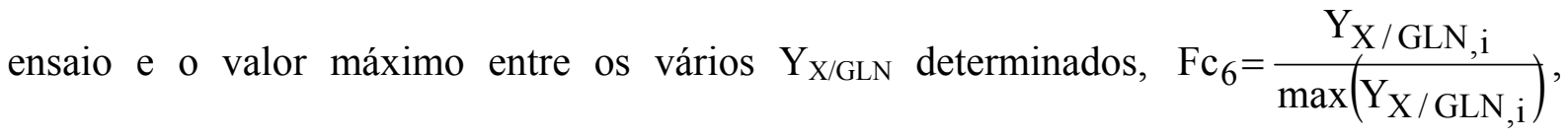
indicado na Figura 5.28 (Equação 5.5.8, Tabela 5.5).

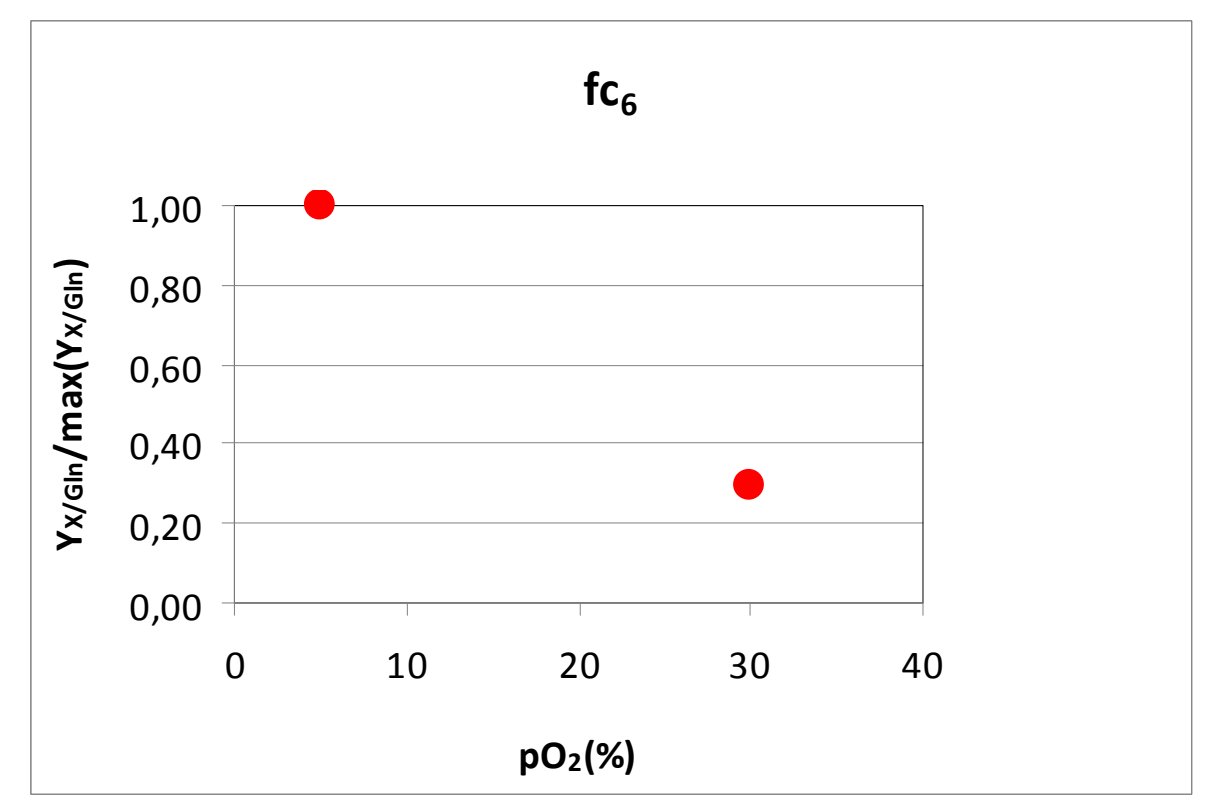

Figura 5.28. Fator de conversão $\mathrm{Fc}_{6}, \mathrm{Y}_{\mathrm{X} / \mathrm{GLN}, \mathrm{i}} / \max \left(\mathrm{Y}_{\mathrm{X} / \mathrm{GLN}, \mathrm{i}}\right)$, em função da concentração de oxigênio dissolvido, $\mathrm{pO}_{2}$ 
b) incorporou-se a influência do oxigênio dissolvido no fator de conversão glutamato em células, $\mathrm{Y}_{\mathrm{X} / \mathrm{GLU}}$, por meio do fator de correção $\mathrm{Fc}_{7}$, calculado como relação entre $\mathrm{Yx} / \mathrm{GLU}$ do

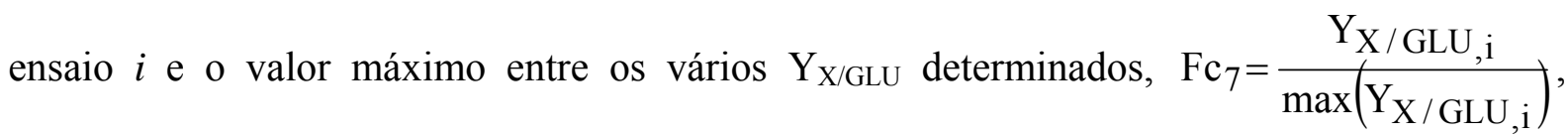
indicado na Figura 5.29 (Equação 5.5.10, Tabela 5.5).

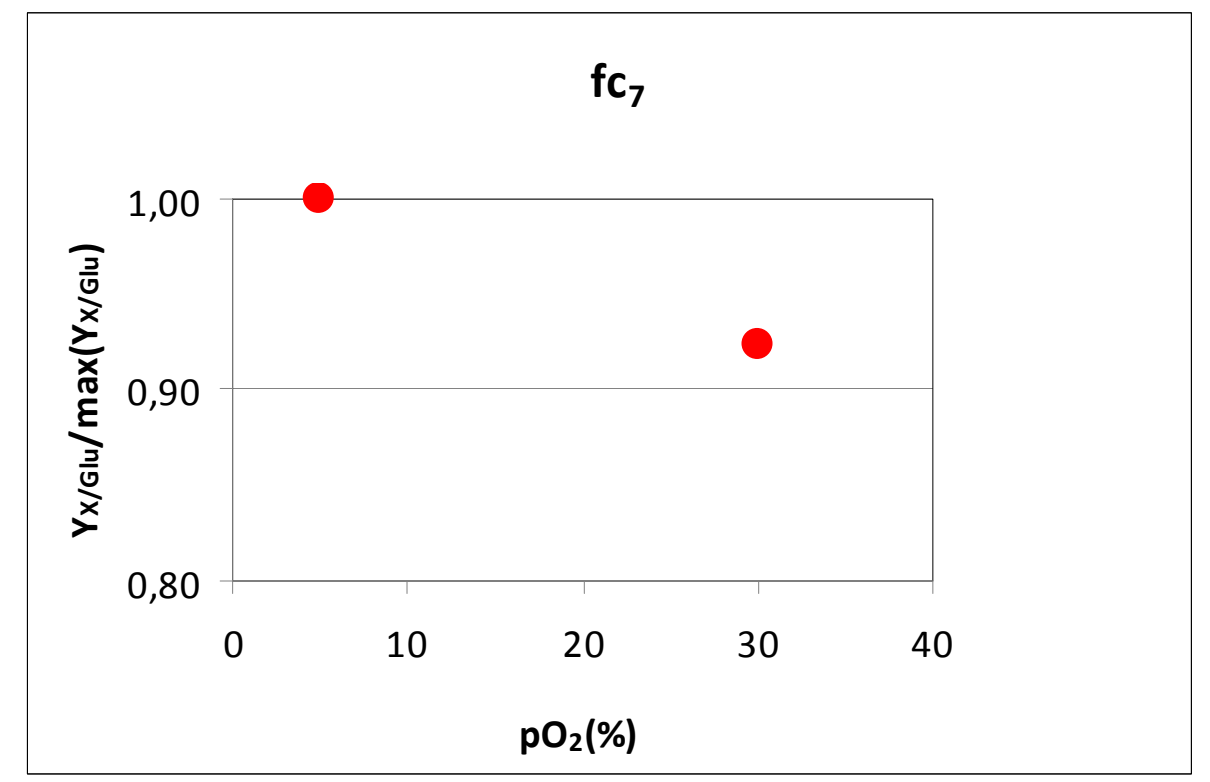

Figura 5.29. Fator de conversão $\mathrm{Fc}_{7}, \mathrm{Y}_{\mathrm{X} / \mathrm{GLU}, \mathrm{I}} / \max \left(\mathrm{Y}_{\mathrm{X} / \mathrm{GLU}, \mathrm{i}}\right)$, em função da concentração de oxigênio dissolvido, $\mathrm{pO}_{2}$.

c) incorporou-se a influência do oxigênio dissolvido no fator de conversão glutamina em $\mathrm{NH}_{4}{ }^{+}, \mathrm{Y}_{\mathrm{NH} 4 / \mathrm{GLN}}$, por meio do fator de correção $\mathrm{Fc}_{8}$, calculado como relação entre $\mathrm{Y}_{\mathrm{NH} 4 / \mathrm{GLN}}$ do

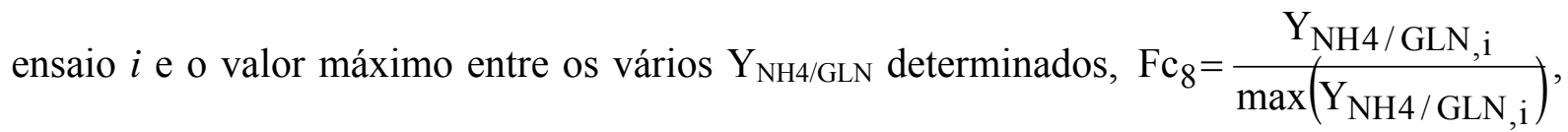
indicado na Figura 30 (Equação 5.5.8, Tabela 5.5). 


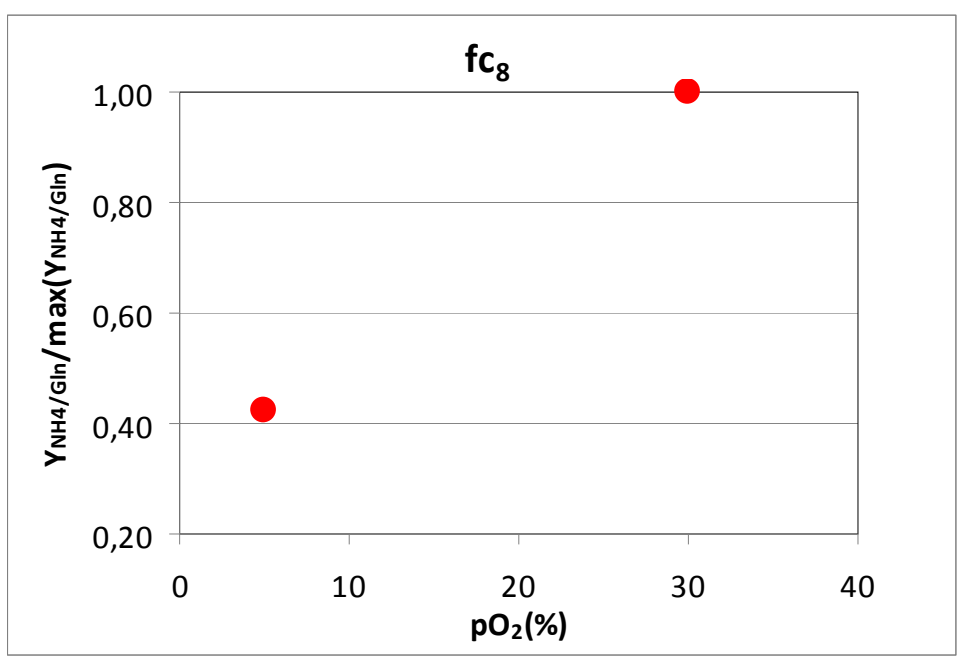

Figura 5.30. Fator de conversão $\mathrm{Fc}_{8}, \mathrm{Y}_{\mathrm{X} / \mathrm{GLN}, \mathrm{i}} / \max \left(\mathrm{Y}_{\mathrm{X} / \mathrm{GLN}, \mathrm{i}}\right)$, em função da concentração de oxigênio dissolvido, $\mathrm{pO}_{2}$.

d) incorporou-se a influência do oxigênio dissolvido no fator de conversão glutamato em $\mathrm{NH}_{4}{ }^{+}, \mathrm{Y}_{\mathrm{NH} 4 / \mathrm{GLU}}$, por meio do fator de correção, $\mathrm{Fc}_{8}$, calculado como relação entre $\mathrm{Y}_{\mathrm{NH} 4 / \mathrm{GLU}}$ do

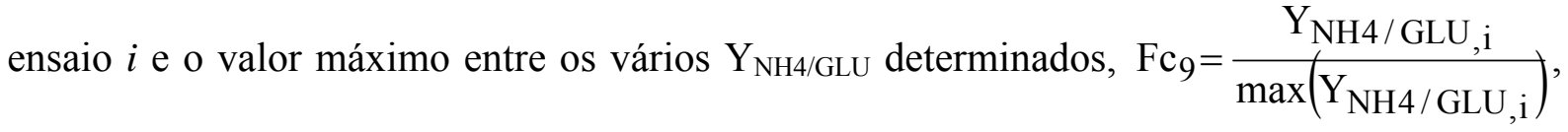
indicado na Figura 5.31 (Equação 5.5.9, Tabela 5.5).

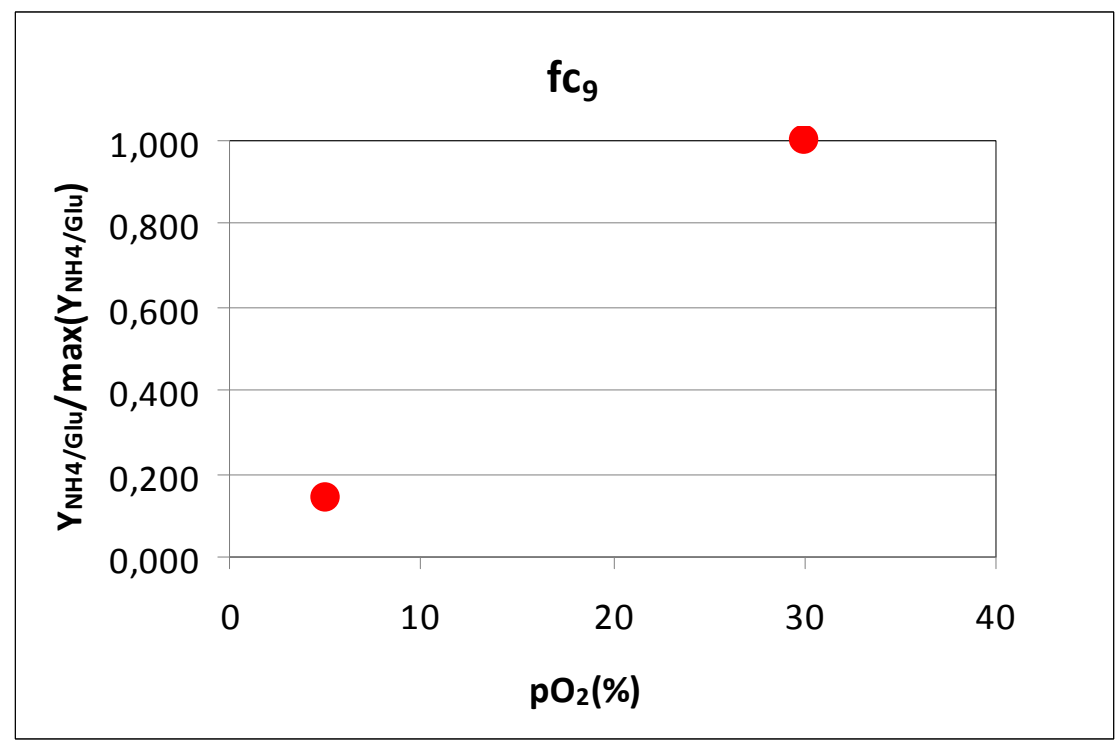

Figura 5.31. Fator de conversão $\mathrm{Fc}_{9}, \mathrm{Y}_{\mathrm{X} / \mathrm{GLN}, \mathrm{i}} / \max \left(\mathrm{Y}_{\mathrm{X} / \mathrm{GLN}, \mathrm{i}}\right)$, em função da concentração de oxigênio dissolvido, $\mathrm{pO}_{2}$.

e) foi proposto um limiar de concentração de glutamina, abaixo do qual inicia-se o consumo de glutamato a partir da análise de dados dos ensaios Ma 02 e Ma-03. A determinação desse 
limiar está indicada na Figura 5.27, formulado como condição para ativar o consumo de glutamato, Equação 5.5.10.

f) foi incorporado o balanço material de glutamato, cujo consumo é ativado quando a glutamina atinge concentrações inferiores ao limiar definido $(1 \mathrm{~g} / \mathrm{L})$, que está indicado na Figura 5.27.

Os resultados do ajuste estão ilustrados nas Figuras 5.32 e 5.33 e na Tabela 5.3,
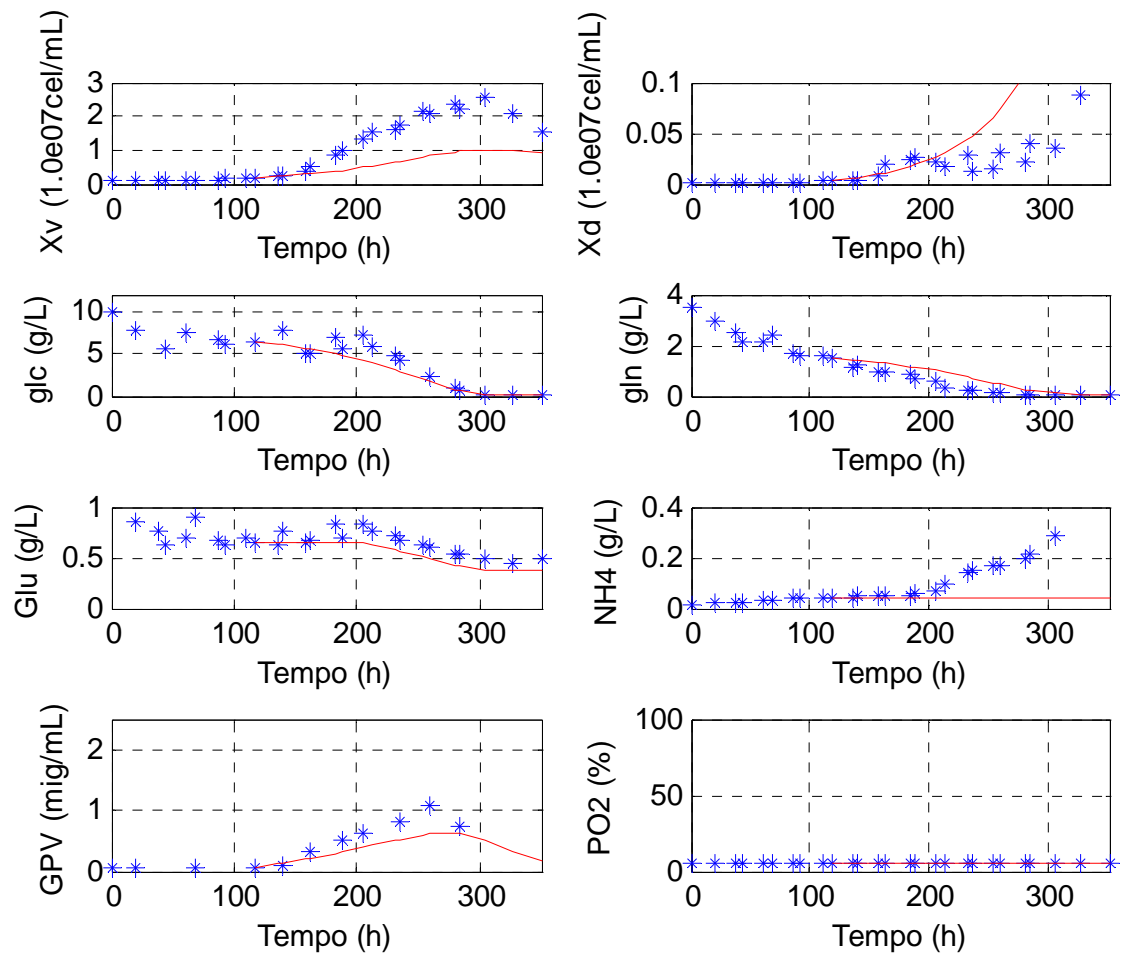

Figura 5.32. Comparação entre dados experimentais e as previsões do modelo 5 para o ensaio Ma-02, célula S2AcGPV2-KTC100, $\mathrm{pO}_{2}=5 \%$ (Quadro A.1, Anexo A). (linha contínua, previsões do modelo; símbolos, dados experimentais).

As previsões do modelo indicam para o ensaio Ma-02 (Figura 5.32) que o esgotamento de glicose e de glutamina interrompe, quase simultaneamente, o crescimento e determinam a concentração máxima do cultivo, característica coerente com os dados obtidos, embora a concentração celular máxima seja significativamente inferior à observada. $\mathrm{Na}$ tabela 5.3 observa-se que o valor de $\mu_{\mathrm{Xmax}}$ ajustado neste modelo é três vezes inferior ao obtido com o modelo 1 . 

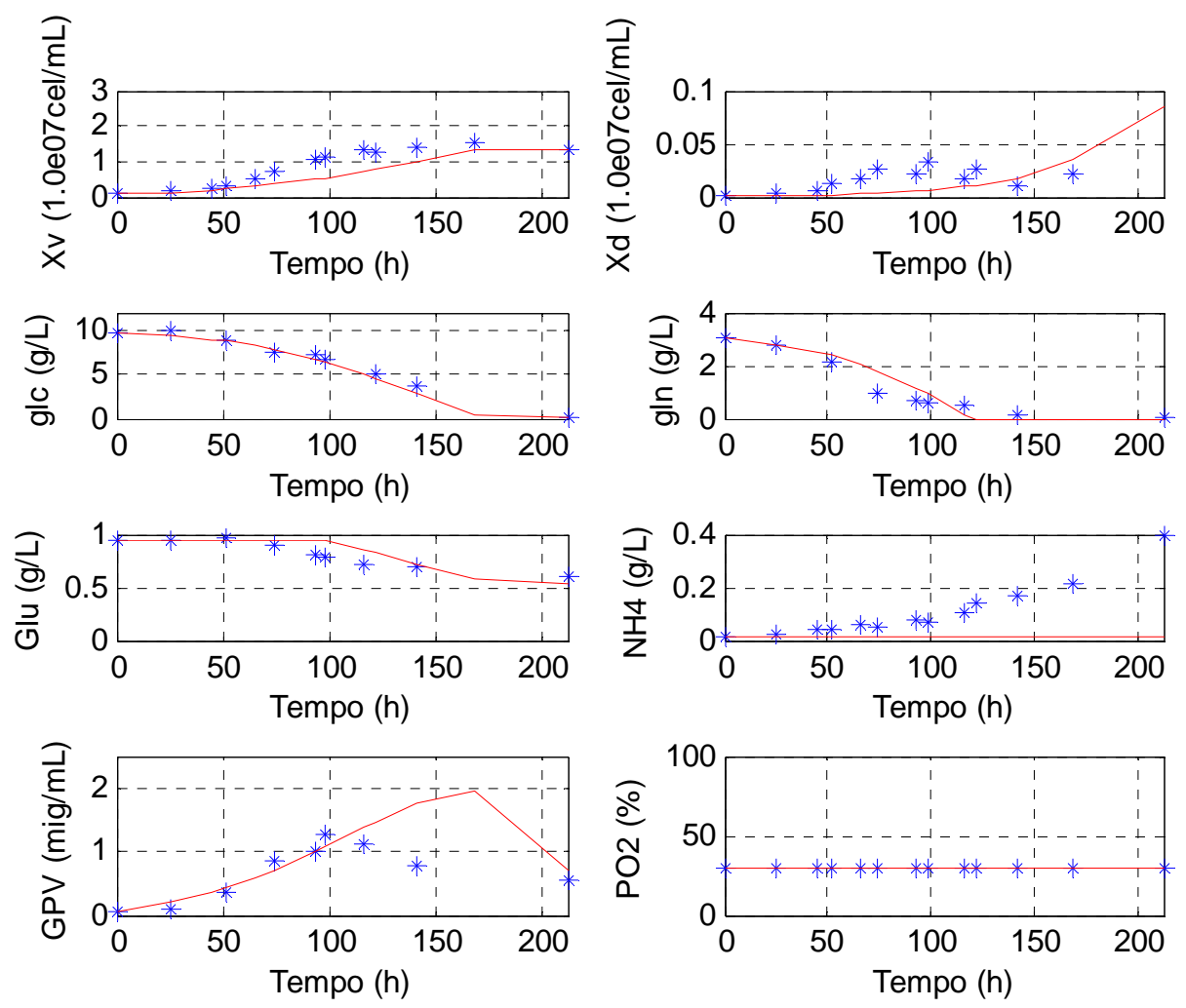

Figura 5.33. Comparação entre dados experimentais e as previsões do modelo 5 para o ensaio Ma-03, célula S2AcGPV2-KTC100, $\mathrm{pO}_{2}=30 \%$ (Quadro A.1, Anexo A). (linha contínua, previsões do modelo; símbolos, dados experimentais).

Para o mesmo ensaio, o modelo não reproduz o decréscimo da concentração de células viáveis observado após $300 \mathrm{~h}$, embora a concentração de células não-viáveis prevista seja superior à observada. Isso sugere a existência de um mecanismo de lise significativo, não previsto no modelo. Como a produção de $\mathrm{NH}_{4}{ }^{+}$está associada exclusivamente ao crescimento celular, o modelo não reproduz o aumento significativo desse metabólito após o fim da fase exponencial. Finalmente, o modelo prevê uma forte degradação da proteína na fase estacionária. As diferenças entre as previsões para as concentrações de GPV e as determinadas experimentalmente podem ser explicadas pelos diferentes perfis de velocidades específicas de crescimento encontradas para esses dois ensaios. Como neste modelo a velocidade específica de formação de GPV é exclusivamente proporcional à velocidade específica de crescimento, o ensaio que permite perfis de velocidade especifica com maiores valores também permitirá maiores concentrações celulares e maiores concentrações de GPV. Isso explica os valores maiores previstos para a concentração de células viáveis e GPV no ensaio Ma-3 (Figura 5.33). De forma geral, quando se compara o ajuste para o mesmo conjunto de dados (Ma-02 e Ma-03) com o Modelo 1a, ainda não é possível afirmar que a incorporação dos fatores que levam em conta a influência do oxigênio dissolvido no 
metabolismo celular permitiu alcançar um ajuste e nível previsões significativamente diferentes É também verdade essa comparação não pode ficar restrita a esse esses dois ensaios, o que comprometeria a importância e a utilidade dos modelos considerados.

\subsection{Modelos que incorporam a mudança de metabolismo em função das condições do cultivo $\left(G L C_{0}, G L N_{0}\right.$ e $\left.\mathrm{pO}_{2}\right)$ via fatores de conversão.}

Neste estagio do trabalho, foram utilizadas todas as análises de todos os ensaios realizados com a célula S2AcGPV2 (ensaios Ma-07 a Ma-17) obtidos por Aguiar (2010) o que permitiu a análise da influência da concentração inicial de glicose e glutamina nos fatores de conversão, análise também realizada por Aguiar (2010) e que permite incorporar a influência da glicose e glutamina no metabolismo celular. A partir dos dados dos ensaios, buscou-se identificar os principais fenômenos do processo que ocorrem nas fases exponencial, estacionaria e de declínio a serem incorporados no modelo. A análise dos fenômenos presentes nas diferentes fases do cultivo está indicada a seguir.

\subsubsection{Análise de Fenômenos (Ensaios Ma-07 a Ma-17)}

a) Duração da fase exponencial.

Dada a complexidade da modelagem da fase lag do cultivo, optou-se por não modelar esta fase caracterizando a sua duração da fase e realizando o ajuste a partir do fim da fase.

b) Influência da concentração inicial de GLC na fase exponencial. Nos ensaios nos quais se variou a concentração inicial de GLC, ensaios Ma-10, Ma-11, Ma-12 e Ma-14, os dados indicados na Figura 5.34 sugerem limitação por glicose apenas quando as concentrações iniciais de GLC são de 1 g/L e 5 g/L (ensaios Ma-11 e Ma-12). Nesses ensaios, o fim da fase exponencial, aparentemente, ocorre quando $\mathrm{GLC}_{0}$ é inferior a 1,5 g/L. Os valores de $\mu_{\mathrm{Xmax}}$ observado nesses ensaios $\left(0,019 \mathrm{~h}^{-1} \mathrm{e} 0,009 \mathrm{~h}^{-1}\right)$ são significativamente menores que $0,027 \mathrm{~h}^{-1}$, valor encontrado no ensaio Ma-10, considerado com referência para os cultivos estudados. A fase exponencial do ensaio Ma-11 está bem caracterizada com 11 pontos e um coeficiente de correlação quadrático $\left(\mathrm{r}^{2}\right)$ de 0,98 a para o ensaio Ma-12 a correção é caracterizada por 12 
pontos e um coeficiente de correlação quadrático de 0,99 . Aparentemente, há limitação em GLC e a células estão utilizando uma via metabólica alternativa, que apresenta um baixo valor de $\mu_{X \max }$ e, assim, o término dessa fase exponencial não se deve ao esgotamento de GLC. Isso já parece um indício claro de limitação do crescimento por GLC e pode orientar uma estimativa inicial da constante de saturação da glicose $\mathrm{k}_{\mathrm{GLC}}$ (Tabela 5.4).

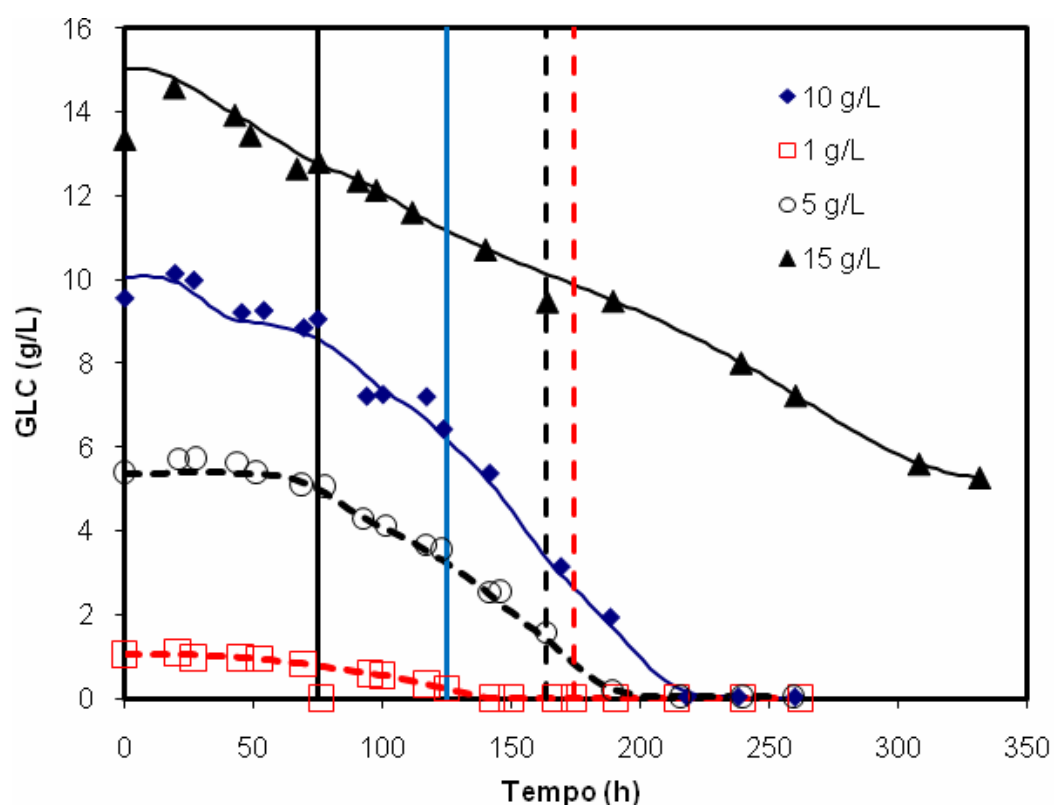

Figura 5.34. Evolução da concentração de glicose sob diferentes GLC $_{0}$ (Ensaios Ma-10, Ma-11, Ma-12 e Ma-14; Quadro A1, Anexo A). Linhas verticais indicam o final da fase exponencial em cada ensaio

Nesses ensaios, $\mathrm{GLC}_{0}=1 \mathrm{~g} / \mathrm{L}(\mathrm{Ma}-11)$ e $\mathrm{GLC}_{0}=5 \mathrm{~g} / \mathrm{L}$ (Ma-12), também é possível afirmar que não se observa limitação do crescimento por esgotamento de GLN, como indica a Figura 5.35 .

c) Influência da concentração inicial de GLN na fase exponencial. Quando se varia GLN $_{0}$ mantendo-se a GLC $_{0}$ em 10,0 g/L (ensaios Ma-10, Ma-15, Ma-16 e Ma-17), os dados sugerem não haver limitação por GLC em nenhum dos ensaios como indica a Figura 5.36. Por outro lado, os dados segurem limitação por GLN nos ensaios com concentrações iniciais de GLN de 1,75 g/L e 0,6 g/L, como indica a Figura 5.36. Nesses casos, o fim da fase exponencial ocorre quando a GLN, aparentemente, se esgotou. No entanto, nos ensaios com concentrações iniciais de GLN de 7,0 g/L e 3,5 g/L , no final da fase exponencial,(linhas verticais), não se observa esgotamento de GLN e de GLC. Isso sugere a existência de outro fator que leva ao fim da fase exponencial, alguma outra limitação por substrato, algum aminoácido, por exemplo, ou a existência de inibição que interrompe a fase exponencial do crescimento pelo acúmulo de algum metabólito inibitório no meio. 


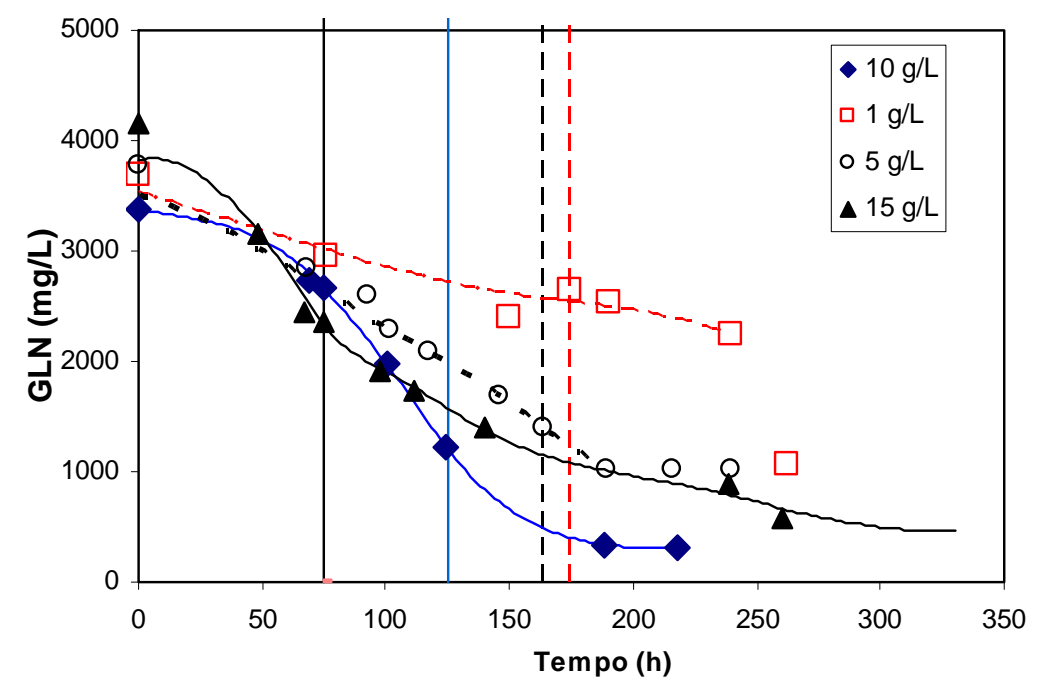

Figura 5.35. Evolução da concentração de glutamina nos ensaios com diferentes $\mathrm{GLC}_{0}$ (Ensaios Ma-10, Ma-11, Ma-12 e Ma-14; Quadro A1, Anexo A). Linhas verticais, final da fase exponencial

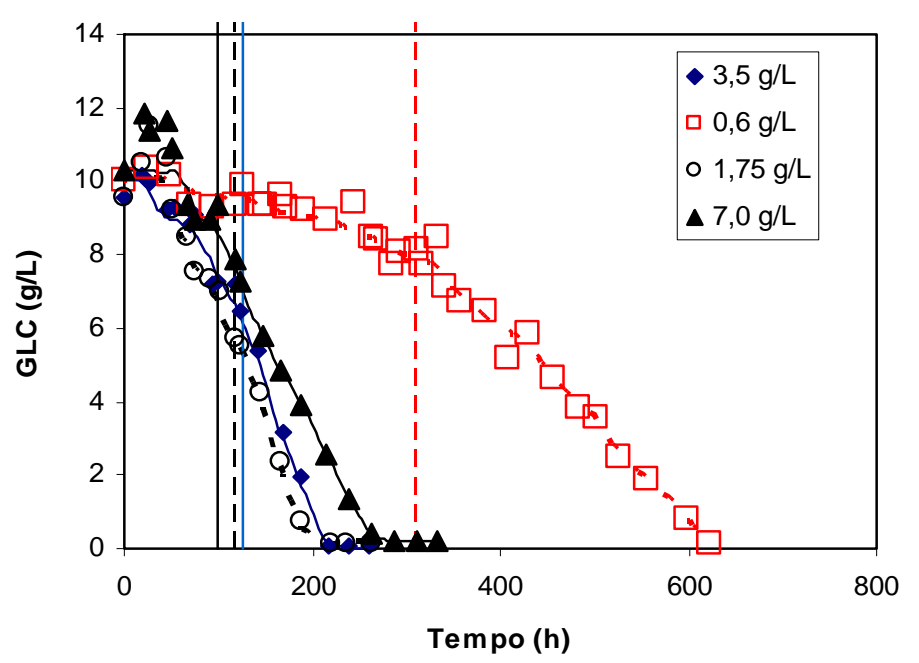

Figura 5.36. Evolução da concentração de glicose nos ensaios com diferentes $\mathrm{GLN}_{0}$ (Ensaios Ma-10, Ma-15, Ma-16 e Ma-17; Quadro A1, Anexo A). Linhas verticais, final da fase exponencial.

$\mathrm{O}$ ensaio Ma-10, $\left(\mathrm{GLC}_{0}=10 \mathrm{~g} / \mathrm{L}\right.$ e $\left.\mathrm{GLN}_{0}=3,5 \mathrm{~g} / \mathrm{L}\right)$, indicado na Figura 5.37, num primeiro momento, sugere limitação por GLN, pois ao final da fase exponencial a concentração de GLN é cerca de 1,0 g/L. Contudo, ao se observar a influência da concentração inicial de GLN na fase exponencial do crescimento em outros ensaios, especialmente o ensaio Ma-16, $\left(\mathrm{GLN}_{0}=1,75 \mathrm{~g} / \mathrm{L}\right)$, indicado na mesma Figura 5.3, observa-se que a célula desenvolve-se com alta velocidade específica de crescimento, $0,025 \mathrm{~h}^{-1}$, mesmo com concentrações de GLN inferiores a $500 \mathrm{mg} / \mathrm{L}$. 


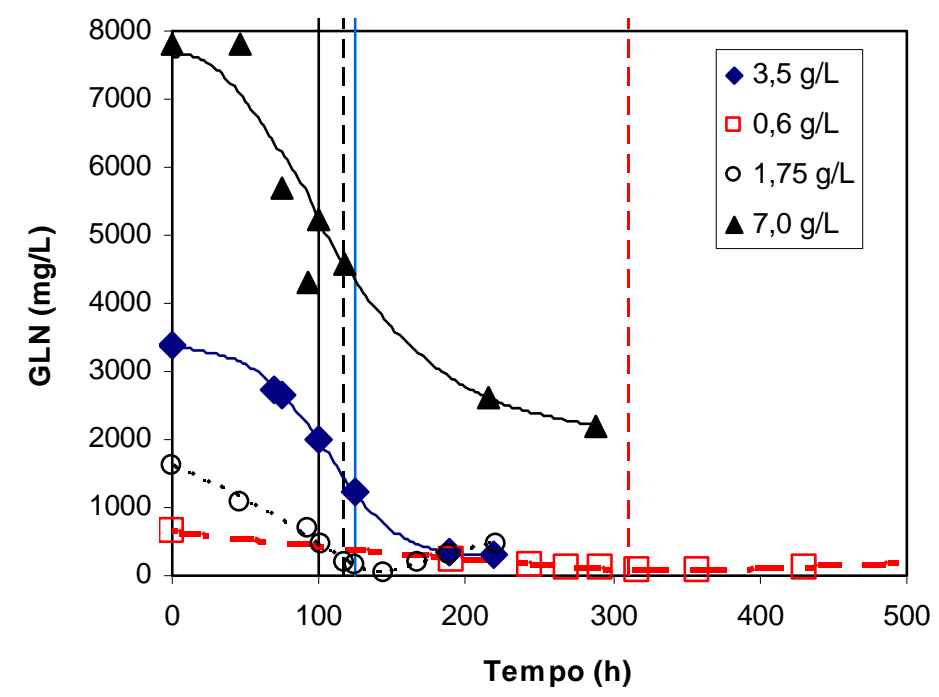

Figura 5.37. Evolução da concentração de glutamina nos ensaios com diferentes $\mathrm{GLN}_{0}$ (Ma-10, Ma-15, Ma-16 e Ma-17; Quadro A1, Anexo A). Linhas verticais, final da fase exponencial.

d) Influência de $\mathrm{NH}_{4}{ }_{4}$ na fase de crescimento exponencial. Ao se analisar os dados obtidos nos ensaios Ma-10 a Ma-17 verifica-se que nos ensaios nos quais o fim da fase exponencial não indica limitação por GLC e GLN (Ma-10, Ma-14 e Ma-17) as concentrações de $\mathrm{NH}_{4}^{+}$ estão entre $70 \mathrm{mg} / \mathrm{L}$ e $163 \mathrm{mg} / \mathrm{L}$ ao final da fase exponencial como indica a Figura 5.38.
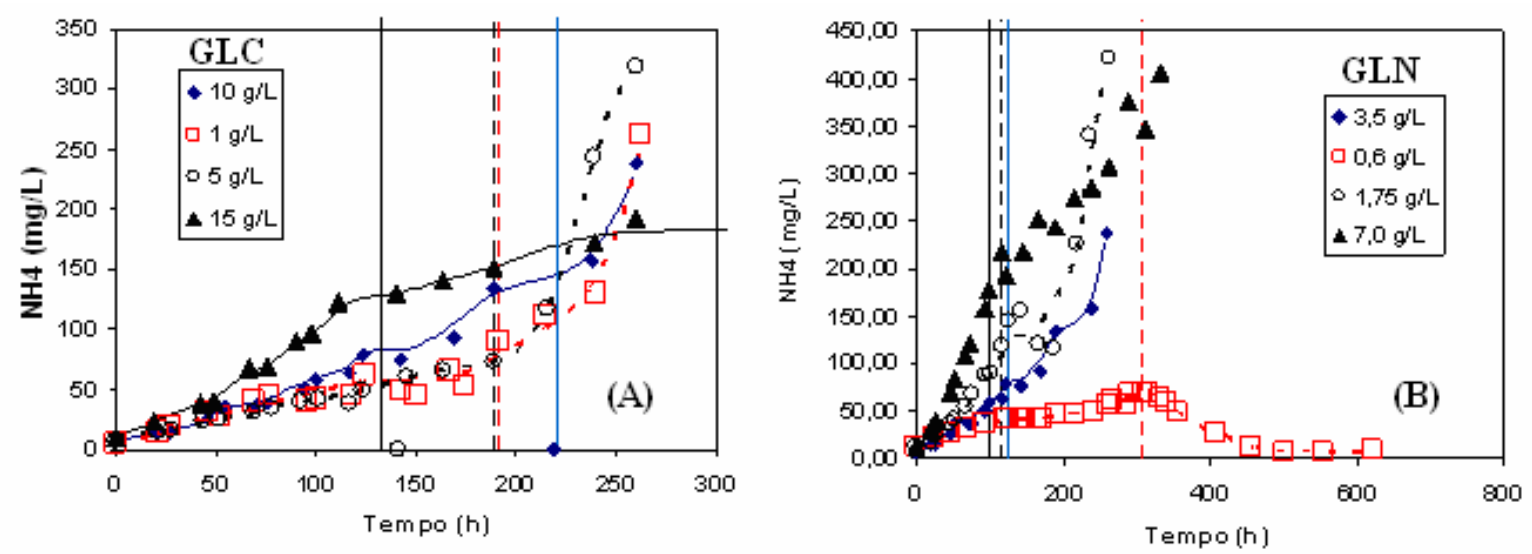

Figura 5.38. Evolução da concentração de $\mathrm{NH}_{4}^{+}$. a) Ensaios com diferentes $\mathrm{GLC}_{0}$ (Ma-10, Ma-11, Ma-12 e Ma-

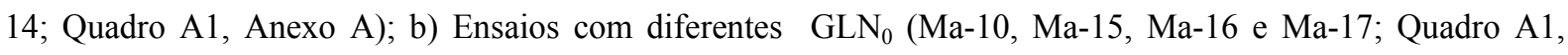
Anexo A). Linhas verticais, final da fase de crescimento exponencial.

Sabe-se que células de Spodoptera frugiperda (Sf9) não acumulam $\mathrm{NH}^{+}$ao longo do cultivo. Células de Drosophila melanogaster, S2, assim como a linhagem Trichoplusia ni (Tn-5), ao contrário, acumulam $\mathrm{NH}_{4}{ }^{+}$. Os dados de literatura informam sobre níveis de inibição de $\mathrm{NH}_{4}$ 
para culturas de células de mamíferos que acumulam $\mathrm{NH}_{4}{ }^{+}$e não foram localizadas referências sobre níveis de inibição por amônio de células S2 ou Tn-5. Para células de mamíferos ocorre inibição quando a concentração de $\mathrm{NH}_{4}{ }^{+}$é superior a valores que podem estar no intervalo entre 36 a 72,1 mg/L. Como a célula S2 tem comportamento similar a células Tn-5 e a células de mamíferos, os valores encontrados sugerem inibição por $\mathrm{NH}_{4}^{+}$ao crescimento da célula.

e) Influência da concentração de GLU na fase exponencial. Os dados obtidos nos ensaios Ma10, Ma-15, Ma-16 e Ma-17, ilustrados na Figura 5.39, indicam as concentrações de GLU ao final da fase exponencial de 849 a $1033 \mathrm{mg} / \mathrm{L}$, sugerindo que GLU não limita o crescimento da célula S2.
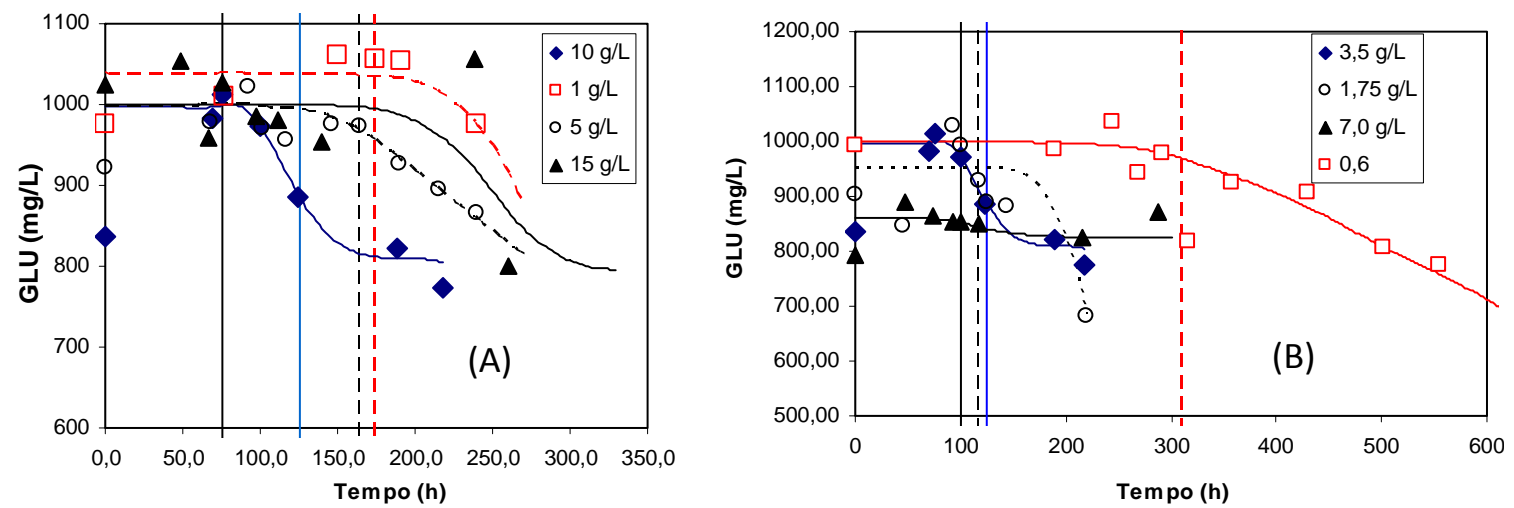

Figura 5.39. Evolução na concentração de glutamato. a) Ensaios com diferentes $\mathrm{GLC}_{0}$ (Ma-10, Ma-11, Ma-12 e Ma-14; Quadro A1, Anexo A); b) Ensaios com diferentes GLN $_{0}$ (Ma-10, Ma-15, Ma-16 e Ma-17; Quadro A1, Anexo A). Linhas verticais, final da fase de crescimento exponencial.

f) Influência da concentração de LAC na fase exponencial. Os ensaios com variação da concentração inicial de GLC (Ma-10, Ma-11, Ma-12 e Ma-14) indicam concentrações de LAC ao final da fase exponencial de 0 a $300 \mathrm{mg} / \mathrm{L}$, como ilustra a Figura 5.40 (A). Os ensaios com variação da concentração inicial de GLN (Ma-10, Ma-15, Ma-16 e Ma-17) indicam concentrações de LAC ao final da fase exponencial de 0 a $180 \mathrm{mg} / \mathrm{L}$ como ilustra a Figura 5.40 (B). A literatura indica inibição por lactato em células de mamíferos para concentrações superiores a 1,7 g/L. Esses dados sugerem, portanto, que lactato não inibe o crescimento das células S2. É importante destacar que as células Sf9 não acumulam lactato em seus cultivos e que as células S2, assim como linhagem Trichoplusia ni, apresentam um comportamento similar a células de mamíferos. 

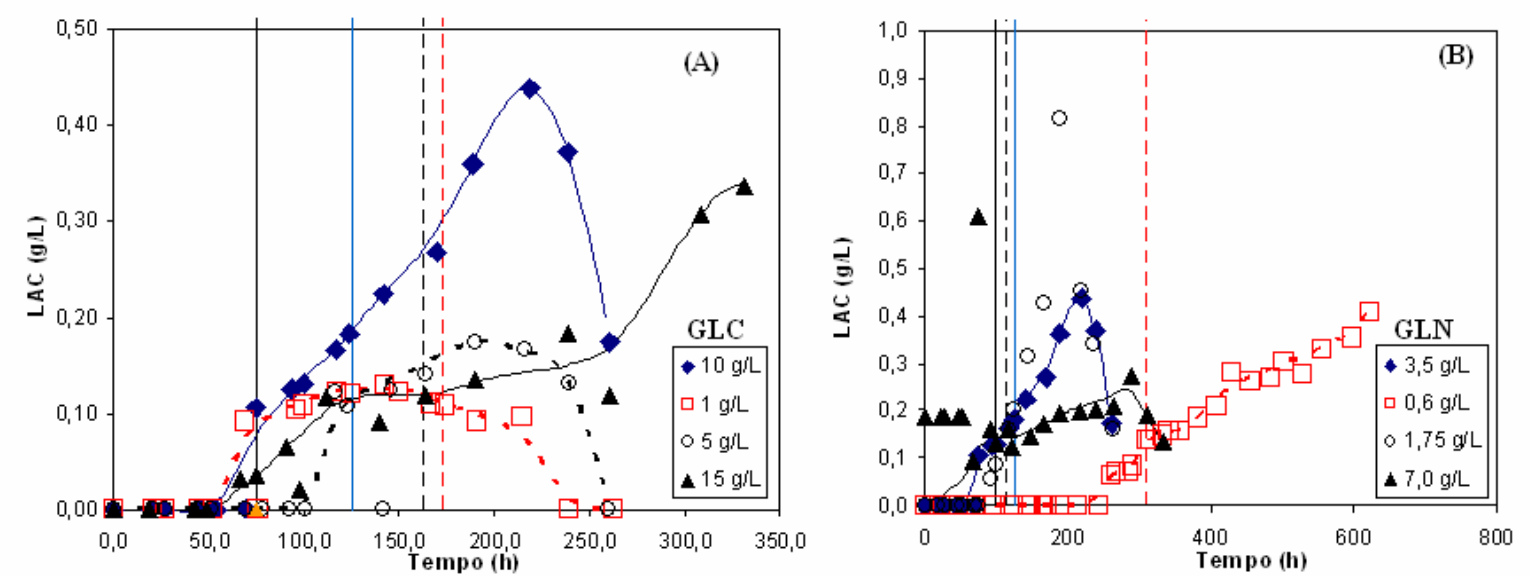

Figura 5.40. Evolução da concentração de lactato. a) Ensaios com diferentes GLC $_{0}$ (Ma-10, Ma-11, Ma-12 e

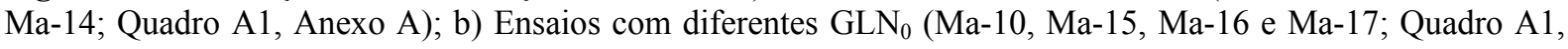
Anexo A). Linhas verticais, final da fase de crescimento exponencial.

g) Influência de $\mathrm{O}_{2}$ no metabolismo de $\mathrm{S} 2$ na fase exponencial de crescimento (Ensaios Ma07 a Ma-10). A influência de $\mathrm{O} 2$ dissolvido na fase exponencial do cultivo foi avaliada a partir dos dados de Aguiar(2010) considerando a sua influência nos seguintes parâmetros: $\mu_{\mathrm{Xmax}}, \mathrm{Y}_{\mathrm{X} / \mathrm{GLC}}, \mathrm{Y}_{\mathrm{LAC} / \mathrm{GLC}}, \mathrm{Y}_{\mathrm{ALA} / \mathrm{GLC}}, \mathrm{Y}_{\mathrm{X} / \mathrm{GLN}}, \mathrm{Y}_{\mathrm{NH} / \mathrm{GLN}}, \mathrm{Y}_{\mathrm{ALA} / \mathrm{GLN}}, \mathrm{Y}_{\mathrm{GPV} / \mathrm{X}}, \mathrm{Y}_{\mathrm{GPV} / \mathrm{GLC}}$. A Figura 5.41 indica um efeito inibidor da concentração de $\mathrm{O}_{2}$ na velocidade específica máxima de crescimento $\left(\mu_{\mathrm{Xmax}}\right)$.

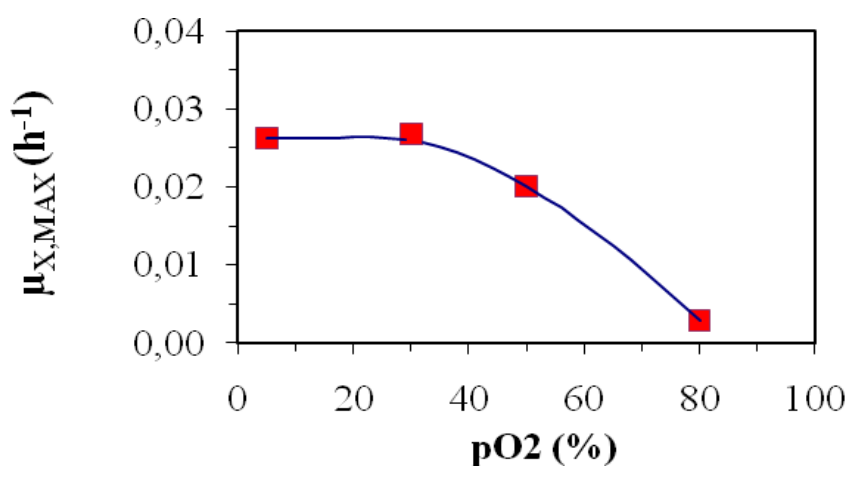

Figura 5.41. Influência da concentração de $\mathrm{O}_{2}$ na velocidade especifica de crescimento ( $\left.\mu_{\mathrm{Xmax}}\right)$. Ensaios Ma-07 a Ma-10 (Quadro A1, Anexo A).

A Figura 5.42 indica uma maior conversão de GLC em células quando a concentração de $\mathrm{O}_{2}$ é igual ou inferior a $30 \%$ e uma diminuição dessa conversão para valores superiores a $30 \%$. Essa mudança na eficiência da conversão de GLC em células sugere uma mudança de metabolismo celular em função da disponibilidade de $\mathrm{O} 2$ no meio. Essa afirmação baseia-se 
no fato de as fases exponenciais estarem muito bem caracterizadas em cada um desses ensaios (AGUIAR, 2010). É possível também afirmar que o sistema está inibido para valores de O2 superiores a $30 \%$ de oxigênio dissolvido.

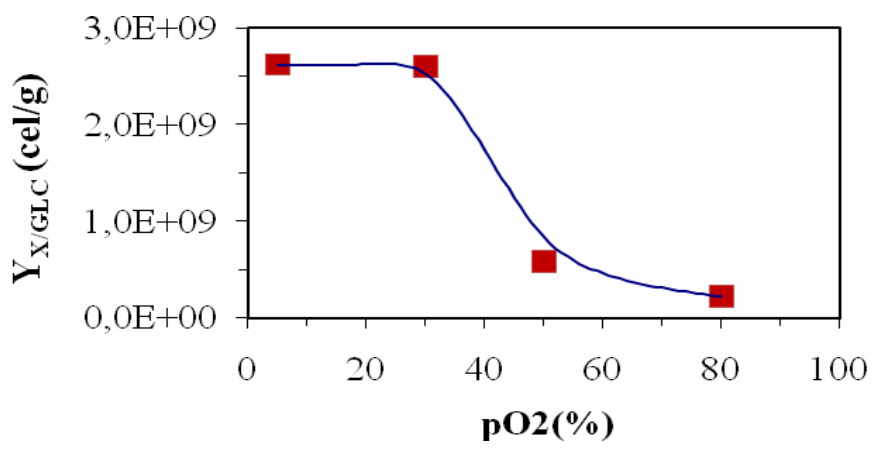

Figura 5.42. Influência da concentração de $\mathrm{O}_{2}$ no fator $\mathrm{Y}_{\mathrm{X} / \mathrm{GLC}}$. Ensaios Ma-07 a Ma-10 (Quadro A.1, Anexo A).

A Figura 5.43 ilustra claramente a afirmação anterior sobre a mudança de metabolismo em função da concentração de $\mathrm{O}_{2}$ no meio, pois, para concentrações inferiores a 40\%, observa-se uma condição que caracteriza um metabolismo fermentativo com formação de lactato. Como mencionado anteriormente, essa resposta pode ser explicada por uma forte inibição das células S2 para concentrações e oxigênio dissolvido acima de $40 \%$, de tal ordem, que $\mu_{\mathrm{Xmax}}$ (Figura 5.41) é bastante reduzida e, consequentemente, deve ser alterado todo o metabolismo celular.

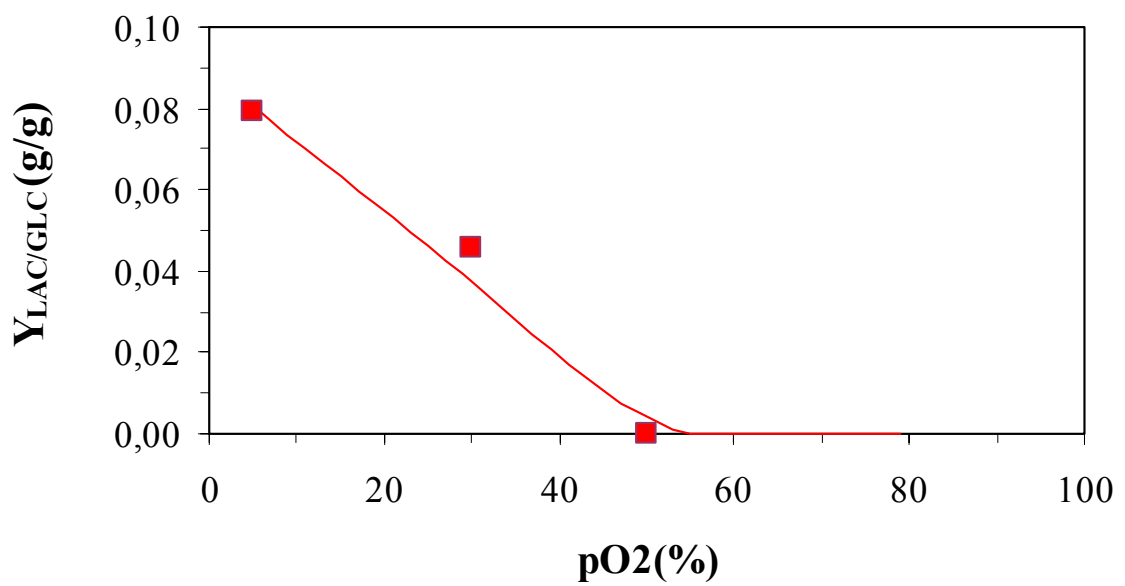

Figura 5.43. Influência da concentração de $\mathrm{O}_{2}$ no fator $\mathrm{Y}_{\mathrm{LAC} / \mathrm{GLC}}$. Ensaios Ma-07 a Ma-10 (Quadro A.1, Anexo A).

A Figura 5.44 ilustra mais uma vez a mudança de metabolismo, já indicada anteriormente, e que também leva a um aumento da conversão de alanina a partir de GLC para concentrações 
de $\mathrm{O}_{2}$ superiores a 50\%. Esse é um dado interessante, pois demonstra que, sob forte estresse ambiental, a célula não é capaz de transformar o carbono (GLC) consumido em material celular e o excreta na forma de um subproduto, no caso alanina. Esse resultado também leva a concluir que quando o metabolismo é mais ativo $\left(\mathrm{pO}_{2}<50 \%\right)$ a célula não é capaz de excretar o excedente de GLC como Ala (um subproduto menos tóxico), mas tem que eliminálo como lactato (Figura 5.43).

A Figura 5.45 indica uma variação na conversão de GLN em células similar a observada para a conversão de GLC (Figura 5.42). Assim, para concentrações de $\mathrm{O}_{2}$ inferiores a 30\%, verificam-se altas conversões e, quando a concentração de $\mathrm{O}_{2}$ é superior a esse valor, baixas conversões. Evidentemente, isso indica uma mudança de metabolismo celular em função da disponibilidade de $\mathrm{O}_{2}$ no meio, com perfil bastante similar ao observado para o fator $\mathrm{Y}_{\mathrm{X} / \mathrm{GLC}}$ (Figura 5.42).

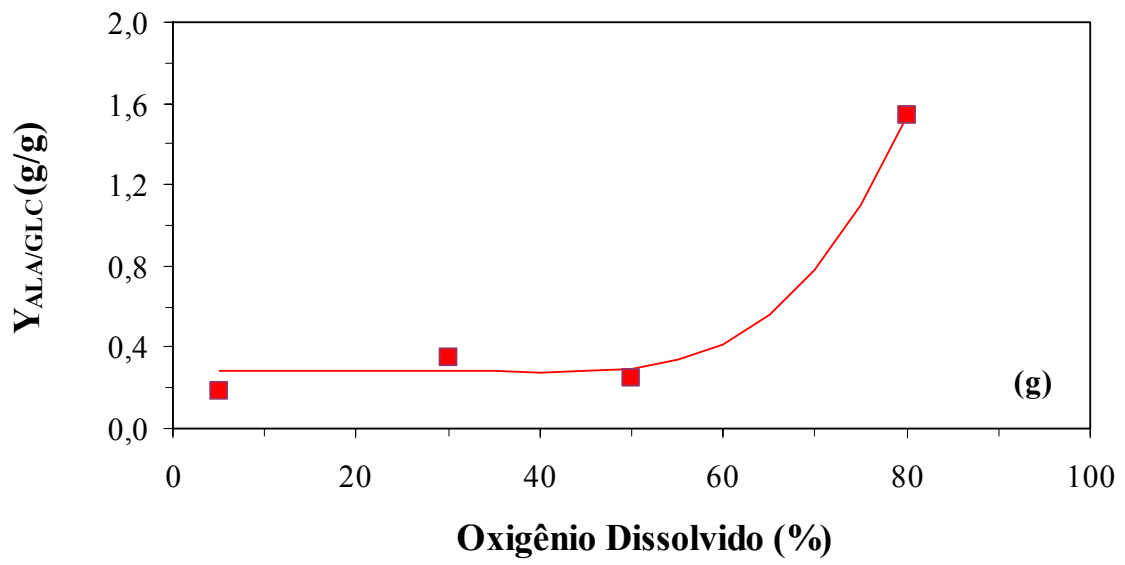

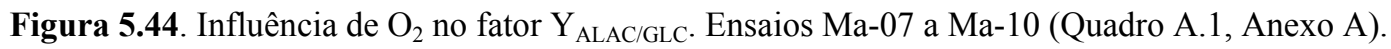

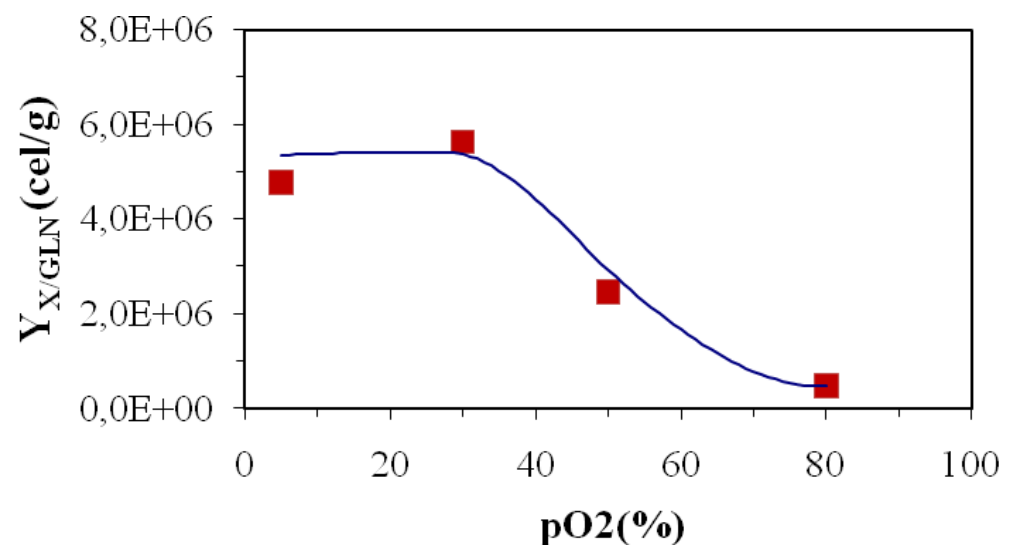

Figura 5.45. Influência de $\mathrm{O}_{2}$ no fator $\mathrm{Y}_{\mathrm{X} / \mathrm{GLN}}$. Ensaios Ma-07 a Ma-10 (Quadro A.1, Anexo A). 
A Figura 5.46 também indica uma variação na conversão de $\mathrm{NH}_{4}{ }^{+}$em células, variação similar à observada para a conversão de alanina a partir de GLC, que também leva a um aumento da conversão a partir de concentrações de $\mathrm{O}_{2}$ superiores a 50\%. Evidentemente isso reafirma as indicações de uma mudança de metabolismo celular em função da disponibilidade de $\mathrm{O}_{2}$ no meio. Reforça também a hipótese de que sob estresse $\left(\mathrm{pO}_{2}>50 \%\right)$ a célula secreta excedente de carbono (aqui GLN) na forma de subproduto do seu metabolismo, neste caso $\mathrm{NH}_{4}^{+}$.

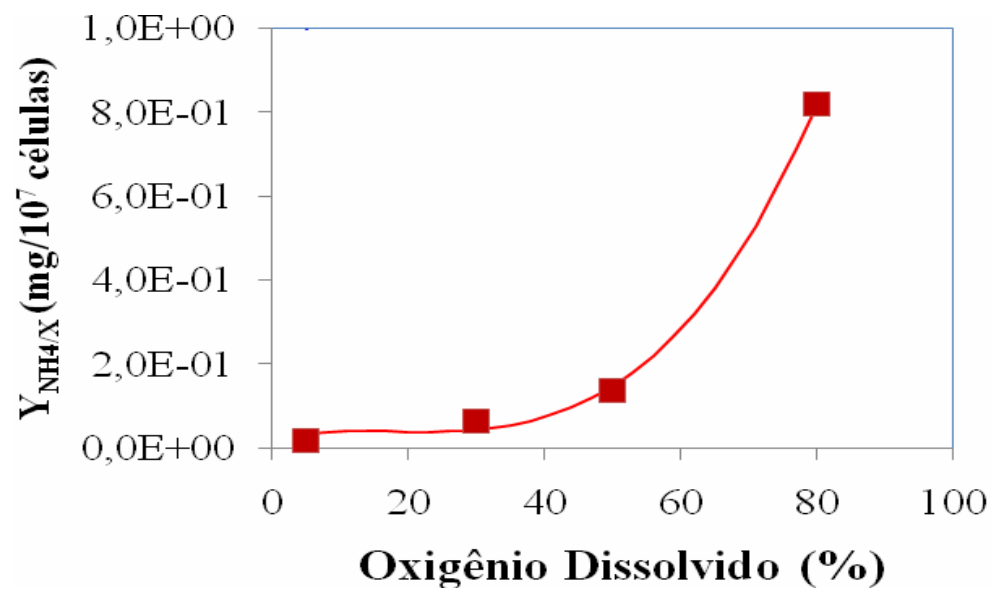

Figura 5.46. Influência de $\mathrm{O}_{2}$ no fator $\mathrm{Y}_{\mathrm{NH} 4 / \mathrm{GLN}}$. Ensaios Ma-07 a Ma-10 (Quadro A.1, Anexo A).

A Figura 5.47 indica um aumento na conversão de GLN em $\mathrm{NH}_{4}{ }^{+}$aproximadamente proporcional ao aumento da concentração de $\mathrm{O}_{2}$ dissolvido no meio, confirmando a resposta observada na Figura 5.45.

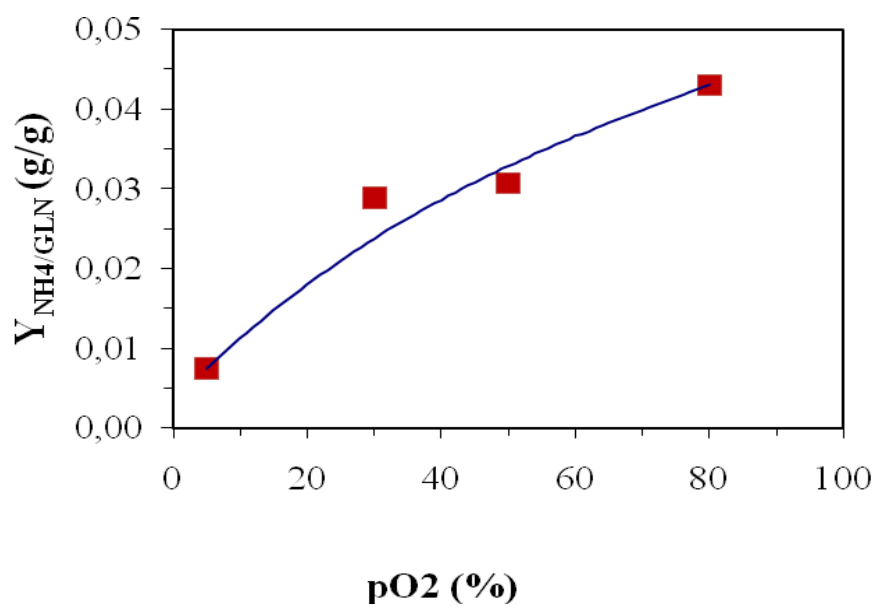

Figura 5. 47. Influência de $\mathrm{O} 2$ no fator $\mathrm{Y}_{\mathrm{NH} 4 / \mathrm{GLN}}$. Ensaios Ma-07 a Ma-10 (Quadro A.1, Anexo A).

A Figura 5.48 indica um aumento da conversão de GLN em ALA em função do teor de $\mathrm{O}_{2}$ dissolvido no meio muito similar à variação observada na conversão de $\mathrm{GLN}$ em $\mathrm{NH}_{4}{ }^{+}$. A formação de alanina é uma resposta celular ao excedente de GLC e GLN, gerado pela 
incapacidade das células de crescer em teores de $\mathrm{pO}_{2}$ elevados, o que se verifica, sobretudo para $\mathrm{pO}_{2}>50 \%$.

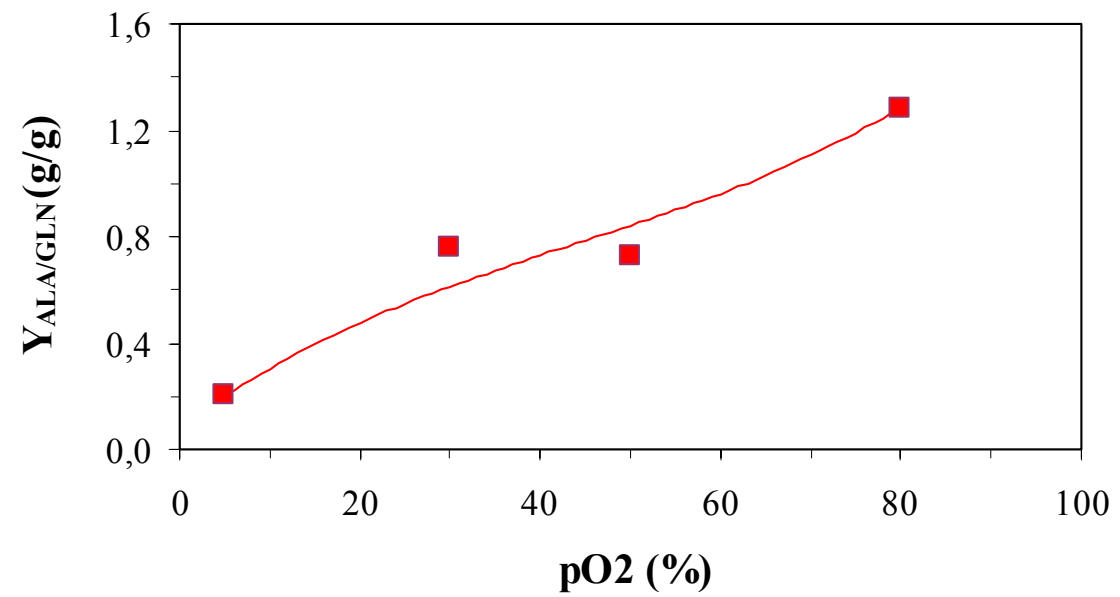

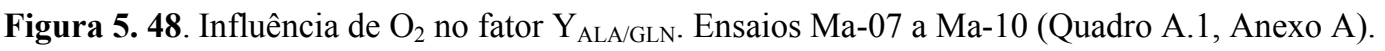

A Figura 5.49 indica um aumento na conversão de GPV por unidade de massa celular em função do aumento do teor de $\mathrm{O}_{2}$ dissolvido no meio. Esse aumento do fator de conversão em concentrações inibidoras de crescimento celular (Figura 5.41) sugere que o oxigênio interfere de forma diferente no processo de crescimento e no de síntese de GPV.

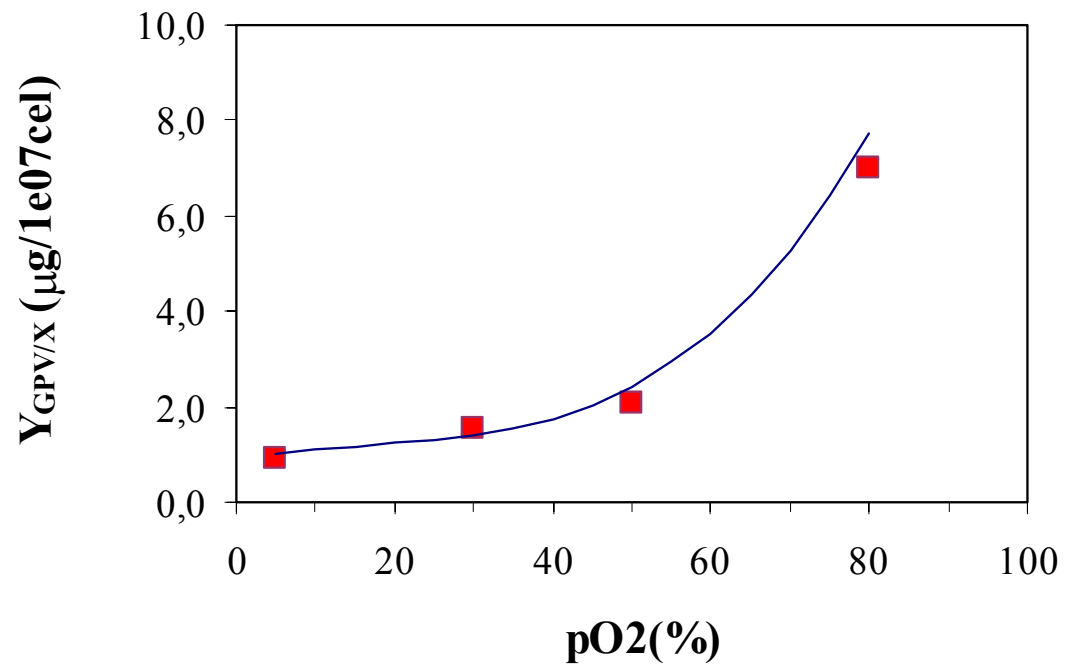

Figura 5. 49. Influência de $\mathrm{O}_{2}$ no fator $\mathrm{Y}_{\mathrm{GPV} / \mathrm{X}}$. Ensaios Ma-07 a Ma-10 (Quadro A.1, Anexo A).

A Figura 5.50 indica uma diminuição da conversão de GPV por unidade de glicose consumida. No entanto, frente aos perfis das demais grandezas analisadas, o efeito do teor de oxigênio no fator $\mathrm{Y}_{\mathrm{GPV} / \mathrm{X}}$ é pequeno. 


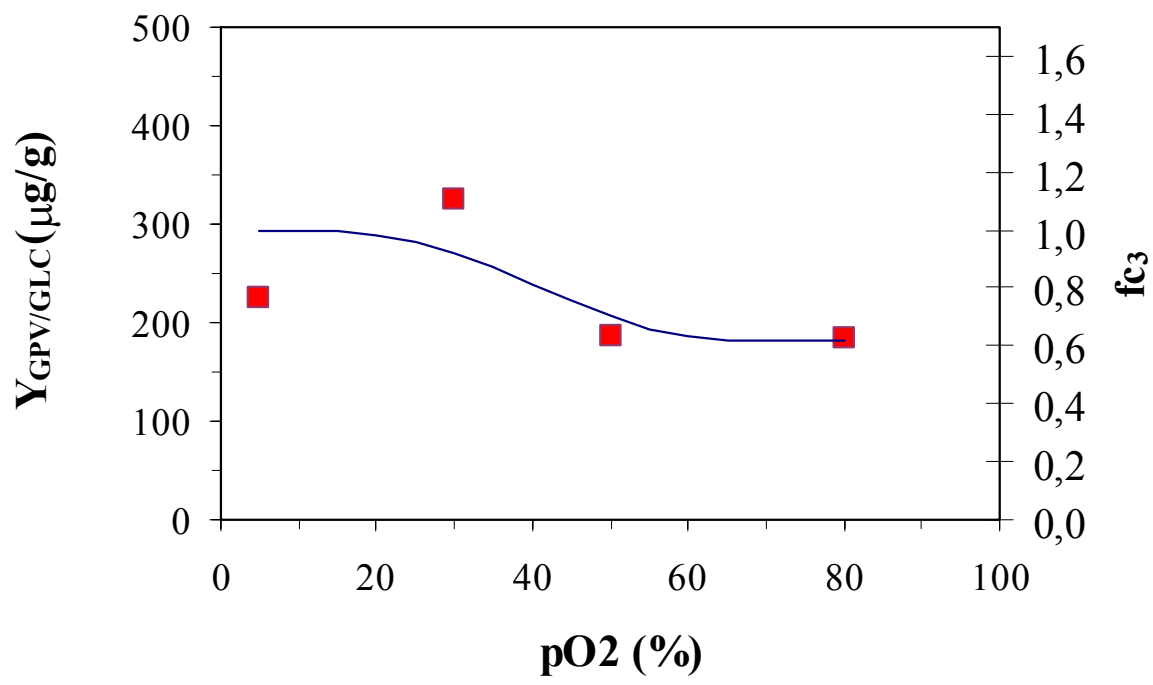

Figura 5. 50. Influência de $\mathrm{O}_{2}$ no fator $\mathrm{Y}_{\mathrm{GPV} / \mathrm{GLC}}$. Ensaios Ma-07 a Ma-10 (Quadro A.1, Anexo A).

h) Influência da concentração inicial de GLC na fase exponencial de crescimento. (Ensaios Ma-10, Ma-11, Ma-12 e Ma-14).

A influência da concentração de GLC inicial durante a fase exponencial do cultivo foi avaliada considerando a sua influência nos seguintes parâmetros: $\mu_{\mathrm{Xmax}}, \mathrm{Y}_{\mathrm{X} / \mathrm{GLC}}, \mathrm{Y}_{\mathrm{LAC} / \mathrm{GLC}}$,

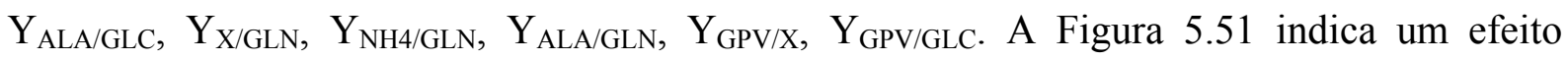
limitante da concentração de GLC na velocidade específica máxima de crescimento $\left(\mu_{\mathrm{Xmax}}\right)$ com valores máximos para concentrações superiores a $10 \mathrm{~g} / \mathrm{L}$. De forma, semelhante ao que se viu no item anterior (efeito de $\mathrm{pO}_{2}$, Figura 5.41). Acredita-se que a limitação em GLC, ocasionou uma mudança de metabolismos, visto que os valores de $\mu_{\mathrm{Xmax}}$ foram calculados a partir de um grande conjunto de pontos experimentais e com boa linearidade (para Ma-11, 15 pontos, $\mathrm{r}^{2}=0,989$; para Ma-12, 13 pontos $\left., \mathrm{r}^{2}=0,9939\right)$.

De forma semelhante ao que foi visto para o efeito do teor de oxigênio, as alterações do metabolismo em decorrência das diferentes concentrações de glicose será observada nas demais grandezas cinéticas analisadas. A Figura 5.52 indica um máximo de conversão de GLC em células quando a concentração inicial de GLC no meio é $10 \mathrm{~g} / \mathrm{L}$ e uma diminuição dessa conversão tanto para concentrações maiores, como para concentrações menores a esse valor. Há duas hipóteses para essa mudança na eficiência da conversão de GLC em células. A primeira sugere uma mudança de metabolismo celular em função da concentração inicial de GLC no meio como já comentado no item anterior e ilustrado pela Figura 5.51. A outra 
hipótese diz respeito não a uma mudança de metabolismo, mas uma distribuição de fluxos de metabólitos em uma dada via e que se aplicaria à condição $\mathrm{GLC}_{0}>1 \mathrm{~g} / \mathrm{L}$.

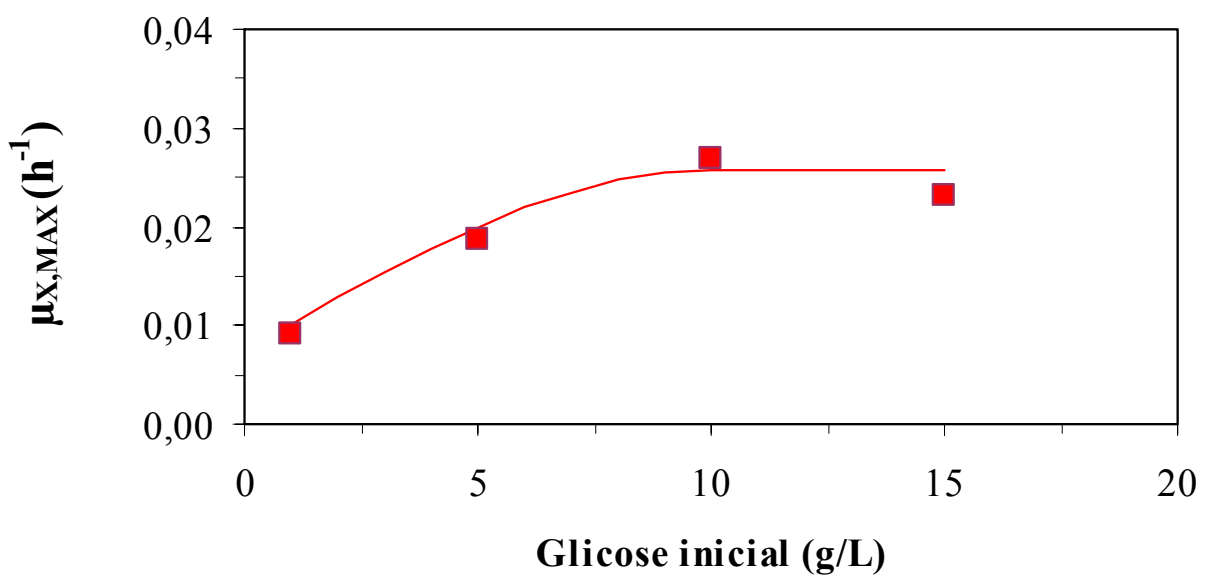

Figura 5.51. Influência da concentração inicial de GLC na velocidade específica de crescimento, $\left(\mu_{\text {Xmax }}\right)$. Ensaios Ma-10, Ma-11, Ma-12 e Ma-14. (Quadro A.1, Anexo A).

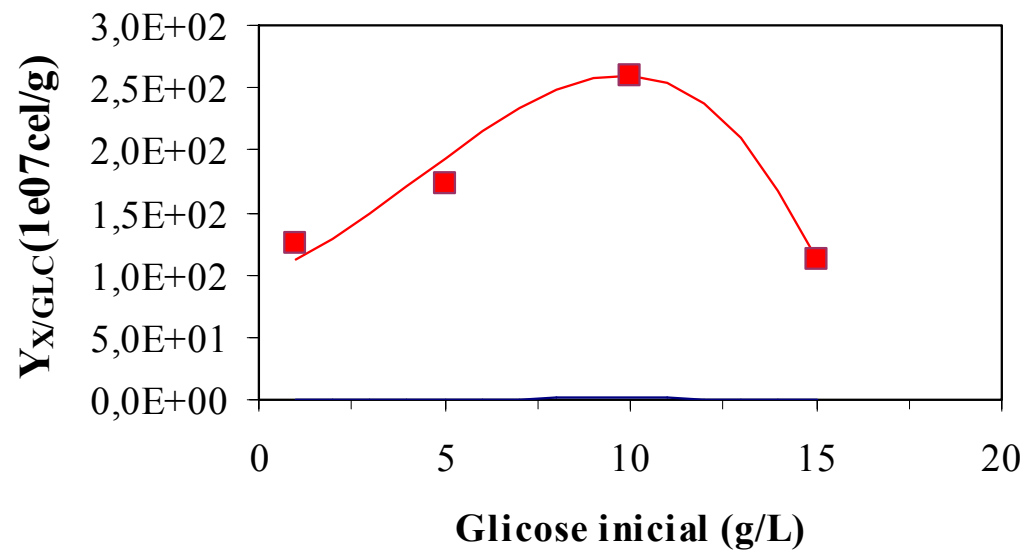

Figura 5. 52. Influência da concentração inicial de GLC no fator de conversão $Y_{X / G L C}$. Ensaios Ma-10, Ma-11, Ma-12 e Ma-14. (Quadro A.1, Anexo A).

A Figura 5.53 indica a pouca influência da concentração inicial de GLC no fator de conversão de glicose em lactato fator esse, como já foi indicado anteriormente (Figura 5.43), farto esse sensível à concentração de $\mathrm{O}_{2}$ no meio. Diferentemente do que se notou nos ensaios com diferentes teores de $\mathrm{pO}_{2}$, aqui os dados sugerem não uma inibição pela $\mathrm{GLC}_{0}$, mas sim uma limitação. 


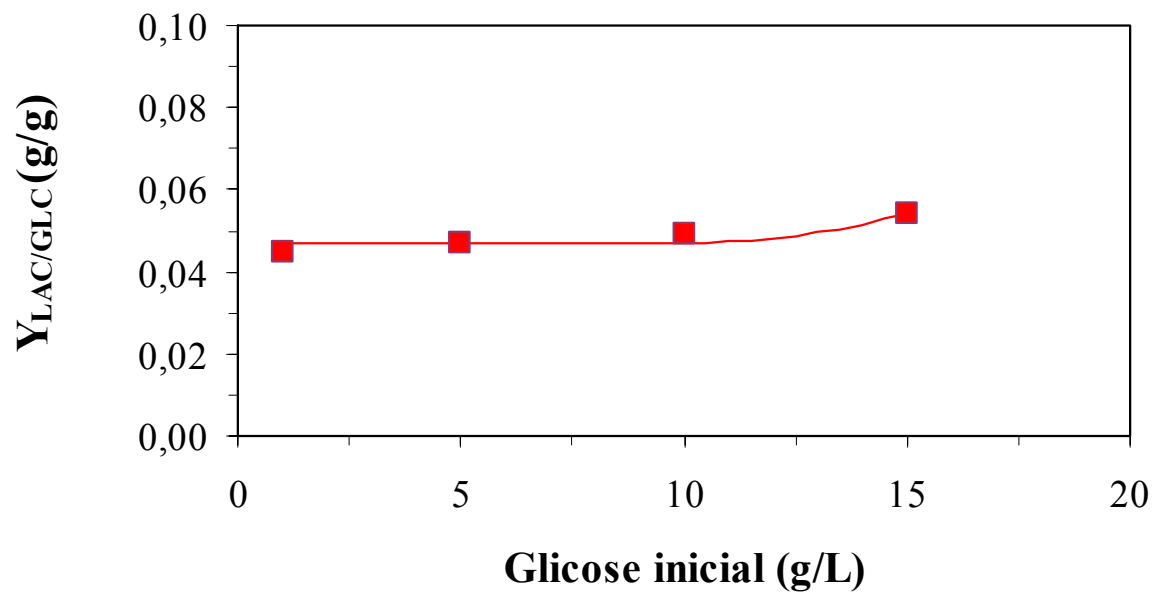

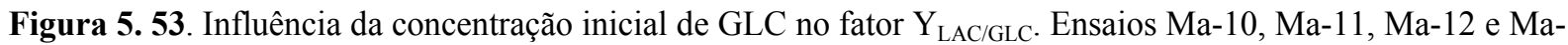
14. (Quadro A.1, Anexo A).

A Figura 5.54 indica uma pequena influência da concentração inicial de GLC na formação de ALA, com a indicação da existência de mínimo quando $\mathrm{GLC}_{0}$ é $10 \mathrm{~g} / \mathrm{L}$. Este perfil está em sintonia com o observado na Figura 5.43. Nas condições em que o desempenho da célula é menor, há maior formação de alanina e vive-versa.

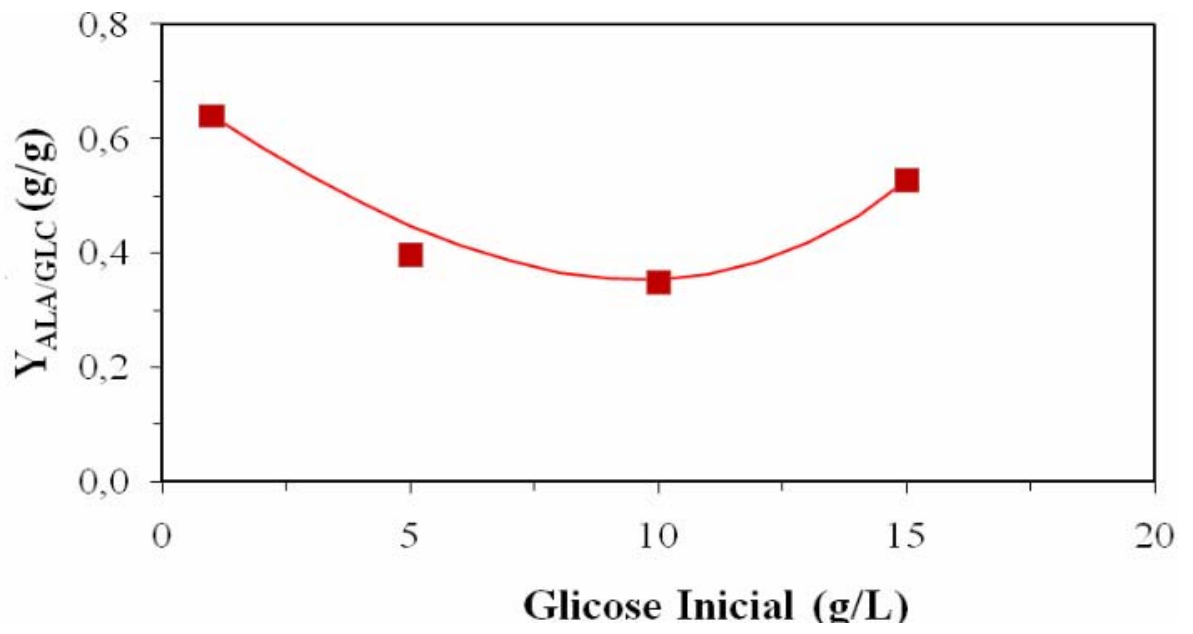

Figura 5. 54. Influência da concentração inicial de GLC no fator $Y_{\mathrm{ALA} / \mathrm{GLC}}$. Ensaios Ma-10, Ma-11, Ma-12 e Ma-14. (Quadro A.1, Anexo A).

A Figura 5.55 indica a existência de valor máximo de conversão de glutamina em células quando a concentração inicial de GLC está entre 7,5 g/L e $10 \mathrm{~g} / \mathrm{L}$. Este perfil é semelhante ao observado para $\mathrm{Y}_{\mathrm{X} / \mathrm{GLC}}$ (Figura 5.52), e que indica um metabolismo mais eficiente quando a $\mathrm{GLC}_{0}$ está na faixa de 5 a $10 \mathrm{~g} / \mathrm{L}$. A interdependência dos metabolismos de GLC e GLN em células animais é um fato conhecido (ALTAMIRANO; GÒDIA; CAIRÓ, 2008). 


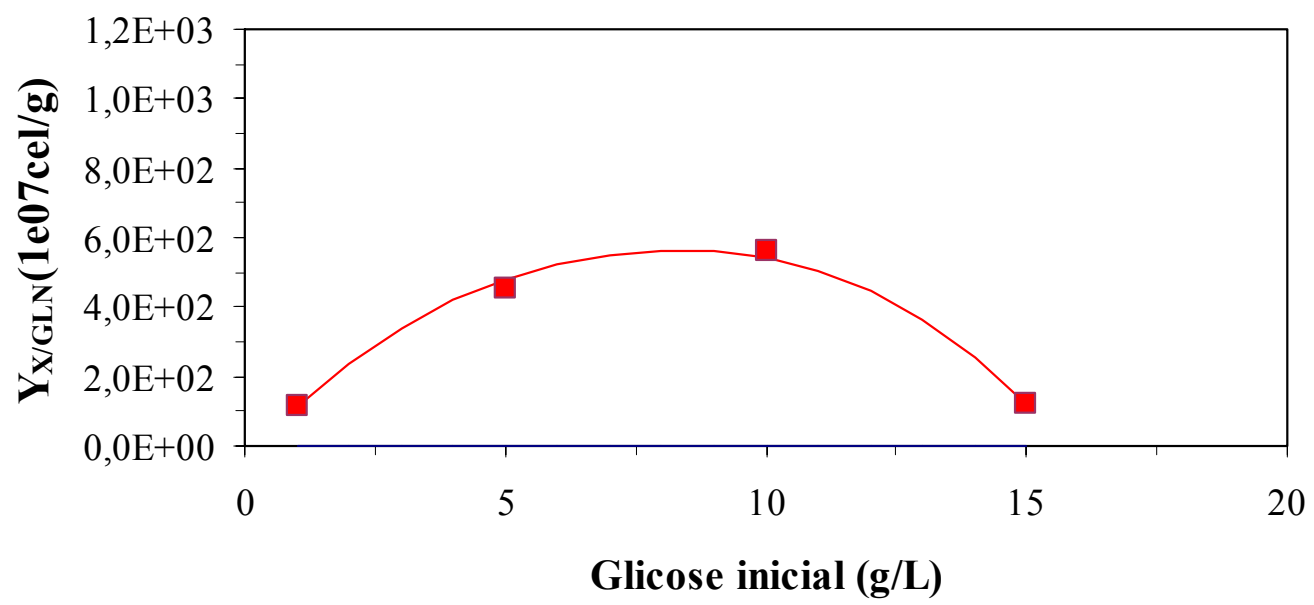

Figura 5. 55. Influência da concentração inicial de GLC no fator $Y_{X / G L N}$. Ensaios Ma-10, Ma-11, Ma-12 e Ma14. (Quadro A.1, Anexo A).

A Figura 5.56 indica um aumento de formação de $\mathrm{NH}^{+}$por unidade de células formadas com o aumento da concentração inicial de glicose no meio acima de $10 \mathrm{~g} / \mathrm{L}$.

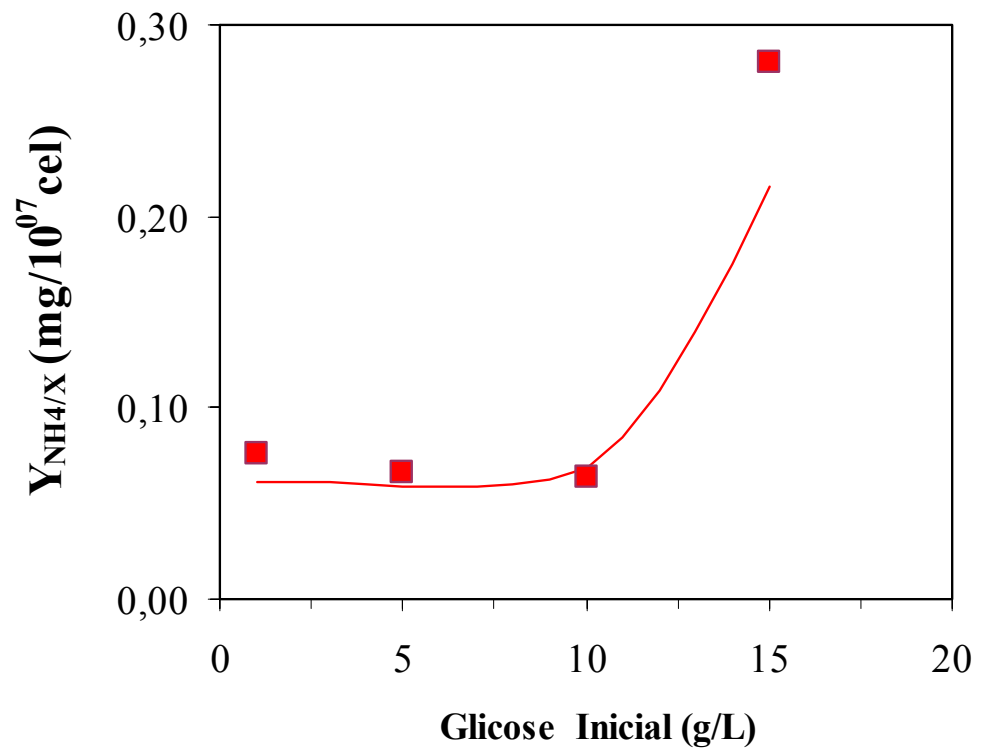

Figura 5. 56. Influência da concentração inicial de GLC no fator $Y_{N H 4 / X}$. Ensaios Ma-10, Ma-11, Ma-12 e Ma14. (Quadro A.1, Anexo A).

A Figura 5.57 indica um aumento da formação de $\mathrm{NH}_{4}$ por unidade de glutamina consumida com o aumento da concentração inicial de glicose no meio, para valores inferiores a $5 \mathrm{~g} / \mathrm{L}$. 


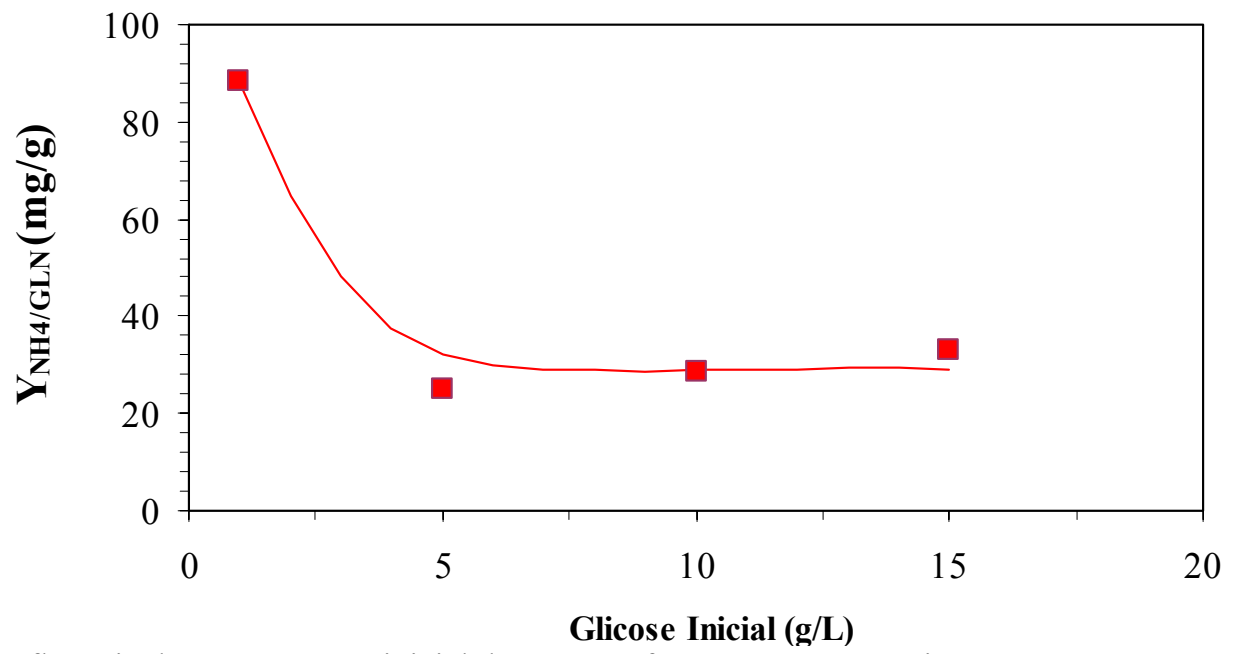

Figura 5. 57. Influência da concentração inicial de GLC no fator $Y_{N H 4 / G L N}$. Ensaios Ma-10, Ma-11, Ma-12 e Ma14. (Quadro A.1, Anexo A).

A Figura 5.58 não indica influência da $\mathrm{GLC}_{0}$ inicial de no fator de conversão de GLN em ALA. É interessante notar que o efeito da $\mathrm{GLC}_{0}$ sobre a síntese de alanina foi distinto quando se relacionaram os dois substratos de origem: GLC (Y $\mathrm{Y}_{\mathrm{ALA} / \mathrm{GLN}}$, Figura 5.54) e GLN (Y $\mathrm{Y}_{\mathrm{ALA} / \mathrm{GLN}}$, Figura 5.58). Isso se explica por uma redistribuição dos fluxos de GLC e GLN de forma distinta.

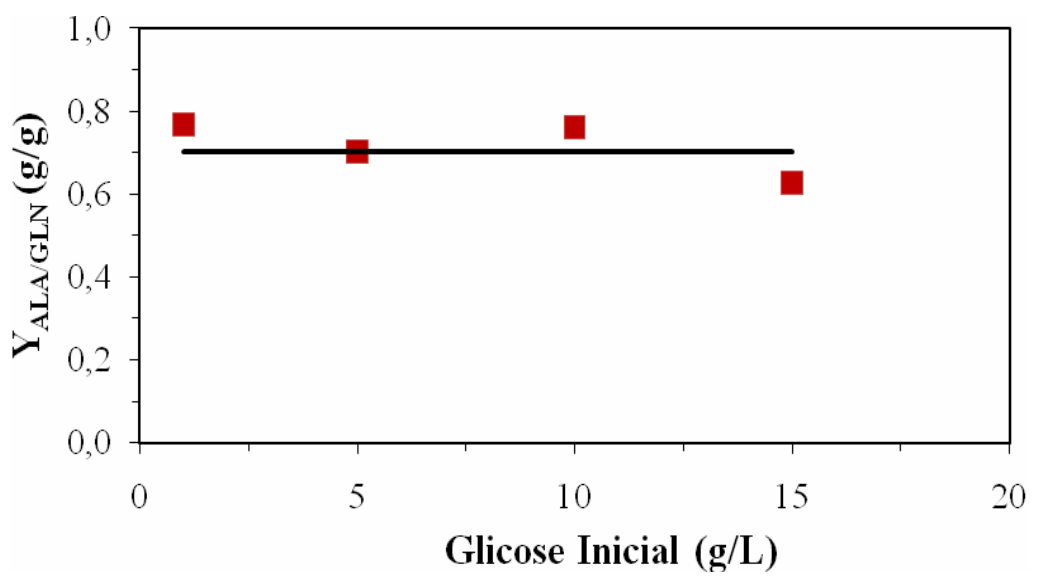

Figura 5.58. Influência da concentração inicial de GLC no fator $Y_{A L A / G L N}$. Ensaios Ma-10, Ma-11, Ma-12 e Ma14. (Quadro A.1, Anexo A).

A Figura 5.59 também não indica influência sobre formação de GPV por unidade de células em função da concentração inicial de GLC. 


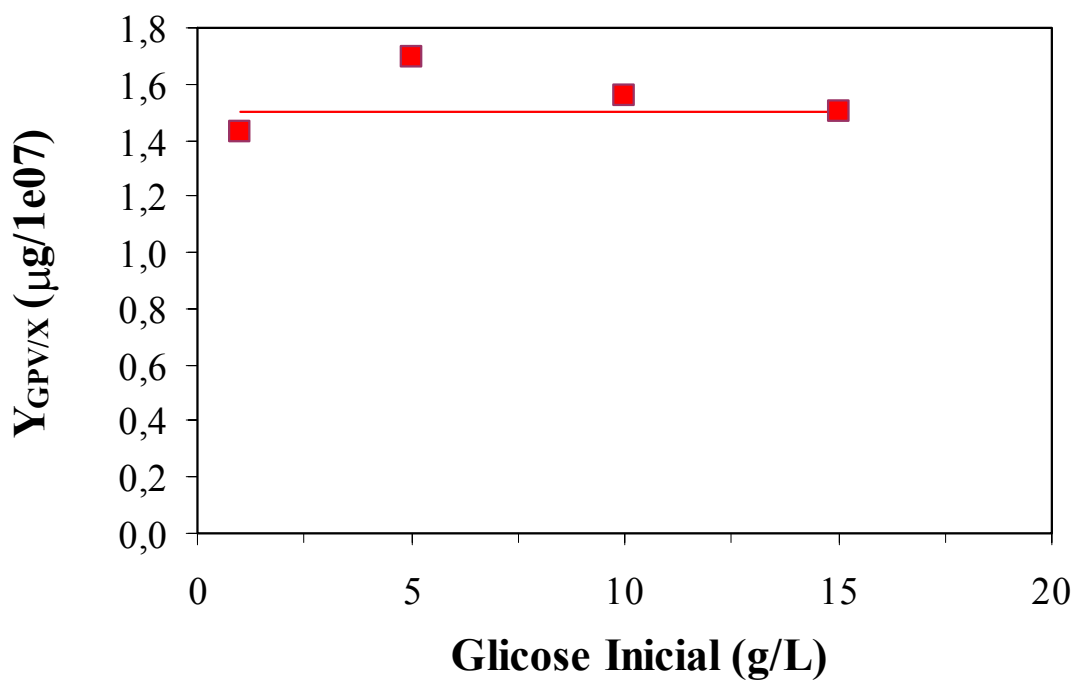

Figura 5. 59. Influência da concentração inicial de GLC no fator $Y_{G P V / X}$. Ensaios Ma-10, Ma-11, Ma-12 e Ma14. (Quadro A.1, Anexo A).

A Figura 5.60 indica a influência da concentração inicial de GLC no fator de conversão de GPV por unidade de células e a existência de máximo de conversão quando a concentração inicial de GLC é $10 \mathrm{~g} / \mathrm{L}$. Diferentemente do que foi observado para o conjunto de ensaios com diferentes $\mathrm{pO}_{2}$, neste caso, o efeito da $\mathrm{GLC}_{0}$ foi similar para o crescimento (Figura 5.52) e para a síntese da proteína (Figura 5.60).

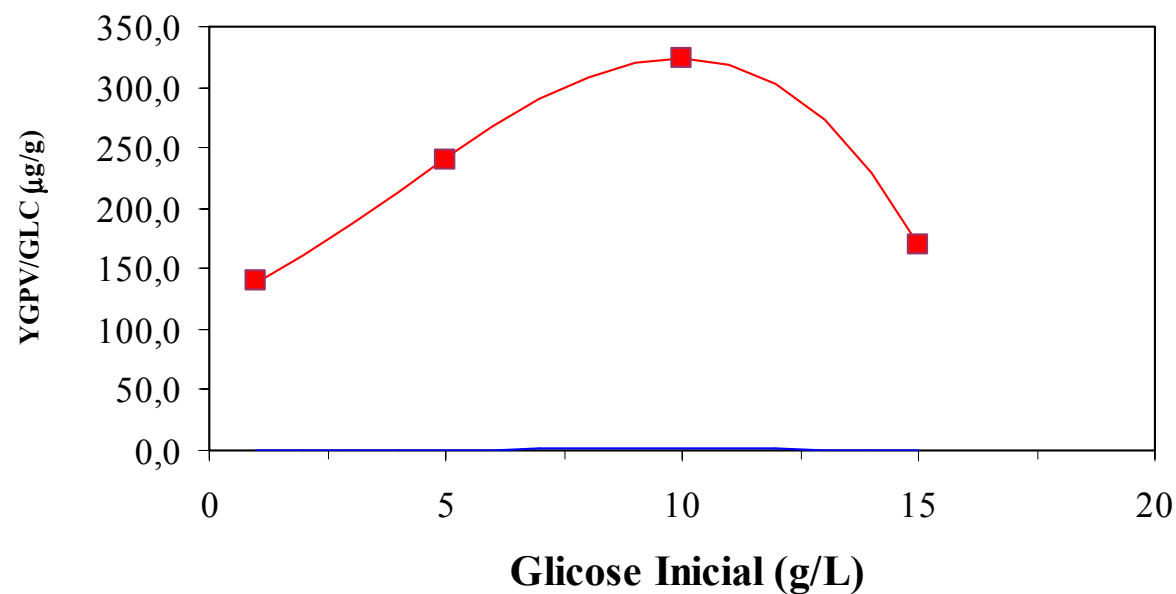

Figura 5. 60. Influência da concentração inicial de GLC no fator $Y_{\mathrm{GPV} / \mathrm{GLC}}$. Ensaios Ma-10, Ma-11, Ma-12 e Ma14. (Quadro A.1, Anexo A).

i) Influência da concentração inicial de GLN na fase exponencial de crescimento (Ma-10, Ma15, Ma-16 e Ma-17). A Figura 5.63 indica um efeito limitante da concentração de $\mathrm{GLN}_{0}$ na velocidade específica de crescimento $\left(\mu_{\mathrm{Xmax}}\right)$ para concentrações de GLN inferiores a 2,0 g/L. Novamente, como a fase exponencial para a condição $\mathrm{GLN}_{0}=0,6 \mathrm{~g} / \mathrm{L}$ é muito bem 
caracterizada ( 8 pontos; $\mathrm{r}^{2}=0,992$ ) acredita-se que a limitação em GLN tenha levado a uma alteração do metabolismo.

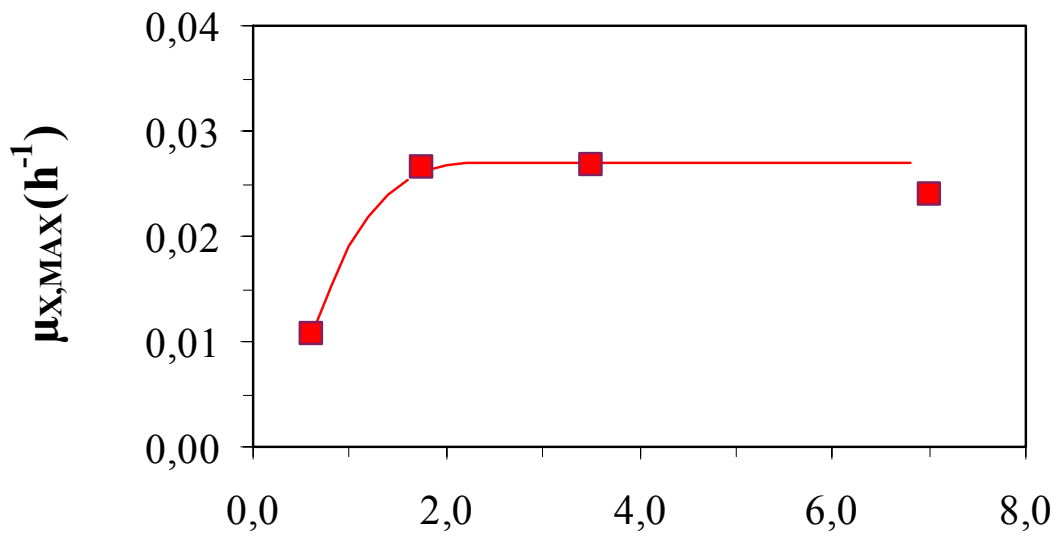

Glutamina inicial $(\mathrm{g} / \mathrm{L})$

Figura 5.61. Influência da concentração inicial de GLN na velocidade específica máxima de crescimento. $\left(\mu_{\mathrm{Xmax}}\right)$. Ensaios Ma-10, Ma-15, Ma-16 e Ma-17. (Quadro A.1, Anexo A)

A Figura 5.62 indica uma diminuição do fator conversão de GLC em células com o aumento da concentração inicial de GLN, que é significativa quando a concentração de GLN é superior a 3,5 g/L. Diferentemente do que aconteceu quando se avaliou o e efeito de $\mathrm{GLC}_{0}$ (Figura 5.52), não se observou uma alteração no padrão de consumo de GLC para a condição de $\mathrm{GLN}_{0}$ baixa, condição indicada como limitante na Figura 5.63. A resposta em termos de LAC e ALA (dois subprodutos) não coincidem com o comportamento observado para o valor de $\mathrm{Y}_{\mathrm{X} / \mathrm{GLC}}$.

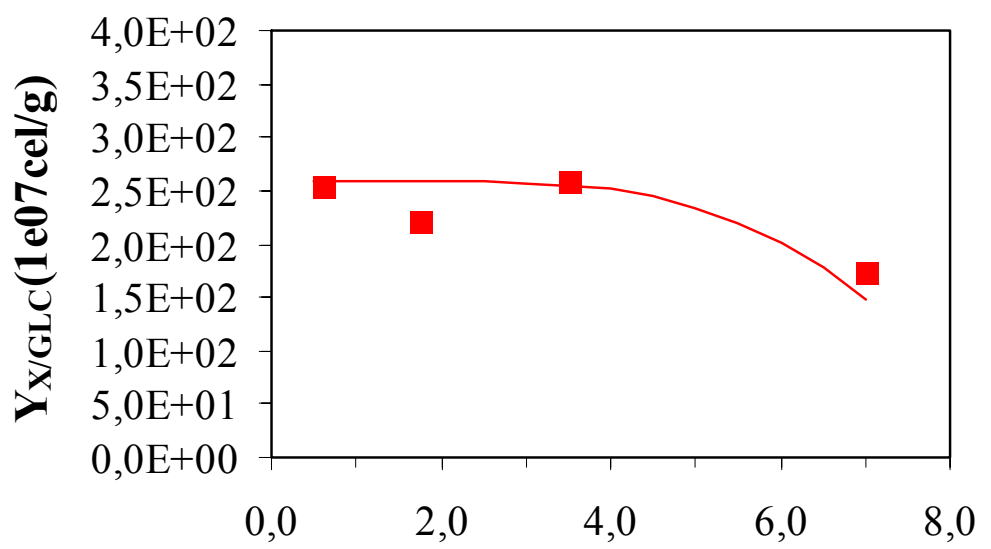

Glutamina inicial (g/L)

Figura 5.62. Influência da concentração inicial de GLN no fator de conversão $Y_{\mathrm{X} / \mathrm{GLC}}$. Ensaios Ma-10, Ma-15, Ma-16 e Ma-17. (Quadro A.1, Anexo A) 
A Figura 5.63 indica a existência de um valor mínimo do fator de conversão de glicose em lactato quando a concentração inicial de GLN no meio é 3,5 g/L.

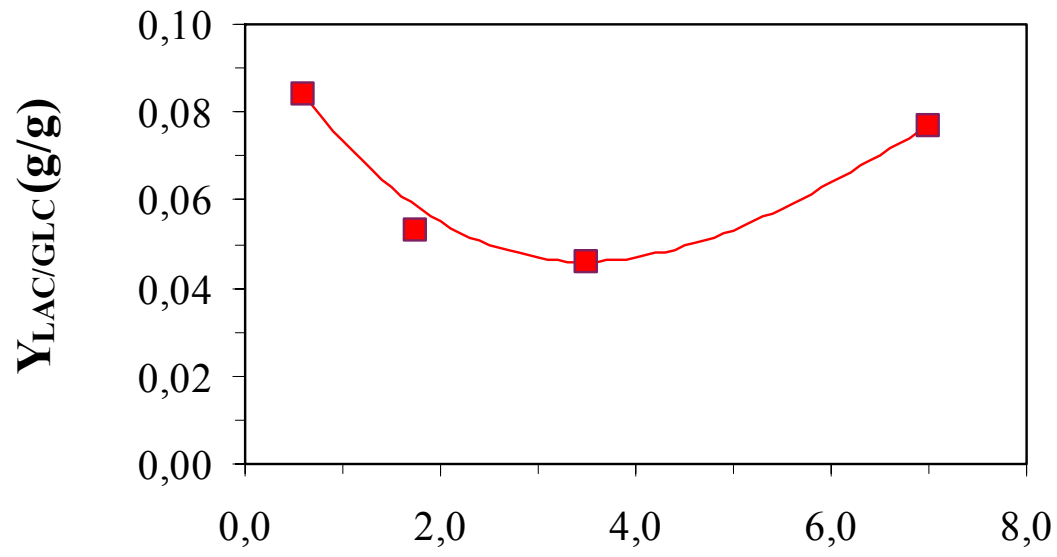

Glutamina inicial (g/L)

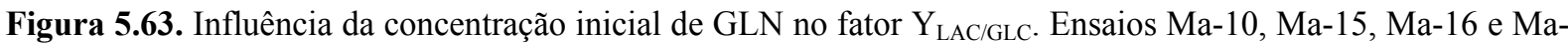
17. (Quadro A.1, Anexo A)

A Figura 5.64 indica aumento do fator de conversão de glicose em alanina quando se aumenta concentração inicial de GLN no meio.

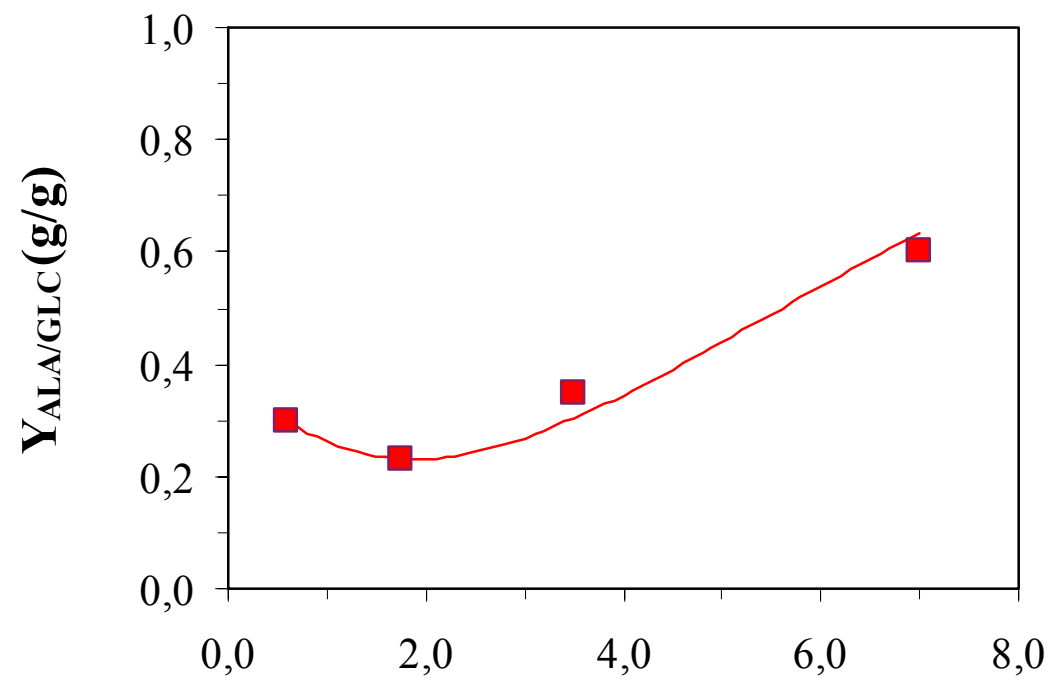

Glutamina Inicial (g/L)

Figura 5. 64. Influência da concentração inicial de GLN no fator $Y_{\mathrm{ALAC} / \mathrm{GLC}}$. Ensaios Ma-10, Ma-15, Ma-16 e Ma-17. (Quadro A.1, Anexo A)

A Figura 5.65 indica a diminuição do fator de conversão de glutamina em células quando se aumenta a concentração inicial de GLN. É interessante notar a maior eficiência na produção 
de células a partir de GLN para a condição de $\mathrm{GLN}_{0}$ que foi considerada limitante (Figura $5.61)$.

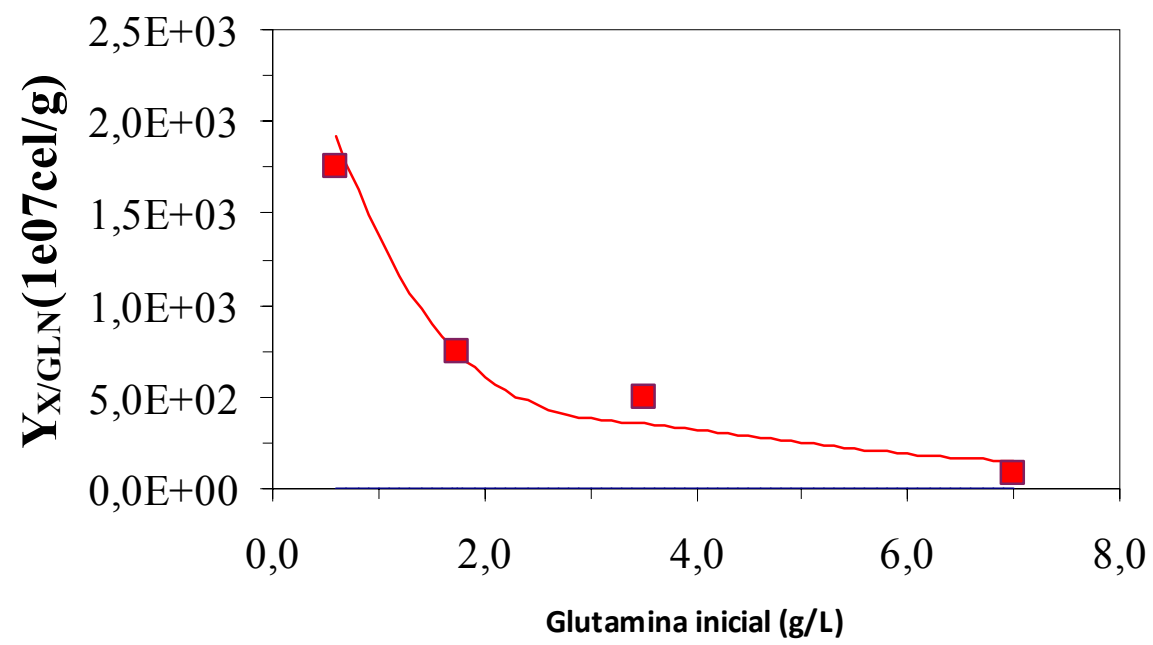

Figura 5.65. Influência da concentração inicial de GLN no fator $Y_{X / G L C}$. Ensaios Ma-10, Ma-15, Ma-16 e Ma17. (Quadro A.1, Anexo A).

A Figura 5.66 indica uma tendência similar à observada quando se analisou a influência da concentração inicial de GLC no fator de conversão de NH4 por unidade de massa celular (Figura 5.56), ou seja, verifica-se aumento de formação de NH4 por células formadas para valores da concentração inicial de glutamina no meio superiores a um certo limite $\left(\mathrm{GLN}_{0}>3,5 \mathrm{~g} / \mathrm{L}\right)$.

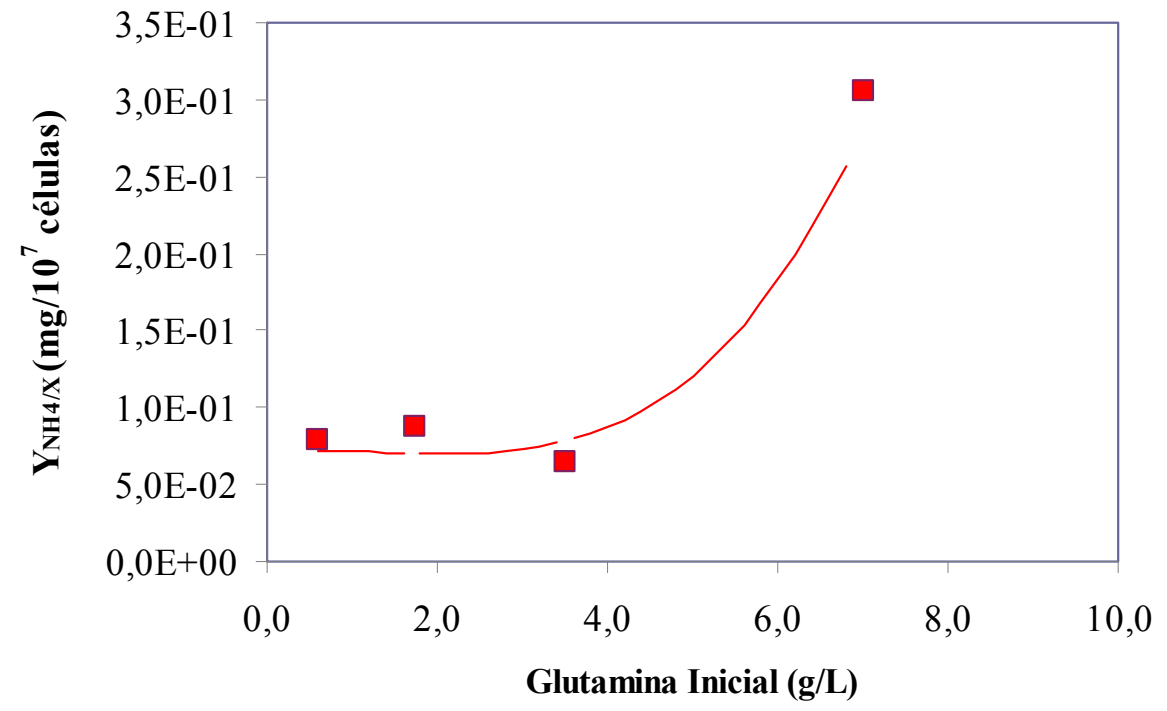

Figura 5.66. Influência da concentração inicial de GLN no fator $Y_{N H 4 / X}$. Ensaios Ma-10, Ma-15, Ma-16 e Ma17. (Quadro A.1, Anexo A). 
A Figura 5.67 indica diminuição do fator de conversão de $\mathrm{NH}_{4}$ por unidade de glutamina consumida com o aumento da concentração inicial de glutamina no meio, tendência similar à observada quando se avaliou a influência do fator de conversão de glutamina em $\mathrm{NH}_{4}{ }^{+} \mathrm{em}$ função da concentração de glicose no meio (Figura 5.57). Entretanto, essa resposta não era esperada visto que a Figura 5.65 indica um metabolismo mais eficiente para valores mais baixos de $\mathrm{GLN}_{0}$.

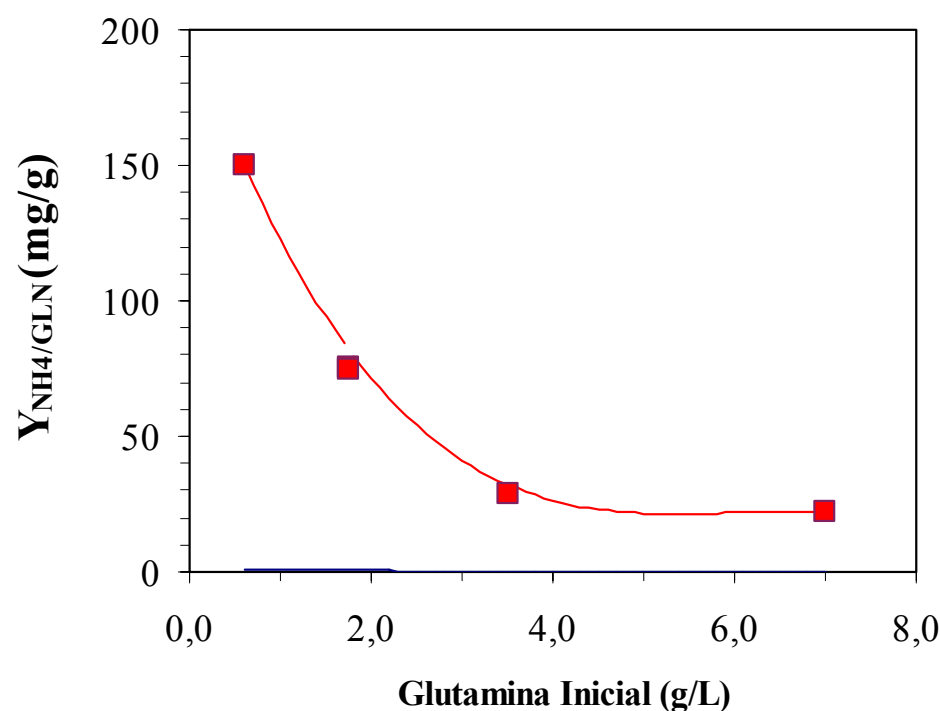

Figura 5.67. Influência da concentração inicial de GLN no fator $Y_{\mathrm{NH} 4 / \mathrm{GLN}}$. Ensaios Ma-10, Ma-15, Ma-16 e Ma17. (Quadro A.1, Anexo A).

A Figura 5.68 indica uma diminuição do fator de conversão de GLN em ALA em função da concentração inicial de GLN. Aqui vale o mesmo comentário feito em relação com quebra de expectativas feita ao se analisar a Figura 5.67.

A Figura 5.69 indica um máximo no fator de conversão de GPV por unidade celular sendo esse máximo encontrado quando a concentração inicial de GLN é 3,5 g/L.

E, finalmente, a Figura 5.70 indica a existência de máximo de conversão de GPV por glicose consumida quando a concentração inicial de GLN é 3,5 g/L. 


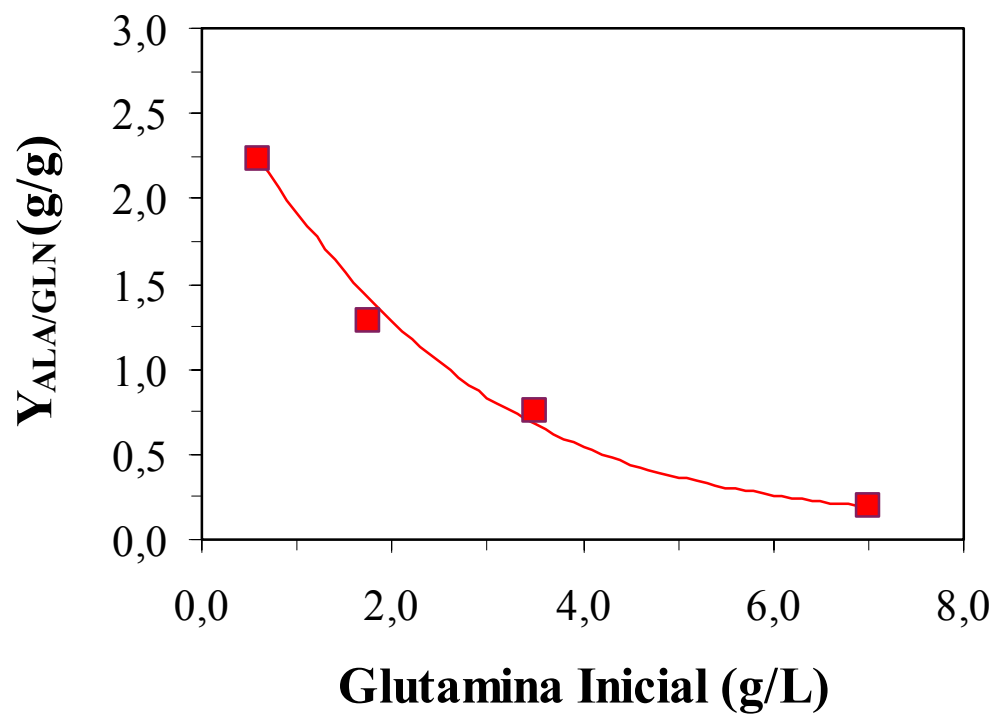

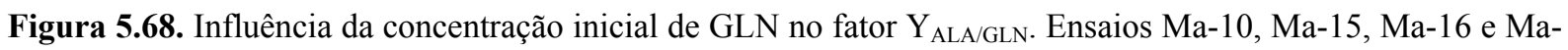
17. (Quadro A.1, Anexo A).

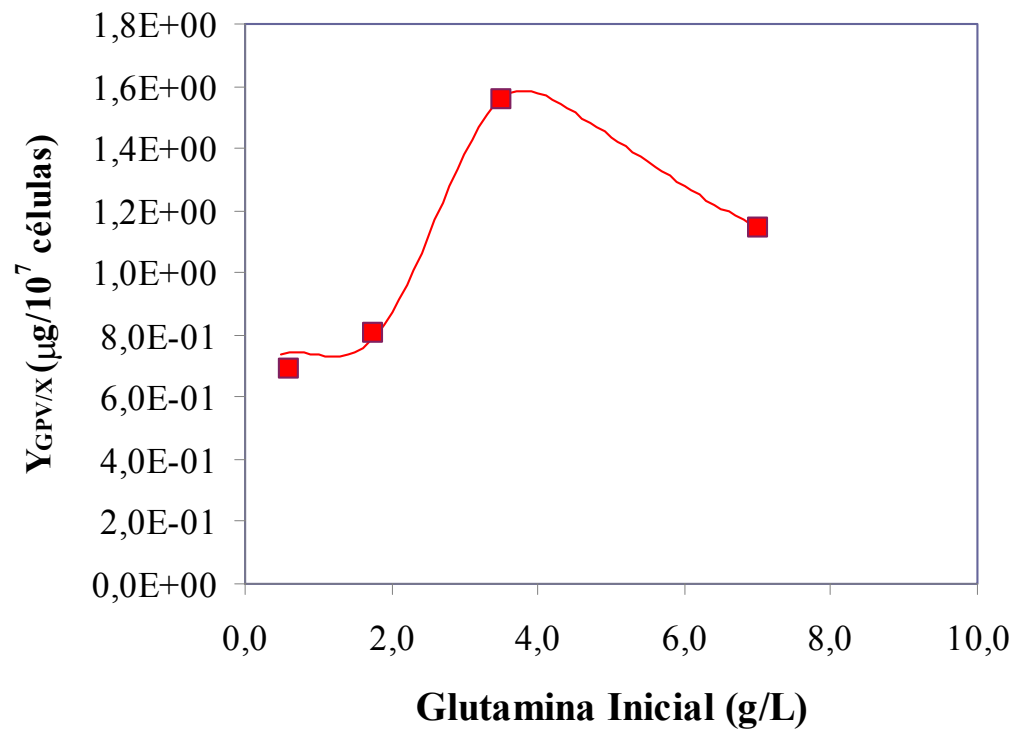

Figura 5.69. Influência da concentração inicial de GLN no fator $Y_{\mathrm{GPV} / \mathrm{X}}$. Ensaios Ma-10, Ma-15, Ma-16 e Ma17. (Quadro A.1, Anexo A).

j) Influência da concentração inicial de GLC na fase de crescimento estacionário, (ensaios Ma-10, Ma-11, Ma-12 e Ma-14). O final do crescimento, início da fase estacionária, ocorre quando há esgotamento de GLC nos ensaios com concentrações iniciais na faixa entre 1 a $10 \mathrm{~g} / \mathrm{L}$ como indica Figura 5.71(a). 


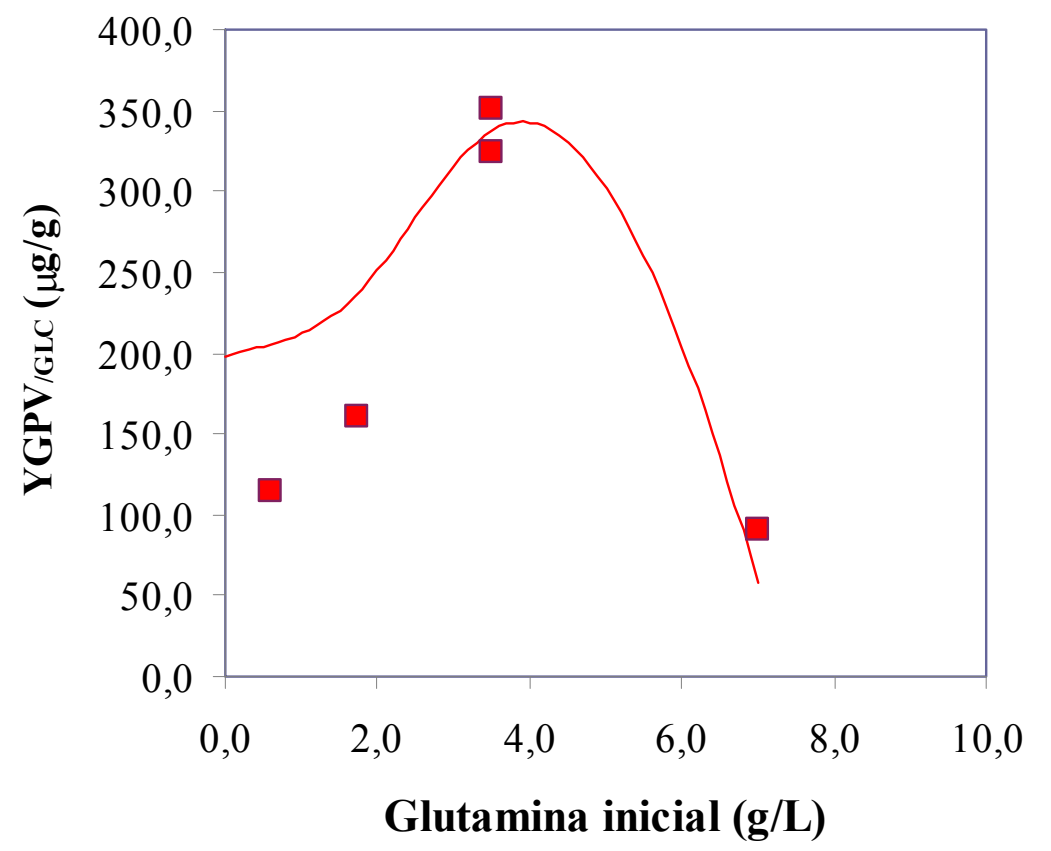

Figura 5.70. Influência da concentração inicial de GLN no fator $Y_{\mathrm{GPV} / \mathrm{GLC}}$. Ensaios Ma-10, Ma-15, Ma-16 e Ma17. (Quadro A.1, Anexo A).
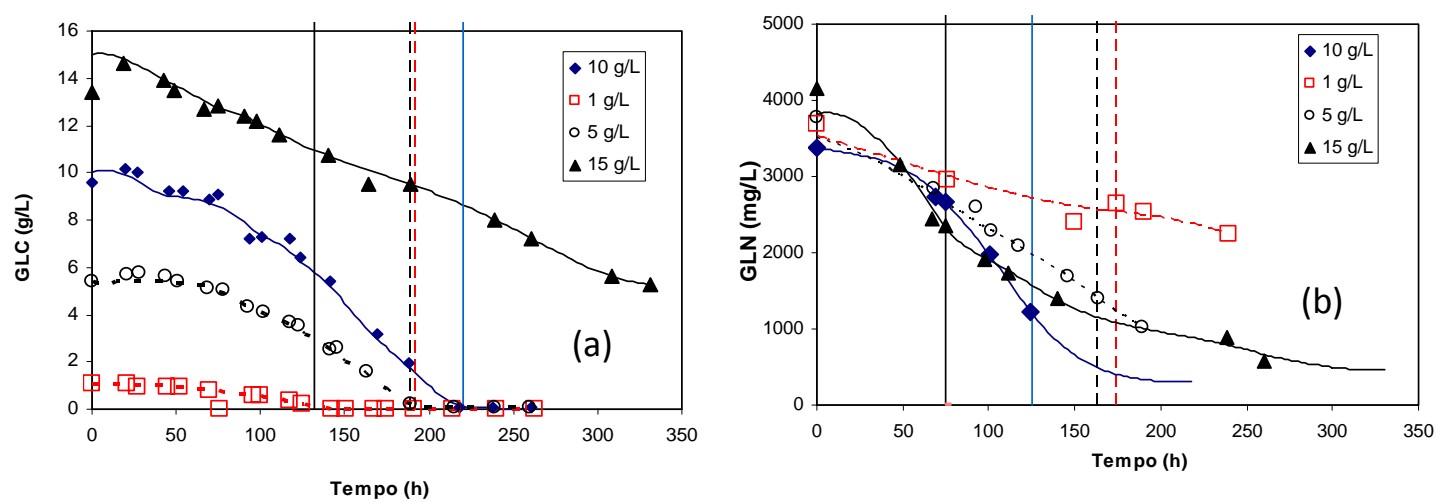

Figura 5.71. Evolução da concentração de GLC (a) e GLN (b) durante os cultivos com diferentes concentrações iniciais de GLC (Ensaios Ma-10, Ma-11, Ma-12 e Ma-14). (Quadro A1, Anexo A). Linhas verticais, final do crescimento.

No ensaio Ma-11 $\left(\mathrm{GLC}_{0}=1 \mathrm{~g} / \mathrm{L}\right)$ a glicose esgota-se antes do final do crescimento (AGUIAR, 2010). A não interrupção do crescimento com o esgotamento de GLC no ensaio Ma-11, por outro lado, obriga a se considerar erros na detecção de GLC nesses (baixos) níveis ou erros na determinação da duração das fases exponencial e estacionária. A Figura 5.71(b) também indica que não há esgotamento de GLN e que, portanto, a fase estacionária não se deve ao esgotamento de glutamina. No ensaio Ma-14 $\left(\mathrm{GLC}_{0}=15 \mathrm{~g} / \mathrm{L}, \mathrm{GLN}_{0}=3,5 \mathrm{~g} / \mathrm{L}\right)$ não se esgota $\mathrm{GLC}_{0}$ e $\mathrm{GLN}_{0}$ no final do crescimento (ver Figura 5.73). Para esse ensaio, a 
interrupção do crescimento, sem esgotamento desses substratos, é uma indicação da existência de outros fatores (limitação por aminoácidos ou inibições por metabólitos, $\mathrm{NH}_{4}{ }^{+}$ou lactato).

h) Influência da concentração inicial de GLN na fase de crescimento estacionária (Ma-10, Ma-15, Ma-16 e Ma-17). Nos ensaios nos quais se variou a concentração inicial de GLN, o final do crescimento ou fase estacionária pode ser atribuído às baixas concentrações de GLN apenas em dois ensaios, $\mathrm{GLN}_{0}=0,6 \mathrm{~g} / \mathrm{L}$ e $\mathrm{GLN}_{0}=1,75 \mathrm{~g} / \mathrm{L}$ (Ma-15 e Ma-16, respectivamente), nos quais a concentração de GLN no meio, ao final do crescimento, foi $88,0 \mathrm{mg} / \mathrm{L}$ e $38,0 \mathrm{mg} / \mathrm{L}$ (AGUIAR, 2010) e como indica a Figura 5.72b. Essas baixas concentrações podem levar a dificuldades no transporte para a célula e constata-se síntese de GLN no meio. O ensaio Ma-10, com $\mathrm{GLN}_{0}$ de 3,5 g/L, há esgotamento apenas de GLC. No ensaio Ma-17, planejado com concentração inicial de $\mathrm{GLN}_{0}$ de 7,0 g/L, não se verifica esgotamento de GLC e GLN ao final da fase estacionária, como indica a Figura 5.72a. Nesse caso, outros fatores devem estar determinando a interrupção do crescimento que não o esgotamento de GLC e GLN.

i) Influência da concentração de $\mathrm{NH}_{4}{ }_{4}^{+}$na fase de crescimento estacionária. Os ensaios Ma-14 $\left(\mathrm{GLC}_{0}=15 \mathrm{~g} / \mathrm{L}, \mathrm{GLN}_{0}=3,5 \mathrm{~g} / \mathrm{L}\right)$ e Ma-17 $\left(\mathrm{GLC}_{0}=10 \mathrm{~g} / \mathrm{L}, \mathrm{GLN}_{0}=7,0 \mathrm{~g} / \mathrm{L}\right)$ nos quais ocorre interrupção do crescimento sem esgotamento de GLC e GLN, a causa aparente do fim do crescimento pode ser atribuída à concentração de $\mathrm{NH}_{4}^{+}$no meio. Nesses ensaios as concentrações de $\mathrm{NH}_{4}{ }^{+}$foram $132 \mathrm{mg} / \mathrm{L}$ e $180 \mathrm{mg} / \mathrm{L}$, respectivamente, como indicado na Figura 5.73.

j) Acúmulo $\mathrm{NH}_{4}{ }_{4}^{+}$na fase de crescimento estacionária. Os ensaios Ma-10, Ma-16 e Ma-17, nos quais se variou a concentração de GLN $_{0}$ (Figura 5.75b), e nos ensaios Ma-10, Ma-11, Ma-12 (Figura 5.75a), que testaram diferentes $\mathrm{GLC}_{0}$, há indicação de aumento na velocidade de acúmulo de $\mathrm{NH}_{4}{ }^{+}$na fase estacionária do cultivo. Esse aumento na velocidade de formação de $\mathrm{NH}_{4}{ }^{+}$, aparentemente, está relacionado ao esgotamento de glicose que leva a uma mudança de metabolismo celular. Nessa condição, as células não podem mais excretar alanina, pois não há disponibilidade de GLC e, assim, o excedente de GLC será metabolizado com liberação de $\mathrm{NH}_{4}{ }^{+}$, aumentando a velocidade de secreção desse subproduto. 

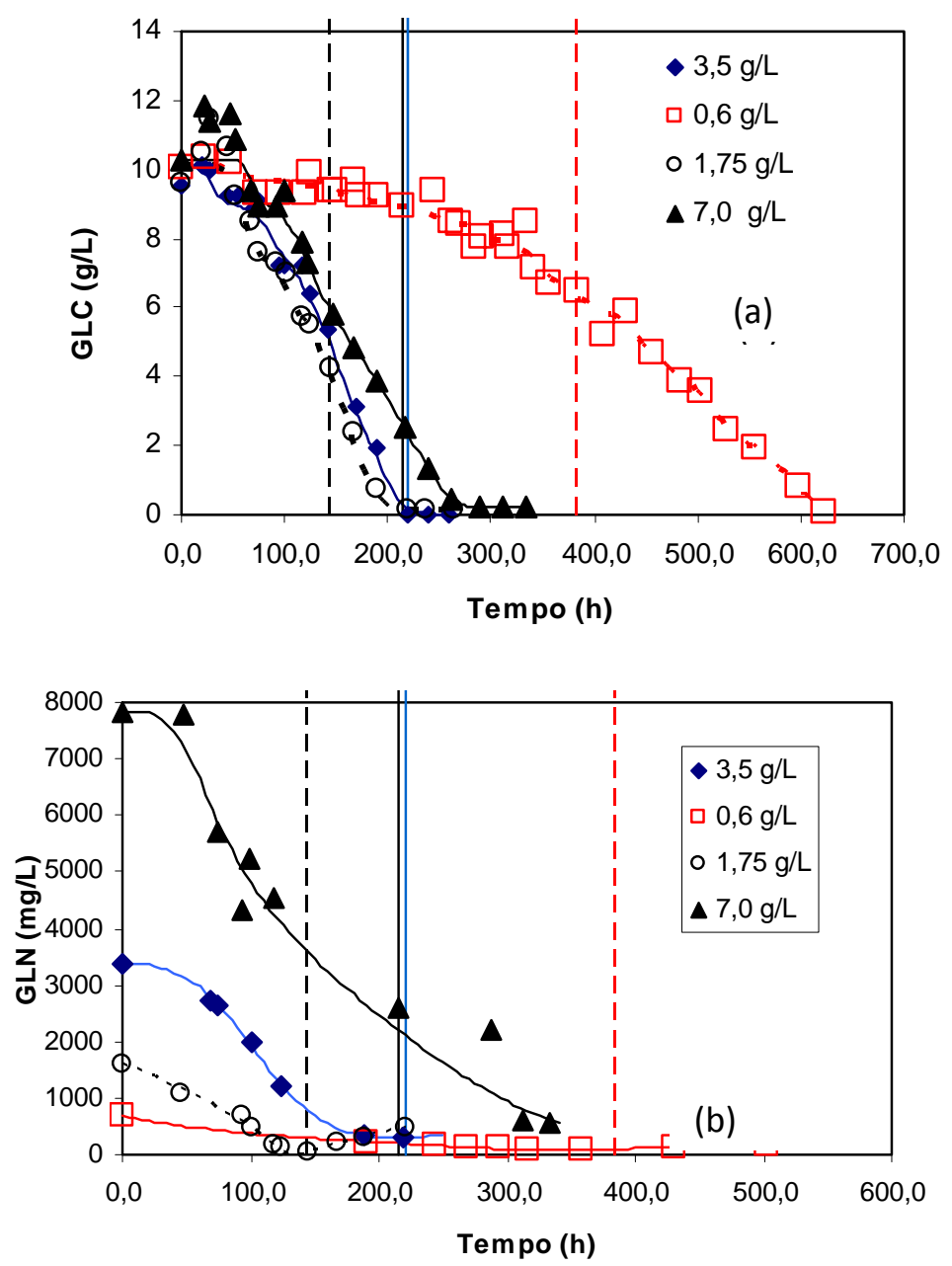

Figura 5.72. Evolução das concentrações de GLC (a) e de GLN (b) nos ensaios com diferentes GLN $_{0}$ (Ensaios Ma-10, Ma-15, Ma-16 e Ma-17). (Quadro A1, Anexo A). Linhas verticais, final do crescimento.
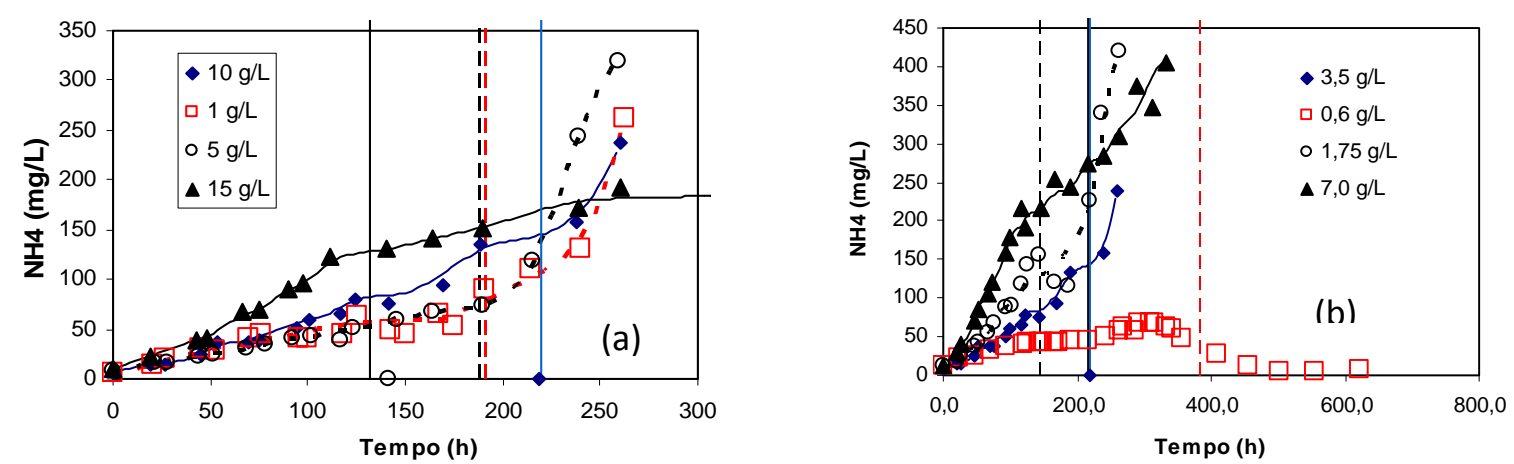

Figura 5.73. Evolução da concentração de $\mathrm{NH}_{4}{ }^{+}$em função da variação de: a) concentração inicial de GLC (Ensaios Ma-10, Ma-11, Ma-12, Ma-14); b) concentração inicial de GLN (Ensaios Ma-10, Ma-15, Ma-16 e Ma17). (Quadro A1, Anexo A). Linhas verticais, final do crescimento. 
As Figuras 5.74 e 5.75 apresentam os dados de formação de $\mathrm{NH}_{4}{ }^{+}$, em comparação com o consumo de GLC. Nas Figuras 5.74a e 5.75b é evidente que a velocidade de formação de $\mathrm{NH}_{4}{ }^{+}$aumenta quando ocorre o esgotamento de GLC. Na Figura 5.75b tal fato não é observado, pois há excesso de GLC durante todo o cultivo. Finalmente, a Figura 5.74b mostra um comportamento distinto, com o aumento da velocidade de formação de $\mathrm{NH}_{4}^{+}$após 100 horas após do esgotamento de GLC. Dados não apresentados evidenciam nesse intervalo a célula consome o lactato formado durante a fase de crescimento. Quando o lactato esgota-se ocorre o aumento da velocidade de síntese de $\mathrm{NH}_{4}^{+}$.
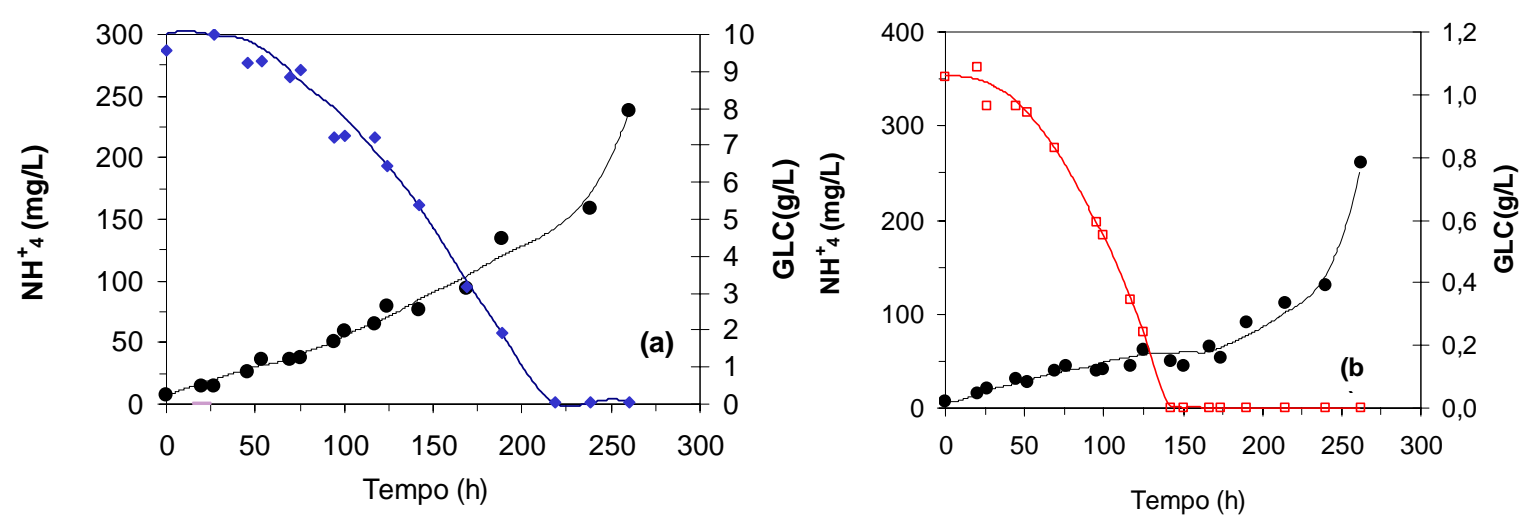

Figura 5.74. Evolução da concentração de $\mathrm{NH}_{4}{ }^{+}$e GLC (b) em função da variação da concentração inicial de GLC: a) $\mathrm{GLC}_{0}=10 \mathrm{~g} / \mathrm{L}$ (Ensaio Ma-10); b) $\mathrm{GLC}_{0}=1,0 \mathrm{~g} / \mathrm{L}$ (Ensaio Ma-11) (Quadro A.1, Anexo A).
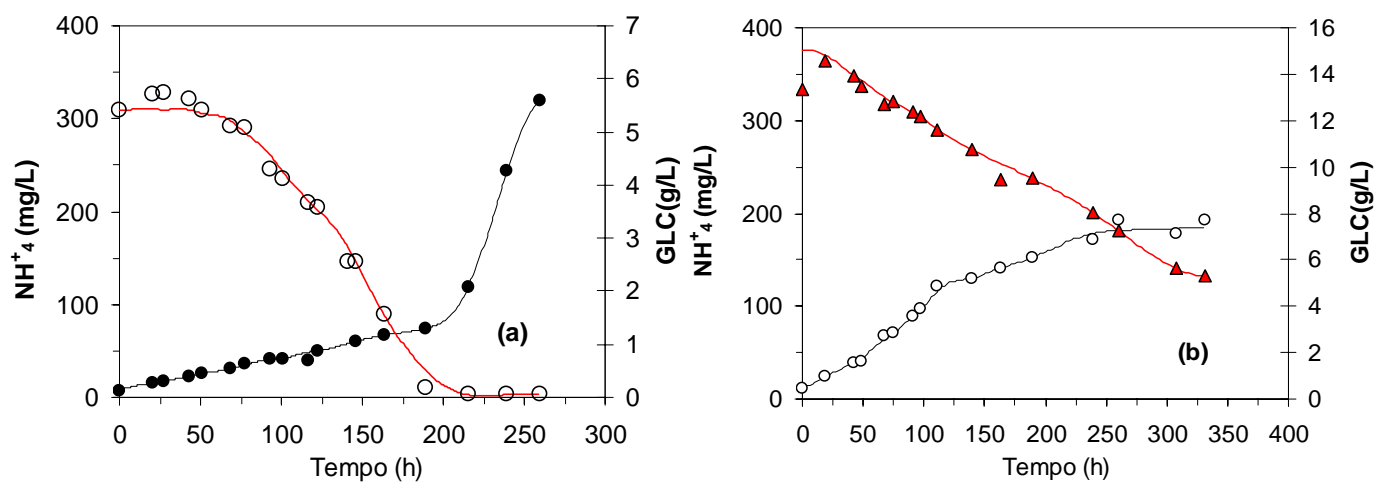

Figura 5.75. Evolução da concentração de $\mathrm{NH}_{4}{ }^{+}$e GLC em função da variação da concentração inicial de GLC: a) $\mathrm{GLC}_{0}=5,0 \mathrm{~g} / \mathrm{L}$ (Ensaio Ma-12); b) $\mathrm{GLC}_{0}=15,0 \mathrm{~g} / \mathrm{L}$ (Ensaio Ma-14) (Quadro A.1, Anexo A).

k) Consumo de alanina na fase de crescimento estacionária. Considerando os resultados dos ensaios Ma-10, Ma-15, Ma-16 e Ma-17, nos quais se variou a concentração inicial de GLN, durante a fase estacionária, verifica-se consumo de alanina acumulada no meio quando ocorre esgotamento de glicose, com exceção de ensaio Ma-15 no qual existe excesso de GLC como 
indica a Figura 5.76a.Também quando se varia a concentração inicial de GLC (ensaios Ma10, Ma-11, Ma-12 e Ma-14), verifica-se consumo de ALA na fase estacionária com exceção do ensaio Ma-14 que apresenta excesso de GLC, como indica a Figura 5.76b.
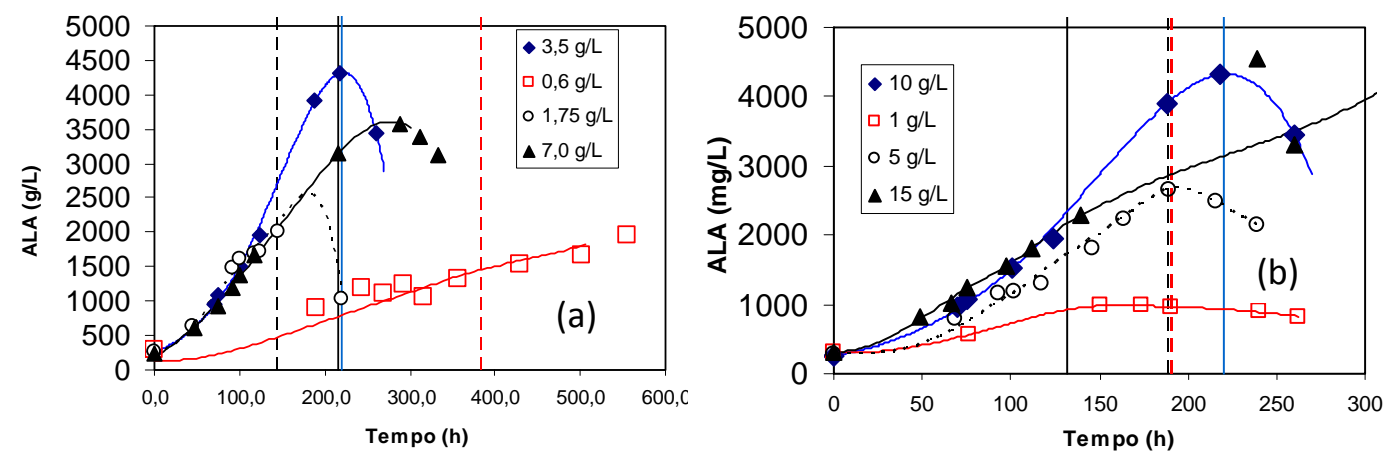

Figura 5.76 Evolução da concentração de ALA; a) Efeito de diferentes GLN $_{0}$ (Ensaios Ma-10, Ma-15, Ma-16, Ma-17; Quadro A.1, Anexo A); b) Efeito de diferentes GLC $_{0}$ (Ensaios Ma-10, Ma-11, Ma-12, Ma-14; Quadro A.1, Anexo A).

1) Influência da concentração de GLC na fase de morte celular (ensaios Ma-10, Ma-11, Ma12, Ma-14). Os dados ilustrados na Figura 5.79a (ensaios Ma-10) indicam o início do declínio da viabilidade celular quando se esgota a GLC para o ensaio Ma-10 (Figura 7.77a) e Ma-12 (Figura 7.77b). Observa-se também uma significativa diminuição da viabilidade celular no ensaio Ma-14 $\left(\mathrm{GLC}_{0}=15 \mathrm{~g} / \mathrm{L}\right)$ quando a concentração de GLC é de cerca de $6 \mathrm{~g} / \mathrm{L}$. Isso indica a influência de outros fatores que não a concentração inicial de GLC na viabilidade celular.

Foram analisadas outras influências na diminuição da viabilidade celular tais como concentração de GLN, lactato e $\mathrm{NH}_{4}{ }^{+}$no ensaio Ma-14 $\left(\mathrm{GLC}_{0}=15 \mathrm{~g} / \mathrm{L}\right)$ e indicadas nas Figuras 5.78, 5.79 e 5.80. É possível verificar que o aumento linear na concentração de LAC, aparentemente, não se correlaciona com a diminuição da viabilidade celular como indica a Figura 5.78. Por outro lado, não se observa o esgotamento de GLN nesse ensaio e a diminuição significa da viabilidade celular ocorre quando a concentração de GLN está em torno de $580 \mathrm{mg} / \mathrm{L}$ como indica a Figura 5.79. Não se atribui essa diminuição de viabilidade a uma possível limitação de GLN, mas essa questão será mais bem tratada no item subsequente. Uma associação mais evidente pode ser verificada entre a concentração de $\mathrm{NH}_{4}^{+}$e a viabilidade celular como indica a Figura 5.80. Verifica-se uma diminuição significativa da viabilidade celular quando a concentração de $\mathrm{NH}_{4}{ }^{+}$atinge $190 \mathrm{mg} / \mathrm{L}$ e que se mantém nesse nível durante a queda de viabilidade. 

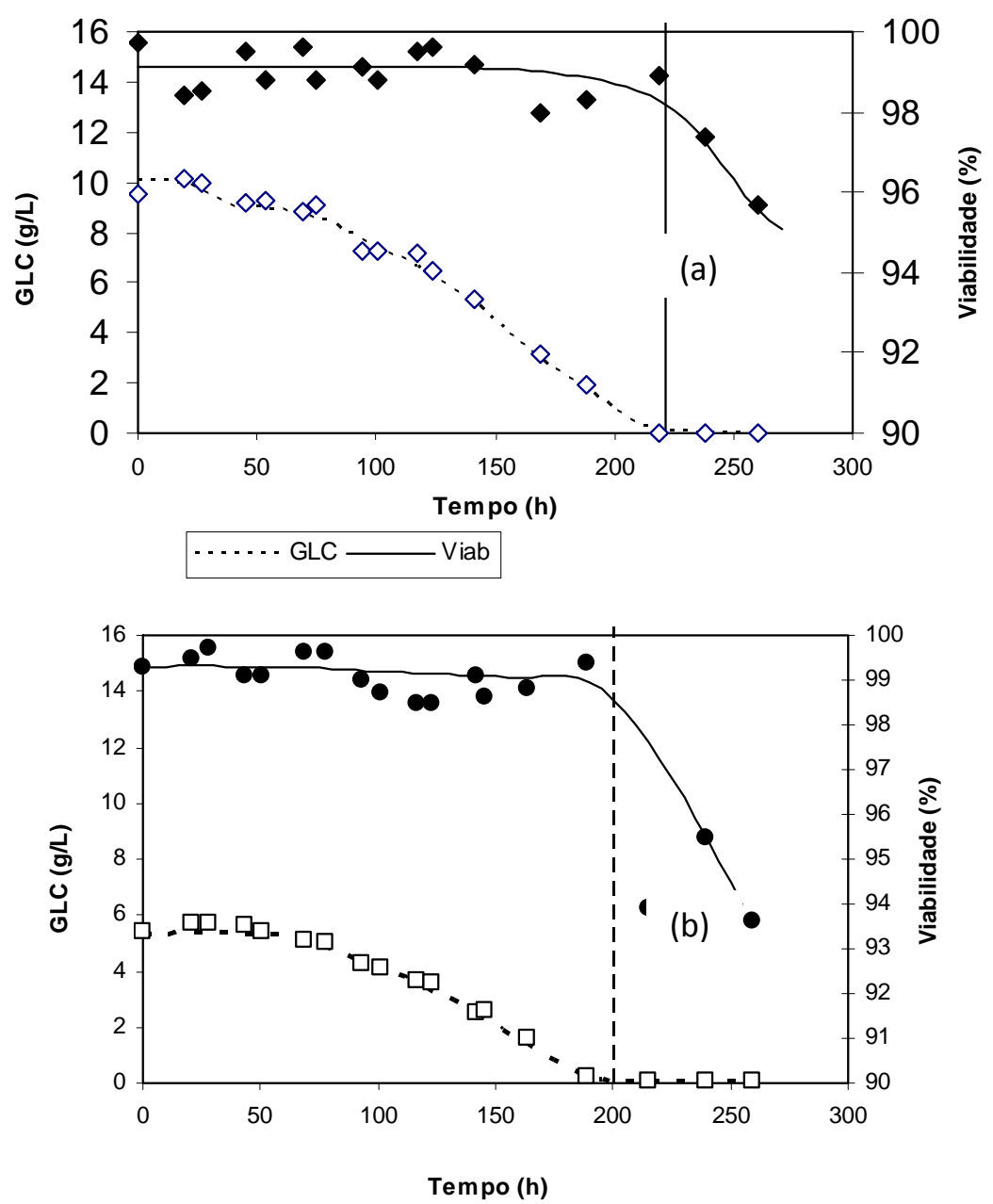

ㅁ GLC — Viab.

Figura 5.77. Evolução da concentração de GLC e a viabilidade celular: a) $\mathrm{GLC}_{0}=10,0 \mathrm{~g} / \mathrm{L}$ (Ensaio Ma-10, Quadro A.1, Anexo A); b) $\mathrm{GLC}_{0}=5,0 \mathrm{~g} / \mathrm{L}$ (Ensaio Ma-1; Quadro A.1, Anexo A). Linha vertical, esgotamento de glicose.

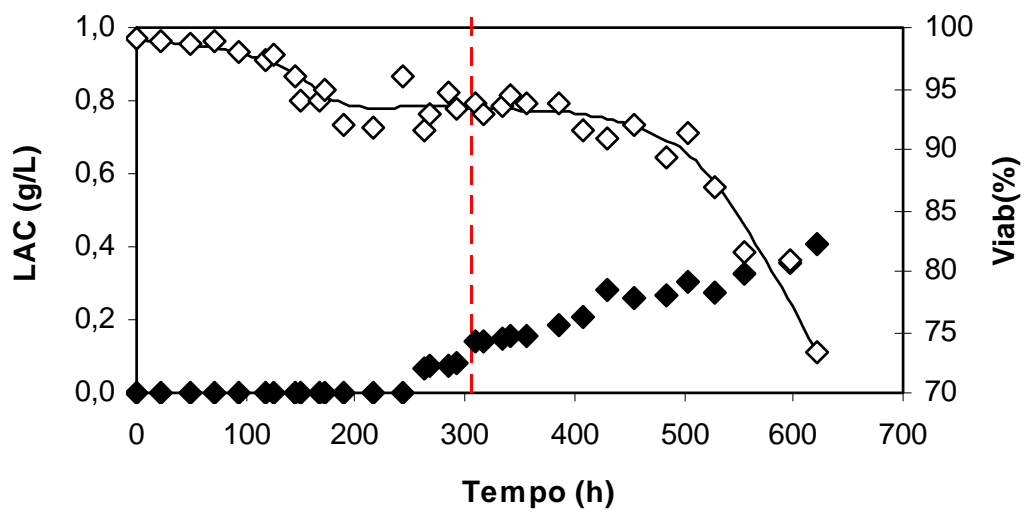

- lac $\diamond$ Viab.

Figura 5.78. Evolução da concentração de $\mathrm{LAC}$ e da viabilidade celular no ensaio Ma-14 $\left(\mathrm{GLC}_{0}=14 \mathrm{~g} / \mathrm{L}\right)$. Linha vertical, início de morte celular. 


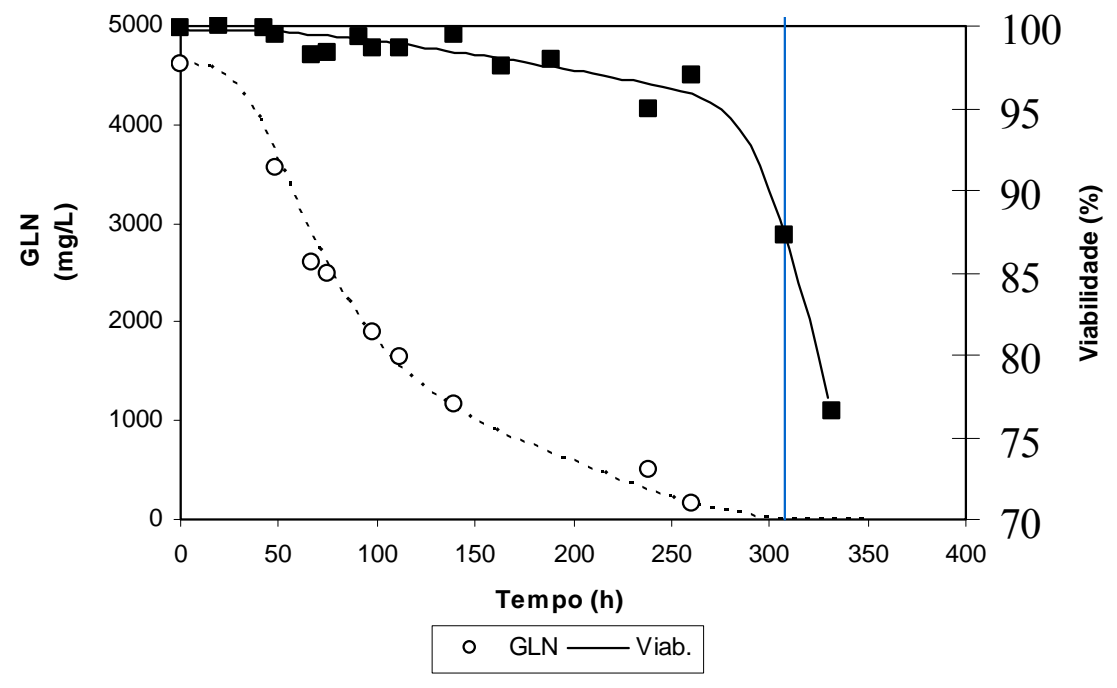

Figura 5.79. Evolução da concentração de GLN e da viabilidade celular no ensaio Ma-14 (GLC $\left.\mathrm{G}_{0}=14 \mathrm{~g} / \mathrm{L}\right)$. Linha vertical; início de morte celular

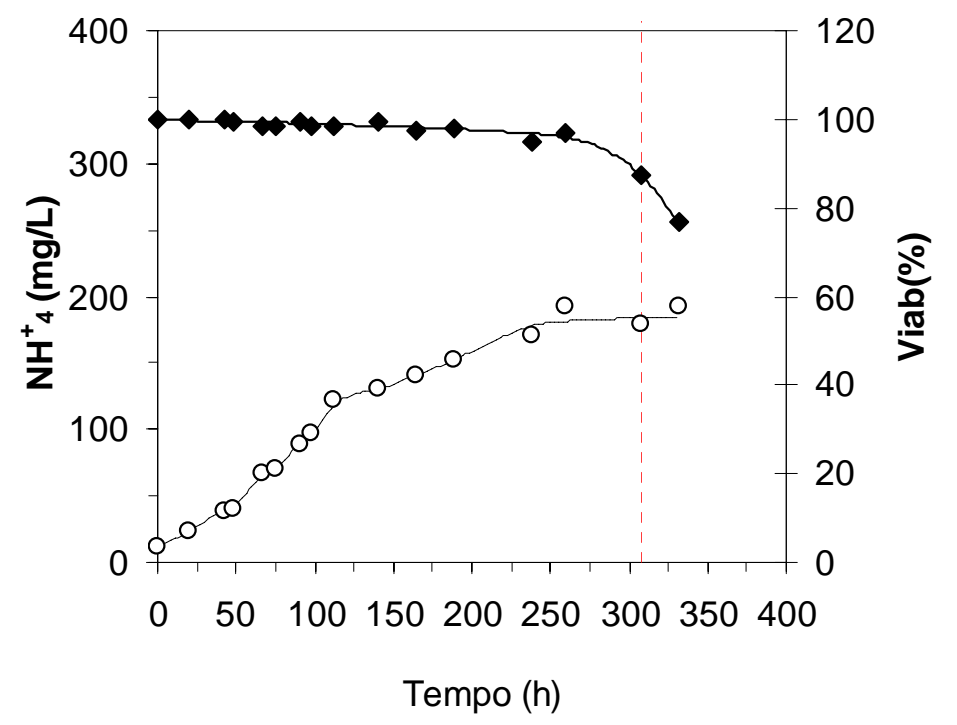

Figura 5.80. Evolução da concentração de $\mathrm{NH}_{4}^{+}$e da viabilidade celular no ensaio Ma-14 $\left(\mathrm{GLC} \mathrm{C}_{0}=14 \mathrm{~g} / \mathrm{L}\right)$. Linha vertical; início de morte celular.

m) Influência da concentração de GLN na fase de morte (ensaios Ma-10, Ma-15, Ma-16 e Ma-17). Os dados relativos aos ensaios com menores valores de $\mathrm{GLN}_{0}$ não permitem relacionar a diminuição significativa da viabilidade com esgotamento de GLN como indica a Figura 5.81. Nos demais ensaios, a concentração de glutamina sempre foi elevada quando a viabilidade celular decrescia. 

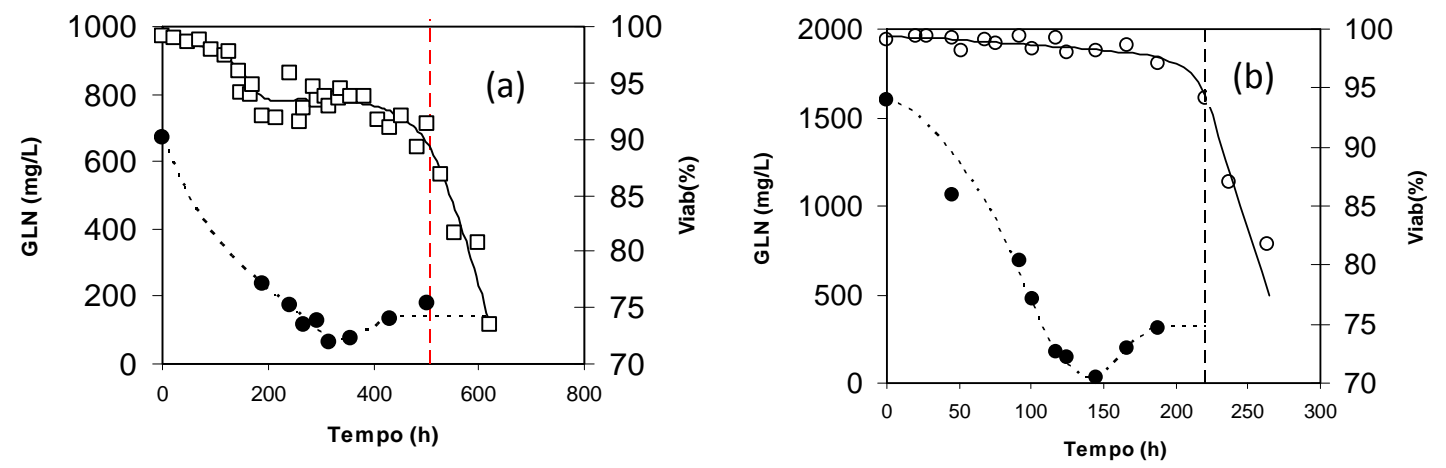

Figura 5.81. Evolução da concentração de GLN e da viabilidade celular: a) Ensaio Ma-15 $\left(\mathrm{GLN}_{0}=0,5 \mathrm{~g} / \mathrm{L}\right)$; b) Ma-16 $\left(\mathrm{GLN}_{0}=1,75 \mathrm{~g} / \mathrm{L}\right)$. Linha vertical, início de morte celular.

No ensaio Ma-16 $\left(\mathrm{GLN}_{0}=1,75 \mathrm{~g} / \mathrm{L}\right)$, a redução da viabilidade pode ser atribuída ao esgotamento de GLC, com, atesta a Figura 5.82.

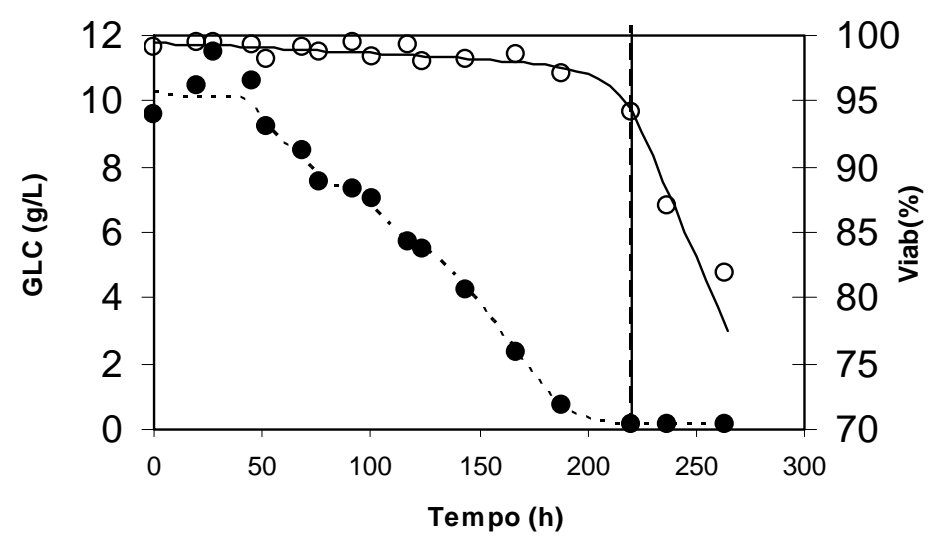

Figura 5.82. Evolução da concentração de GLC e da viabilidade celular no ensaio Ma-16 $\left(\mathrm{GLN}_{0}=1,75 \mathrm{~g} / \mathrm{L}\right)$. Linha vertical, início de morte celular

No entanto, a diminuição de viabilidade no ensaio Ma-15 $\left(\mathrm{GLN}_{0}=0,6 \mathrm{~g} / \mathrm{L}\right)$ não se explica da mesma forma como indica a Figura 5.83. Tão pouco é possível correlacionar a morte celular nesse ensaio com a produção de inibidor como $\mathrm{NH}_{4}{ }^{+}$(ver Figura 5.84). A formação de lactato foi também avaliada, visto ser este um inibidor clássico em culturas de células animais (Figura 5.85). Entretanto, parece pouco provável que concentrações da ordem de $0,3 \mathrm{~g} \mathrm{~g} / \mathrm{L}$ possam ter tal efeito danoso. Assim, com os dados disponíveis até o momento, não é possível explicar esse comportamento. 


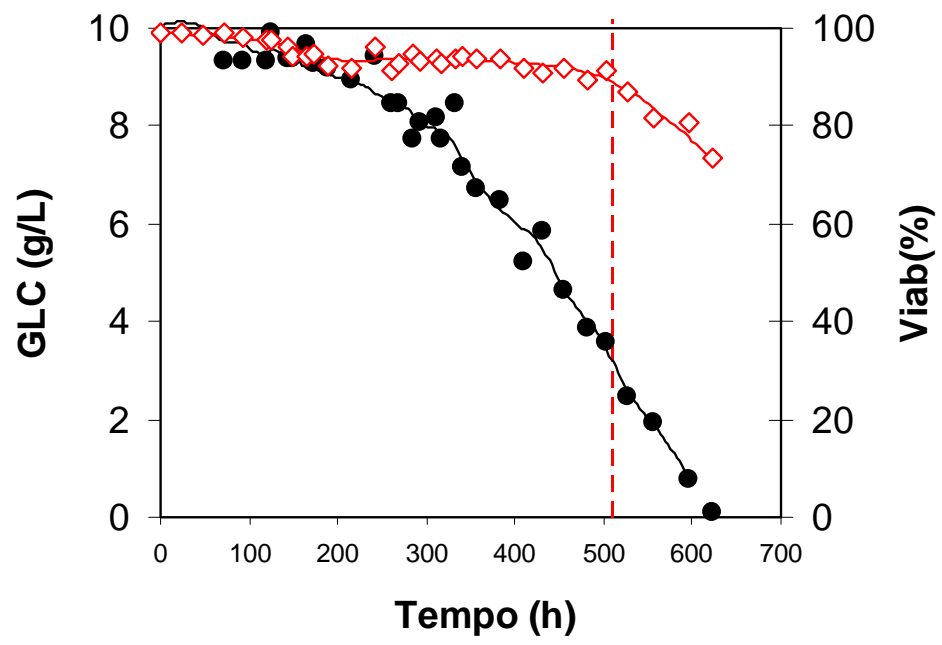

Figura 5.83. Evolução da concentração de GLC e da viabilidade celular no ensaio Ma-15 $\left(\mathrm{GLN}_{0}=0,6 \mathrm{~g} / \mathrm{L}\right)$. Linha vertical, início de morte celular

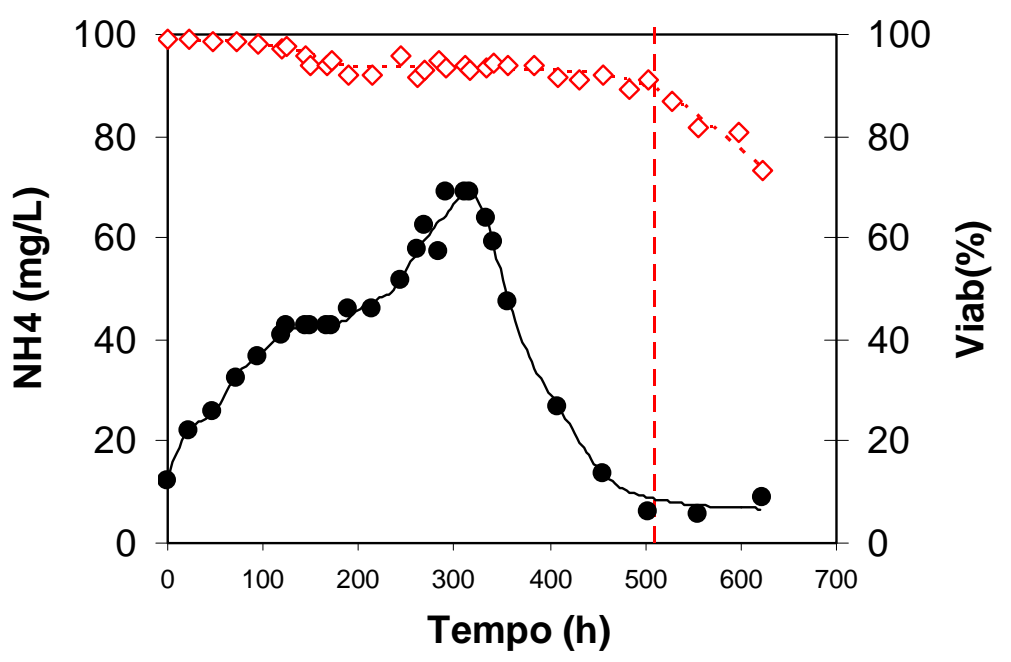

Figura 5.84. Evolução da concentração de $\mathrm{NH}_{4}{ }^{+}$e da viabilidade celular no ensaio Ma-15 $\left(\mathrm{GLN}_{0}=0,6 \mathrm{~g} / \mathrm{L}\right)$. Linha vertical, início de morte celular.

Os dados apresentados sugerem a influência do esgotamento de GLC e da formação de $\mathrm{NH}_{4}$ na diminuição da viabilidade celular. 


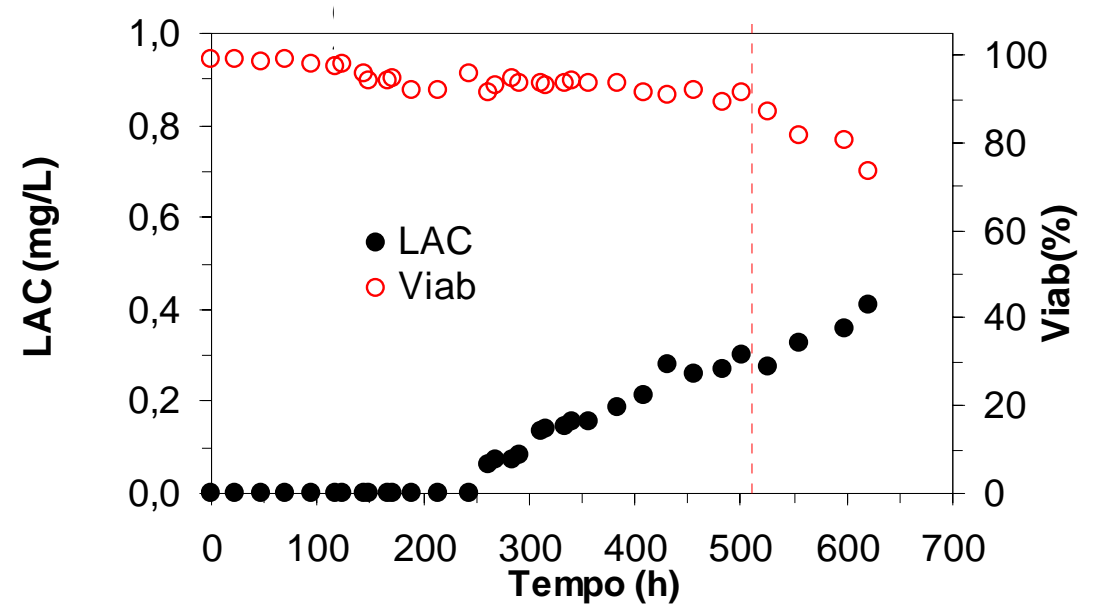

Figura 5.85. Evolução da concentração de LAC e da viabilidade celular no ensaio Ma-15 $\left(\mathrm{GLN}_{0}=0,6 \mathrm{~g} / \mathrm{L}\right)$. Linha vertical, início de morte celular. Linha vertical, início de morte celular

n) Influência das concentrações iniciais de GLC e de GLN na formação de GPV. A Figura 5.86 apresenta perfís típicos de formação da glicoproteína do vírus da raiva (GPV, medida em $\mu \mathrm{g} / \mathrm{mL})$ e do teor celular dessa proteína $\left(\mathrm{GPV}_{\mathrm{E}}\right.$, medido em $\mu \mathrm{g} / 10^{7}$ cel) que é sintetizada na membrana celular. Aguiar (2010) apresentou resultados referentes à síntese de GPV para diferentes concentrações iniciais de GLC e de GLN. Suas principais conclusões foram:

- $\quad \mathrm{GLC}_{0}$ não influi no teor de GPV nas células, mas se observou valor máximo para $\mathrm{GLC}_{0}=10,0 \mathrm{~g} / \mathrm{L}$.

- $\quad$ o teor de GPV diminui para valores de $\mathrm{GLN}_{0}$ inferiores a 3,5 g/L e, semelhante o que foi observado para diferentes concentrações iniciais de glicose, a curva de GPV apresentou um valor máximo para $\mathrm{GLN}_{0}=3,5 \mathrm{~g} / \mathrm{L}$.

Aguiar (2010) indicou, ainda, que a inibição por $\mathrm{NH}_{4}{ }^{+}$seria responsável pela redução no teor de GPV, fato que ocorreu invariavelmente em todos os experimentos (Figura 5.86, $\mathrm{t}=90 \mathrm{~h}$ ). Essa redução do valor de $\mathrm{GPV}_{\mathrm{E}}$ ocorreu em diversos instantes do cultivo; em alguns antes da fase exponencial de crescimento; em outros, após o término dessa fase. Isso indica que os fatores que controlam o crescimento e a síntese da proteína podem ser distintos.

Neste trabalho foram utilizadas novas análises de aminoácidos, visando à identificação de um possível composto limitante. Infelizmente, não foi possível realizar as análises em todos os experimentos devido ao custo da análise. Entre os aminoácidos medidos, particularmente 
entre os que se esgotam ou apresentam concentrações que podem limitar o processo, destacam-se a glutamina e a cistina.

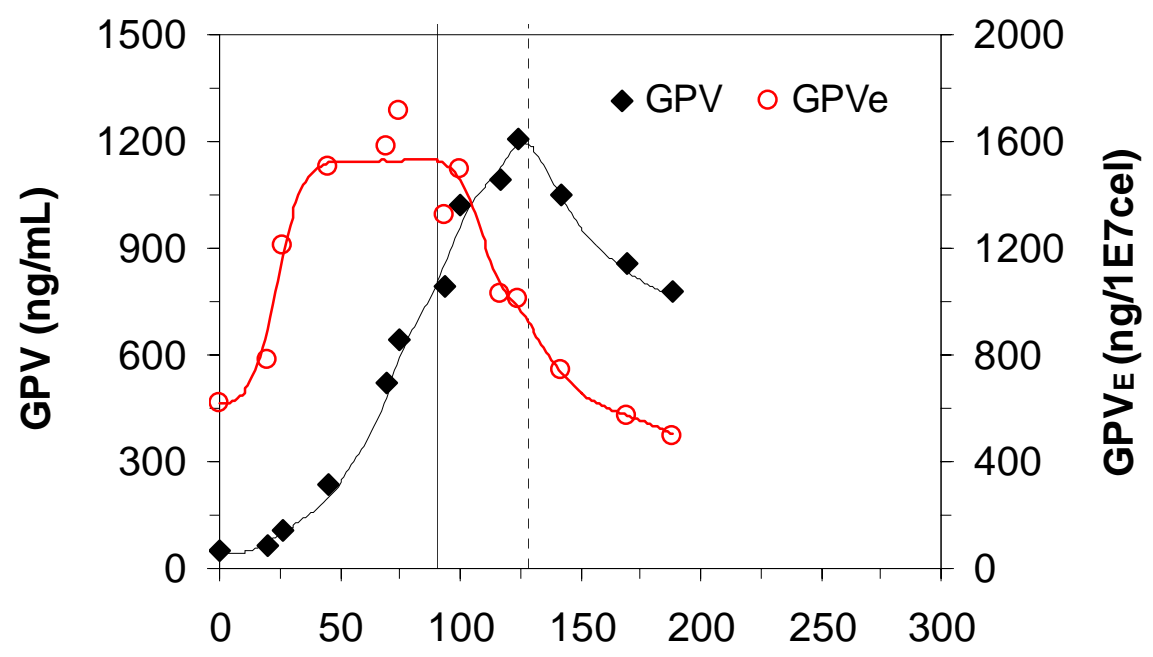

Figura 5.86. Evolução da concentração de GPV e do teor $\mathrm{GPV}_{\mathrm{E}}$ no ensaio Ma-10 $\left(\mathrm{GLC}_{0}=10,0 \mathrm{~g} / \mathrm{L}\right)$. Linhas verticais: $\mathrm{t}_{\mathrm{GPV} \text { max }}$ - linha tracejada; $\mathrm{t}_{\mathrm{GPVEmax}}$ - linha contínua.

A Figura 5.87 permite avaliar a influência de GLN e cistina (CYS) na síntese da proteína. Nesse ensaio (Ma-10) o fim do patamar de teor de GPV ocorre em $90 \mathrm{~h}$ quando a concentração de cistína, como indica a Figura 5.89, atingiu valores bastante baixos $(1,1 \mathrm{mg} / \mathrm{L})$ o que sugere limitar da síntese da proteína por esse aminoácido. No ensaio Ma-11, o fim do patamar do teor máximo de GPV ocorre em 166 h (Figura 5.88) e a concentração de cistina estava em torno de $1,3 \mathrm{mg} / \mathrm{L}$ nesse instante (Figura 5.89). Novamente essa concentração de cistina baixa também sugere limitação da síntese da proteína.

No ensaio Ma-15 $\left(\mathrm{GLN}_{0}=0,6 \mathrm{~g} / \mathrm{L}\right)$, o fim do patamar do teor de GPV ocorreu em $243 \mathrm{~h}$ (Figura 5.90) houve esgotamento de cistina no meio a partir da duzentas horas de cultivo como indicam, a Figura 5.91. Nesse caso, não é tão clara a relação entre o esgotamento em cistina e o comprometimento da síntese da proteína. 


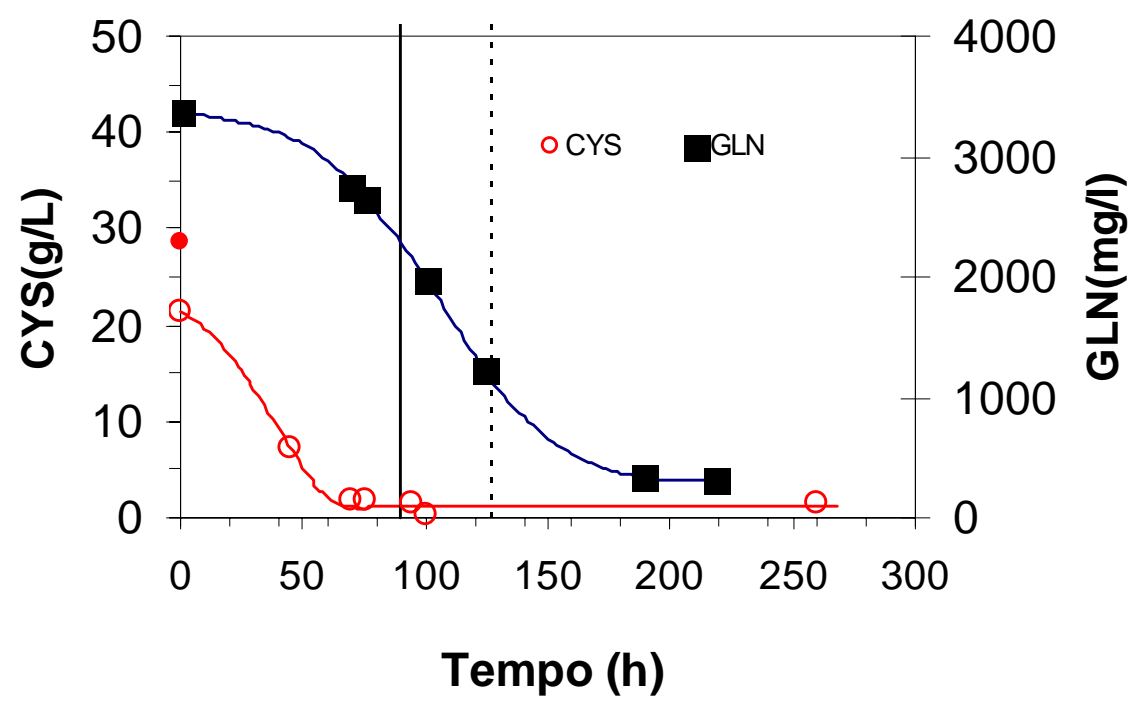

Figura 5.87 Evolução da concentração de CYS e GLN no ensaio Ma-10 $\left(\mathrm{GLC}_{0}=10,0 \mathrm{~g} / \mathrm{L}\right)$. Linhas verticais: $\mathrm{t}_{\mathrm{GPV} \max }$ - linha tracejada; $\mathrm{t}_{\mathrm{GPVEmax}}$ - linha contínua.

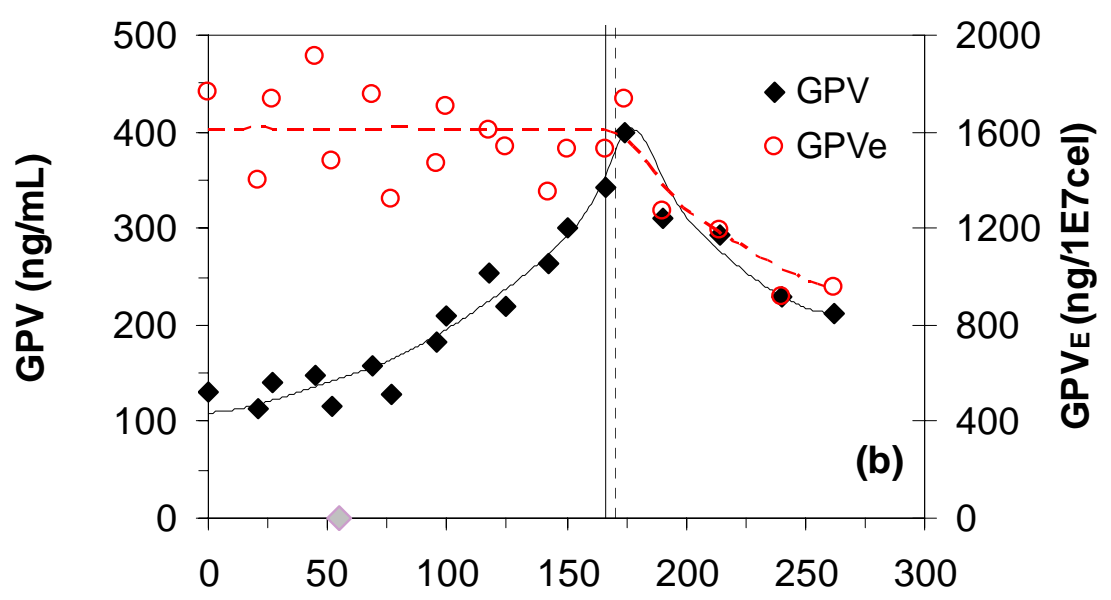

Figura 5.88. Evolução da concentração de GPV e GPVe no ensaio Ma-11 $\left(\mathrm{GLC}_{0}=1,0 \mathrm{~g} / \mathrm{L}\right)$. Linhas verticais: $\mathrm{t}_{\mathrm{GPV} \max }$ - linha tracejada; $\mathrm{t}_{\mathrm{GPVEmax}}$ - linha contínua. 


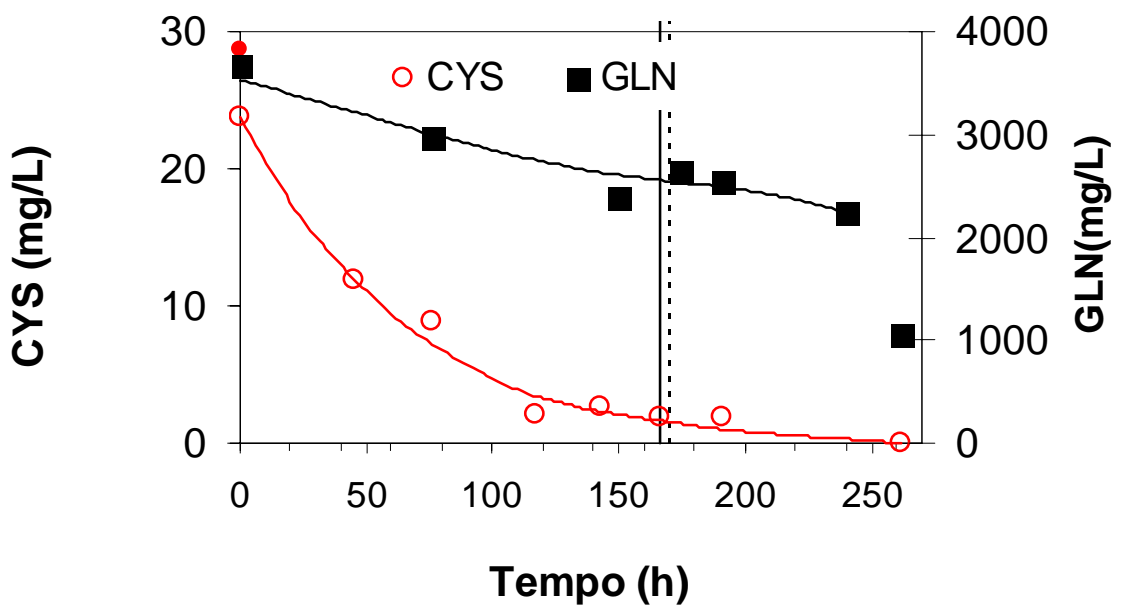

Figura 5.89. Evolução da concentração de CYS e GLN no ensaio Ma-11 $\left(\mathrm{GLC}_{0}=1,0 \mathrm{~g} / \mathrm{L}\right)$. Linhas verticais: $\mathrm{t}_{\mathrm{GPV} \max }$ - linha tracejada; $\mathrm{t}_{\mathrm{GPVEmax}}$ - linha contínua.

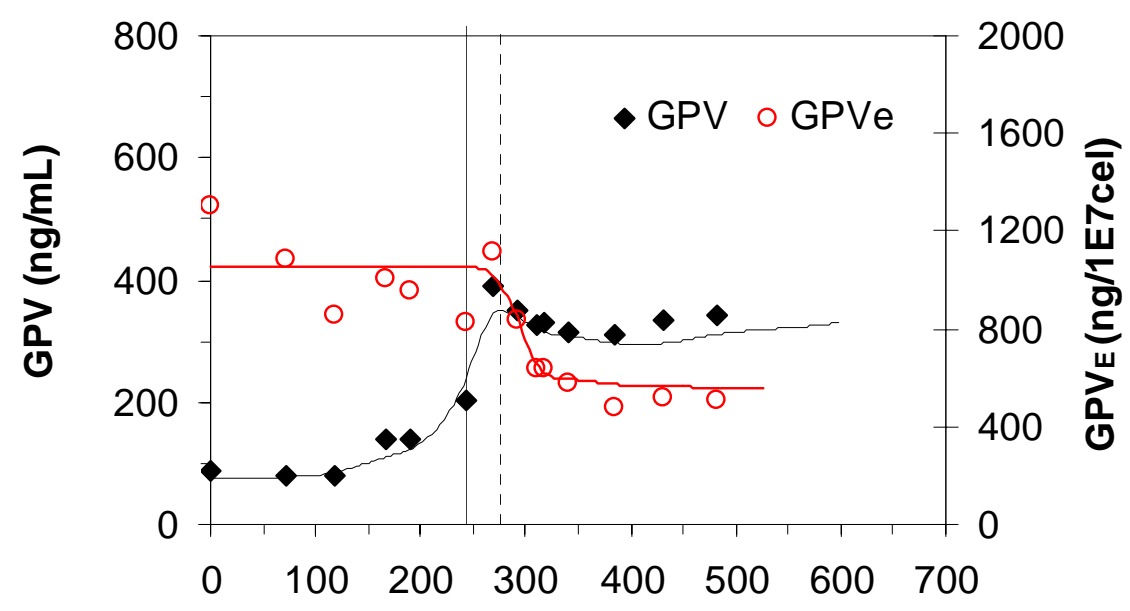

Figura 5.90. Evolução da concentração de GPV e GPVe no ensaio Ma-15 $\left(\mathrm{GLN}_{0}=0,6 \mathrm{~g} / \mathrm{L}\right)$. Linhas verticais: $\mathrm{t}_{\mathrm{GPV} \max }$ - linha tracejada; $\mathrm{t}_{\mathrm{GPVEmax}}$ - linha contínua. 


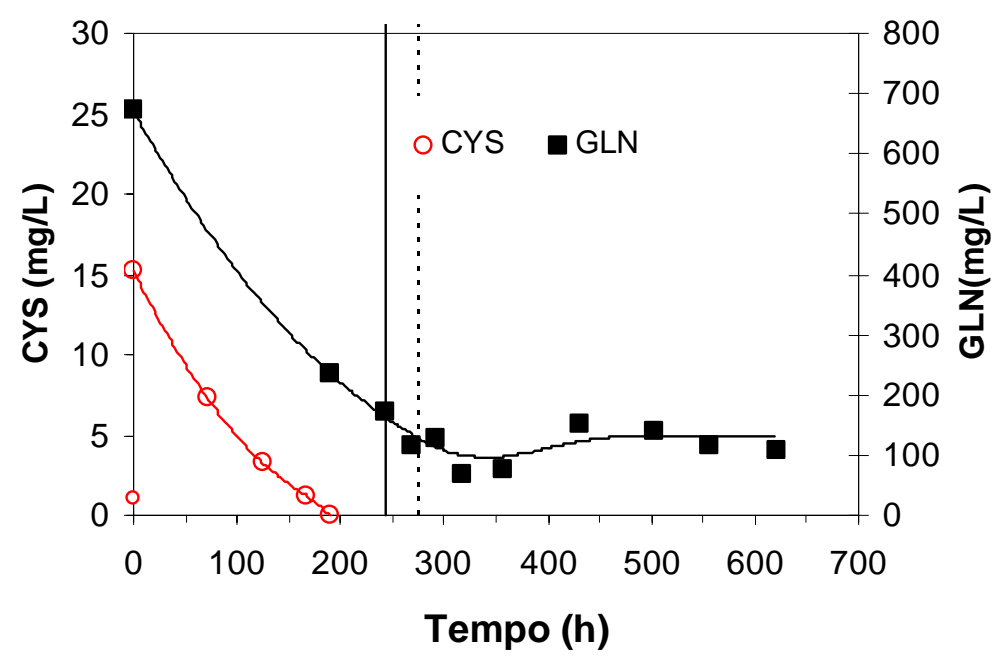

Figura 5.91. Evolução da concentração de CYS e GLN no ensaio Ma- $15\left(\mathrm{GLN}_{0}=0,6 \mathrm{~g} / \mathrm{L}\right)$. Linhas verticais: $\mathrm{t}_{\mathrm{GPV} \max }$ - linha tracejada; $\mathrm{t}_{\mathrm{GPVEmax}}$ - linha contínua.

Para o ensaio Ma-17, o fim do patamar do teor de GPV ocorre em 80 h (Figura 5.92) quando a concentração de cistina era cerca de $2 \mathrm{mg} / \mathrm{L}$ que, aparentemente, poderia limitar a síntese da proteína como indica a Figura 5.93.

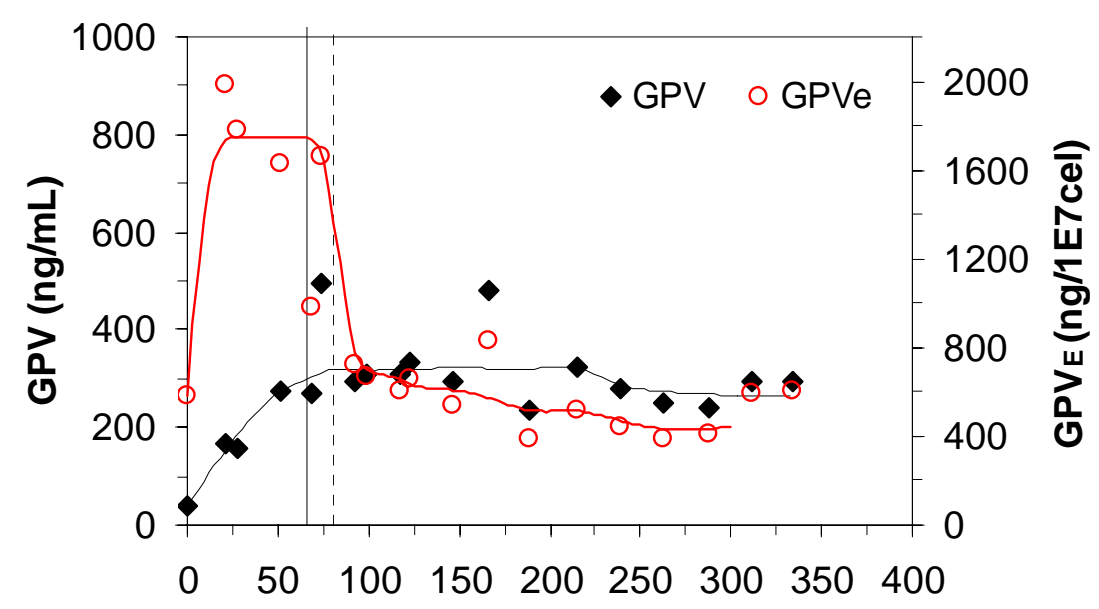

Figura 5.92. Evolução da concentração de GPV e $\mathrm{GPV}_{\mathrm{E}}$ no ensaio Ma-17 $\left(\mathrm{GLN}_{0}=7,0 \mathrm{~g} / \mathrm{L}\right)$. Linhas verticais: $\mathrm{t}_{\mathrm{GPV} m a x}$ - linha tracejada; $\mathrm{t}_{\mathrm{GPVEmax}}$ - linha contínua. 


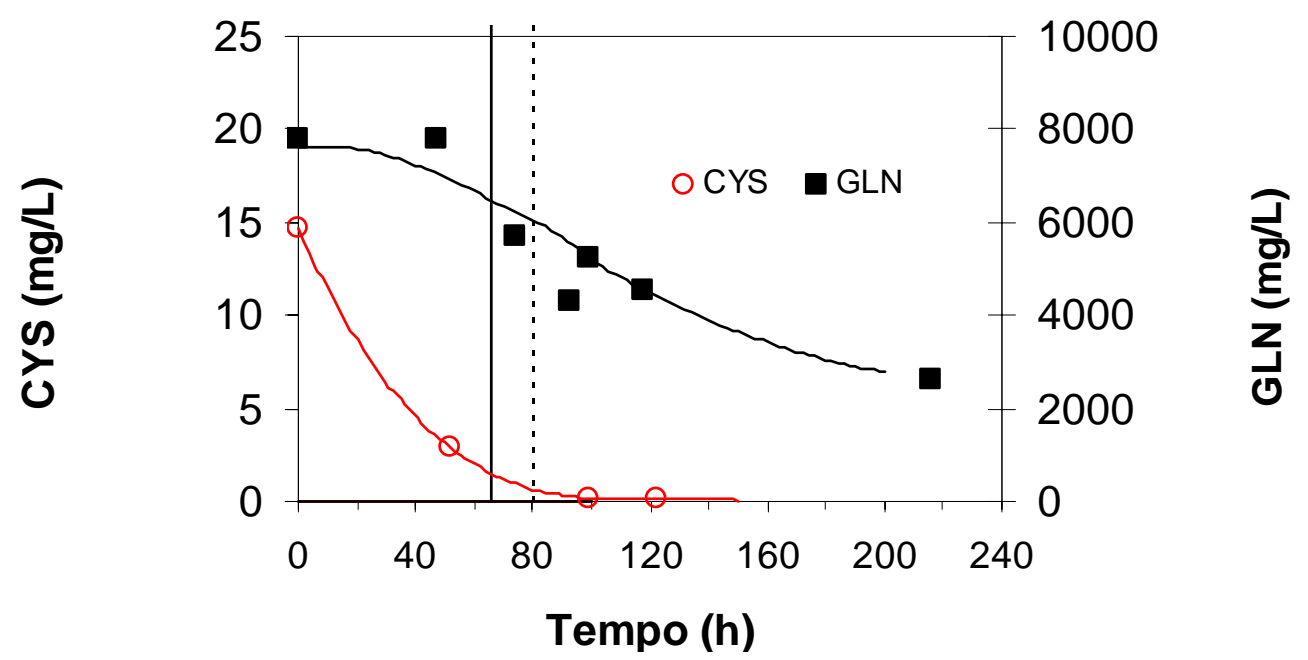

Figura 5.93. Evolução da concentração de CYS e GLN no ensaio Ma-17 $\left(\mathrm{GLN}_{0}=7,0 \mathrm{~g} / \mathrm{L}\right)$. Linhas verticais: $\mathrm{t}_{\mathrm{GPV} \max }$ - linha tracejada; $\mathrm{t}_{\mathrm{GPVEmax}}$ - linha contínua.

No entanto, os dados do ensaio Ma-07 sugerem o fim do patamar de teor de GPV em $45 \mathrm{~h}$ (Figura 5.94) quando a concentração de cistina é superior a $5 \mathrm{mg} / \mathrm{L}$ (18\% do valor inicial) que, aparentemente, não seria limitante para a síntese da proteína como pode ser verificado na Figura 5.95.

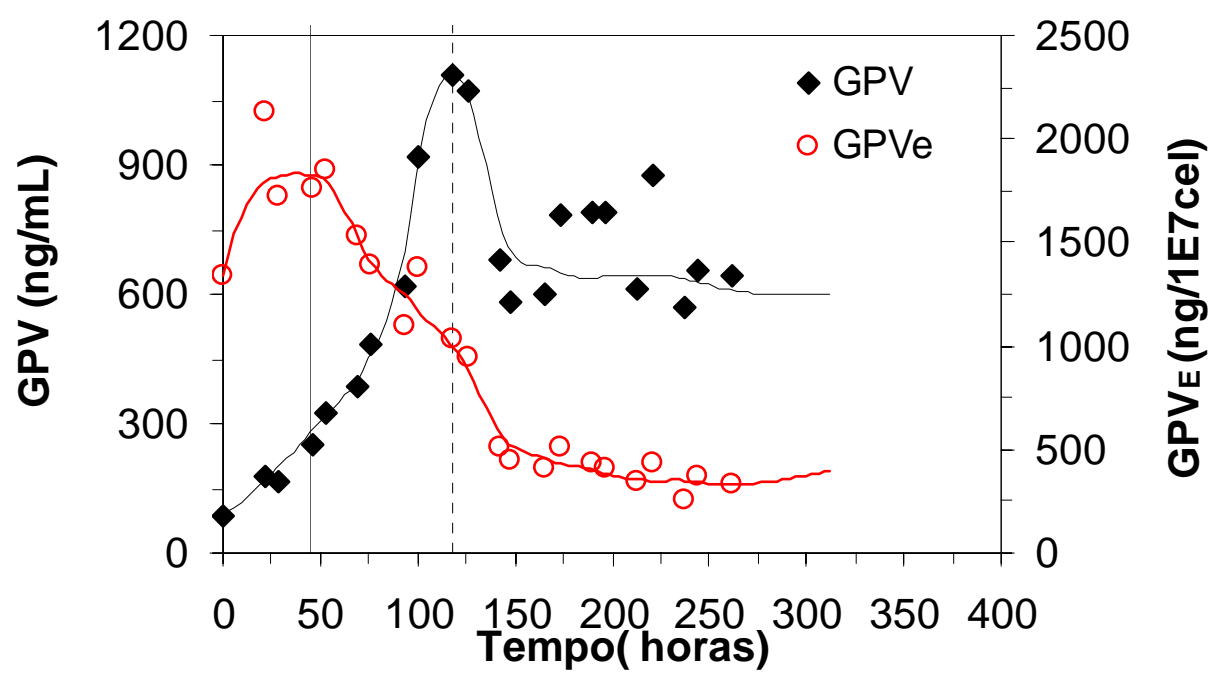

Figura 5.94. Evolução da concentração de GPV e GPVe no ensaio Ma-07 ( $\left.\mathrm{GLC}_{0}=10,0 \mathrm{~g} / \mathrm{L}, \mathrm{GLN}_{0}=3,5 \mathrm{~g} / \mathrm{L}\right)$. Linhas verticais: $\mathrm{t}_{\mathrm{GPV} \max }$ - linha tracejada; $\mathrm{t}_{\mathrm{GPVEmax}}$ - linha contínua. 


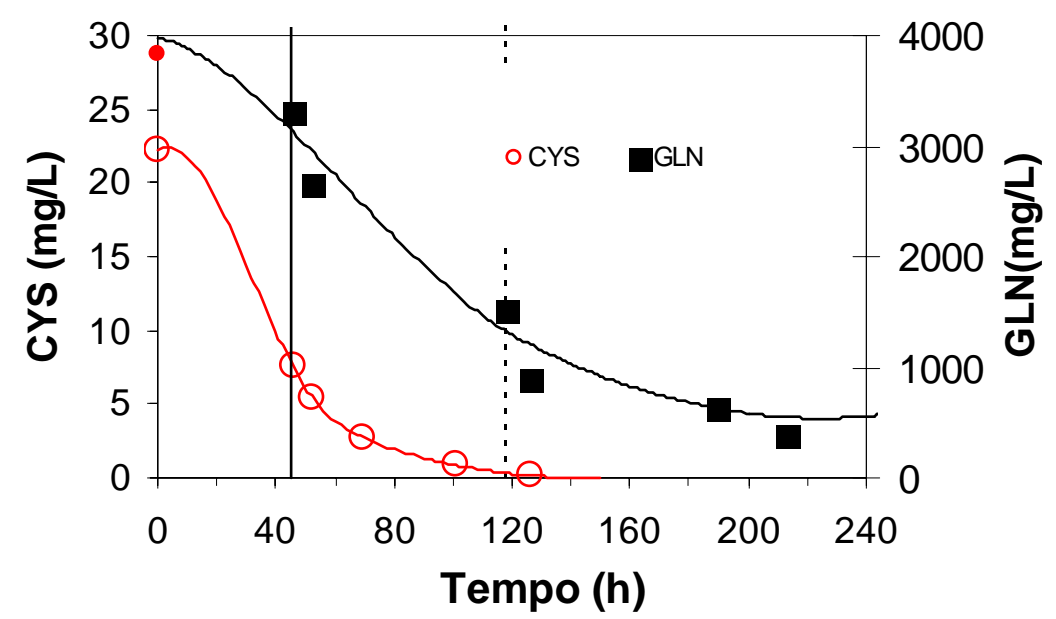

Figura 5.95. Evolução da concentração de CYS e GLN no ensaio Ma-07 $\left(\mathrm{GLC}_{0}=10,0 \mathrm{~g} / \mathrm{L}, \mathrm{GLN}_{0}=3,5 \mathrm{~g} / \mathrm{L}\right)$. Linhas verticais: $\mathrm{t}_{\mathrm{GPV} \max }$ - linha tracejada; $\mathrm{t}_{\mathrm{GPVEmax}}$ - linha contínua.

Assim, não é possível caracterizar de forma segura uma limitação da síntese de GPV devido ao esgotamento de GLN ou CYS e será adotada a proposição de Aguiar (2010) de limitação da síntese por inibição de $\mathrm{NH}_{4}^{+}$.

\subsubsection{Modelo 6. Inclusão de fatores para incorporar a influência de $\mathrm{pO}_{2}, \mathrm{GLC}_{0}$ e $\mathrm{GLN}_{0}$.}

Assim, a partir das análises dos fenômenos observados, foi feita uma nova proposta de modelo que manteve algumas hipóteses anteriores e introduziu, além de incorporar fatores de correção para as mudanças metabólicas resultantes dos efeitos de diferentes condições de $\mathrm{pO}_{2}$, $\mathrm{GLC}_{0}$ e $\mathrm{GLN}_{0}$.

Neste modelo, busca-se incorporar uma característica evidenciada nos ensaios realizados e indicada na Tabela 5.1 e que revela uma variabilidade metabólica superior às observadas em cultivos com outras células animais. Essa variabilidade metabólica também se evidencia na dependência de grandezas cinéticas como a velocidade específica de crescimento e dos fatores de conversão com as variáveis ambientais do cultivo como o teor de oxigênio dissolvido e as concentrações de glicose e de glutamina. Nesta proposta de modelo não-estruturado, essa variabilidade metabólica foi incorporada com o auxílio de fatores de correção, $\mathrm{Fc}_{\mathrm{s}}$, que modificam essas grandezas que na modelagem usual são mantidas constantes. Assim, foram estabelecidos fatores adimensionais a partir das Figuras 5.41 a 5.70 para modelar a cinética do processo. Esses fatores, contudo, foram calculados na fase exponencial de crescimento e, evidentemente, não se pode afirmar que sejam os mesmos para as outras fases do processo, 
especialmente nas fases finais, quando GLC e GLN tornam-se limitantes e o metabolismo celular sofre outras alterações.

Essas alterações da cinética do processo decorrentes das alterações das condições de cultivo e da variabilidade metabólica foram incluídas, não apenas com os fatores de correção, mas também pela definição de quatro situações características do processo que apresentam dinâmicas diferentes e que foram implementadas por IF lógicos. Essas quatro situações, quatro blocos de programação diferentes, foram assim caracterizadas:

Caso 1. Sem limitação de GLC e GLN;

Caso 2. Sem limitação de GLC e com limitação de GLN;

Caso 3. Com limitação de GLC e sem limitação de GLN;

Caso 4. Com ambas as limitações: GLC e GLN.

O novo conjunto de equações que representa o Modelo 6 está indicado na Tabela 5.6 e as suas características principais são:

- a velocidade específica de crescimento é limitada por glicose e glutamina e inibida por $\mathrm{NH}_{4}{ }^{+}$(Equação 5.6.1);

- a velocidade específica de morte celular é inibida por glicose e modulada por $\mathrm{NH}_{4}^{+}$ (Equação 5.6.2);

- o consumo de glicose foi considerado para três finalidades do metabolismo celular: crescimento, formação de alanina e manutenção celular (Equação 5.6.3);

- há consumo de glutamina para duas finalidades do metabolismo celular: crescimento celular, e formação de $\mathrm{NH}_{4}{ }^{+}$;

- formação de glutamina quando a concentração de glutamina atinge valores inferiores a 0,1g/L (Equação 5.6.14). 
Tabela 5.6. Equações do modelo 6

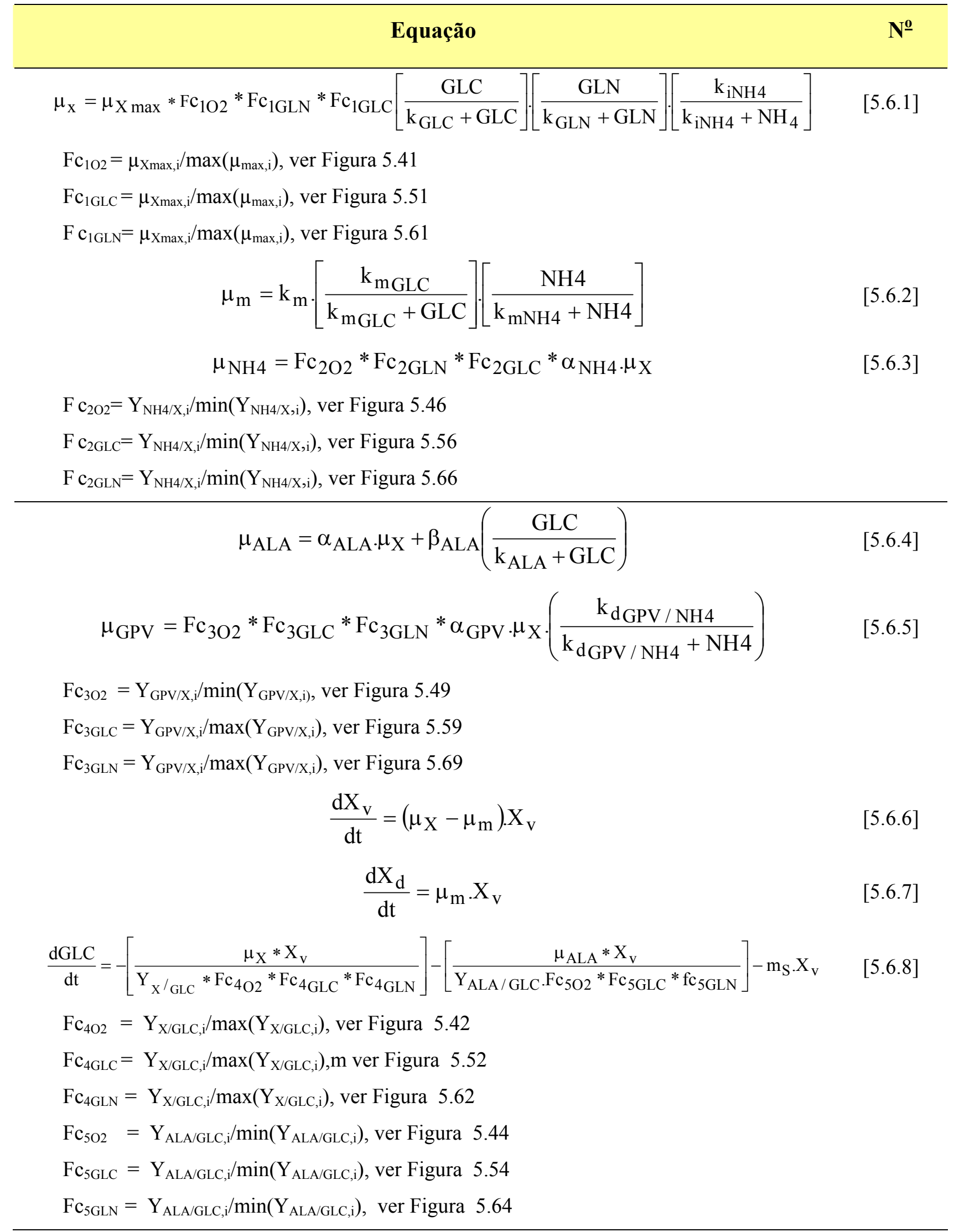


Bloco 1. Sem limitação de glicose (GLC $>=0,1 \mathrm{~g} / \mathrm{L})$ e sem limitação de $\operatorname{GLN}(\mathrm{GLN}>=0,10 \mathrm{~g} / \mathrm{L})$

$\frac{\mathrm{dGLN}}{\mathrm{dt}}=-\left[\frac{\mu_{\mathrm{X}} \cdot \mathrm{X}_{\mathrm{V}}}{\mathrm{Y}_{\mathrm{X} / \mathrm{GLN}} * \mathrm{Fc}_{6 \mathrm{O} 2} * \mathrm{Fc}_{6 \mathrm{GLC}} * \mathrm{Fc}_{6 \mathrm{GLN}}}\right]-\left[\alpha_{\mathrm{NH} 4} \frac{\mu_{\mathrm{X}} \cdot \mathrm{X}_{\mathrm{V}}}{\mathrm{Y}_{\mathrm{NH} 4 / \mathrm{GLN}} * \mathrm{Fc}_{7 \mathrm{O} 2} * \mathrm{Fc}_{7 \mathrm{GLC}} * \mathrm{Fc}_{7 \mathrm{GLN}}}\right]$

$\mathrm{Fc}_{6 \mathrm{O} 2}=\mathrm{Y}_{\mathrm{X} / \mathrm{GLN}, \mathrm{i}} / \max \left(\mathrm{Y}_{\mathrm{X} / \mathrm{GLN}, \mathrm{i}}\right)$, ver Figura 5.45

$\mathrm{Fc}_{6 \mathrm{GLC}}=\mathrm{Y}_{\mathrm{X} / \mathrm{GLN}, \mathrm{i}} / \max \left(\mathrm{Y}_{\mathrm{X} / \mathrm{GLN}, \mathrm{i}}\right)$, ver Figura 5.55

$\mathrm{Fc}_{6 \mathrm{GLN}}=\mathrm{Y}_{\mathrm{X} / \mathrm{GLN}, \mathrm{i}} / \max \left(\mathrm{Y}_{\mathrm{X} / \mathrm{GLN}, \mathrm{i}}\right)$, ver Figura 5.65

$\mathrm{Fc}_{7 \mathrm{O} 2}=\mathrm{Y}_{\mathrm{NH} 4 / \mathrm{GLN}, \mathrm{i}} / \min \left(\mathrm{Y}_{\mathrm{NH} 4 / \mathrm{GLN}, \mathrm{i}}\right)$, ver Figura 5.47

$\mathrm{Fc}_{7 \mathrm{GLC}}=\mathrm{Y}_{\mathrm{NH} 4 / \mathrm{GLN}, \mathrm{i}} / \min \left(\mathrm{Y}_{\mathrm{NH} 4 / \mathrm{GLN}, \mathrm{i}}\right)$, ver Figura 5.57

$\mathrm{Fc}_{7 \mathrm{GLN}}=\mathrm{Y}_{\mathrm{NH} 4 / \mathrm{GLN}, \mathrm{i}} / \max \left(\mathrm{Y}_{\mathrm{NH} 4 / \mathrm{GLN}, \mathrm{i}}\right)$, ver Figura 5.67

$$
\begin{gathered}
\frac{\mathrm{dALA}}{\mathrm{dt}}=\mu_{\mathrm{ALA}} * \mathrm{Xv} \\
\frac{\mathrm{dNH}_{4}^{+}}{\mathrm{dt}}=\mu_{\mathrm{NH} 4} * \mathrm{X}_{\mathrm{v}} \\
\frac{\mathrm{dGPV}}{\mathrm{dt}}=\mu_{\mathrm{GPV}} * \mathrm{Xv}-\mathrm{k}_{\mathrm{dGPV}} * \mathrm{GPV} \\
\frac{\mathrm{dGLU}}{\mathrm{dt}}=0
\end{gathered}
$$

Bloco 2. Sem limitação GLC (GLC>= 0,1 g/L) e com limitação de GLN (GLN<0,1 g/L)

$$
\begin{gathered}
\frac{\mathrm{dGLN}}{\mathrm{dt}}=\mathrm{k}_{\sin \mathrm{GLN}} * \mathrm{Y}_{\mathrm{GLN} / \mathrm{GLU}} \\
\frac{\mathrm{dNH}_{4}^{+}}{\mathrm{dt}}=\mu_{\mathrm{NH} 4} * \mathrm{Xv}-\mathrm{k}_{\sin \mathrm{GLN}} * \mathrm{Y}_{\mathrm{NH} 4 / \mathrm{GLU}} \\
\frac{\mathrm{dALA}}{\mathrm{dt}}=\mu_{\mathrm{ALA}} * \mathrm{Xv} \\
\frac{\mathrm{dGLU}}{\mathrm{dt}}=-\mathrm{k}_{\sin \mathrm{GLN}}
\end{gathered}
$$


Tabela 5.6. Equações do modelo 6 (continuação)

Equação

Bloco 3. Com limitação GLC (GLC $<0,1$ g/L) e sem limitação de GLN(GLN>=0,1 g/L)

$$
\begin{aligned}
& \frac{\mathrm{dGLN}}{\mathrm{dt}}=-\left[\frac{\mu_{\mathrm{X}} \cdot \mathrm{X}_{\mathrm{v}}}{\mathrm{Y}_{\mathrm{X} / \mathrm{GLN}} * \mathrm{Fc}_{6 \mathrm{O} 2} * \mathrm{Fc}_{6 \mathrm{GLC}} \cdot \mathrm{Fc}_{6 \mathrm{GLN}}}\right]-\left[\alpha_{\mathrm{NH} 4} \frac{\mu_{\mathrm{X}} \cdot \mathrm{X}_{\mathrm{V}}}{\mathrm{Y}_{\mathrm{NH} 4 / \mathrm{GLN}} * \mathrm{Fc}_{7 \mathrm{O} 2} * \mathrm{Fc}_{7 \mathrm{GLC}} * \mathrm{Fc}_{7 \mathrm{GLN}}}\right] \\
& \mathrm{Fc}_{6 \mathrm{O} 2}=\mathrm{Y}_{\mathrm{X} / \mathrm{GLN}, \mathrm{i}} / \max \left(\mathrm{Y}_{\mathrm{X} / \mathrm{GLN},}, \mathrm{i}\right) \text {, ver Figura } 5.45 \\
& \mathrm{Fc}_{6 \mathrm{GLC}}=\mathrm{Y}_{\mathrm{X} / \mathrm{GLN}, \mathrm{i}} / \max \left(\mathrm{Y}_{\mathrm{X} / \mathrm{GLN}}, \mathrm{i}\right) \text {, ver Figura } 5.55 \\
& \mathrm{Fc}_{6 \mathrm{GLN}}=\mathrm{Y}_{\mathrm{X} / \mathrm{GLN}, \mathrm{i}} / \max \left(\mathrm{Y}_{\mathrm{X} / \mathrm{GLN}}, \mathrm{i}\right) \text {, ver Figura } 5.65 \\
& \mathrm{Fc}_{7 \mathrm{O} 2}=\mathrm{Y}_{\mathrm{NH} 4 / \mathrm{GLN}, \mathrm{i}} / \max \left(\mathrm{Y}_{\mathrm{NH} 4 / \mathrm{GLN}}, \mathrm{i}\right) \text {, ver Figura } 5.47 \\
& \mathrm{Fc}_{7 \mathrm{GLC}}=\mathrm{Y}_{\mathrm{NH} 4 / \mathrm{GLN}, \mathrm{i}} / \max \left(\mathrm{Y}_{\mathrm{NH} 4 / \mathrm{GLN}}, \mathrm{i}\right) \text {, ver Figura } 5.57 \\
& \mathrm{Fc}_{7 \mathrm{GLN}}=\mathrm{Y}_{\mathrm{NH} 4 / \mathrm{GLN}, \mathrm{i}} / \max \left(\mathrm{Y}_{\mathrm{NH} 4 / \mathrm{GLN}}, \mathrm{i}\right) \text {, ver Figura } 5.67 \\
& \frac{\mathrm{dNH}_{4}}{\mathrm{dt}}=\mu_{\mathrm{NH} 4} * \mathrm{Xv}+\mathrm{k}_{\mathrm{dALA}} * \mathrm{Y}_{\mathrm{NH} 4 / \mathrm{ALA}} \\
& \frac{\mathrm{dALA}}{\mathrm{dt}}=-\mathrm{k}_{\mathrm{dALA}} \\
& \frac{\mathrm{dGLU}}{\mathrm{dt}}=0
\end{aligned}
$$

Bloco 4. Com limitação de GLC (GLC<0,1 g/L) e com limitação de GLN (GLN $<0,1$ g/L)

$$
\frac{\mathrm{dGLN}}{\mathrm{dt}}=\mathrm{k}_{\sin \mathrm{GLN}} * \mathrm{Y}_{\mathrm{GLN} / \mathrm{GLU}}
$$

$$
\begin{aligned}
\frac{\mathrm{dNH}_{4}}{\mathrm{dt}}=\mu_{\mathrm{NH} 4} * \mathrm{Xv}+\mathrm{k}_{\mathrm{dALA}} * \mathrm{Y}_{\mathrm{NH} 4 / \mathrm{ALA}}-\mathrm{k}_{\sin \mathrm{GLU}} * \mathrm{Y}_{\mathrm{NH} 4 / \mathrm{GLU}} \\
\frac{\mathrm{dALA}}{\mathrm{dt}}=-\mathrm{k}_{\mathrm{dALA}} \\
\frac{\mathrm{dGLU}}{\mathrm{dt}}=-\mathrm{k}_{\sin \mathrm{GLN}}
\end{aligned}
$$

- formação de $\mathrm{NH}_{4}{ }^{+}$associada ao crescimento celular (Equação 5.6.3) em quatro situações distintas dependo das concentrações de glicose e glutamina: sem limitação de glicose e de glutamina, (Equação 5.6.11); sem limitação de glicose e com limitação de glutamina, (Equação 5.6.15); com limitação de glicose e sem limitação de glutamina, (Equação 5.6.17); com limitação de glicose e com limitação de glutamina, (Equação 5.6.20); 
- consumo de $\mathrm{NH}_{4}{ }^{+}$para síntese de glutamina, incluído nas Equações 5.6.14 e 5.6.20;

- formação de $\mathrm{NH}_{4}{ }^{+}$devido ao consumo de alanina quando há limitação de glicose, incluído na Equação 5.6.17;

- formação de GPV associada ao crescimento celular e sujeita a inibição por $\mathrm{NH}_{4}$, (Equação 5.6.5);

- degradação de GPV, incluída na Equação 5.6.12;

- formação de alanina parcialmente associada ao crescimento celular e limitada por GLC, (Equação 5.6.5);

- consumo de alanina quando há esgotamento de glicose no meio, incluída na Equação 5.6.18;

- consumo de glutamato e $\mathrm{NH}_{4}{ }^{+}$quando há esgotamento de glutamina, (Equações 5.6.16 e Equações 5.6.15, respectivamente);

- consumo de glutamato condicionado ao esgotamento de GLN (Equação 5.6.16);

Dessa forma, o modelo incorpora alterações metabólicas em função das concentrações de glutamina, glicose e teores de oxigênio dissolvido do meio.

Todas essas alternativas foram implementadas no programa CI_ Mod6 (Anexo B) na subrotina FCN por meio de if lógicos que alteram a dinâmica do processo e a sua formulação pode ser mais bem compreendida pela Figura 5.96.

\subsubsection{Modelo 6a Ajuste do modelo para a etapa inicial de crescimento (Bloco 1).}

Decidiu-se realizar, preliminarmente, o ajuste do modelo aos dados dos ensaios Ma-07, Ma08, Ma-09, Ma-10, Ma-11, Ma-12, Ma-15 e Ma-16 na fase na qual não se caracteriza limitação por glicose e glutamina, ou seja, considerando apenas as equações que correspondem ao bloco lógico 1. Os resultados do ajuste estão indicados na Figuras 5.97 a Figura 5.104 e na Tabela 5.7. Foram feitas tentativas considerando o conjunto completo de ensaios, porém ficou evidente que a estrutura do modelo fenomenológico proposto não era capaz de contemplar as respostas obtidas nos ensaios Ma-14 $\left(\mathrm{GLC}_{0}=15 \mathrm{~g} / \mathrm{L}\right)$ e Ma-17 $\left(\mathrm{GLN}_{0}=7 \mathrm{~g} / \mathrm{L}\right)$. Esses dois ensaios, então, foram excluídos do conjunto de dados utilizados para realizar o ajuste de parâmetros. 


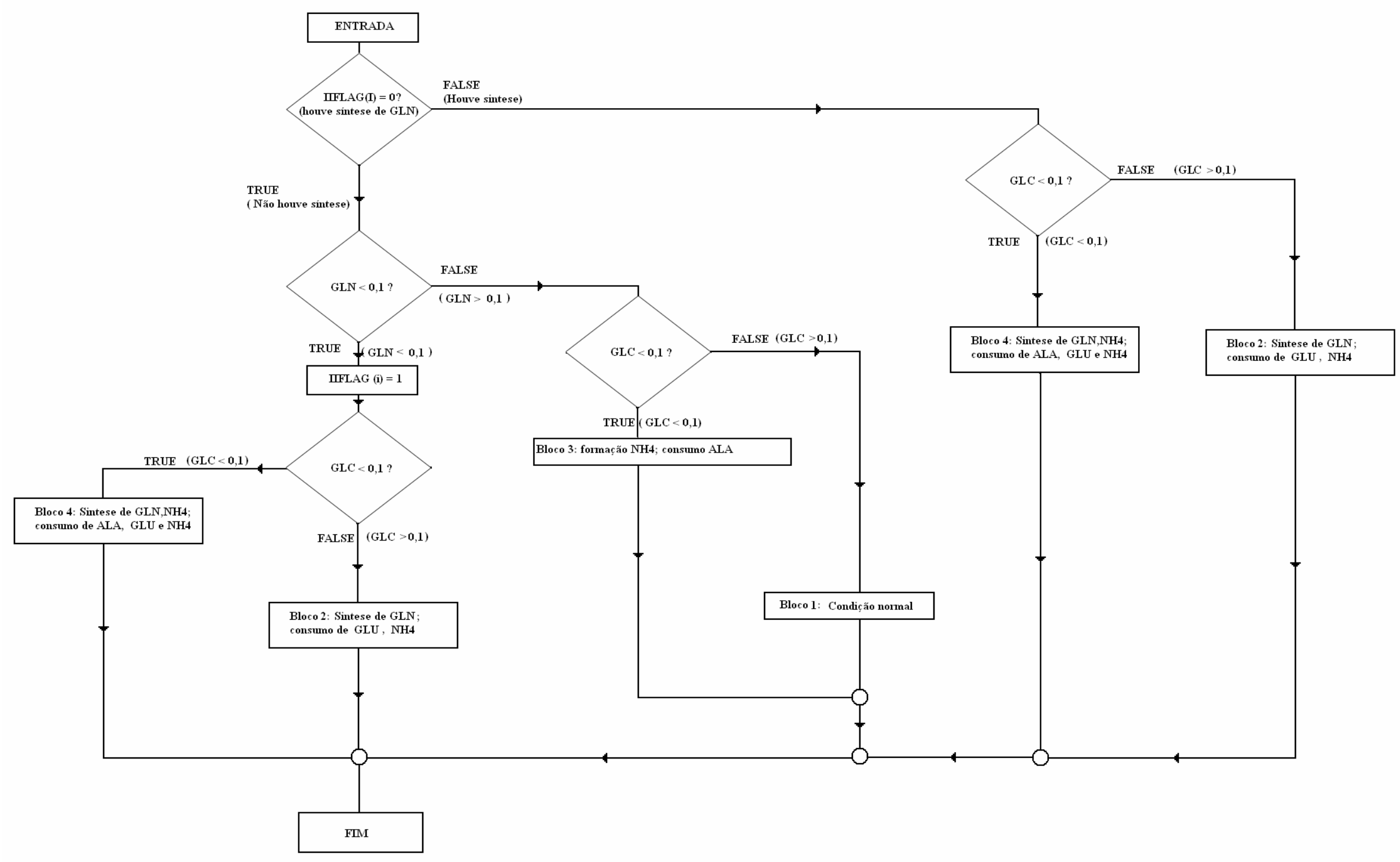

Figura 5.96. Diagrama de blocos da dinâmica do processo (subrotina FCN) com os IF lógicos para os diferentes blocos identificados no modelo 

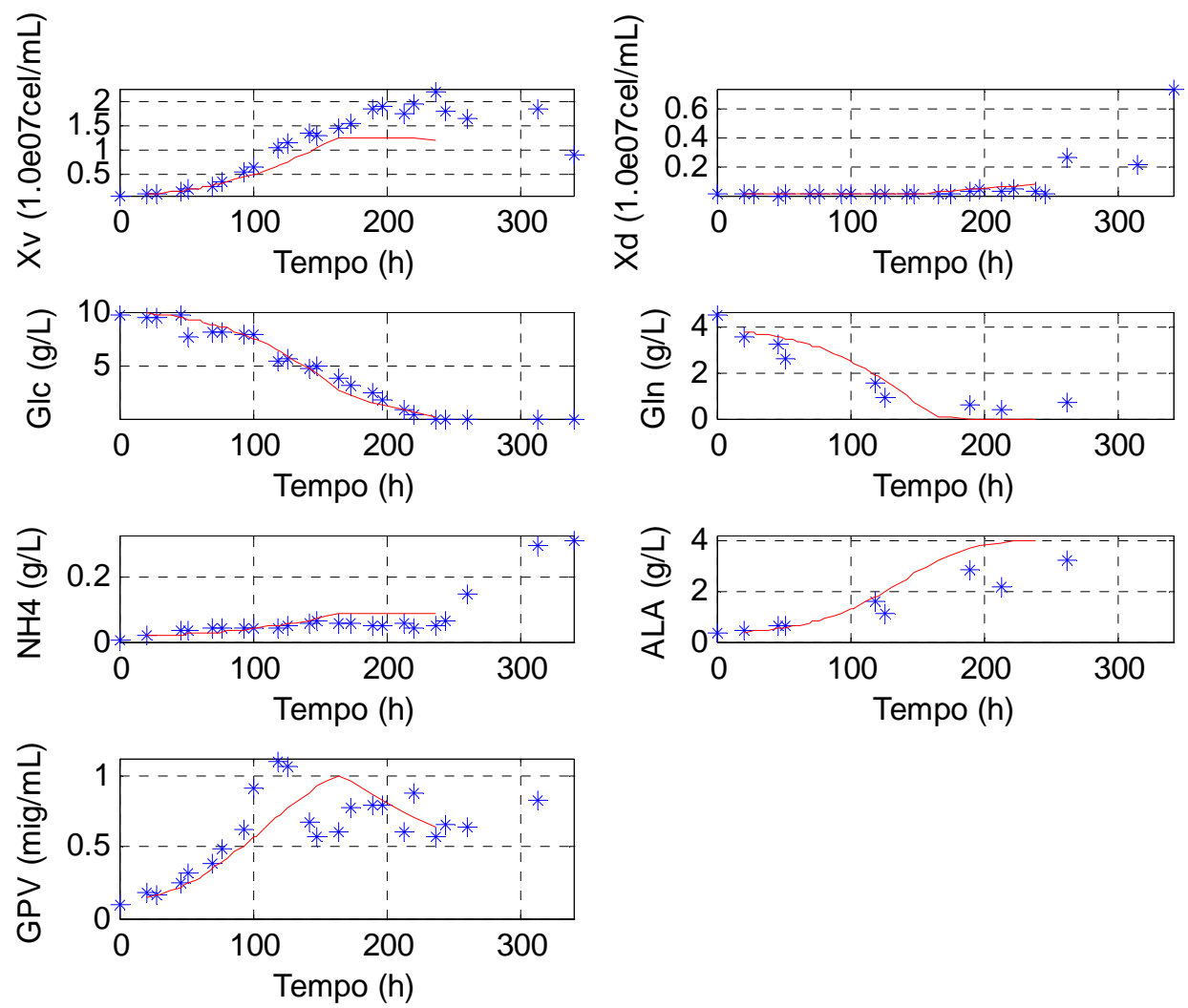

Figura 5.97 Comparação entre dados experimentais e as previsões do modelo 6a para o ensaio Ma-07, célula S2AcGPV2, $\mathrm{pO}_{2}=5 \%$ (Quadro A.1, Anexo A). (linha contínua, previsões do modelo, símbolos; dados experimentais).
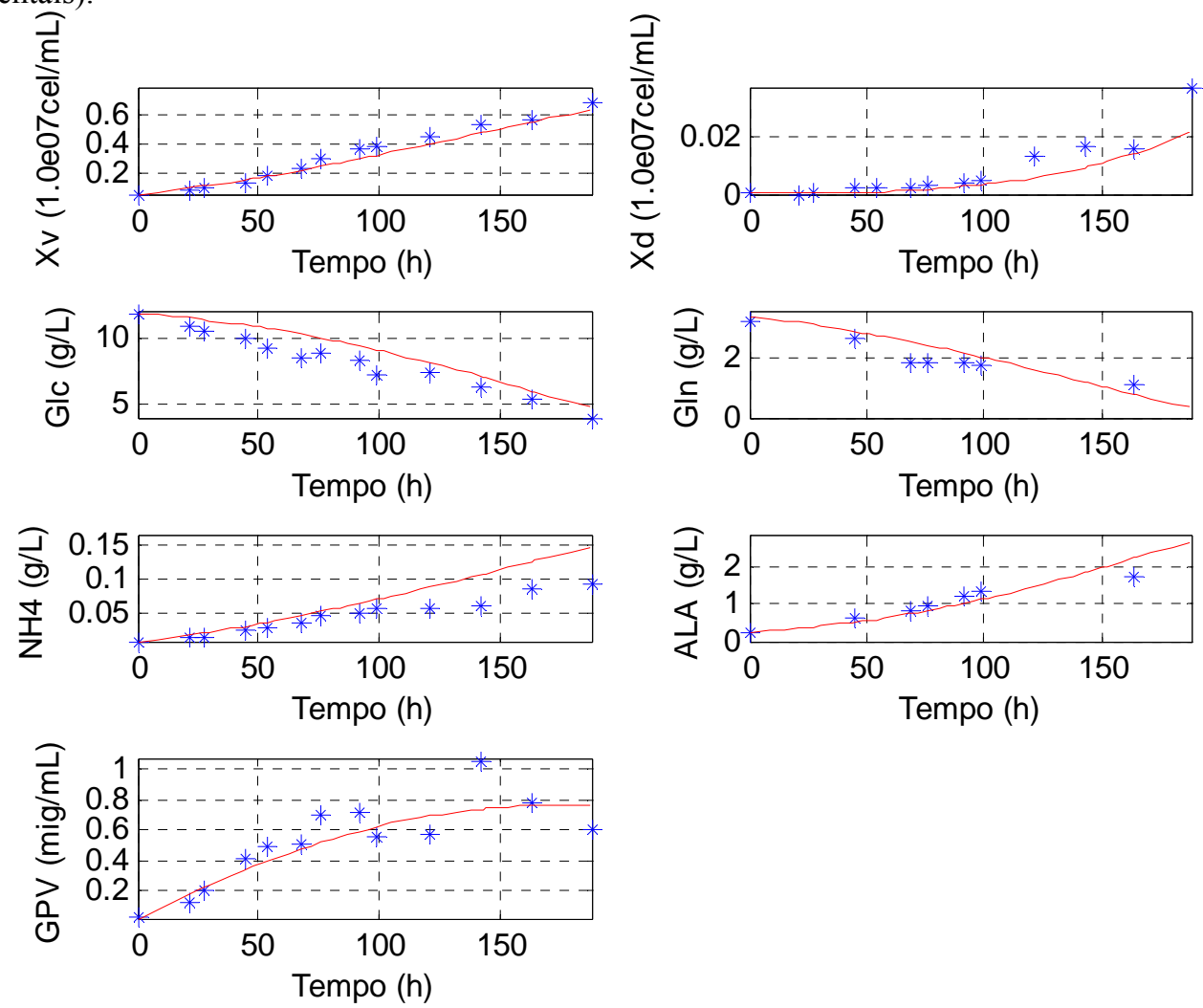

Figura 5.98 Comparação entre dados experimentais e as previsões do modelo 6a para o ensaio Ma-08, célula S2AcGPV2, $\mathrm{pO}_{2}=50 \%$ (Quadro A.1, Anexo A) (linha contínua, previsões do modelo; símbolos, dados experimentais). 
वे
है
0
0
0
0
0
d
$\vec{x}$
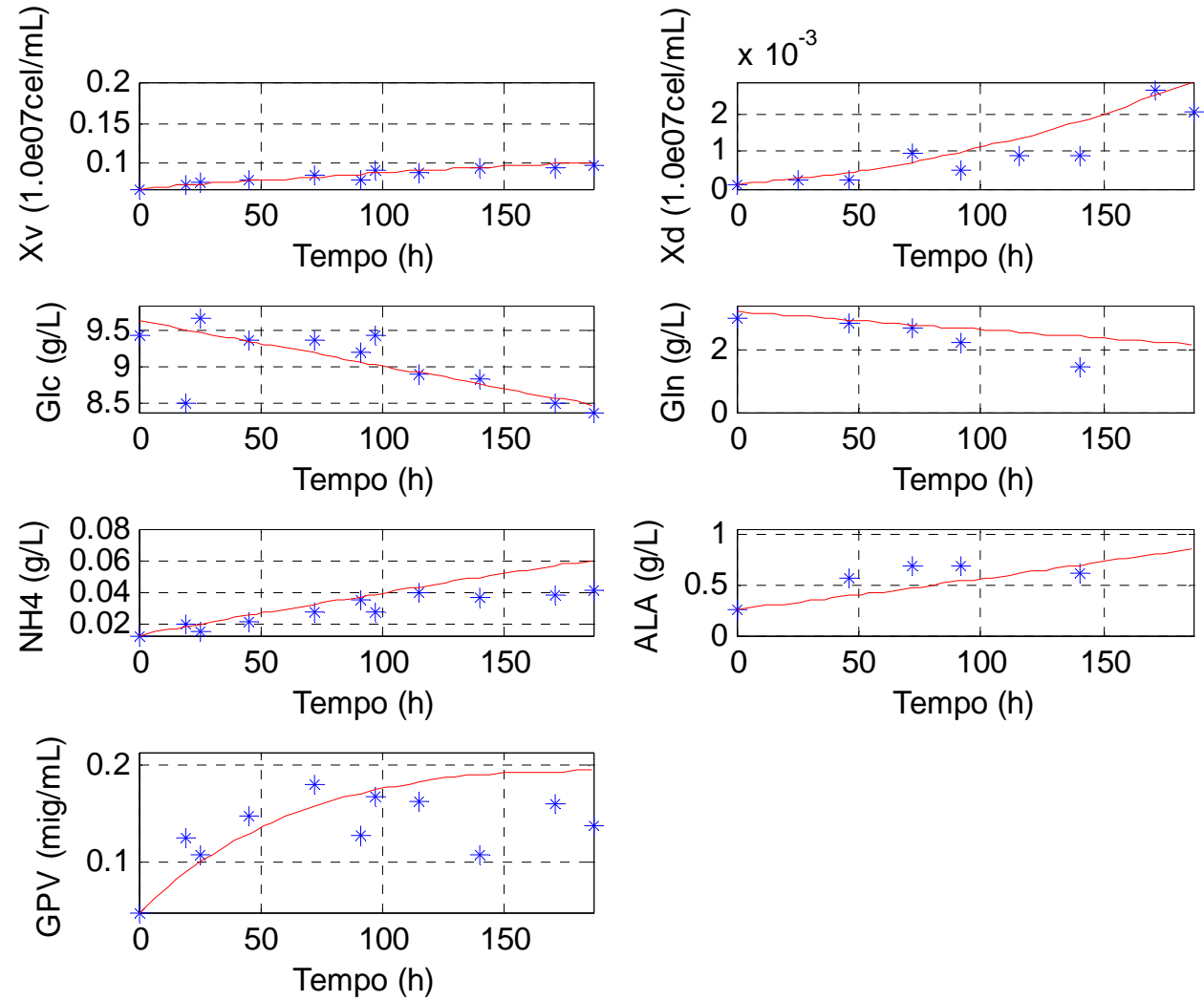

Figura 5.99. Comparação entre dados experimentais e as previsões do modelo 6a para o ensaio Ma-09 célula S2AcGPV2, $\mathrm{pO}_{2}=80 \%$ (Quadro A.1, Anexo A). (linha contínua, previsões do modelo; símbolos, dados experimentais).
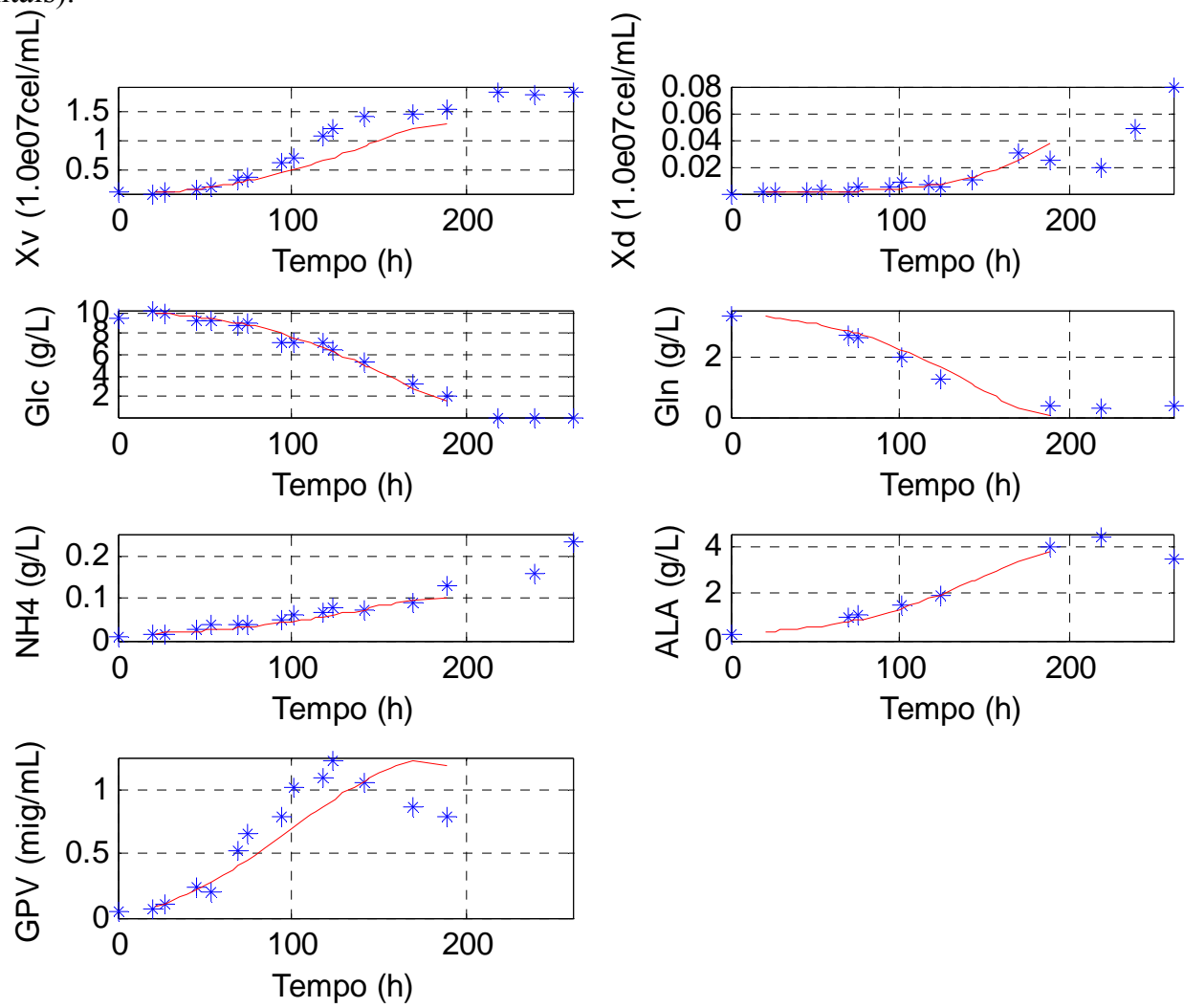

Figura 5.100. Comparação entre dados experimentais e as previsões do modelo 6a para o ensaio Ma-10 célula S2AcGPV2, pO2 = 30\% (Quadro A.1, Anexo A). (linha contínua, previsões do modelo; símbolos, dados experimentais). 

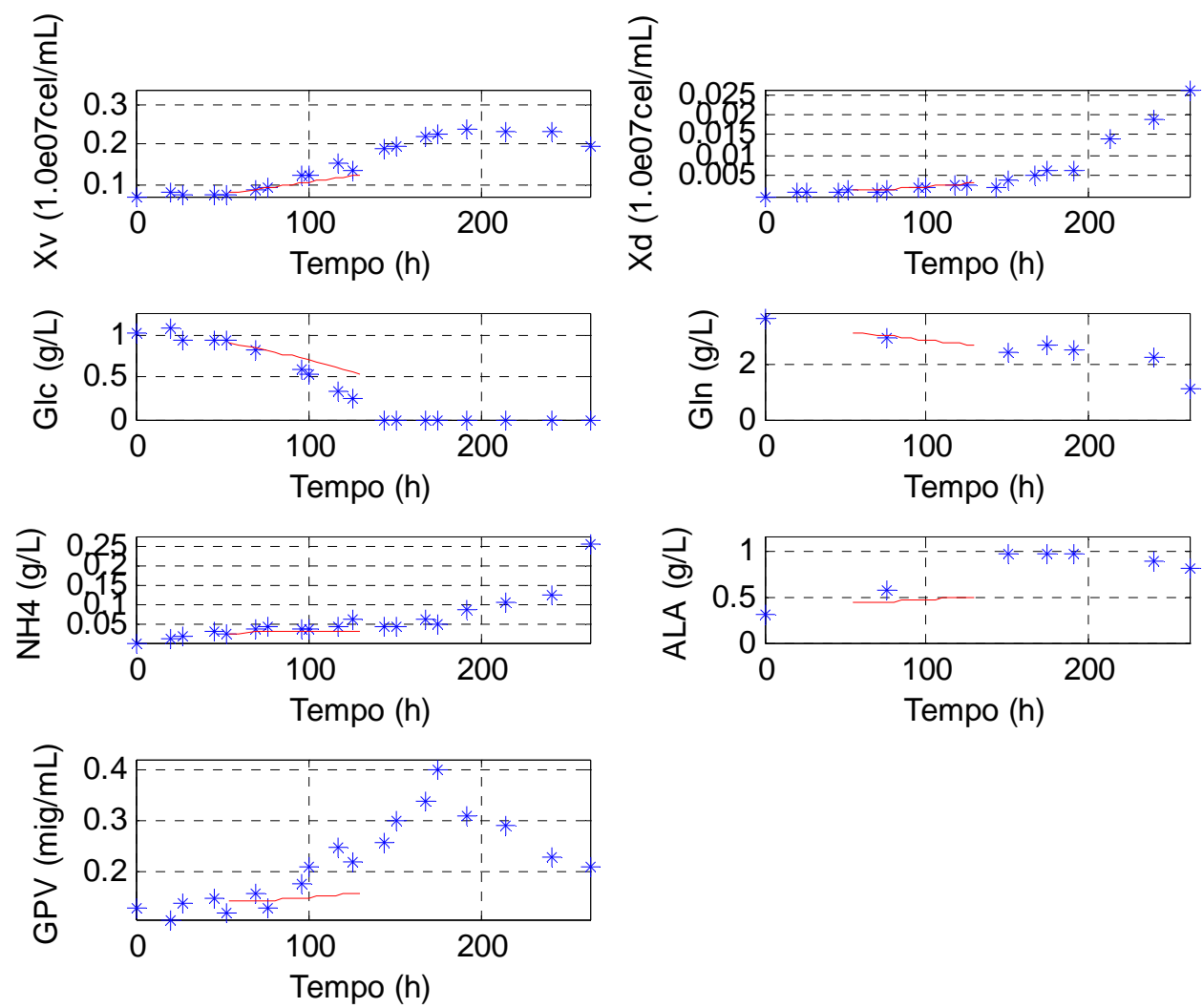

Figura 5.101. Comparação entre dados experimentais e as previsões do modelo 6a para o ensaio Ma-11 célula S2AcGPV2, GLC $_{0}=1,0 \mathrm{~g} / \mathrm{L}$ (Quadro A.1, Anexo A). (linha contínua, previsões do modelo; símbolos, dados experimentais).
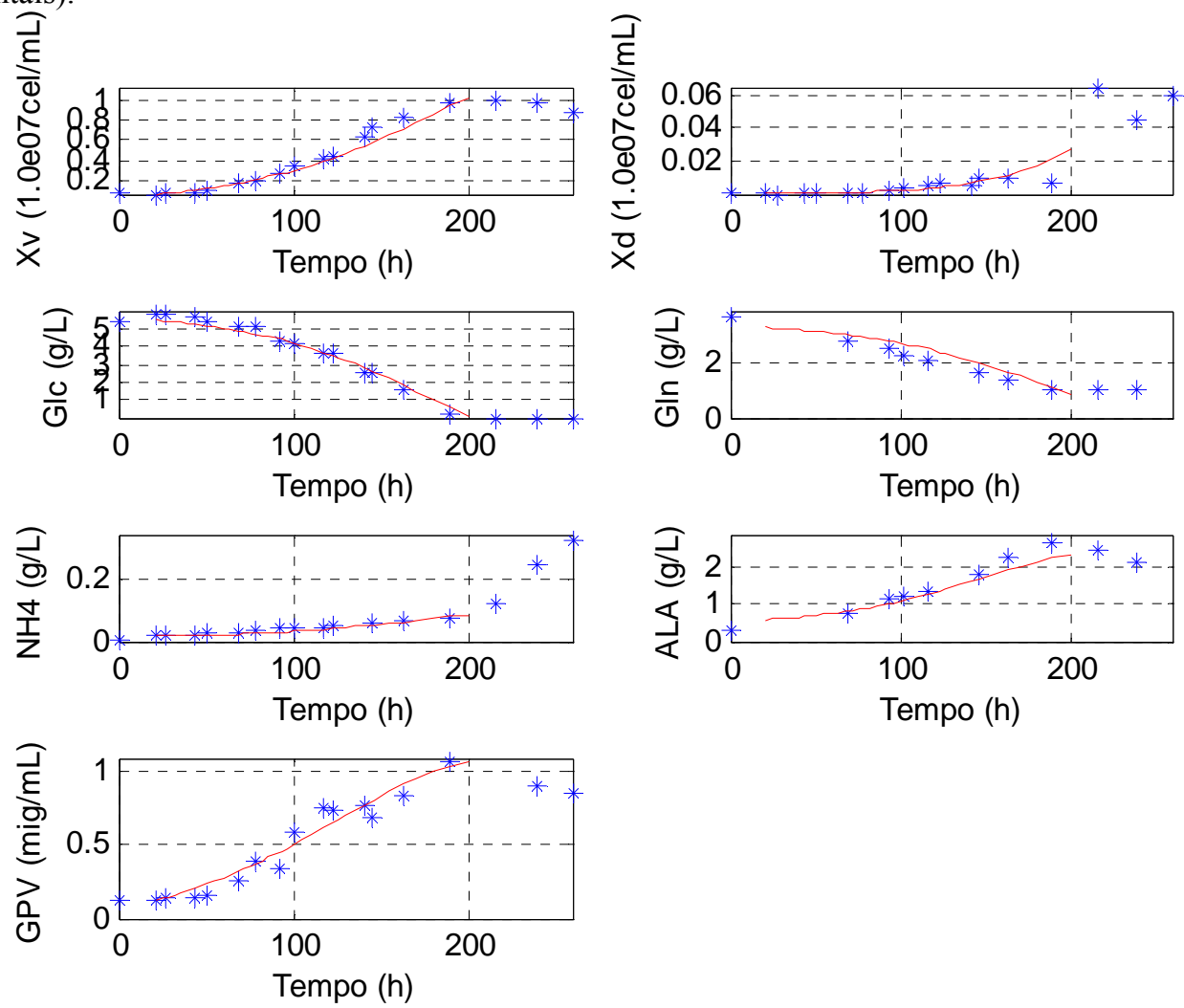

Figura 5.102. Comparação entre dados experimentais e as previsões do modelo 6a para o ensaio Ma-12, célula S2AcGPV2, GLC $_{0}=5,0 \mathrm{~g} / \mathrm{L}$. (Quadro A.1, Anexo A). (linha contínua, previsões do modelo; símbolos, dados experimentais). 

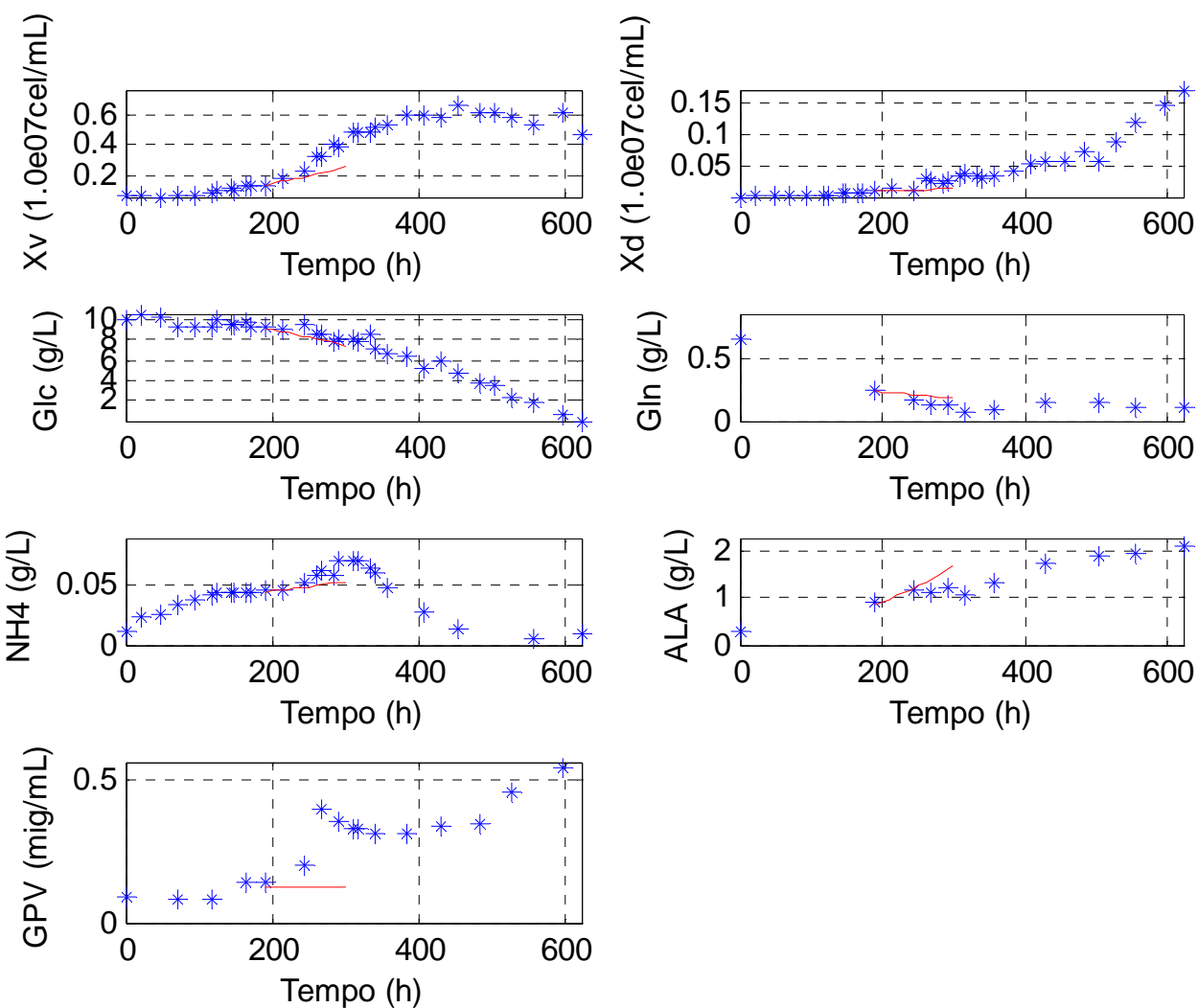

Figura 5.103. Comparação entre dados experimentais e as previsões do modelo 6a para o ensaio Ma-15 célula S2AcGPV2, GLN ${ }_{0}=0,6 \mathrm{~g} / \mathrm{L}$ (Quadro A.1, Anexo A). (linha contínua, previsões do modelo; símbolos, dados experimentais).
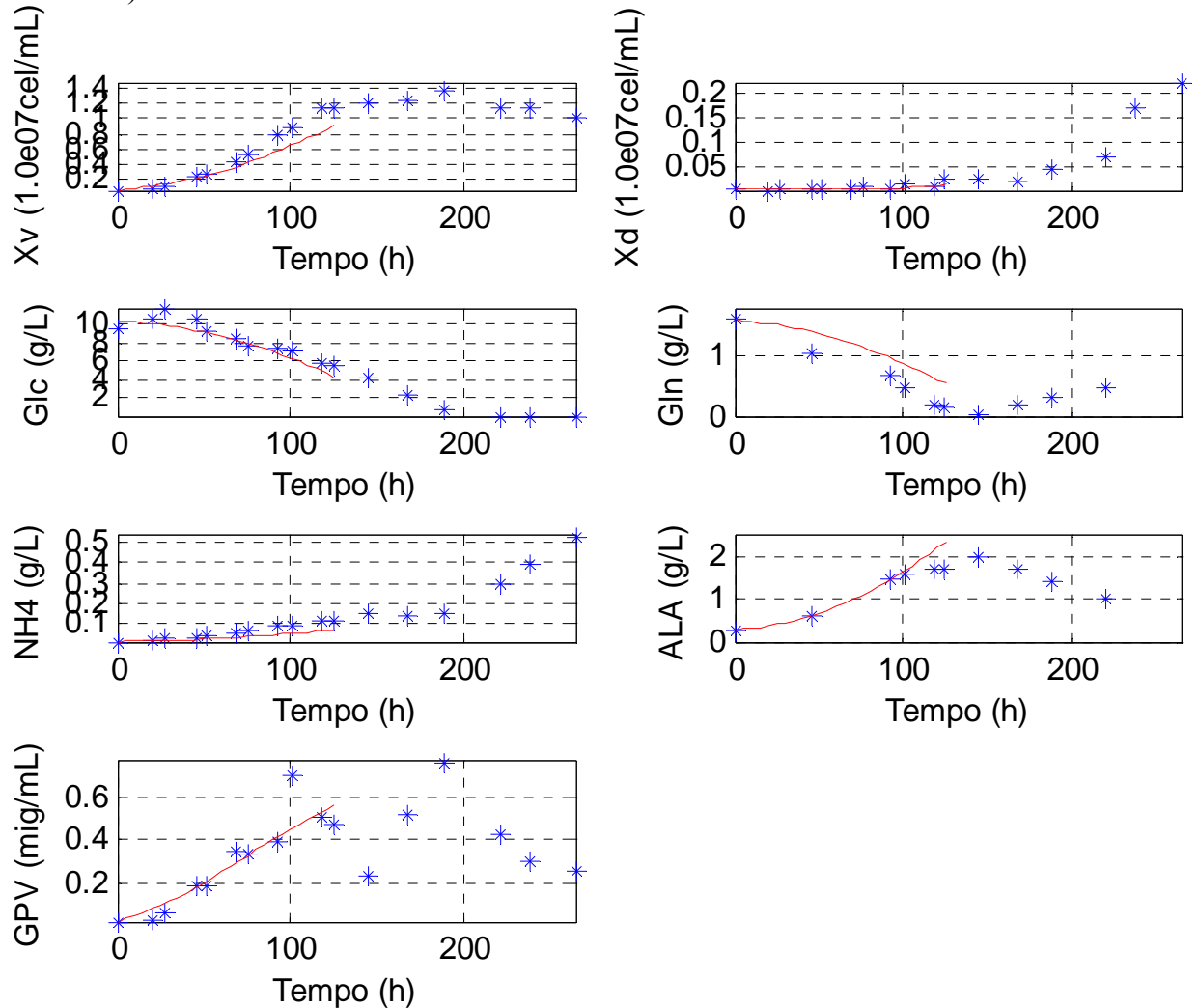

Figura 5.104. Comparação entre dados experimentais e as previsões do modelo 6a para o ensaio Ma-16, célula $\mathrm{S} 2 \mathrm{AcGPV} 2, \mathrm{GLN}_{0}=1,75 \mathrm{~g} / \mathrm{L}$ (Quadro A.1, Anexo A). (linha contínua, previsões do modelo; símbolos, dados experimentais). 
Tabela 5.7. Valores dos parâmetros para o modelo 6. Ensaios considerados Ma-07 a Ma-12, Ma-15 e Ma-16. (5 \% < $\left.\mathrm{pO}_{2}<80 \% ; 1,1 \mathrm{~g} / \mathrm{L}<\mathrm{GLC}_{0}<10,0 \mathrm{~g} / \mathrm{L} ; 0,6 \mathrm{~g} / \mathrm{L}<\mathrm{GLN}_{0}<3,5 \mathrm{~g} / \mathrm{L}\right)$. Célula S2AcGPV2.

\begin{tabular}{|c|c|c|c|c|}
\hline Parâmetro & & Modelo 6a & Modelo 6b & Modelo 6c $(* *)$ \\
\hline$\mu_{\mathrm{Xmax}}(1 / \mathrm{h})$ & PAR(1) & $4,00 \mathrm{E}-02^{(*)}$ & $4,00 \mathrm{E}-02(*)$ & $4,00 \mathrm{E}-02^{(*)}$ \\
\hline $\mathrm{k}_{\mathrm{GLC}}(\mathrm{g} / \mathrm{L})$ & $\operatorname{PAR}(2)$ & $3,02 \mathrm{E}-01$ & $0,596 \mathrm{E}+00$ & $0,624 \mathrm{E}+00$ \\
\hline $\mathrm{k}_{\mathrm{GLN}}(\mathrm{g} / \mathrm{L})$ & $\operatorname{PAR}(3)$ & $6,87 \mathrm{E}-02$ & $0,101 \mathrm{E}+00$ & $0,260 \mathrm{E}-01$ \\
\hline $\mathrm{ki}_{\mathrm{NH} 4}(\mathrm{~g} / \mathrm{L})$ & $\operatorname{PAR}(4)$ & $0,435 \mathrm{E}-01$ & $0,435 \mathrm{E}-01$ & $0,444 \mathrm{E}-01$ \\
\hline $\mathrm{k}_{\mathrm{m}}(1 / \mathrm{h})$ & $\operatorname{PAR}(5)$ & $0,221 \mathrm{E}-02$ & $0,221 \mathrm{E}-02$ & $0,247 \mathrm{E}-02$ \\
\hline $\mathrm{k}_{\mathrm{mGLC}}(\mathrm{g} / \mathrm{L})$ & $\operatorname{PAR}(6)$ & $1,04 \mathrm{E}+00$ & $0,164 \mathrm{E}+02$ & $0,199 \mathrm{E}+02$ \\
\hline $\mathrm{k}_{\mathrm{mNH} 4}(\mathrm{~g} / \mathrm{L})$ & $\operatorname{PAR}(7)$ & $0,233 \mathrm{E}+00$ & $0,265 \mathrm{E}+00$ & $0,383 \mathrm{E}+00$ \\
\hline$\alpha_{\mathrm{NH} 4}\left(\mathrm{Y}_{\mathrm{NH} 4 \mathrm{X}}\right)$ & $\operatorname{PAR}(8)$ & $0,546 \mathrm{E}-01$ & $0,546 \mathrm{E}-01$ & $0,697 \mathrm{E}-01$ \\
\hline$\alpha_{\mathrm{ALA}}\left(\mathrm{Y}_{\mathrm{ALAX}}\right)$ & $\operatorname{PAR}(9)$ & $0,714 \mathrm{E}-03$ & $0,965 \mathrm{E}-03$ & $0,604 \mathrm{E}-03$ \\
\hline$\beta_{\mathrm{ALA}}$ & PAR(10) & 0,749E-04 & $0,253 \mathrm{E}-04$ & $0,318 \mathrm{E}-04$ \\
\hline $\mathrm{k}_{\mathrm{ALA}}$ & $\operatorname{PAR}(11)$ & $0,978 \mathrm{E}+01$ & $0,100 \mathrm{E}-01$ & $0,100 \mathrm{E}-04$ \\
\hline$\alpha_{\mathrm{GPV}}\left(\mathrm{Y}_{\mathrm{GPVX}}\right)$ & $\operatorname{PAR}(12)$ & $0,230 \mathrm{E}+01$ & $0,230 \mathrm{E}+01$ & $0,231 \mathrm{E}+01$ \\
\hline $\mathrm{k}_{\mathrm{dGPVNH} 4}$ & $\operatorname{PAR}(13)$ & $0,488 \mathrm{E}-01$ & $0,488 \mathrm{E}-01$ & $0,351 \mathrm{E}-01$ \\
\hline $\mathrm{Y}_{\mathrm{XGLC}}$ & $\operatorname{PAR}(14)$ & $6,00 \mathrm{E}+02$ & $0,186 \mathrm{E}+03$ & $0,188 \mathrm{E}+03$ \\
\hline $\mathrm{Y}_{\mathrm{ALAGLC}}$ & $\operatorname{PAR}(15)$ & $0,719 \mathrm{E}+00$ & $0,649 \mathrm{E}+03$ & $0,667 \mathrm{E}+03$ \\
\hline $\mathrm{m}_{\mathrm{S}}$ & PAR(16) & $0,163 \mathrm{E}-04$ & $0,821 \mathrm{E}-07$ & $0,821 E-07^{(*)}$ \\
\hline $\mathrm{Y}_{\mathrm{XGLN}}$ & $\operatorname{PAR}(17)$ & $2,43 \mathrm{E}+01$ & $0,280 \mathrm{E}+04$ & $0,299 \mathrm{E}+04$ \\
\hline $\mathrm{Y}_{\mathrm{NH} 4 \mathrm{GLN}}$ & $\operatorname{PAR}(18)$ & $3,37 \mathrm{E}+03$ & $3,37 \mathrm{E}+03$ & $0,307 \mathrm{E}+03$ \\
\hline $\mathrm{k}_{\mathrm{dGPV}}$ & PAR(19) & $0,652 \mathrm{E}-02$ & $0,786 \mathrm{E}-02$ & $0,519 \mathrm{E}-02$ \\
\hline $\mathrm{k}_{\mathrm{sinGLN}}$ & $\operatorname{PAR}(20)$ & - & $0,587 \mathrm{E}-05$ & $0,167 \mathrm{E}-02^{(*)}$ \\
\hline$Y_{\text {GLNGLU }}$ & $\operatorname{PAR}(21)$ & - & $1,01^{(*)}$ & $1,01 E+00^{(*)}$ \\
\hline $\mathrm{Y}_{\mathrm{NH} 4 \mathrm{GLU}}$ & $\operatorname{PAR}(22)$ & - & $0,124^{(*)}$ & $1,24 \mathrm{E}-01^{(*)}$ \\
\hline $\mathrm{k}_{\mathrm{dALA}}$ & $\operatorname{PAR}(23)$ & - & 0,68897E-02 & $0,760 \mathrm{E}-02$ \\
\hline $\mathrm{Y}_{\mathrm{NH} 4 \mathrm{ALA}}$ & PAR(24) & - & $\mathbf{0 , 2 0 3}{ }^{(*)}$ & $2,03 \mathrm{E}-01^{(*)}$ \\
\hline SSR & - & $0,145 \mathrm{E}+03$ & $0,267 \mathrm{E}+03$ & $0,240 \mathrm{E}+03$ \\
\hline Inclinação(C.A.) & - & $0,997 \mathrm{E}+00$ & $0,102 \mathrm{E}+01$ & $0,104 \mathrm{E}+01$ \\
\hline $\mathrm{R}^{2}$ & - & $0,899 \mathrm{E}+00$ & $0,879 \mathrm{E}+00$ & $0,855 \mathrm{E}+00$ \\
\hline
\end{tabular}

(*) parâmetros mantidos constantes; (**) Ensaio Ma-15 não foi considerado.

Para realizar o ajuste do modelo 6a, Bloco 1, foram considerados os dados dos ensaios mencionados excluindo-se, em cada ensaio, os dados referentes a tempos de cultivo da fase lag e os tempos nos quais as concentrações de GLC ou GLN eram inferiores a 0,1 g/L. Em alguns casos isso acarretou em um conjunto de pontos pouco representativo do ensaio (Ensaio Ma-11 e Ma-15). Por outro lado, esse conjunto permitiu um primeiro ajuste de parâmetros, uma primeira avaliação da qualidade do modelo proposto avaliado as suas previsões da dinâmica do processo. 
Uma das características destacadas no processo do ajuste não-linear de parâmetros é a sua dependência dos valores iniciais adotados no ajuste (HIMMELBLAU, 1970). Para evitar a obtenção de mínimos locais no ajuste, tomou-se o cuidado de alterar os valores iniciais e, principalmente, adotou-se o procedimento de adotar como estimativa inicial os valores estimados na tentativa anterior. A primeira estimativa inicial foi fundamentada na análise preliminar dos fenômenos e na estimativa preliminar dos parâmetros realizada nessa etapa.

O ajuste realizado é um ajuste com restrições, pois para cada parâmetro foi estipulado um intervalo (valor mínimo e valor máximo) (Tabela 5.6). Esse intervalo também foi definido a partir da avaliação preliminar dos parâmetros sendo adotado o seguinte critério: o extremo superior foi calculado como sendo igual ao dobro do valor experimental máximo encontrado; o limite inferior como sendo a metade o valor experimental máximo calculado. Os valores calculados a partir dos dados experimentais estão indicados nas Figuras 5.41 a 5.70. Para alguns parâmetros, especialmente as constantes de saturação, havia uma estimativa inicial da análise preliminar de fenômenos que indicava valores a serem adotados. Em outros casos, para os quais não havia uma avaliação preliminar, adotaram-se, por segurança, intervalos amplos para a busca dos parâmetros. A Tabela 5.8 indica o intervalo de busca adotado para os parâmetros no ajuste do modelo $6 \mathrm{a}$.

A velocidade específica de crescimento, $\mu_{\text {Xmax }}$, foi mantida constante em $0,04 \mathrm{~h}^{-1}$, em decorrência de observações feitas durante o ajuste. Verificou-se que o parâmetro sempre alcançava o valor máximo do intervalo definido $\left(0,01\right.$ a $\left.0,05 \mathrm{~h}^{-1}\right)$. Como é bastante conhecida a interação de parâmetros no ajuste não-linear (HIMMELBLAU, 1970), também se verificou que os outros parâmetros do modelo eram muito sensíveis a esse parâmetro. Em função dessa interação, decidiu-se fixar o parâmetro no valor experimental máximo observado com essa célula (SWIECH, 2007; BATISTA, 2007) .

A partir de uma avaliação visual é possível afirmar que as previsões do modelo ajustam-se aos dados experimentais e podem ser feitas duas importantes ressalvas: o intervalo utilizado e as previsões do modelo são muito pouco representativos da dinâmica dos ensaios Ma-11 e Ma15 e, evidentemente, trata-se de ajuste parcial da dinâmica do processo (Figuras 101 a 5.103). 
Tabela 5.8. Intervalo adotado para ajuste dos parâmetros para o modelo 6a.

\begin{tabular}{clccc}
\hline Parâmetros & $\begin{array}{c}\text { Denominação } \\
\text { no programa }\end{array}$ & Valor min & Valor max & Unidades \\
& & & & \\
\hline$\mu_{\mathrm{Xmax}}$ & $\operatorname{PAR}(1)$ & 0,04 & 0,04 & $\left(\mathrm{~h}^{-1}\right)$ \\
$\mathrm{k}_{\mathrm{GLC}}$ & $\operatorname{PAR}(2)$ & 0,01 & 2,5 & $(\mathrm{~g} / \mathrm{L})$ \\
$\mathrm{k}_{\mathrm{GLN}}$ & $\operatorname{PAR}(3)$ & 0,01 & 1,5 & $(\mathrm{~g} / \mathrm{L})$ \\
$\mathrm{k}_{\mathrm{iNH} 4}$ & $\operatorname{PAR}(4)$ & 0,001 & 0,3 & $(\mathrm{~g} / \mathrm{L})$ \\
$\mathrm{k}_{\mathrm{m}}$ & $\operatorname{PAR}(5)$ & $1,0 \mathrm{E}-06$ & 0,5 & $(1 / \mathrm{h})$ \\
$\mathrm{k}_{\mathrm{mGLC}}$ & $\operatorname{PAR}(6)$ & 0,0001 & 11,0 & $(\mathrm{~g} / \mathrm{L})$ \\
$\mathrm{k}_{\mathrm{mNH} 4}$ & $\operatorname{PAR}(7)$ & $1 \mathrm{E}-02$ & 0,3 & $(\mathrm{~g} / \mathrm{L})$ \\
$\alpha_{\mathrm{NH} 4}\left(\mathrm{Y}_{\mathrm{NH} 4 \mathrm{X}}\right)$ & $\operatorname{PAR}(8)$ & $1 \mathrm{E}-3$ & 2,0 & $(\mathrm{mg} / 1,0 \mathrm{E} 07 \mathrm{cel})$ \\
$\alpha_{\mathrm{ALA}}\left(\mathrm{Y}_{\mathrm{ALAX}}\right)$ & $\operatorname{PAR}(9)$ & $1 \mathrm{E}-4$ & 0,06 & $(\mathrm{~g} / 1.0 \mathrm{E} 7 \mathrm{cel} . \mathrm{h})$ \\
$\beta_{\mathrm{ALA}}$ & $\operatorname{PAR}(10)$ & $1 \mathrm{E}-6$ & 0,7 & $(\mathrm{~g} / 1.0 \mathrm{E} 7 \mathrm{cel} . \mathrm{h})$ \\
$\mathrm{k}_{\mathrm{ALA}}$ & $\operatorname{PAR}(11)$ & 0,01 & 10,0 & $(\mathrm{~g} / \mathrm{L})$ \\
$\alpha_{\mathrm{GPV}}\left(\mathrm{Y}_{\mathrm{GPVX}}\right)$ & $\operatorname{PAR}(12)$ & 0,01 & 15 & $(\mu \mathrm{GPV} / 1,0 \mathrm{E} 7 \mathrm{cel})$ \\
$\mathrm{k}_{\mathrm{dGPVNH} 4}$ & $\operatorname{PAR}(13)$ & 0,01 & 0,3 & $(\mathrm{~g} / \mathrm{L})$ \\
$\mathrm{Y}_{\mathrm{XGLC}}$ & $\operatorname{PAR}(14)$ & 1 & 620,0 & $(1,0 \mathrm{E} 07 \mathrm{cel} / \mathrm{g})$ \\
$\mathrm{Y}_{\mathrm{ALAGLC}}$ & $\operatorname{PAR}(15)$ & 0,01 & 650,0 & $(\mathrm{~g} / \mathrm{g})$ \\
$\mathrm{ms}$ & $\operatorname{PAR}(16)$ & $1 \mathrm{E}-8$ & 0,1 & $(\mathrm{~g} / 1,0 \mathrm{E} 07 \mathrm{cel}, \mathrm{h})$ \\
$\mathrm{Y}_{\mathrm{XGLN}}$ & $\operatorname{PAR}(17)$ & 10,0 & $4,5 \mathrm{E}+03$ & $1,0 \mathrm{E} 07 \mathrm{cel} / \mathrm{g}$ \\
$\mathrm{Y}_{\mathrm{NH} 4 \mathrm{GLN}}$ & $\operatorname{PAR}(18)$ & $1 \mathrm{E}-3$ & 650,0 & $(\mathrm{mg} / \mathrm{g})$ \\
$\mathrm{k}_{\mathrm{dGPV}}$ & $\operatorname{PAR}(19)$ & $1 \mathrm{E}-6$ & 1,0 & $(1 / \mathrm{h})$ \\
\hline & & & &
\end{tabular}

Foi feita a análise estatística dos resultados obtidos, o que exigiu a avaliação do erro experimental dos ensaios. Para a estimativa do erro experimental foram realizados 15 ensaios em condições padrão [ensaios C07, C08, C09, C10, C12, C14, C15, C16, C17, resultados estão indicados no trabalho de Aguiar (2010)]. Esses ensaios permitiram estimar a variância do erro experimental das variáveis Xv e Xd como indica a Tabela 5.9. 
Tabela 5.9 Estimativa das variâncias experimentais

\begin{tabular}{lcccc}
\hline Variável de estado & Np & $\begin{array}{l}\text { Somatória } \\
\text { dos resíduos }\end{array}$ & Médias & SSE $_{\mathbf{Y}}$ \\
\hline Xv & 110 & 2,131 & 16 & 0,0277 \\
Xd & 112 & 14,983 & 15 & 0,1561 \\
\hline
\end{tabular}

Para as demais variáveis cujo erro não foi estimado neste trabalho (GLC, GLN, $\mathrm{NH}_{4}^{+}, \mathrm{LAC}_{\text {, }}$ GPV, ALA, GLU) foram utilizadas as variâncias estimadas por Suárez (2002) ou consideradas análogas às variáveis estimadas nesse trabalho como foi o caso do erro experimental de ALA, que foi considerada igual ao de glutamina $(0,0388)$, e GPV que foi considerada como igual à variância de Xd $(0,0388)$, a pior variância experimental observada, e estão indicadas na Tabela 5.10.

Tabela 5.10 Estimativa das variâncias experimentais

\begin{tabular}{lcc}
\hline Variável de estado & SSE $_{\mathbf{Y}}$ & Referência \\
& & \\
\hline GLC & $\mathbf{0 , 0 1 8 1}$ & Suárez (2002) \\
GLN & $\mathbf{0 , 0 3 8 8}$ & Suárez (2002) \\
NH4 & $\mathbf{0 , 0 3 0 1}$ & Suárez (2002) \\
ALA & $\mathbf{0 , 0 3 8 8}$ & - \\
GLU & $\mathbf{0 , 0 3 8 8}$ & Suárez (2002) \\
GPV & $\mathbf{0 , 1 5 6 1}$ & - \\
GLOBAL & $\mathbf{0 , 0 6 2 0}$ & \\
\hline
\end{tabular}

A análise exige o cálculo da variância proveniente da falta de adequação do modelo aos dados experimentais, também denominada falta de ajuste (lack off it), $\mathrm{SS}_{\mathrm{LOF}}$, conforme indicado no item 4.6.2. Os resultados encontrados estão indicados na Tabela 5.11. 
Tabela 5.11. Valores de F para o modelo 6a.

\begin{tabular}{lc}
\hline Parâmetro & Valor \\
\hline SS $_{\text {LOF }}$ & $\mathbf{0 , 0 3 1}$ \\
SS $_{\text {PE,Global }}$ & $\mathbf{0 , 0 6 2}$ \\
Fcal & $\mathbf{0 , 9 4 7}$ \\
F(1- $\boldsymbol{\alpha} ; \mathbf{N}-\mathbf{p} ; \mathbf{N}-\mathbf{n m})$ & $\mathbf{0 , 9 5 5}$ \\
\hline Graus de liberdade ,df1 & 1567 \\
Graus de liberdade df2 & 2072 \\
$1-\alpha$ & 0,95 \\
\hline
\end{tabular}

A análise indica que o modelo é validado $(\mathrm{Fcal}<\mathrm{F})$ no intervalo de dados utilizados, contudo como o modelo é um modelo parcial e não representa a dinâmica do processo em suas fases finais, buscou-se ampliar o ajuste a um intervalo de dados maior.

\subsubsection{Modelo 6b. Ajuste do modelo em todas as fases do processo (Bloco 1, Bloco 2, Bloco} 3 e Bloco 4).

Para o ajuste do modelo $6 \mathrm{~b}$ adotaram-se todos os dados dos ensaios Ma-07, Ma-08, Ma-09, Ma-10, Ma-11, Ma-12, Ma-15 e Ma-16 o que implicou utilizar os blocos de programação que representam todas as fases do cultivo (Tabela 5.6). Deve-se, contudo, observar que o ensaio Ma-15 apresentou uma característica particular, pois indicou um consumo $\mathrm{NH}^{+}$na fase estacionária do cultivo. Como essa característica não era prevista pelo modelo nesta etapa do ajuste, foram utilizados dados até 400 horas do cultivo. Os resultados do ajuste estão indicados nas Figuras 5.105 a 5.112 e na Tabela 5.7. 

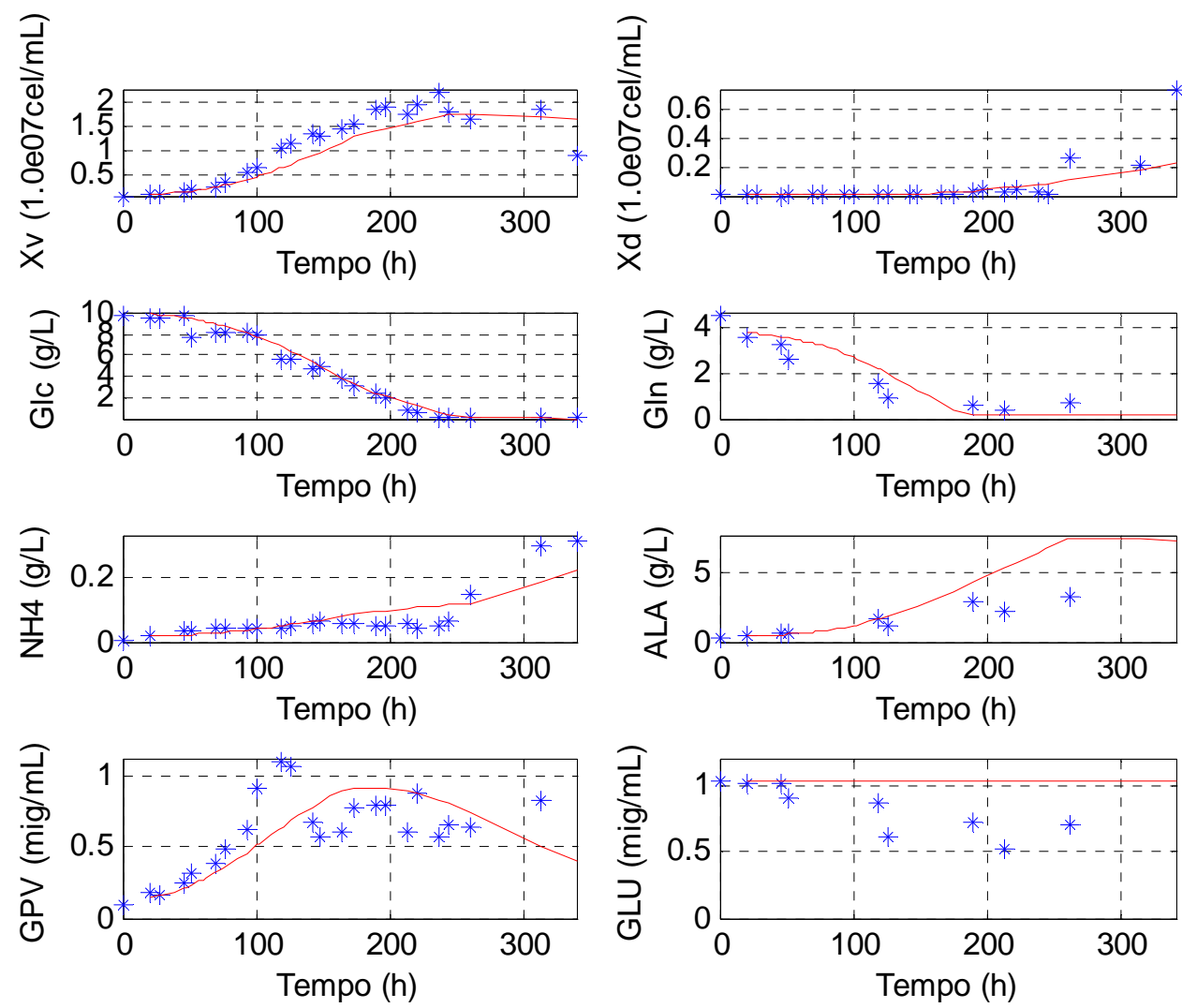

Figura 5.105. Comparação entre dados experimentais e as previsões do modelo $6 \mathrm{~b}$ para o ensaio Ma-07, célula $\mathrm{S} 2 \mathrm{AcGPV} 2, \mathrm{pO}_{2}=5 \%$ (Quadro A.1, Anexo A). (linha contínua, previsões do modelo; símbolos, dados experimentais).
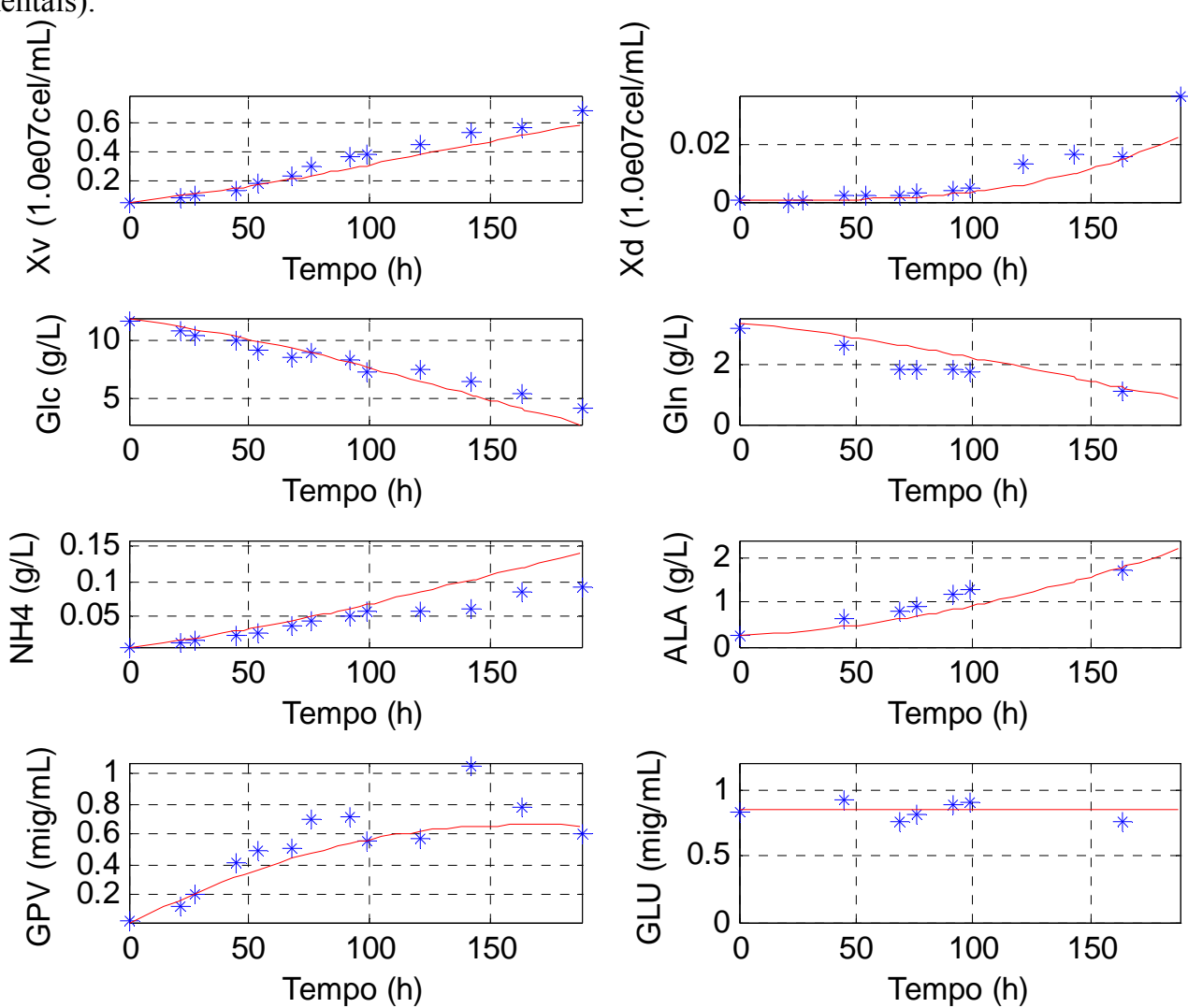

Figura 5.106. Comparação entre dados experimentais e as previsões do modelo $6 \mathrm{~b}$ para o ensaio Ma- 08 , célula $\mathrm{S} 2 \mathrm{AcGPV} 2, \mathrm{pO}_{2}=50 \%$ (Quadro A.1, Anexo A). (linha contínua, previsões do modelo; símbolos, dados experimentais). 


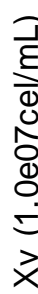
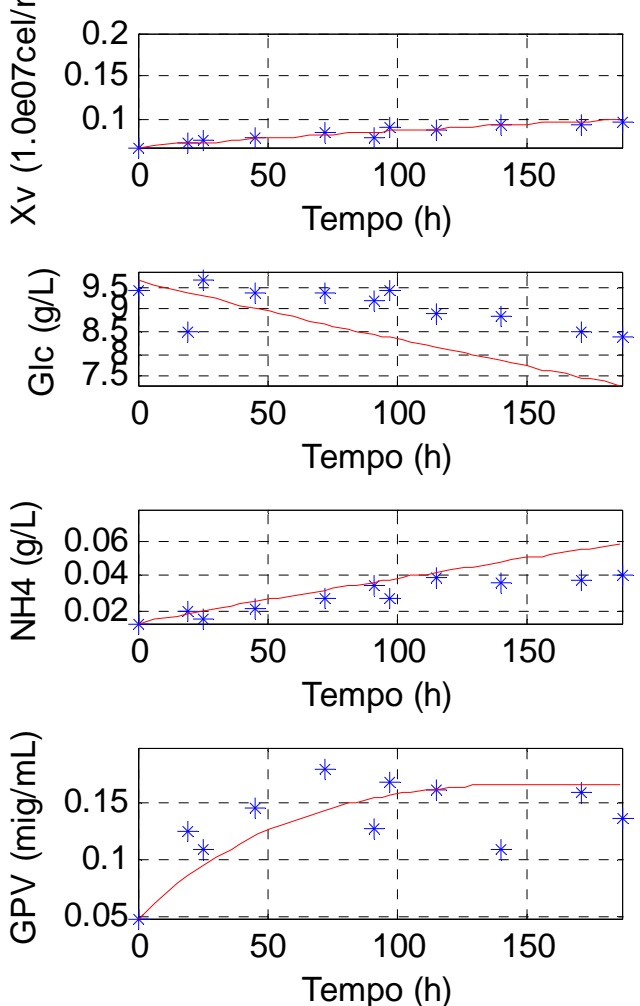
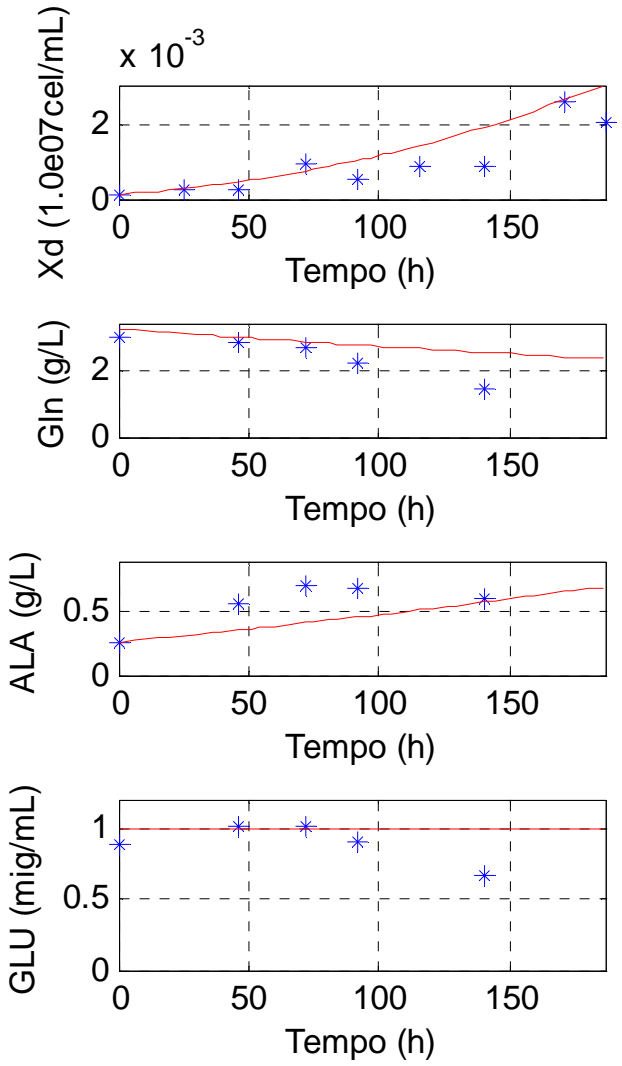

Figura 5.107. Comparação entre dados experimentais e as previsões do modelo $6 \mathrm{~b}$ para o ensaio Ma-09 célula S2AcGPV2, $\mathrm{pO}_{2}=80 \%$ (Quadro A.1, Anexo A). (linha contínua, previsões do modelo; símbolos, dados experimentais).
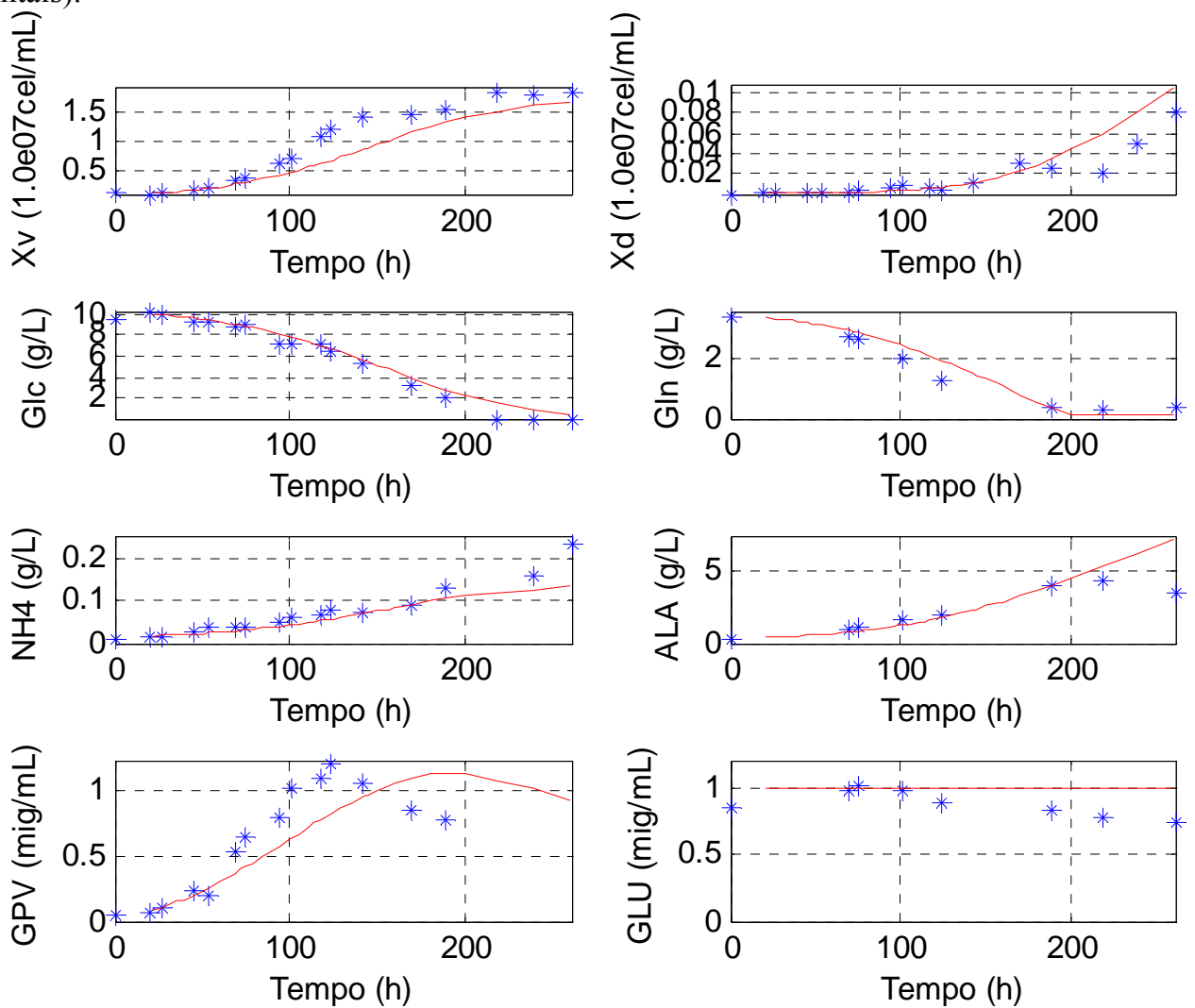

Figura 5.108. Comparação entre dados experimentais e as previsões do modelo $6 \mathrm{~b}$ para o ensaio Ma-10 célula S2AcGPV2, pO2 = 30\% (Quadro A.1, Anexo A). (linha contínua, previsões do modelo; símbolos, dados experimentais). 

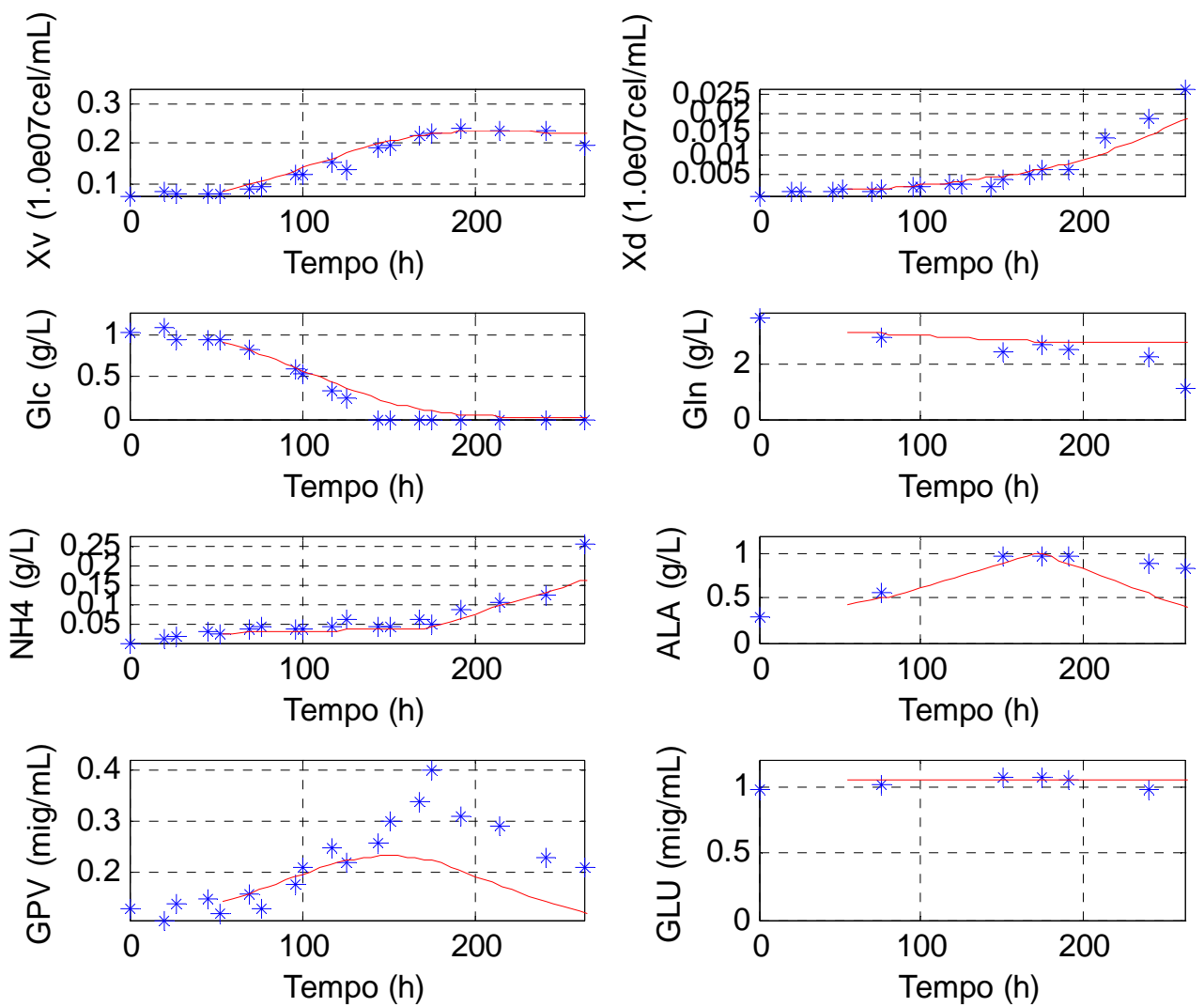

Figura 5.109. Comparação entre dados experimentais e as previsões do modelo 6 para o ensaio Ma-11 célula S2AcGPV2, GLC $_{0}=1,0 \mathrm{~g} / \mathrm{L}$ (Quadro A.1, Anexo A). (linha contínua, previsões do modelo; símbolos, dados experimentais).
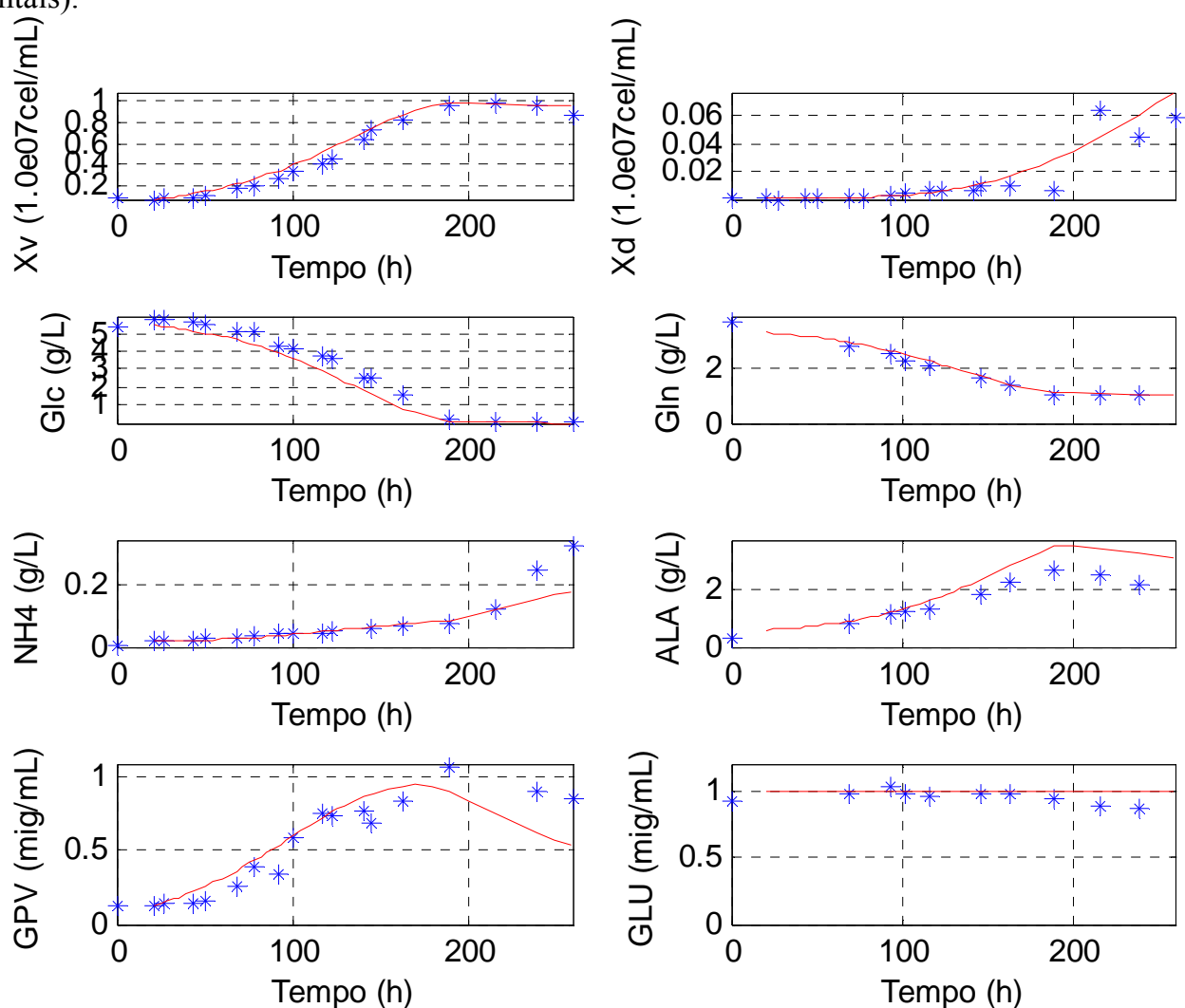

Figura 5.110. Comparação entre dados experimentais e as previsões do modelo 6 para o ensaio Ma-12, célula $\mathrm{S} 2 \mathrm{AcGPV} 2, \mathrm{GLC}_{0}=5,0 \mathrm{~g} / \mathrm{L}$ (Quadro A.1, Anexo A). (linha contínua, previsões do modelo; símbolos, dados experimentais). 

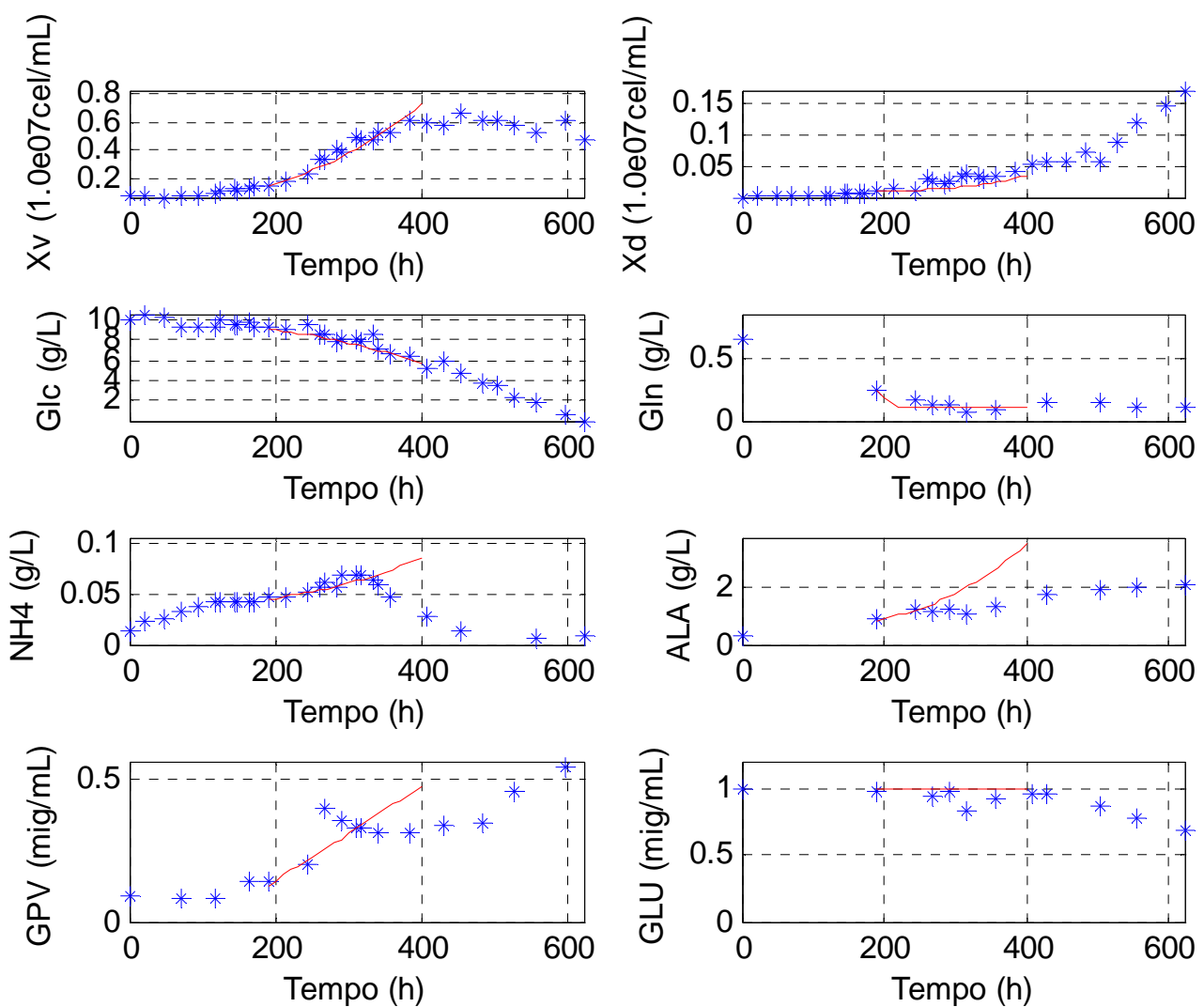

Figura 5.111. Comparação entre dados experimentais e as previsões do modelo $6 \mathrm{~b}$ para o ensaio Ma-15 célula $\mathrm{S} 2 \mathrm{AcGPV} 2, \mathrm{GLN}_{0}=0,6 \mathrm{~g} / \mathrm{L}$ (Quadro A.1, Anexo A). (linha contínua, previsões do modelo; símbolos, dados experimentais).
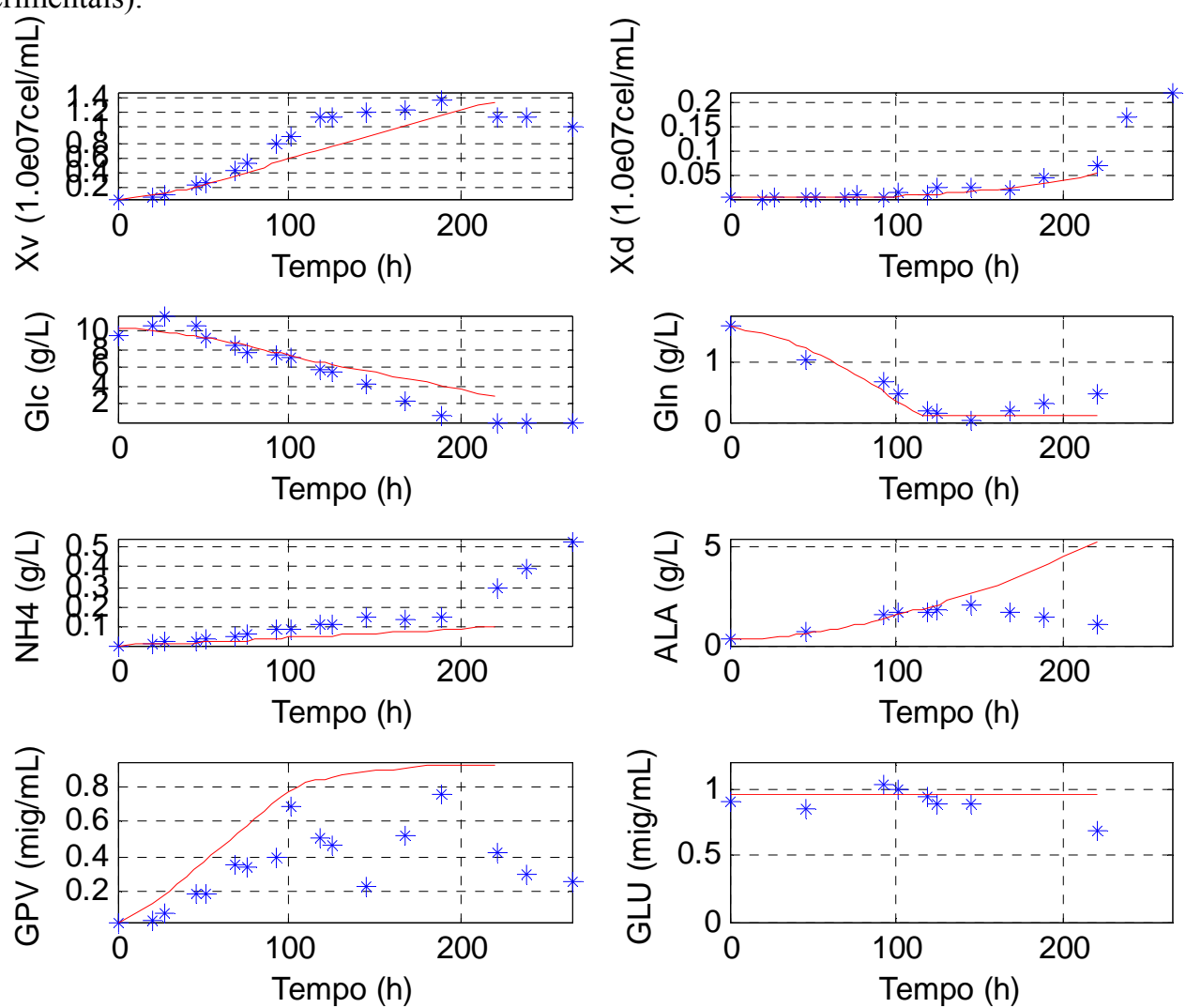

Figura 5.112. Comparação entre dados experimentais e as previsões do modelo $6 \mathrm{~b}$ para o ensaio Ma-16 célula S2AcGPV2, GLN G $_{0}$ 1,75 g/L (Quadro A.1, Anexo A). (linha contínua, previsões do modelo; símbolos, dados experimentais). 
No ajuste do modelo 6b, os parâmetros 21, 22 e 24 ( $\mathrm{Y}_{\mathrm{GLN} / \mathrm{GLU}}, \mathrm{Y}_{\mathrm{NH} 4 / \mathrm{GLU}}$ e $\left.\mathrm{Y}_{\mathrm{NH} 4 / \mathrm{ALA}}\right)$ foram calculados como indica a Tabela 5.12 e mantidos constantes. O intervalo de busca dos demais parâmetros utilizados está indicado na Tabela 5.13.

Tabela 5.12. Valores dos fatores de conversão utilizados no modelo $6 \mathrm{~b}$.

\begin{tabular}{lclclc}
\hline & $\begin{array}{c}\text { Massa Molar } \\
(\mathbf{g} / \mathbf{m o l})\end{array}$ & & $\begin{array}{c}\text { Massa Molar } \\
(\mathbf{g} / \mathbf{m o l})\end{array}$ & \multicolumn{1}{c}{$\begin{array}{c}\text { Fator de } \\
\text { conversão }(\mathbf{g} / \mathbf{g})\end{array}$} & Valor \\
\hline GLU & 145,09 & $\mathrm{GLN}$ & 146,13 & $\mathrm{Y}_{\mathrm{GLN} / \mathrm{GLU}}$ & 1,0071 \\
ALA & 89,09 & $\mathrm{NH}_{4}{ }^{+}$ & 18,04 & $\mathrm{Y}_{\mathrm{NH} 4+/ \mathrm{ALA}}$ & 0,2025 \\
GLU & 145,09 & $\mathrm{NH}_{4}{ }^{+}$ & 18,04 & $\mathrm{Y}_{\mathrm{NH} 4+\mathrm{GLU}}$ & 0,1243 \\
\hline
\end{tabular}

Tabela 5.13. Intervalo adotado para ajuste dos parâmetros para o modelo 6 b.

\begin{tabular}{|c|c|c|c|c|}
\hline Parâmetros & $\begin{array}{l}\text { Denominação } \\
\text { no programa }\end{array}$ & Valor mín & Valor max & Unidades \\
\hline$\mu_{\text {Xmax }}$ & $\operatorname{PAR}(1)$ & 0,040 & 0,040 & $(1 / h)$ \\
\hline $\mathrm{k}_{\mathrm{GLC}}$ & $\operatorname{PAR}(2)$ & 0,1 & 2,0 & $(g / L)$ \\
\hline $\mathrm{k}_{\mathrm{GLN}}$ & $\operatorname{PAR}(3)$ & 0,01 & 1,50 & $(g / L)$ \\
\hline $\mathrm{k}_{\mathrm{iNH} 4}$ & $\operatorname{PAR}(4)$ & 0,001 & 0,5 & $(\mathrm{~g} / \mathrm{L})$ \\
\hline $\mathrm{k}_{\mathrm{m}}$ & $\operatorname{PAR}(5)$ & $1,0 \mathrm{E}-06$ & 0,5 & $(1 / h)$ \\
\hline $\mathrm{k}_{\mathrm{mGLC}}$ & $\operatorname{PAR}(6)$ & 0,001 & 15 & $(\mathrm{~g} / \mathrm{L})$ \\
\hline $\mathrm{k}_{\mathrm{mNH} 4}$ & $\operatorname{PAR}(7)$ & $5,0 \mathrm{E}-06$ & 0,3 & $(\mathrm{~g} / \mathrm{L})$ \\
\hline$\alpha_{\mathrm{NH} 4}$ & $\operatorname{PAR}(8)$ & $1,0 \mathrm{E}-03$ & 2,0 & $(\mathrm{mg} / 1,0 \mathrm{E} 07 \mathrm{cel})$ \\
\hline$\alpha_{\mathrm{ALA}}$ & PAR(9) & $2,0 \mathrm{E}-04$ & $5,0 \mathrm{E}-02$ & (g/1.0E7cel.h) \\
\hline$\beta_{\mathrm{ALA}}$ & PAR(10) & $1,0 \mathrm{E}-06$ & $1,0 \mathrm{E}-03$ & (g/1.0E7cel.h) \\
\hline $\mathrm{k}_{\mathrm{ALA}}$ & $\operatorname{PAR}(11)$ & $1,0 \mathrm{E}-03$ & 50 & $(g / L)$ \\
\hline$\alpha_{\mathrm{GPV}}$ & $\operatorname{PAR}(12)$ & 0,01 & 15 & $(\mu \mathrm{GPV} / 1,0 \mathrm{E}+07 \mathrm{cel})$ \\
\hline $\mathrm{k}_{\mathrm{dGPV} / \mathrm{NH} 4}$ & $\operatorname{PAR}(13)$ & 0,01 & 0,3 & $(\mathrm{~g} / \mathrm{L})$ \\
\hline $\mathrm{Y}_{\mathrm{X} / \mathrm{GLC}}$ & PAR(14) & 20,0 & 200 & $(1,0 \mathrm{E} 07 \mathrm{cel} / \mathrm{g})$ \\
\hline $\mathrm{Y}_{\mathrm{ALA} / \mathrm{GLC}}$ & $\operatorname{PAR}(15)$ & 0,01 & 650 & $(g / g)$ \\
\hline $\mathrm{m}_{\mathrm{s}}$ & PAR(16) & $1,0 \mathrm{E}-8$ & 0,1 & (g/1,0E07cel. h) \\
\hline $\mathrm{Y}_{\mathrm{X} / \mathrm{GLN}}$ & $\operatorname{PAR}(17)$ & 150 & 4500 & $(1,0 \mathrm{E} 07 \mathrm{cel} / \mathrm{g})$ \\
\hline $\mathrm{Y}_{\mathrm{NH} / \mathrm{GLN}}$ & PAR(18) & 1,9E-04 & 350 & $(\mathrm{mg} / \mathrm{g})$ \\
\hline $\mathrm{k}_{\mathrm{dGPV}}$ & PAR(19) & $1,0 \mathrm{E}-04$ & 1,0 & $(1 / \mathrm{h})$ \\
\hline $\mathrm{k}_{\text {SinGLN }}$ & PAR(20) & 0,01 & 50 & $(1 / h)$ \\
\hline $\mathrm{k}_{\mathrm{dALA}}$ & PAR(23) & $1,0 \mathrm{E}-7$ & 10 & $1 / \mathrm{h}$ \\
\hline
\end{tabular}

As previsões do modelo acompanham, na maioria dos casos, a evolução dos dados experimentais com algumas ressalvas importantes. Em dois ensaios, Ma-10 (Figura 5.108) e Ma-16 (Figura 5.112), o modelo não reproduz a velocidade específica máxima de crescimento experimental, subestimando a valor determinado, provavelmente pela forte inibição por $\mathrm{NH}_{4}{ }^{+}$ prevista pelo modelo. No ensaio Ma-16, o modelo subestima o consumo de glicose na fase 
final do crescimento e, em decorrência, também não acompanha a evolução de $\mathrm{NH}_{4}{ }^{+}$e $\mathrm{ALA}$ e o consumo de GLU no mesmo ensaio. A produção de GPV é subestimada no ensaio Ma-11 (Figura 5.109) e superestimada no ensaio Ma-16, previsões que estão, aparentemente, relacionadas à alteração no teor de GPV na célula em função das condições de cultivo e que não estão incorporadas no modelo. A concentração de ALA prevista pelo modelo nos ensaios Ma-07 (Figura 5.105) e Ma-15 (Figura 5.111) é muito superior à observada, especialmente após esgotamento de glicose. Certamente esse comportamento deve-se ao alto valor de $\mathrm{Y}_{\mathrm{ALA} / \mathrm{GLC}}$ ajustado para esse conjunto de dados, 900x maior que o valor encontrado para o Bloco 1 (Modelo 6a, Tabela 5.7). Essa enorme variação sugere que o parâmetro é pouco sensível para o conjunto de dados utilizado. Além disso, os parâmetros $\mathrm{Y}_{\mathrm{X} / \mathrm{GLN}}$ e $\mathrm{k}_{\mathrm{ALA}}$ também sofreram uma variação drástica (115x e 0,001x, respectivamente, como indica a Tabela 5.7).

Foi feita a análise estatística e os resultados estão indicados na Tabela 5.14.

Tabela 5.14. Valores de F para o modelo 6b.

\begin{tabular}{lc}
\hline \multicolumn{1}{c}{ Parâmetro } & Valor \\
\hline $\mathrm{SS}_{\mathrm{LOF}}$ & 0,063 \\
$\mathrm{SS}_{\mathrm{PE}, \text { Global }}$ & 0,062 \\
Fcal & 1,01 \\
$\mathrm{~F}(1-\alpha ; \mathrm{N}-\mathrm{p} ; \mathrm{N}-\mathrm{nm})$ & 0,956 \\
$\mathrm{df} 1$ & 2146 \\
$\mathrm{df} 2$ & 2072 \\
$1-\alpha$ & 0,95 \\
\hline
\end{tabular}

A análise indica que o modelo não é validado, pois Fcal é maior que o $\mathrm{F}$ tabelado para as condições do ajuste, o que levou a uma busca de um conjunto de dados que pudesse validar o modelo.

\subsubsection{Modelo 6c. Ajuste do modelo 6 em todas as fases do processo (Bloco 1, Bloco 2, Bloco 3 e Bloco 4), sem o ensaio Ma-15.}

Antes do ajuste para o conjunto de dados considerado foi feito um ajuste do modelo 6 para cada ensaio individualmente, considerando em cada caso todos os blocos lógicos que correspondem a todas as fases identificadas do processo. Dessa forma, pode-se avaliar a 
qualidade do ajuste obtido individualmente e suas limitações. Nesses ajustes, verificou-se que o modelo, mesmo incorporando o consumo de $\mathrm{NH}_{4}{ }^{+}$para a síntese de glutamina a partir de glutamato, não foi capaz de prever o consumo de $\mathrm{NH}_{4}{ }^{+}$no nível observado no ensaio Ma-15. Dessa forma, o ensaio Ma-15 foi retirado do conjunto de dados utilizados para ajustar o modelo. Essa redução no conjunto de dados necessariamente reduz a amplitude e capacidade de aplicação do modelo, porém representa um compromisso em aplicação e precisão possível de ser estabelecido neste estágio do trabalho. Por outro lado, verificou-se que o parâmetro 16, $\mathrm{m}_{\mathrm{s}}$, manteve o mesmo valor encontrado no ajuste anterior (modelo 6b) quando se fez o ajuste individual do modelo aos ensaios e, por essa razão, foi mantido constante no valor anteriormente encontrado. Isso é uma indicaçãodo baixo consumo de glicose para manutenção celular. O ensaio Ma-16 é o único ensaio no qual existe uma formação significativa de glutamina na fase final do cultivo (Figura 5.112) . O valor do parâmetro $20, \mathrm{k}_{\text {sinGLN }}$, ajustado para o ensaio Ma-16, foi mantido constante para o ajuste dos demais parâmetros do modelo 6c. Os intervalos de busca dos parâmetros do modelo 6c estão indicados na Tabela 15.15 e os resultados do ajuste estão indicados na Figuras 5.113 a 5.119 e na Tabela 5.7.

Tabela 5.15. Intervalo adotado para ajuste dos parâmetros para o modelo 6c.

\begin{tabular}{|c|c|c|c|c|}
\hline Parâmetro & Denominação & Valor mínimo & Valor máximo & Unidades \\
\hline $\mathrm{k}_{\mathrm{GLC}}$ & $\operatorname{PAR}(2)$ & 0,2 & 2,5 & $(\mathrm{~g} / \mathrm{L})$ \\
\hline $\mathrm{k}_{\mathrm{GLN}}$ & PAR(3) & 0,0 & 1,5 & $(g / L)$ \\
\hline $\mathrm{k}_{\mathrm{iNH} 4}$ & $\operatorname{PAR}(4)$ & 0,001 & 0,5 & $(\mathrm{~g} / \mathrm{L})$ \\
\hline $\mathrm{k}_{\mathrm{m}}$ & $\operatorname{PAR}(5)$ & $1,0 \mathrm{E}-06$ & 0,5 & $(1 / \mathrm{h})$ \\
\hline $\mathrm{k}_{\mathrm{mGLC}}$ & $\operatorname{PAR}(6)$ & 0,1 & 15 & $(\mathrm{~g} / \mathrm{L})$ \\
\hline $\mathrm{k}_{\mathrm{mNH} 4}$ & $\operatorname{PAR}(7)$ & 0,01 & 0,5 & $(\mathrm{~g} / \mathrm{L})$ \\
\hline$\alpha_{\mathrm{NH} 4}$ & $\operatorname{PAR}(8)$ & $1,0 \mathrm{E}-04$ & 2,0 & $(\mathrm{mg} / 1,0 \mathrm{E}+07 \mathrm{cel})$ \\
\hline$\alpha_{\mathrm{ALA}}$ & PAR(9) & $2,0 \mathrm{E}-4$ & $5,0 \mathrm{E}-02$ & (g/1.0E+07cel.h) \\
\hline$\beta_{\mathrm{ALA}}$ & $\operatorname{PAR}(10)$ & $1,0 \mathrm{E}-06$ & $1,0 \mathrm{E}-03$ & (g/1.0E+07cel.h) \\
\hline $\mathrm{k}_{\mathrm{ALA}}$ & $\operatorname{PAR}(11)$ & $1,0 \mathrm{E}-05$ & 50 & $(g / L)$ \\
\hline$\alpha_{\mathrm{GPV}}$ & $\operatorname{PAR}(12)$ & 0,01 & 15 & $(\mu \mathrm{gGPV} / 1,0 \mathrm{E}+07 \mathrm{ce}$ \\
\hline $\mathrm{k}_{\mathrm{dGPVNH} 4}$ & $\operatorname{PAR}(13)$ & 0,01 & 0,5 & $(g / L)$ \\
\hline $\mathrm{Y}_{\mathrm{X} / \mathrm{GLC}}$ & $\operatorname{PAR}(14)$ & 50 & 200 & $(1,0 \mathrm{E}+07 \mathrm{cel} / \mathrm{g})$ \\
\hline $\mathrm{Y}_{\mathrm{ALA} / \mathrm{GLC}}$ & $\operatorname{PAR}(15)$ & $1,0 \mathrm{E}-02$ & 700 & $(g / g)$ \\
\hline $\mathrm{Y}_{\mathrm{X} / \mathrm{GLN}}$ & $\operatorname{PAR}(17)$ & 150 & 4500 & $1,0 \mathrm{E}+07 \mathrm{cel} / \mathrm{g}$ \\
\hline $\mathrm{Y}_{\mathrm{NH} 4 / \mathrm{GLN}}$ & $\operatorname{PAR}(18)$ & $1,0 \mathrm{E}-03$ & 350 & $(\mathrm{mg} / \mathrm{g})$ \\
\hline $\mathrm{k}_{\mathrm{dGPV}}$ & $\operatorname{PAR}(19)$ & $1,0 \mathrm{E}-04$ & 1 & $(1 / \mathrm{h})$ \\
\hline $\mathrm{k}_{\mathrm{dALA}}$ & $\operatorname{PAR}(23)$ & $1,0 \mathrm{E}-07$ & 50 & $(1 / \mathrm{h})$ \\
\hline
\end{tabular}



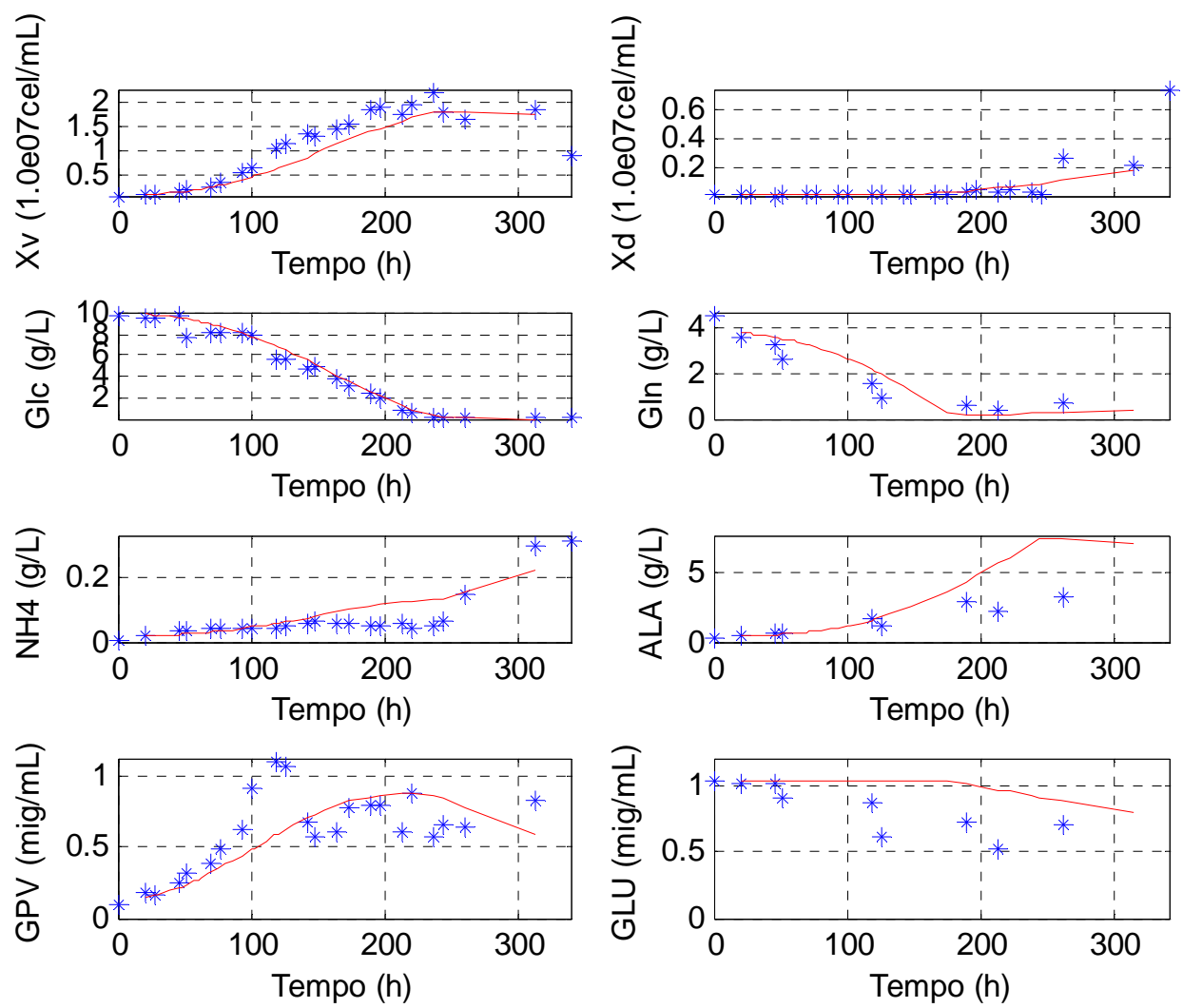

Figura 5.113. Comparação entre dados experimentais e as previsões do modelo $6 \mathrm{c}$ para o ensaio Ma-07, célula S2AcGPV2, $\mathrm{pO}_{2}=5 \%$ (Quadro A.1, Anexo A). (linha contínua, previsões do modelo; símbolos, dados experimentais).
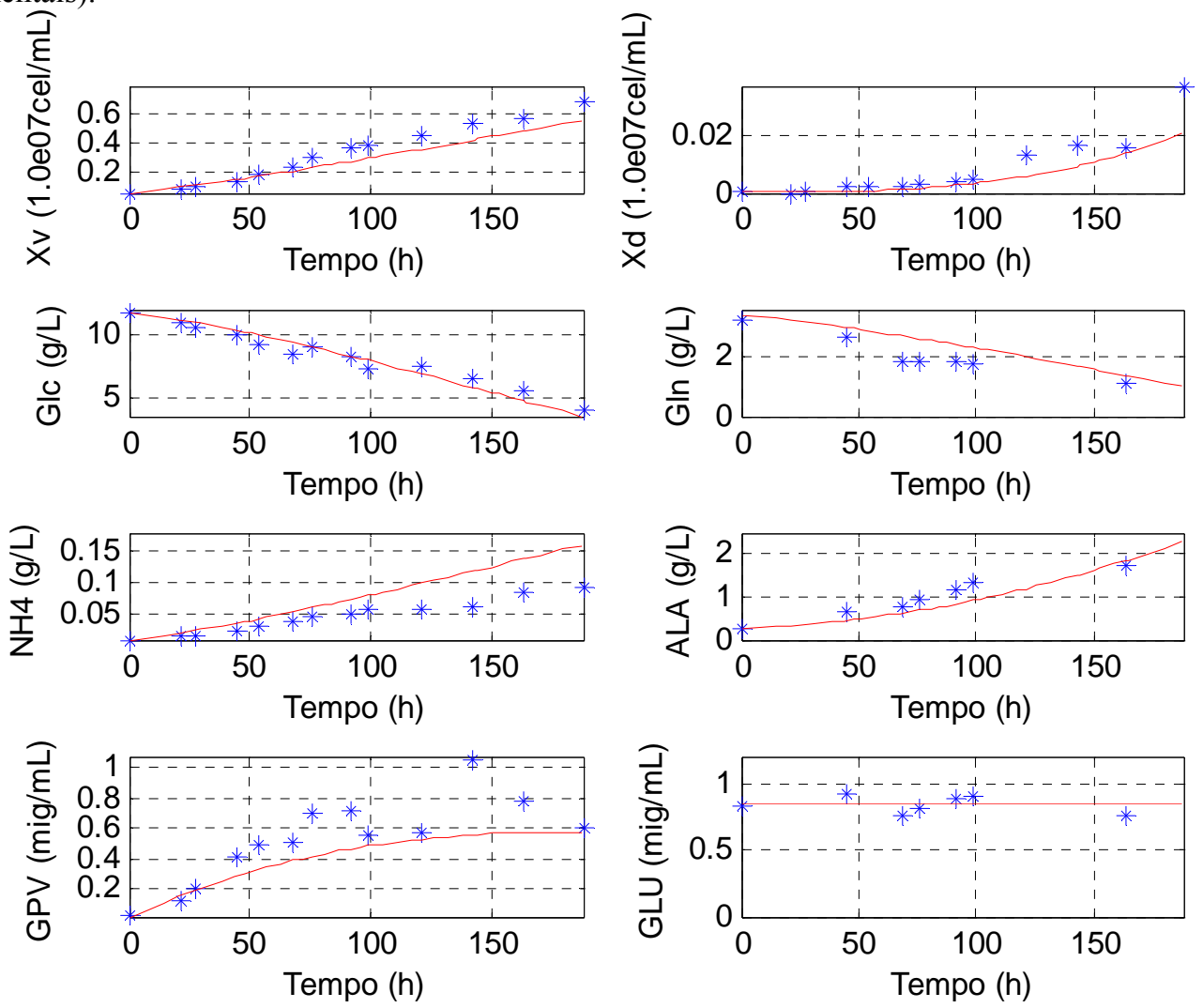

Figura 5.114. Comparação entre dados experimentais e as previsões do modelo $6 \mathrm{c}$ para o ensaio Ma- 08 , célula $\mathrm{S} 2 \mathrm{AcGPV} 2, \mathrm{pO}_{2}=50 \%$ (Quadro A.1, Anexo A). (linha contínua, previsões do modelo; símbolos, dados experimentais). 

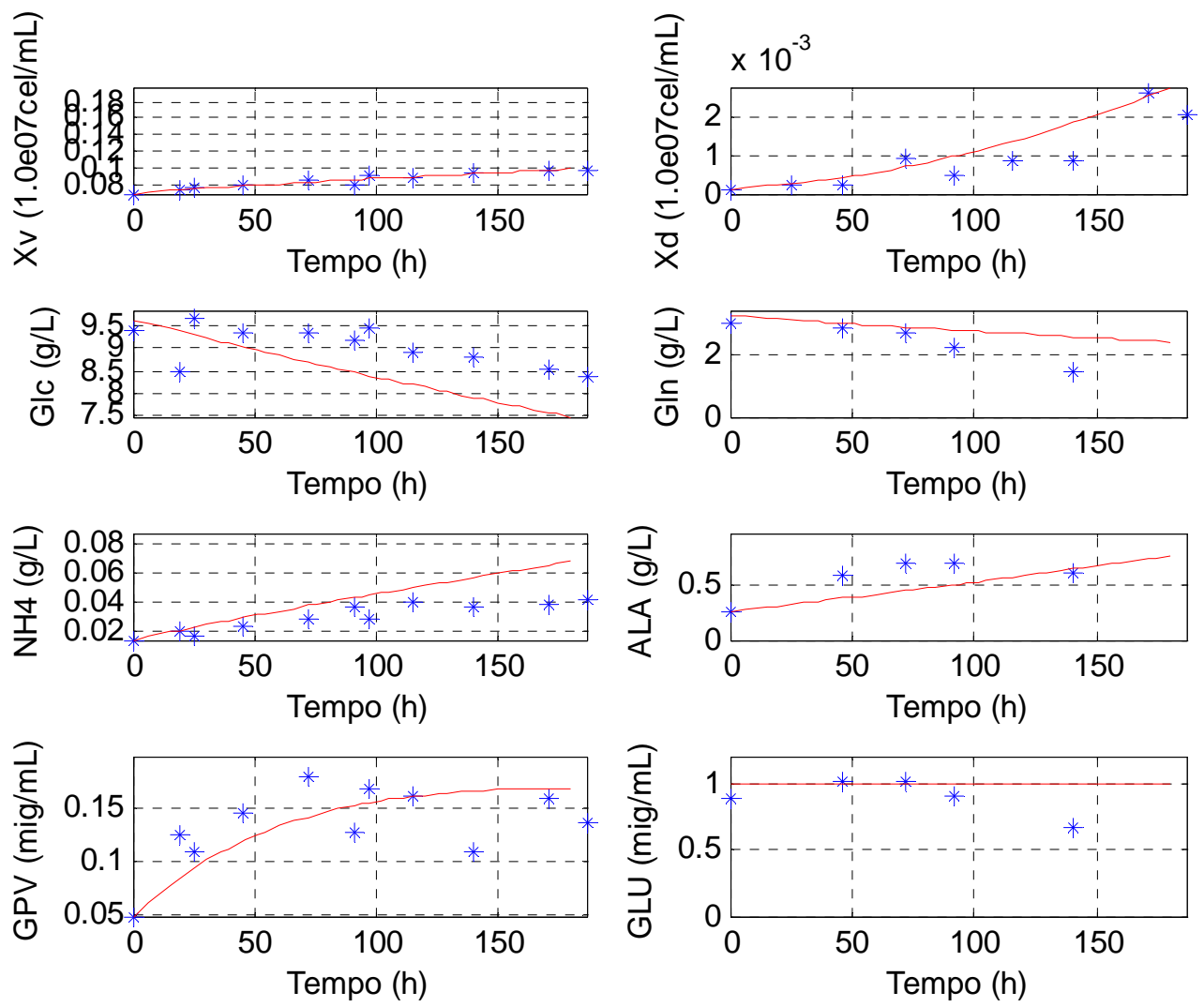

Figura 5.115. Comparação entre dados experimentais e as previsões do modelo $6 c$ para o ensaio Ma-09, célula S2AcGPV2, $\mathrm{pO}_{2}=80 \%$ (Quadro A.1, Anexo A). (linha contínua, previsões do modelo; símbolos, dados experimentais).
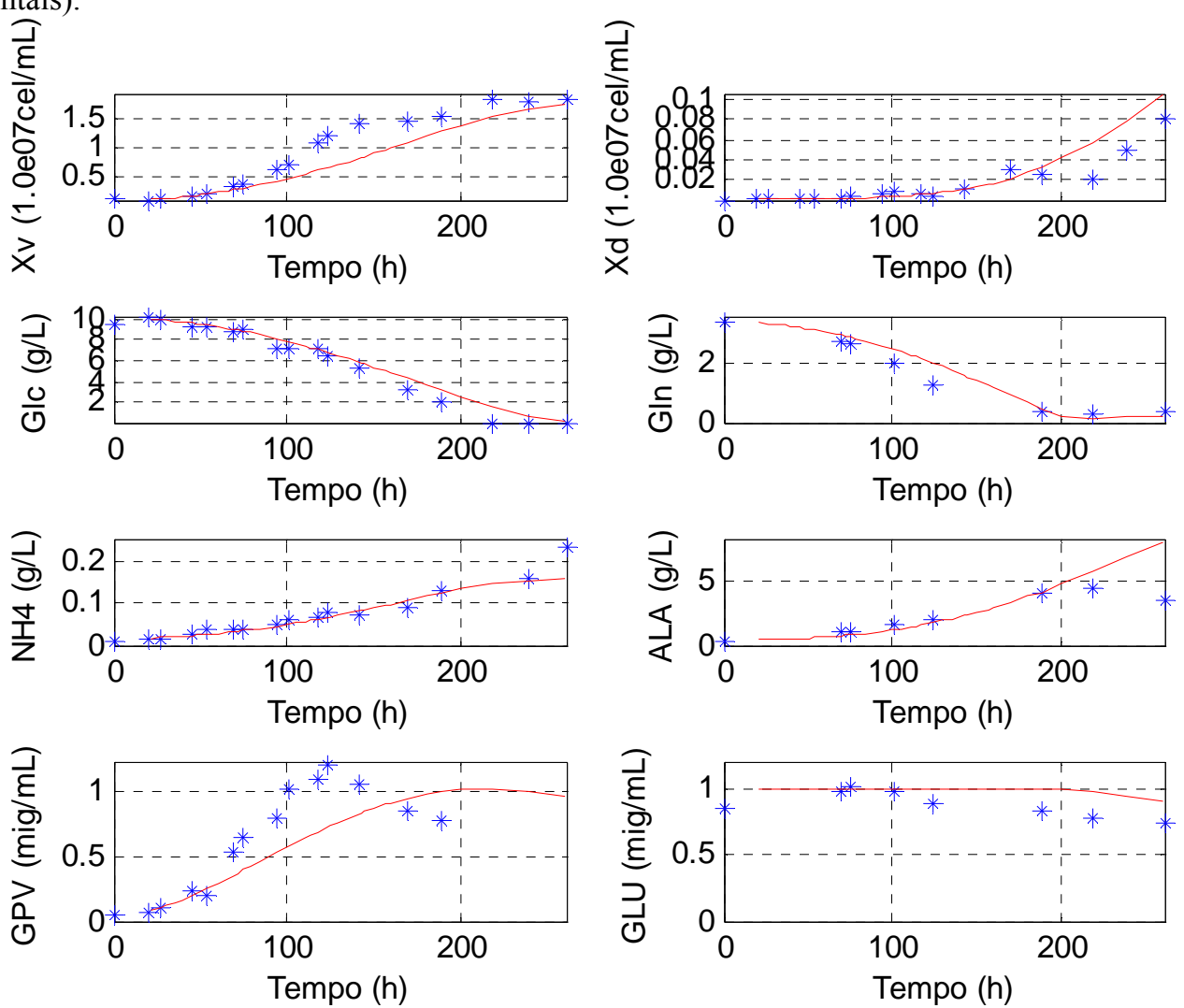

Figura 5.116. Comparação entre dados experimentais e as previsões do modelo $6 \mathrm{c}$ para o ensaio Ma-10, célula $\mathrm{S} 2 \mathrm{AcGPV} 2, \mathrm{pO}_{2}=30 \%$ (Quadro A.1, Anexo A). (linha contínua, previsões do modelo, símbolos, dados experimentais). 

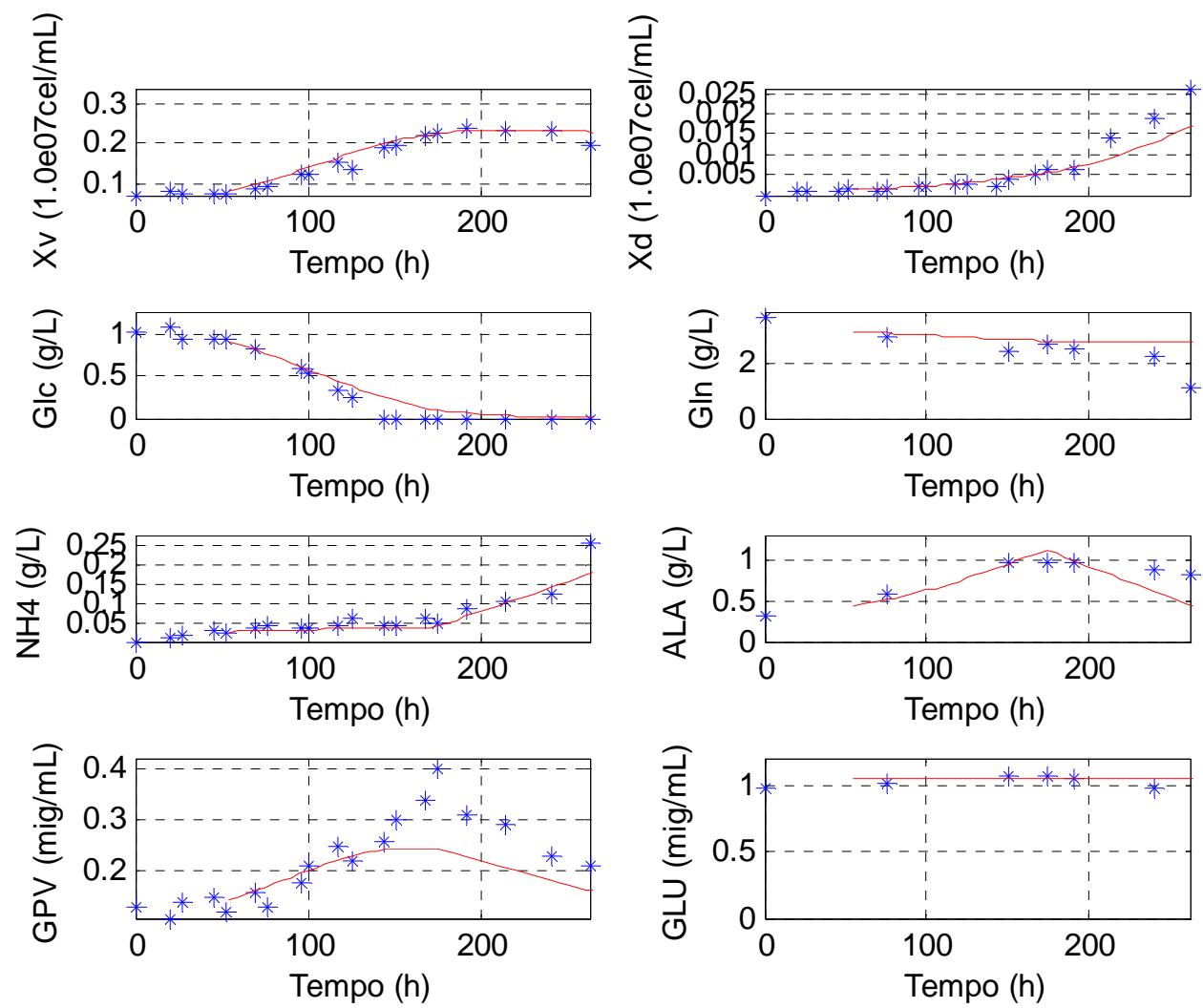

Figura 5.117. Comparação entre dados experimentais e as previsões do modelo 6c para o ensaio Ma-11, célula $\mathrm{S} 2 \mathrm{AcGPV} 2, \mathrm{GLC}_{0}=1,0 \mathrm{~g} / \mathrm{L}$ (Quadro A1, Anexo A). (linha contínua, previsões do modelo; símbolos, dados experimentais).
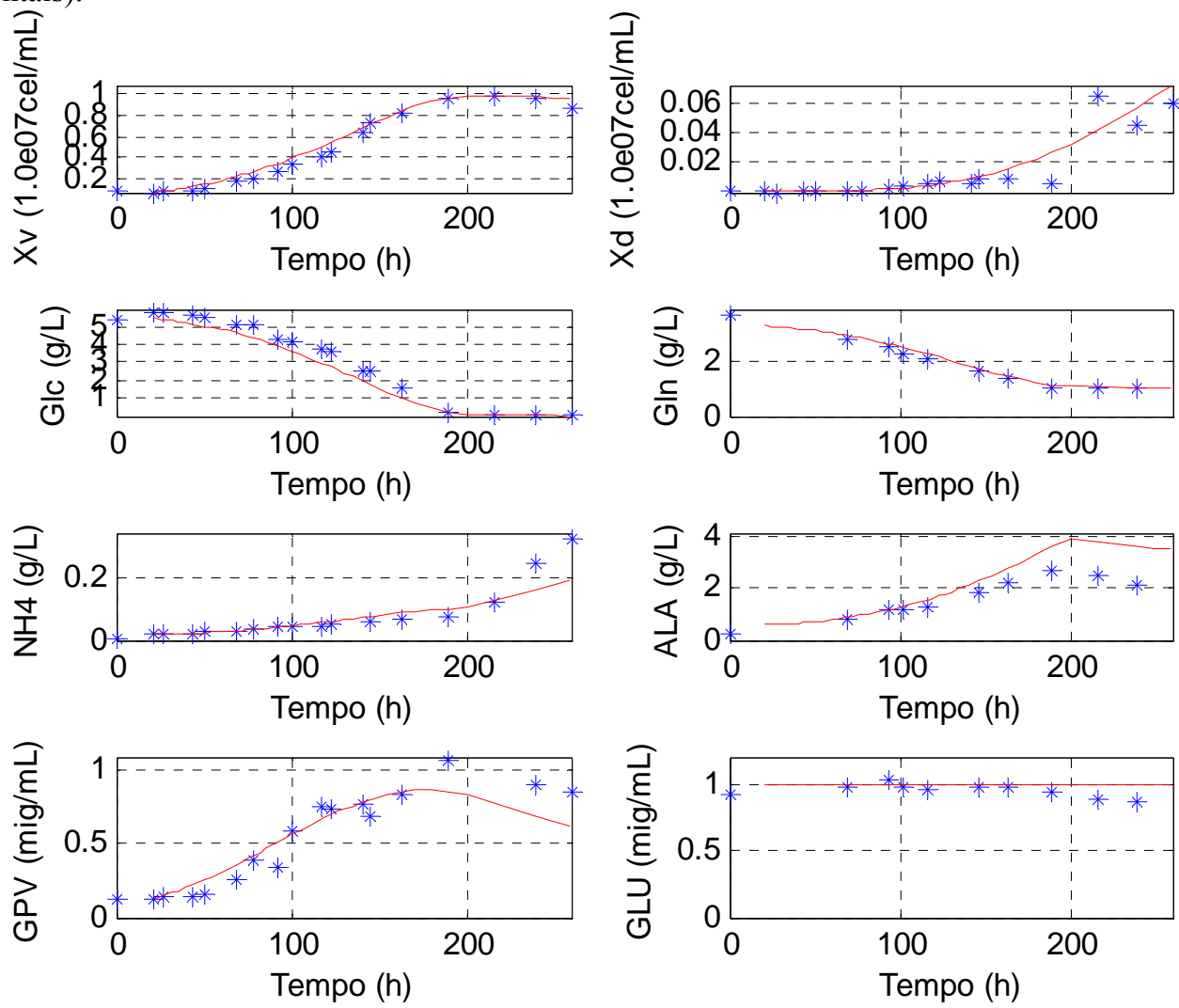

Figura 5.118. Comparação entre dados experimentais e as previsões do modelo $6 \mathrm{c}$ para o ensaio Ma-12, célula $\mathrm{S} 2 \mathrm{AcGPV} 2, \mathrm{GLC}_{0}=5,0 \mathrm{~g} / \mathrm{L}$ (Quadro A.1, Anexo A). (linha contínua, previsões do modelo; símbolos, dados experimentais). 

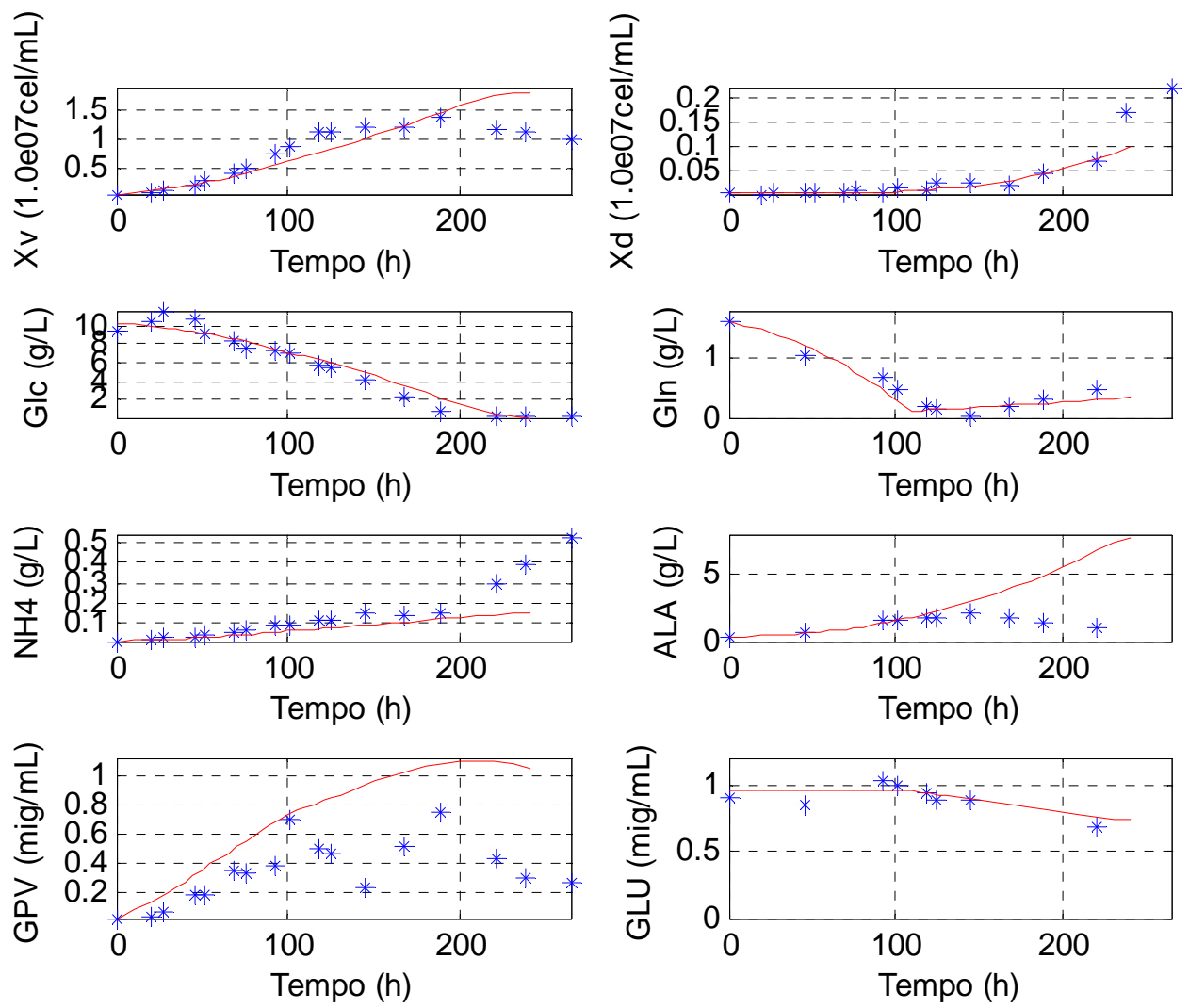

Figura 5.119. Comparação entre dados experimentais e as previsões do modelo $6 c$ para o ensaio Ma-16, célula S2AcGPV2, GLN ${ }_{0}=1,75 \mathrm{~g} / \mathrm{L}$ (Quadro A.1, Anexo A). (linha contínua, previsões do modelo; símbolos, dados experimentais).

A partir dos resultados obtidos é possível constatar que o modelo 6c proposto apresenta dificuldades para ajustar todos os dados experimentais. Contudo é possível validar o modelo para o conjunto de ensaios utilizados com um nível de significância de 85 \% como indica a Tabela 5.16.

Tabela 5.16. Valores de F para o modelo $6 \mathrm{c}$

\begin{tabular}{lc} 
Parâmetro & Valor \\
\hline $\mathrm{SS}_{\mathrm{LOF}}$ & 0,059 \\
$\mathrm{SS}_{\mathrm{PE}, \text { Global }}$ & 0,062 \\
Fcal & 0,947 \\
$\mathrm{~F}(1-\alpha ; \mathrm{N}-\mathrm{p} ; \mathrm{N}-\mathrm{nm})$ & 0,955 \\
\hline $\mathrm{df1}$ & 1999 \\
$\mathrm{df2}$ & 2072 \\
$1-\alpha$ & 0,85 \\
\hline
\end{tabular}

A partir do ajuste realizado e dos parâmetros obtidos verifica-se que o modelo 6 c ajustado prevê de forma bastante adequada os seguintes fenômenos biológicos: 
a) a limitação do crescimento por glicose para concentrações inferiores a $0,6 \mathrm{~g} / \mathrm{L}$ ( $\mathrm{k}_{\mathrm{GLC}}$, Tabela 5.7), valor coerente com a análise preliminar dessa constante realizada no item 5.3.1b, sendo que a fase estacionária de crescimento advém do esgotamento de glicose no meio. Em um caso, o modelo prevê esgotamento simultâneo de glicose e de glutamina (ensaio Ma-07), como indica a Figura 5.113.

b) o crescimento celular previsto pelo modelo acompanha a evolução experimental da concentração celular, porém não reproduz o valor de $\mu_{X \max }$ e a duração da fase exponencial nos ensaios Ma-10 e Ma-16, como indicam as Figuras 5.116 e 5.119. A velocidade especifica máxima de crescimento simulada é inferior à determinada experimentalmente, em decorrência, a concentração celular nessa fase é subestimada no ensaio Ma-10. A diminuição da velocidade específica de crescimento no modelo é decorrência da influência da concentração de $\mathrm{NH}_{4}{ }^{+}$já que GLC e GLN não limitam o crescimento. Também não é possível descartar a possibilidade de erro experimental nesses ensaios, uma vez que esse erro é elevado e, de forma geral, há uma boa aderência das previsões com os dados experimentais.

c) A evolução da concentração de glicose prevista praticamente coincide com a evolução experimental com exceção dos valores encontrados no ensaio Ma-09, ensaio sujeito a forte inibição por oxigênio dissolvido e para o qual o modelo prevê um consumo maior de glicose que o verificado experimentalmente, como indica a Figura 5.115. Como essa é uma medida que tem boa precisão analítica, isso sugere que a dependência do metabolismo de glicose para níveis de oxigênio dissolvido elevados ainda não está suficientemente formulada no modelo.

d) praticamente não ocorre limitação do crescimento por GLN, pois a constante de saturação estimada é de $0,026 \mathrm{~g} / \mathrm{L}\left(\mathrm{k}_{\mathrm{GLN}}\right.$, Tabela 5.7). Essa característica deve estar associada ao fato de haver síntese de GLN quando esse substrato está em baixas concentrações, ou seja, quando a concentração de glutamina no meio é aparentemente inferior a $0,1 \mathrm{~g} / \mathrm{L}$. As curvas de evolução de GLN durante o cultivo, previstas pelo modelo, acompanham os dados experimentais, mostrando pequenos desvios no ensaio Ma-09 e no ensaio Ma-11, como indicam as Figuras 5.115 e 5.117. O ajuste do ensaio Ma-16 indica que a constante de síntese, $\mathrm{k}_{\text {sinGLN }}$, é 0,170E02 gGLU/L.h o que explica adequademente o aumento da concentração de GLN observada. O fator de rendimento de glutamina em células $\left(\mathrm{Y}_{\mathrm{X} / \mathrm{GLN}}\right)$ ajustado, 2989,5 10 ${ }^{7} \mathrm{cel} / \mathrm{g}_{\mathrm{GLN}}$, está acima do intervalo de valores estimados experimentalmente (entre $47,0 \quad 10^{7} \mathrm{cel} / \mathrm{g}_{\mathrm{GLN}}$ a 
$\left.1920 \times 10^{7} \mathrm{cel} / \mathrm{g}_{\mathrm{GLN}}\right)$ o que indica que o fluxo de glutamina para o crescimento é menor que o indicado pela estimativa inicial do parâmetro.

e) uma forte inibição do crescimento pelo íon $\mathrm{NH}_{4}{ }^{+}$dado a valor da constante de inibição encontrada $(0,0444 \mathrm{~g} / \mathrm{L})$. Esse valor implica um efeito inibitório elevado e pode explicar, como já comentado, a diferença entre as previsões do modelo com os dados experimentais nos ensaios Ma-10 e Ma-16, uma vez que concentrações dessa ordem são encontradas, por exemplo, na fase exponencial de crescimento nesses ensaios.

f) aumento da velocidade de formação de $\mathrm{NH}_{4}{ }^{+}$regulada pelo esgotamento de glicose. Possivelmente, a glutamina, nesse caso, passa a ser incorporada ao ciclo dos ácidos tricarboxílicos pela ação das enzimas PAG e GDH que a convertem a $\alpha$-cetoglutarato com formação de dois grupos $\mathrm{NH}_{4}{ }^{+}$como indicado nas Figura 3.2. Durante a fase de crescimento exponencial, quando há glicose em excesso, como já mencionado por Drews et al. (2000), as células Sf9 podem realizar uma transferência parcial de nitrogênio para ALA sem formação de $\mathrm{NH}_{4}{ }^{+}$. Entende-se, portanto, que na fase exponencial de crescimento, com a formação de alanina, e ao final do crescimento com esgotamento de GLC ocorram transformações com estequiometrias diferentes de formação de $\mathrm{NH}_{4}{ }^{+}$. As previsões do modelo acompanham a tendência experimental com exceção o ensaio Ma-16, como indica a Figura 5.119, que, por não prever o esgotamento de GLC, não prevê o aumento da velocidade de formação desse produto ao final do cultivo.

g) velocidade de morte celular de ordem zero, pois os valores das constantes de inibição da morte celular por GLC e $\mathrm{NH}_{4}{ }^{+}$encontrados são altos $(19,9 \mathrm{~g} / \mathrm{L}$ e $0,383 \mathrm{~g} / \mathrm{L}$, respectivamente), frente às concentrações medidas durante o cultivo. Esse resultado não era esperado, pois pela análise prévia de fenômenos e pelas indicações da literatura havia a expectativa de verificar aumento da velocidade de morte celular com baixas concentrações de glicose e com o aumento da concentração de $\mathrm{NH}_{4}{ }^{+}$no meio. As previsões do modelo acompanham a tendência experimental com exceção do ensaio Ma-16 (Figura 5.119).

h) velocidade formação de alanina associada ao crescimento celular. Como já foi dito (itens 3.2.1 e 3.2.20), ALA pode ser considerada como o destino mais importante para o piruvato resultante do metabolismo da glicose e, portanto, dependente da concentração de glicose. Por 
outro lado, como também já afirmado, a formação de alanina parece depender igualmente da disponibilidade de glutamina (Figura 5.58; BATISTA et al., 2009a; AGUIAR, 2010) e de outros fatores como, por exemplo, o nível de oxigênio dissolvido no meio, Figura 5.58. O modelo reproduz essa dependência da cinética de formação de ALA com esses dois substratos durante a fase exponencial de crescimento, pois a síntese de alanina é interrompida quando há esgotamento desses dois substratos. Foi adotada uma formulação que admitia cinética de formação de ALA parcialmente associada ao crescimento, pois se verificou formação desse aminoácido, mesmo sem crescimento celular, porém sem esgotamento de GLC e GLN. O valor da constante $\mathrm{k}_{\mathrm{ALA}}$ corresponde à expressão (5.6.4), encontrado no ajuste do modelo $6 \mathrm{c} \mathrm{e}$ cujo valor e 0,100E-04 g/L, indica que o termo não associado ao crescimento é de ordem zero em relação à glicose, ou seja, esse termo não depende da concentração de GLC. É importante destacar que o modelo, em alguns casos, tende a superestimar a concentração de alanina durante o cultivo, como indicam as Figuras 5.113 e 5.119.

i) consumo de alanina com o esgotamento de glicose. Porém, verifica-se que o consumo desse aminoácido está subestimado, como indica a Figura 5.119 (ensaio Ma-16).

j) formação de GPV associada ao crescimento e inibição da síntese pelo acúmulo de $\mathrm{NH}_{4}{ }^{+}$. A constante de inibição dessa síntese sugere que esse efeito é destacado quando as concentrações de $\mathrm{NH}_{4}{ }^{+}$são superiores a $35 \mathrm{mg} / \mathrm{L}$, valores encontrados no cultivo antes do final da fase exponencial. Esse resultado reforça a hipótese formulada por Aguiar (20110) que indicou ser a inibição por $\mathrm{NH}_{4}{ }^{+}$responsável pela redução no teor de GPV nas células. $\mathrm{O}$ valor máximo de GPV ocorre quando deixam de haver crescimento e a síntese de GPV e passa a prevalecer o efeito da degradação da proteína. As previsões do modelo acompanham a tendência experimental com exceção dos ensaios Ma-10 e Ma-10 (Figuras 5.116 e 5.119) para os quais o modelo não prevê degradação significativa da proteína. Novamente, é importante destacar que o que erro experimental na determinação da GPV deve ser elevado, o que torna difícil a caracterização de sua dinâmica no processo.

k) consumo de glutamato para formação de glutamina. Nos ensaios Ma-7, Ma-10 e Ma-16, nos quais a concentração de GLN atinge valores inferiores a $0,1 \mathrm{~g} / \mathrm{L}$, o modelo prevê consumo de glutamato como se verifica experimentalmente. Nos demais ensaios, nos quais a concentração de GLN não atinge esse limiar, o modelo não prevê consumo de GLU. 
Experimentalmente isso também é verificado, com exceção do ensaio Ma-9 que indica consumo de GLU, mesmo concentrações de GLN superiores a 1 g/L. 


\section{CONCLUSÕES}

Os estudos iniciais sobre o metabolismo da linhagem de Drosophila melanogaster trasfectada para expressar a glicoproteína do vírus da raiva compararam dados experimentais obtidos por diferentes pesquisadores do nosso grupo e permitiu confirmar uma série de hipóteses levantadas pelo grupo ao longo dos trabalhos realizados:

1. A linhagem S2AcGPV2 apresenta comportamento metabólico significativamente distinto em resposta a alterações no meio ambiente, que podem decorrer das condições iniciais impostas ao sistema, ou da própria evolução do cultivo.

2. Em diferentes meios de cultura (SF900 II ${ }^{\circledR}$, TC100 modificado e IPL-41 modificado) foi possível observar valores muito diferentes para as principais grandezas que caracterizam o crescimento e a síntese de proteína, respectivamente, a velocidade específica máxima de crescimento $\left(\mu_{\mathrm{Xmax}}\right)$ e as medidas do teor de proteína nas células $\left(\mathrm{GPV}_{\mathrm{E}}\right)$ e da sua concentração máxima (GPV). Os valores de $\mu_{\text {Xmax }}$ estão na faixa de 0,0028 a $0,05 h^{-1}$, uma variação de aproximadamente 18x; enquanto os valores relativos à produção da GPV apontam para as faixas $177<\mathrm{GPV}_{\max }<1205 \mathrm{ng} / \mathrm{mL}$, uma variação de $6,8 \mathrm{x}$, e $1716<\mathrm{GPV}_{\text {Emax }}<2800 \mathrm{ng} / 10^{7} \mathrm{cel}$, uma variação de 1,6x (considerando dados advindos apenas da metodologia otimizada para determinação da GPV);

3. Essa variabilidade de respostas observadas, que pode ser explicada por uma grande flexibilidade da linhagem S2 para se adaptar às condições ambientais, aparentemente alterando os fluxos metabólicos pelas principais vias de assimilação da glicose e da glutamina, tornou impossível a proposição de um modelo único que representasse as cinéticas de crescimento celular, consumo de substratos (GLC e GLN), produção de produto (GPV) e produção de subprodutos $\left(\mathrm{NH}_{4}{ }^{+}\right.$e LAC) nos três diferentes meios de cultura;

4. Uma proposta preliminar de modelo (modelos 1 e 2 ) para um conjunto de ensaios realizados em um mesmo meio de cultura (TC100AG - modificado) sob diferentes condições de oxigênio dissolvido ( 5 a 80 \% da saturação em ar) considerou: 
a) Crescimento celular duplamente limitado por GLC e por GLN representado por uma estrutura matemática tipo Monod; e, ao mesmo tempo, inibido por amônio, que foi simulado por uma inibição do tipo hiperbólica;

b) Efeito limitante e ao mesmo tempo inibitório do oxigênio dissolvido sobre o crescimento celular que foi representado de duas formas distintas: segundo a proposição de Andrews (1968) e também como sugerido por Wu (1988);

c) Morte celular limitada por $\mathrm{NH}_{4}{ }^{+}$e inibida por GLC e GLN;

d) Formação de amônio e GPV associados ao crescimento celular;

e) Degradação de GPV segundo uma cinética de primeira ordem;

f) Consumo de glicose para formação de material celular, síntese da proteína de interesse e manutenção;

g) Consumo de glutamina para formação de material celular e formação de amônio;

h) Os ajustes obtidos com esse conjunto de equações foram considerados ruins segundo uma análise visual;

Dada a enorme dificuldade de se representar as alterações no metabolismo celular empregando um equacionamento do tipo fenomenológico não-estruturado, adotaram-se as seguintes formulações matemáticas para interpretar essa flexibilidade da linhagem S2AcGPV2, cultivada em meio TC100, sob condições variáveis de $\mathrm{pO}_{2}$ (5 a $80 \%$ da saturação em ar), de $\operatorname{GLC}_{0}(1$ a $15 \mathrm{~g} / \mathrm{L})$ e de $\operatorname{GLN}_{0}(0,6$ a $7 \mathrm{~g} / \mathrm{L})$ :

5. A influência das condições de cultivo, em especial, do teor de oxigênio dissolvido, da concentração inicial de glicose e da concentração inicial de glutamina, sobre as grandezas de processo, na fase exponencial, foi formulada como fatores de correção $\left(\mathrm{Fc}_{\mathrm{ij}}\right)$ para $\mathrm{o}$ efeito da variável $\mathrm{j}\left(\mathrm{O}_{2}, \mathrm{GLC}_{0}\right.$ ou $\left.\mathrm{GLN}_{0}\right)$ sobre o parâmetro i $\left(\mu_{\mathrm{Xmax}}, \mathrm{Y}_{\mathrm{X} / \mathrm{GLC}}, \mathrm{Y}_{\mathrm{X} / \mathrm{GLN}}\right.$, $\left.\mathrm{Y}_{\mathrm{NH} 4 / \mathrm{GLN}}, \mathrm{Y}_{\mathrm{ALA} / \mathrm{GLC}}, \mathrm{Y}_{\mathrm{NH} 4 / \mathrm{X}}, \mathrm{Y}_{\mathrm{GPV} / \mathrm{X}}\right)$, definidos como a relação $\left(\mathrm{Fc}_{\mathrm{ij}}\right) / \max \left(\mathrm{Fc}_{\mathrm{ij}}\right)$.

A incorporação desses fatores de correção nos modelos 4,5 e 6a, em condições de cultivo sem limitação em GLC ou GLN, resultou em modelos que representam adequadamente os dados experimentais (análise visual). Mas o modelo 6a, só foi validado estatisticamente (teste $\mathrm{F}, \propto=95 \%$ ), considerando valores de erro experimental calculados e disponíveis na literatura, quando foram eliminados os ensaios com maiores concentrações iniciais de 
GLC e GLN. Dessa forma, o modelo é válido no intervalo de $5<\mathrm{pO}_{2}<80 \%, 1<\mathrm{GLC}_{0}<10$ $\mathrm{g} / \mathrm{L}$ e $0,6<\mathrm{GLN}_{0}<3,5 \mathrm{~g} / \mathrm{L} ;$

6. Formulação matemática independente para as quatro diferentes situações metabólicas observadas - sem limitação em GLC ou GLN, com limitação apenas em GLC, com limitação apenas em GLN e, finalmente, limitada em GLC e em GLN - com as equações sendo organizadas segundo uma seqüência de "if”s" lógicos, para direcionar o metabolismo;

7. O modelo $6 \mathrm{c}$, que representa as quatro diferentes situações metabólicas observadas (item 6) permite prever as seguintes características do cultivo:

a) Velocidade específica de crescimento caracterizada por ser do tipo Monod com múltipla limitação de substratos (glicose e glutamina) e com inibição hiperbólica por $\mathrm{NH}_{4}^{+}$;

b) Limitação do crescimento por glicose para concentrações inferiores a 0,6 g/L;

c) Não limitação do crescimento por GLN, pois a constante de saturação estimada é de $0,026 \mathrm{~g} / \mathrm{L}$;

d) Forte inibição do crescimento pelo íon $\mathrm{NH}_{4}{ }^{+}$dado o valor da constante de inibição encontrada $(0,0444 \mathrm{~g} / \mathrm{L})$;

e) Consumo de glicose caracterizado, fundamentalmente, para duas finalidades: crescimento celular e formação de alanina;

f) Velocidade específica de morte celular é uma cinética de ordem zero, tendo em vista os valores ajustados para os parâmetros $\mathrm{k}_{\mathrm{mNH} 4}(0,383 \mathrm{~g} / \mathrm{L}) \mathrm{k}_{\mathrm{mGLC}}(19,9 \mathrm{~g} / \mathrm{L})$;

g) Formação de glutamina quando a concentração de glutamina atinge valores inferiores a $0,1 \mathrm{~g} / \mathrm{L}$. A constante de síntese, $\mathrm{k}_{\text {sinGLN }}, 0,170 \mathrm{E}-02 \mathrm{gGLN} / \mathrm{L} . \mathrm{h}$, explica adequadamente o aumento da concentração de glutamina observada

h) Consumo de glutamato condicionado ao esgotamento de GLN para formação de glutamina;

i) Velocidade específica de formação de alanina parcialmente associada ao crescimento celular. $\mathrm{O}$ valor da constante $\mathrm{k}_{\mathrm{ALA}}$ encontrado no ajuste do modelo $6 \mathrm{c}$ indica que o termo não associado ao crescimento é de ordem zero em relação à glicose;

j) Formação de $\mathrm{NH}_{4}{ }^{+}$associada ao crescimento celular e aumento da velocidade formação regulada pela glicose; 
k) Formação de GPV associada ao crescimento celular e sujeita a inibição por $\mathrm{NH}_{4}$, pois não se encontrou elementos para concluir a existência de limitação da síntese por esgotamento de aminoácidos, em particular, por glutamina ou cistina;

1) Degradação da proteína na fase estacionária do crescimento;

m) O modelo foi validado, com nível de significância de $85 \%$, para a faixa de $5<\mathrm{pO}_{2}<80 \%, 1<\mathrm{GLC}_{0}<10 \mathrm{~g} / \mathrm{L}$ e $1,75<\mathrm{GLN}<3,5$. 


\section{REFERÊNCIAS ${ }^{1}$}

AGUIAR, M. A. Estudo Cinético de células de Drosophila melanogaster transfectadas para a produção da glicoproteína da raiva em biorreator. Dissertação (Mestrado em Biotecnologia)- Instituto de Ciências Biomédicas, Universidade de São Paulo, São Paulo, 2010.

AGUiAR, M. A.; BARRAL, M. F., PICCOLI, R. A. M.; LÉO, P.; ASTRAY, R. M.; ANDRADE, R. J. AUGUSTO, E.F.P. Influência da Concentração de Oxigênio Dissolvido no Crescimento e Produção de Células de Drosophila melanogaster Transfectadas para a Expressão da Glicoproteína do Vírus da Raiva. In: SIMPÓSIO NACIONAL DE BIOPROCESSOS -SINAFER. 2009. Natal. Anais do XVII Simpósio Nacional de Bioprocessos. Natal: UFRN. 2009. 1-5p

ALTAMIRANO, C.; GÒDIA, F.; CAIRÓ, J. J. Metabolismo de células de mamíferos cultivadas in vitro. In: MORAES, A. M.; AUGUSTO, E. F. P.; CASTILHO, L. R. (Eds.) Tecnologia do cultivo de células animais: de biofármacos a terapia gênica. São Paulo: Roca, 2008. p. 81-104.

ALTAMIRANO, C.; ILLANES A.; BECERRA S.; CAIRO J.J.; GÒDIA, F. Considerations on the lactate consumption by $\mathrm{CHO}$ cells in the presence of galactose. Journal of Biotechnology, v. 125, p.547-556, 2006a.

ALTAMIRANO, C.; ILLANES, A.; CANESSA, R.; BECERRA, S. Specific nutrient supplementation of defined serum-free medium for the improvement of $\mathrm{CHO}$ cells growth and t-PA production. Electronic Journal of Biotechnology, v. 9, p.61-67, 2006 b.

AMABLE, P.; BUTLER, M. Cell metabolism and its control in culture. In: CASTILHO, L. R.; MORAES A. M.; AUGUSTO, E. F. P.; BUTLER, M. (Orgs.). Animal Cell Technology: from Biopharmaceuticals to Gene Therapy. London: Taylor \& Francis, 2008. p.75-110.

ANDREWS, J. F. A mathematical model for the continuous culture of microorganisms utilizing inhibitory substrates. Biotechnology and Bioengeeniring, v. 10, p.707-723, 1968.

ANTONIUKAS, L.; GRAMMEL, H.; REICHL, U. Production of hantavirus Puumala nucleocapsid protein in Saccharomyces cerevisiae for vaccine and diagnostics. Journal of Biotechnology, v. 124, p.347-362, 2006.

ASSENGA, S. P.; YOU, M.; SHY, C. H.; YAMAGISHI, J.; SAKAGUCHI, T.; ZHOU, J.; KIBE, M. K.; XUAN, X.; FUJISAKI, K. The use of a recombinant baculovirus expressing a chitinase from the hard tick Haemaphysalis longicornis and its potential application as a bioacaricide for tick control. Parasitology Research, v. 98, p.111-118, 2006.

\footnotetext{
De acordo com:

ASSOCIAÇÃO BRASILEIRA DE NORMAS TÉCNICAS, NBR 6023: Informação e documentação: referências: elaboração, Rio de Janeiro, 2002,
} 
ASTRAY, R. M.; AUGUSTO, E.; YOKOMIZO, A. Y.; PEREIRA, C. A. Analytical approach for the extraction of recombinant membrane viral glycoprotein from stably transfected Drosophila melanogaster cells. Biotechnology Journal, v. 3, p. 98-103, 2008.

AUgusto, E. F. P., BARRAL, M. F., PICCOLI, R. A. M. Modelos de crescimento e formação de produtos no cultivo de células animais. In: MORAES, A. M., AUGUSTO, E. F. P., CASTILHO, L. R. (Eds.), Tecnologia do Cultivo de Células Animais: de Biofármacos a Terapia Gênica. São Paulo: Roca, 2008, p. 170-215.

BACHMANN, A. S.; CORPUZ, G.; HARELD, W.P.; WANG, G.; COLLER, B. A. A simple method for the rapid purification of copia virus-like particle from Drosophila Schneider 2 cell. Journal of Virological Methods, v. 115, p. 159- 165, 2004.

BANKS, D. J.; HUA, G.; ADANG, M. Clonig of a Heliothis virescens 110kda aminopeptidase $\mathrm{N}$ in Drosophila S2 cells. Insect Biochemsitry and MolecularBiology, v. 33, p. 499- 508, 2003.

BASSANEZI, R. C. Ensino - Aprendizagem com Modelagem Matemática. São Paulo: Contexto, 2002. 389p.

BATISTA, F. R. X.; PEREIRA, C. A.; MENDONCA, R. Z.; MORAES, A. M. Evaluation of concentrated milk whey as a supplement for SF9 Spodoptera frugiperda cells in culture. Electronic Journal of Biotechnology, v. 9, p.522-532, 2006.

BATISTA, F. R. X. Formulação de meio de cultura livre de proteína animal para células de Drosophila melanogaster produtoras da glicoproteína $\mathbf{G}$ do vírus da raiva. Tese (Doutorado em Engenharia Química). Faculdade de Engenharia Química, Universidade Estadual de Campinas, Campinas. 2007.

BATISTA, F. R. X.; PEREIRA, C. A.; MENDONCA, R. Z.; MORAES, A. M. Formulation of a protein-free medium based on IPL-41 for the sustained growth of Drosophila melanogaster S2 cells. Cytotechnology, v. 57, p. 11-22, 2008.

BATISTA, F. R. X.; MORAES, A. M.; BÜNTEMEYER, H.; NOLL, T. Influence of culture conditions on recombinant Drosophila melanogaster S2 cells producing rabies virus glycoprotein cultivated in serum-free medium. Biologicals, v. 37, p. 108-118, 2009a.

BATISTA F. R. X.; GRECO, K. N.; ASTRAY, R. M.; JORGE, S. A. C.; AUGUSTO, E. F. P.; PEREIRA, C. A.; MENDONÇA, R. Z.; MORAES, A. M. Behavior of wild-type and transfected S2 cells cultured in two different media. Aceito para publicação em Applied Biochemistry and Biotechnology, 2009b.

BATT, C.; KOMPALA, S. K. A structured modelling framework for dynamics of hybridoma growth in continuous suspension cultures. Biotechnology and Bioengeeniring, v. 34, p. 515$531,1989$. 
BEBBINGTON, C.R.; RENNER, G.; THOMSON, S.; KING, D.; ABRAMS, D.; YARRANTON, G.T.; High-level expression of a recombinant antibody from myeloma cells using a glutamine synthetase gene as an amplifiable selectable marker. Biotechnology, v. 10, p.169-175, 1992.

BEDARD, C.; TOM, R.; KAMEN, A. Growth, nutrient consumption, and end-product accumulation in Sf-9 and BTI-EAA insect cell cultures: insights into growth limitation and metabolism. Biotechnology Progress, v. 9, p. 615-624, 1993.

BENSLIMANE, C.; ELIAS, C. B.; HAWARI, J.; KAMEN, A. Insights into the Central Metabolism of Spodoptera frugiperda (Sf-9) and Trichoplusia ni BTI-Tn-5B1-4(Tn-5) Insect Cells by Radiolabeling Studies. Biotechnology Progress, v. 21, p. 78-86, 2005.

BERNAL, V.; CARINHAS, N.; YOKOMIZO, A. Y.; CARRONDO, M. J.; ALVES, P. M. Cell density effect in the baculovirus-insect cells system: A quantitative analysis of energetic metabolism. Biotechnology and Bioengeeniring, v.104, p. 162-180, 2009.

BIRCH, J. R.; THOMPSON, P. W.; BORASTON, R. Production of monoclonal antibodies in large-scale cell culture. Biochemical Society Transactions, v. 13, p. 10-12, 1985.

BIRCH, J. R.; LAMBERT, K.; THOMPSON, P. W.; KENNEY, A. C.; WOOD, L. A. Antibody production with airlift fermenters . In: LYDERSEN, B. K. (Ed.). Large Scale Cell Culture Technology. Munch: Hanser, 1993, p. 1-20.

BHATIA, R.; JESIONOWSKI, G.; FERRANCE, J.; ATAAI, M. M. Insect cell physiology. Cytotechnology, v. 24, p. 1-9, 1997.

BONOMI, A.; FLEURY, A.T.; PICCOLI, A.M.; QUIROZ, L.H.C.; PEREIRALIMA, P.S.;TANNURI,E.A.; MATTOS; M. N. Modelagem matemática, otimização e controle avançado do processo de produção de plástico biodegradável a partir de cana de açúcar por via fermentativa. IN: CONGRESSO DE EQUIPAMENTOS E AUTOMAÇÃO DA INDÚSTRIA QUÍMICA. 1999. São Paulo. Anais do $4^{\circ}$ Congresso de Equipamentos e Automação da Indústria Química: São Paulo: 1999.

BOVO, R.; GALESI, A.; JORGE, S.; PICCOLI, R.; MORAES, A.; PEREIRA, C.; AUGUSTO, E. Kinetic response of a Drosophila melanogaster cell line to different medium formulations and culture conditions. Cytotechnology, v. 57, p. 23-35, 2008.

BREE, M. A.; DHURJATI, P.; GEOGHEGAN, R.; ROBNETT, B. Kinetic modelling of hybridoma cell growth and immunoglobulin production in a large-scale suspensions culture. Biotechnology and Bioengeeniring, v. 32, p. 1067-1072, 1988.

BUTLER, M. Animal cell cultures: recent achievements and perspectives in the production of biopharmaceuticals. Applied Biochemistry and Biotechnology, v. 68, p. 283-291, 2005.

BUTLER, M.; JENKINS, H. Nutritional aspects of the growth of animal cells in culture. Journal of Biotechnology, v. 12, p. 97-110, 1989. 
CASTRO, M. E. B.; SOUZA, M. L.; SIHLER, W.; RODRIGUES, J. C. M.; RIBEIRO, B. M. Biologia molecular de baculovírus e seu uso no controle biológico de pragas no Brasil. Pesquisa Agropecuária Brasileira, v. 34, p. 1733-1761, 1999.

CHA, H. J.; SHIN, H. S.; LIM, H. J.; CHO, H. S.; DALAL, N. N.; PHAM, M. Q.; BENTLEY, W. E. Comparative production of human interleukin-2 fused with green fluorescent protein in several recombinant expression systems. Biochemical Engineering Journal, v. 24, p. 225-233, 2005.

CHICO, E.; RODRÍGUEZ, G.; FIGUEIREDO, A. Biorreatores para células animais. In: MORAES, A. M.; AUGUSTO, E. F. P.; CASTILHO, L. R. (Eds.). Tecnologia do Cultivo de Células Animais. São Paulo: Rocca, 2008. p. 216-254.

COWGER, N. L.; O'CONNOR, K. C.; HAMMOND, T. G.; LACKS, D. J.; NAVAR, G. L. Characterization of bimodal cell death of insect cells in a rotating-wall vessel and shaker flask. Biotechnology and Bioengeeniring, v. 64, p. 14-26, 1999.

CRUZ, H. J.; FREITAS, C. M.; ALVES, P. M.; MOREIRA, J. L.; CARRONDO, M. J. T. Effects of ammonia and lactate on growth, metabolism, and productivity of BHK cells. Enzyme and Microbial Technology, v. 27, p.43-52, 2000a.

CRUZ, P. E.; GONCALVES, D.; ALMEIDA, J.; MOREIRA, J. L.; CARRONDO, M. J. T. Modeling retrovirus production for gene therapy. 2. Integrated optimization of bioreaction and downstream processing. Biotechnology Progress, v. 16, p. 350-357, 2000 b.

DALILI, M.; OLLIS, D. F. Transient kinetics of hybridome growth and monoclonal antibody production on serum-limited cultures. Biotechnology and Bioengeeniring, v. 33, 984-990, 1989.

DALILI, M.; SAYLES, G. D.; OLLIS, D. F. Glutamine- limited batch hybridoma growth and antibody production: experiment and model. Biotechnology and Bioengeeniring, v. 36, p. 74-82, 1990.

DE TREMBLAY, M.; PERRIER, M.; CHAVARIE, C.; ARCHAMBAULT, J. Optimization of fed-batch cultute of hybridoma cell using dynamic programing: single and multi feed case. Bioprocess Engineering, v. 7, p.229-234, 1992.

DEMAIN, A. L.; VAISHNAV, P. Production of recombinant proteins by microbes and higher organisms. Biotechnology Advances, v. 27, p. 297-306, 2009.

DEML, L.; WOLF, H.; WAGNER, R. High level expression of hepatitis B virus surface antigen in stably transfeted Drossophila Schneider -2 cells. Journal of Virogical Methods, v.79, p. 191-203, 1999a.

DEML, L.; S HIRMBECK,R.; REIMANN, J. ; WOLF, H.; WAGNER, R. Purification and characterization of hepatitis B virus surface antigen particles produced in Drossophila Schneider -2 cells. Journal of Virogical Methods, v.79, p. 205-217, 1999 b. 
DEUTSCHMANN, S. M.; JAGER, V. Optimization of the growth conditions of Sf21 insect cells for high- density perfusion culture in stirred-tank bioreactors. Enzyme and Microbial Technology, v. 16, p. 506-512, 1994.

DOVERSKOG, M., HAN, L., HÄGGSTRÖM, L. Cystine/cysteine metabolism in cultured Sf9 cells:influence of cell physiology on biosynthesis, amino acid uptake and growth. Cytotechnology, v. 26, p. 91-102, 1998.

DOVERSKOG, M.; LJUNGGREN, J.; ÖHMAN, L.; HÄGGSTRÖM, L. Physiology of cultured animal cells. Journal of Biotechnology, v. 59, p. 103-115, 1997.

DOVERSKOG, M.; JACOBSSON, U.; CHAPMAN, B. E.; KUCHEL, P. W.; HÄGGSTRÖM, L. Determination of NADH-dependent glutamate synthase (GOGAT) in Spodoptera frugiperda (Sf9) insect cells by a selective 1H/15N NMR in vitro assay. Journal of Biotechnology, v. 79, p. 87-97, 2000.

DREWS, M.; DOVERSKOG, M. Ö. L.; CHAPMAN, B. E.; JACOBSSON, U.; KUCHEL, P. W.; HÄGGSTRÖM, L. Pathways of glutamine metabolism in Spodoptera frugiperda (Sf9) insect cells: evidence for the presence of the nitrogen assimilation system, and a metabolic switch by 1H/15N NMR. Journal of Biotechnology, v. 78, p. 23-37, 2000.

DREWS, M.; DOVERSKOG, M.; ÍHMAN, L.; CHAPMAN, B. E.; JACOBSSON, U.; KUCHEL, P.W.;HÄGGSTRÖM, L. Pathways of glutamine metabolism in Spodoptera frugiperda ( $\mathrm{Sf9}$ ) insect cells: evidence for the presence of the nitrogen assimilation system, and a metabolic switch by 1H/15N NMR. Journal of Biotechnology, v. 78, p. 23-37, 2000.

DREWS, M.; PAALME, T.; VILU, R. The Growth and Nutrient Utilization of the Insect-Cell Line Spodoptera-Frugiperda Sf9 in Batch and Continuous-Culture. Journal of Biotechnology, v. 40, p. 187-198, 1995.

ELIAS, C. B.; CARPENTIER, E.; DUROCHER, Y.; BISSON, L.; WAGNER, R.; KAMEN, A. Improving Glucose and Glutamine Metabolism of Human HEK 293 and Trichoplusiani Insect Cells Engineered To Express a Cytosolic Pyruvate Carboxylase Enzyme. Biotechnology Progress, v. 19, p. 90-97, 2003.

EUROPA, A. F.; GAMBHIR, A.; FU, P. C.; HU, W. S. Multiple steady states with distinct cellular metabolism in continuous culture of mammalian cells. Biotechnology and Bioengineering, v. 67, p. 25-34, 2000.

FERRANCE, J. P.; GOEL, A.; ATAAI, M. M. Utilization of glucose and amino acids in insect cell cultures: Quantifying the metabolic flows within the primary pathways and medium development. Biotechnology and Bioengeeniring, v. 42, p. 697-707, 1993.

FERRAZ, L.P.C. Proposição de um modelo fenomenológico estruturado cibernético para o processo de produção de copolímeros de polihidroxialcanoatos por via fermentativa. 
Dissertação (Mestrado em Engenharia Química). Escola Politécnica. Universidade de São Paulo. São Paulo. 1999.

FIBER CELL SYSTEMS INC. HOLLOW Fiber Bioreactors and Related Products. Disponível em http://www.fibercellsystems.com/documents/brochure.pdf. 2008. Acesso em 14-7-2009.

FOLlSTAD, B. D.; BALCARCEL, R. R.; STEPHANOPOULOS, G.; WANG, D. I. C. Metabolic flux analysis of hybridoma continuous culture steady state multiplicity. Biotechnology and Bioengineering, v. 63, p. 675-683, 1999.

FRAME, K. K.; HU, W. S. Kinect study of hybridoma cell growth in continuos culture. I. A model for non-producing cell. Biotechnology and Bioengeeniring, p. 55-64, $1991 \mathrm{a}$.

FRAME, K. K.; HU, W. S. Comparison of growth kinetics of producing and nonproducing hybridoma cells in batch culture. Enzyme and Microbial Technology, v. 13, p. 690-696, $1991 b$.

FRESHNEY, R.I. Culture of Animal Cells - A Manual of Basic Technique. 5a edição, New York: Wiley-Liss, 2005.

FROMENT, G.; BISCHOFF, K. B. Chemical Reator Analysis and Design. New York: John Wiley and Sons, 1979.

FROMENT, G. F.; HOSTEN, L. H. Catalytic Kinetics: Modelling. In: ANDERSON, J. R.; BOUDART, M. (Eds.) Catalysis. Science and Technology. New York: Springer-Verlag, 1981.

GAERTNER, J. G.; DHURJATI, P. Fractional factorial study of hybridoma behavior. 1. Kinetics of growth and antibody production. Biotechnology Progress, v. 9, p. 298-308, 1993a.

GAERTNER, J. G.; DHURJATI, P. Fractional factorial study of hybridoma behavior. 2. Kinetics of nutrient uptake and waste production. Biotechnology Progress, v. 9, p. 309-316, $1993 b$.

GALESI, A. L. L.; PEREIRA, C. A.; MORAES, A. M. Culture of transgenic Drosophila melanogaster Schneider 2 cells in serum-free media based on TC100 basal medium. Biotechnology Journal, v. 2, p. 1399-1407, 2007.

GALESI, A. L. L. Cultivo de células de Drosophila melanogaster em diferentes formulações de meios de cultura livres de soro visando a produção da glicoproteína do vírus da raiva. Tese (Doutorado em Engenharia Química). Faculdade de Engenhara Química. UNICAMP.Campinas. 2007.

GALESI, A. L. L.; AGUIAR, M. A.; ASTRAY, R. M.; AUGUSTO, E. F. P.; MORAES, A. M. Growth of recombinant Drosophila melanogaster Schneider 2 cells producing rabies virus 
glycoprotein in bioreactor employing serum-free medium. Cytotechnology, v. 57, p. 73-81, 2008.

GAUDIN, Y.; RUIGROK, R. W.; TUFFEREAU, C.; KNOSSOW, M.; FLAMAND, A. Rabies virus glycoprotein is a trimer. Virology, v. 187, p. 627-632, 1992.

GAUDIN, Y. Folding of rabies virus glycoprotein: epitope acquisition and interaction with endoplasmic reticulum chaperones. Journal of Virology, v. 71, p. 3742-3750, 1997.

GHOSH, S.; PARVEZ, M. K.; BANERJEE, K.; SARIN, S. K.; HASNAIN, S. E. Baculovirus as mammalian cell expression vector for gene therapy: an emerging strategy. Molecular Therapy, v. 6, p. 5-11, 2002.

GIBSON, K. R.; VANEK, P. G.; KALOSS, W. D.; COLlIER, G. B.; CONNAUGHTON, J. F.; ANGELICHIO, M.; LIVI, G. P.; FLEMING, P. J. Expression of dopamine- $\beta$-hydroxylase in Drosophila Schneider 2 cell - Evidence of mechanism of membrane-binding other than uncleved sinal peptide. Journal of Biological Chemistry, v. 268, p. 9490-9495, 1993.

GLACKEN, M. W.; ADEMA, E.; SINKSKEY, A. J. Mathematical description of hybridoma culture kinetics . I. Initial metabolic rates. Biotechnology and Bioengeeniring, v. 32, p. 491$506,1988$.

GLACKEN, M. W.; HUANG, C.; SINSKEY, A. J. Mathematical description of hybridoma culture kinetics:III. Simulation of fed-batch bioreactors. Journal of Biotechnology, v. 10, p. 39-66, 1989.

GUARDIA, M. J.; GAMBHIR, A.; EUROPA, A. F.; RAMKRISHNA, D.; HU, W. S. Cybernetic modeling and regulation of metabolic pathways in multiple steady states of hybridoma cells. Biotechnology Progress, v. 16, p. 847-853, 2000.

GRIFFIN, T. J.; SETH, G.; XIE, H.; BANDHAKAVI, S.; HU, W. S. Advancing mammalian cell culture engineering using genome-scale technologies. Trends in Biotechnology, v. 25, p. 401-408, 2007.

HAMMONS,C.;NARCISO, H. Hhabdoviridae. $\quad$ Disponível em http://www.stanford.edu/group/virus/rhabdo/2005/index.htm, acesso em 3/08/2009.

HAGGSTROM L. Animal cell metabolism. In: Spier R (Ed.), Encyclopedia of Cell Technology. New York: Wiley \& Sons , 2000. pp. 392-411

HARIGAE, M.; MATSUMURA, M.; KATAOKA, H. Kinetic study on HBs-MAb production in continuous cultivation. Journal of Biotechnology, v. 34, p. 227-235, 1994.

HILlER, G. W.; AESCHLIMANN, A. D.; CLARK, D. S.; BLANCH, H. W. A kinetic analysis of hybridoma growth and metabolism in continuous suspension culture on serum-free medium. Biotechnology and Bioengeeniring, v. 38, p. 733-741, 1991. 
HIMMELBLAU, D.M. Process Analysis by Statistical Methods. New York: John Wiley \& Sons. 1970.

HITZEMAN, R. A.; HAGIE, F. E.; LEVINE, H. L.; GOEDDEL, D. V.; AMMERER, G.; HALL, B. D. Expression of A Human-Gene for Interferon in Yeast. Nature, v. 293, p. $717-$ $722,1981$.

IKONOMOU, L.; SCHNEIDER, Y. J.; AGATHOS, S. N. Insect cell culture for industrial production of recombinant proteins. Applied Microbiology and Biotechnology, v. 62, p. 120, 2003.

JAIN, E.; KUMAR, A. Upstream processes in antibody production: evaluation of critical parameters. Biotechnology Advances, v. 26, p. 46-72, 2008.

JANG, J. D.; BARFORD, J. P. An unstructured kinetic model of macromolecular metabolism in batch and fed-batch cultures of hybridoma cells producing monoclonal antibody. Biochemical Enginering Journal, v. 4, p. 153-168, 2000.

JEON, H. K.; CHANG, K. H.; KIM, K. I.; CHUNG, I. K. Funtional expression of recombinat tumstatin in stably trnsformed Drosophila melanogaster S2 cell. Biotechnology Letters, v. 244, p. 102-109, 1998.

JO, E. C.; PARK, H. J.; PARK, J. M.; KIM, K. H. Balanced nutrient fortification enables high density hybridoma cell culture in batch culture. Biotechnology and Bioengeeniring, v. 36, p. 717-722, 1990.

KAHANER, D.; MOLER, C. B.; NASH, S. Numerical methods and software : computer methods for mathematical computations . Englewood: Prentice-Hall, 1989.

KANG, C. Y. Expression of human immunodeficiency virus genes using baculovirus expression system. Molecular Biotechnology, v. 8, p. 173-187, 1997.

KEEN MJ, HALE C. The use of serum-free medium for the production of functionally active humanised monoclonal antibody from NSO mouse myeloma cells engineered using glutamine synthetase as a selectable marker. Cytotechnology, v, 18, p.207-217. 1996.

KIRKPATRICK, R. B.; GANGULY, S.; ANGELICHIO, M; GRIEGO, S.; SHATZMAN, A.; SILVERMAN, C.; ROSEMBERG, M. Heavy chain dimmers as well as complete antibodies are efficiently formed and secreted from Drosophila via BiP-mediated pathway. Journal of Biological Chemsitry, v. 270, n. 34, p. 19800-19805.

KEEN M. J., HALE C. The use of serum-free medium for the production of functionally active humanised monoclonal antibody from NSO mouse myeloma cells engineered using glutamine synthetase as a selectable marker. Cytotechnology, v, 18, p.207-217. 1996. 
KUNKEL, J. P.; JAN, D. C.; JAMIESON, J. C.; BUTLER, M. Dissolved oxygen concentration in serum-free continuous culture affects N-linked glycosylation of a monoclonal antibody. Journal of Biotechnology,v.2, p.55-71, 1998.

KUNKEL, J. P.; JAN, D. C.; BUTLER, M.; JAMIESON, J. C. Comparisons of the glycosylation of a monoclonal antibody produced under nominally identical cell culture conditions in two different bioreactors. Biotechnology Progress. v. 16, p. 462-470, 2000.

KUROKAWA, H.; PARK, Y.; IIJIMA, S.; KOBAYASHI, T. Growth characteristics in fedbatch culture of hybridoma cells with control of glucose and glutamine concentration. Biotechnology and Bioengeeniring, v. 44, p.95-103, 1994.

LEE, J. M.; PARK, J.H.; PARK, J.O.; CHANG, K.H.; CHUNG, I.S. Exession of recombinat erythropoietin stably transformed Drosophila melanogaster S2 cells. In vitro Cellular \& Developmental Biology - Animal, v. 36, p. 348-350, 2000.

Correlation between steady-state cell concentration and cell death of hybridoma cultures in chemostat. Biotechnology and Bioengeeniring, v. 45, p.18-26, 1995.

LEE, Y.-K.; YAP, P.-K.; TEOH, A.-P. Correlation between steady-state cell concentration and cell death of hybridoma cultures in chemostat. Biotechnology and Bioengeeniring, $v$. 45, p.18-26, 1995.

LÉO, P.; GALESI, A. L. L.; SUAZO, C. A. T.; MORAES, A. M. Células Animais: Conceitos Básicos. In: MORAES, A. M.; AUGUSTO, E. F. P.; CASTILHO, L. R. (Eds.), Tecnologia do Cultivo de Células Animais: de Biofármacos a Terapia Gênica. São Paulo: Roca, 2008, p. $15-41$.

LIM HJ, CHA HJ. Observation and modeling of induction effect on human transferrin production from stably transfected Drosophila S2 cell culture. Enzyme and Microbial Technology, v. 39, p.208-214, 2006

LINARDOS, T. I.; KALOGERAKIS, N.; BEHIE, L. A.; LAMONTAGNE, L. R. The Effect of Specific Growth-Rate and Death Rate on Monoclonal-Antibody Production in Hybridoma Chemostat Cultures. Canadian Journal of Chemical Engineering, v. 69, p.429-438, 1991.

LINZ, M.; ZENG, A. P.; WAGNER, R.; DECKWER, W. D. Stoichiometry, kinetics, and regulation of glucose and amino acid metabolism of a recombinant BHK cell line in batch and continuous cultures. Biotechnology Progress, v.13, p.453-463, 1997.

LIU, L.; SPURRIER, J.; BUTT, T. R.; STRICKLER, J. E. Enhanced protein expression in the baculovirus/insect cell system using engineered SUMO fusions. Protein Expression and Purification, v.62, p21-28, 2008.

LUEDEKING, R.; PIRET, E. L. A kinetic study of the lactic acid fermentation. Batch process at controlled $\mathrm{pH}$. Reprinted from Journal of Biochemical and Microbiological Technology 
Engineering Vol. I, No. 4. Pages 393-412 (1959). Biotechnology and Bioengeeniring. v.67, p.636-644, 2000.

MARTINELLE K.; WESTLUND, A.; HAGGSTROM, L. Saturable ammonium ion transport in myeloma and hybridoma cells is mediated by the $\mathrm{Na}+\mathrm{K}+2 \mathrm{Cl}$--cotransporter. Biotechnology Letters, v. 20, p.81-86, 1998.

MARTINELLE, K.; HAGGSTROM, L. Effects of NH4+ and K+ on the energy metabolism in Sp2/0-Ag14 myeloma cells. Cytotechnology, v. 29, p.45-53, 1999.

MCQUEEN, A.; MEILHOC, E.; BAILEY, J.E. Flow effects on the viability and lysis of suspended mammaliancells. Biotechnology Letters, v. 9, p. 831-836. 1987

MCQUEEN, A.; BAILEY, J. E. Effect of ammonium ion and extracellular $\mathrm{pH}$ on hybridoma cell methabolism and antibody production. Biotechnology and Bioengeeniring., v.35, p.1067-1077, 1990.

MEISENHOLDER, G. Postmodern Culture Maximizing Cell Culture Output At Every Level. The Scientist, v. 13, p.14-21,1999. Imagem disponível em <http://images.thescientist.com/content/figures/images/yr1999/july/jul_art/brunswick.gif $>$ acessada em julho de 2009.

MENDONÇA, R. Z.; PALOMARES, L. A.; RAMIREZ, O. T. An insight into insect cell metabolism through selective nutrient manipulation. Journal of Biotechnology, v.72, p. 61$75,1999$.

MENESES-ACOSTA, A.; MENDONCA, R.; MERCHANT, H.; COVARRUBIAS, L.; RAMIREZ, O. Comparative characterization of cell death between Sf9 insect cells and hybridoma cultures. Biotechnology and Bioengeeniring, v. 72, p.441-457, 2001.

MEUWLY, F.; RUFFIEUX, P. A.; KADOURI, A.; VON STOCKAR, U. Packed-bed bioreactors for mammalian cell culture: Bioprocess and biomedical applications. Biotechnology Advances, v. 25, p. 45-56, 2007.

MILLER, W. M.; WILKE, C. R.; BLANCH, H. W. Effects of dissolved oxygen concentration on hybridoma growth and metabolism in continuous culture. The Journal of Cellular Physiology, v.132, p.524-530, 1987.

MILLER, W. M.; BLANCH, H. W.; WILKE, C. R. A kinetic analysis of hybridoma growth and metabolism in batch and continuous suspension culture: Effect of nutrient concentration, dilution rate, and pH. Biotechnology and Bioengeeniring, v.32, p.947-965, 1988.

MILLER, W. M.; BLANCH, H. W.; WILKE, C. R. Transient responses of hybridoma cells to nutrient additions in continuous culture I . Glucose pulse and step changes. Biotechnology and Bioengeeniring, v.33, p.477-486, 1989a. 
MILLER, W. M.; BLANCH, H. W.; WILKE, C. R. Transient responses of hybridoma cells to nutrient additions in continuous culture: II . Glutamine pulse and step changes. Biotechnology and Bioengeeniring, v. 33, p. 477-486, $1989 \mathrm{~b}$.

MIRZAEI, M.; XU, Y.; ELIAS, C. B.; PRAKASH, S. Nonviral Production of Human Interleukin-7 in Spodoptera Frugiperda Insect Cells as a Soluble Recombinant Protein. Journal of Biomedicine and Biotechnology, ID 637942, 2009, 8 p.

MONOD, J. Recherches sur la croissance des cultures bacteriennes. Paris, Hermann et Cie., 1942.

MONTOR, W. R.; SOGAYAR, M. C. Insetos como biofábricas de proteínas humanas. Ciência Hoje, agosto, p. 17-23, 2003.

NEGRETE, A.; KOTIN, R. M. Production of recombinant adeno-associated vectors using two bioreactor configurations at different scales. Journal of Virological Methods, v.145, p.155-161, 2007.

NELDER, J.A.; MEAD, R. A simplex method for functions minimization. Computer Journal, v. 7, p. 308-313, 1965.

NEWLAND, M.; GREENFIELD, P. F.; REID, S. Hybridoma growth limitations: the roles of energy metabolism and ammonia production. Cytotechnology, v. 3, p. 215-229, 1990.

NILSANG, S.; NEHRU, V.; PLIEVA, F. M.; NANDAKUMAR, K. S.; RAKSHIT, S. K.; HOLMDAHL, R.; BO MATTIASSON, B.; KUMAR, A. Three-dimensional culture for monoclonal antibody production by hybridoma cells immobilized in macroporous gel particles. Biotechnology Progress, v. 24, p. 1122-1131, 2008.

NOLLERT, M. U.; DIAMOND, S. L.; MCINTIRE, L. V. Hydrodynamic shear stress and mass transport modulation of endothelial cell metabolism. Biotechnology and Bioengeeniring, v. 38, p. 588-602, 1991.

ÖHMAN, L.; LJUNGGREN, J.; HAGGSTROM, L. Induction of A Metabolic Switch in Insect Cells by Substrate Limited Fed-Batch Cultures. Applied Microbiology and Biotechnology, v. 43, p. 1006-1013, 1995.

ÖHMAN, L.; ALARCON, M.; LJUNGGREN, J.; RAMQVIST, A. K.; HAGGSTROM, L. Glutamine is not an essential amino acid for Sf-9 insect cells. Biotechnology Letters, v. 18, p. $765-770,1996$.

OZTURK, S. S.; RILEY, M. R.; PALSSON, B. O. Effects of ammonia and lactate on hybridoma growth, metabolism, and antibody production. Biotechnology and Bioengeeniring, v. 39, p. 418-431, 1992. 
PALOMARES, L. A.; LOPEZ, S.; RAMIREZ, O. T. Utilization of oxygen uptake rate to assess the role of glucose and glutamine in the metabolism of infected insect cell cultures. Biochemical Engineering Journal, v. 19, p. 87-93, 2004.

PAREDES, C.; PRATS, E.; CAIRO, J. J.; AZORIN, F.; CORNUDELlA, L.; GODIA, F. Modification of glucose and glutamine metabolism in hybridoma cells through metabolic engineering. Cytotechnology, v. 30, p. 85-93, 1999.

PELLEGRINI. , M. P.; PINTO, R., C., V.; CASTILHO, L., R. Mecanismos de crescimento e morte de células animais cultivadas In vitro. In: In: MORAES, A. M.; AUGUSTO, E. F. P.; CASTILHO, L. R. (Eds.) Tecnologia do cultivo de células animais: de biofármacos a terapia gênica. São Paulo: Roca, 2008. p. 138-169.

PORTNER, R.; SCHAFER, T. Modelling hybridoma cell growth and metabolism--a comparison of selected models and data. Journal of Biotechnology, v. 49, p. 119-135, 1996.

REUVENY, S.; VELEZ, D.; MACMILLAN, J. D.; MILLER, L. Factors affecting cell growth and monoclonal antibody production in stirred reactors. Journal of Immunological Methods, v. 86, p. 53-59, 1986.

RHIEL, M.; MITCHELllogEAN, C. M.; MURHAMMER, D. W. Comparison of Trichoplusia ni BTI-Tn-5B1-4 (High Five((TM))) and Spodoptera frugiperda Sf-9 insect cell line metabolism in suspension cultures. Biotechnology and Bioengineering, v. 55, p. 909920, 1997.

ROYCE, P. N. A Discussion of Recent Developments in Fermentation Monitoring and Control from A Practical Perspective. Critical Reviews in Biotechnology, v. 13, p. 117-149, 1993 .

SCHNEIDER, Y. J.; LAVOIX, A. Monoclonal antibody production in semi-continuous serum- and protein-free culture. Effect of glutamine concentration and culture conditions on cell growth and antibody secretion. Journal of Immunological Methods, v. 129, p. 251-268, 1990.

SCHNEIDER, M.; MARISON, I. W.; VON STOCKAR, U. The importance of ammonia in mammalian cell culture . Journal of Biotechnology, v. 46, p. 161-185, 1996.

SIDOLI, F. R.; MANTALARIS, A.; ASPREY, S. P. Modelling of Mammalian Cells and Cell Culture Processes. Cytotechnology, v. 44, p. 27-46, 2004.

SINGH, V. Disposable bioreactor for cell culture using wave-induced agitation. Cytotechnology, v. 30, p.149-158, 1999.

SHISHIDO, T.; KURATA, N.; YOON, M. E.; TANAKA, T.; YAMAJI, H.; FUKUDA, H.; KONDO, A. A high-level expression vector containing selectable marker for continuous 
production of recombinant protein in insect cells. Biotechnology Letters, v. 31, p. 623-627, 2009.

SONDERGAARD L. Drosophila cells can be grown to high cell densities in bioreactor. Biotechnology Techniques, v. 10, p.161-166. 1996.

SUÁREZ, I. Estudo do processo de cultivo de células de hibridomas: modelagem matemática e otimização preliminar do processo. Tese (Doutorado em Engenharia Química). EPUSP.São Paulo. 2002.

SUGIURA, T.; AMANN, E. Properties of two insect cell lines useful for the Baculovirus expression system in serum-free culture. Biotechnology and Bioengineering, v. 51, p. 494499, 1996.

SURESHKUMAR, G. K.; MUTHARASAN, R. The influence on temperature on a mouse hybrodoma growth and monoclonal antiobody production. Biotechnology and Bioengeeniring, v.37, p. 292-295, 1991.

SWIECH, K. Identificação de aspectos cinéticos e fisiológicos chave no cultivo de células de Drosophila melanogaster S2 para a produção de glicoproteína do vírus da raiva (GPV) recombinante. Tese (Doutorado em Engenharia Química). Departamento de Engenharia Química, Universidade Federal de São Carlos, São Carlos. 2007.

SWIECH, K.; DA SILVA, C. S.; ARANTES, M. K.; DOS SANTOS, A. S.; ASTRAY, R. M.; PEREIRA, C. A.; SUAZO, C. A. Characterization of growth and metabolism of cells transfected with the rabies-virus glycoprotein gene. Biotechnology and Applied Biochemistry, v.49, p.41-49, 2008a.

SWIECH, K.; ROSSI, N.; SILVA, B. G.; JORGE, S. A.; ASTRAY, R. M.; SUAZO, C. A. Bioreactor culture of recombinant Drosophila melanogaster S2 cells: characterization of metabolic features related to cell growth and production of the rabies virus glycoprotein. Cytotechnology, v. 57, p.61-66, 2008 b.

SWIECH, K.; ROSSI, N.; ASTRAY, R. M.; SUAZO, C. A. Enhanced production of recombinant rabies virus glycoprotein (rRVGP) by Drosophila melanogaster S2 cells through control of culture conditions. Cytotechnology, v. 57, p. 67-72, $2008 \mathrm{c}$.

TEIXEIRA, A.; CUNHA, A. E.; CLEMENTE, J. J.; MOREIRA, J. L.; CRUZ, H. J.; ALVES, P. M.; CARRONDO, M. J. T.; OLIVEIRA, R. Modelling and optimization of a recombinant BHK-21 cultivation process using hybrid grey-box systems. Journal of Biotechnology, v. 118, p. 290-303, 2005.

THARANKAN, J. P.; CHAU, P. C. Serum free batch production of IgM. Biotechnology Letters, v. 8, p. 457-462, 1986. 
VALlE, M.; KESTER, M.; BURNS, A.; MARX, S.; SPIEGEL, A.; SHILOACH, J. Production and purification of human menin from Drosophila melanogaster S2 cells using stirred tank reactor. Cytotechnology, v. 35, p. 127-135, 2001.

VELEZ, D.; REUVENY, S.; MILLER, L.; MACMILLAN, J. D. Kinetics of monoclonal antibody production in low serum growth medium. Journal of Immunological Methods, v. 86, p. 45-52, 1986.

VOLESKY, B.; VOTRUBA, J. Modeling and Optimization of Fermentation Processes. Amsterdam: Elsevier, 1992.

YIN, J. C.; LI, G. X.; REN, X. F.; HERRLER, G. Select what you need: A comparative evaluation of the advantages and limitations of frequently used expression systems for foreign genes. Journal of Biotechnology, v. 127, p. 335-347, 2007.

YOKOMIZO, A. Y.; JORGE, S. A.; ASTRAY, R. M.; FERNANDES, I.; RIBEIRO, O. G.; HORTON, D. S.; TONSO, A.; TORDO, N.; PEREIRA, C. A. Rabies virus glycoprotein expression in Drosophila S2 cells. I. Functional recombinant protein in stable co-transfected cell line. Biotechnol Journal, v. 2, p. 102-109, 2007.

WARNOCK, J. N.; MERTEN, O. W.; AL RUBEAI, M. Cell culture processes for the production of viral vectors for gene therapy purposes. Cytotechnology, v. 50, p. 141-162, 2006.

WU, Y. C.; HAO, O. J.; SCHOLZE, R. J. Treatment of leachate from a solid waste landfill site using a two-stage anaerobic filter. Biotechnology and Bioengeeniring, v.31, p. 257-266, 1988.

ZENG, A. P.; DECKWER, W. D.; HU, W. S. Determinants and rate laws of growth and death of hybridoma cells in continuous culture. Biotechnology and Bioengeeniring, v. 57, p. 642$654,1998 \mathrm{a}$.

ZENG, A. P.; HU, W. S.; DECKWER, W. D. Variation of stoichiometric ratios and their correlation for monitoring and control of animal cell cultures. Biotechnology Progress, v. 14, p. 434-441, 1998 b.

ZENG, A. P.; DECKWER, W. D. Model simulation and analysis of perfusion culture of mammalian cells at high cell density. Biotechnology Progress, v. 15, p. 373-382, 1999.

ZENG, C. Q. Y.; WENTZ, M. J.; COHEN, J.; ESTES, M. K.; RAMIG, R. F. Characterization and replicase activity of double-layered and single-layered rotavirus-like particles expressed from baculovirus recombinants. Journal of Virology, v. 70, p. 2736-2742, 1996.

ZHOU, W. C.; REHM, J.; EUROPA, A.; HU, W. S. Alteration of mammalian cell metabolism by dynamic nutrient feeding. Cytotechnology, v. 24, p. 99-108, 1997. 


\section{ANEXO A.}

Quadro A1. Quadro dos ensaios utilizados para estudo de fenômenos cinéticos e ajuste preliminar de parâmetros.

Quadro A2. Composição dos meios utilizados nos trabalhos. 
Quadro A1. Quadro dos ensaios utilizados para estudo de fenômenos cinéticos e ajuste preliminar de parâmetros. Ensaios realizados em batelada.

\begin{tabular}{|c|c|c|c|c|c|c|c|c|}
\hline Referência & Ensaio & Célula & Meio & $\mathrm{pH}$ & OD(\%) & \multicolumn{3}{|c|}{ Pluronic (\% v/v) } \\
\hline \multirow{5}{*}{$\begin{array}{l}\text { Galesi } \\
(2007)\end{array}$} & RE-1 & \multirow{5}{*}{ S2AcGPV2 } & \multirow{5}{*}{ TC100_AG } & \multirow{5}{*}{$6,00-6,25$} & 40,0 & \multicolumn{3}{|c|}{0,1} \\
\hline & RE-2 & & & & 40,0 & \multicolumn{3}{|c|}{0,1} \\
\hline & RE-3 & & & & 30,0 & \multicolumn{3}{|c|}{0,1} \\
\hline & RE-4 & & & & 30,0 & \multicolumn{3}{|c|}{0,3} \\
\hline & RE-5 & & & & 30,0 & \multicolumn{3}{|c|}{0,6} \\
\hline \multirow{6}{*}{$\begin{array}{l}\text { Swiech } \\
(2007)\end{array}$} & AP_1 & \multirow{6}{*}{ S2AcGPV2 } & \multirow{6}{*}{ SF900 II ${ }^{\circledR}$} & $6,3-6,7$ & $89-0,8$ & \multirow{6}{*}{\multicolumn{3}{|c|}{ Desconhecido }} \\
\hline & AP_2 & & & $6-6,5$ & $90-0$ & & & \\
\hline & AP_3 & & & $5,9-7,10$ & $77-52$ & & & \\
\hline & Bio_2 & & & 6,2 & 50,0 & & & \\
\hline & Bio_3 & & & 6,2 & 50,0 & & & \\
\hline & Bio_5 & & & 6,2 & 50,0 & & & \\
\hline \multirow{5}{*}{$\begin{array}{l}\text { Batista } \\
(2007)\end{array}$} & $5 \%$ & \multirow{5}{*}{ S2AcGPV2 } & \multirow{5}{*}{ IPL $41 \mathrm{FB}$} & \multirow{5}{*}{6,3} & 5,0 & \multirow{5}{*}{\multicolumn{3}{|c|}{0,1}} \\
\hline & $20 \%$ & & & & 20,0 & & & \\
\hline & $40 \%$ & & & & 40,0 & & & \\
\hline & $60 \%$ & & & & 60,0 & & & \\
\hline & $95 \%$ & & & & 95,0 & & & \\
\hline \multirow{16}{*}{$\begin{array}{c}\text { Aguiar } \\
(2009) \mathrm{e} \\
\text { Aguiar } \\
(2010)\end{array}$} & Ma-02 & \multirow{4}{*}{$\begin{array}{c}\text { S2AcGPV2_KTC10 } \\
0\end{array}$} & \multirow{4}{*}{ TC100-AG } & \multirow{4}{*}{$6,00-6,25$} & 5,0 & \multirow{4}{*}{\multicolumn{3}{|c|}{0,6}} \\
\hline & Ma-03 & & & & 30,0 & & & \\
\hline & Ma-04 & & & & 50,0 & & & \\
\hline & Ma-06 & & & & 80,0 & & & \\
\hline & & & & & & GLC & GLN & Pluroni \\
\hline & Мa-07 & \multirow{11}{*}{ S2AcGPV2 } & \multirow{11}{*}{ TC100-AG } & \multirow{11}{*}{$6,00-6,25$} & 5,0 & 10,0 & 3,5 & 0,6 \\
\hline & Ma-08 & & & & 50,0 & 10,0 & 3,5 & 0,6 \\
\hline & Ma-09 & & & & 80,0 & 10,0 & 3,5 & 0,6 \\
\hline & Ma-10 & & & & 30,0 & 10,0 & 3,5 & 0,6 \\
\hline & Ma-11 & & & & 30,0 & 1,0 & 3,5 & 0,6 \\
\hline & Ma-12 & & & & 30,0 & 5,0 & 3,5 & 0,6 \\
\hline & Ma-13 & & & & 30,0 & 15,0 & 3,5 & 0,6 \\
\hline & Ma-14 & & & & 30,0 & 15,0 & 3,5 & 0,6 \\
\hline & Ma-15 & & & & 30,0 & 10,0 & 0,6 & 0,6 \\
\hline & Ma-16 & & & & 30,0 & 10,0 & 1,75 & 0,6 \\
\hline & Ma-17 & & & & 30,0 & 10,0 & 7,00 & 0,6 \\
\hline
\end{tabular}


Quadro A2. Composição dos meios utilizados nos trabalhos.

\begin{tabular}{|c|c|c|c|}
\hline Componentes & TC100-AG, (Galesi, 2007) & SF900 II ${ }^{\circledR}$ (Swiech, 2007) & IPL41-FA (Batista, 2007) \\
\hline $\mathrm{CaCl}_{2}$ & 996,6 & n.d. & 500,0 \\
\hline $\mathrm{KCl}$ & 2870,0 & n.d. & 1200,0 \\
\hline $\mathrm{MgCl}_{2}$ & 1070,0 & n.d. & 1068,18 \\
\hline $\mathrm{MgSO}_{4}$ & 1360,0 & n.d. & 918,26 \\
\hline $\mathrm{NaCl}$ & 500,0 & n.d. & 2850,0 \\
\hline $\mathrm{NaHCO}_{3}$ & 350,0 & n.d. & 350,0 \\
\hline $\mathrm{NaH}_{2} \mathrm{PO}_{4} \cdot \mathrm{H}_{2} \mathrm{O}$ & 1008,7 & n.d. & 1160,0 \\
\hline Glicose & 10000,0 & 10000,0 & 10000,0 \\
\hline Frutose & & n.d. & 500 \\
\hline Sacarose & & 2000,0 & 1650,0 \\
\hline Lactose & & & 2000,0 \\
\hline Maltose & & 1200,0 & 1026,9 \\
\hline Ac. Fumárico & & n.d. & 4,40 \\
\hline Ac. $\alpha$-cetoglutárico & & n.d. & 29,60 \\
\hline Ac. Málico & & n.d. & 53,60 \\
\hline Extrato de levedura & 3000,0 & & 6,0 \\
\hline Pluronic F68 & $0,1 \%(\mathrm{~m} / \mathrm{v})$ & & \\
\hline Emulsão lipídica & $1 \%(\mathrm{~m} / \mathrm{m})$ & & $1 \%(\mathrm{v} / \mathrm{v})$ \\
\hline Triptose & 2000,0 & & \\
\hline L-Alanina & 225,0 & 360,0 & \\
\hline B-Alanina & & & 300,0 \\
\hline L-Arginina & & 330,0 & \\
\hline L-Arginina-HCl & 666 & & 800,0 \\
\hline L-Asparagina & 350 & 1100,0 & 1307,8 \\
\hline Ȧcido aspártico & 350,0 & - & 1300,0 \\
\hline L-Cisteína & & 45,0 & \\
\hline L-Cistina & & - & 119,14 \\
\hline L-Cistina- $2 \mathrm{HCl}$ & 28,7 & & \\
\hline Fenilalanina & 150 & 870,0 & 1000,0 \\
\hline Ac. Glutâmico & 600,0 & 1650,0 & 1500,0 \\
\hline L-Glicina & 650 & 570,0 & 200,0 \\
\hline L-Glutamina & 3500,0 & 2300,0 & 3500,0 \\
\hline L-Histidina & 3700 & 220,0 & 200,0 \\
\hline L-Isoleucina & 50 & 760,0 & 750,0 \\
\hline L-Leucina & 75 & 360,0 & 250,0 \\
\hline L-Lisina & & 640,0 & \\
\hline L-Lisina-HCl & 625 & & 700,0 \\
\hline L-Metionina & 50 & 1000,0 & 14800,0 \\
\hline Prolina & 350 & 600,0 & 506,5 \\
\hline Hidroxi-L-prolina & & & 800,0 \\
\hline Serina & 550 & 310,0 & 200,0 \\
\hline Treonina & 175 & 350,0 & 200,0 \\
\hline Triptofano & 100 & - & 100,0 \\
\hline Tirosina & 72,02 & 230,0 & 600,0 \\
\hline Valina & 100 & 620,0 & 6500,0 \\
\hline Biotina & 0,01 & n.d. & 0,16 \\
\hline Cloreto de colina & & n.d. & 20,0 \\
\hline Ac. Fólico & 0,02 & n.d. & 0,08 \\
\hline Inositol & 0,02 & n.d. & 0,40 \\
\hline Niacina & 0,02 & n.d. & - \\
\hline Ac. Aminobenzóico & 0,02 & n.d. & 0,32 \\
\hline Ac pantotenaico & 0,02 & n.d. & 0,008 \\
\hline Piridoxina & 0,02 & n.d. & - \\
\hline Roboflavina & 0,02 & n.d. & 0,08 \\
\hline Tiamina & 0,52 & n.d. & 0,8 \\
\hline $\mathrm{B}_{12}$ & & & 0,24 \\
\hline
\end{tabular}




\section{ANEXO B}

PROGRAMA CI_mod6.for 


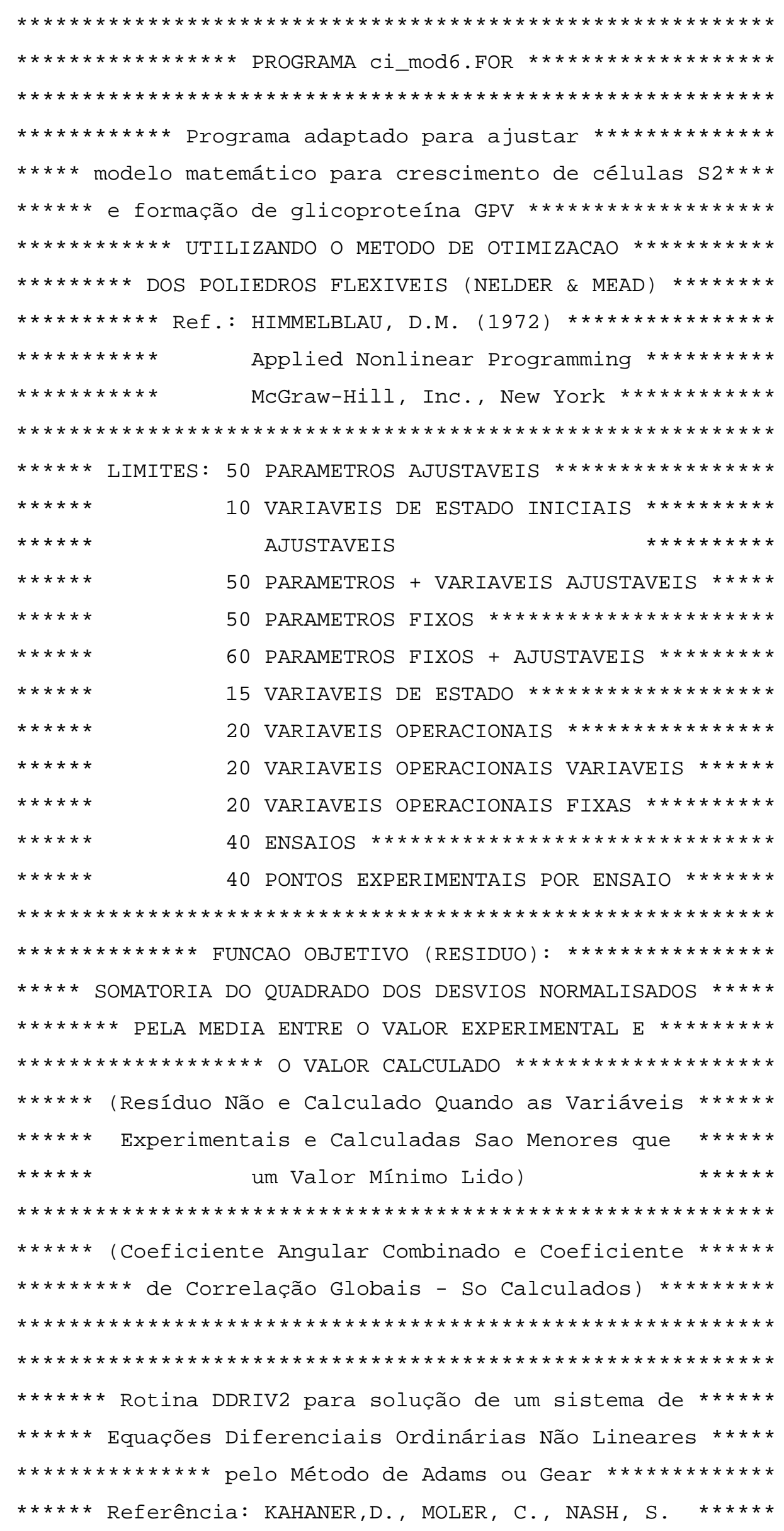




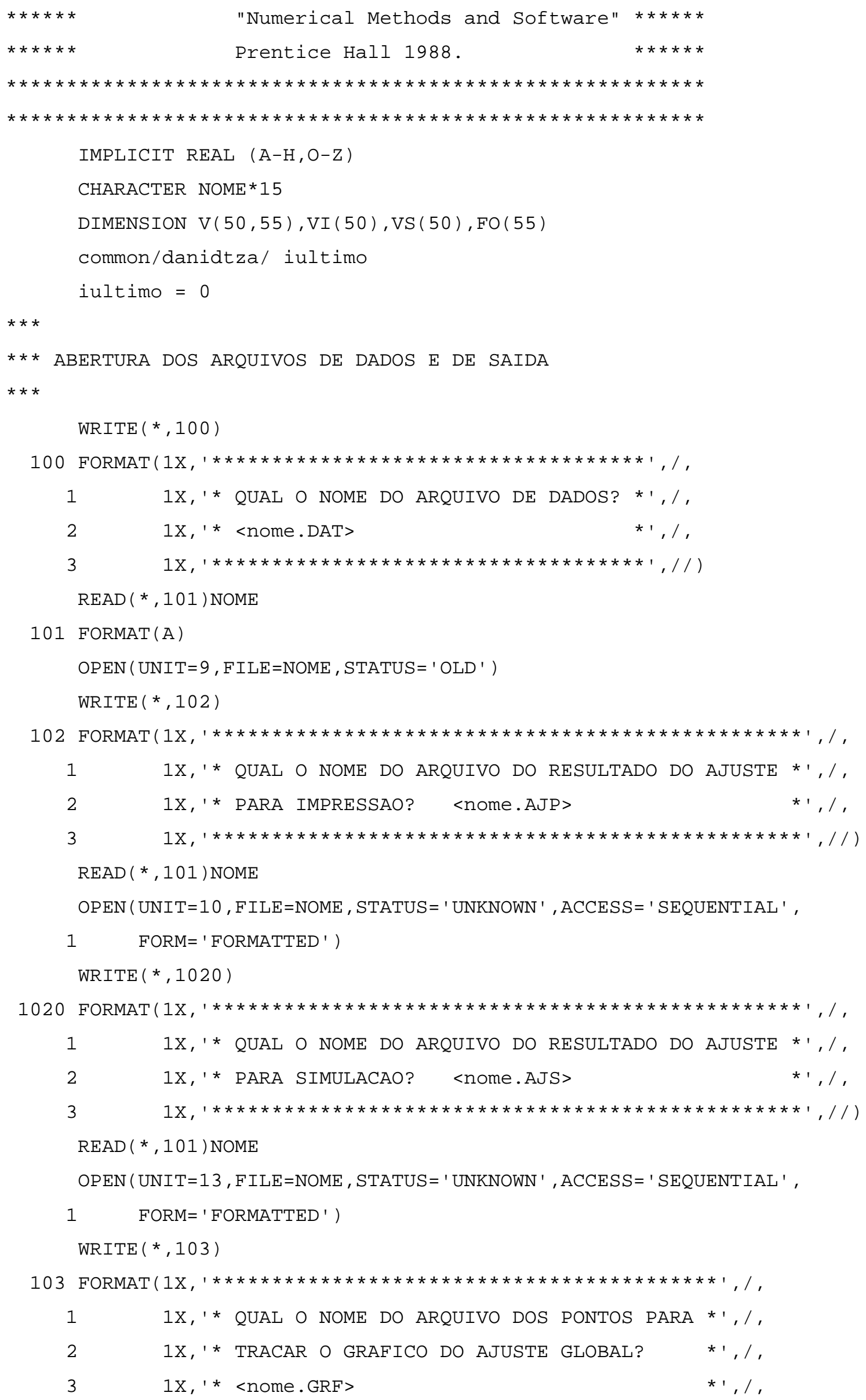




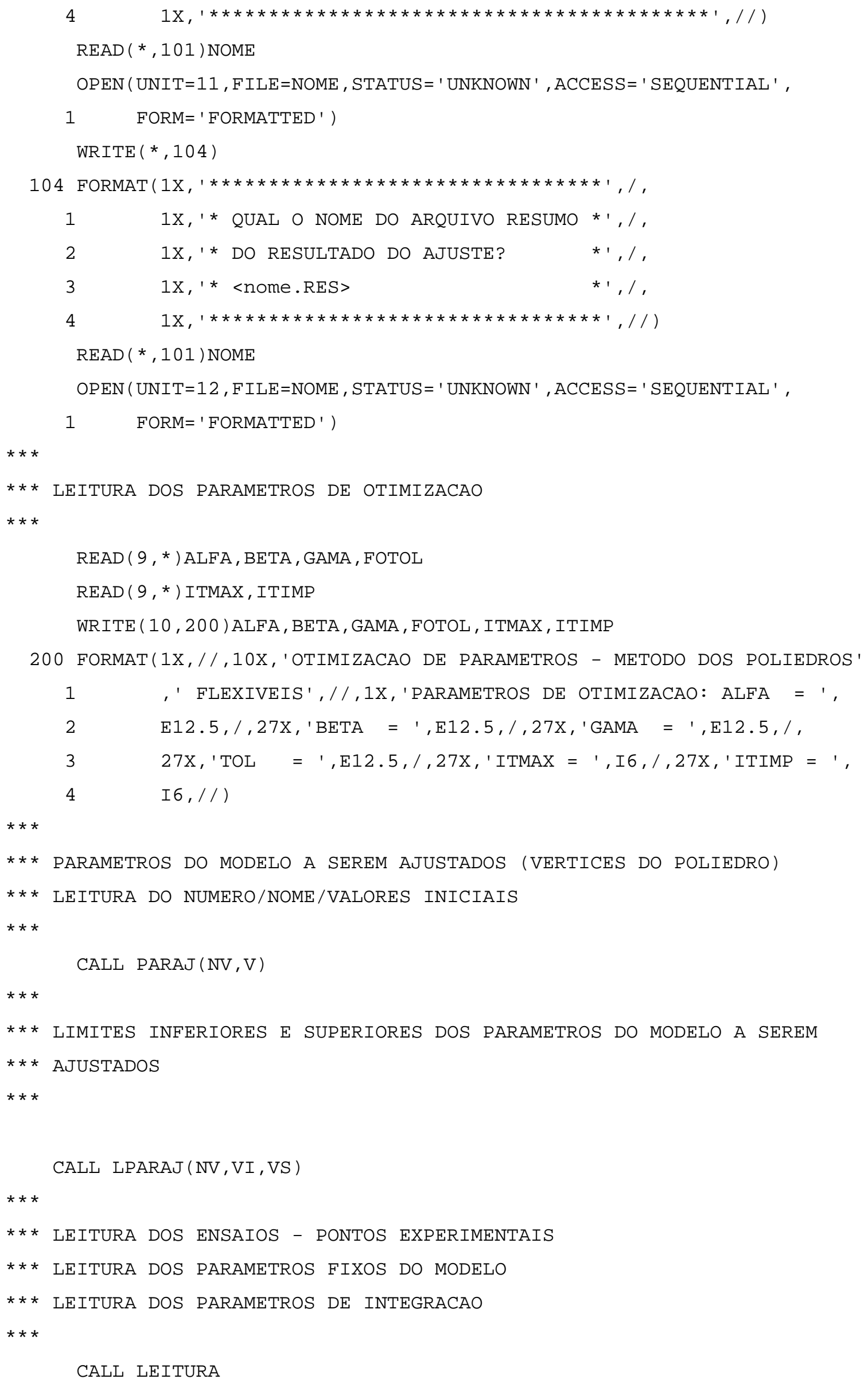




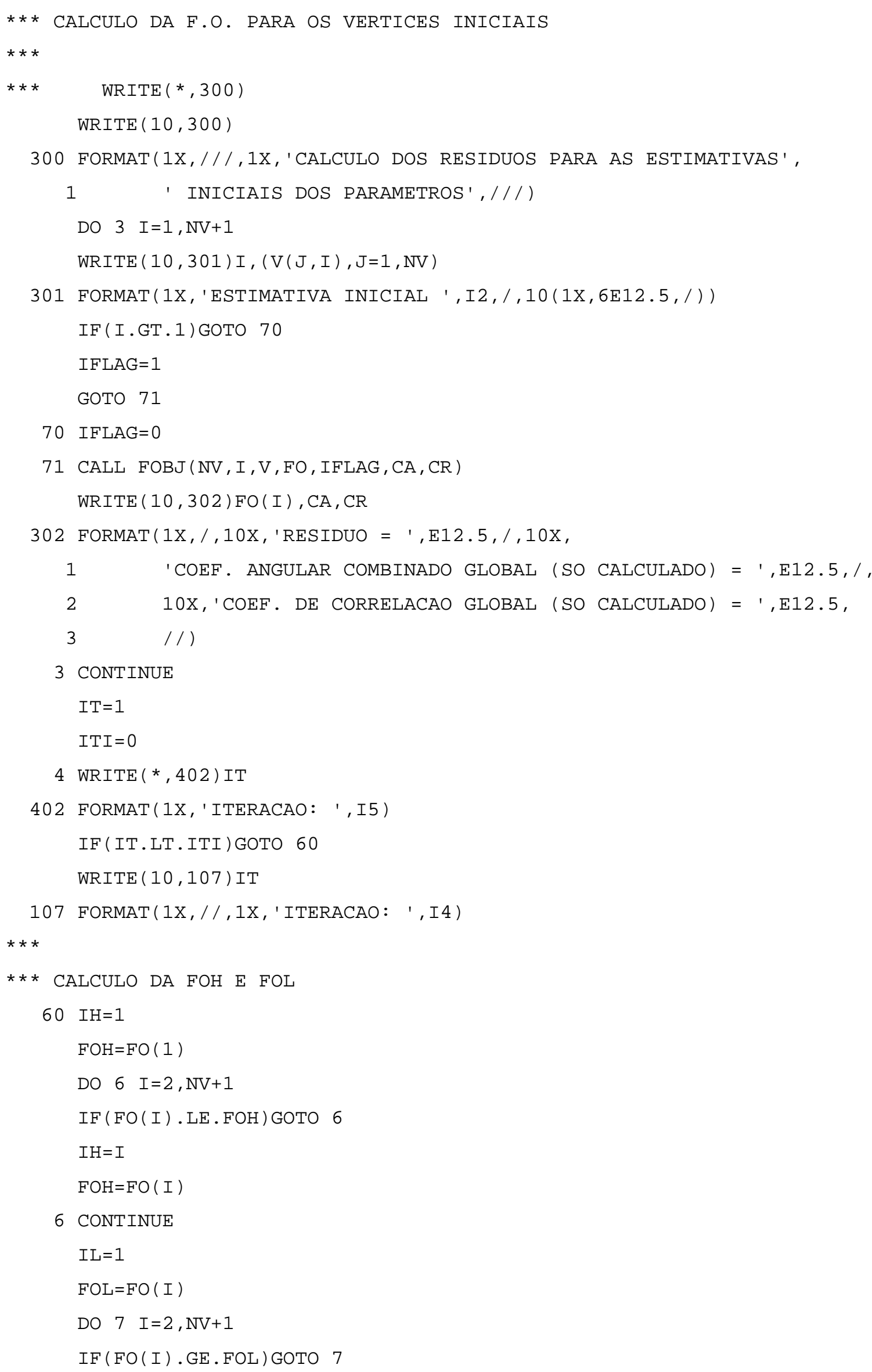




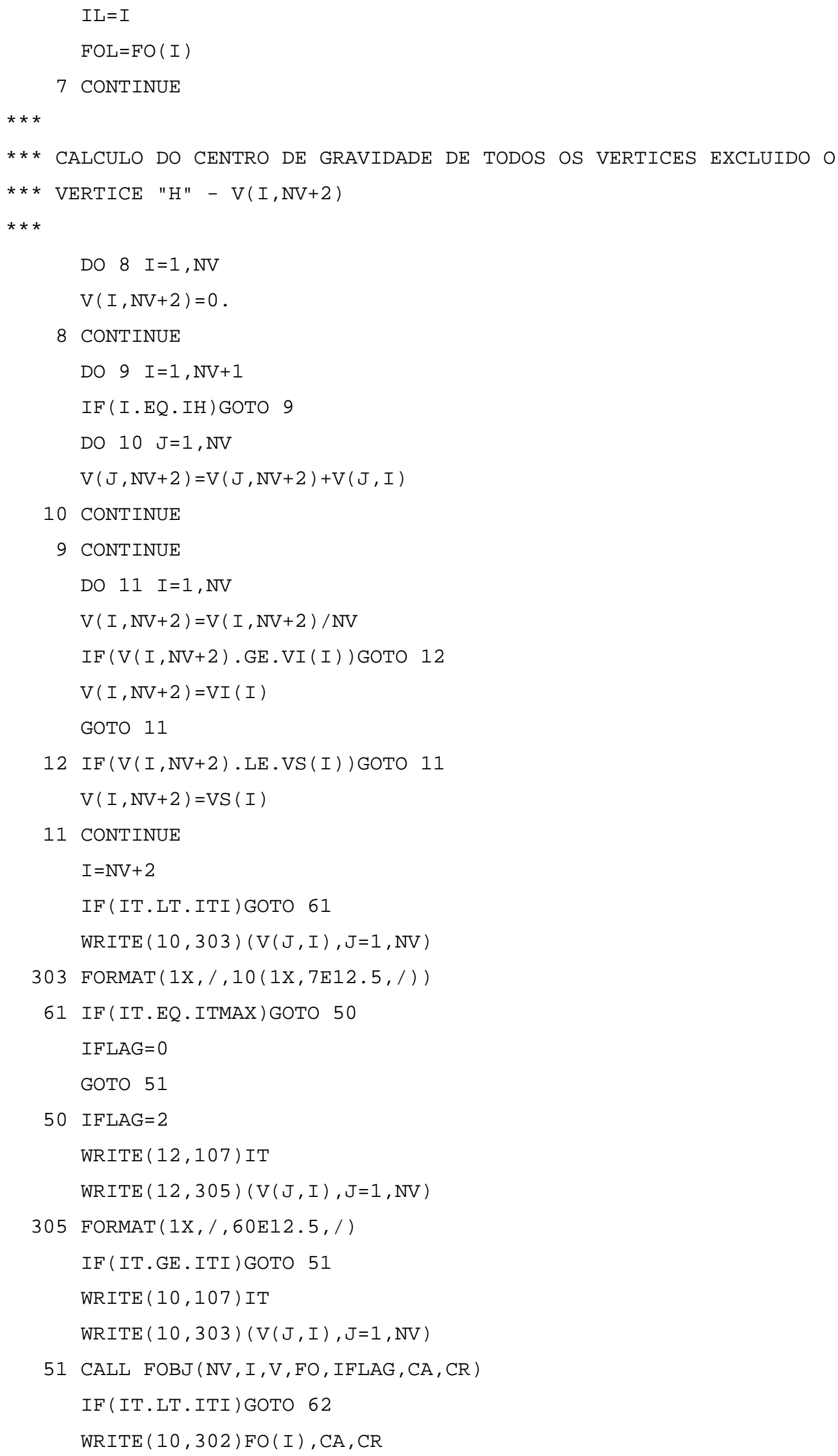




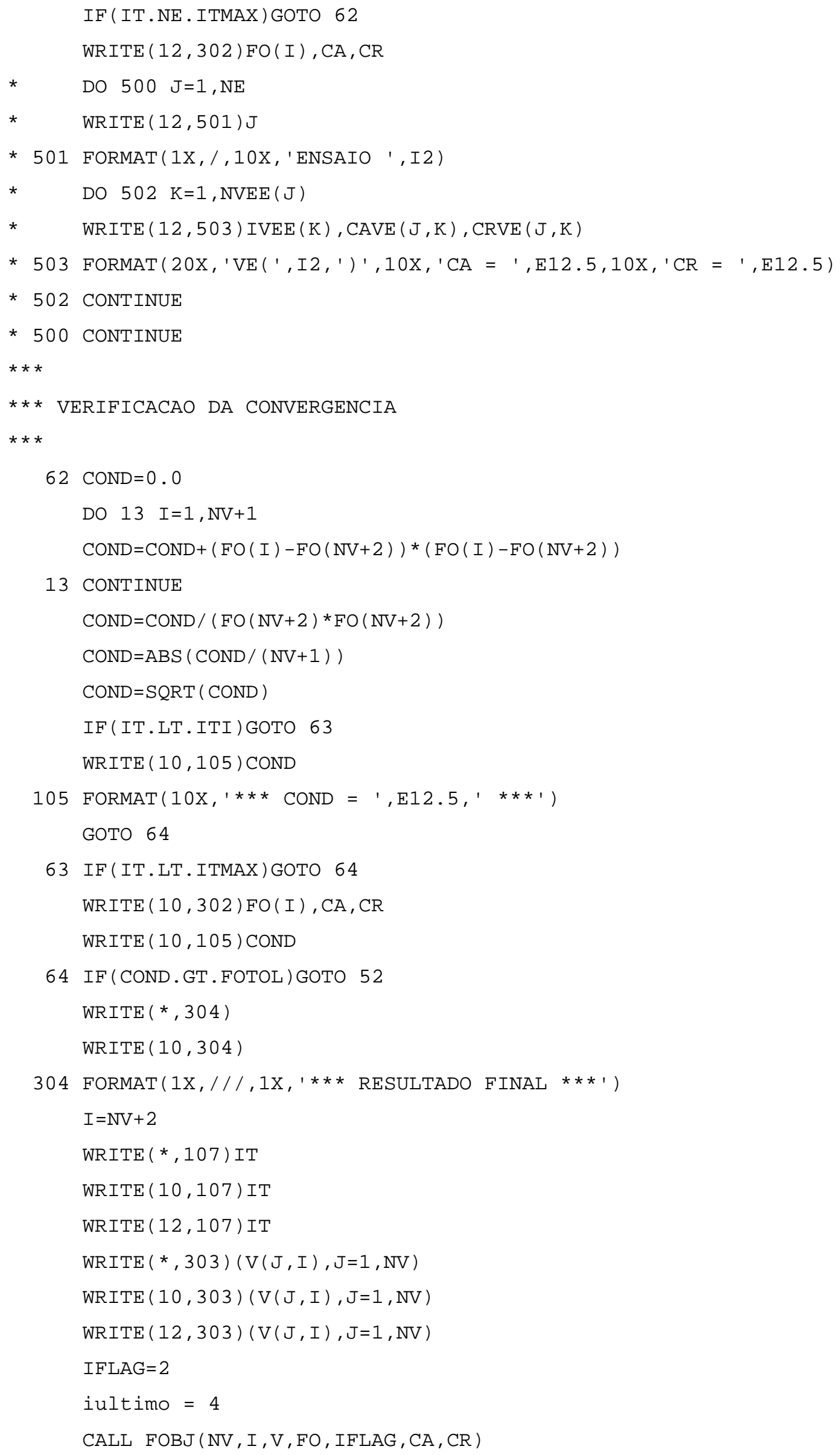




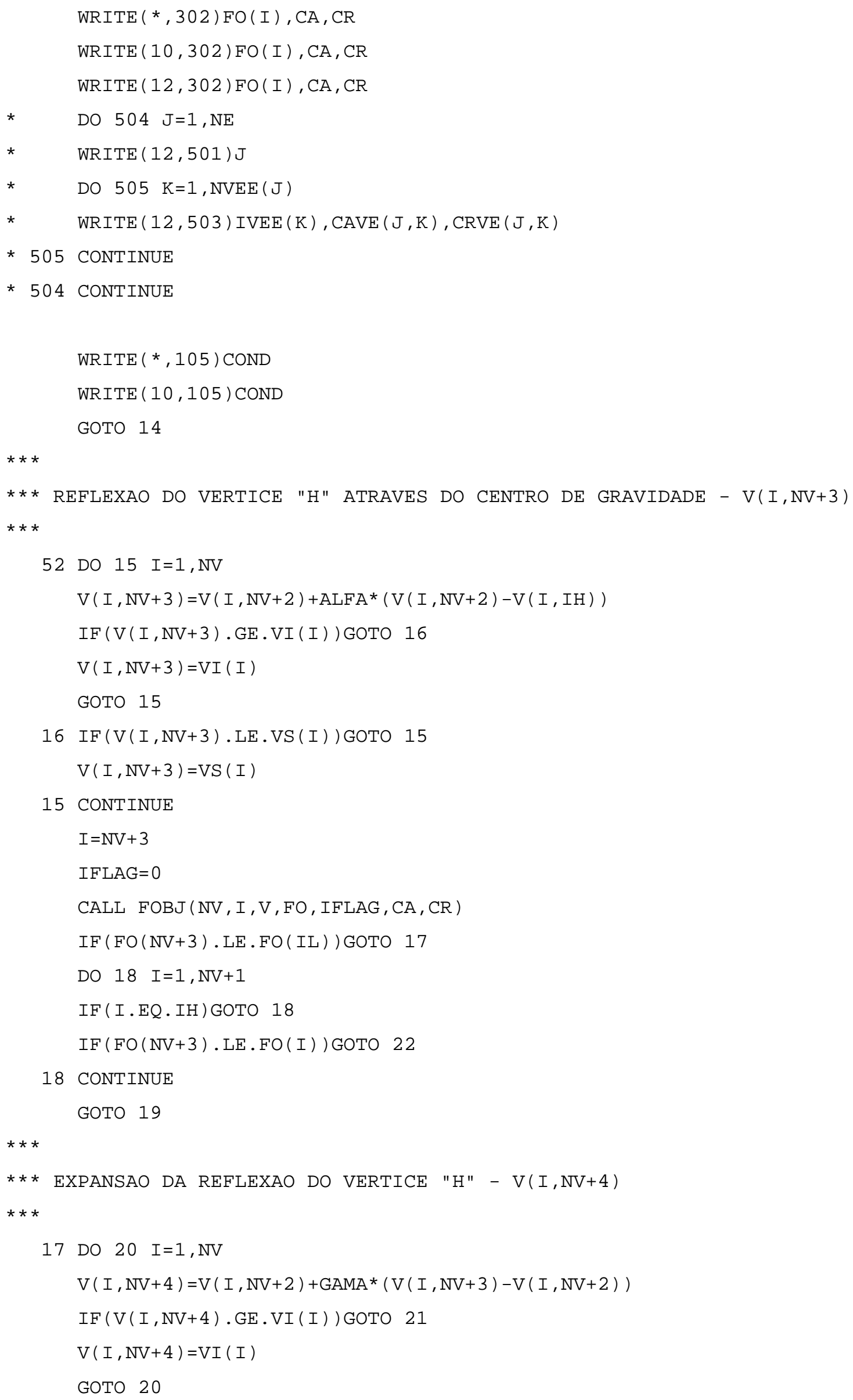


$21 \operatorname{IF}(V(I, N V+4) . L E . V S(I))$ GOTO 20

$\mathrm{V}(\mathrm{I}, \mathrm{NV}+4)=\mathrm{VS}(\mathrm{I})$

20 CONTINUE

$\mathrm{I}=\mathrm{NV}+4$

IFLAG $=0$

CALL FOBJ (NV, I, V, FO, IFLAG, CA, CR)

$\operatorname{IF}(\mathrm{FO}(\mathrm{NV}+4), \mathrm{GE} . \mathrm{FO}(\mathrm{NV}+3)) \mathrm{GOTO} 22$

* Substituicao do Vertice $V(I$, IH $)$ Pelo Vertice $V(I, N V+4)$

DO $23 \mathrm{I}=1, \mathrm{NV}+1$

IF ( I . NE. IH)GOTO 23

DO $24 \mathrm{~J}=1, \mathrm{NV}$

$\mathrm{V}(\mathrm{J}, \mathrm{I})=\mathrm{V}(\mathrm{J}, \mathrm{NV}+4)$

24 CONTINUE

IFLAG $=0$

CALL FOBJ (NV, I, V, FO, IFLAG, CA, CR)

GOTO 25

23 CONTINUE

GOTO 26

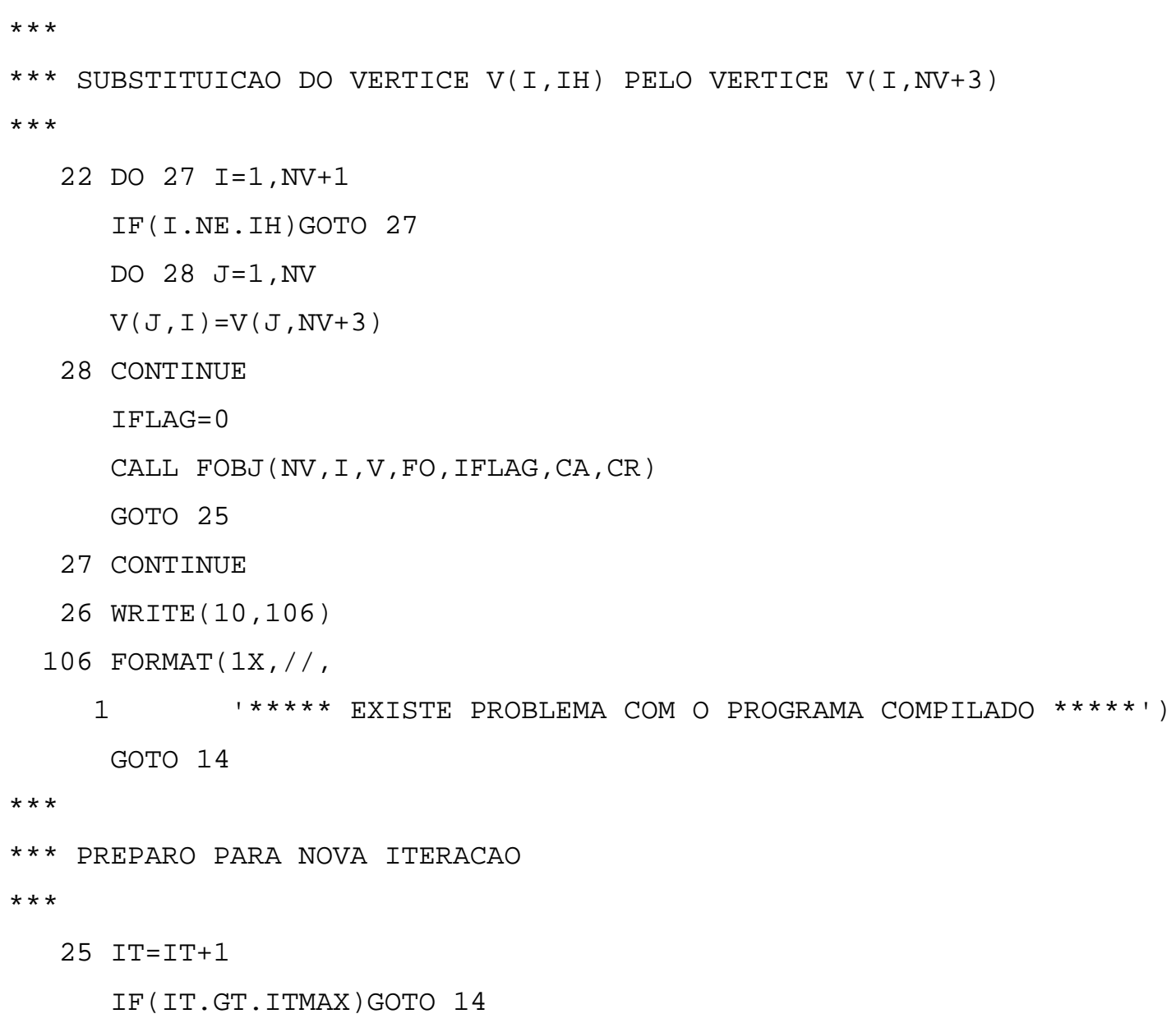




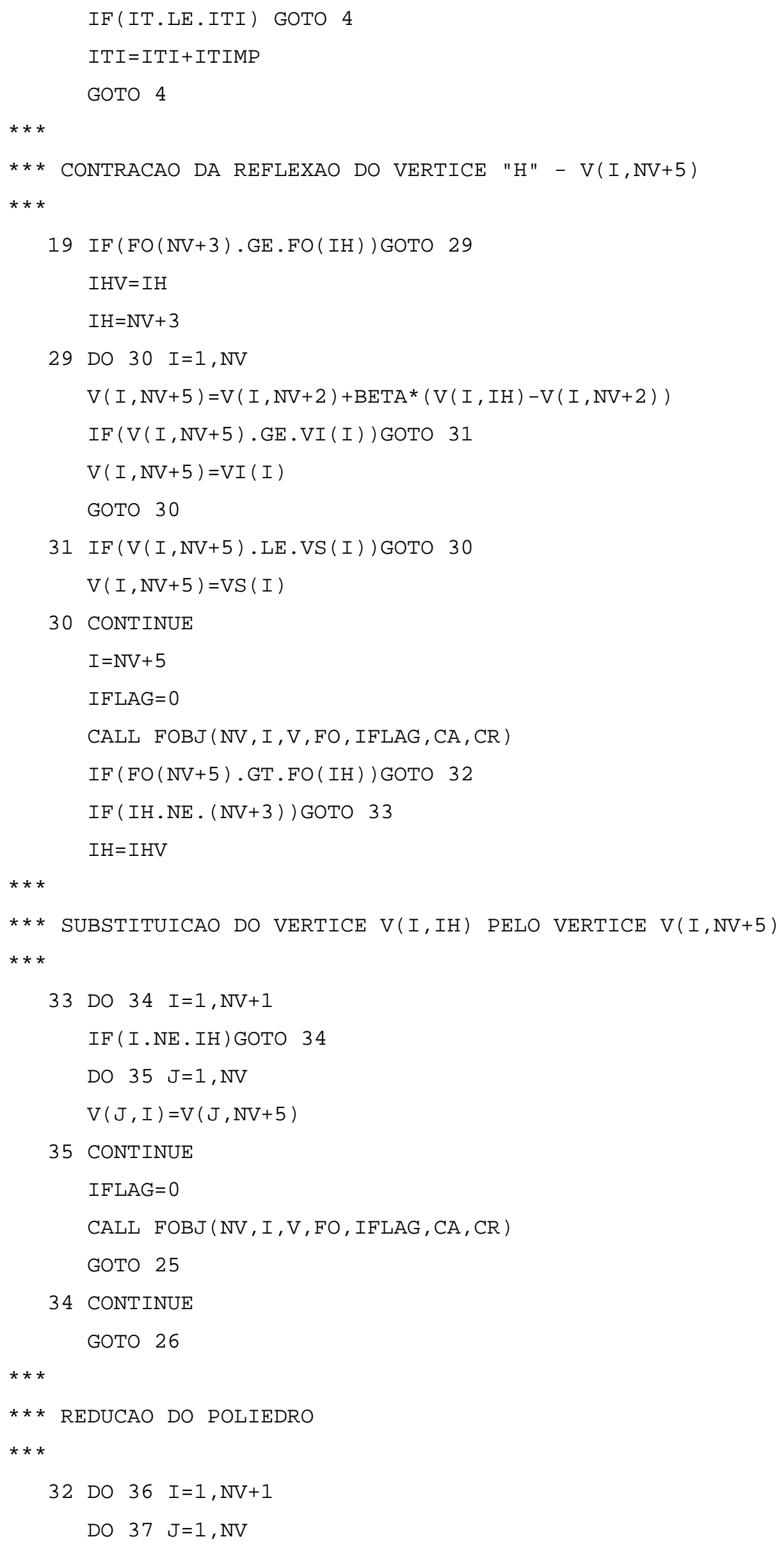




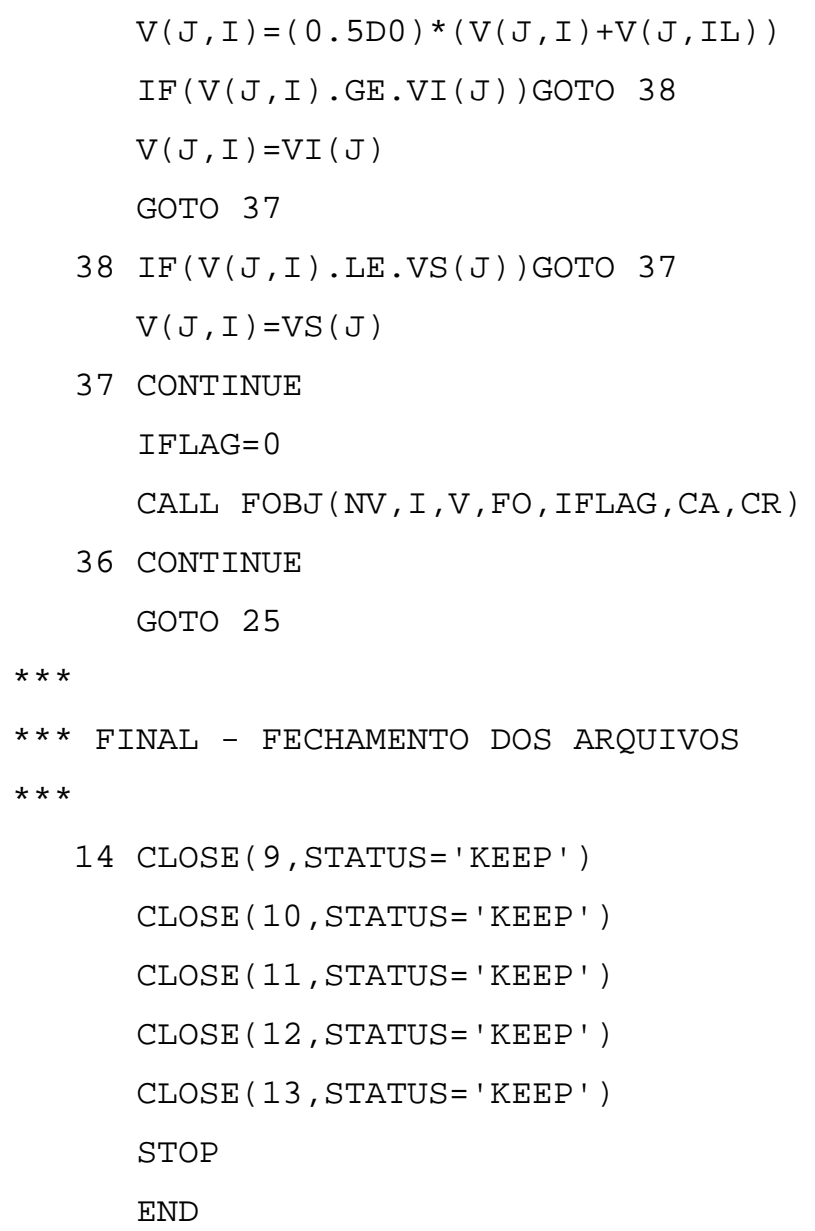

\section{SUBROTINA PARA LEITURA DOS PARAMETROS E VARIAVEIS INICIAIS}

$* * * * * * *$ DO MODELO A SEREM AJUSTADOS (VERTICES DO POLIEDRO) $* * * * * * *$ $* * * * * * * * * * * * * * * * * * * * * * * * * * * * * * * * * * * * * * * * * * * * * * * * * * * * * * * * * * * * * * * * *$

SUBROUTINE PARAJ $(N V, V)$ CHARACTER NOMPAR $(50) * 5$

REAL V $(50,55)$

* NV = NUMERO DE PARAMETROS A SEREM AJUSTADOS

* NOMPAR = NOME DOS PARAMETROS A SEREM AJUSTADOS

* $\mathrm{V}$ = PARAMETROS DO MODELO A SEREM AJUSTAdOS

*

$\operatorname{READ}\left(9,{ }^{*}\right) \mathrm{NV}$

$\operatorname{WRITE}(10,100) \mathrm{NV}$

100 FORMAT( $1 \mathrm{X}$, ' NUMERO DE PARAMETROS A SEREM AJUSTADOS: ', I2, /)

DO $2 \mathrm{I}=1, \mathrm{NV}$

$\operatorname{READ}(9,104) \operatorname{NOMPAR}(\mathrm{I})$

104 FORMAT $(A)$ 
2 CONTINUE

$\operatorname{WRITE}(10,101)(\operatorname{NOMPAR}(\mathrm{I}), \mathrm{I}=1,4)$

101 FORMAT(1X, 'ESTIMATIVA INICIAL DOS PARAMETROS: ' , 4X, 3(A5, 6X), A5)

IF (NV. LE. 4)GOTO 4

DO $3 \mathrm{I}=5, \mathrm{NV}, 4$

$\mathrm{J}=\mathrm{I}+3$

$\operatorname{WRITE}(10,102)$ (NOMPAR $(K), K=I, J)$

102 FORMAT (40X, 3(A5, 6X) , A5)

3 CONTINUE

$4 \mathrm{I}=1$

$\operatorname{READ}\left(9,{ }^{*}\right)(\mathrm{V}(\mathrm{J}, \mathrm{I}), \mathrm{J}=1, \mathrm{NV})$

$\operatorname{WRITE}(10,103)(\mathrm{V}(\mathrm{J}, \mathrm{I}), \mathrm{J}=1, \mathrm{NV})$

103 FORMAT $(1 \mathrm{X}, /, 13(36 \mathrm{X}, 4 \mathrm{E} 11.5, /))$

DO $1 \mathrm{I}=2, \mathrm{NV}+1$

$\operatorname{READ}\left(9,{ }^{*}\right)(\mathrm{V}(\mathrm{J}, \mathrm{I}), \mathrm{J}=1, \mathrm{NV})$

1 CONTINUE

DO $5 \mathrm{I}=2, \mathrm{NV}+1,4$

$\operatorname{WRITE}(10,105) \mathrm{V}(\mathrm{I}-1, \mathrm{I}), \mathrm{V}(\mathrm{I}, \mathrm{I}+1), \mathrm{V}(\mathrm{I}+1, \mathrm{I}+2), \mathrm{V}(\mathrm{I}+2, \mathrm{I}+3)$

105 FORMAT (1X, /, 36X, E11.5, /, 47X,E11.5, /, 58X, E11.5,/,69X, E11.5)

5 CONTINUE

$\operatorname{WRITE}(*, 200)$

200 FORMAT(1X, 'PARAMETROS LIDOS', /)

RETURN

END

SUBROTINA PARA LEITURA DOS LIMITES INFERIORES E SUPERIORES DOS PARAMETROS E VARIAVEIS INICIAIS DO MODELO $* * * * * * * * * *$

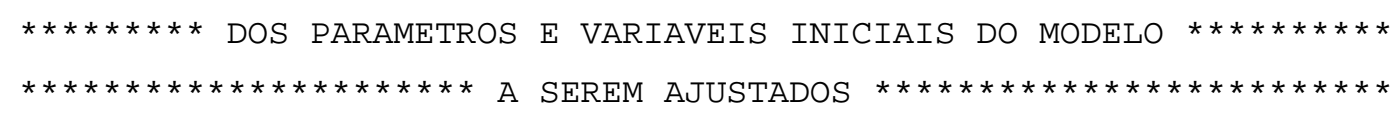

SUBROUTINE LPARAJ(NV, VI, VS)

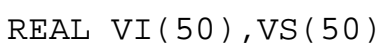

DO $1 \mathrm{I}=1, \mathrm{NV}$

$\operatorname{READ}\left(9,{ }^{*}\right) \operatorname{VI}(\mathrm{I}), \operatorname{VS}(\mathrm{I})$

1 CONTINUE

$\operatorname{WRITE}(10,100)(\mathrm{VI}(\mathrm{J}), \mathrm{J}=1, \mathrm{NV})$

100 FORMAT( $1 \mathrm{X}, /, 1 \mathrm{X}$, 'LIMITE INFERIOR DOS PARAMETROS: ',4E11.5,/, 
$\operatorname{WRITE}(10,101)(\operatorname{VS}(\mathrm{J}), \mathrm{J}=1, \mathrm{NV})$

101 FORMAT( $1 \mathrm{X}, /, 1 \mathrm{X}$, 'LIMITE SUPERIOR DOS PARAMETROS: ',4E11.5, /, 1 $12(36 \mathrm{X}, 4 \mathrm{E} 11.5, / /))$

$\operatorname{WRITE}\left({ }^{*}, 200\right)$

200 FORMAT(1X, 'LIMITE DOS PARAMETROS LIDO',/)

RETURN

END

SUBROTINA PARA LEITURA DOS ENSAIOS - PONTOS EXPERIMENTAIS

$* * * * * * * * * *$ (MAXIMO DE 40 ENSAIOS COM 40 PONTOS/ENSAIO $* * * * * * * * * * *$

E COM NO MAXIMO 20 VARIAVEIS OPERACIONAIS FIXAS,

20 VARIAVEIS OPERACIONAIS VARIAVEIS

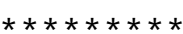

(NUM TOTAL MAXIMO DE 20 VARIAVEIS OPERACIONAIS)

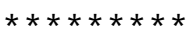

E 15 VARIAVEIS DE ESTADO)

$\star \star \star \star * \star * \star *$

50 PARAMETROS FiXOS dO MODELO

(PARA UM TOTAL MAXIMO DE 60 PARAMETROS)

10 VARIAVEIS DE ESTADO INICIAIS AJUSTAVEIS $* * * * * * * * * * * * *$

LEITURA DOS PARAMETROS DE INTEGRACAO

SUBROUTINE LEITURA

IMPLICIT REAL (A-H, O-Z)

CHARACTER NOMEVO $(20) * 4, \operatorname{NOMEVE}(15) * 4, \operatorname{NOMPAF}(50)$ * 5

DIMENSION IPARF(50), PARF(50), $\operatorname{VEL}(15), \operatorname{VOVL}(20)$

COMMON PAR(60), $\operatorname{VOA}(20), \mathrm{J}$

COMMON NE, NVEE $(40), \operatorname{IVEE}(40,15)$

COMMON IPARV (50), NPARF, NVO

COMMON NPARAJ, NVEAJ, IVEAJ (10)

COMMON NVOF $(40), \operatorname{IVOF}(40,20), \operatorname{VOF}(40,20)$

COMMON VO(40,40,20), NPE(40), $\operatorname{NVOV}(40), \operatorname{IVOV}(40,20), \operatorname{VEEM}(40,15)$,

$1 \operatorname{TE}(4 \odot, 4 \odot), \operatorname{VEE}(4 \odot, 4 \odot, 15), \operatorname{T\odot }(4 \odot), \operatorname{VE} \odot(4 \odot, 15), \operatorname{Vem} \operatorname{Vin}(40,15)$

COMMON MSTATE, EPS, EWT, MSTATEA

Common/barral/VEEINI $(40,15)$, NENSCONT, $\operatorname{VOFIX}(40,20)$, IBAN

no. de parâmetros ajustáveis e variáveis de estado ajustáveis 
$\operatorname{READ}\left(9,{ }^{*}\right)$ NPARAJ, NVEAJ

$* * * * * * * *$ índice de parâmetros ajustáveis e var. de estado ajustáveis $\operatorname{READ}\left(9,{ }^{*}\right)(\operatorname{IPARV}(\mathrm{I}), \mathrm{I}=1, \operatorname{NPARAJ})$

IF (NVEAJ.EQ. $\odot)$ GOTO 50

$* * * * * * * *$ índice de parâmetros de variáveis de estado ajustáveis

$\operatorname{READ}\left(9,{ }^{*}\right)(\operatorname{IVEAJ}(\mathrm{I}), \mathrm{I}=1, \operatorname{NVEAJ})$

$* * * * * * * * \quad$ numero de parâmetros fixos

$50 \operatorname{READ}\left(9,{ }^{*}\right) \mathrm{NPARF}$

IF(NPARF.EQ.๑)GOTO 1111

$\operatorname{READ}\left(9,{ }^{\star}\right)(\operatorname{IPARF}(\mathrm{I}), \mathrm{I}=1, \mathrm{NPARF})$

DO $1 \mathrm{I}=1$, NPARF

$\operatorname{READ}(9,100) \operatorname{NOMPAF}(\mathrm{I})$

$100 \quad$ FORMAT $(A)$

1 CONTINUE

IF (NPARF . GT . 4)GOTO 2

$\operatorname{WRITE}(10,101)(\operatorname{NOMPAF}(\mathrm{I}), \mathrm{I}=1, \mathrm{NPARF})$

101 FORMAT( $1 \mathrm{X}, / /, 1 \mathrm{X}$, 'PARAMETROS FIXOS DO MODELO: ' , 3X, 3(A5, 8X) , A5)

GOTO 3

$2 \operatorname{WRITE}(10,101)(\operatorname{NOMPAF}(\mathrm{I}), \mathrm{I}=1,4)$

$\operatorname{WRITE}(10,102)$ (NOMPAF ( I ), I=5, NPARF)

102 FORMAT $(12(24 \mathrm{X}, 4 \mathrm{~A} 13, /))$

$3 \operatorname{READ}\left(9,{ }^{*}\right)(\operatorname{PARF}(\mathrm{I}), \mathrm{I}=1, \mathrm{NPARF})$

$\operatorname{WRITE}(10,103)(\operatorname{PARF}(\mathrm{I}), \mathrm{I}=1, \mathrm{NPARF})$

103 FORMAT (13(26X, 4E13.5, / ) )

$\mathrm{J}=1$

DO $4 \mathrm{I}=1,60$

$\operatorname{IF}($ I . NE. IPARF ( J ) ) GOTO 4

$\operatorname{PAR}(\mathrm{I})=\operatorname{PARF}(\mathrm{J})$

$\mathrm{J}=\mathrm{J}+1$

4 CONTINUE

$1111 \operatorname{READ}\left(9,{ }^{*}\right) \mathrm{NVE}, \mathrm{NVO}$

DO $5 \mathrm{I}=1, \mathrm{NVE}$

$\operatorname{READ}(9,100) \operatorname{NOMEVE}(\mathrm{I})$

5 CONTINUE

$\operatorname{WRITE}(10,104) \operatorname{NOMEVE}(1)$

104 FORMAT $\left(1 \mathrm{X}, / /, 1 \mathrm{X}\right.$, 'VARIAVEIS DE ESTAdo: $\left.\operatorname{VE}(1)={ }^{\prime}, \mathrm{A} 4\right)$

DO $6 \mathrm{I}=2, \mathrm{NVE}$

$\operatorname{WRITE}(10,105)$ I, NOMEVE (I)

$105 \operatorname{FORMAT}\left(22 \mathrm{X}, \operatorname{VE}\left({ }^{\prime}, \mathrm{I} 2,{ }^{\prime}\right)=\right.$ ', A4 $)$

6 CONTINUE 


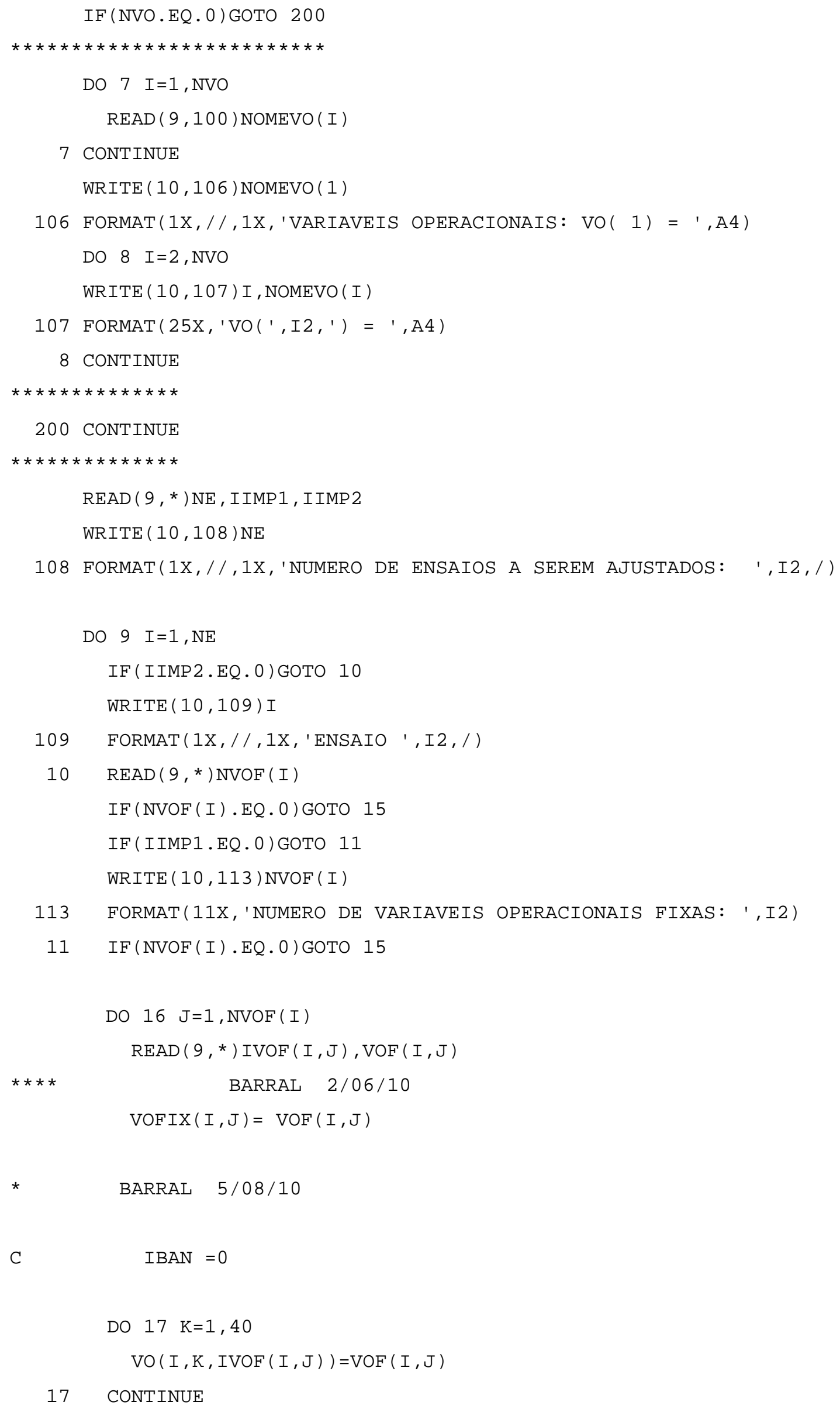

CONTINUE 


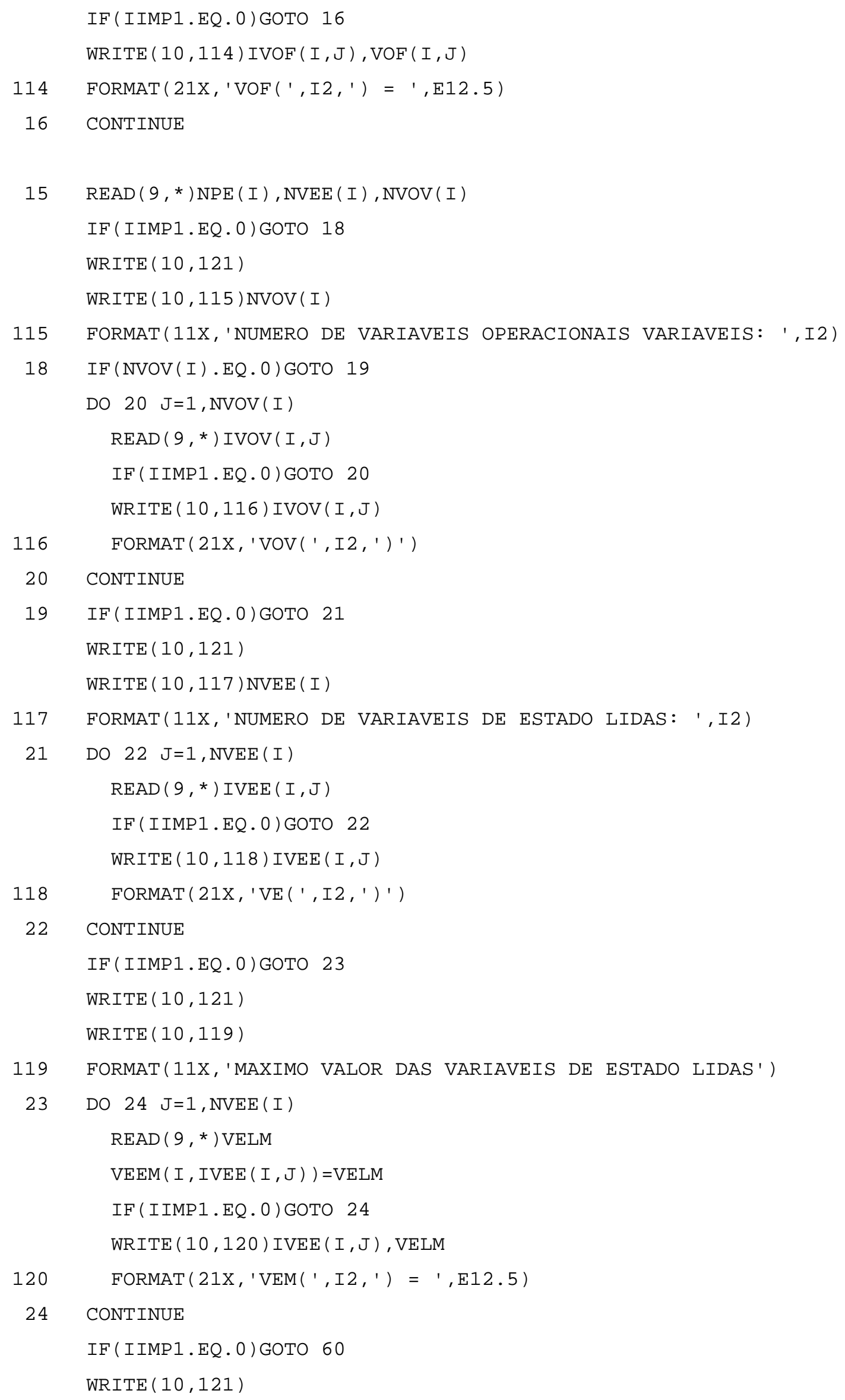




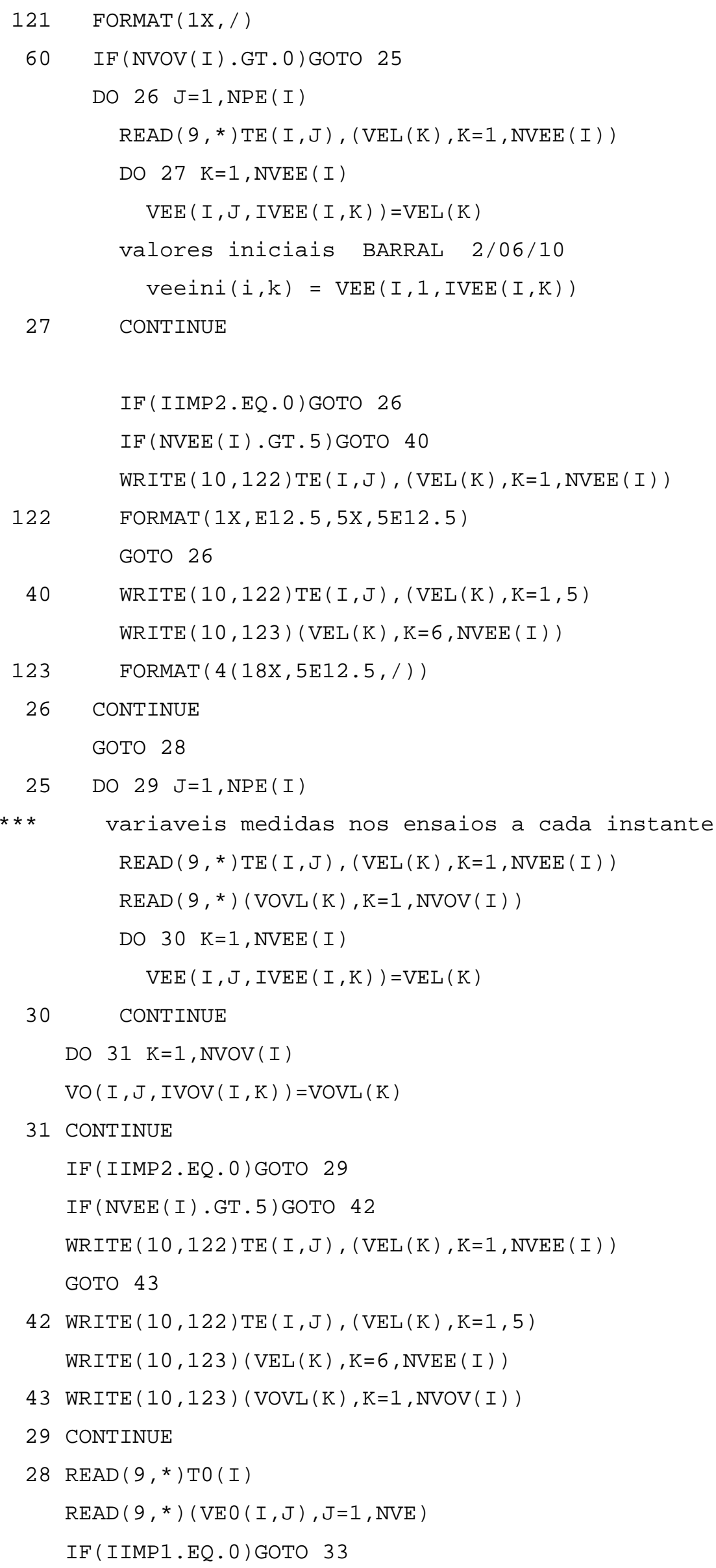




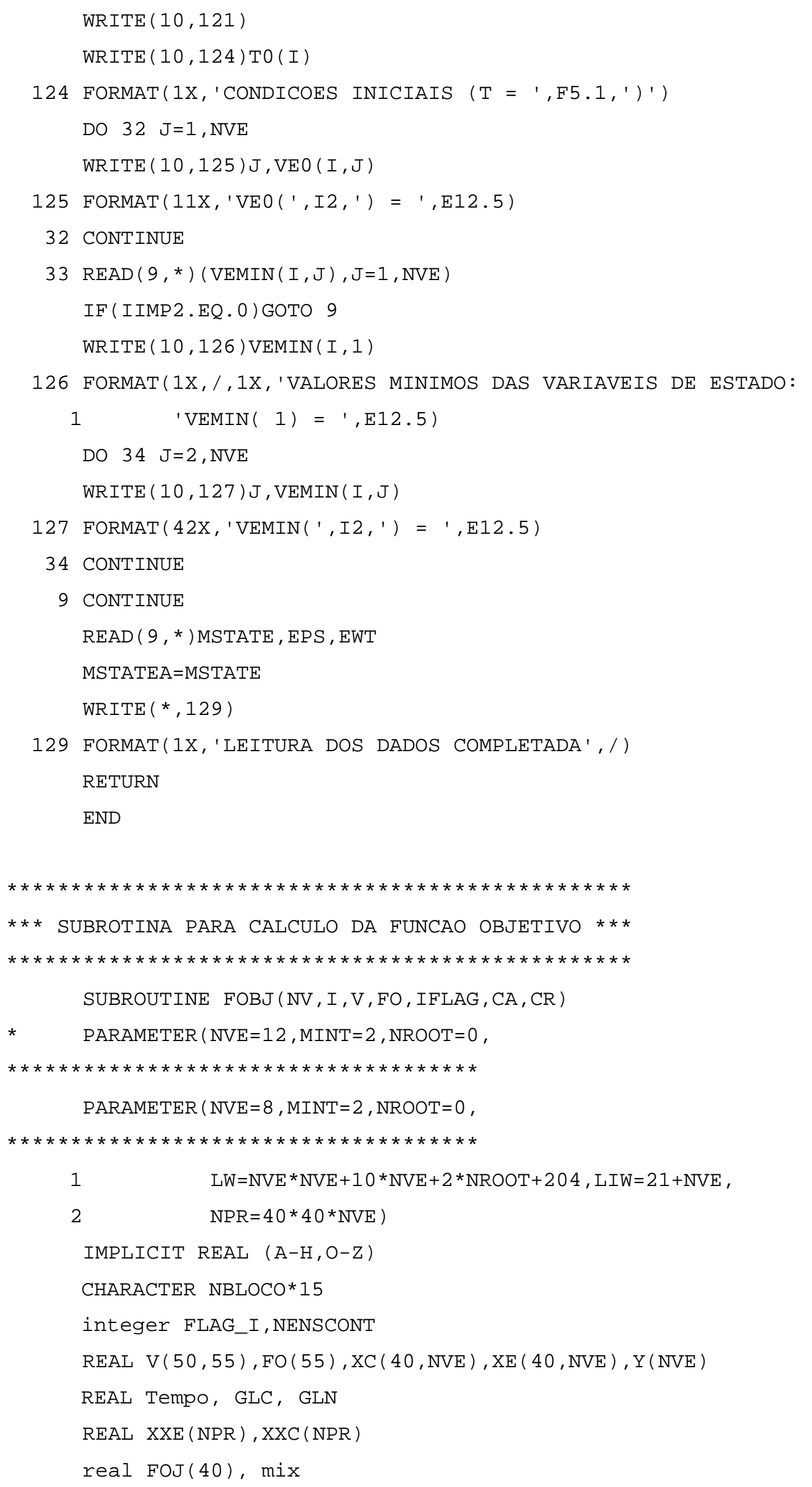

IMPLICIT REAL (A-H, O-Z)

CHARACTER NBLOCO $* 15$

integer FLAG_I, NENSCONT

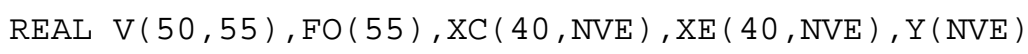

REAL Tempo, GLC, GLN

REAL XXE(NPR), XXC(NPR)

real $F 0 J(40), \operatorname{mix}$ 


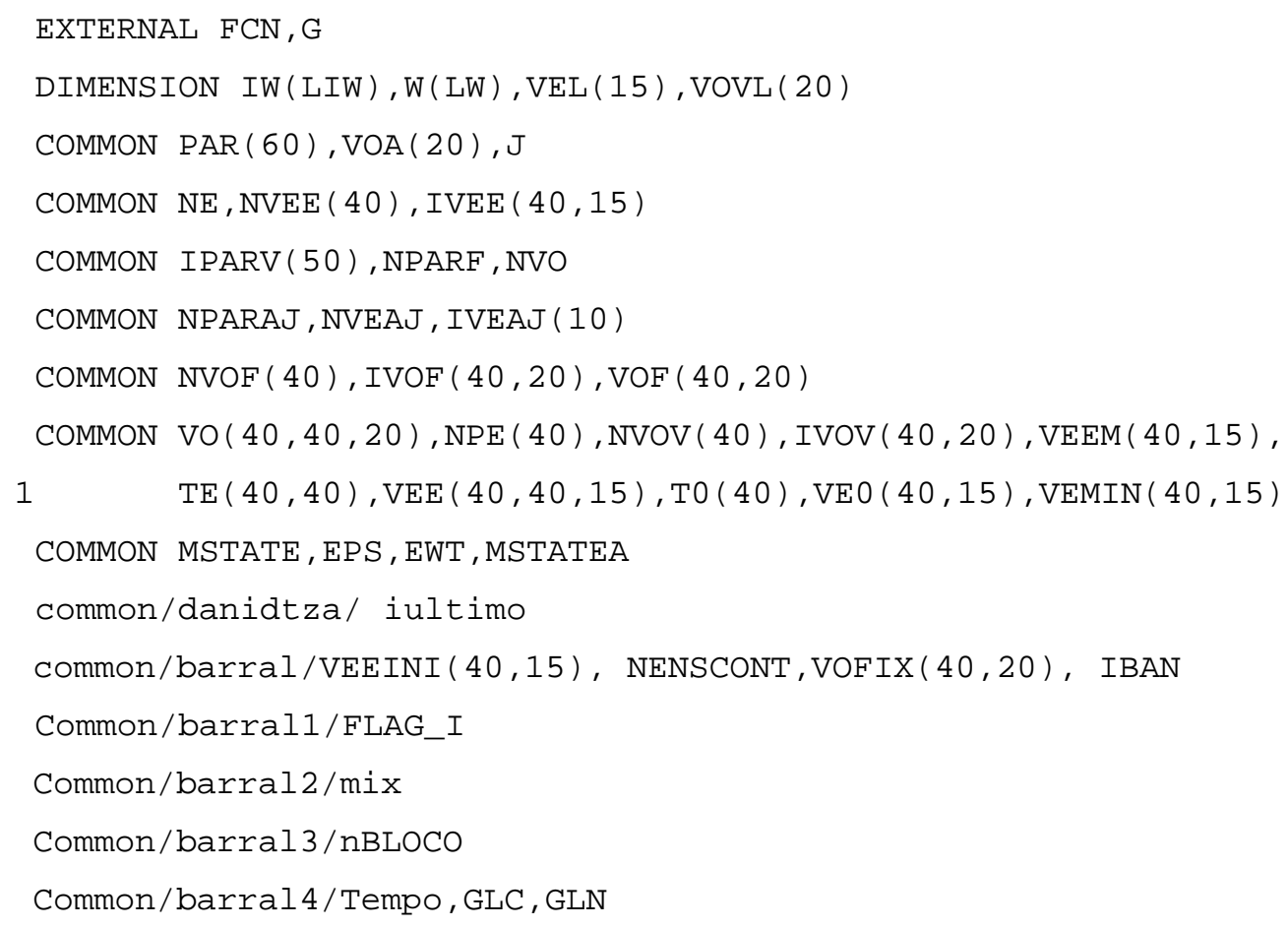




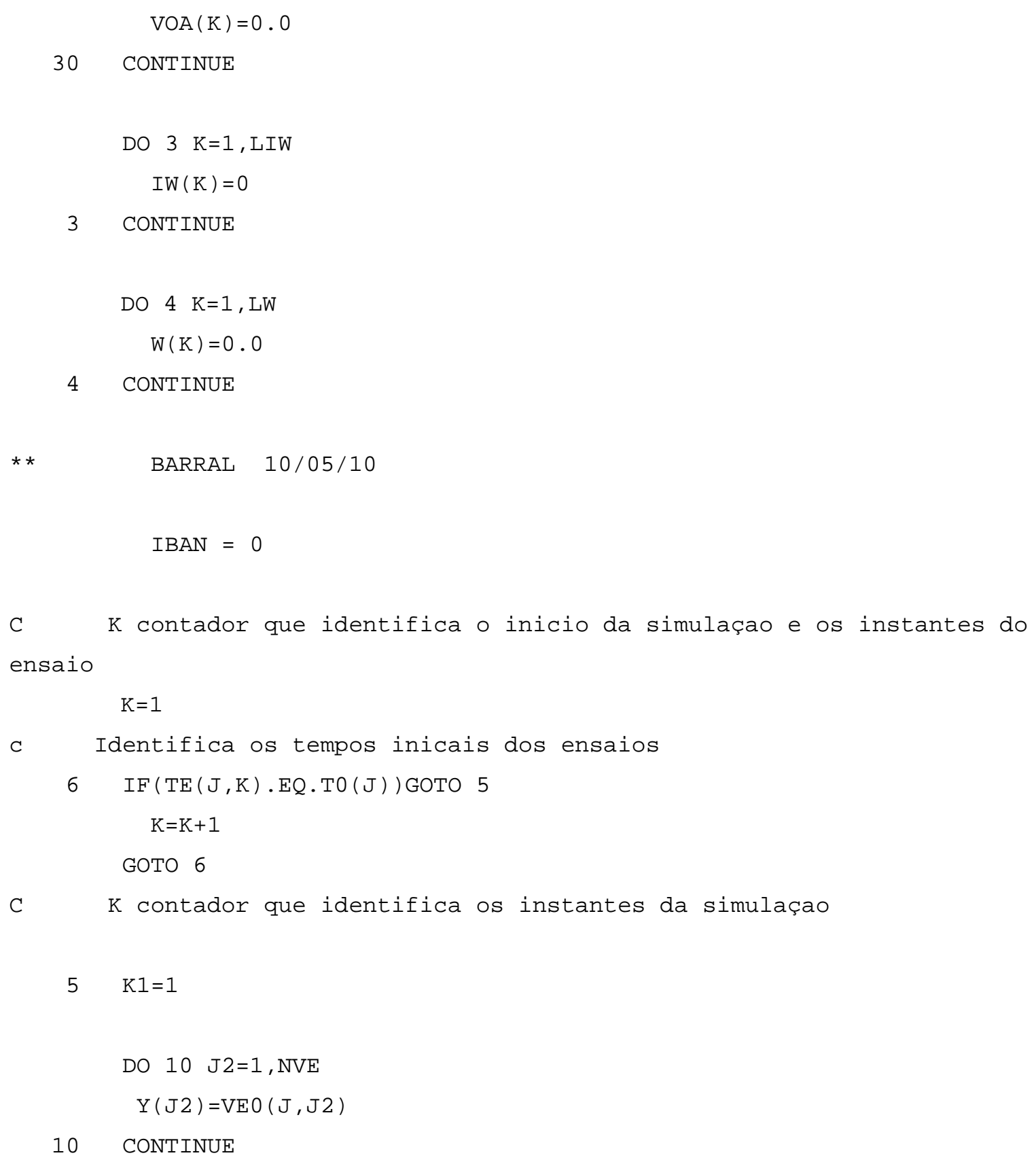




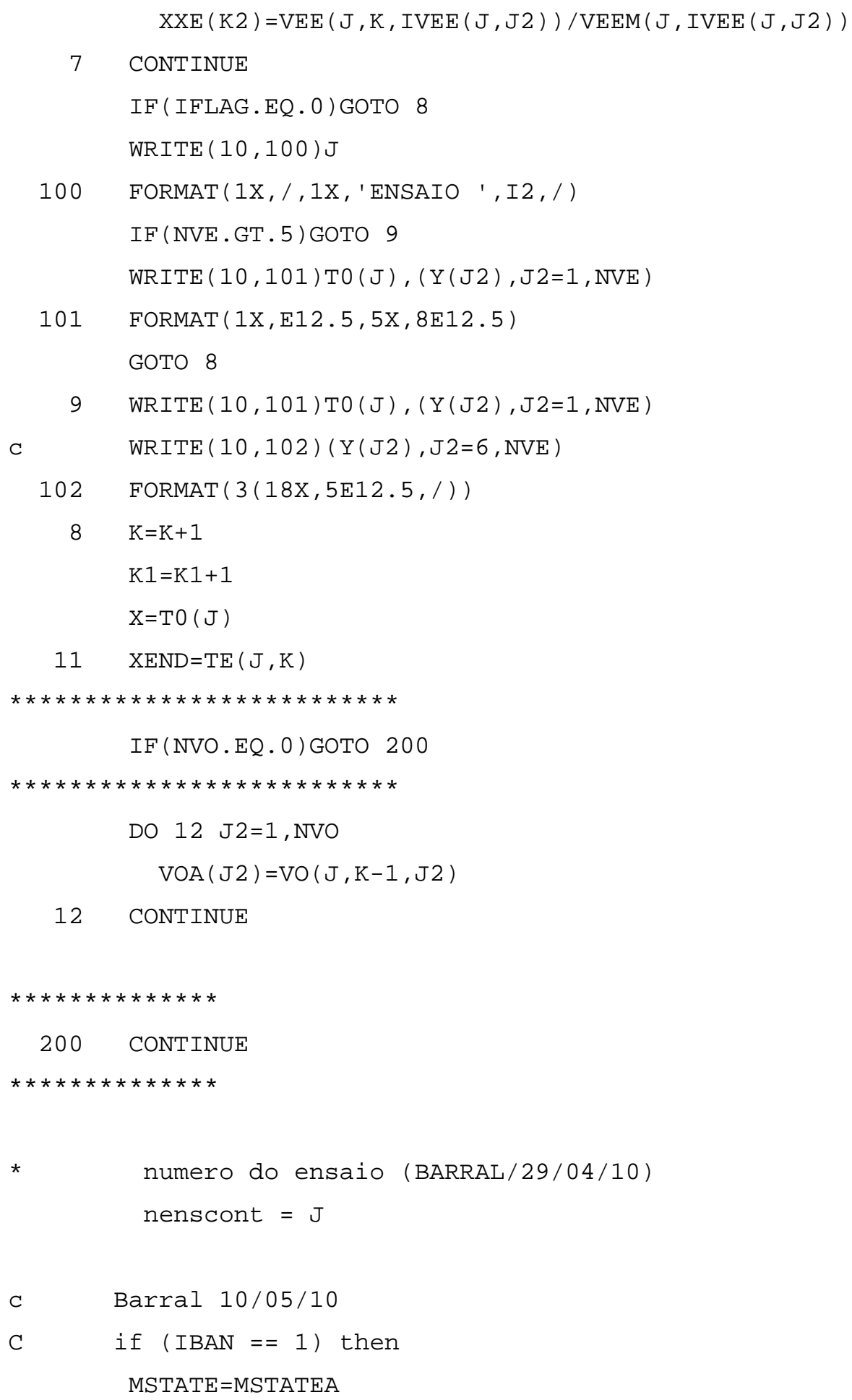


IND $=\odot$

DO $14 \mathrm{~J} 2=1, \operatorname{NVEE}(\mathrm{J})$

$\operatorname{IF}(\operatorname{VEE}(\mathrm{J}, \mathrm{K}, \operatorname{IVEE}(\mathrm{J}, \mathrm{J} 2))$. GE . ๑ . ๑) GOTO 14

IND $=$ IND +1

14 CONTINUE

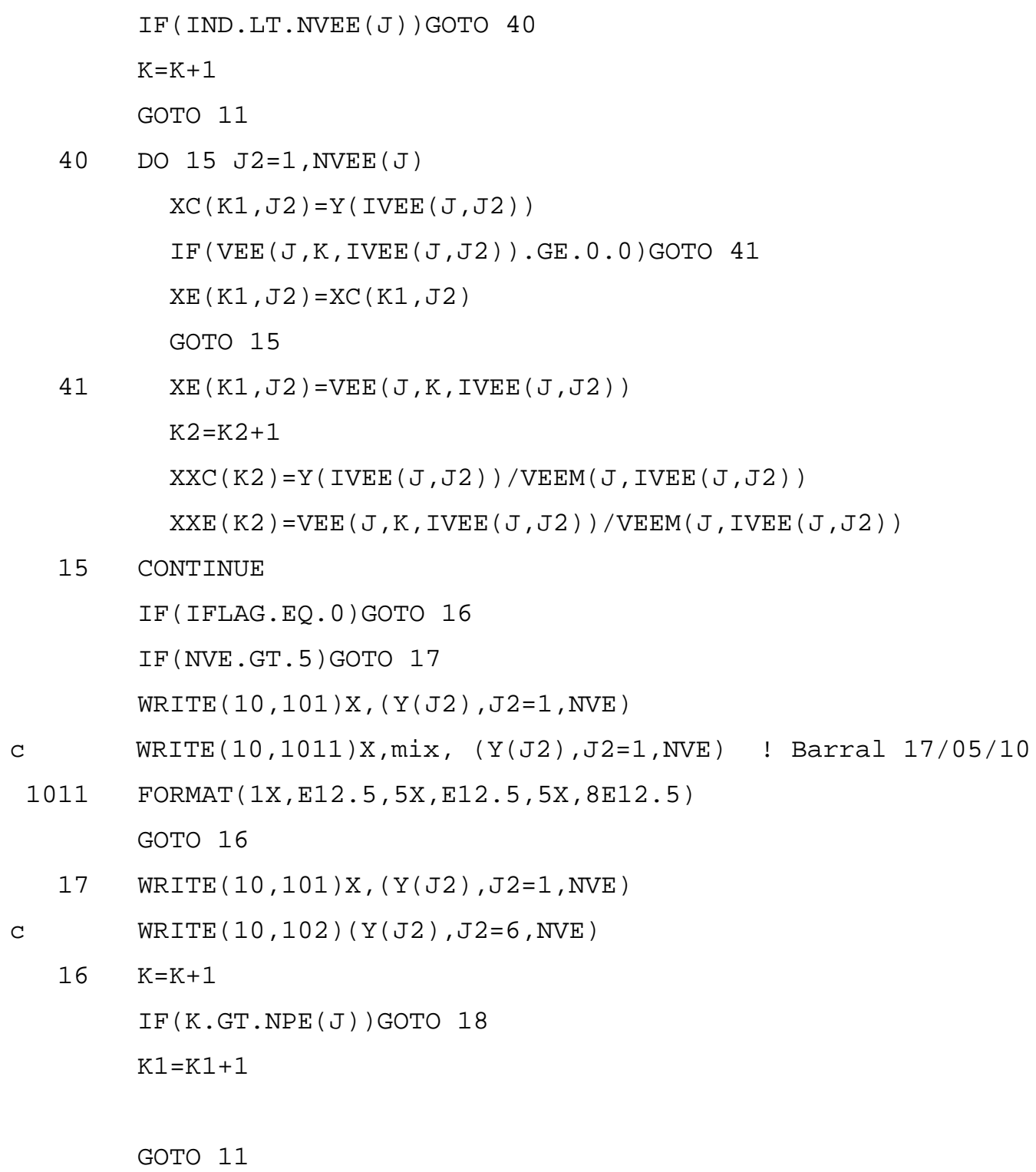




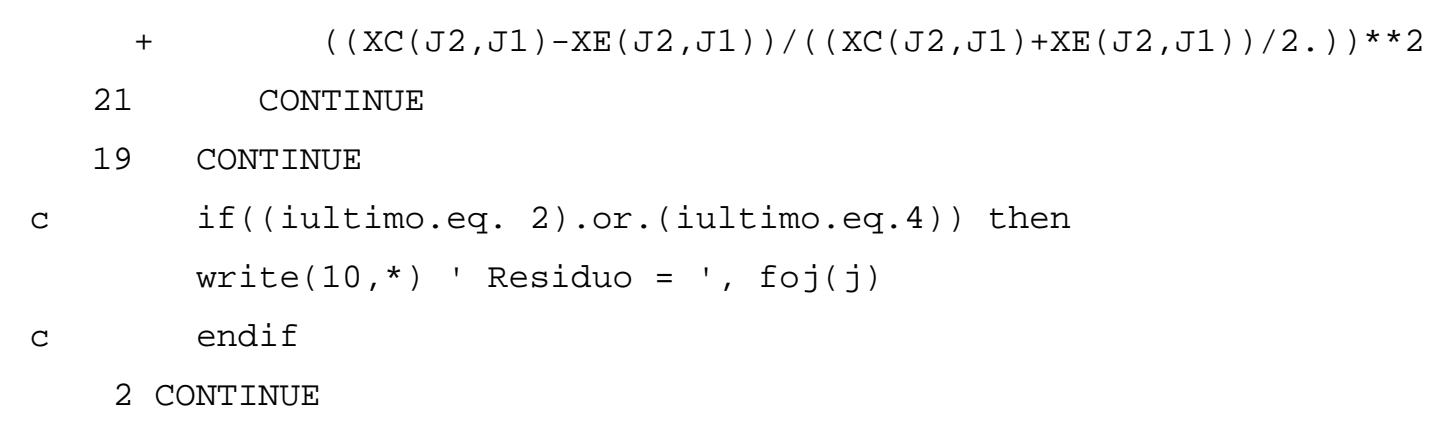

$S X=0 . \odot$

$S Y=\odot . \odot$

$S X Y=0.0$

$S X 2=0.0$

$\mathrm{SY} 2=0 . \odot$

D0 $23 \mathrm{~J} 1=1, \mathrm{~K} 2$

$\mathrm{SX}=\mathrm{SX}+\mathrm{XXE}(\mathrm{J} 1)$

$\mathrm{SY}=\mathrm{SY}+\mathrm{XXC}(\mathrm{J} 1)$

$\mathrm{SXY}=\mathrm{SXY}+\mathrm{XXE}(\mathrm{J} 1){ }^{*} \mathrm{XXC}(\mathrm{J} 1)$

$\mathrm{SX} 2=\mathrm{SX} 2+\mathrm{XXE}(\mathrm{J} 1) * X X E(\mathrm{~J} 1)$

$\mathrm{SY} 2=\mathrm{SY} 2+\mathrm{XXC}(\mathrm{J} 1){ }^{*} \mathrm{XXC}(\mathrm{J} 1)$

IF (SX2 . NE . ०.०)GOTO 231

$\mathrm{SX} 2=\odot \cdot 1 \mathrm{E}-\odot 6$

$S X=\odot .1 E-06$

231 IF (SY2.NE.๑.๑)GOTO 23

SY $2=0.1 \mathrm{E}-06$

$S Y=0.1 E-06$

23 CONTINUE

$\mathrm{CA}=\mathrm{SXY} / \mathrm{SX} 2$

$A U X=\left(K 2 * S X 2-S X{ }^{*} S X\right) *(K 2 * S Y 2-S Y * S Y)$

IF (AUX.GT. . . $)$ GOTO 51

$A U X=\odot .1 E-06$

$51 \mathrm{CR}=(\mathrm{K} 2 * \mathrm{SXY}-\mathrm{SX} * \mathrm{SY}) / \mathrm{SQRT}(\mathrm{AUX})$

IF (IFLAG . NE . 2) GOTO 24

$\operatorname{WRITE}(11,103) \mathrm{K} 2$

103 FORMAT $(1 X, I 5)$

DO $25 \mathrm{~J}=1, \mathrm{~K} 2$

$\operatorname{WRITE}(11,104) \operatorname{XXE}(\mathrm{J}), \operatorname{XXC}(\mathrm{J})$

104 FORMAT (1X, 2E12.5)

25 CONTINUE 
GOTO 24

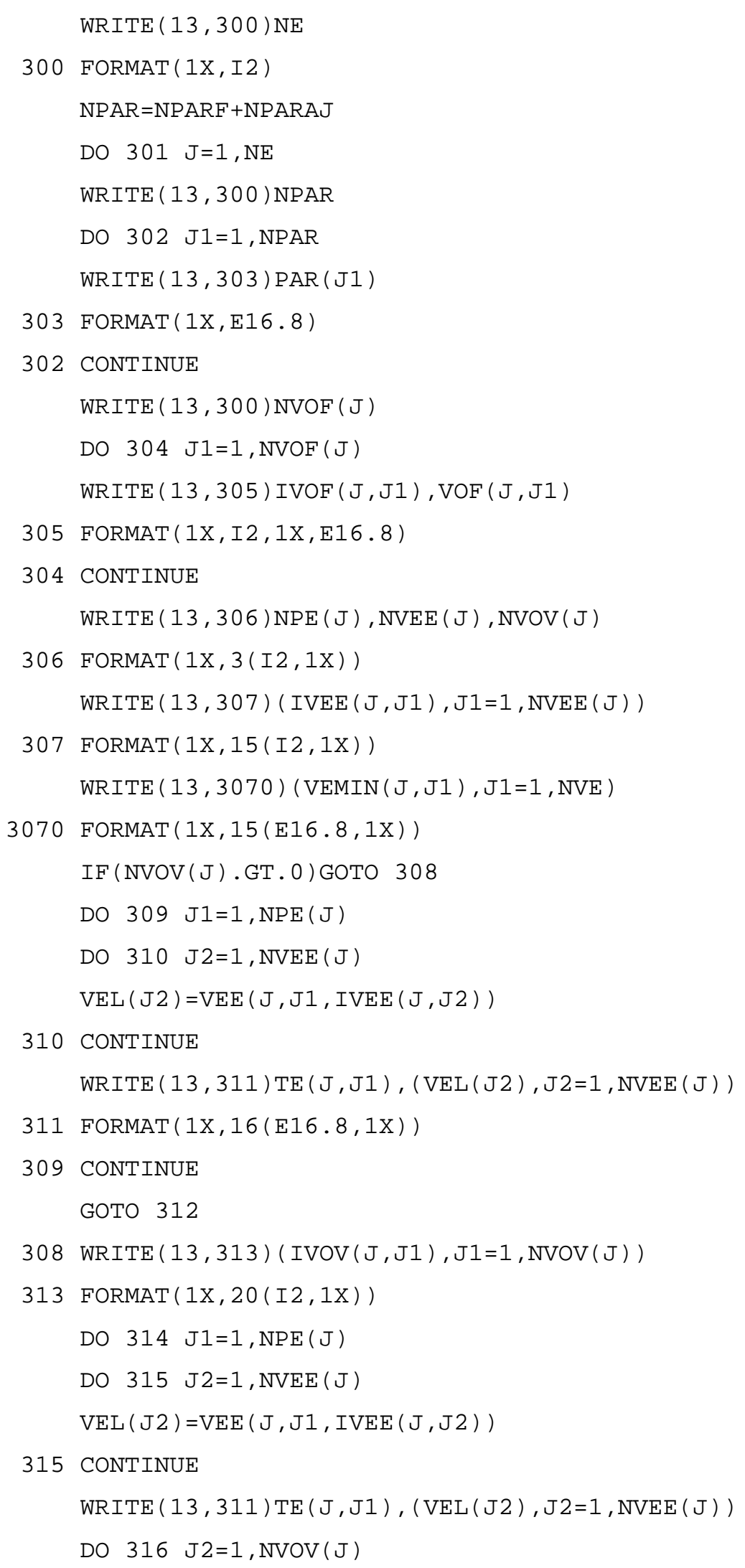


$\operatorname{VOVL}(\mathrm{J} 2)=\operatorname{VO}(\mathrm{J}, \mathrm{J} 1, \operatorname{IVOV}(\mathrm{J}, \mathrm{J} 2))$

316 CONTINUE

$\operatorname{WRITE}(13,317)(\operatorname{VOVL}(\mathrm{J} 2), \mathrm{J} 2=1, \operatorname{NVOV}(\mathrm{J}))$

317 FORMAT $(1 \mathrm{X}, 20(\mathrm{E} 16.8,1 \mathrm{X}))$

314 CONTINUE

$312 \operatorname{WRITE}(13,300) \mathrm{NVE}$

$\mathrm{DX}=\odot .1$

$\operatorname{TF}=\operatorname{TE}(\mathrm{J}, \operatorname{NPE}(\mathrm{J}))+\odot .099$

$\operatorname{WRITE}(13,318) \mathrm{T} \odot(\mathrm{J}), \mathrm{DX}, \mathrm{TF}$

318 FORMAT (1X, 3(E16.8, 1X))

IF (NVEAJ . EQ . $\odot)$ GOTO 320

DO $321 \mathrm{~J} 1=1, \mathrm{NVEAJ}$

$\operatorname{VE} \odot(J, \operatorname{IVEAJ}(J 1))=\operatorname{V}(\operatorname{NPARAJ}+J 1, I)$

321 CONTINUE

$320 \operatorname{WRITE}(13,311)(\operatorname{VE} \odot(\mathrm{J}, \mathrm{J} 1), \mathrm{J} 1=1, \operatorname{NVE})$

$\operatorname{WRITE}(13,319) M S T A T E A$, EPS, EWT

319 FORMAT (1X, I1 , 2(1X, E16.8))

301 CONTINUE

24 RETURN

END

SUBRotina PARA CALCUlo DAS DERIVAdas

$* * *$ (Subrotina a Ser Escrita pelo Usuario do Programa) $* * *$

$* * * * * * * * * * * * * * * * * * * * * * * * * * * * * * * * * * * * * * * * * * * * * * * * * * * * * * * * * *$

SUBROUTINE FCN $(N, X, Y, Y P R I M E)$

IMPLICIT REAL $(A-H, O-Z)$

CHARACTER NBLOCO $* 15$

integer NENSCONT

integer flag_I, N

REAL MIX, MID, MIGPV, MINH4, MIALA

REAL FF, fc1, fc2, fc3,fc4,fc5

REAL glc $\odot$, gln $\Theta$, glcin, glnin, po20, po2in

REAL Tempo, GLC, GLN

DIMENSION $\mathrm{Y}(\mathrm{N}), \mathrm{YPRIME}(\mathrm{N})$

COMMON PAR(60), $\operatorname{VOA}(20), \mathrm{J}$

Common/barral/VEEINI $(40,15)$, NENSCONT, $\operatorname{VOFIX}(40,20)$, IBAN

Common/barral1/FLAG_I

Common/barral2/mix 
Common/barral3/nBLOCO

Common/barral4/Tempo, GLC, GLN

$$
\begin{aligned}
& \operatorname{PAR}(1)=\operatorname{mimax} \quad(1 / \mathrm{h}) \\
& \operatorname{PAR}(2)=k G l c \quad(g / l) \\
& \operatorname{PAR}(3)=k G l n \quad(g / 1) \\
& \operatorname{PAR}(4)=k i N H 4 \quad(g / 1) \\
& \operatorname{PAR}(5)=\mathrm{km} \quad(1 / \mathrm{h}) \\
& \operatorname{PAR}(6)=\mathrm{kmGlc} \quad(\mathrm{g} / \mathrm{l}) \\
& \operatorname{PAR}(7)=\mathrm{kmNH} 4 \quad(\mathrm{~g} / 1) \\
& \operatorname{par}(8)=\text { Alfa_NH4 }(\mathrm{mg} / 1.0 \mathrm{e} \odot 7 \mathrm{cell}) \\
& \operatorname{PAR}(9)=\text { Alfa_ALA (g/1.0e07cel) } \\
& \operatorname{PAR}(10)=\text { Beta_ALA }(\mathrm{g} / 1.0 \mathrm{e} \odot 7 \mathrm{cel} . \mathrm{h}) \\
& \operatorname{PAR}(11)=\text { KALAGLC } \quad(\mathrm{g} / \mathrm{L}) \\
& \operatorname{PAR}(12)=A l f a \_G P V \quad(\mu g / 1.0 e 7 c e l) \\
& \operatorname{PAR}(13)=\operatorname{kdGPVNH} 4 \quad(\mathrm{~g} / \mathrm{L}) \\
& \operatorname{PAR}(14)=\text { YXGlC } \quad(1.0 \mathrm{e} 7 \mathrm{cel} / \mathrm{g}) \\
& \operatorname{PAR}(15)=\text { YALAGLC } \quad(\mathrm{g} / \mathrm{g}) \\
& \operatorname{PAR}(16)=m s \quad(g / 1 e 07 c e l . h) \\
& \operatorname{PAR}(17)=\text { YXGln } \quad(1.0 \mathrm{e} \odot 7 \mathrm{cel} / \mathrm{g}) \\
& \operatorname{PAR}(18)=\text { YNH4Gln } \quad(\mathrm{mg} / \mathrm{g}) \\
& \operatorname{PAR}(19)=\operatorname{kdGPV} \quad(1 / \mathrm{h}) \\
& \operatorname{par}(20)=k \operatorname{sinGLN} \\
& \operatorname{par}(21=\text { YGLNGLU } \\
& \operatorname{par}(22)=\text { YNH4GLU } \\
& \operatorname{par}(23)=\mathrm{kdAla} \\
& \operatorname{par}(24)=\text { YNH4ALA } \\
& Y(1)=X V \\
& \text { (1. } 0 \text { e07cel/ml) } \\
& Y(2)=X d \\
& \text { (1. } 0 \mathrm{e} 07 \mathrm{cel} / \mathrm{ml} \text { ) } \\
& Y(3)=G L C \\
& (\mathrm{~g} / \mathrm{L}) \\
& Y(4)=G L N
\end{aligned}
$$

do $i=1, n$ 
else

glnin $=3.5$

end if

if $($ glcin $==1.0)$ then

fc1glc $=0.390 \quad$ ! celula P2, adriana mimax

C

fc1glc $=1.00 \quad$ ! Barral teste 25/05/05

fc2glc $=1.000 \quad$ ! celula P2, adriana YNH4X

fc3glc $=1.000 \quad$ ! celula P2, adriana Ygpvx

fc4glc $=0.431$ ! celula P2, adriana Yxglc

C

fc4glc $=1.00 \quad$ ! Barral teste 25/05/05

fc5glc $=1.808 \quad$ ! celula P2, adriana YAlaglc

fc6glc $=0.219$ ! celula P2, adriana Yxgln

C

fc6glc $=1.00 \quad$ ! Barral teste 25/05/05

fc7glc $=3.024$ ! celula P2, adriana Ynh4gln

C

fc7glc $=1.00 \quad$ ! Barral teste 25/05/05

end if

if $(\operatorname{glcin}==5 . \odot)$ then

fc1glc $=0.780 \quad$ ! celula P2, adriana mimax

C

fc1glc $=1.0 \quad$ ! Barral teste 25/05/05

fc2glc $=0.980$ ! celula P2, adriana YNH4X

fc3glc $=1.000$ ! celula P2, adriana Ygpvx

fc4glc $=0.747$ ! celula P2, adriana Yxglc

fc5glc $=1.265$ ! celula P2, adriana YAlaglc

C

fc5glc $=1.00 \quad !$ Barral teste 25/05/06

fc6glc $=0.836$ ! celula P2, adriana Yxgln

fc7glc $=1.092 \quad$ ! celula P2, adriana Ynh4gln

end if

if $($ glcin $==10 . \Theta)$ then

fc1glc $=1.000 \quad$ ! celula P2, adriana mimax

fc2glc $=1.020 \quad$ ! celula P2, adriana YNH4X

C

fc2glc $=1.00 \quad$ ! Barral teste 25/05/05

fc3glc $=1.000 \quad$ ! celula P2, adriana Ygpvx

fc4glc $=1.000 \quad$ ! celula P2, adriana Yxglc

fc5glc $=1.000 \quad$ ! celula P2, adriana YAlaglc

fc6glc $=0.953 \quad$ ! celula P2, adriana Yxgln

fc7glc $=0.983 \quad$ ! celula P2, adriana Ynh4gln 
end if

$$
\begin{array}{rlrl}
\text { if }(\text { glcin }= & =15.0) \text { then } \\
\text { fc1glc } & =0.860 & \text { ! celula P2, } \\
\text { fc2glc }=4.400 & \text { ! celula P2, adriana YNH4X } \\
\text { fc2glc }=1.00 & \text { ! Barral teste 25/05/05 } \\
\text { fc3glc }=1.000 & \text { ! celula P2, adriana Ygpvx } \\
\text { fc4glc }=0.435 & \text { ! celula P2, adriana Yxglc } \\
\text { fc5glc }=1.489 & \text { ! celula P2, adriana YAlaglc } \\
\text { fc5glc }=1.00 & \text { ! Barral teste 25/05/05 } \\
\text { fc6glc }=0.230 & \text { ! celula P2, adriana Yxgln } \\
\text { fc7glc }=0.99 & \text { ! celula P2, adriana Ynh4gln }
\end{array}
$$$$
\text { C }
$$$$
\text { C }
$$

end if

$$
\begin{aligned}
& \text { if }(g \operatorname{lnin}==0.6) \text { then } \\
& \text { fc1gln }=0.401 \quad \text { ! celula P2, adriana mimax } \\
& \text { fc2gln }=1.000 \quad \text { ! celula P2, adriana YNH4X } \\
& \text { fc3gln }=0.470 \quad \text { ! celula P2, adriana Ygpvx } \\
& \text { fc4gln }=1.000 \quad \text { ! celula P2, adriana Yxglc } \\
& \text { fc5gln }=1.000 \quad \text { ! celula P2, adriana YAlaglc } \\
& \text { fc6gln }=1.000 \quad \text { ! celula P2, adriana Yxgln } \\
& \text { fc7gln }=1.000 \quad \text { ! celula P2, adriana Ynh4gln } \\
& \text { end if } \\
& \text { if }(\operatorname{glnin}==1.75) \text { then } \\
& \text { fc1gln }=0.969 \quad \text { ! celula P2, adriana mimax } \\
& \text { fc2gln }=1.000 \quad \text { ! celula P2, adriana YNH4X } \\
& \text { fc3gln }=0.499 \quad \text { ! celula P2, adriana Ygpvx } \\
& \text { fc4gln }=1.00 \quad \text { ! celula P2, adriana Yxglc } \\
& \text { fc5gln }=0.799 \quad \text { ! celula P2, adriana YAlaglc } \\
& \text { fc6gln }=0.384 \quad \text { ! celula P2, adriana Yxgln } \\
& \text { fc7gln }=0.549 \quad \text { ! celula P2, adriana Ynh4gln } \\
& \text { if }(\text { glnin }==3.5) \text { then } \\
& \text { fc1gln }=1.000 \quad \text { ! celula P2, adriana mimax } \\
& \text { fc2gln }=1.000 \quad \text { ! celula P2, adriana YNH4X } \\
& \text { fc3gln }=0.980 \quad \text { ! celula P2, adriana Ygpvx } \\
& \text { fc4gln }=0.99 \quad \text { ! celula P2, adriana Yxglc } \\
& \text { fc5gln }=1.031 \quad \text { ! celula P2, adriana YAlaglc } \\
& \text { fc6gln }=0.184 \quad \text { ! celula P2, adriana Yxgln }
\end{aligned}
$$




$$
\begin{array}{lll}
\text { fc602 }=0.540 & \text { ! celula P2, adriana Yxgln } \\
\text { fc702 }=4.390 & \text { ! celula P2, adriana Ynh4gln }
\end{array}
$$

end if

$$
\begin{aligned}
\text { if }(\text { po2in } & =80.0) \text { then } & & \\
\text { fc102 } & =0.110 & & \text { ! celula P2, adriana mimax } \\
\text { fc202 } & =23.429 & & \text { ! celula P2, adriana YNH4X } \\
\text { fc302 } & =7.03 & & \text { ! celula P2, adriana Ygpvx } \\
\text { fc402 } & =0.08 & & \text { ! celula P2, adriana Yxglc } \\
\text { fc502 } & =5.420 & & \text { ! celula P2, adriana YAlaglc } \\
\text { fc6o2 } & =0.090 & & \text { ! celula P2, adriana Yxgln } \\
\text { fc702 } & =5.730 & & \text { ! celula P2, adriana Ynh4gln } \\
\text { end if } & & &
\end{aligned}
$$

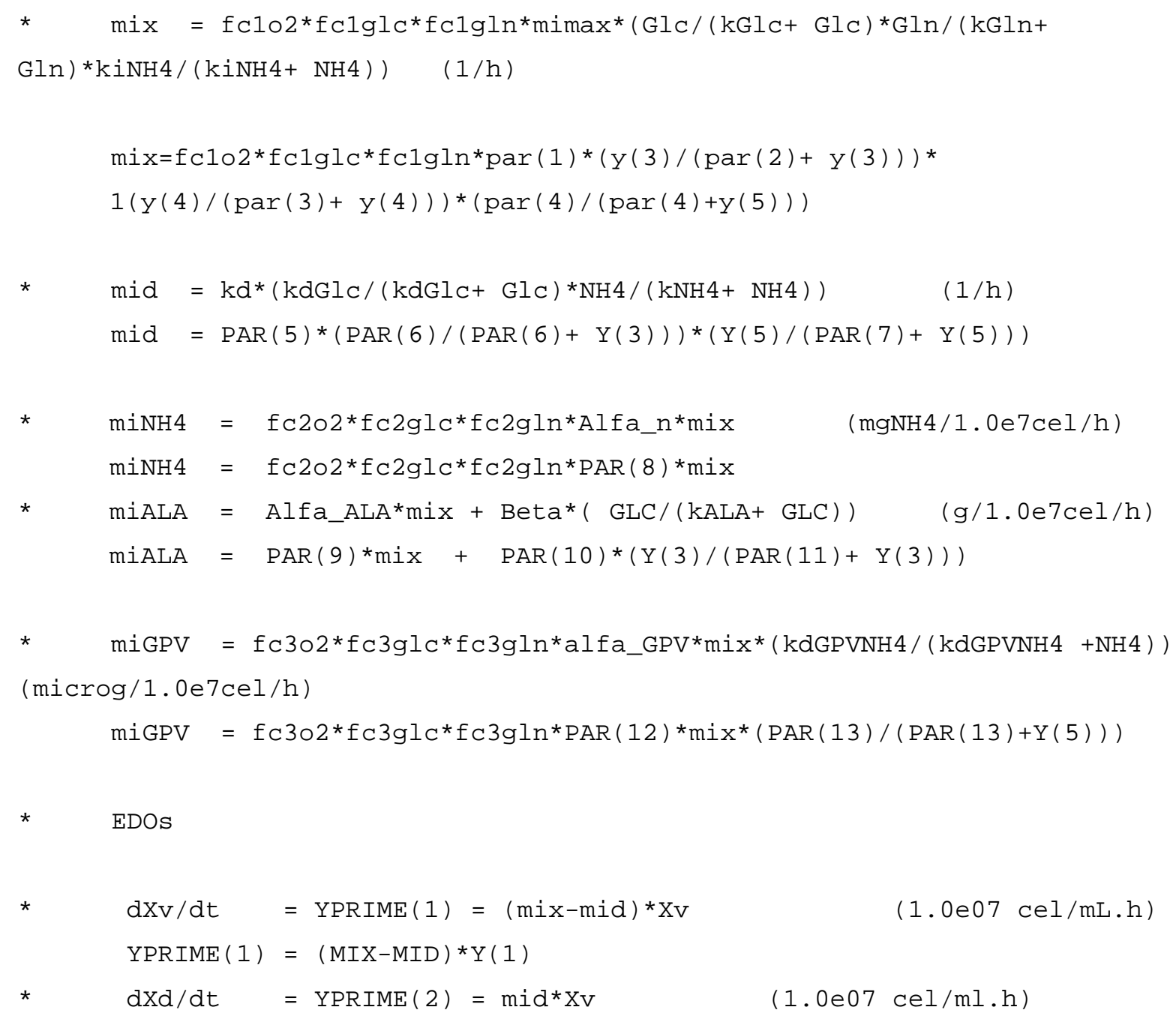




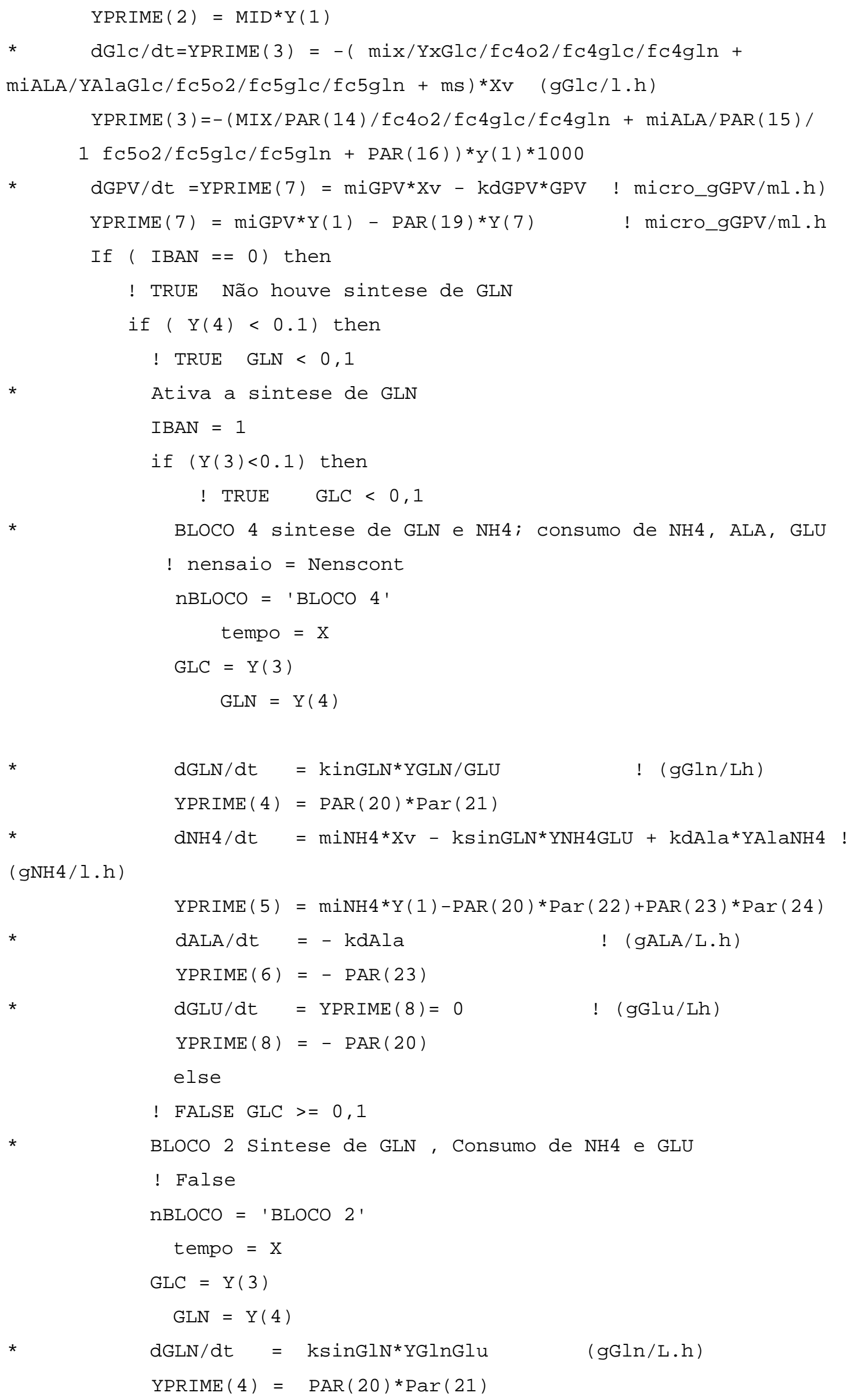




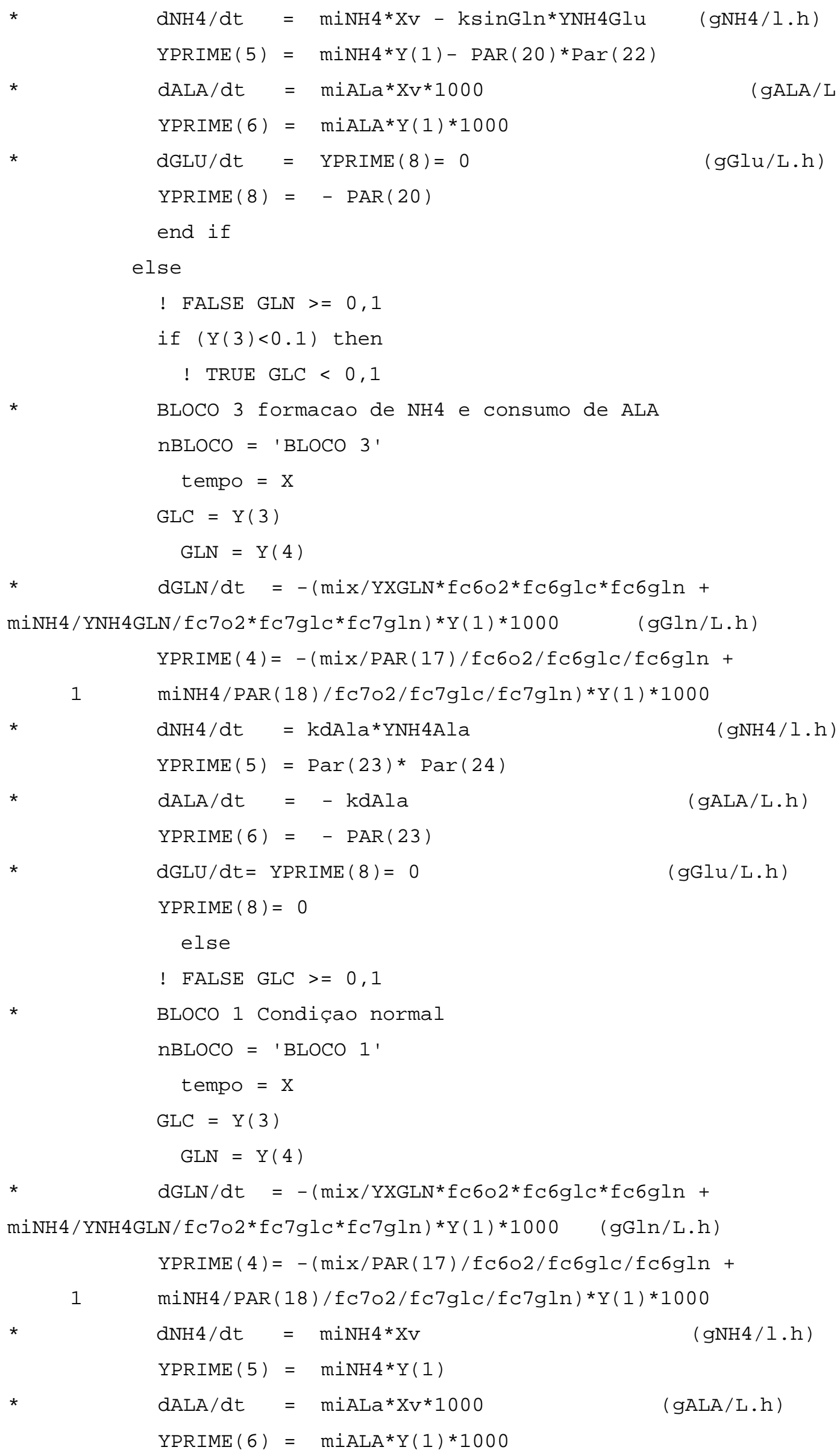




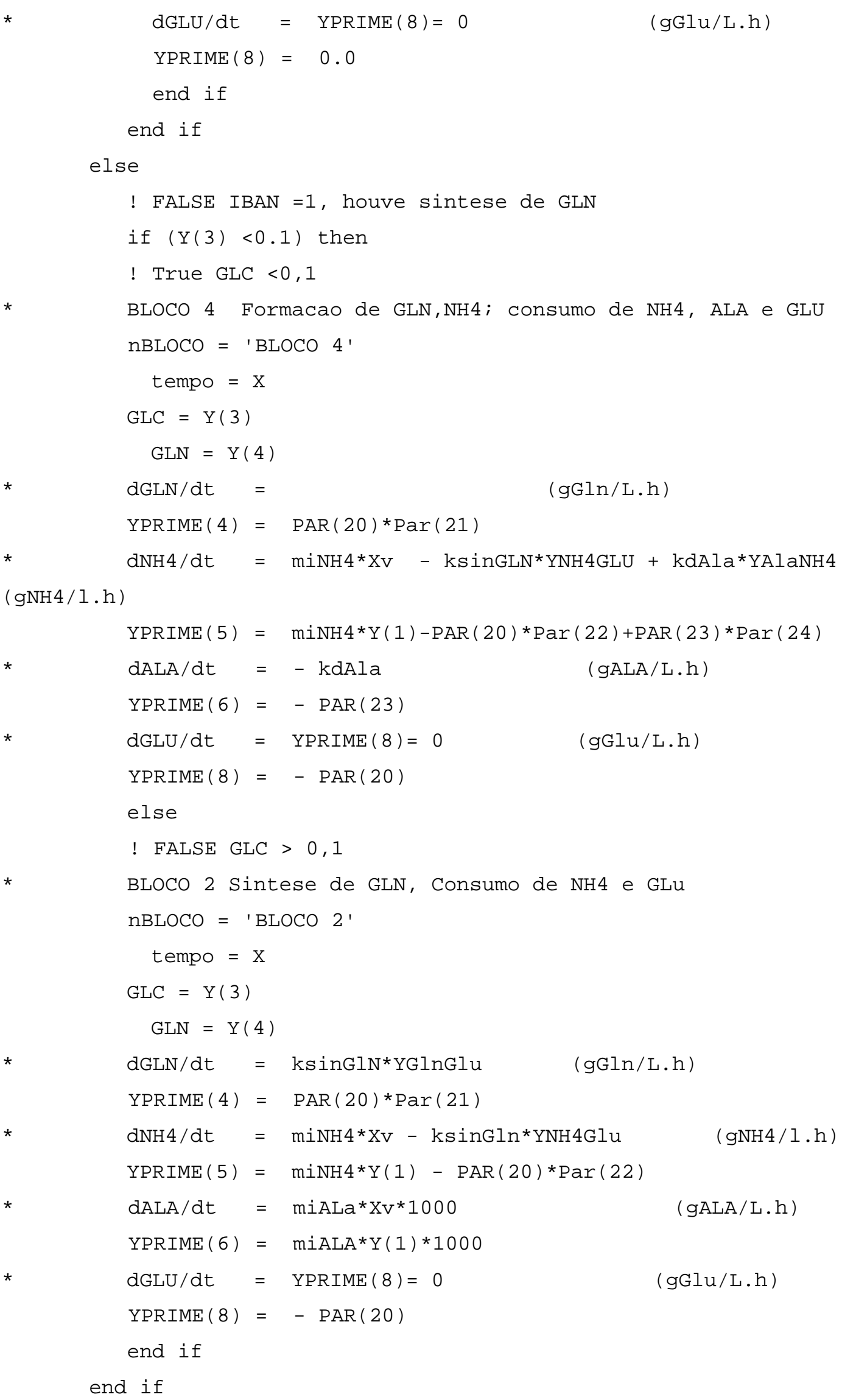


END

FUNCTION $G(N, X, Y$, NROOT)

IMPLICIT REAL (A-H, O-Z)

DIMENSION $Y(N)$

COMMON PAR(60), $\operatorname{VOA}(20), \mathrm{J}$

$\mathrm{G}=\odot . \odot$

RETURN

END 